$$
\text { UNIVERSIDADE DE SÃO PAULO }
$$

FACULDADE DE FILOSOFIA, LETRAS E CIÊNCIAS HUMANAS

DEPARTAMENTO DE LINGUÍSTICA

PROGRAMA DE PÓS-GRADUAÇÃO EM SEMIÓTICA E LINGUÍSTICA GERAL

INDAIÁ DE SANTANA BASSANI

FORMAÇÃO E INTERPRETAÇÃO DOS VERBOS DENOMINAIS

DO PORTUGUÊS DO BRASIL

Dissertação apresentada como pré-requisito para obtenção do título de Mestre no Programa de Pós-Graduação em Semiótica e Linguística Geral da Faculdade de Filosofia, Letras e Ciências Humanas da Universidade de São Paulo.

SÃO PAULO

2009 
UNIVERSIDADE DE SÃO PAULO

FACULDADE DE FILOSOFIA, LETRAS E CIÊNCIAS HUMANAS

DEPARTAMENTO DE LINGUISTICA

PROGRAMA DE PÓS-GRADUAÇÃO EM SEMIÓTICA E LINGUÍSTICA GERAL

FORMAÇÃO E INTERPRETAÇÃO DOS VERBOS DENOMINAIS

DO PORTUGUÊS DO BRASIL

Indaiá de Santana Bassani

Dissertação apresentada como pré-requisito para obtenção do título de Mestre no Programa de PósGraduação em Semiótica e Linguística Geral da Faculdade de Filosofia, Letras e Ciências Humanas da Universidade de São Paulo.

Orientadora: $\operatorname{Prof}^{\mathrm{a}} \mathrm{Dr}^{\mathrm{a}}$ Ana Paula Scher

SÃO PAULO

2009 


\author{
UNIVERSIDADE DE SÃO PAULO \\ FACULDADE DE FILOSOFIA, LETRAS E CIÊNCIAS HUMANAS \\ DEPARTAMENTO DE LINGUISTICA \\ PROGRAMA DE PÓS-GRADUAÇÃO EM SEMIÓTICA E LINGUÍSTICA GERAL \\ Indaiá de Santana Bassani

\section{FORMAÇÃO E INTERPRETAÇÃO DOS VERBOS DENOMINAIS DO PORTUGUÊS DO BRASIL}

\author{
Humanas da Universidade de São Paulo. \\ Área de Concentração: Semiótica e Linguística Geral \\ Orientador: Prof ${ }^{\mathrm{a}} \mathrm{Dr}^{\mathrm{a}}$ Ana Paula Scher \\ BANCA EXAMINADORA
}

Dissertação apresentada como pré-requisito para obtenção do título de Mestre no Programa de Pós-Graduação em Semiótica e Linguística Geral da Faculdade de Filosofia, Letras e Ciências

Prof $^{\mathrm{a}} \mathrm{Dr}^{\mathrm{a}}$ Ana Paula Scher

Instituição: FFLCH-USP

Presidente

Prof $^{\mathrm{a}}$ Dr$^{\mathrm{a}}$ Esmeralda Vailati Negrão

Instituição: FFLCH-USP

Titular

Prof. Dr. Luiz Carlos Schwindt

Instituição: UFRGS - Externo

Titular 
ESSA PESQUISA FOI APOIADA PELA FAPESP - FUNDAÇÃO DE AMPARO À PESQUISA DO ESTADO DE SÃO PAULO

PROCESSO N. 07/02304-6 
"- Se quer seguir-me, narro-Ihe, não uma aventura, mas experiência, a que me induziram, alternadamente, séries de raciocínios e intuições. Tomou-me tempo, desânimos, esforços.

Dela me prezo, sem vangloriar-me".

João Guimarães Rosa 
DEDICATÓRIA

À minha mãe, Eliane, companheira de todas as horas, primeira e maior professora. Mãe, você é meu exemplo.

Ao Fidel, companheiro de quase uma vida. E pela vida toda. 


\section{AGRADECIMENTOS}

Em primeiro lugar, agradeço imensamente à minha querida orientadora Prof ${ }^{a}$ $\mathrm{Dr}^{\mathrm{a}}$ Ana Paula Scher. Ana, você é meu exemplo de comprometimento acadêmico. Além de identificação, tenho por você imensa admiração e carinho. Obrigada pela orientação cuidadosa. Espero que nossa relação, pessoal e profissional, se estenda ainda por muitos anos.

Agradeço aos meus pais, Eliane e Armando, e aos meus irmãos, Daniel e Jussara, por entenderem e apoiarem minhas escolhas, por sempre me escutarem e respeitarem minhas opiniões. Aos meus primos, que influenciaram direta ou indiretamente em minha formação através das palavras de incentivo: Tércio e Thiago Esperandio e Analy Bassani.

Pelas contribuições sempre atentas a este trabalho, agradeço a todos os integrantes e colegas do Grupo de Estudos em Morfologia Distribuída (GREMD): Ana Scher, Aline Rodero, Fabiana Baldim, Rafael Minussi, Rafael Frates, Larissa Andrade, Alessandro Boechat, Sonia Rocha, Julio Barbosa, Paula Armelin; aos integrantes "eventuais" Marcus Lunguinho, Leonor Simioni, Rerisson Cavalcante, Lídia Lima. Aos que estão longe, mas contribuíram com ideias e palavras de apoio, os sempre queridos “irmãos mais novos acadêmicos" João Paulo Cyrino e Luiza Zandoná.

Aos professores do Departamento de Linguística pelas contribuições a esse trabalho e pelas contribuições à minha formação, acadêmica e pessoal: Profa $^{a}$ Esmeralda Negrão, obrigada pelas contribuições no exame de qualificação, por ter me ensinado um pouco sobre a arte de lecionar quando fui sua monitora e pela preocupação comigo e com todos os alunos de pós-graduação do DL-USP; Profa Evani Viotti, obrigada por ser sempre tão solícita e simpática e pelas orientações desde a Iniciação Científica; aos professores Luciana Storto, Alessandro Boechat, 
Marcos Lopes, Marcello Modesto e Jairo Nunes pelos conhecimentos adquiridos em seus cursos de pós-graduação e pelas contribuições e discussões acerca desta dissertação. Agradeço ao Prof. Mário Viaro do DLCV-USP pelas contribuições acerca de morfologia histórica e ao Prof. Zwinglio Guimarães do IF-USP pelo auxílio com a extração dos dados do dicionário.

Aos funcionários do Departamento de Linguística, Érica Flávia, Ben Hur Euzébio e Robson Dantas, muito obrigada pela paciência e eficiência.

Um agradecimento especial aos amigos de todas as horas, das mais ansiosas às mais divertidas... Muito divertidas! Aline Rodero, Fabiana Baldim, Julio Barbosa, Leonor Simioni, Lucia Helena Rozario, Marcus Lunguinho, Rafael Minussi e Rerisson Cavalcante. Obrigada por encontrar em vocês a alegria e leveza necessárias para encarar os momentos difíceis.

Aos meus queridos colegas de graduação que se tornaram grandes amigos e sempre me acompanham, mesmo à distância: Fabíola Santos, Paola Ferro, Fátima Baia e Walter Sano.

Á minha grande "amiga-irmã", Larissa Fonseca: Lari, obrigada pelo apoio incondicional. E à minha grande amiga Marlene Teixeira, obrigada pela força!

À Laura Helena Silveira e Maria Carmen Viana pelo exemplo de pesquisadoras competentes e comprometidas.

Aos meus amigos Hemerson Siqueira e Alexandre Bueno pelas conversas sobre essa nossa vida acadêmica.

Agradeço a todos os falantes que se dispuseram a responder os meus "cerca de" 35 testes por "cerca de" 15 dias: obrigada pela paciência! 
Fidel, obrigada por completar minha vida. Obrigada também pelas contribuições a este trabalho, seja como estatístico competente, seja como ouvinte paciente.

À FAPESP e ao CNPq pelo apoio a esta pesquisa. 


\section{RESUMO}

Em uma visão etimológica, o Verbo Denominal (VD) é aquele verbo que surgiu historicamente a partir de uma base nominal. Os dicionários consideram que um verbo é denominal quando sua forma nominal cognata tem uma datação anterior nos registros da língua. Há, dessa forma, duas maneiras de tratar a relação entre nome e verbo: em uma perspectiva sincrônica ou diacrônica. Como há certa mistura no tratamento do fenômeno, faz-se necessária uma distinção entre critérios etimológicos e sincrônicos para a determinação do que é um verbo denominal.

No presente trabalho, buscamos encontrar critérios formais e sincrônicos para saber quais verbos diacronicamente considerados como denominais podem também ser assim considerados em uma análise sincrônica de formação das palavras e em quais casos há razões comprovadas para propor o abandono do rótulo denominal.

Partimos de uma amostra de 4.548 verbos etimologicamente denominais do português, retirados do Dicionário Houaiss da Língua Portuguesa, e a restringimos por critérios de frequência a 95 verbos, que constituíram de fato o objeto de análise do estudo. Submetemos todos os verbos a testes estruturais de formação de sentenças sugeridos por Kyparsky (1987), Hale \& Keyser (2002) e Arad (2003), a saber: Alternância Causativo-incoativo (Teste1); Alternância Média (Teste 2); Presença de Expressão Perifrástica (Teste 3); Presença de Objeto Cognato (Teste 4); Presença de Adjunto Cognato (Teste 5); Presença de Adjuntos Hipônimos e Hiperônimos (Teste 6). As sentenças foram submetidas a julgamento de 40 falantes nativos de português brasileiro. Os resultados apontaram para uma heterogeneidade no comportamento da classe geral dos VDs. Em suma, há um grupo para os quais os testes indicam uma etapa nominal (gramaticalidade para testes 3,(4),5 e 6) e um outro grupo para os quais os testes não indicam a presença de uma etapa nominal na formação (agramaticalidade para testes 3,5 e 6). Há verbos que participam e não participam de alternâncias (gramaticalidade e agramaticalidade para testes 1 e 2) e, por fim, há um 
grupo de verbos em que uma acepção remete a uma etapa nominal e outra acepção remete a ausência de etapa nominal.

Após observar alternativas de análise em teorias lexicalistas de regras de formação de palavras (Basílio, 1993) e sintaxe-lexical (Hale \& Keyser, 2002), conseguimos diferenciar estruturas com uma etapa nominal (denominais) de estruturas derivadas diretamente da raiz com base nos pressupostos da teoria da Morfologia Distribuída (Halle \& Marantz, 1993; Harley \& Noyer, 1999), mais especificamente Arad (2003), Marantz (2008) e Harley (2005). Conseguimos representar estruturalmente os diferentes tipos de (supostos) VDs no que se refere ao seu comportamento sintático e sua relação semântica com os (supostos) nomes formadores.

Em primeiro lugar, tratamos dois grandes grupos: o primeiro contém os verbos que são formados a partir da categorização de uma raiz por um nome (n) e, em seguida, por um verbo (v) (estruturas denominais sincrônicas) e o segundo por verbos que são formados pela categorização direta de uma raiz $(\sqrt{ })$ por um verbo $(v)$ (estruturas não-denominais). No primeiro grupo, o dos denominais, observamos diferenças no comportamento sintático e sugerimos para eles diferentes tipos de estruturas: de alternância, de não-alternância e location/locatum. Em seguida, discutimos dois tipos de fenômenos que culminam na formação tanto de verbos denominais quanto de verbos derivados diretamente da raiz para aqueles que parecem, em princípio, tratar-se de um só verbo (verbos com estruturas denominais e estruturas de maneira e "Mesmo" verbo com comportamentos opostos).

Por fim, a maior contribuição teórica deste trabalho está em que avançamos no esclarecimento da diferença entre uma formação sincrônica e diacrônica de palavras, mostrando que nem sempre a explicação histórica é a única possível. 
Palavras-chave: Verbos Denominais; Estrutura Argumental, Morfologia, Sintaxe, Sincronia. 


\begin{abstract}
From an etymologycal point of view, the Denominal Verb is the one that derives historically from a nominal base. Dictionaries consider a verb as denominal when its cognate nominal form is older than the verbal one in language records. Thus, there are two ways of treating what is called denominal verb, regarding the relation between the noun and the verb: from a synchronic or from a dyachronic perspective. Since the description of this class is rather misleading, it is necessary to make a distinction between etymological and synchronic criteria in the definition of what a denominal verb is.
\end{abstract}

For these reasons, the aim of this work is i) to find out synchronic and formal criteria to know which denominal verbs, from a diachronic point of view, can also be considered as such under a synchronic analysis of word formation and ii) in which cases can real reasons be found for the abandonment of the label "denominal".

We started from a sample of 4.548 etymologically denominal verbs in Portuguese, collected from Dicionário Houaiss da Língua Portuguesa, and, due to a frequency criteria, we reduced it to 95 verbs that constitute, in fact, the object of this study. We submmited all the verbs to structural tests of sentence formation suggested by Kyparsky (1987), Hale \& Keyser (2002) and Arad (2003), namely: InchoativeCausative Alternation (Test 1); Middle Alternation (Test 2); Presence of Periphrastic Expression (Test 3); Presence of Cognate Object (Test 4); Presence of Cognate Adjunct (Test 5); Presence of Hiponimous and Hiperonimous Adjunction (Test 6). The sentences were submitted to the judgement of 40 native speakers of Brazilian Portuguese. The results pointed to heterogeneity in the behaviour of the general class of denominal verbs. To sum up, there is a group of verbs to which the tests indicated a nominal stage in the derivation of the verb (grammaticality for tests 3 (4), 5 and 6) and another group of verbs to which the tests did not indicate the presence of that nominal 
stage (agrammaticality for tests 3, 5 and 6). There are verbs that do and do not participate in alternations (gramaticality and agramaticality for tests 1 and 2) and, finally, there is a group of verbs for which one meaning indicates a nominal stage and the other meaning indicates the absence of such a nominal stage.

After observing some analysis under lexicalist theories based on word formation rules (Basílio, 1993) or under lexico-syntactic approaches such as Hale \& Keyser (2002), we could offer an analysis under which it is possible to distinguish the so-called denominal verbs in two classes: i) those represented by structures that include a nominal stage in the derivation (denominals), ii) those represented by structures in which the verb is derived directly from roots. This analysis is based on the Distributed Morphology model (Halle \& Marantz, 1993; Harley \& Noyer, 1999), more specifically, on Arad (2003), Marantz (2008) and Harley (2005).

Our first step was to separate the two big groups: the first containing verbs that are derived from the categorization of a root $(\sqrt{ })$ by a noun $(n)$ and, then, by a verb (v) (synchronic denominal structures), and the second group containing verbs that are derived from the direct categorization of a root $(\sqrt{ })$ by a verb ( $v$ ) (non-denominal structures). In the first group, the denominal one, we observed that the sentences containing such verbs presented different syntactic behaviors and we suggested different kinds of structures: alternating, non-alternating and location/locatum. In sequence, we discussed some verbs that led us to suggest that they can be formed either as denominal verbs or as root-derived ones.

We could then represent the structure of different types of so-called denominal verbs regarding their syntactic behavior and the relation they establish with the noun formed by the same root. 
Finally, the major theoretic contribution of this work is that we improved in clarifying the difference between a synchronic and a dyachronic word formation process, showing that the historical explanation is not always the single possibility.

Key-words: Denominal Verbs; Argument Structure, Morphology, Syntax, Synchrony. 


\section{SUMÁRIO}

1. INTRODUÇÃO: O QUE SÃO VERBOS DENOMINAIS? .....................................

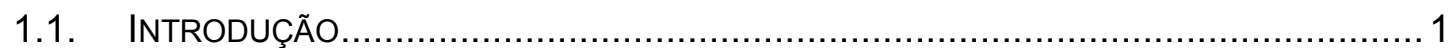

1.1.1. A Formação dos Verbos Denominais no $P B$........................................ 6

1.1.2. A Interpretação dos Verbos Denominais no PB ................................... 7

1.2. Conclusão da SEÇÃo, OBJetivos E ORganizaÇÃo do TrabalHo...................... 9

2. ESTUDOS MORFOLÓGICOS EM GRAMÁTICA GERATIVA ............................11

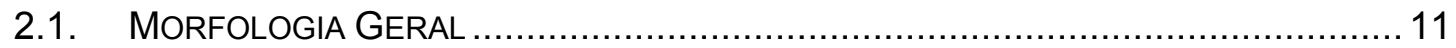

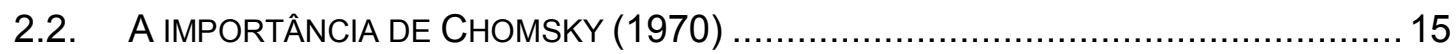

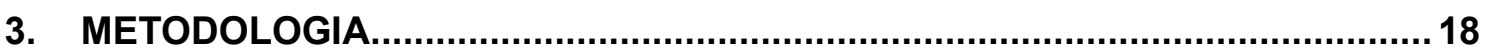

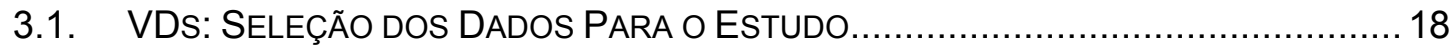

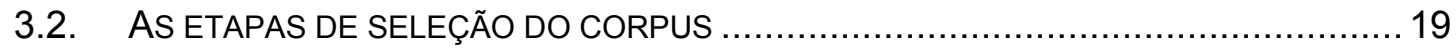

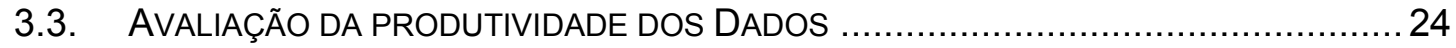

3.4. CORROBORANDO E QUESTIONANDO A ETIMOLOGIA DOS VERBOS SELECIONADOS 27

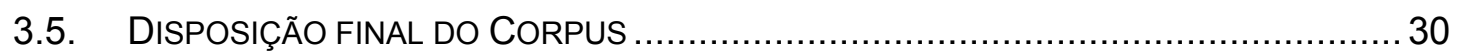

3.6. ALGUMAS DESCRIÇÕES MORFOLÓGICAS A PARTIR DO CORPUS TOTAL .................. 32

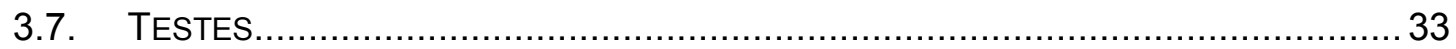

3.7.1. Testes sintáticos para a identificação de estrutura argumental.............. 33

3.7.2. Testes com Falantes .................................................................. 39

4. RESULTADOS E DESCRIÇÃO DOS DADOS ................................................ 45

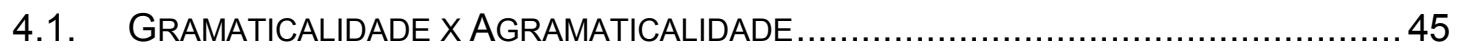

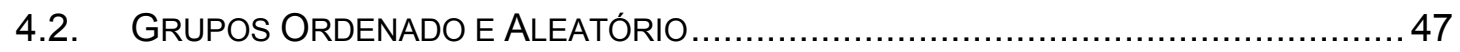

4.3. COMPORTAMENTO GERAL FRENTE AOS TESTES ........................................ 49

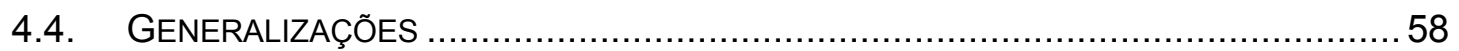

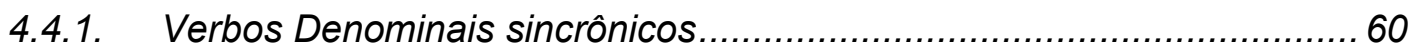

4.4.1.1. Gramaticalidade para o Teste 3 - Expressão Perifrástica ...................61 61

4.4.1.2. Gramaticalidade para o teste 5 - Adjuntos Cognatos.........................69 69

4.4.1.3. Gramaticalidade para Teste 4 - Objetos Cognatos ...........................69 69

4.4.1.4. Gramaticalidade para Teste 6 - Adjuntos Hipônimos e Hiperônimos 71

4.4.1.5. Conclusão da Subseção: verbos denominais sincrônicos .................. 80

4.4.2. Verbos "não denominais" sincrônicos: derivados da raiz ....................... 80

4.4.2.1. Agramaticalidade ou Indeterminação para Teste 3, 4, 5 e $6 \ldots \ldots \ldots \ldots . . . . .80$

4.4.2.2. Conclusão da subseção: verbos não-denominais ............................ 84

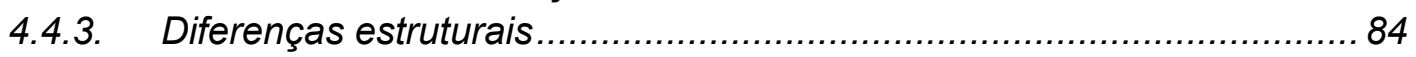

4.4.3.1. Verbos Alternantes: Alternância Causativo-Incoativa ......................... 84

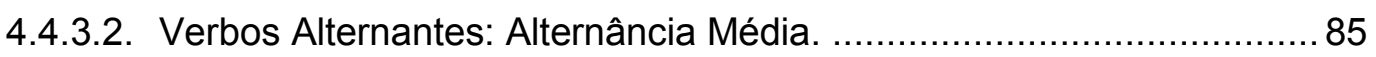

4.4.4. Verbos com dois sentidos: dois verbos? ........................................... 86

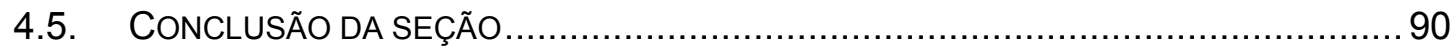

5. POR QUE AS REGRAS NÃO FUNCIONAM? ............................................... 91

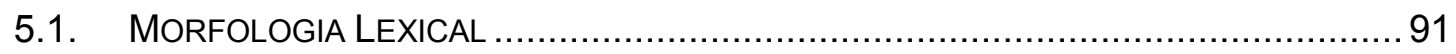

5.1.1. Os VDs em uma análise baseada em regras de formação .................... 92

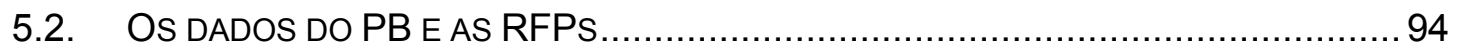


6.1. A SINTAXE LEXICAL DE HALE \& KEYSER (2002) .......................................... 97

6.1.1. A proposta de Hale \& Keyser (2002) ................................................ 97

6.1.2. O modelo de Estrutura Argumental.............................................. 97



6.1.4. O que é, então, ser denominal no modelo de Hale \& Keyser (2002)?.. 107

6.1.5. A estrutura argumental dos VDs: uma tentativa de análise ................. 110

6.1.6. Conclusão da subseção .............................................................. 116

6.2. VERBOS DENOMINAIS À LUZ DA MORFOLOGIA DISTRIBUÍDA ............................... 116

6.2.1. Morfologia Distribuída: "Lexicalism is dead, deceased, demised, no more, passed on..." (Marantz, 1997) ............................................................. 116

6.2.2. Arad (2003): restrições de localidade e Verbos Denominais................. 121

6.2.3. Marantz (2008): Corroborando a noção de fases em palavras ............ 127

6.2.4. Harley (2005): a incorporação de modo.......................................... 131

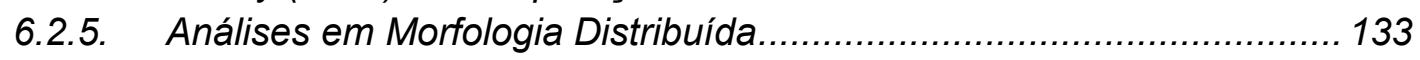

6.2.5.1. Verbos com Estruturas Denominais sincrônicas ............................ 133

6.2.5.1.1. Verbos com Estruturas denominais não alternantes .................. 134

6.2.5.1.2. Verbos com Estruturas denominais alternantes ....................... 140

6.2.5.1.3. Verbos com Estruturas location/locatum .................................. 145

6.2.5.2. Verbos com Estruturas não-denominais: derivados da raiz.............. 148

6.2.5.3. Verbos com Estruturas Denominais e estruturas "de maneira" ..... 153

6.2.5.4. "Mesmo" verbo com comportamentos opostos. Dois verbos? .......... 155

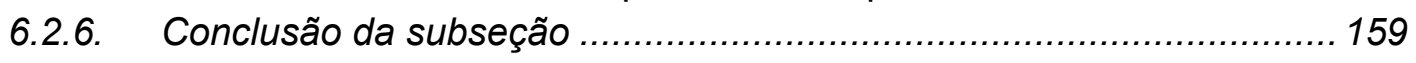

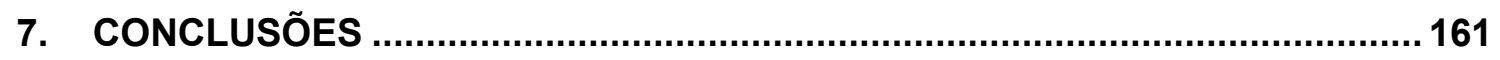

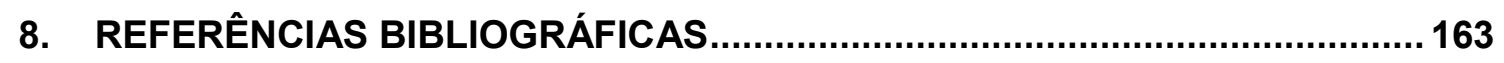

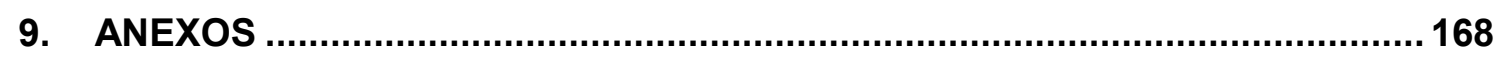




\section{INTRODUÇÃO: O QUE SÃO VERBOS DENOMINAIS?}

\subsection{Introdução}

Assume-se que um verbo é denominal quando é formado a partir de um nome, podendo ser esse nome pertencente à categoria de substantivo ou adjetivo. Logo, chama-se verbo denominal em português aquele que se forma a partir da junção, a um nome, de uma vogal temática verbal (a, e ou $i)$ e uma marca de flexão infinitiva $(-r$, como em perfum-a-r) ou, se se tratar de um verbo flexionado, da adição de uma marca finita (como em "eu perfum-e-i o ambiente"). Ainda, pode haver a realização de afixos "verbalizadores" em alguns casos, como -ec- ou -iz- presentes em amanhecer e cristalizar, respectivamente.

Essas marcas verbais podem ser fonologicamente realizadas ou podem ser não-realizadas, como na maioria das palavras do inglês. Nesse último caso, diz-se que houve simplesmente conversão ou derivação zero.

Como dito, em português, há adição de morfemas ao nome para que esse passe a constituir um verbo. Na visão mais tradicional do fenômeno, a Gramática Normativa (Bechara, 2002) aponta 1 e 2 como características morfológicas gerais dos Verbos Denominais (doravante, VDs) no português do Brasil (PB):

1. São formados por derivação sufixal (substantivo + sufixo):
a. perfume + -ar $>$ perfumar
b. esquema + -izar > esquematizar
c. salto + -itar $>$ saltitar.

2. São formados por derivação parassintética (prefixo + substantivo + sufixo):
a. en- + tarde + -ecer > entardecer
b. en- + caixote + -ar > encaixotar 
c. a- + conselho + -ar > aconselhar.

Já em inglês, por exemplo, a derivação de nome em verbo pode ocorrer com adição da morfologia verbal, como na adição do sufixo -en ao nome red, que transforma-se em redden, e a white, que transforma-se em whiten, mas, como dito, na maioria das formações, ocorre derivação zero, como em dance>dance. cough>cough, saddle>saddle.

Em uma visão etimológica, o VD é aquele verbo que surgiu, historicamente, a partir de uma base nominal. Os dicionários consideram que um verbo é denominal quando sua forma nominal cognata tem uma datação anterior nos registros da língua.

Perguntas do tipo "Esse verbo vem do nome ou o nome é que vem do verbo?", "Estudar vem de estudo ou estudo de estudar" já são velhas conhecidas dos estudiosos de morfologia. Em uma perspectiva diacrônica, como a usada pelo dicionário, parece haver critérios claros para fazer essa distinção, ainda que esses critérios não nos revelem nada acerca dessas estruturas e da interpretação que lhes é atribuída pelos falantes.

Contudo, para tratar da formação desses tipos de verbos sincronicamente, ou seja, para entender como o falante que forma esse tipo de verbo o interpreta ao utilizálo na fala, será necessário refinar esses critérios. Assim, por exemplo, será preciso definir se, para dizer "O menino estudou muito ontem", o falante precisar formar o verbo estudar passando, necessariamente, por um estágio nominal. Isso não parece consensual entre os falantes, que apresentam dúvidas sobre a questão. Chega-se, dessa forma, a duas maneiras de tratar o que chamamos de denominal: em uma perspectiva sincrônica ou em uma perspectiva diacrônica. No entanto, por vezes, há certa mistura no tratamento do fenômeno. Faz-se necessária uma distinção entre critérios etimológicos e sincrônicos para a determinação do que é uma palavra denominal. Vejamos o exemplo da descrição da etimologia do verbo arcar no 
dicionário eletrônico Houaiss da Língua Portuguesa. O verbo arcar possui duas entradas, $\operatorname{arcar}^{1}$ e arcar $^{2}$. Vejamos as entradas registradas e suas respectivas acepções:

\section{I.Arcar ${ }^{1}$ :}

\section{verbo}

- transitivo direto

1 dar forma de arco a

Ex.: arcar as sobrancelhas

- transitivo direto, intransitivo e pronominal

2 sofrer ou impor força para baixo; curvar(-se), arquear(-se), vergar(-se)

Ex.: <arcando o dorso, apanhou os sapatos $><$ de tão pesados, os ramos arcavam $>$ <arcou-se-lhe o corpo com o passar dos anos>

- transitivo direto

3 guarnecer de arcos, apertar com arcos

Ex.: mandou arcar barris e pipas

Etimologia: lat. árcuo ou árquo, as, ávi, átum, áre 'dobrar em arco, arquear'; ver arco e 1arc-; f.hist. 1552 arcado, 1617 arcar.

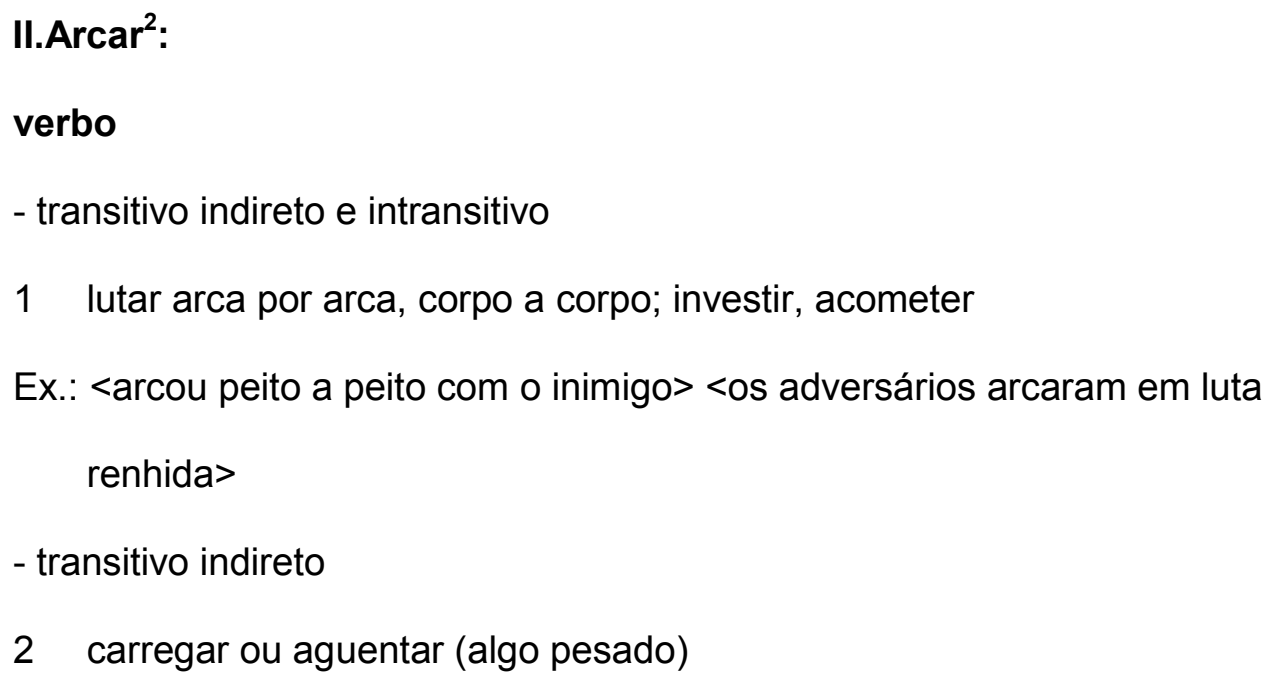


Ex.: os mais fortes arcavam com pedras enormes

transitivo indireto

$3(1688)$

arrostar, enfrentar

Ex.: arcar com a responsabilidade dos próprios atos

intransitivo

4 Uso: formal.

ofegar, respirar com dificuldade (por emoção ou cansaço)

Ex.: correndo e saltando, os guerreiros arcavam

Etimologia: arca + -ar; ver 1arc-; f.hist. a data 1599 é para arcou 'carregou', e a data SXVII é para arcando 'ofegando'

A descrição do significado do verbo $\operatorname{arcar}^{1}$ ainda retém a relação ou a necessidade da presença, ou denotação, do substantivo arco. Diferentemente, os significados atribuídos ao verbo $\operatorname{arcar}^{2}$, parecem se distanciar mais do substantivo arca e se aproximar da interpretação de verbos como carregar, aguentar, enfrentar em uma perspectiva sincrônica, como na sentença abaixo:'

(1) No fim das contas, tivemos que arcar com as consequências daquela festa.

Confirmamos que o verbo $\operatorname{arcar}^{1}$ ainda pode manter uma relação com o objeto pela boa formação de sentenças como esta a seguir:

(2) No fim das contas, decidi arcar as sobrancelhas em vez de deixá-las retas ${ }^{2}$.

\footnotetext{
${ }^{1}$ sVXII = século XVII

${ }^{2} \mathrm{O}$ verbo arcar é pouco utilizado, talvez porque exista a forma arquear, mais produtiva, que segundo a etimologia, forma-se de arco+ear.
} 
Assim, vê-se que, apesar de não haver hoje em dia mais nenhuma relação entre a entrada $\operatorname{arcar}^{2}$ e arca ainda se mantém a descrição no item etimologia, ao passo que, no item $\operatorname{arcar}^{1}$, que ainda parece manter essa relação na realização de muitas sentenças, a etimologia não é explicitada. Segue-se, assim, que embora o dicionário apresente certos critérios de julgamento do que é denominal ou não, esses não correspondem às intuições atuais dos falantes.

Entretanto, não pretendemos considerar uma falha o fato de que as descrições do dicionário com relação à formação de VDs não correspondam às intuições e/ou processos mentais dos falantes, por não ser esse o objetivo do dicionário, que é uma compilação dos itens lexicais da língua.

Diferentemente, o presente trabalho filia-se aos estudos da Gramática Gerativa, que procuram não somente descrever as línguas naturais, mas investigar suas estruturas e as operações que elas envolvem. Nesse sentido, uma análise sincrônica da formação de VDs não pode se restringir à descrição em tipos morfológicos, tal como apresentada pela Gramática Tradicional, ou à descrição etimológica, apresentada pelo dicionário. Uma descrição extremamente geral, como aquela, ou histórica, como essa, não mostra a complexidade dessa classe chamada de VDs, na medida em que não revelam nenhum tipo de informação sobre a estrutura desses verbos, ou seja, sobre as estruturas argumentais que podem ser associadas a eles $^{3}$ e nem sobre as interpretações que Ihes podem ser atribuídas. Esses critérios não revelam se VDs diacrônicos se mantém como denominais em uma análise sincrônica ou se podem ser considerados palavras simples, formadas diretamente de raízes.

Buscaremos, por esses motivos, encontrar critérios formais e sincrônicos para saber quais verbos diacronicamente considerados como denominais podem também

\footnotetext{
${ }^{3}$ Assumimos com Marantz (2008) que as estruturas argumentais são de fato estruturas sintáticas, e não lexicais.
} 
ser assim considerados em uma análise sincrônica de formação das palavras e em quais casos há razões comprovadas para propor o abandono do rótulo denominal.

\subsubsection{A Formação dos Verbos Denominais no PB}

Em geral, os trabalhos sobre os VDs no PB que têm como objetivo tratar da formação dos mesmos se inserem em uma perspectiva gerativista lexicalista e se aproximam muito do aspecto descritivo e pouco do aspecto explicativo. Com o intuito de esclarecer o estatuto dos VDs no PB, Basílio (1993) aponta que há três possibilidades excludentes de análises para a formação da classe dos Verbos Denominais como um todo:

a) Por Afixação ao Radical - Sugere que as unidades lexicais mínimas formadoras de palavras são os radicais e que a partir deles podem ser derivados tanto um substantivo quanto um verbo:

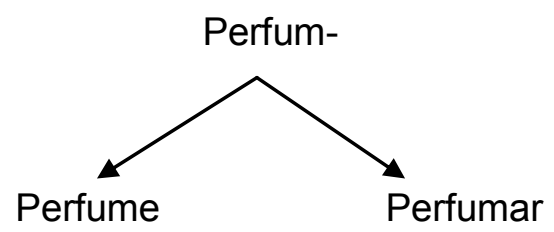

b) Por Derivação - Os verbos como perfumar seriam formados por adição de um sufixo formador de verbos (-ar) a um substantivo e os verbos como desossar seriam formados por adição simultânea de prefixo e sufixo (des- e -ar no caso) ao substantivo. Esses processos derivacionais são denominados respectivamente de Derivação Sufixal e Derivação Parassintética.

c) Por Conversão - Ocorreria uma "adaptação temática flexional". Em outras palavras, uma Vogal Temática é acrescentada ao substantivo adaptando-o a uma conjugação verbal. Nessa alternativa, o processo se daria em nível flexional. Por 
exemplo, teríamos o verbo perfumar, em que ao substantivo perfume seria acrescida a vogal temática a- em nível sintático e então haveria uma conversão em verbo:

(3) $\quad[\text { perfum }\{\text { e }\}]_{s} \rightarrow[$ [perfume $\left.] s\{a\}\right] \vee>[$ perfum $\{a r\}]$

No fim, a autora prefere assumir que a formação de VDs está relacionada a um processo derivacional, mas deixa claro que a questão não está definitivamente resolvida:

"Por outro lado, embora possamos estabelecer claramente os inconvenientes morfológicos de cada proposta, o problema de análise das construções focalizadas permanece, dado o estado controverso de uma grande parte dos pressupostos morfológicos envolvidos na discussão..." (Basílio, 1993:302).

Nessa pesquisa, buscaremos avaliar o tratamento dado pela autora aos VDs à luz de novos dados.

\subsubsection{A Interpretação dos Verbos Denominais no PB}

Além da formação do VD, há questões importantes sobre a sua interpretação. Em geral, assume-se que o sentido dos substantivos que os formam continua disponível nos verbos resultantes, como vemos abaixo:

(4) O funcionário encaixotou todas as mercadorias.

Interpretação: as mercadorias foram colocadas em caixas/caixotes. Não podemos dizer que ele as colocou em sacos (ensacar) ou as transformou em pacotes (empacotar). 
(5) A coordenadora planejou a reunião por horas.

Interpretação: pressupõe-se que há um plano de reunião.

Contudo, em sentenças como as abaixo, parece que a interpretação do VD é independente da denotação do nome que lhe corresponde:

(6) A professora vive martelando aquela estória de como é difícil passar no vestibular.

(7) "Slap: Consiste em bater (martelar) com o polegar (thumb = T) ..." 4

(8) “...muita gente que o anda a martelar com perguntas a respeito." 5

Vemos que a denotação do instrumento martelo não participa, necessariamente, da interpretação do VD. A presença desse instrumento não é essencial para que os eventos descritos acima ocorram.

Inicialmente, algumas hipóteses mais evidentes podem ser levantadas, como a de um uso metafórico do verbo martelar para as sentenças de (6) a (8); mas como explicar a boa formação de (9), em que o verbo martelar, combinado com o sintagma preposicional com o pau, parece ser interpretado da mesma forma como quando ocorre com o sintagma preposicional com o martelo, seu suposto primitivo, em (11)?

(9) Eu martelei o prego com um pau que encontrei lá.

(10) Eu martelei o prego com a sola do sapato ${ }^{6}$

(11) Eu martelei o prego com um martelo que encontrei lá.

\footnotetext{
${ }^{4}$ Instruções retiradas do site http://www.metalvox.com.br/colunasmusicais1.asp

${ }^{5}$ Retirado de blog particular da internet

${ }^{6}$ Exemplos de sentenças em que o sintagma preposicional introduz um nome diferente daquele que formou o Verbo Denominal não são novidades na literatura. Trabalhos como Kiparsky (1982) apresentaram essa possibilidade para sentenças do inglês, que foram mais tarde retomadas em Arad (2003) e debatidas em Harley \& Haugen (2007). A possibilidade de ocorrência dessas sentenças no PB também já foi atestada em Scher (2006).
} 
Há, na literatura, uma teoria de metáforas muito ampla e desenvolvida e, por vezes, a questão da metáfora é tratada com extrema simplicidade. Neste trabalho, não nos deteremos ao estudo das metáforas e, por essa razão, preferiremos utilizar o termo sentido conotativo em lugar de sentido metafórico.

\subsection{Conclusão da Seção, Objetivos e Organização do Trabalho}

Nessa introdução, retomamos e discutimos as questões que motivaram este trabalho e apontamos brevemente as questões que serão mais bem tratadas no decorrer das próximas seções.

Partindo da análise de 95 verbos considerados pelos registros de dicionário como denominais, nosso objetivo principal é mostrar que deve existir, de fato, uma diferenciação entre palavras denominais em uma abordagem sincrônica e em uma abordagem diacrônica. Observamos que palavras diacronicamente denominais podem, na sincronia, não ter mais relação alguma com a palavra que supostamente Ihes deu origem. Verificaremos se, nesses casos, o que ocorre é uma derivação diretamente da raiz e não de uma outra palavra, nos termos de Marantz (2001) e Arad (2003).

Ainda, teoricamente, caminhamos no sentido do esclarecimento da diferença entre o que é um VD em uma análise sincrônica e em uma análise diacrônica. Mostraremos, ainda, que modelos morfossintáticos e semânticos, como Hale \& Keyser (2002) (doravante, H\&K, 2002), Arad (2003), Marantz (2000, 2001, 2008), Harley (2005) podem revelar mais detalhes sobre a estrutura complexa do verbo denominal do que um modelo lexicalista baseado em regras de formação.

O restante da dissertação se organiza da seguinte maneira:

- Na seção 2, abrimos espaço para uma brevíssima discussão acerca da história dos estudos dos processos de formação de palavras; 
- Na seção 3, está descrita a metodologia de seleção dos dados de VDs estudados e a metodologia de realização de testes com falantes;

- Na seção 4, apresentamos os resultados obtidos a partir dos testes e, por meio desses resultados, encontramos generalizações, especialmente sobre o tipo de verbo no que cerne à sua relação com o nome formador: se é denominal ou não;

- Na seção 5, mostramos porque as regras de formação de palavras apresentadas em Basílio não podem enxergar as diferentes propriedades morfossintáticas desses verbos, justificando, assim a procura de teorias alternativas de análise;

- Na seção 6, buscamos alternativas de análise. Apresentamos algumas análises com base na sintaxe lexical de H\&K. Nesse modelo, há tratamentos satisfatórios para os VDs do tipo location e locatum, por exemplo; entretanto, é necessário buscar ferramentas em outros modelos para explicar de modo mais satisfatório o conjunto total dos dados e, assim, tentamos agregar à análise o tratamento sugerido pelo modelo da Morfologia Distribuída. Esse modelo permite uma distinção entre formações de palavras a partir de raízes e formação de palavras a partir de outras palavras, cujas raízes foram categorizadas em uma primeira fase da derivação. A noção de fases de interpretação no nível da palavra parece explicar alguns fenômenos de interpretação de VDs;

- A seção 7 conclui o trabalho. 


\section{ESTUDOS MORFOLÓGICOS EM GRAMÁTICA GERATIVA}

\subsection{Morfologia Geral}

O termo Morfologia é definido, de forma geral, como "estudo da forma, da configuração, da aparência externa da matéria" (Houaiss, 2002). Nos estudos de gramática e, posteriormente, nos estudos linguísticos, esse termo passou a designar o estudo da constituição das palavras e dos processos pelos quais elas são formadas. Foram denominadas de morfemas as unidades mínimas significativas, que constituem o material utilizado nos processos de formação de palavras (Bloomfield, 1926 apud Peter, 2003).

O estudo da Morfologia em Linguística teve maior atenção durante o período do estruturalismo. Sobre isso, Rocha (2003) afirma:

"com relação ao nosso campo de interesse, pode-se dizer que a morfologia alcançou um progresso notável no estruturalismo. Preocupados com a segmentação e a classificação dos morfemas, os linguistas americanos levaram essa técnica ao extremo, o que, sem dúvida, apesar dos exageros, veio beneficiar os estudos da morfologia. A preocupação com essa técnica era tão grande, que outros componentes, como a sintaxe e a semântica foram deixados de lado, tendo sido pouco estudados nesse período." (ROCHA, 2003:28-29).

É fato que o período do estruturalismo ficou consagrado como o período de glória dos morfólogos, mas o estudo da morfologia não foi totalmente abandonado em escolas posteriores. Na Teoria Gerativa, especialmente a partir do trabalho de Chomsky, 1970, abriu-se espaço para um enfoque na competência do falante em formar e analisar palavras, e especialmente palavras complexas da língua. 
Atualmente, há estudos morfológicos no Brasil filiados à Teoria Gerativa e que se concentram em problemas de representação lexical (Basílio, 1999), mas o início dos estudos morfológicos sobre a Língua Portuguesa se deu com os estudos descritivos de Mattoso Câmara, ainda filiado aos estudos estruturalistas. É nesse período que podemos encontrar uma das questões consideradas relevantes para o estudo da formação de palavras: a divisão entre uma morfologia flexional e uma morfologia derivacional ou lexical.

Em Mattoso Câmara (1970), o autor afirma que essa separação existe e pode ser bem justificada. A derivação em nível flexional (derivatio naturalis) é aquela que não permite a criação de novos vocábulos a partir de primitivos, ou seja, não é possível alterar a natureza categorial do vocábulo que sofreu mudança e formar uma palavra inédita na língua. As mudanças sofridas pelo vocábulo ocorrem quando um sufixo flexional ou uma desinência se juntam a um radical a fim de promover uma alteração destinada a adequá-lo a determinada estrutura sintática. Sobretudo, segundo Mattoso Câmara, esse processo é obrigatório e sistematicamente coerente para os nomes e verbos do português. Os nomes recebem flexão de número e gênero e os verbos recebem flexão de tempo, modo, aspecto, pessoa e número.

Por outro lado, a formação em nível derivacional é vista como o processo designado para a criação de novas palavras na língua. Por meio da junção de um afixo derivacional a um radical existente, ou da subtração de um afixo em casos de derivação regressiva, o falante pode criar novos vocábulos de acordo com sua "vontade comunicativa" (derivatio voluntaria). Essa junção pode alterar a classe gramatical de um vocábulo e tem um caráter aleatório, segundo Mattoso Câmara, não sendo possível prever qualquer sistematicidade no processo de formação de novas palavras ${ }^{7}$.

\footnotetext{
${ }^{7}$ Veremos adiante que uma das tarefas a que se propõe a linguística da formação de palavras é encontrar os processos sistemáticos pelos quais passam certas palavras, ou seja, os padrões de formação de palavras.
} 
Assim, por um lado, a formação de novas palavras se caracteriza como um processo derivacional que ocorre no léxico da língua, e a mudança no paradigma verbal por razões de flexão como um processo flexional, que ocorre em nível sintático.

Dessa divisão entre morfologia derivacional e morfologia flexional surge a separação entre processos de formação que ocorrem no léxico e processos que ocorrem na sintaxe.

Inicialmente, dentro das visões mais ortodoxas da Teoria Gerativa, em que se acredita e busca comprovar a existência de um aparato responsável pela competência linguística do ser humano, assume-se que os processos de derivação lexical e flexional ocorrem em diferentes componentes da arquitetura da gramática; o léxico e a sintaxe, respectivamente. Essas visões, que surgem com mais força a partir de Chomsky (1970), são chamadas de lexicalistas. Podem-se distinguir duas correntes dentro dos estudos lexicalistas; uma forte e uma fraca.

O lexicalismo dito fraco assume a distinção entre uma morfologia derivacional e uma morfologia flexional, em que haveria a necessidade de se tratar cada uma em um componente gerativo distinto. A derivação é do âmbito do léxico enquanto a flexão é do âmbito da sintaxe. Anderson (1982) é um trabalho que representa essa corrente.

Já o lexicalismo forte assume a distinção entre derivação e flexão, mas não acredita na necessidade de tratar estes processos em componentes distintos. (Di Sciullo \& Willians, 1987).

Uma terceira corrente lexicalista ficou conhecida como separacionismo. Um trabalho lexicalista separacionista é o de Beard $(1995)^{8}$, segundo Harley \& Noyer (1999). O separacionismo caracteriza teorias morfológicas em que os mecanismos

\footnotetext{
${ }^{8}$ A Hipótese separacionista da teoria chamada Lexeme-Morpheme Base Morphology divide todo o processo de derivação lexical e flexional em três processos: derivação lexical, derivação flexional e "spelling" morfológico. A derivação envolve operações sobre as funções abstratas lexicais e funções de categoria funcional, como [+Plural, -Singular], [+Passado, -Presente], [+1pessoa], etc. "Spelling" é a realização puramente fonológica de categorias morfológicas de qualquer lexema de base que passou por tal derivação. Uma descrição detalhada dos fundamentos dessa teoria pode ser encontrada na página do autor: http://www.facstaff.bucknell.edu/rbeard/.
} 
para produzir as formas das expressões sintática e semanticamente complexas são separados dos mecanismos que produzem as formas das expressões fonológicas correspondentes. A Morfologia Distribuída é um tipo de teoria morfológica separacionista, mas não tem cunho lexicalista, como veremos.

Em uma abordagem de cunho lexicalista, o léxico é, ao lado do componente sintático, um componente gerativo, onde existem processos produtivos de formação de palavras, além de desempenhar a função de local de armazenamento de palavras existentes e reconhecidas pelos falantes de uma língua. Nesse componente, os processos são independentes da sintaxe e representados por meio de regras específicas.

A visão lexicalista proposta por Chomsky (1970) vai contra certas visões transformacionalistas de fenômenos como a nominalização derivada ${ }^{9}$ do inglês, que assumem que as nominalizações sempre são formadas a partir de sentenças. A visão transformacionalista sugere que a formação dessas nominalizações, e muitos outros fenômenos, são comportados por regras do componente sintático, sem descartar, sobretudo, a existência de um léxico como local de armazenamento e componente categorial.

Contudo, além dessas duas visões, há uma versão recente da Teoria Gerativa, a $M D$, que sugere que todo o processo de formação de palavras ou sentenças ocorre no componente sintático, com possíveis alterações no componente morfológico, póssintático. Em MD, elimina-se a presença e a necessidade do léxico como componente gerativo e mesmo como local de armazenamento de palavras, e assumem-se outros modos de armazenar informações.

Estando a formação de VDs, objeto de estudo deste trabalho, incluída no fenômeno mais geral de formação de palavras, faz-se necessária uma séria discussão

\footnotetext{
9 Para ilustrar, um exemplo de nominalização derivada do inglês: "Jonh's refusal of the offer".
} 
teórica sobre as diferentes abordagens presentes na Teoria Gerativa e sobre as vantagens e desvantagens em se assumir uma ou outra.

Se assumirmos uma visão lexicalista, ou mesmo transformacional, devemos aceitar que os VDs são formados por regras do componente lexical que transformam substantivos em verbos. Se aceitarmos a visão da MD, devemos assumir que a formação de VDs se dá em nível sintático através da categorização de uma raiz por um nome e então por um núcleo verbal, em seguida.

A seguir, apresentaremos, de forma breve, a discussão introduzida pelo trabalho de Chomsky (1970), e o modo como ela serviu de inspiração para as duas abordagens possíveis e mais relevantes para a formação de palavras, a serem apresentadas e discutidas neste trabalho.

\subsection{A importância de Chomsky (1970)}

Em linhas gerais, o trabalho de Chomsky (1970) coloca uma questão para a tendência que se apresentava até o momento, ou seja, para a tendência a considerar o componente categorial da base, que, junto com o sistema de transformações constituem a sintaxe, como um local super poderoso. Nesse local, podiam-se gerar diversas estruturas de forma independente, até mesmo aquelas que pareciam ser do domínio do léxico.

Diante da necessidade de dar conta de alguns problemas descritivos, o autor coloca a questão sobre qual seria a melhor alternativa para a descrição da arquitetura da gramática: expandir o léxico e simplificar o componente categorial (Hipótese lexicalista) ou simplificar o léxico e expandir o sistema de transformações para absorver os processos de formação que eram considerados lexicais (Hipótese transformacional).

Chomsky afirma que a melhor resposta para essa questão será descoberta com base nos dados empíricos e, por isso, lança mão do fenômeno das 
nominalizações derivadas, gerundivas e mistas do inglês para discuti-la. Não nos deteremos aqui na argumentação de Chomsky, por não ser esse o foco do presente trabalho.

Contudo, a defesa de Chomsky da hipótese lexicalista para certas formações abriu espaço para uma série de trabalhos de cunho lexicalista. Nesses trabalhos, o léxico é colocado como um local necessariamente gerativo, com operações que não podem ser realizadas por outros componentes, como a sintaxe. Dentre alguns trabalhos ilustres de cunho lexicalista, estão Aronoff (1976) e Di Sciullo \& Williams (1977).

Por outro lado, um fato interessante consiste em que, a partir da discussão em Chomsky (1970) para o tratamento das nominalizações, Marantz (1997) sugere uma interpretação alternativa para os resultados apresentados por aquele autor. De acordo com Marantz, para dar conta de nomes como destruction e growth, sem ter de dizer que tais nomes derivam de sentenças como $X$ destroyed $Y$ e $X$ grows $Y$, Chomsky sugere a ampliação das regras do componente categorial, incluindo regras que permitem que nomes, tanto quanto verbos, selecionem argumentos. Dessa forma, permite que essas nominalizações sejam derivadas sem que passem, necessariamente, por um estágio verbal para serem, posteriormente, transformadas em nomes. Em sua interpretação, essa sugestão de Chomsky não implica que nominalizações como essas devam ser derivadas no léxico, como sugeriram diversos trabalhos sobre o tema que se seguiram a Remarks. Na realidade, para Marantz, Chomsky (1970) foi o ponto de partida para os estudos em MD, que, no mais simples de seus fundamentos, defende que as palavras podem ser formadas diretamente de raízes por operações do componente sintático.

Para Marantz, "Remarks" introduz a noção de que categorias lexicais podem ser identificadas e diferenciadas por seus traços internos $(+/-\mathrm{N},+/-\mathrm{V})$ em uma 
tentativa de preservar a definição distribucional de categorias gramaticais, isso contextualizado pelo modelo X'.

"Maintaining a strict correspondence between distribution and meaning implied that "N" and "V" need not have any essential internal properties. N's were elements that shared distribution, and as a result shared meaning. NPs containing nominalizations have the meaning of sentences, as predicted by the transformational analysis, or so the argument went."10 (p. 13-14)

"X-bar theory says that, essentially, all the "lexical" grammatical categories have the same distribution, taking a complement to form an X', which takes a specifier to yield X-max: the categories are distinguished (only) by their internal features." ${ }^{11}$ (p.14)

Dessa forma, vemos que o que Remarks ressalta não é a divisão entre os lugares de formação de nominalizações, logo, de palavras, mas sim a configuração sintática em que essa transformação ocorre. ${ }^{12}$

Aberta a discussão para os tipos de abordagem de formação de palavras, partiremos para o estudo dos VDs e, adiante, observaremos como diferentes modelos de análise, a saber, Morfologia Lexical, Sintaxe lexical e Morfologia Distribuída, cobrem os fatos descritos.

\footnotetext{
${ }^{10}$ Manter uma correspondência estrita entre distribuição e significado implicou que $\mathrm{N}$ e $\mathrm{V}$ não precisam ter nenhuma propriedade interna essencial. N's são elementos que partilham distribuição, e como resultado partilham significado. NPs contendo nominalizações têm o significado de sentenças, como previsto pela análise transformacional, e assim se construiu a argumentação.

${ }^{11}$ A teoria X-barra diz que, necessariamente, todas as categorias gramaticais "lexicais" têm a mesma distribuição, tomando um complemento para formar um X', que toma um especificador para resultar em Xmáximo: as categorias são distintas (apenas) por seus traços internos.

${ }^{12}$ Para mais uma abordagem deste assunto, cf. Scher (2004).
} 


\section{METODOLOGIA}

\subsection{VDs: Seleção dos Dados Para o Estudo}

A seleção das ocorrências de VDs exigiu alguns critérios metodológicos que merecem ser descritos.

A primeira questão com a qual nos deparamos foi como delimitar o que estamos tratando por VDs. Que verbos devemos selecionar quando buscamos os VDs do PB? De que ponto de vista queremos selecionar esses verbos: a partir de sua interpretação, de sua formação ou de sua estrutura? Se optarmos pelo ponto de vista de sua formação, o faremos considerando-a sincrônica ou diacronicamente?

Como um dos objetivos deste trabalho é fazer uma descrição morfológica dos VDs, achamos por bem começar pelos verbos registrados como denominais no maior registro possível de verbos de uma língua: o dicionário, mais especificamente, o Dicionário Houaiss da Língua Portuguesa.

O dicionário nos pareceu uma boa opção para obter de forma confiável e abrangente as ocorrências de verbos a serem analisadas, especialmente em nível morfológico.

Contudo, algumas questões ainda deveriam ser definidas. Partindo do dicionário, fomos levados a optar pela seleção do ponto de vista etimológico ${ }^{13}$. Nessa perspectiva, os VDs são aqueles que são tratados como tendo, em sua história de formação, uma etapa em que um substantivo deu origem a um verbo.

\footnotetext{
13 Apesar de o Dicionário Houaiss, de onde foram extraídos os dados, não ser um dicionário exclusivamente etimológico, ele é considerado uma fonte confiável nesse aspecto por estudiosos da área de morfologia histórica (c.f. Viaro, 2008). Agradeço ao Prof. Dr. Mário Eduardo Viaro do Departamento de Letras Clássicas e Vernáculas da Universidade de São Paulo pela colaboração com a parte de morfologia histórica.
} 


\subsection{As etapas de seleção do corpus}

O primeiro recorte do nosso corpus da amostra total do dicionário foi feito da forma que descrevemos a seguir. ${ }^{14}$

\section{a. Primeira etapa de seleção: critério de formação}

Selecionamos todos os verbetes que pertenciam à categoria Verbo e tinham em sua especificação etimológica uma formação mínima do tipo [Substantivo +

Sufixo]. Como essa especificação era mínima, ela nos permitiu também abarcar as formações parassintéticas, em que, além do sufixo previsto pelo algoritmo acima, também há um prefixo, não excluído por esse algoritmo.

A figura 3.2.1 abaixo ilustra como o verbo martelar é apresentado no dicionário e como ele é especificado quanto a sua etimologia: martelo + ar.

Figura 3.2.1 Etimologia de Martelar no Dicionário

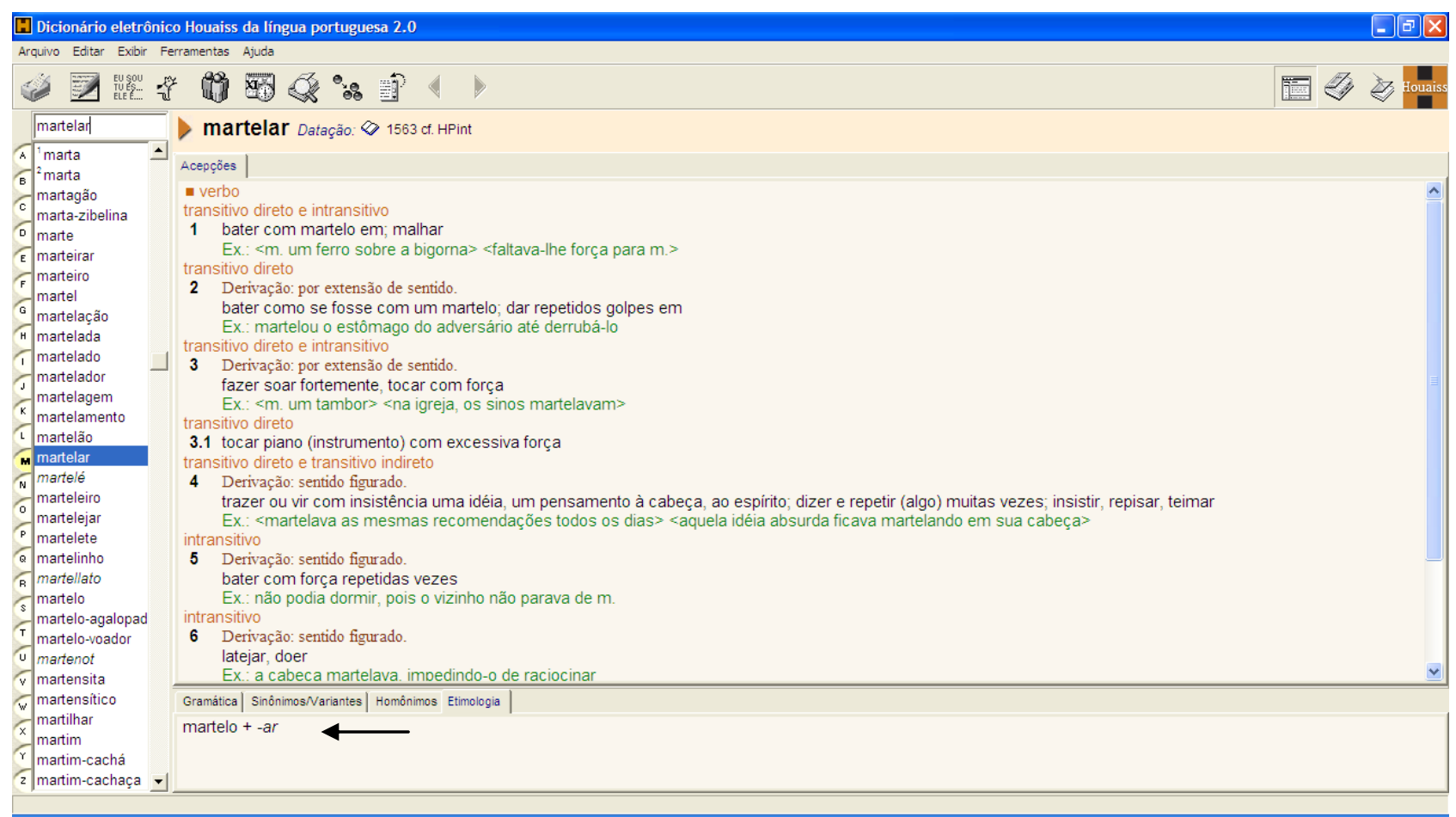

\footnotetext{
${ }^{14}$ Agradecemos ao Prof. Dr. Zwinglio Guimarães do Instituto de Física da Universidade de São Paulo pela ajuda com a extração dos verbos a partir do dicionário eletrônico.
} 
Ainda, as formações parassintéticas, como no verbo engavetar, também foram selecionadas a partir desse primeiro recorte, vejamos a sua especificação na figura 3.2.2:

Figura 3.2.2 Etimologia de Engavetar no dicionário.

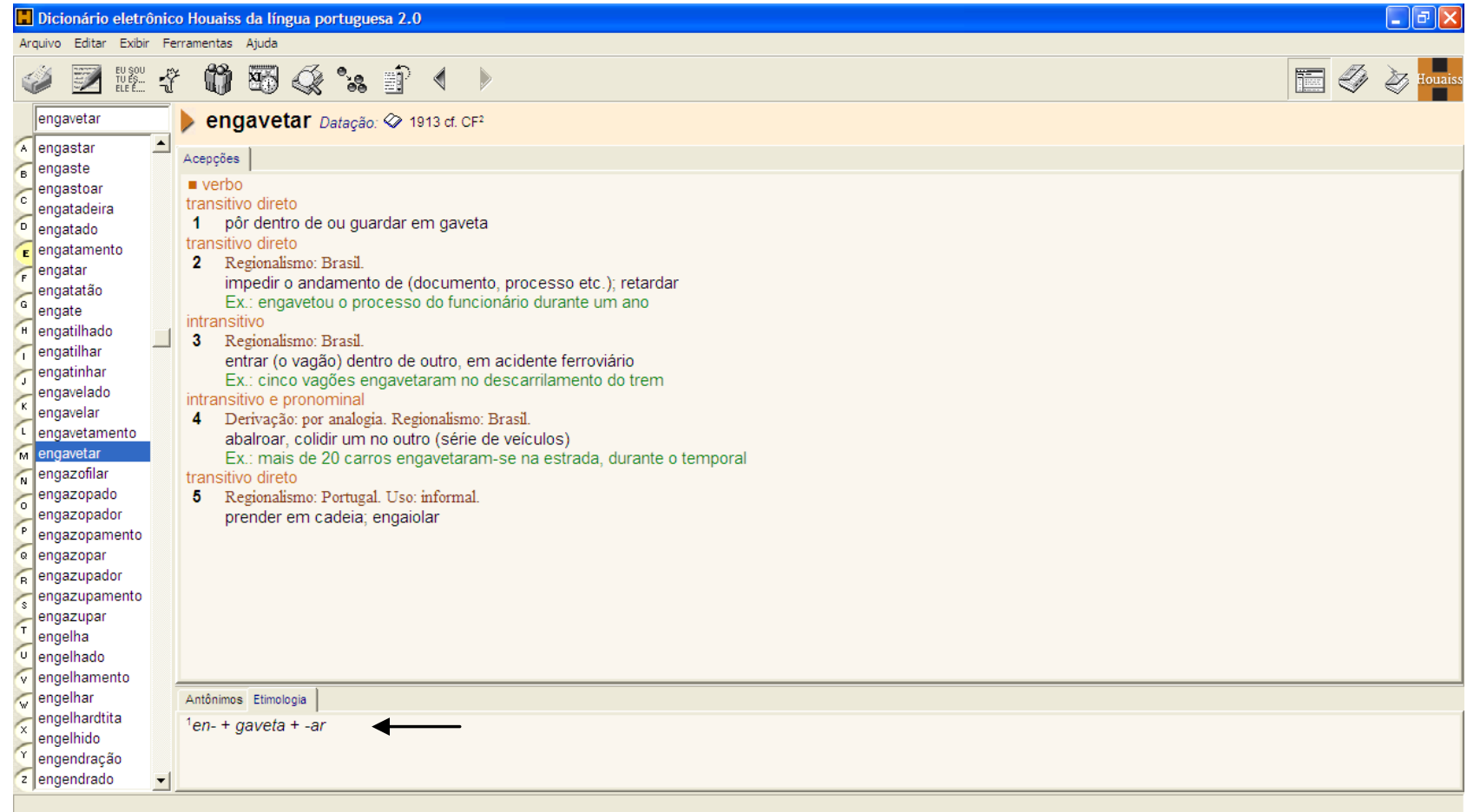

Ao todo, na primeira seleção descrita acima foram obtidos 6.172 ocorrências de verbos.

Apesar de podermos dizer que ambos os substantivos e adjetivos podem formar verbos denominais, é possível fazer uma distinção entre aqueles verbos que são formados a partir de substantivos e aqueles que são formados a partir de $\operatorname{adjetivos}^{15}$.

Embasadas nessa diferenciação já utilizada na literatura, tomamos a atitude metodológica de restringir o corpus de análise às formações denominais que o

\footnotetext{
${ }^{15}$ Hale \& Keyser (1993) mostraram diferenças estruturais entre os processos de formação de denominais e deadjetivais. Ampliaremos essa discussão mais adiante no trabalho.
} 
dicionário registra como derivadas de substantivos. As formações deadjetivais nos interessam e serão retomadas em trabalho futuro, mas não cabem no presente trabalho. Entendamos um pouco mais o filtro aplicado.

\section{b. Segunda Etapa de Seleção: critério de categoria}

A partir das 6.172 ocorrências obtidas na primeira seleção, aplicamos o critério que diz que o substantivo formador do verbo não pode ter dupla acepção, uma em que ele pertence à categoria de substantivo e outra em que ele pertence à categoria de adjetivo, como ocorre com o vocábulo visual, por exemplo. Vejamos esse caso:

Figura 3.2.3 Acepções de Visual no dicionário.

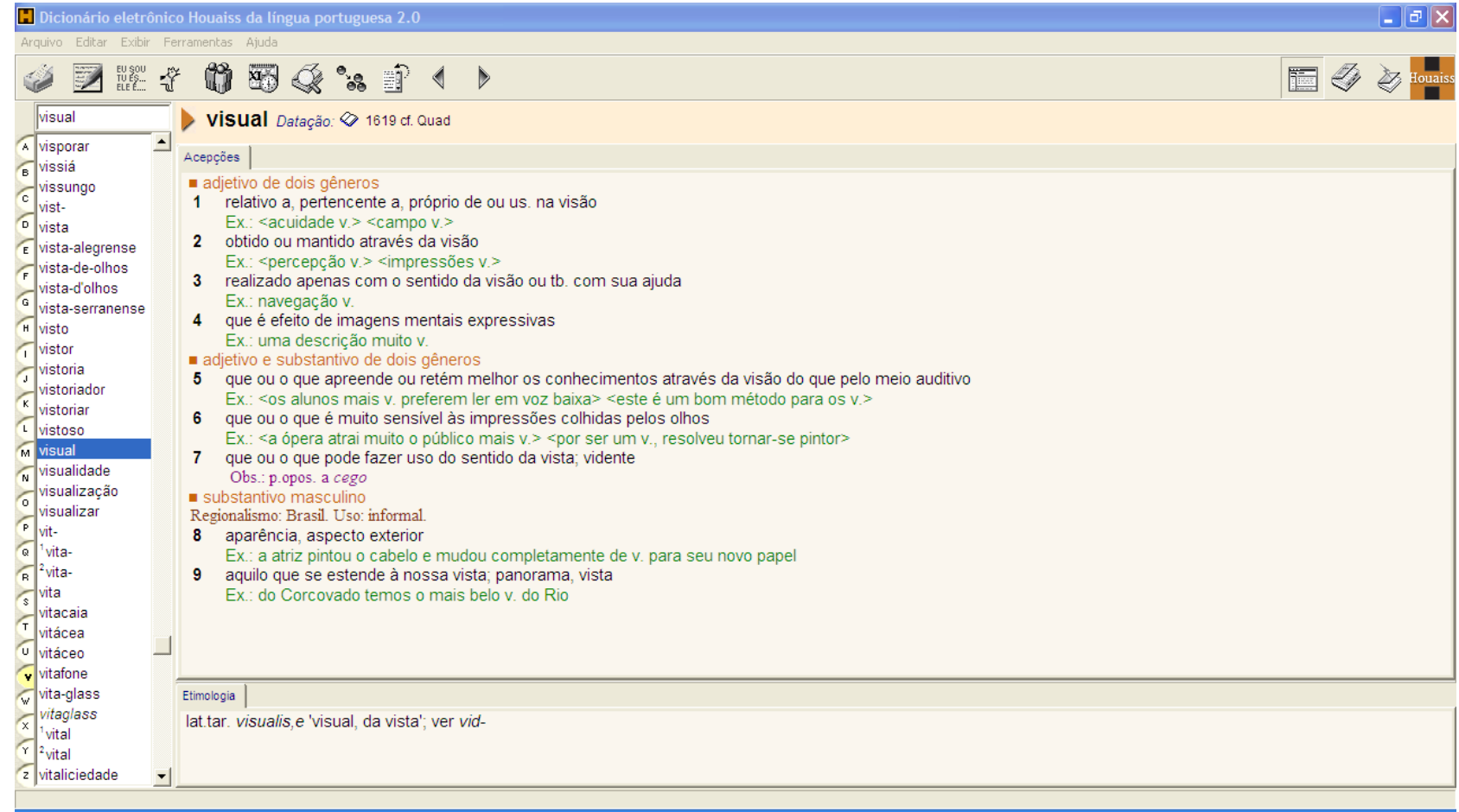

O verbo visualizar significa, segundo a primeira acepção do dicionário Houaiss, "tornar visual, convertendo algo abstrato em imagem mentap"16, sendo o visual

\footnotetext{
${ }^{16}$ As outras acepções para esse verbo são: 2) Tornar (algo) visível mediante determinado recurso; 3) Formar uma imagem visual mental de (algo que não existe ou que não está diante dos olhos), imaginar.
} 
primitivo um adjetivo e não um substantivo. Por essa razão, estaríamos tratando de uma formação deadjetival e não denominal. Visualizar era um verbo que fazia parte de nossa primeira seleção, mas como tem dupla acepção, uma em que é adjetivo e outra em que é substantivo, ele foi excluído de nosso corpus, assim como os demais da mesma natureza.

Esse novo filtro de seleção nos permitiu refinar nosso corpus aos verbos estritamente denominais, ou seja, derivados somente de substantivos. Chegamos assim a 4.548 ocorrências de verbos.

Em suma, selecionamos 4.548 verbos a partir dos seguintes critérios:

- Ser verbo

- Ter especificado no item etimologia, no mínimo [verbete + sufixo]

- Ter nesse verbete uma única acepção de substantivo.

\section{c. Terceira Etapa de Seleção: critério de uso}

Como já dissemos, apesar de o dicionário constituir uma fonte confiável de seleção dos dados, há desvantagens em sua utilização. O dicionário registra verbetes já obsoletos na língua, muitos que já estão mortos na língua falada e na escrita e outros que só ocorrem em variantes literárias.

Percebemos que, da amostra total de 4.548 verbos, muitos deles são pouco usados na língua falada ou totalmente arcaicos em qualquer aspecto da linguagem, manifestada por língua falada ou escrita.

Como um teste inicial, selecionamos de forma aleatória os 10 verbos abaixo e notamos que muitos deles são pouco ou nada, usados. 


\section{Tabela 3.2.1 Seleção aleatória de VDs}

\begin{tabular}{|c|}
\hline Verbos selecionados aleatoriamente \\
\hline Ababalhar \\
\hline Aleirar \\
\hline Atavizar \\
\hline Charamelar \\
\hline Destrambelhar \\
\hline Encruzar \\
\hline Estenozar \\
\hline Influenciar \\
\hline Parabolizar \\
\hline Sapremar \\
\hline
\end{tabular}

Fora influenciar e outros verbos que parecem ser pouco produtivos, como destrambelhar e parabolizar. A maioria tem um uso arcaico ou literário e não seriam reconhecidos pelos falantes do português brasileiro atual.

No entanto, é interessante notar que quase todos, nove, seguem o padrão de formação substantivo + sufixo -ar e um deles segue o padrão substantivo + -izar, que também poderia ser considerado uma variação de -ar (-iz+-ar), assim como ocorre com -Ihar (-Ih-+-ar), em ababalhar. Assim, mesmo sem contar o critério de uso, eles seriam perfeitamente analisáveis em relação a sua morfologia.

Vemos, então, que esses verbos seguem os padrões de formação esperados e seriam úteis em nossas análises descritivas dos aspectos morfológicos, mas não haveria modo de investigar seu estatuto sintático e semântico na sincronia, já que grande parte dos falantes, inclusive nós, não teria intuição para julgar testes realizados com palavras cujo sentido desconhece.

Além disso, muitas das ocorrências retiradas do dicionário ou são produtivas na modalidade do português europeu e não do português brasileiro, com o qual estamos 
comprometidos nesse trabalho ${ }^{17}$, ou são ocorrências registradas na escrita, em textos literários, e que não são produtivamente utilizadas na fala.

Logo, em termos Saussureanos ${ }^{18}$, estamos preocupados em descrever o estatuto sincrônico dos VDs e não o seu estatuto diacrônico. Nossa maior preocupação se dá com as ocorrências de verbos que são realmente atualizados na fala.

Tal atitude metodológica pode ser questionada, pois, se estamos buscando um estatuto sincrônico dos VDs na língua, por que partimos de uma definição etimológica para selecionar o corpus de análise, logo diacrônica? Retomaremos essa questão na seção 3.4 .

\subsection{Avaliação da produtividade dos Dados}

Para que obtivéssemos resultados do uso dos verbos da amostra com o menor viés pessoal possível, fizemos uso de uma ferramenta de busca em textos na internet.

Foi desenvolvido um programa computacional de busca automática na linguagem Python ${ }^{19}$ que consulta de forma sistemática os verbos no site $\underline{w w w . g o o g l e . c o m . b r}$ com os seguintes filtros: idioma português e páginas do Brasil.

Entendemos que os textos produzidos na internet abrangem diferentes indivíduos, de diversas idades e regiões do Brasil; situações formais, tal como em textos científicos e jornais, e informais, tal como em blogs pessoais e salas de batepapo.

Dado que os verbos podem aparecer morfologicamente em diversas conjugações no português, concordando em pessoa e número, e em diversos modos

\footnotetext{
17 Poderemos, em momento futuro, fazer comparações entre as formações do português brasileiro e português europeu, mas, de início, constituiremos o corpus do estudo somente com dados do PB. O dicionário Houaiss registra também regionalismos de Portugal não usados no Brasil.

18 Para uma distinção entre a abordagem sincrônica e diacrônica em linguística, v. Sausurre, F. A Linguística Estática e a Linguística Evolutiva. In: Curso de Linguística Geral. São Paulo: Cultrix, 1969, p. 94-116.

${ }^{19}$ Agradecemos a Fidel Beraldi do Instituto de Matemática e Estatística da Universidade de São Paulo pelo desenvolvimento do programa e pela análise estatística.
} 
(indicativo, subjuntivo, imperativo), tivemos que criar um critério de busca. Decidimos por buscar somente a forma do infinitivo de cada verbo. Assim, todos os verbos tiveram a mesma chance e foram comparados igualmente quanto ao seu número de ocorrências.

Em seguida, cada verbo foi consultado no site de busca e obteve-se o total de ocorrências em sites da internet.

Para garantir dados fidedignos de ocorrências, a lista de verbos foi consultada três vezes da seguinte forma:

a. Ordenados por ordem alfabética, de A a Z;

b. Ordenados por ordem alfabética inversa, de Z a A;

c. Ordenados aleatoriamente.

Ao fim, obtivemos quatro listas com o número de ocorrências para cada verbo. Comparamos as ocorrências de cada verbo em cada rodada e extraímos a média, chegando a uma lista final, que pode ser vista no Anexo 01. A frequência dos verbos teve distribuição conforme o gráfico 1, abaixo.

Gráfico 3.3.1. Frequência.




A esses 4.548 verbos, foi aplicada uma Análise de Cluster. A Análise de Cluster é um método estatístico que busca agrupar elementos com base na similaridade entre eles, nesse caso, a similaridade quanto ao número de ocorrências. Optamos por dividir os verbos em 3 grupos. Conforme tabela 2.3.1 e Gráfico 2.3.2, abaixo:

Tabela 3.3.1. Grupos por frequência

\begin{tabular}{|ccc|}
\hline Cluster & \# Verbos & \% \\
\hline C1 & 4.453 & $97,91 \%$ \\
C2 & 83 & $1,82 \%$ \\
C3 & 12 & $0,26 \%$ \\
\hline Total & $\mathbf{4 . 5 4 8}$ & \\
\hline
\end{tabular}

\section{Gráfico 3.3.2. Grupos por frequência}

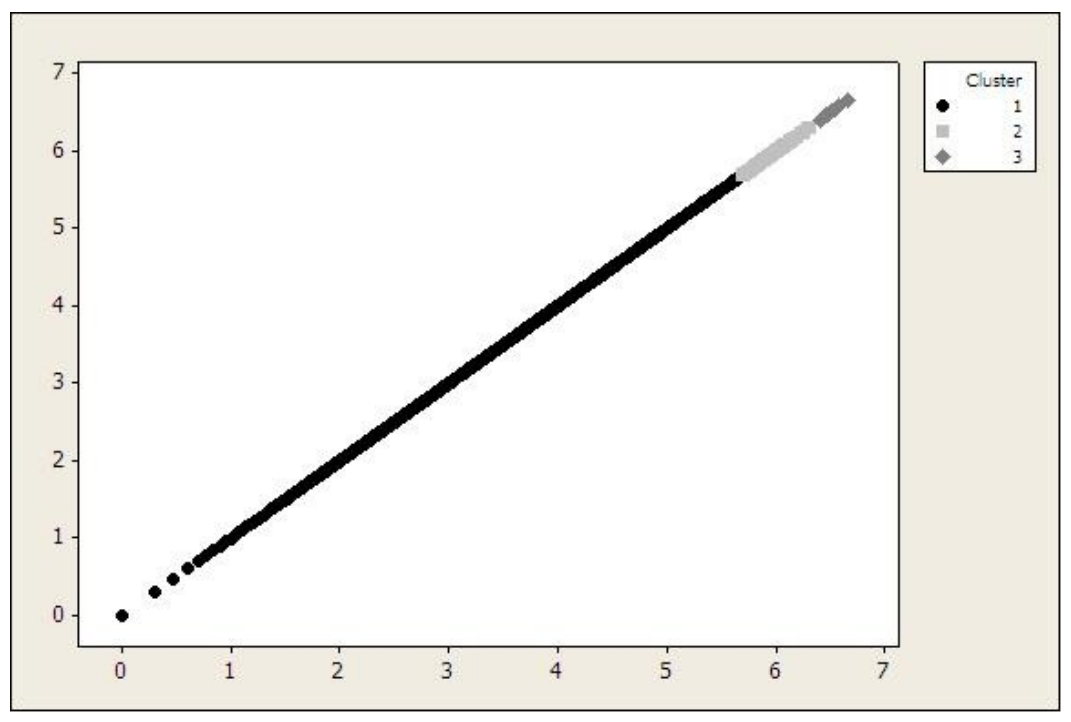

Assim, o grupo que tem os verbos mais frequentes é o grupo 3 , com 12 ocorrências, seguido pelo grupo 2, que conta com 83 verbos e, por fim, há o grupo 3 com a maioria dos verbos, 4454. Dentre os dados, alguns verbos, como o verbo parlamentar, foram interpretados pelo site de busca como adjetivos e não verbos e, 
por isso, obtiveram um grande número de ocorrências. Como não há uma maneira de restringir a busca por categoria, decidimos não utilizar esses dados no estudo.

Nesta dissertação, iremos trabalhar com os grupos 2 e 3 da amostra total, pelos motivos já descritos acima. No entanto, há alguns verbos que se encontram no Grupo 1, mas são importantes para explicitação descritiva e teórica. São VDs clássicos apontados na literatura sobre diversas línguas, especialmente em Kyparsky (1982, 1997), Arad (2003), Hale \& Keyser (2002), Harley (2005, 2007). Entre eles estão engarrafar (to bottle) e martelar (to hammer). Incluiremos, dessa forma, alguns verbos pertencentes ao Grupo 1 na explicitação e investigação dos fatos, quando necessário. Tratar esses verbos, apesar de não serem parte da amostra principal, ampliará o escopo de alcance do trabalho no que se refere às questões lançadas por esses importantes trabalhos. Desse modo, o número final totaliza 95 verbos dentre dados dos Grupos 1, 2 e 3 (Anexo 02).

\subsection{Corroborando e questionando a etimologia dos verbos selecionados}

Na seção 3.1, colocamos a possível questão de uma contradição ao trabalhar com VDs na sincronia partindo de uma seleção com base em critérios de formação etimológica.

Em parte, essa escolha já foi justificada, por ser um dos objetivos desse trabalho, descrever os VDs em seus aspectos morfológicos e, para tal, o dicionário se mostrou uma fonte rica e mais completa possível de ocorrências. Assim o recorte etimológico fez-se necessário.

Além disso, o sentido mais geral de denominal remete realmente a "palavra que é derivada de um nome"; aqui restringimos para "ser derivado de um substantivo", e decidiu-se então começar a seleção pela ideia mais básica do fenômeno para que fosse possível refinar até chegarmos a outras definições de denominal. 
Contudo, apesar de o Dicionário Houaiss da língua Portuguesa parecer ser uma fonte confiável no que se refere à etimologia dos dados, este não se trata de um dicionário etimológico. Segundo Mário Eduardo Viaro:

“O grande passo do Dicionário Houaiss (2002) face aos até então existentes foi o modo como tratou a etimologia. Embora não se intitule um dicionário etimológico, superou tudo o que se havia feito até então" (Viaro, M.E. Revista Língua Portuguesa, Ed. 37. Set/2008)

Pelo fato de o dicionário utilizado na primeira seleção não se tratar de um dicionário etimológico, fez-se necessária uma investigação mais profunda da história desses verbos. Tal investigação deve-se ao fato de que estamos interessados em partir de um recorte dentro do sistema linguístico do português a fim de investigar determinados nomes que se transformaram em verbo dentro desse sistema e descartar verbos que já existiam em latim e deram origem a outros verbos em português. Vejamos um exemplo. A etimologia do verbo causar no dicionário Houaiss aponta que ele é derivado do nome causa. No entanto, dois dicionários etimológicos consultados apontam que o verbo causar deriva do verbo correspondente latino: "CausAR vb. 'ser causa de' do latim causari, pretextar, alegar" (Cunha, 1999) e "do latim causari, pretextar, alegar" (Machado, 1967).

Assim, desenham-se dois contextos de derivação etimológica possíveis no que se refere aos dados estudados ${ }^{20}$ :

\footnotetext{
${ }^{20}$ As setas com linhas pontilhadas indicam relação de derivação diacrônica e as setas plenas indicam relação sincrônica.
} 
Figura 3.4.1. Derivação Sincrônica e Diacrônica

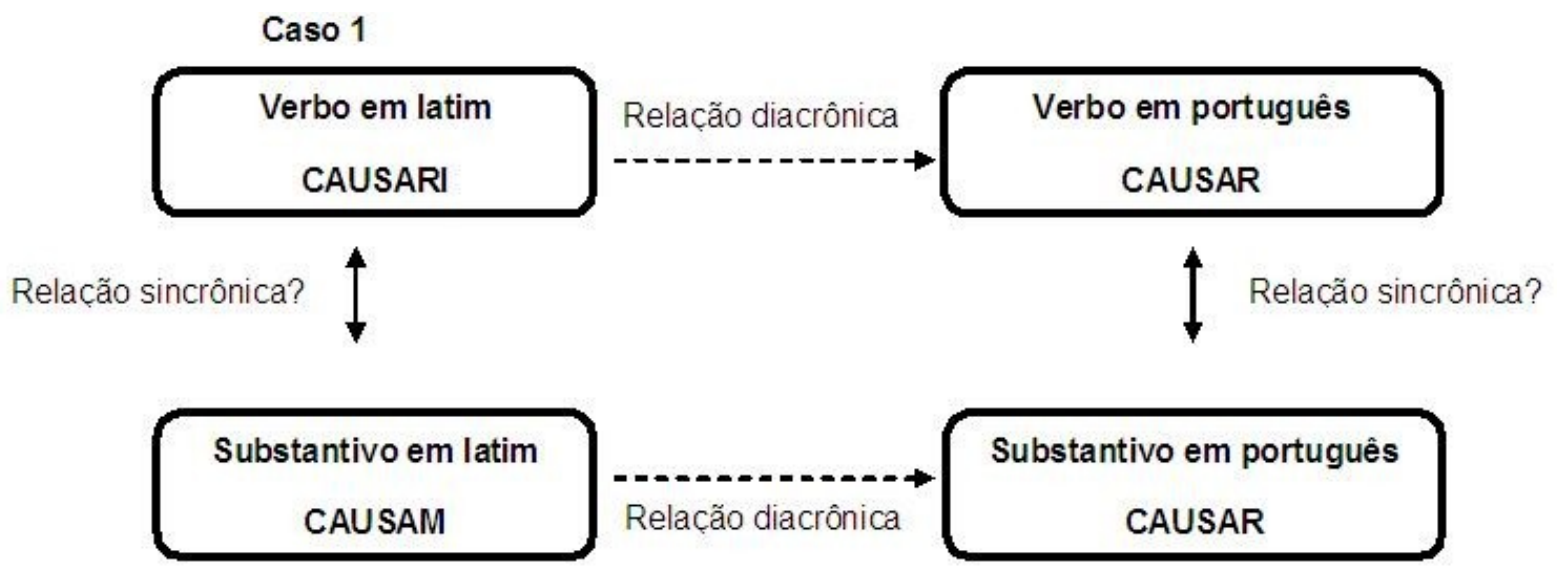

Caso 2

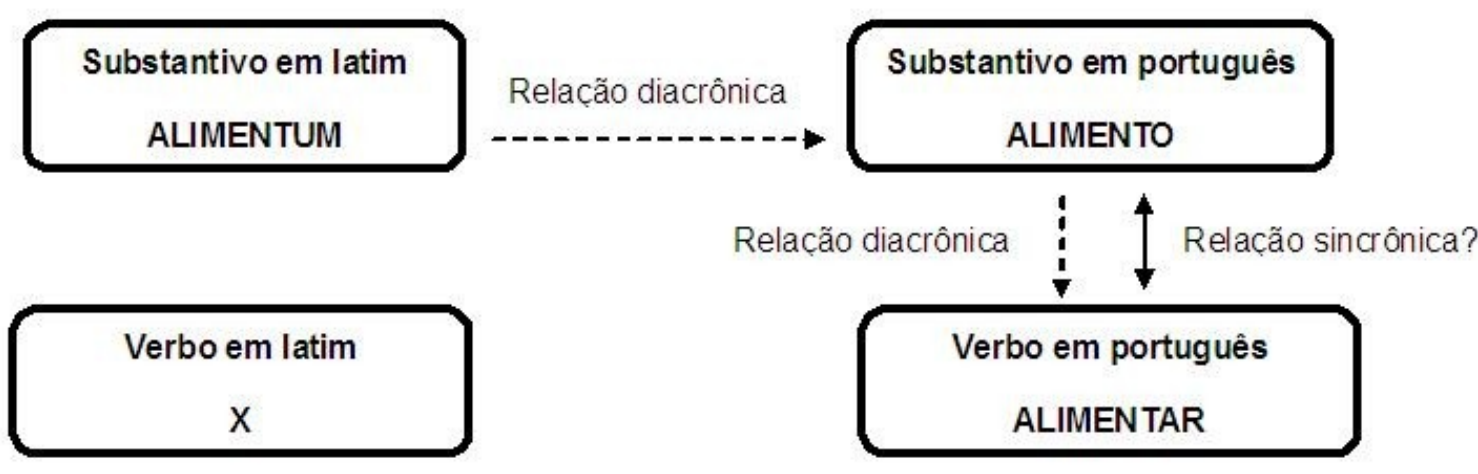

No caso 1, havia duas palavras em latim que, etimologicamente, geraram as duas entradas em português, tanto o substantivo quanto o verbo. No caso 2 , havia somente uma entrada em latim, o substantivo, que deu origem ao substantivo em português e esse, por sua vez, deu origem ao verbo. Em uma abordagem diacrônica dentro do sistema do português, somente podemos chamar de denominais os verbos que se enquadram no caso 2. Assim, causar não seria um verbo denominal do ponto de vista etimológico dentro do português, mas alimentar seria.

Frente a esse quadro, os 95 verbos utilizados efetivamente na pesquisa foram investigados nos dicionários etimológicos de José Pedro Machado, Dicionário Etimológico da Língua Portuguesa, e de Antonio Geraldo da Cunha, Dicionário Etimológico Nova Fronteira da Língua Portuguesa. 
A grande maioria dos verbos, 81, teve sua origem denominal etimológica confirmada, ao passo que outros 27 verbos não constavam como denominais nas entradas desses dicionários ${ }^{21}$. A etimologia desses verbos ou apontava uma origem latina ou uma origem de alguma outra língua românica, como o francês, por exemplo. Para o verbo analisar, por exemplo, ambos os dicionários indicam uma origem a partir do verbo analyser, do francês.

A partir dessa investigação etimológica, surge a questão: devemos considerar verbos do caso 1 no estudo? Ora, se nosso trabalho busca investigar as relações sincrônicas, por que não investigar a relação entre verbos como causar, que, apesar de não terem sua origem denominal comprovada, podem manter uma relação sincrônica para os falantes? A comprovação de tal relação sincrônica só poderá colaborar para a distinção entre as duas abordagens. Ou seja, no sentido contrário, mesmo verbos não-denominais em uma perspectiva sincrônica podem ter adquirido esse característica na sincronia.

\subsection{Disposição final do Corpus}

Todas as ocorrências selecionadas foram transpostas para uma planilha Excel e organizadas da seguinte forma. Tomemos como exemplo o verbo acreditar na figura abaixo:

Figura 3.5.1. Verbo acreditar

\begin{tabular}{c|c|c|c|c|c|c|c|c|}
\multicolumn{1}{c|}{ Verbo } & Ordem & Frequência & Cluster & Tipo & (prefixo) & (base) & (Ligaçäo) & (Sufixo) \\
\hline acreditar & 267 & 3085000 & 3 & P & a- & crédito & & -ar \\
\hline
\end{tabular}

Na primeira coluna está o número correspondente a sua colocação em ordem alfabética; na segunda coluna está a sua frequência de aparição em site de busca da internet; na terceira coluna está o Cluster, ou grupo ao qual o verbo pertence; na

\footnotetext{
${ }^{21}$ A tabela com esses 27 verbos encontra-se no Anexo 06.
} 
quarta coluna está o verbo; na quinta coluna está o tipo morfológico do verbo (S para sufixal e $\mathrm{P}$ para parassintético) nas colunas seguintes dividimos o verbo em prefixo, base, elementos de ligação e sufixo.

Há um ponto a esclarecer sobre o que estamos chamando de elementos de ligação. O elemento de ligação pode representar um elemento que é introduzido na derivação, associado à base tornando-a apta a receber os sufixos verbais, como em calorificar (calor+i+ficar). Contudo, em alguns casos, o que é tido como elemento de ligação pode ser uma modificação sofrida pela base. Há casos ambíguos, como o que vem demonstrado no exemplo abaixo. A vogal $-i$ - pode ser considerada uma modificação da vogal -e da palavra base. Consideraremos essa distinção na hora de fazer as análises. Na figura 3.5.3. abaixo, damos uma visão geral da planilha.

\section{Figura 3.5.2. Verbo basificar}

\begin{tabular}{c|c|c|c|c|c|c|c|c|}
\hline Verbo & Ordem & Frequência & Cluster & Tipo & (prefixo) & (base) & (Ligaçäo) & (Sufixo) \\
\hline basificar & 1072 & 196 & 1 & S & & base & -i- & -ficar \\
\hline
\end{tabular}

\section{Figura 3.5.3. Visão Geral da Planilha}

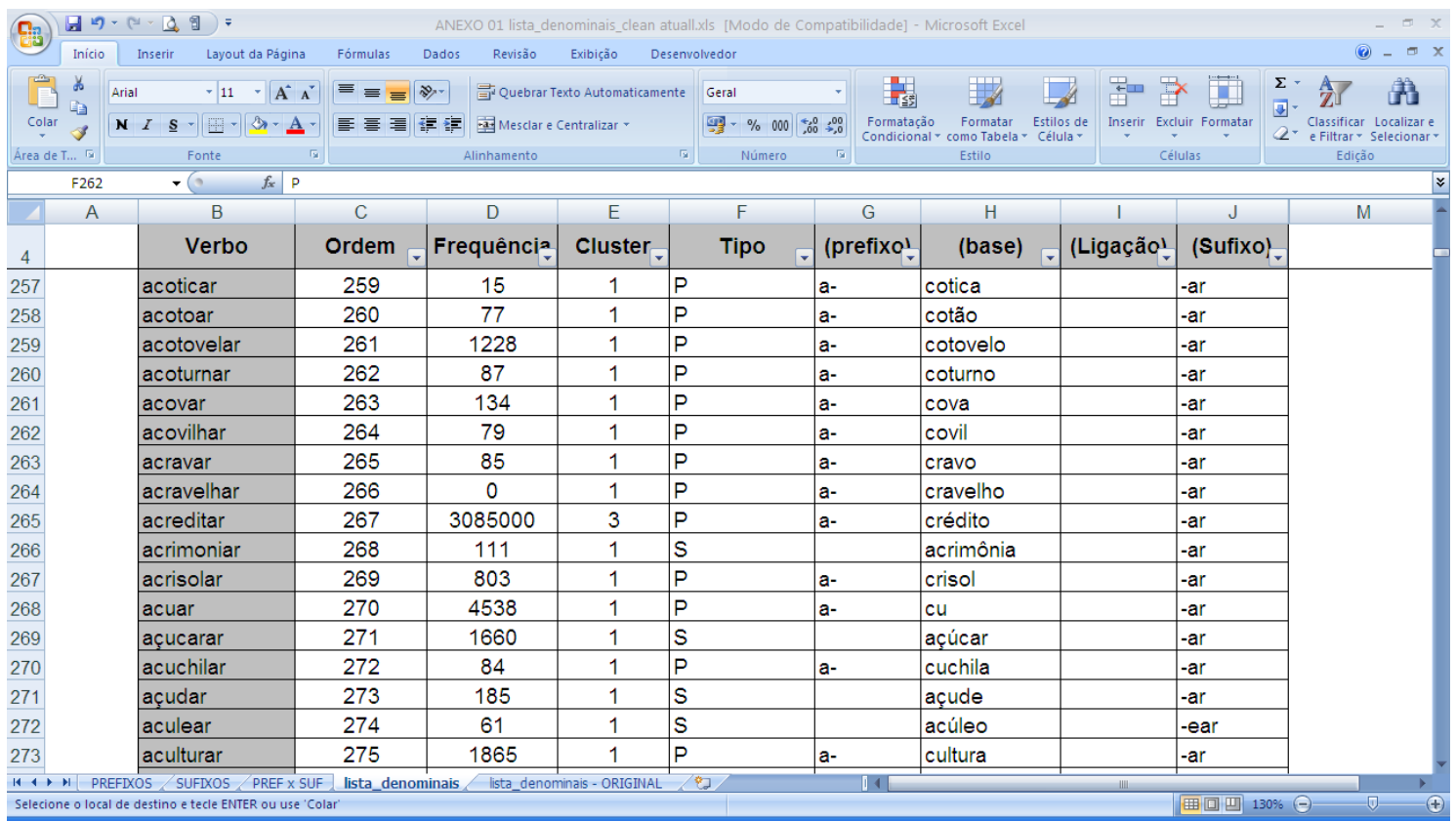




\subsection{Algumas descrições morfológicas a partir do Corpus Total}

Algumas análises descritivas simples foram feitas e retratam o Corpus total dos Dados de VDs.

\section{Gráfico 3.6.1. Tipo de Formação}



Gráfico 3.6.2. Prefixos envolvidos na formação ${ }^{22}$



${ }^{22}$ Foram colocados em "outros" prefixos com menos de 15 ocorrências: so-, trans- ,im- ,e- , in-, con-, sub-, ex-, extra-, tres-, tra-, sobre-, pro-, tras-, bis-, ab-, mal-, retro-, com-, tri-, res-. 


\section{Gráfico 3.6.3. Sufixos envolvidos na formação ${ }^{23}$}

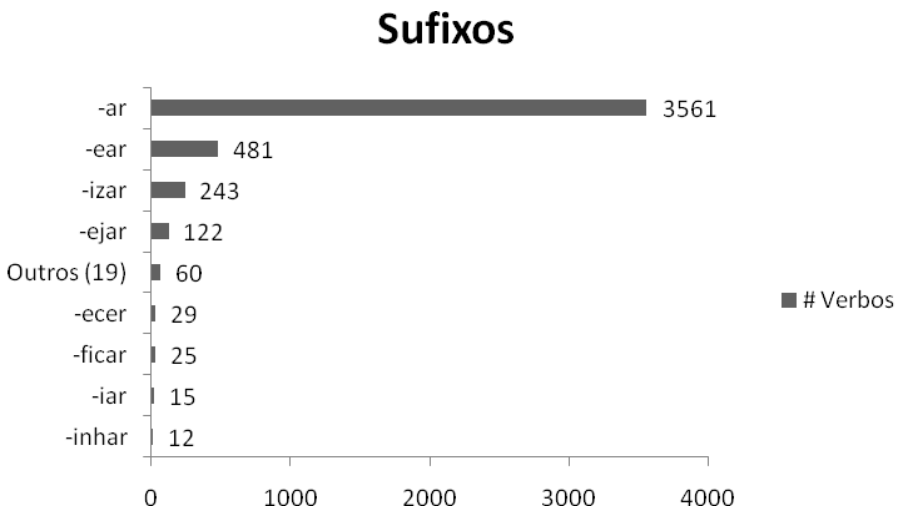

\subsection{Testes}

Nesta seção, descreveremos os procedimentos de realização dos testes. Comecemos pela justificativa da escolha dos mesmos.

\subsubsection{Testes sintáticos para a identificação de estrutura argumental}

$\mathrm{Na}$ literatura relevante sobre VDs em uma perspectiva sincrônica, especialmente em H\&K (2002) e Arad (2003), encontram-se testes para a identificação de estruturas em que há um estágio nominal anterior à formação efetiva do verbo. Esses testes servirão como base para as avaliações dos dados do PB.

De H\&K (2002), utilizaremos os testes descritos abaixo, de T1 a T6 ${ }^{24}$.

\section{T1 - Transitivização causativo-incoativa ou transitivo-intransitiva (automática)}

Se um verbo puder aparecer tanto em uma sentença transitiva quanto em uma sentença intransitiva com sentido incoativo, ou seja, de mudança de estado, ele será representado pela estrutura diádica composta (explicitada na seção 6.1). Esse teste

\footnotetext{
${ }^{23}$ Foram colocados em "outros" prefixos com menos de 12 ocorrências: -ir, -icar, -oar, -ilhar, -açar, -alhar, -entar, -iscar, -grafar, -lhar, -ujar, -olhar, -oçar, -zoar, -uçar, -anhar, -ivar, -elar, -ichar.

${ }^{24}$ Os julgamentos dos exemplos apresentados são resultantes da pesquisa com falantes.
} 
identifica, assim, verbos ditos inacusativos de alternância. Os autores afirmam que a maioria desses casos apresenta uma estrutura de verbo deadjetival.

De outra forma, verbos como laugh e dance falham em participar da alternância, não apresentando uma contraparte transitiva; trata-se de verbos inergativos.

Uma questão surge quando os autores se deparam com a possibilidade de alternância de verbos do tipo location/locatum em alguns casos (v. seção 6.1), mas não em outros:

(12) Mud splashed on the wall. (A lama espirrou na parede)

(13) *Saddle soap smeared on my chaps. (O sabão espalhou nas minhas calças de couro).

Não são todos os verbos desse tipo que permitem a alternância. Os autores explicam as relações de ligação entre um núcleo e seus argumentos pela presença de traços $\left[ \pm\right.$ proximativo] ou $[ \pm \text { obviativo }]^{25}$. Parece que é preciso que haja uma relação muito próxima entre o argumento interno e o verbo para que a alternância possa ocorrer. Nesse caso, o que prevalece é o traço [+proximativo] ([-obviativo]). Diferentemente, se a relação mais relevante for a que se dá entre verbo e argumento externo, esse traço será [+obviativo] ([-proximativo]). O verbo splash tem uma relação lexical mais próxima com mud do que com um possível argumento externo. Por outro lado, o verbo smear tem essa relação com o argumento externo, tanto que a ausência desse torna a sentença agramatical. Por isso, eles propõem a subdivisão em verbos de maneira do paciente (pacient-manner verbs) e verbos de maneira do agente (agent-

\footnotetext{
${ }^{25}$ Esses traços são traços de maneira semânticos e de caráter enciclopédico, que tentam representar a "força" da relação do núcleo lexical com seus argumentos. O traço [+ obviativo] revela que o verbo é do tipo focado no agente e o traço [+ proximativo] revela que o traço é do tipo focado no objeto.
} 
manner verbs). Deixamos o restante dessa discussão para a parte de observação dos resultados, se relevante ${ }^{26}$.

Enfim, é importante ressaltar para o momento que VDs, em geral, não participam de Alternância causativo-incoativa. A maioria das formações que permite essa alternância configura verbos deadjetivais:

(14) Lula criticou a seleção.

(15) *A seleção criticou.

O suposto VD criticar não forma uma boa sentença quando colocado nesse tipo de alternância; por outro lado, o verbo apodrecer (podre), deadjetival, se comporta bem.

(16) O calor apodreceu a fruta.

(17) A fruta apodreceu.

\section{T2 - Alternância Média}

A alternância de tipo Média está em geral disponível para as estruturas diádicas compostas projetadas em geral por verbos do tipo location/locatum, que são estruturas cujo núcleo é uma preposição que toma um núcleo nominal como seu complemento e, ainda, são conhecidas como denominais, justamente porque são derivadas, de algum modo, de um nome. É fato que preposições funcionais expressam uma relação e, por isso, pedem saturação de argumentos, projetando assim uma estrutura argumental:

(18) I shelved those small books. (Eu emprateleirei aqueles livros pequenos)

\footnotetext{
${ }^{26}$ Para mais detalhes, cf. Hale \& Keyser, 2002:29-45.
} 
(19) Small books shelf easily. (Livros pequenos emprateleiraram fácil)

(20) He saddled a quarter horse. (Ele selou um cavalo de corrida)

(21) A quarter horse saddles easily. (Cavalo de corrida sela fácil)

Alguns VDs do tipo location/locatum tendem a permitir a alternância média. As estruturas deadjetivais também permitem essa alternância. Entretanto, outros tipos de VDs tendem a ficar estranhos.

(22) Processo de cassação engaveta rapidinho

(23) Cavalo manso sela rápido.

(24) *Seleção brasileira critica muito.

\section{T3 - Expressões perifrásticas com verbo leve + nome formador}

A observação da possibilidade de obter formas analíticas a partir de certos verbos pode levar à identificação de estruturas argumentais. Verbos inergativos como laugh e dance, podem aparecer em estruturas como make DP laugh e make DP dance, enquanto verbos inacusativos como redden e clear podem aparecer em estruturas como turn red e turn clear. Ainda, VDs do tipo location/locatum podem figurar em estruturas como put the books on the shelf ou get the horse with a saddle, respectivamente, como já observado.

Por possuírem, em sua constituição interna, um estágio nominal antes de serem categorizados por um núcleo verbal, os VDs podem ser parafraseados por um verbo leve e o substantivo que o formou. Vejamos o exemplo com o verbo fazer + nome:

(25) O Lula fez uma crítica/críticas à seleção. 


\section{T4 - Ocorrência de Objeto Cognato}

VDs do inglês, que são do tipo inergativo, possibilitam, em geral, a ocorrência de um objeto cognato na posição do nome formador. O mesmo acontece em português com o verbo dançar, por exemplo, em Ela dançou uma dança esquisita. Entretanto, em PB, há verbos transitivos que também podem possibilitar a ocorrência de objetos $\operatorname{cognatos}^{27}$. Nesse sentido, verificamos que alguns VDs que não são inergativos podem ocorrer com Objetos Cognatos, outros não:

(26) O sorteio agrupou três grupos de times bons.

(27) *Ela praticou uma prática de yoga tranquila.

\section{T5 - Ocorrência de Adjunto Cognato}

Em sentenças com VDs e adjuntos associados, o nome que formou o VD pode ser retomado de forma morfologicamente idêntica no adjunto.

(28) Lula criticou a seleção com uma crítica construtiva.

T6 - Ocorrência de Adjuntos hipônimos e hiperônimos (semanticamente relacionados)

Em sentenças com VDs e adjuntos associados, o nome que formou o VD pode ser retomado por um nome semanticamente associado ao nome formador, mas não morfologicamente idêntico.

(29) Lula criticou a seleção com um parecer negativo. (crítica é um tipo de parecer, opinião).

\footnotetext{
${ }^{27}$ Para um estudo sobre a natureza dos objetos cognatos no PB, c.f. Leung, 2007.
} 
Em suma, os testes 1 e 2 identificam qual a estrutura sintática do verbo, se ele pode sofrer alternância ou não, enquanto os testes 3 a 6 revelam o tipo de relação que se estabelece entre nome primitivo e o suposto verbo denominal formado a partir dele. Quanto mais positivo for o comportamento de um verbo frente aos testes 3 a 6 , em especial, mais haverá uma relação denominal sincrônica.

Além dos testes de H\&K, Arad (2003) propõe, mais do que testes, três critérios para distinguir palavras derivadas de raízes e palavras derivadas de outras palavras existentes na língua, são eles:

$$
\begin{aligned}
& \text { C1 - Critério de identidade morfológica; } \\
& \text { C2 - Critério de identidade fonológica; } \\
& \text { C3 - Critério de identidade semântica. }
\end{aligned}
$$

Haveria, então, pistas morfológicas, fonológicas e semânticas para investigar se há um nome presente dentro de um verbo.

A forma de seleção dos dados relevantes para esta pesquisa já nos garantia que todos os nomes tivessem identidade morfológica e fonológica com os verbos. Dessa forma, fez-se necessária somente a checagem de identidade semântica, que pode ser contemplada, especialmente, por meio dos testes de Expressão Perifrástica, da presença de objetos cognatos e de adjuntos cognatos e metafóricos, de H\&K.

Submetemos todos os dados obtidos através da seleção aos seis testes de H\&K (2002), formando assim seis sentenças para cada verbo a partir de uma sentença base. Em seguida, todas as sentenças formadas a partir dos 95 verbos foram submetidas aos julgamentos de falantes nativos de português brasileiro. Para os verbos apontar, traçar e processar foram formadas duas sentenças em cada um dos testes, sendo uma com cada sentido que esse verbo pode possuir, como mostram os exemplos em seguida: 
(30) O desenhista traçou o desenho no papel.

(31) O técnico traçou a estratégia.

(32) O funcionário processou o chefe.

(33) O computador processou os dados.

(34) O aluno apontou o lápis.

(35) A comissão apontou falhas no projeto.

\subsubsection{Testes com Falantes}

Apesar de ser uma prática comum entre os estudos gerativistas a realização de testes de intuição a partir das intuições do próprio pesquisador, consideramos que os resultados seriam mais confiáveis se submetêssemos os testes aos julgamentos de falantes nativos do português brasileiro de modo sistemático ${ }^{28}$.

Foram selecionados 40 falantes com idades entre 19 e 58 anos com nível superior completo ou em curso.

Por se tratar de um grande número de dados, no total 662 sentenças, os dados foram divididos em 19 grupos de 35 a 42 sentenças e enviados em 19 dias para que os falantes respondessem com mais confiabilidade, evitando o cansaço.

Como estratégia metodológica, os falantes foram divididos em dois grupos, cada um com 20 indivíduos. Ao primeiro grupo, as sentenças foram enviadas de forma ordenada, ou seja, a sentença-base de um determinado verbo foi agrupada com as seis sentenças geradas por meio dos testes, como no modelo 1 em seguida. Para o

\footnotetext{
${ }^{28}$ Agradecemos à Prof $^{\mathrm{a}} \mathrm{Dr}^{\mathrm{a}}$ Luciana Storto por esse apontamento.
} 
segundo grupo, as sentenças foram agrupadas de forma aleatória, como no modelo 2 em seguida. ${ }^{29}$

Tal metodologia visa saber se os falantes tendem a considerar as sentenças melhores quando veem a base de onde ela é gerada ou se isso não faz diferença nos julgamentos.

${ }^{29}$ O software de pesquisa Question Pro® (www.questionpro.com) foi utilizado para desenvolvimento, envio e controle dos questionários. 
Olá. Responda SIM para sentenças aceitáveis e NÃO para as sentenças estranhas. Obrigada!

1. Eu estudei a vida marinha.

S SIM

2. A vida marinha estudou.

SIM

C NÃO

3. A vida marinha estuda fácil.

SIM

NÃO

4. Eu fiz um estudo sobre a vida marinha.

SIM

N NÃO

5. Eu estudei um estudo sobre a vida marinha.

SIM

NÃO

6. Eu estudei a vida marinha com um estudo minucioso.

SIM

C NÃO

\footnotetext{
${ }^{30}$ A definição de gramaticalidade foi explicada aos sujeitos no momento do envio da pesquisa por email,
} como pode ser visto no Anexo 03 


\section{MODELO 2 (Teste Aleatório 01)}

Olá. Responda SIM para sentenças aceitáveis e NÃO para as sentenças estranhas. Obrigada!

1. O jovem rapaz enfeitiçou.

SIM

NÃO

2. O funcionário engarrafou o vinho branco.

SIM

NÃO

3. Estudantes despreparados influenciam fácil.

SIM

NÃO

4. O aluno depositou a tese com um depósito rápido.

SIM

NÃO

5. O político favoreceu seus parentes com benefícios indevidos.

(C) SIM

NÃO

6. Eu martelei o prego.

SIM

C NÃO

7. Os documentos armazenaram.

SIM

NÃO

Os testes foram finalizados em 19 dias e os resultados estão expostos na seção 4. 
Dada a grande quantidade de sentenças a julgar, alguns dos falantes não completaram o conjunto dos 19 testes durante os 19 dias. A tabela abaixo mostra a quantidade de falantes que completaram o teste em cada grupo:

Tabela 3.7.2.1. Distribuição de respondentes por dia

\begin{tabular}{|c|c|c|}
\hline & ALEATÓRIO & ORDENADO \\
\hline DIA 1 & 20 & 20 \\
\hline DIA 2 & 19 & 20 \\
\hline DIA 3 & 20 & 19 \\
\hline DIA 4 & 16 & 19 \\
\hline DIA 5 & 18 & 19 \\
\hline DIA 6 & 17 & 20 \\
\hline DIA 7 & 17 & 20 \\
\hline DIA 8 & 17 & 19 \\
\hline DIA 9 & 15 & 20 \\
\hline DIA 10 & 14 & 19 \\
\hline DIA 11 & 16 & 19 \\
\hline DIA 12 & 15 & 18 \\
\hline DIA 13 & 14 & 17 \\
\hline DIA 14 & 14 & 17 \\
\hline DIA 15 & 13 & 16 \\
\hline DIA 16 & 13 & 17 \\
\hline DIA 17 & 12 & 17 \\
\hline DIA 18 & 11 & 16 \\
\hline DIA 19 & 13 & 17 \\
\hline
\end{tabular}

Gráfico 3.7.2.1. Taxa de participação dos falantes:

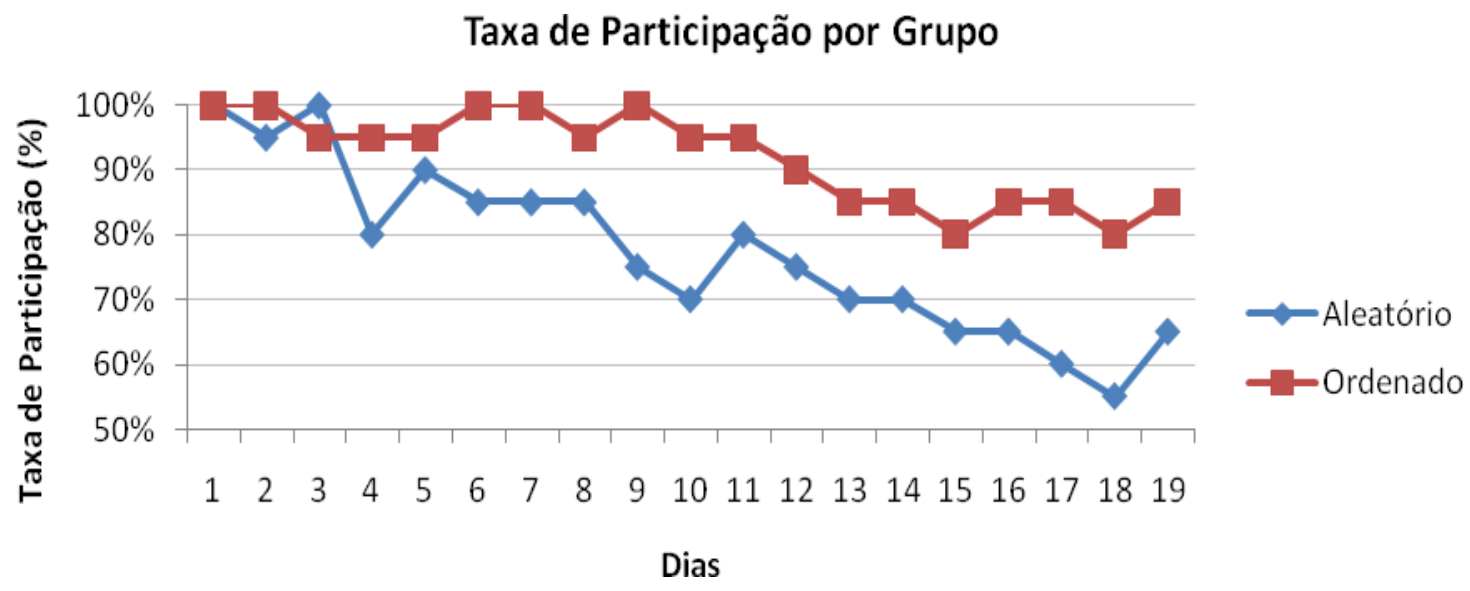


Com relação aos dados de amostragem do estudo, observou-se que praticamente nenhum sujeito começou a responder uma sequência de perguntas, um grupo de 35 a 42 questões, e abandonou (drop out). Ainda, os tempos de julgamento foram estatisticamente iguais para o grupo aleatório e determinístico (ou ordenado). $\mathrm{O}$ tempo mediano da pesquisa foi de 3,5 minutos. Por fim, o grupo aleatório obteve maior taxa de desistência do que o grupo ordenado. O Anexo 04 apresenta uma análise da amostragem, com tempos de resposta e taxas de participação dos falantes. 


\section{RESULTADOS E DESCRIÇÃO DOS DADOS}

Nesta seção, descreveremos os resultados obtidos através dos testes de julgamento de gramaticalidade realizados pelos falantes.

\subsection{Gramaticalidade $\times$ Agramaticalidade}

Nos testes, o falante poderia escolher a opção SIM para sentenças gramaticais e a opção NÃO para sentenças agramaticais. O objetivo destes era o de chegar a um julgamento padrão, que refletiria a intuição de um falante nativo de português brasileiro. Assim, inicialmente, a cada sentença somente estariam disponíveis duas alternativas: gramatical ou agramatical. Entretanto, a análise estatística revelou que, para algumas sentenças, os julgamentos foram realizados de forma dividida, tal que não se pôde determinar com confiança uma diferença entre os julgamentos, ou seja, se tal sentença é agramatical ou gramatical com relação ao conjunto dos julgamentos. Logo, passou-se a ter o seguinte quadro: sentenças julgadas como gramaticais; sentenças julgadas como agramaticais; sentenças com julgamento indeterminado. Para essas últimas, não foi possível atribuir estatisticamente um valor, segundo o teste binomial de proporção.

O teste binomial é usado em experimentos que admitem somente duas alternativas como resposta, no caso, gramatical ou agramatical. O teste avalia a probabilidade das frequências poderem ser consideradas estatisticamente diferentes ou não, ainda que sejam desiguais em termos puramente numéricos, ou seja, em contagem. Em suma, o teste binomial de proporção avalia em que medida os valores de $\mathrm{p}$ e q podem diferir, no caso, em que medida as respostas do grupo ordenado e aleatório convergiram ou se distanciaram. 


\section{Tabela 4.1.1. Teste Binomial de Proporção (Gramatical x Agramatical)}

\begin{tabular}{lcc}
\multicolumn{3}{c}{ Grupo Ordenado } \\
\hline Julgamento & $\#$ & $\%$ \\
\hline Gram./Agram. & 424 & $62 \%$ \\
Indeterminado & 258 & $38 \%$ \\
\hline Total & 682 & $100 \%$
\end{tabular}

Para o grupo ordenado, foi possível atribuir julgamentos claros a 424 sentenças, enquanto para 258 não se pode determiná-los.

\section{Tabela 4.1.2. Teste Binomial de Proporção (Gramatical x Agramatical)}

\begin{tabular}{lcc}
\multicolumn{3}{c}{ Grupo Aleatório } \\
\hline Julgamentos & $\#$ & $\%$ \\
\hline Gram./Agram. & 394 & $58 \%$ \\
Indeterminado & 288 & $42 \%$ \\
\hline Total & 682 & $100 \%$
\end{tabular}

De forma bastante parecida, no grupo aleatório, 394 sentenças puderam ser rotuladas como gramaticais ou agramaticais ao passo que 288 ficaram indeterminadas quanto a sua gramaticalidade.

Para uma demonstração, vejamos a tabela com duas sentenças abaixo:

\begin{tabular}{|c|c|c|c|c|c|c|c|}
\hline Exemplo 4.1.1. & \multicolumn{3}{|c|}{$\begin{array}{cc}\text { Grupo } & \text { Teste de } \\
\text { Ordenado } & \text { Proporção } \\
\end{array}$} & \multicolumn{2}{|c|}{$\begin{array}{c}\text { Grupo } \\
\text { Aleatório }\end{array}$} & \multirow{2}{*}{$\begin{array}{c}\begin{array}{c}\text { Teste de } \\
\text { Proporção }\end{array} \\
5 \%\end{array}$} & \multirow{2}{*}{$\begin{array}{c}\text { Nível de } \\
\text { Significância }\end{array}$} \\
\hline SENTENÇA & SIM & NÃO & $5 \%$ & SIM & NÃO & & \\
\hline a.Eu fiz um estudo sobre a vida marinha & 19 & 1 & $<0.001$ & 13 & 0 & $<0.001$ & DET. \\
\hline b.A professora avaliou uma avaliação fraca & 10 & 10 & 1,0 & 5 & 8 & 0.58 & INDET. \\
\hline
\end{tabular}

A sentença Eu fiz um estudo sobre a vida marinha pode ser avaliada como gramatical. Por outro lado, para a sentença A professora avaliou uma avaliação fraca, os resultados divididos não privilegiaram o SIM ou o NÃO, sendo impossível determinar-Ihe o valor. 


\subsection{Grupos Ordenado e Aleatório}

As sentenças que compõem os seis testes para cada um dos 95 verbos, mais uma sentença-base a partir da qual as outras foram geradas, foram dispostas de forma ordenada e de forma aleatória, como já foi dito. Essa divisão visava a observar se os julgamentos dos falantes podiam ser motivados pela apresentação do conjunto de sentenças do mesmo verbo ou não. Por exemplo, haveria diferenças quanto ao julgamento da sentença $A$ professora avaliou uma avaliação fraca se inserida no contexto 1 ou 2 abaixo?

\section{Exemplo 4.2.1.: Contexto de inserção}

\begin{tabular}{|c|c|}
\hline Contexto 1: ordenado & Contexto 2: aleatório \\
\hline $\begin{array}{l}\text { (8) A professora avaliou os alunos. } \\
\text { (9) Os alunos avaliaram. } \\
\text { (10) Os alunos de } 4^{a} \text { série avaliam bem. } \\
\text { (11) A professora fez uma boa valia dos alunos. } \\
\text { (12) A professora avaliou uma avaliação fraca. } \\
\text { (13) A professora avaliou os alunos com uma } \\
\text { valia deficiente. } \\
\text { (14) A professora avaliou os alunos com um teste } \\
\text { deficiente } \\
\text {... }\end{array}$ & $\begin{array}{l}\text { (2) Poucos voluntários listam rápido. } \\
\text { (3) Eu fiz um estudo sobre a vida marinha. } \\
\text { (4) O bando causou a briga por um motivo } \\
\text { estúpido. } \\
\text { (5) A professora avaliou uma avaliação } \\
\text { fraca. } \\
\text { (6) (Com amigos) brinca fácil. } \\
\text { (7) O homem caminhou na lua. } \\
\text { (8) Ele desejou aquele objeto com um } \\
\text { querer incontido. }\end{array}$ \\
\hline
\end{tabular}

Dentre os resultados das sentenças que mostraram diferença estatística entre os julgamentos de gramaticalidade (SIM) e agramaticalidade (NÃO), tanto no grupo determinístico quanto no grupo aleatório, essa diferença mostrou-se no mesmo sentido na maioria dos casos, ou seja, se de uma dada sentença pode-se concluir sua gramaticalidade (SIM) ou agramaticalidade (NÃO), o resultado para essa sentença permaneceu o mesmo tanto no grupo ordenado quanto no grupo aleatório. Tal fato se deu em 331 sentenças.

No que se refere às sentenças com resultado indeterminado, essas são, na grande maioria, as mesmas nos grupos ordenado e aleatório, 195 casos. 
Tabela 4.2.1. Comparação Grupos Ordenado e Aleatório: contagem

\begin{tabular}{|l|cc|c|}
\cline { 2 - 3 } \multicolumn{1}{c|}{} & \multicolumn{2}{c|}{ Julgamento - Aleatório } & \multicolumn{1}{c|}{} \\
\hline Julgamento - Ordenado & Gram./Agram. & Indeterminado & Total \\
\hline Gram./Agram. & 331 & 93 & 424 \\
Indeterminado & 63 & 195 & 258 \\
\hline Total & 394 & 288 & 682 \\
\hline
\end{tabular}

A tabela 4.2.1. mostra que das 682 sentenças julgadas por ambos os grupos, no grupo Aleatório, foi possível atribuir julgamentos (gramatical ou agramatical) para 394 sentenças, enquanto para 288 sentenças os julgamentos ficaram indeterminados. Já para o grupo ordenado, 424 sentenças puderam ter julgamentos atribuídos, enquanto 258 foram indeterminados. Em 331 sentenças, pode-se atribuir julgamentos em ambos os grupos, ao passo que para 195 sentenças houve indeterminação, também em ambos os grupos.

Tabela 4.2.2. Comparação Grupos Ordenado e Aleatório: percentual

\begin{tabular}{|l|cc|c|}
\cline { 2 - 3 } \multicolumn{1}{c|}{} & \multicolumn{2}{c|}{ Julgamento - Aleatório } & \multicolumn{1}{c|}{} \\
\hline Julgamento - Ordenado & Gram./Agram. & Indeterminado & Total \\
\hline Gram./Agram. & $49 \%$ & $14 \%$ & $62 \%$ \\
Indeterminado & $9 \%$ & $29 \%$ & $38 \%$ \\
\hline Total & $58 \%$ & $42 \%$ & $100 \%$ \\
\hline
\end{tabular}

A tabela 4.2.2 apresenta os mesmos resultados de 4.2.1. em forma de porcentagem. Os dados mostram que $78 \%(49 \%+29 \%)$ das sentenças apresentaram convergência independentemente do grupo a que pertenciam. 
Tabela 4.2.3. Julgamentos determinados: grupos ordenado e aleatório

\begin{tabular}{|c|c|c|c|}
\hline & \multicolumn{2}{|c|}{ Julgamento Aleatório } & \multirow[b]{2}{*}{ Total } \\
\hline Julgamento Ordenado & $\mathrm{N}$ & $S$ & \\
\hline $\mathrm{N}$ & 77 & 0 & 77 \\
\hline$S$ & 0 & 254 & 254 \\
\hline Total & 77 & 254 & 331 \\
\hline
\end{tabular}

Ainda, a tabela 4.2.3. chama atenção para a distribuição das 331 sentenças às quais foi possível atribuir um julgamento. Vê-se que não houve discordância no julgamento dessas sentenças. Em ambos os grupos, 77 foram julgadas como agramaticais e 254 como gramaticais.

Por essas razões, decidiu-se agrupar os resultados, com a junção de julgamentos atribuídos a sentenças dispostas de forma ordenada ou aleatória.

Com a fusão dos grupos ordenado e aleatório, houve um aumento da amostra e, assim, uma maior capacidade estatística de determinar julgamentos. Em outras palavras, com o aumento da amostra, pudemos obter mais sentenças válidas para o estudo. Com isso, passamos de 331 para 495 sentenças com julgamentos determinados e passamos de 195 para 187 sentenças com julgamentos indeterminados.

Tabela 4.2.4. Agrupamento Ordenado e Aleatório

\begin{tabular}{lcc} 
Julgamentos & $\#$ & $\%$ \\
\hline Gram./Agram. & 495 & $73 \%$ \\
Indeterminado & 187 & $27 \%$ \\
\hline Total & 682 & $100 \%$
\end{tabular}

\subsection{Comportamento geral frente aos testes}

As 682 sentenças geradas a partir dos seis testes levaram ao seguinte resultado geral exposto na tabela abaixo. 
Tabela 4.3.1. Tabela Geral

\begin{tabular}{|c|c|c|c|c|c|}
\hline Testes & Julgamentos & Total & Proporção & Valor $\mathbf{P}$ & $\begin{array}{c}\text { Grupo } \\
\text { Final }\end{array}$ \\
\hline Sentença-base & $\begin{array}{l}\text { SIM } \\
\text { NÃO }\end{array}$ & $\begin{array}{c}3193 \\
57\end{array}$ & $\begin{array}{c}98 \% \\
2 \%\end{array}$ & $<0,001$ & $\mathbf{S}$ \\
\hline $\begin{array}{l}\text { 1.Alternância Causativo- } \\
\text { Incoativa ou } \\
\text { Transitivo-intransitiva }\end{array}$ & $\begin{array}{l}\text { SIM } \\
\text { NÃO }\end{array}$ & $\begin{array}{l}1111 \\
2143\end{array}$ & $\begin{array}{l}34 \% \\
66 \% \\
\end{array}$ & $<0,001$ & $\mathbf{N}$ \\
\hline 2.Alternância Média & $\begin{array}{l}\text { SIM } \\
\text { NÃO }\end{array}$ & $\begin{array}{l}1605 \\
1614\end{array}$ & $\begin{array}{l}50 \% \\
50 \%\end{array}$ & 0,89 & $\mathbf{I}$ \\
\hline 3.Expressão perifrástica & $\begin{array}{l}\text { SIM } \\
\text { NÃO }\end{array}$ & $\begin{array}{c}2749 \\
492\end{array}$ & $\begin{array}{l}85 \% \\
15 \%\end{array}$ & $<0,001$ & S \\
\hline 4.Objetos Cognatos & $\begin{array}{l}\text { SIM } \\
\text { NÃO }\end{array}$ & $\begin{array}{l}1013 \\
2258\end{array}$ & $\begin{array}{l}31 \% \\
69 \%\end{array}$ & $<0,001$ & $\mathbf{N}$ \\
\hline 5.Adjuntos Cognatos & $\begin{array}{l}\text { SIM } \\
\text { NÃO }\end{array}$ & $\begin{array}{l}2008 \\
1232\end{array}$ & $\begin{array}{l}62 \% \\
38 \%\end{array}$ & $<0,001$ & $\mathbf{S}$ \\
\hline $\begin{array}{l}\text { 6.Adjuntos Hipônimos e } \\
\text { Hiperônimos }\end{array}$ & $\begin{array}{l}\text { SIM } \\
\text { NÃO }\end{array}$ & $\begin{array}{c}2439 \\
733 \\
\end{array}$ & $\begin{array}{l}77 \% \\
23 \% \\
\end{array}$ & $<0,001$ & $\mathbf{S}$ \\
\hline $\begin{array}{l}\text { Total Soma de SIM } \\
\text { Total Soma de NÃO }\end{array}$ & & $\begin{array}{l}14118 \\
8529\end{array}$ & & & \\
\hline
\end{tabular}

Como esperado, para as sentenças-base, $98 \%$ dos falantes a julgaram como gramaticais.

No que se refere ao teste que transformava a sentença-base em uma sentença de alternância causativo-incoativa ou transitivo-intransitiva (teste 1), 2.143 sentenças foram julgadas como agramaticais contra 1.111 sentenças gramaticais. Em porcentagem, $66 \%$ de julgamentos agramaticais. Esse resultado indica que, dentre a classe geral dos VDs, existem verbos de alternância e verbos que não alternam. Mais um fato confirmatório da heterogeneidade dessa classe.

O teste de alternância média apresentou 1605 julgamentos gramaticais contra 1614 julgamentos agramaticais. Por conta dessa divisão muito próxima, da quantidade de falantes que julgaram as sentenças como gramaticais ou agramaticais ser muito parecida, o resultado para esse teste ficou indeterminado. Novamente, vê-se heterogeneidade frente a esse teste. 
As expressões perifrásticas, formadas com diferentes verbos, que descrevemos com detalhes mais adiante, foram aceitas em $85 \%$ dos casos, em 2.749 sentenças contra 492 resultados agramaticais. A existência dessa grande maioria de expressões perifrásticas indica que ainda há a presença de alguma relação entre nome primitivo e verbo para muitos desses verbos.

A presença de objetos cognatos foi aceita em apenas $31 \%$ das sentenças contra $69 \%$ de rejeição. Dessa forma, para o conjunto de dados, a presença de objetos cognatos não é aceita em geral. Veremos na próxima seção, quais os verbos que permitiram a presença de tais objetos.

Com relação à presença de adjuntos cognatos e adjuntos hipônimos e hiperônimos, os julgamentos apontam para uma aceitação desses adjuntos com os verbos estudados. A relação presente e explicitada pelo adjunto morfologicamente ou semanticamente relacionado ao verbo pode indicar uma presença de relação denominal sincrônica.

\subsubsection{Resultados de gramaticalidade teste a teste:}

Apresentamos, abaixo, algumas tabelas informativas dos julgamentos apresentados pelos falantes frente aos testes descritos acima: 


\subsubsection{Teste 1: Alternância Causativo-incoativa}

\begin{tabular}{|l|c|}
\hline \multicolumn{2}{|l|}{ Alternância C-I ou T-I } \\
\hline Teste 1 & \# Verbos \\
\hline Indeterminados & 29 \\
Agramaticias & 59 \\
Gramaticais & 10 \\
\hline Total geral & $\mathbf{9 8}$ \\
\hline
\end{tabular}

\begin{tabular}{|l|ll|l|}
\hline \multicolumn{1}{|c|}{ Gramaticais } & \multicolumn{2}{|c|}{ Agramaticais } & Indeterminados \\
\hline cristalizar & estudar & rastrear & enfeitiçar \\
assustar & enfrentar & capturar & apontar2 \\
colar & complementar & desfrutar & incrementar \\
valorizar & alimentar & modelar & movimentar \\
fechar & aproveitar & favorecer & processar2 \\
amanhecer & desejar & focar & misturar \\
embarcar & engarrafar & basear & pesquisar \\
estrear & selar & liderar & cadastrar \\
marcar & escovar & privilegiar & veicular \\
acabar & beneficiar & acostumar & acreditar \\
& praticar & cruzar & brincar \\
& faltar & listar & agrupar \\
& criticar & analisar & encarar \\
& relatar & causar & auxiliar \\
& caminhar & testar & processar1 \\
& arcar & empacotar & ingressar \\
& resgatar & agulhar & regulamentar \\
& subsidiar & arrumar & casar \\
& arriscar & memorizar & engavetar \\
& apontar1 & agendar & encurralar \\
& armazenar & depositar & martelar \\
& interessar & sediar & abraçar \\
& programar & implementar & filtrar \\
& influenciar & forçar & somar \\
& concentrar & economizar & adiar \\
& apostar & traçar1 & copiar \\
& sinalizar & traçar2 & avaliar \\
& almoçar & suplementar & gerenciar \\
& evidenciar & providenciar & aprimorar \\
& & registrar & \\
\hline
\end{tabular}




\subsubsection{Teste 2: Alternância Média}

\begin{tabular}{|l|r|}
\hline \multicolumn{2}{|l|}{ Alternância Média } \\
\hline Teste 2 & \# Verbos \\
\hline Indeterminados & 46 \\
Agramaticais & 27 \\
Gramaticais & 25 \\
\hline Total geral & $\mathbf{9 8}$ \\
\hline
\end{tabular}

\begin{tabular}{|c|c|c|c|}
\hline Gramaticais & Agramaticais & \multicolumn{2}{|c|}{ Indeterminados } \\
\hline $\begin{array}{l}\text { enfeitiçar } \\
\text { encurralar } \\
\text { selar } \\
\text { escovar } \\
\text { cristalizar } \\
\text { assustar } \\
\text { colar } \\
\text { agrupar } \\
\text { misturar } \\
\text { processar2 } \\
\text { valorizar } \\
\text { pesquisar } \\
\text { apontar1 } \\
\text { fechar } \\
\text { amanhecer } \\
\text { modelar } \\
\text { embarcar } \\
\text { estrear } \\
\text { marcar } \\
\text { acabar } \\
\text { filtrar } \\
\text { empacotar } \\
\text { arrumar } \\
\text { agendar } \\
\text { registrar }\end{array}$ & $\begin{array}{l}\text { Estuda } \\
\text { enfrentar } \\
\text { alimentar } \\
\text { aproveitar } \\
\text { desejar } \\
\text { praticar } \\
\text { faltar } \\
\text { criticar } \\
\text { relatar } \\
\text { encarar } \\
\text { arcar } \\
\text { subsidiar } \\
\text { arriscar } \\
\text { apontar2 } \\
\text { interessar } \\
\text { apostar } \\
\text { almoçar } \\
\text { desfrutar } \\
\text { favorecer } \\
\text { focar } \\
\text { basear } \\
\text { privilegiar } \\
\text { acostumar } \\
\text { causar } \\
\text { testar } \\
\text { brincar } \\
\text { sediar }\end{array}$ & $\begin{array}{l}\text { influenciar } \\
\text { adiar } \\
\text { cadastrar } \\
\text { caminhar } \\
\text { evidenciar } \\
\text { suplementar } \\
\text { traçar1 } \\
\text { liderar } \\
\text { acreditar } \\
\text { copiar } \\
\text { ingressar } \\
\text { abraçar } \\
\text { providenciar } \\
\text { depositar } \\
\text { agulhar } \\
\text { incrementar } \\
\text { traçar2 } \\
\text { aprimorar } \\
\text { capturar } \\
\text { armazenar } \\
\text { listar } \\
\text { memorizar } \\
\text { analisar } \\
\text { sinalizar }\end{array}$ & $\begin{array}{l}\text { somar } \\
\text { forçar } \\
\text { engarrafar } \\
\text { economizar } \\
\text { engavetar } \\
\text { avaliar } \\
\text { auxiliar } \\
\text { regulamentar } \\
\text { rastrear } \\
\text { cruzar } \\
\text { concentrar } \\
\text { resgatar } \\
\text { movimentar } \\
\text { gerenciar } \\
\text { veicular } \\
\text { implementar } \\
\text { martelar } \\
\text { casar } \\
\text { complementar } \\
\text { beneficiar } \\
\text { processar1 } \\
\text { programar }\end{array}$ \\
\hline
\end{tabular}


4.3.1.3. Teste 3: Expressão Perifrástica

\begin{tabular}{|l|r|}
\hline \multicolumn{2}{|l|}{ Expressão Perifrástica } \\
\hline Teste 3 & \# Verbos \\
\hline Indeterminados & 09 \\
Agramaticais & 07 \\
Gramaticais & 82 \\
\hline Total geral & $\mathbf{9 8}$ \\
\hline
\end{tabular}

\begin{tabular}{|ll|l|l|}
\hline & Gramaticais & Agramaticais & Indeterminados \\
\hline Estudar & evidenciar & & \\
enfrentar & rastrear & faltar & casar \\
complementar & amanhecer & arcar & agrupar \\
acreditar & capturar & apontar2 & avaliar \\
alimentar & modelar & concentrar & arrumar \\
aproveitar & adiar & desfrutar & encarar \\
desejar & cadastrar & causar & cruzar \\
enfeitiçar & favorecer & brincar & \\
engavetar & focar & & \\
engarrafar & embarcar & \\
encurralar & estrear & & \\
selar & basear & & \\
martelar & abraçar & & \\
escovar & liderar & & \\
cristalizar & marcar & & \\
assustar & privilegiar & & \\
beneficiar & copiar & & \\
colar & acostumar & & \\
praticar & listar & & \\
criticar & analisar & & \\
relatar & testar & & \\
caminhar & empacotar & & \\
misturar & agulhar & & \\
resgatar & aprimorar & & \\
subsidiar & memorizar & & \\
processar1 & agendar & & \\
processar2 & auxiliar & & \\
valorizar & depositar & & \\
arriscar & sediar & & \\
pesquisar & implementar & & \\
apontar1 & gerenciar & \\
armazenar & veicular & \\
interessar & forçar & & \\
ingressar & economizar & & \\
programar & traçar1 & \\
influenciar & suplementar & & \\
fechar & movimentar & & \\
somar & incrementar & & \\
apostar & providenciar & & \\
sinalizar & registrar & & \\
almoçar & regulamentar & & \\
\hline
\end{tabular}




\subsubsection{Teste 4: Objetos Cognatos}

\begin{tabular}{|l|r|}
\hline \multicolumn{2}{|l|}{ Objetos Cognatos } \\
\hline Teste 4 & \# Verbos \\
\hline Indeterminados & 32 \\
Agramaticais & 59 \\
Gramaticais & 07 \\
\hline Total geral & 98 \\
\hline
\end{tabular}

\begin{tabular}{|c|c|c|c|}
\hline Gramaticais & \multicolumn{2}{|c|}{ Agramaticais } & Indeterminados \\
\hline $\begin{array}{l}\text { estudar } \\
\text { agrupar } \\
\text { apontar1 } \\
\text { amanhecer } \\
\text { testar } \\
\text { empacotar } \\
\text { traçar1 }\end{array}$ & $\begin{array}{l}\text { complementar } \\
\text { acreditar } \\
\text { alimentar } \\
\text { aproveitar } \\
\text { enfeitiçar } \\
\text { engavetar } \\
\text { escovar } \\
\text { cristalizar } \\
\text { assustar } \\
\text { beneficiar } \\
\text { casar } \\
\text { praticar } \\
\text { faltar } \\
\text { criticar } \\
\text { encarar } \\
\text { arcar } \\
\text { resgatar } \\
\text { subsidiar } \\
\text { processar1 } \\
\text { arriscar } \\
\text { pesquisar } \\
\text { apontar2 } \\
\text { armazenar } \\
\text { interessar } \\
\text { ingressar } \\
\text { influenciar } \\
\text { fechar } \\
\text { concentrar } \\
\text { capturar } \\
\text { favorecer }\end{array}$ & $\begin{array}{l}\text { focar } \\
\text { estrear } \\
\text { basear } \\
\text { abraçar } \\
\text { privilegiar } \\
\text { acostumar } \\
\text { cruzar } \\
\text { acabar } \\
\text { filtrar } \\
\text { analisar } \\
\text { causar } \\
\text { agulhar } \\
\text { brincar } \\
\text { aprimorar } \\
\text { arrumar } \\
\text { memorizar } \\
\text { agendar } \\
\text { auxiliar } \\
\text { depositar } \\
\text { sediar } \\
\text { implementar } \\
\text { gerenciar } \\
\text { veicular } \\
\text { forçar } \\
\text { economizar } \\
\text { suplementar } \\
\text { movimentar } \\
\text { incrementar } \\
\text { providenciar }\end{array}$ & $\begin{array}{l}\text { avaliar } \\
\text { marcar } \\
\text { registrar } \\
\text { cadastrar } \\
\text { relatar } \\
\text { listar } \\
\text { encurralar } \\
\text { misturar } \\
\text { regulamentar } \\
\text { somar } \\
\text { evidenciar } \\
\text { caminhar } \\
\text { processar2 } \\
\text { sinalizar } \\
\text { programar } \\
\text { modelar }\end{array}$ \\
\hline
\end{tabular}




\subsubsection{Teste 5: Adjuntos Cognatos}

\begin{tabular}{|l|r|}
\hline \multicolumn{2}{|l|}{ Adjuintos Cognatos } \\
\hline Teste 5 & \# Verbos \\
\hline Indeterminados & 47 \\
Agramaticais & 09 \\
Gramaticais & 42 \\
\hline Total geral & 98 \\
\hline
\end{tabular}

\begin{tabular}{|l|l|ll|}
\hline \multicolumn{1}{|c|}{ Gramaticais } & \multicolumn{1}{c|}{ Agramaticais } & \multicolumn{2}{c|}{ Indeterminados } \\
\hline Estudar & & & desfrutar \\
complementar & avaliar & depositar & interessar \\
alimentar & casar & aproveitar & aprimorar \\
desejar & arcar & ingressar & causar \\
enfeitiçar & apontar2 & somar & implementar \\
engavetar & concentrar & regulamentar & enfrentar \\
engarrafar & acostumar & praticar & cristalizar \\
encurralar & acabar & economizar & faltar \\
selar & arrumar & capturar & focar \\
martelar & memorizar & processar2 & programar \\
escovar & & resgatar & brincar \\
beneficiar & & auxiliar & registrar \\
colar & & traçar2 & pesquisar \\
criticar & & suplementar & liderar \\
relatar & & gerenciar & privilegiar \\
encarar & & incrementar \\
caminhar & & modelar & providenciar \\
agrupar & & influenciar & sediar \\
subsidiar & & estrear & cruzar \\
valorizar & & arriscar \\
apontar1 & & agendar \\
armazenar & & listar \\
fechar & & misturar & almoçar \\
sinalizar & & acreditar \\
evidenciar & & & \\
rastrear & & & \\
amanhecer & & & \\
cadastrar & & & \\
favorecer & & & \\
embarcar & & & \\
basear & & & \\
abraçar & & & \\
marcar & & & \\
filtrar & & & \\
analisar & & & \\
testar & & & \\
empacotar & & & \\
agulhar & & \\
veicular & & & \\
forçar & & & \\
traçar1 & & & \\
movimentar & & \\
processar1 & & & \\
\hline
\end{tabular}


4.3.1.6. Teste 6: Adjuntos Hipônimos e Hiperônimos (H\&H) (semanticamente relacionados)

\begin{tabular}{|l|r|}
\hline \multicolumn{2}{|l|}{ Adjuintos H\&H } \\
\hline Teste 6 & \# Verbos \\
\hline Indeterminados & 27 \\
Agramaticais & 03 \\
Gramaticais & 68 \\
\hline Total geral & 98 \\
\hline
\end{tabular}

\begin{tabular}{|c|c|c|c|}
\hline \multicolumn{2}{|c|}{ Gramaticais } & Agramaticais & Indeterminados \\
\hline $\begin{array}{l}\text { estudar } \\
\text { avaliar } \\
\text { enfrentar } \\
\text { complementar } \\
\text { acreditar } \\
\text { alimentar } \\
\text { desejar } \\
\text { enfeitiçar } \\
\text { engavetar } \\
\text { engarrafar } \\
\text { encurralar } \\
\text { selar } \\
\text { martelar } \\
\text { escovar } \\
\text { cristalizar } \\
\text { assustar } \\
\text { beneficiar } \\
\text { colar } \\
\text { praticar } \\
\text { criticar } \\
\text { relatar } \\
\text { encarar } \\
\text { caminhar } \\
\text { agrupar } \\
\text { misturar } \\
\text { subsidiar } \\
\text { processar1 } \\
\text { valorizar } \\
\text { arriscar } \\
\text { pesquisar } \\
\text { apontar1 } \\
\text { armazenar } \\
\text { ingressar } \\
\text { fechar }\end{array}$ & $\begin{array}{l}\text { somar } \\
\text { apostar } \\
\text { sinalizar } \\
\text { evidenciar } \\
\text { rastrear } \\
\text { amanhecer } \\
\text { cadastrar } \\
\text { favorecer } \\
\text { focar } \\
\text { embarcar } \\
\text { estrear } \\
\text { basear } \\
\text { abraçar } \\
\text { marcar } \\
\text { privilegiar } \\
\text { listar } \\
\text { filtrar } \\
\text { causar } \\
\text { testar } \\
\text { empacotar } \\
\text { agulhar } \\
\text { aprimorar } \\
\text { agendar } \\
\text { auxiliar } \\
\text { sediar } \\
\text { implementar } \\
\text { gerenciar } \\
\text { veicular } \\
\text { forçar } \\
\text { traçar1 } \\
\text { suplementar } \\
\text { movimentar } \\
\text { incrementar } \\
\text { providenciar }\end{array}$ & $\begin{array}{l}\text { concentrar } \\
\text { acabar } \\
\text { arrumar }\end{array}$ & $\begin{array}{l}\text { depositar } \\
\text { brincar } \\
\text { almoçar } \\
\text { aproveitar } \\
\text { copiar } \\
\text { traçar2 } \\
\text { economizar } \\
\text { apontar2 } \\
\text { modelar } \\
\text { programar } \\
\text { interessar } \\
\text { acostumar } \\
\text { casar }\end{array}$ \\
\hline
\end{tabular}




\subsection{Generalizações}

Um dos objetivos deste trabalho é definir quais VDs diacrônicos podem manterse com essa denominação em uma abordagem sincrônica. Entretanto, além dessa hipótese, pudemos confirmar através dos testes realizados que a classe geral dos VDs não tem um comportamento homogêneo, podendo se dividir em grupos. Assim, há aqueles verbos que participam de alternâncias e os que não participam, há expressões perifrásticas formadas com diversos tipos de verbos leves, há aqueles que permitem e os que não permitem ocorrência de objeto cognato e o mesmo se dá com os adjuntos cognatos e hipônimos e hiperônimos. Nesta seção, buscaremos generalizações a partir dos resultados, procurando encontrar regularidades no comportamento de subgrupos de verbos da classe geral dos VDs. Primeiramente, apresentaremos aqueles verbos que parecem manter uma relação de derivação com os substantivos formadores (os chamaremos de denominais), em seguida apresentaremos o grupo de verbos que parece ter perdido essa relação através do tempo, não podendo ser considerados denominais em uma análise sincrônica.

Os testes estatísticos de correlação mostraram que há proximidade entre os resultados dos testes 3 (expressão perifrástica), 4 (objeto cognato), 5 (adjunto cognato) e 6 (adjunto hipônimo e hiperônimo), por um lado, e dos testes 1 (alternância causativo-incoativa) e 2 (alternância média), por outro (Gráficos 4.4 .1 e 4.4.2). Esses resultados podem ser interpretados da seguinte forma. Os testes de 3 a 6 apresentam indícios da relação (resultados gramaticais) ou não-relação (resultados agramaticais) entre nome e verbo, enquanto os testes 1 e 2 apresentam características da estrutura sintática do verbo, em especial, no que diz respeito à possibilidade de alternância (resultados gramaticais) e não-alternância (resultados agramaticais). Assim, analisaremos os verbos por meio de dois fatores: relação com nome e estrutura sintática. 


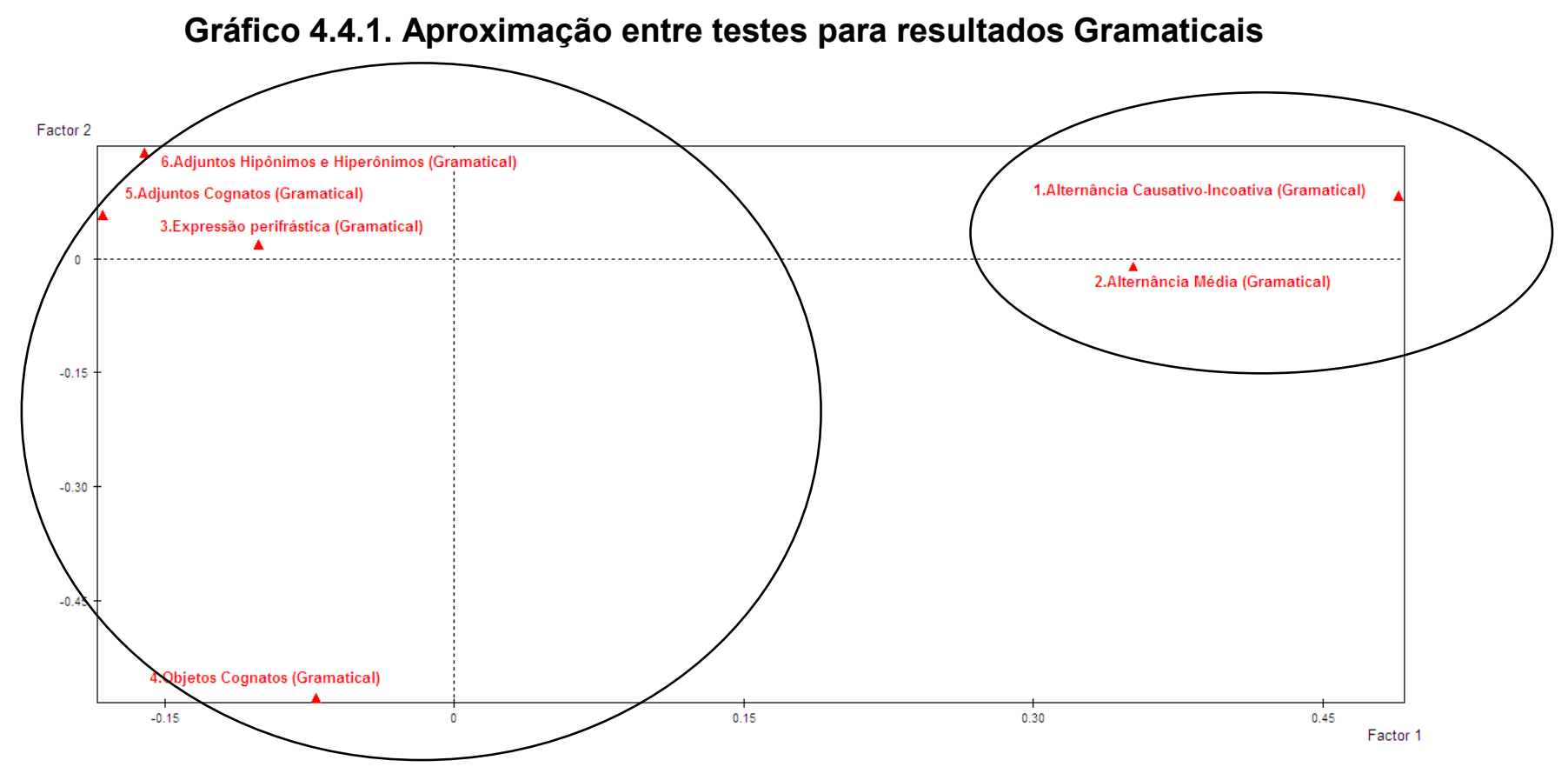

Gráfico 4.4.2. Aproximação entre testes para resultados Gramaticais (Verbos)

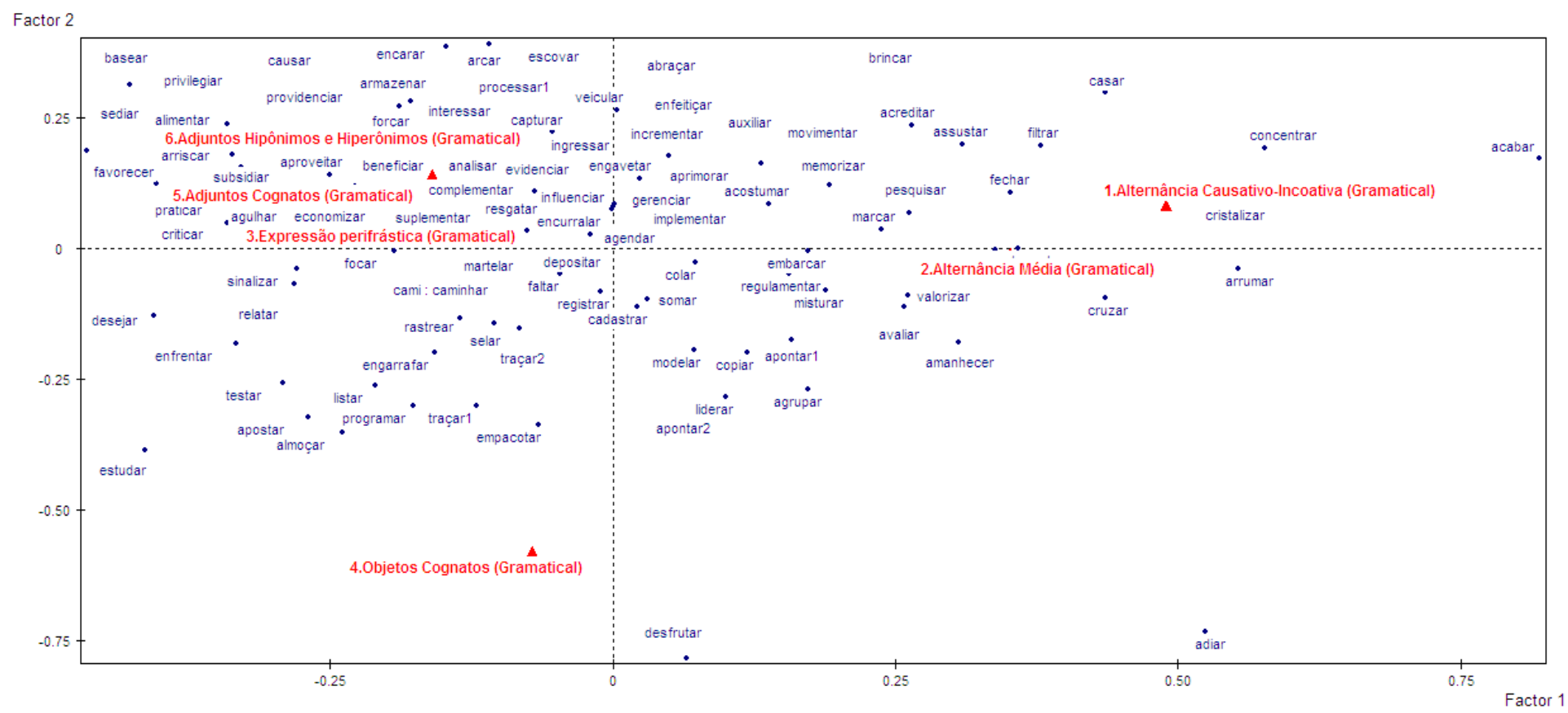

O gráfico 4.4.1. indica que os verbos que se mostraram gramaticais nos testes 3, 4, 5 e 6 apresentam resultados aproximados. O mesmo ocorre entre os testes 1 e 2, como esperado, por serem ambos testes de alternância. O gráfico 4.4.1. apresenta a 
mesma informação com a apresentação dos verbos que mostraram gramaticalidade frente a esses testes localizando-se próximos a eles.

Os resultados de todos os testes para os 95 verbos estão disponibilizados no anexo 05.

\subsubsection{Verbos Denominais sincrônicos}

Quanto mais gramaticalidade um verbo mostrar frente aos testes, mais se revelará uma relação de derivação entre nome e verbo.

Os testes que se mostraram mais relevantes para o reconhecimento de estruturas denominais foram o teste 3 , Expressão Perifrástica, o teste 4 , de Objetos Cognatos e o teste 5, Adjuntos Cognatos. Esses testes revelam a presença de uma relação entre nome e verbo formado. Os outros dois testes, Alternância causativoincoativa e Alternância média, também são importantes na identificação de estruturas denominais, mas, além disso, na identificação do tipo de estrutura sintática que possui esse ou aquele verbo. Por último, o teste 6, de Adjuntos Hipônimos e Hiperônimos, pode ser considerado de duas formas a serem discutidas adiante.

A maioria dos verbos analisados em nossa amostra mantém ainda uma relação com o nome formador. Apesar de agruparmos os verbos abaixo em uma mesma categoria, a de denominais sincrônicos, há graus de variação na intensidade e no tipo de relação semântica que esses verbos mantêm com seus nomes. Assim a interpretação do grupo não é totalmente homogênea. Ainda, esse grande grupo também não é totalmente homogêneo no aspecto estrutural. Compõem esse grupo todos os verbos que mostraram gramaticalidade frente aos testes de Expressão Perifrástica, (Objeto Cognato), Adjunto Cognato, Adjunto Hipônimo ou Hiperônimo. 


\subsubsection{Gramaticalidade para o Teste 3 - Expressão Perifrástica}

Observamos que o teste de expressão perifrástica se mostrou como o mais importante no reconhecimento de estruturas denominais. Vejamos a sentença abaixo:

(36) O garoto abraçou o amigo.

(37) O garoto deu um abraço no amigo.

Se é possível que haja uma sentença como (37), que tem o mesmo significado de (36), mas com a realização plena do substantivo cognato ao verbo, isso quer dizer que elas mantém uma relação entre si. Representamos estruturalmente essa relação, de forma simplificada para o momento, da maneira sugerida em H\&K (1993, 2002):

(38)

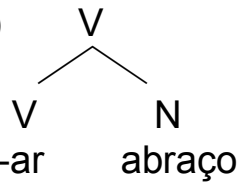

(39)

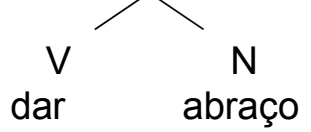

Dessa forma, em primeiro lugar, serão considerados denominais em uma abordagem sincrônica os verbos que possuírem expressões perifrásticas com verbos leves e substantivos com sentido idêntico, são eles os verbos:

Enfrentar, complementar, acreditar, alimentar, aproveitar, desejar, enfeitiçar, engavetar, engarrafar, encurralar, selar, martelar, escovar, cristalizar, assustar, beneficiar, colar, praticar, criticar, relatar, misturar, resgatar, subsidiar, processar1 (jurídico), arriscar, pesquisar, apontar1 (o lápis), armazenar, interessar, ingressar, programar, influenciar, somar, apostar, sinalizar, almoçar, evidenciar, rastrear, amanhecer, capturar, adiar, cadastrar, favorecer, focar, embarcar, estrear, basear, abraçar, liderar, marcar, privilegiar, copiar, acostumar, listar, analisar, testar, empacotar, agulhar, aprimorar, memorizar, agendar, auxiliar, depositar, sediar, 
implementar, gerenciar, veicular, forçar, economizar, traçar1 (o desenho), suplementar, movimentar, incrementar, providenciar, registrar, regulamentar.

Os verbos modelar, fechar, valorizar, caminhar e estudar, apesar de apresentarem expressões perifrásticas gramaticais, não as têm com sentido idêntico. Entendamos melhor com a explicitação dos tipos de verbos leves formadores.

\section{Tipos de Expressões Perifrásticas: verbos leves}

\section{a. Fazer + substantivo}

A maior parte das expressões perifrásticas da amostra se forma com o verbo fazer. Dentre as julgadas como gramaticais com fazer e o substantivo formador, há dois tipos de relação: uma em que a leitura é exatamente correlata a do verbo e outra que tem uma interpretação um pouco diferente.

O verbo estudar pode ter uma perífrase com fazer um estudo, mas as sentenças imediatamente abaixo não parecem ter o mesmo sentido:

(40) Eu estudei Matemática

(41) Eu fiz um estudo de Matemática.

Quando alguém estuda matemática, não necessariamente produz um estudo de matemática. Poucos casos dentre os verbos listados acima apresentam um comportamento parecido:

(42) O homem caminhou na lua.

(43) O homem fez um caminho na lua.

(44) O artista modelou a peça.

(45) O artista fez um modelo da peça de cerâmica. 
As sentenças acima não parecem ter interpretações idênticas, mas mesmo assim foram julgadas como gramaticais. No entanto, em todos os outros casos, a expressão parece ter o mesmo sentido do verbo, vejamos alguns ${ }^{31}$ :

(46) Os laboratórios testaram os medicamentos em ratos.

(47) Os laboratórios fizeram testes com os medicamentos em ratos.

(48) O político favoreceu os parentes.

(49) O político fez favores a seus parentes.

(50) A recepcionista cadastrou os candidatos.

(51) A recepcionista fez o cadastro dos candidatos.

(52) O piloto relatou as falhas.

(53) O piloto fez um relato das falhas.

(54) O Lula criticou a seleção.

(55) O Lula fez uma crítica à seleção.

\section{b. Dar + substantivo}

O mesmo fenômeno de interpretação parece ocorrer com o verbo leve dar.

(56) Eu acreditei no sujeito.

(57) Eu dei um crédito ao sujeito.

(58) O garoto abraçou o amigo

(59) O garoto deu um abraço no amigo.

(60) O modelo econômico beneficiou os mais pobres.

(61) O modelo econômico deu benefícios aos mais pobres.

(62) A mãe alimentou o recém-nascido.

(63) A mãe deu alimento ao recém-nascido.

(64) O monitor auxiliou o professor na aula.

\footnotetext{
${ }^{31}$ A totalidade dos dados pode ser vista no Anexo 05
} 
(65) O monitor deu auxílio ao professor na aula.

(66) O palhaço assustou a criança.

(67) O palhaço deu um susto na criança.

(68) O estudo evidenciou os fatos.

(69) O estudo deu evidências aos fatos.

(70) As luzes incrementaram a festa.

(71) As luzes deram um incremento especial à festa.

(72) O governo subsidiou o encontro ecológico

(73) O governo deu subsídio ao encontro ecológico.

(74) O ministro privilegiou o filho.

(75) O ministro deu privilégios ao filho.

(76) O professor aprimorou o método de ensino.

(77) O professor deu primor ao método de ensino.

Em comunicação pessoal, alguns dos falantes observaram que julgaram a seguinte expressão perifrástica como gramatical, mas não com sentido correlato à sentença-base. Isso significa que não há evidências fortes, então, para que se assuma que valorizar é derivado de valor em uma formação sincrônica ${ }^{32}$.

(78) O mercado valorizou o real.

(79) O mercado deu valor ao real.

\section{c. Pôr/Colocar substantivo em X (Locatum) e Pôr colocar X em substantivo (Location)}

Novamente, a maioria apresenta interpretação correlata, mas uma delas não, com o verbo fechar.

\footnotetext{
${ }^{32}$ Entretanto, o tipo de complemento parece influenciar na interpretação na sentença. Para uma sentença como "O João dá valor à namorada" pode-se ter uma paráfrase mais correlata com "O João valoriza a namorada". Contudo, consideramos o resultado a partir da sentença julgada.
} 


\section{Locatum:}

(80) O policial sinalizou o esconderijo das drogas.

(81) O policial colocou sinais no esconderijo das drogas.

(82) O professor focou em gramática nas aulas.

(83) O professor colocou foco em gramática nas aulas.

(84) A índia enfeitiçou o jovem rapaz.

(85) A índia colocou um feitiço no jovem rapaz.

(86) O peão selou o cavalo.

(87) O peão pôs a sela no cavalo.

(88) O funcionário processou o chefe.

(89) O funcionário pôs um processo no chefe.

\section{Location:}

(90) A assistente agendou a reunião

(91) A assistente colocou a reunião na agenda.

(92) A imprensa veiculou a notícia.

(93) A Imprensa colocou a notícia em veículos de porte.

(94) Os marinheiros embarcaram a mercadoria.

(95) Os marinheiros colocaram a mercadoria no barco.

(96) O atleta movimentou o barco.

(97) O juiz regulamentou a lei.

(98) O juiz colocou a lei em regulamento.

(99) A secretária armazenou os documentos.

(100) A secretária colocou os documentos no armazém.

(101) A secretária engavetou o processo de cassação.

(102) A secretária pôs o processo de cassação na gaveta.

(103) O funcionário engarrafou o vinho branco. 
(104) O funcionário pôs o vinho branco nas garrafas.

(105) O jogador arriscou a vida.

(106) A doceira empacotou os doces.

(107) A doceira pôs os doces no pacote.

(108) O peão encurralou o boi bravo.

(109) O peão pôs o boi no curral.

As seguintes sentenças apresentam a mesma estrutura argumental das sentenças de location, mas o complemento da preposição é um termo que não denota local; é, antes, um nome abstrato. Mesmo assim, as manteremos nessa seção, pela semelhança estrutural.

(110) O jogador pôs a vida em risco.

(111) O atleta colocou o barco em movimento.

Certamente, a maioria dos falantes interpretou fechou a porta como "passar do estado de aberta a fechada" e a sentença com colocou fecho na porta como "não havia fecho e passou a ter". Por isso, não podemos dizer que essas sentenças são correlatos semânticos.

(112) O Paulo fechou a porta.

(113) O Paulo colocou o fecho na porta.

\section{d. Casos Isolados}

Alguns verbos têm expressões perifrásticas com verbos leves, se é que podemos chamá-los assim, específicos. Constituem expressões fixas, no senso comum do termo, como tirar proveito. 


\section{- $\quad$ Tirar + substantivo}

(114) O rapaz aproveitou a oportunidade.

(115) O rapaz tirou proveito da oportunidade.

\section{- Tornar + substantivo}

Nesse tipo de sentença em que há um sentido de tornar, transformar, as expressões perifrásticas levam a uma interpretação de mudança de estado, como nos verbos deadjetivais. Como há mudança de estado, esses verbos participam da alternância causativo-incoativa. Nesse momento, nos perguntamos se faz realmente sentido falar em distinção entre denominal e deadjetival. Para esse caso, não parece haver muita distinção.

(116) A noite tornou-se manhã rapidamente.

\section{- Encontrar + substantivo}

(117) A comissão rastreou contas ilegais.

(118) A comissão encontrou rastros de contas ilegais.

\section{- Tomar + substantivo}

(119) Ana providenciou o jantar.

(120) Ana tomou providências para o jantar.

\section{- $\quad$ Adquirir + substantivo}

(121) O bebê (se) acostumou a dormir sem os pais.

(122) O bebê adquiriu o costume de dormir sem os pais. 


\section{- $\quad$ Ser + substantivo}

(123) O presidente liderou a comissão.

(124) O presidente foi o líder da comissão.

- Comer + substantivo

(125) A família almoçou cedo.

(126) A família comeu o almoço cedo.

\section{- Furar + com substantivo}

(127) A costureira agulhou o dedo.

(128) A costureira furou o dedo com a agulha.

- Causar +substantivo

(129) O show interessou o público.

(130) O show causou interesse no público.

(131) Aquele livro influenciou os estudantes.

(132) Aquele livro causou influência sobre os estudantes.

\section{- $\quad$ Acrescentar + substantivo + a}

(133) A empresa adiou o lançamento dos produtos.

(134) A empresa acrescentou dia ao lançamento dos produtos.

\section{- Usar como + substantivo}

(135) O juiz se baseou nas evidências.

(136) O juiz usou como base as evidências. 


\section{- Guardar em + substantivo}

(137) O estudante memorizou a tabuada.

(138) O estudante guardou a tabuada na memória.

\subsubsection{Gramaticalidade para o teste 5 - Adjuntos Cognatos}

As expressões perifrásticas são o teste mais forte na identificação de VDs. Todos os verbos que são gramaticais para o teste 3 também o são para o teste 5 Adjuntos Cognatos - (Os verbos agrupar, encarar e filtrar foram indeterminados quanto à gramaticalidade). Assim, o teste 5 parece corroborar os resultados do teste 3 . As sentenças abaixo com adjuntos cognatos ilustram a relação entre nome e verbo. Vejamos algumas:

(139) O garoto abraçou o amigo com um abraço carinhoso.

(140) O sorteio agrupou os times com grupos bons.

(141) A costureira agulhou o dedo com a agulha mais fina.

(142) A mãe alimentou o recém-nascido com um alimento saudável.

(143) O dia amanheceu com uma linda manhã.

(144) O chefe analisou os relatórios com uma análise minuciosa.

(145) O menino apontou o lápis com uma ponta fina.

(146) A secretária armazenou os documentos no armazém pequeno.

(147) O juiz se baseou em evidências com bases sólidas.

(148) O modelo econômico beneficiou os mais pobres com benefícios úteis.

\subsubsection{Gramaticalidade para Teste 4 - Objetos Cognatos}

Os seguintes verbos foram julgados como gramaticais quando combinados com um objeto cognato: estudar, agrupar, apontar1 (fazer ponta), amanhecer, testar, 
empacotar, traçar1(fazer desenho ${ }^{33}$. Vejamos as sentenças abaixo julgadas como gramaticais pelos falantes:

(149) A doceira empacotou um pacote de doces.

(150) O desenhista traçou traços fortes no papel.

(151) O sorteio agrupou três grupos de times bons.

(152) O menino apontou a ponta (quebrada) do lápis.

(153) Amanheceu uma linda manhã.

(154) Os laboratórios testaram um teste novo para os medicamentos.

(155) Eu estudei um estudo sobre a vida marinha.

Nas sentenças de (149) a (154), o comportamento parece ser realmente de objeto cognato, um objeto produzido através do evento denotado pelo verbo. Entretanto, muitos falantes não interpretaram a sentença com o verbo estudar com um sentido cognato. Quando alguém estuda um estudo de matemática, não necessariamente produz um estudo de matemática, na realidade, na maioria das vezes não produz, mas estuda o estudo de um terceiro ${ }^{34}$.

Como observamos anteriormente, os verbos produtivos com objetos cognatos são, em geral, do tipo inergativo, como dançar (uma dança/um samba) ou rir (uma risada). Em nossa amostra, composta na maioria de verbos transitivos, os poucos verbos que se mostraram gramaticais com objetos cognatos são transitivos, com exceção de amanhecer, que pode ser considerado inacusativo ou de alternância. Como grande parte dos verbos da amostra não apresenta uma estrutura de verbos

\footnotetext{
${ }^{33}$ Estamos assumindo que objetos cognatos são aqueles morfologicamente idênticos, em primeiro, lugar ao verbo. Outros critérios podem ser usados para se definir o que é um objeto cognato. $O$ estamos entendendo com a noção mais estrita do termo cognato.

${ }^{34}$ Os julgamentos ficaram divididos para essa sentença. No grupo ordenado, 17 a consideraram como gramatical e 3 como agramatical, no Grupo aleatório, houve 8 julgamentos gramaticais e 8 agramaticais.
} 
inergativos, é esperado que não se realizem com objetos cognatos ${ }^{35}$. Por serem verbos transitivos e já apresentarem um objeto realizado, na maioria dos casos, a ocorrência do objeto cognato não é permitida. Assim, a agramaticalidade de determinados verbos frente ao teste 4 não parece se dar por conta de esses verbos não serem denominais, mas por outras razões.

\subsubsection{Gramaticalidade para Teste 6 - Adjuntos Hipônimos e Hiperônimos}

O teste 6 pode ser interpretado de duas formas. Se considerarmos os apontamentos de Kiparsky para os verbos denominais instrumentais do inglês, que dizem que a presença do substantivo na interpretação do evento implica a relação de denominalidade, enquanto a ausência e a possibilidade de combinar verbos denominais com outros substantivos, semanticamente relacionados, implica a "nãodenominalidade", diremos que a gramaticalidade para o teste 6 implica a ausência do nome formador na estrutura. Os exemplos de Kiparsky ilustram esse fato:

(156) He hammered the nail with a rock. (Kiparsky, 1982 - example 14)

Ele martelou o prego com uma pedra.

Segundo Kiparsky, na sentença (156), não é necessária a presença do nome hammer na estrutura. Essa sentença seria formada sem um estágio de nome no léxico. Por outro lado, a agramaticalidade da sentença (157) revela que a presença do nome tape é necessária na estrutura do verbo to tape, também no léxico.

(157) *They taped the picture to the wall with pushpins.

Eles "fitou" o quadro na parede com tachinhas.

\footnotetext{
${ }^{35}$ Para um estudo detalhado sobre as estruturas com objetos cognatos, v. Leung, 2007.
} 
No entanto, Harley \& Haugen (2007), apresentam uma visão diferente desse tipo de distinção. Em primeiro lugar, eles não consideram sentenças como (158) abaixo como agramaticais:

(158) Lola taped the poster to the wall with band-aids / mailing-labels.

Lola "fitou" o poster na parede com band-aids / etiquetas.

Segundo os autores, não se pode chegar a qualquer distinção sintática entre os verbos tape e hammer, a distinção é pragmática. Para eles, esses verbos instrumentais sempre envolvem a concatenação de raízes com $v$ indicador de modo.

Com esse olhar teórico, podemos observar o teste 6 da seguinte forma. Embora seja possível neles a existência de um nome não cognato ao verbo, esse nome é sempre hipônimo ou hiperônimo ou contém propriedades relacionados com a do nome formador, o que pode garantir a relação com o nome formador e/ou a preservação do modo de realização. Somente para os três verbos abaixo, constatouse a agramaticalidade:

(159) *A Paula arrumou a casa com um caminho caprichado.

(160) ${ }^{*} \mathrm{O}$ candidato concentrou a maioria dos votos com um meio absoluto.

(161) *Ele acabou o relatório com uma ponta grande.

Por meio desses dados, vemos que a relação entre rumo e arrumar foi perdida, pois quando combinamos esse verbo com um nome semanticamente relacionado, arrumar-rumo-caminho, há agramaticalidade. O mesmo se dá com concentrar-centromeio, acabar-cabo-ponta.

Finalmente, poderia concluir-se o seguinte sobre o teste 6. Quando há realmente agramaticalidade julgada pelos falantes, como em (159) a (161), há indícios 
de perda de relação entre nome e verbo; no entanto, quando há gramaticalidade, podemos ter a manutenção da formação do verbo a partir do nome ou da preservação do modo de realização do evento, mesmo que o verbo seja formado diretamente da raiz, como parece ser o caso do verbo martelar.

Em outros casos em que assumimos que parece haver uma etapa nominal e a presença de um adjunto não cognato é permitida, percebemos que se tratam sempre de adjuntos hipônimos ou hiperônimos ao nome cognato:

(162) O funcionário engarrafou o vinho branco nos galões errados.

(163) ?O funcionário engarrafou o vinho nas gavetas.

A sentença em (163) mostra que apesar de gaveta ser um container, que poderia preservar o modo de realização de engarrafar (restringir, guardar), esse adjunto não forma uma boa sentença.

\section{Sentenças com adjuntos que preservam o modo de realização da ação}

Por outro lado, vemos que há um conjunto de verbos (agulhar, colar, escovar, martelar, traçar1) que se mantém comportam bem tanto com os adjuntos $\mathrm{H} \& \mathrm{H}$ quanto com adjuntos que somente mantém o modo de realização da ação. Vejamos as sentenças com os adjuntos $\mathrm{H} \& \mathrm{H}$ e, em seguida, os mesmos verbos em sentenças em que somente o modo de realização da ação se preserva:

(164) A enfermeira agulhou o dedo com a injeção do paciente.

(165) Eu colei o caderno com goma-arábica.

(166) A moça escovou o cabelo com o pente de madeira.

(167) Eu martelei o prego com a sola do sapato. 
(168) O desenhista traçou o desenho no papel com riscos fortes.

(169) A funcionária agulhou a chefe com aqueles comentários.

(170) A mentira colou bem.

(171) Ela escovou os cabelos com a mão mesmo.

(172) Eu martelei o prego com a sola do sapato.

(173) O desenhista traçou um esboço no ar com as mãos.

Investiguemos com mais detalhes algumas sentenças com o verbo martelar:

(174) O Pedro martelou o prego.

(175) \#O Pedro martelou os pregos com o martelo.

(176) O Pedro martelou os pregos com o martelo grande.

(177) O Pedro martelou o prego com a sola do sapato.

(178) O Pedro martelou a cabeça da gente com aquela conversa chata.

(179) Aquela conversa chata ficou martelando na minha cabeça.

Nas sentenças acima, percebe-se que os sintagmas preposicionais adicionados têm, em sua estrutura, um substantivo modificado por um adjetivo, (176), pois uma sentença com uma combinação do tipo martelar com um martelo soaria redundante, (175), ou seja, as mesmas exigências de formação de um objeto cognato se aplicam ao adjunto cognato.

Podemos interpretar o fato de que sempre que temos o verbo martelar sozinho, ou seja, sem especificação do instrumento utilizado para martelar ou do que ficou martelando, como em (177) a (179), temos a formação do verbo passando pela formação do nome: (174). Quando martelo ou um instrumento cognato não é denotado 
no evento (picareta, por exemplo), admitimos uma interpretação que mantém somente o modo de realização do evento, contido na raiz martel-.

Nos dados acima, mantém-se o modo/maneira da atividade que se tem em uma interpretação canônica, mas com outro tipo de "instrumento". Isso pode indicar que o objeto que substitui o objeto canônico compartilha com ele propriedades que podem fazê-lo figurar na mesma situação de instrumento daquela ação, deixando-a inalterada. Vejamos que não seria comum dizer que alguém vai escovar os dentes com uma régua ou martelar com uma gelatina, a não ser que houvesse um contexto pragmático muito bem definido ${ }^{36}$. São sentenças que parecem ter uma natureza interpretativa diferente. São conhecidas como sentenças metafóricas no senso mais comum ${ }^{37}$.

O que é inesperado de alguma forma, e muito interessante de outra, é a possibilidade de esses substantivos, que possivelmente formaram os verbos, não serem denotados no evento descrito por esses verbos. Há outras evidências em verbos do português que não fazem parte da amostra principal.

(180) Esses caminhões estão me encaixotando/Os motoristas estão me encaixotando (com os caminhões)

(181) O rapaz foi encurralado pela situação.

(182) O supervisor engavetou (com aqueles gritos) os projetos dele, antes mesmo de ele terminar de explicar.

(183) A professora vive martelando aquela história de passar no vestibular (com conversas tediosas).

\footnotetext{
${ }^{36}$ Ana Paula Scher apontou que uma sentença como "Nossa, olha como a Maria deixou a cabeça do prego: parece que ela martelou com gelatina!" seria possível em um contexto em que o prego tivesse sido muito mal martelado.

${ }^{37}$ Estamos usando o termo metáfora com o sentido mais geral possível. Há uma extensa literatura sobre o tema que não iremos abordar neste trabalho (c.f. Lakoff \& Johnson, 1970; Lakoff, 1977). Por isso, não pretendemos sugerir um tratamento para esse fenômeno.
} 
No contexto da sentença em (180), em que o falante está no trânsito, dois caminhões se aproximam muito de seu carro, fazendo com que ele se sinta em uma posição que lembra uma caixa/caixote. Não há caixa "real" na situação de fala e nenhum ouvinte que estivesse fora ou dentro do contexto iria interpretar como se o falante realmente estivesse dentro de uma caixa por dois motivos: seres humanos não são usualmente colocados em caixas e caminhões não podem ser agentes dessa ação. Como o uso é metafórico, esses aspectos que corroborariam a interpretação estrita são minimizados e os aspectos relevantes, como a posição em forma de caixa em que os caminhões se colocam, são ressaltados.

Na sentença (181), certamente não há curral nenhum na situação. O rapaz sentiu-se encurralado porque não sabia que decisão tomar. Sentiu-se sem opções, sem alternativas, sem ter para onde ir e, assim, como algo que está preso em um curral.

No mesmo sentido, nenhum papel foi colocado dentro de uma gaveta na sentença em (182). Ideias foram expostas e não foram avaliadas positivamente, não foram aceitas. A recusa pelo supervisor significa algo como um engavetamento, um esquecimento ou desistência daqueles projetos.

Ainda, em (183), não há nenhum martelo presente na ação. A professora fala sempre a mesma história, repetidamente, assim como são repetidas as marteladas da atividade de martelar. O pastor que prega, não usa pregos e a família que "embarca no voo" não vê barcos.

Para as sentenças em que a atividade expressa pelo verbo é da mesma natureza que em uma sentença de interpretação estrita (martelar com o martelo, martelar com a picareta), o modo se mantém e há uma relação metafórica entre os instrumentos, o canônico e o "alternativo". Há duas maneiras de pensar a relação que existe entre esses instrumentos. A primeira é a de que martelo e picareta pertencem a uma categoria maior, a das ferramentas e, por isso, podemos usar tanto um quanto 
outro. A segunda nos diz que martelo e picareta compartilham de certas propriedades e, por isso, podem ser tomados um pelo outro. A primeira explicação funciona bem quando estamos comparando martelo e picareta, mas não da conta de explicar uma sentença estranha como (184) e outra aparentemente bem interpretada como (185):

(184) ? O Pedro martelou o prego com aquela pá. ${ }^{38}$

(185) Eu martelei o prego com a sola do sapato. ${ }^{39}$

O salto de um sapato não é uma ferramenta e não pertence à mesma classe que martelo, pelo menos no consenso da maioria das pessoas. Por outro lado, uma pá é uma ferramenta de jardinagem, mas não é instrumento facilmente usado para martelar, não se pode manter o modo da ação. Qualquer objeto que compartilhe minimamente alguma característica com um martelo pode ser usado para martelar, se assim for requerido pelo contexto. Para explicar esses casos, precisamos lançar mão de um conceito mais geral que diz que:

"MARTELAR É BATER DE MANEIRA X COM UM OBJETO Y, COMPATÍVEL COM A ATIVIDADE DE MARTELAR".

O objeto $Y$ deve ser compatível com a atividade de martelar. Ser compatível pode significar ser usado em lugar de um martelo, e assim, ser parecido, fazer as vezes de um martelo. O mesmo pode ser aplicado para as sentenças abaixo:

(186) É feio, é horrível, é ridículo remar com o pé da frente. (Scher, 2006)

\footnotetext{
${ }^{38}$ Essa sentença não foi submetida a julgamentos pelos falantes, pois não cabia no teste 6 .

${ }^{39}$ Essa sentença foi julgada como gramatical pelos falantes.
} 
"REMAR É MOVIMENTAR-SE DA MANEIRA X COM UM OBJETO Y, COMPATÍVEL COM A ATIVIDADE DE REMAR"

(187) Se não tiver jeito, guincho seu carro com minha caminhonete.

"GUINCHAR É PUXAR/ARRASTAR DA MANEIRA X COM UM OBJETO Y COMPATÍVEL COM A ATIVIDADE DE GUINCHAR"

(188) Você pode escovar os dentes do seu gato com o dedo para ele se acostumar.

"ESCOVAR É LIMPAR PELO MOVIMENTO X COM UM OBJETO Y COMPATÍVEL COM A ATIVIDADE DE ESCOVAR"

(189) Devemos pentear o cabelo com escova de cerdas macias naturais.

"ESCOVAR É ARRUMAR PELO MOVIMENTO X COM UM OBJETO Y COMPATÍVEL COM A ATIVIDADE DE PENTEAR"

Há um processo que mapeia a sentença conotativa em termos de um conceito mais geral nas sentenças em que os objetos compatíveis não são necessários. Vejamos a sentença (181), repetida abaixo. Nesse caso, a conotação é mais abstrata e geral e poderia ser colocada nos seguintes termos:

(190) O rapaz foi encurralado pela situação.

"ENCURRALAR É PRENDER/DEIXAR SEM SAÍDA". 
Da mesma forma, haveria, para as sentenças em (180) a (183), repetidas abaixo, conceitos mais gerais:

(191) Esses caminhões estão me encaixotando/Os motoristas estão me encaixotando (com os caminhões).

"ENCAIXOTAR É PRENDER/LIMITAR O ESPAÇO"

(192) O supervisor engavetou os projetos dele, antes mesmo dele terminar de explicar (com aqueles gritos).

"ENGAVETAR É ARQUIVAR/LIMITAR ACESSO"

(193) A professora vive martelando aquela história de passar no vestibular (com conversas tediosas).

\section{"MARTELAR É REPETIR"}

Finalmente, chegamos à seguinte conclusão. Parece haver duas derivações possíveis: uma para as sentenças com o verbo martelar em que há a denotação de um martelo (derivação denominal) e outra para as sentenças em que a denotação do martelo não é necessária, em que há somente manutenção do modo/maneira de realização da ação (derivação diretamente da raiz). Voltaremos a esse assunto nas seções de análise. 


\subsubsection{Conclusão da Subseção: verbos denominais sincrônicos}

Nesta seção, definimos qual o comportamento dos verbos denominais sincrônicos. Em suma, eles têm expressões perifrásticas com o nome formador, permitem adjuntos cognatos e somente uma minoria deles têm objetos cognatos. Sempre permitem a realização de adjuntos hipônimos, hiperônimos e semanticamente relacionados. Alguns desses verbos, instrumentais ou de maneira, podem ter uma derivação em que prescindem da presença do nome formador.

\subsubsection{Verbos "não denominais" sincrônicos: derivados da raiz}

\subsubsection{Agramaticalidade ou Indeterminação para Teste 3, 4, 5 e 6.}

Como dito, quanto maior a gramaticalidade de um verbo frente aos testes 3,4 , 5 e 6, mais ele se revela como denominal. Por outro lado, os verbos que apresentarem agramaticalidade para esses testes, em especial aqueles que apresentam agramaticalidade ou indeterminação para todos esses testes ao mesmo tempo ${ }^{40}$, mostram que não mantém mais relação com o substantivo formador. Os verbos acabar, arcar, arrumar, avaliar, brincar, casar, causar, concentrar, cruzar, desfrutar, faltar, apontar2 (indicar), traçar2 (definir), processar2 (processar dados) apresentaram esse comportamento, ou seja, são agramaticais para todos os testes realizados.

Vejamos que o teste com expressões perifrásticas com o nome cognato gera sentenças agramaticais para todos eles:

(194) *Ele pôs cabo no relatório. (acabar)

(195) *A empresa fez a arca com os custos. (arcar)

(196) *A comissão fez uma ponta das falhas. (apontar2)

\footnotetext{
40 Muitos verbos que não possuem objetos cognatos possuem expressões perifrásticas, adjuntos cognatos e adjuntos hipônimos e hiperônimos. Nesses casos, não é possível afirmar que são verbos nãodenominais somente por esse teste. Consideraremos o conjunto dos resultados.
} 
(197) *O bando fez uma causa a briga. (causar)

(198) *A professora fez uma boa valia dos alunos. (avaliar)

(199) *A Paula deu um rumo à casa. (arrumar)

(200) *O aluno fez uma falta à aula. (faltar)

(201) *O candidato fez um centro da maioria dos votos. (concentrar)

(202) *Ela fez uma cruz com o caminho. (cruzar)

(203) *O grupo não fez fruto da viagem. (desfrutar)

(204) *A criança fez brinco com o amigo. (brincar)

(205) *O técnico fez os traços da estratégia. (traçar2)

(206) ?O computador fez o processo dos dados. (processar2)

Nota-se que, apesar de não haver paráfrase possível com nenhum dos supostos nomes formadores, podemos ter paráfrases aceitáveis com as nominalizações desses verbos em alguns $\operatorname{casos}^{41}$.

(207) *A professora fez uma boa valia dos alunos. (avaliar)

(208) A professora fez uma boa avaliação dos alunos.

No mesmo sentido, a falta de relação entre nome e verbo é evidenciada pelo teste 4 de objetos cognatos, sentenças (209) a (220).

(209) *O bando causou uma causa estúpida.

(210) *A comissão apontou a ponta das falhas.

(211) *O grupo não desfrutou bons frutos da viagem.

(212) *O técnico traçou traços fortes da estratégia.

(213) *O aluno faltou três faltas esse ano.

\footnotetext{
${ }^{41}$.Nesses casos, a nominalização já passou por um estágio verbal, e, por isso, apresenta relação com o verbo. Não nos aprofundaremos nos detalhes desses fatos aqui.
} 
(214) *A criança brincou um brinco com o amigo.

(215) *O candidato concentrou um centro absoluto da maioria dos votos.

(216) *A Paula arrumou um rumo da casa.

(217) *A professora avaliou uma valia fraca. ${ }^{42}$

(218) *A empresa arcou a arca dos custos.

(219) *Ele acabou um cabo do relatório.

(220) *Ela cruzou uma cruz estreita com o caminho.

No teste 5 de adjuntos cognatos, para dois dos verbos não foi possível determinar a gramaticalidade por conta dos julgamentos divididos, para esses casos atribuímos o sinal "?", entendido aqui como indeterminação. Entretanto, para a maioria das sentenças pode-se constatar a agramaticalidade, o que corrobora os resultados dos testes anteriores, ou seja, a agramaticalidade nesses casos, só vem corroborar ainda mais a ausência desses nomes na formação dos verbos.

(221) *A empresa arcou com os custos com uma arca enorme.

(222) ?O técnico traçou a estratégia com traços precisos.

(223) * A comissão apontou as falhas com a ponta fina.

(224) *O grupo não desfrutou a viagem com bons frutos.

(225) ?O bando causou a briga por uma causa estúpida.

(226) *Ele acabou o relatório com um cabo grande.

(227) *O candidato concentrou a maioria dos votos com um centro absoluto.

(228) *O aluno faltou à aula com uma falta inesperada.

(229) *A criança brincou com o amigo com um brinco engraçado.

(230) *A Paula arrumou a casa com um rumo certo.

\footnotetext{
42 Houve um erro de formulação com relação a esse teste para o verbo avaliar. A sentença foi enviada aos falantes como "A Professora avaliou uma avaliação fraca", quando deveria ter sido formada com valia. Atribuímos a essa sentença o nosso julgamento de gramaticalidade.
} 
(231) *Ela cruzou o caminho com uma cruz estreita.

(232) *A professora avaliou os alunos com uma valia deficiente.

Vejamos que, novamente, como foi mostrado no teste de paráfrases, o nome não expressa mais relação semântica com o verbo. Contudo, nominalizações podem figurar como adjuntos cognatos. Esperamos o mesmo resultado no teste com Adjuntos hipônimos e hiperônimos.

(233) ? O Aluno faltou à aula esse ano com ausências inesperadas.

(234) A professora avaliou os alunos com um teste deficiente.

(235) O bando causou a briga por um motivo estúpido.

(236) * A empresa arcou com os custos com uma navegação enorme.

(237) * A Paula arrumou a casa com um caminho caprichado.

(238) * O candidato concentrou a maioria dos votos com um meio absoluto.

(239) - impossível formular teste para o verbo cruzar.

(240) - impossível formular teste para o verbo desfrutar.

(241) *A criança brincou com o amigo com um adereço engraçado.

(242) *O técnico traçou a estratégia com riscos fortes.

(243) * A comissão apontou as falhas com um bico exagerado.

(244) * Ele acabou o relatório com uma ponta grande.

O adjunto metafórico em que há um nome que compartilhe propriedades semânticas com o suposto nome formador não é possível na grande maioria dos casos. Entretanto, na sentença (234) o teste foi formulado com o nome teste como cognato de hipônimo ou hiperônimo para valia, o que constitui um erro. Nesse caso, o resultado não deve ser considerado. A sentença (235) também se mostrou gramatical com o nome motivo. No geral, esse teste parece endossar os anteriores. 


\subsubsection{Conclusão da subseção: verbos não-denominais}

Concluímos, e mostraremos em nossa análise, que os verbos acabar, arcar, arrumar, avaliar, brincar, casar, causar, concentrar, cruzar, desfrutar, faltar, apontar2 (indicar), traçar2 (definir) e processar2 (processar dados) não devem compor estruturas com um estágio nominal com o suposto nome formador com base nos resultados dos testes $3,4,5$ e 6 . Para eles, sugeriremos formações a partir da raiz.

\subsubsection{Diferenças estruturais}

Enquanto os testes 3, 4, 5 e 6 revelam principalmente informações sobre a relação entre nome e verbo, os testes 1 e 2 têm a principal função de indicar qual o tipo de estrutura argumental que um verbo possui, podendo, através dessa informação, mostrar indícios também sobre a relação nome e verbo.

\subsubsection{Verbos Alternantes: Alternância Causativo-Incoativa}

Os verbos que permitem a alternância causativo-incoativa são embarcar, assustar, fechar, acabar, amanhecer, estrear, cristalizar, valorizar, colar e marcar. Todos os outros verbos mostraram-se agramaticais ou indeterminados.

(245) A mercadoria embarcou.

(246) A criança assustou.

(247) A porta fechou.

(248) O relatório acabou.

(249) O dia amanheceu.

(250) A série Alice estreou.

(251) O açúcar cristalizou. 
(252) O real valorizou.

(253) O caderno colou.

(254) Minha roupa marcou (com o cinto de segurança).

\subsubsection{Verbos Alternantes: Alternância Média.}

Os verbos que participam de alternância causativo-incoativa também participam de alternância média, e alguns outros além desses. São eles os verbos embarcar, amanhecer, escovar, pesquisar, selar, filtrar, apontar2, empacotar, agendar acabar, valorizar, assustar, fechar, cristalizar, processar2, agrupar, modelar, estrear, colar, marcar, registrar, arrumar, enfeitiçar, encurralar e misturar ${ }^{43}$. Todos os outros verbos mostraram-se agramaticais ou indeterminados.

(255) Mercadoria organizada embarca fácil.

(256) O dia amanhece rapidamente em João Pessoa.

(257) Cabelo liso escova fácil.

(258) Voluntários dispostos pesquisam rápido.

(259) Cavalo manso sela rápido.

(260) Água limpa filtra rápido.

(261) Lápis bom aponta fácil.

(262) Doce quente não empacota bem.

(263) Reunião urgente agenda rápido.

(264) Relatório de aula acaba rápido.

(265) O real valoriza bem.

(266) Criança pequena assusta fácil.

(267) Porta sanfonada não fecha fácil.

43 Não iremos nos aprofundar aqui nos motivos que fazem com que esses verbos tenham as características de alternância causativo-incoativa Utilizaremos esses resultados para propor estruturas. Para detalhes sobre a natureza alternante desses verbos, v. Kato, 1999, 2000; Bowers, 2002, Bassani, 2008. 
(268) Açúcar de confeiteiro cristaliza rápido.

(269) Poucos dados processam rápido.

(270) Os times agruparam bem.

(271) Peça de cerâmica modela bem.

(272) Boas séries estréiam sempre.

(273) Caderno de folha boa cola fácil.

(274) Roupa de seda marca fácil.

(275) Compras com código de barras registram rápido.

(276) Casa pequena arruma rápido.

(277) Rapaz jovem enfeitiça fácil.

(278) Boi bravo não encurrala rápido.

(279) Ingredientes naturais misturam fácil.

Alguns dos verbos que participam de alternância média são os verbos considerados por H\&K (2002) como verbos do tipo location ou locatum (destacados em negrito acima). Esses verbos têm formas perifrásticas prototípicas com verbos em colocar $x$ em $\sqrt{ }$ (colocar o papel na gaveta), e colocar $\sqrt{ }$ em $x$ (colocar sela no cavalo) ou fazer $x$ ficar com y (fazer o cavalo ficar com a sela), respectivamente.

\subsubsection{Verbos com dois sentidos: dois verbos?}

Três verbos selecionados na amostra apresentavam duas acepções bem distintas e igualmente produtivas. Por isso, os registramos inicialmente com dois índices, como fazem muitas teorias lexicalistas. Os verbos apontar com sentido de fazer ponta (apontar1) e indicar (apontar2) e de; processar, com sentido jurídico (processar1) e da informática (processar2) e traçar, com sentido de fazer traços (traçar1) e de definir (traçar2). Os testes realizados corroboram de forma muito 
interessante a distinção entre os dois tipos de interpretação dos verbos apontar, traçar e processar. Vejamos os resultados dos testes:

\section{Apontar1}

(280) O aluno apontou o lápis.

(281) ?O lápis apontou.

(282) Lápis bom aponta fácil.

(283) O menino (re)fez a ponta do lápis.

(284) O menino apontou a ponta (quebrada) do lápis.

(285) O menino apontou o lápis com a ponta fina.

(286) O menino apontou o lápis com um bico exagerado.

Apontar2

(287) A comissão apontou falhas no projeto.

(288) *As falhas apontaram.

(289) *Falhas grotescas apontam fácil.

(290) *A comissão apontou a ponta das falhas.

(291) *A comissão fez uma ponta das falhas.

(292) * A comissão apontou as falhas com a ponta fina.

(293) *A comissão apontou as falhas com um bico exagerado.

Para o verbo apontar1 com sentido de fazer ponta no lápis, em que há relação com o nome formador, todos os testes apresentam gramaticalidade, mostrando a relação de denominalidade $((280)$ a (286)). Por outro lado, para apontar2 com sentido de indicar não mantém mais relação com o nome formador e, por isso, não pode ser considerado denominal, o que é corroborado pela agramaticalidade dos testes de 
(287) a (293). Os testes para traçar seguem no mesmo sentido, com algumas nuances de julgamento.

Traçar1

(294) O desenhista traçou o desenho no papel.

(295) *O desenho traçou no papel.

(296) ? Desenho simples traça rápido.

(297) O desenhista fez os traços do desenho no papel.

(298) O desenhista traçou traços fortes no papel.

(299) O desenhista traçou o desenho no papel com traços fortes.

(300) O desenhista traçou o desenho no papel com riscos fortes.

Traçar2

(301) O técnico traçou a estratégia.

(302) *A estratégia traçou.

(303) ?Estratégia simples traça rápido.

(304) ?O técnico fez os traços da estratégia.

(305) ?O técnico traçou traços fortes da estratégia.

(306) ?O técnico traçou a estratégia com traços precisos.

(307) ?O técnico traçou a estratégia com riscos fortes.

Para processar1, há mais indícios de relação entre processar e processo (gramaticalidade para testes 3, 5 e 6 ). Para processar2 (da informática), realmente parece haver menor indício de relação entre o verbo processar e o nome processo, mas essa relação poderia se estabelecer com processamento, o nome usual para a entidade de "processar dados".

Processar1 
(308) O funcionário processou o chefe.

(309) ?O chefe processou. ${ }^{44}$

(310) ?Chefes corruptos processam rápido.

(311) O funcionário pôs um processo no chefe.

(312) *O funcionário processou um processo contra o chefe.

(313) O funcionário processou o chefe com um processo pesado.

(314) O funcionário processou o chefe com uma ação pesada.

\section{Processar2}

(315) O computador processou os dados.

(316) ?Os dados processaram. ${ }^{45}$

(317) Poucos dados processam rápido.

(318) ?O computador fez o processo dos dados. ${ }^{46}$

(319) O computador processou um processo lento dos dados.

(320) ?O computador processou os dados com um processo lento ${ }^{47}$.

(321) O computador processou os dados com uma rodada lenta.

Mostraremos na seção de análise que não é necessário que se assuma que há dois verbos diferentes para esses casos. É possível explicar tais diferenças estruturais ou de estrutura argumental se assumirmos que em um dos sentidos há uma etapa nominal antes da formação do verbo (fazer ponta, fazer traço, colocar processo) e em

\footnotetext{
44 Apesar de ser estatisticamente indeterminado, na contagem, a maioria de respostas foi de agramaticalidade.

45 Apesar de ser estatisticamente indeterminado, na contagem, a maioria de respostas foi de gramaticalidade.

46 Apesar de ser estatisticamente indeterminado, na contagem, a maioria de respostas foi de gramaticalidade.

47 Apesar de ser estatisticamente indeterminado, na contagem, a maioria de respostas foi de agramaticalidade.
} 
outro não, esse verbo é formado diretamente da raiz (indicar, definir, processar dados).

\subsection{Conclusão da seção}

Nesta seção, apontamos as generalizações decorrentes dos testes. Em suma, há um grupo para os quais os testes indicam uma etapa nominal (gramaticalidade para testes $3,(4), 5,6)$ e um outro grupo para os quais os testes não indicam a presença de uma etapa nominal na formação (agramaticalidade para testes 3,5,6). Há verbos que participam e não participam de alternâncias (gramaticalidade e agramaticalidade para testes 1 e 2) e, por fim, há um grupo de verbos em que uma acepção remete a uma etapa nominal e outra acepção remete a ausência de etapa nominal. Nas análises, deveremos tratar cada acepção desses verbos em um grupo diferente. Após selecionar os dados e descrevê-los, tentaremos analisá-los em busca de uma explicação para as generalizações encontradas e, por fim, tentaremos chegar a algum tipo de previsão quanto ao comportamento dos VDs no PB. 


\section{POR QUE AS REGRAS NÃO FUNCIONAM?}

\subsection{Morfologia Lexical}

A Morfologia Lexical, filiada aos estudos de gramática gerativa, tem como interesse estudar a competência lexical do falante em formar, reconhecer e julgar a aceitabilidade de palavras de sua língua.

O léxico mental do falante é, nesse modelo, o local de estoque de unidades lexicais. Essas unidades lexicais são bases e afixos, definidos como morfemas da língua que ficam armazenados e se relacionam de forma peculiar no léxico. 0 componente lexical possui, além das bases e afixos, processos que permitem a união desses itens e a formação de palavras da língua, com as quais a sintaxe opera, formando sentenças a partir de outros processos particulares da sintaxe.

O interesse dos estudiosos em morfologia lexical está em descrever o conhecimento do falante que o torna capaz de entender a estrutura e a constituição das palavras e seu inter-relacionamento semântico-formal, de formar palavras novas na língua e saber que elas são aceitáveis, ao mesmo tempo em que sabem que certas formações de palavras são impossíveis e são de certa maneira bloqueadas. (Sandmann, 1992:12).

Em Basílio (1996), são sugeridas estruturas que subjazem as formações lexicais do português. Segundo a autora, o conhecimento lexical do falante nativo inclui:

a. Conhecimento de uma lista de entradas lexicais - itens formados;

b. Conhecimento da estrutura interna dos itens lexicais, assim como relações entre os vários itens;

c. Conhecimento subjacente à capacidade de formar entradas lexicais novas, desde que sejam pertencentes à língua. 
De posse desses conhecimentos, o falante pode fazer uso de regras disponíveis em seu léxico mental.

Sobre as regras Sandmann (1978) afirma que:

"Por regras, se entenderão, por outro lado, os vários conjuntos de regularidades ou constâncias das unidades abstraíveis que compõem atual ou potencialmente o léxico" (p. 2).

As regras contidas no léxico podem ser Regras de Formação de Palavras (RFP), Regras de Análise Estrutural (RAE) e Regras de Redundância Lexical (RRL) ${ }^{48}$.

As RFPs são aquelas que permitem ao falante formar palavras novas na língua a partir de material pré-existente. Já as RAEs são as que permitem ao indivíduo analisar a estrutura de palavras morfologicamente complexas e, ainda, as RRLs são quaisquer regras que expressem relações sistemáticas entre palavras e conjuntos de palavras no léxico. As RFPs e as RAEs são as mais relevantes para este trabalho.

\subsubsection{Os VDs em uma análise baseada em regras de formação}

Em um modelo lexicalista, a formação de um verbo a partir de uma base substantiva se dá por meio de uma RFP do tipo da apresentada por Basílio (1993) e reproduzida de forma adaptada, como mostrada abaixo:

$$
\left.[\mathrm{X}]_{\mathrm{s}} \rightarrow[\mathrm{X}]_{\mathrm{s}} \mathrm{a}\right]_{\mathrm{V}}
$$

(323) $[X]_{s} \rightarrow\left[\text { pref }[X]_{s} \text { a }\right]_{v}$

As regras em (322) e (323), em linhas gerais, podem ser lidas da seguinte forma: a uma base substantival, adiciona-se uma vogal temática e um sufixo verbal

\footnotetext{
${ }^{48}$ A analogia, outro processo de formação de palavras, não constitui uma regra estrutural. (Sandmann, 1976).
} 
para que se tenha como resultado um verbo complexo. O mesmo ocorre com a formação parassintética, com a diferença de que há um a prefixação de um morfema ao mesmo tempo em que o sufixo é adicionado. Dessa forma, toda a classe dos VDs, com toda sua heterogeneidade, fica restrita morfossintaticamente a dois tipos, considerando-se seu processo de formação.

Além disso, a autora assume que a formação de VDs deve estar relacionada a um processo derivacional, como os apresentados nas regras (322) e (323) acima, mas deixa claro que a questão não está definitivamente resolvida.

A pergunta que se coloca é se a formação de VDs ocorre em nível derivacional, por formar novos verbos a partir de substantivos, ou em nível flexional. Esse impasse certamente só existe em um modelo que faz uma distinção severa entre morfologia derivacional e flexional, entre processos inerentes ao léxico e processos inerentes à sintaxe.

Corroborando a visão lexicalista fraca, em que há real distinção entre operações do léxico e operações da sintaxe, Basílio (1996) defende que a extrapolação de processos sintáticos para a descrição de processos de formação de palavras dificulta o desenvolvimento de estudos de cunho lexical propriamente dito. A afirmação quer defender a separação entre léxico e sintaxe e argumentar contra uma abordagem transformacionalista de formação de palavras, nos moldes de Lees (1960).

Os lexicalistas, defensores da existência das regras lexicais, apontam como argumento contra a adoção dos mesmos princípios para gerar palavras e sentenças o fato de haver lexicalização de palavras após sua formação versus a impossibilidade de lexicalização de sentenças:

"palavras, contrariamente a sentenças, são formadas e passam normalmente a integrar um acervo ou estoque da língua chamado léxico, o qual á atualizado cada vez que o falante faz uso da língua. 
Como em geral o falante se serve de unidades lexicais usuais já incorporadas ao patrimônio e apenas raramente aciona sua competência lexical para formar vocábulos novos, a formação nova desperta, com maior ou menor intensidade, como se verá abaixo, a sensação de novidade, o que não acontece comumente com a sentença, que é, a rigor, sempre nova, pois não é memorizada ou estocada." (Sandmann, 1978:7)

Sandmann (1978), citando Aronoff (1976), corrobora a visão sobre a distinção entre regras do léxico e regras da sintaxe:

"we can think of them as once-only rules. They are thus different from the rules of the syntax and the phonology which must apply in the derivation of every sentence". (Aronoff, 1976 apud Sandmann, 1978) ${ }^{49}$

Considerando-se as devidas modificações, ainda hoje, a discussão sobre a natureza dos processos de formação de palavras e sentenças, se são os mesmos ou se são diversos, permanece viva. Neste trabalho, iremos argumentar por um tratamento uniforme para formação de palavras e sentenças, em que ambos processos ocorrem no nível sintático.

\subsection{Os dados do PB e as RFPs}

Considerando a heterogeneidade dos dados encontrados em nossa amostra, parece óbvio que as regras de formação não podem dar conta da riqueza dessa classe. Esse tratamento deixa a desejar tanto em termos descritivos quanto em termos

\footnotetext{
49، Podemos pensá-las como regras de única aplicação. Elas são diferentes então das regras da sintaxe e da fonologia que devem se aplicar na derivação de toda sentença". (Tradução nossa).
} 
explicativos. Em nossa amostra, encontramos padrões de formação distintos, que parecem indicar diferentes tipos de VDs, que parecem ter diferentes estruturas.

Uma regra de formação de palavras que tem escopo principal sobre a mudança de categoria pré-estabelecida no léxico e que diz, de forma geral, "ligue um substantivo a um sufixo verbal e forme um verbo denominal" não é capaz de explicitar por ela mesma as particularidades de cada uma das classes de verbos e nem tem poder de distinguir verbos denominais sincrônicos de verbos derivados diretamente da raiz.

As regras não conseguem explicitar, por exemplo, a diferença entre um verbo como martelar e um verbo como cristalizar. Eles seriam igualmente descritos pela mesma RFP mas por diferentes sufixos. No entanto, já vimos até o momento que, com relação à estrutura argumental, um verbo como cristalizar permite uma alternância causativo-incoativa do tipo A fábrica cristalizou o açúcar/O açúcar cristalizou, ao passo que o verbo martelar não permite essa alternância: Eu martelei o prego/*O prego martelou. Além disso, as regras não esclarecem nada sobre o modo de realização presente em verbos como martelar, mas não em verbos como cristalizar, que parecem apresentar mais uma mudança de estado, aproximando-se da classe chamada de deadjetival.

Nesse modelo, teríamos a seguinte descrição e explicação extremamente simplória para os verbos martelar e cristalizar:

(324) [martelo $]_{\mathrm{s}} \rightarrow[\text { [martelo }]_{\mathrm{s}}$ a $]_{\mathrm{v}}=$ martelar

(325) ${ }^{*}[$ cristal] $\mathrm{s} \rightarrow[$ [cristal] s [iz]a] $\vee=$ cristalizar

Por fim, verbos como martelar seriam sempre considerados como derivados do nome, o que não parece ser o caso. 
No que cerne às formações parassintéticas, podemos dizer que a natureza do prefixo também é relevante na formação, comportando-se de diversas formas, mas na regra, todos os prefixos têm o mesmo estatuto. O prefixo de um verbo parassintético pode ter um estatuto de preposição verdadeira, ocorrendo abertamente em expressões perifrásticas do verbo, ou pode ter simplesmente um estatuto de prefixo. Em engavetar, por exemplo, o prefixo é uma preposição que seleciona argumentos, como revela a paráfrase colocar em gaveta. Por outro lado, temos casos como enfrentar, também uma formação tida como parassintética, em que não é óbvio que o prefixo en- seja a preposição em. A paráfrase para enfrentar seria "fazer frente a" e, nesse caso, o prefixo en- não se revela como preposição.

A diferenciação somente em termos de ser sufixal ou parassintético não é suficiente para tratar os VDs. A impossibilidade de diferenciar tipos de VDs, especialmente estruturais, por meio das regras de formação nos leva a descartá-las e querer investigar se uma proposta morfossintática pode apresentar as ferramentas necessárias para analisar e compreender a natureza dessas formações com mais detalhes do que um modelo lexicalista baseado em regras. 


\section{ALTERNATIVAS DE ANÁLISE}

6.1. A sintaxe lexical de Hale \& Keyser (2002)

\subsubsection{A proposta de Hale \& Keyser (2002)}

Apresentaremos, nesta seção, a proposta de estrutura argumental de Hale e Keyser (2002) e sua relação com a formação e, principalmente, identificação de VDs de um ponto de vista sintático. Primeiramente, devemos dizer que H\&K (2002) é uma proposta desenvolvida a partir do texto de Hale \& Keyser (1993). No entanto, o texto de 2002 apresenta diferenças importantes em relação àquele.

Diz-se que o modelo é híbrido porque, assim como a morfologia lexical, ele prevê a existência de um léxico gerativo, mas, assim como a MD, acredita que palavras são formadas pelas mesmas operações que formam sentenças. Passemos à observação desse modelo.

\subsubsection{O modelo de Estrutura Argumental}

H\&K apresentam um modelo teórico que pretende apreender as possíveis estruturas argumentais de qualquer tipo de verbo em qualquer língua. A grande inovação desse modelo está em que os autores acreditam que o comportamento de determinados verbos pode ser explicado pelo seu tipo de estrutura argumental. Entende-se por estrutura argumental as configurações sintáticas e/ou estruturais projetadas por um item lexical.

Nesse modelo, a semântica, a sintaxe, a morfologia e a fonologia estão todas relacionadas na determinação de que tipo de estrutura argumental o item lexical irá projetar.

Em geral, os itens lexicais que projetam uma estrutura sintática são os verbos, ou outros itens mediados por verbos, como veremos adiante. 
O método utilizado para identificar diferentes tipos de estruturas argumentais é constituído principalmente por testes de alternância. Após realizar testes de alternância causativo-incoativa e de alternância média em dados de diversas línguas, de diferentes famílias linguísticas, como o Inglês (Germânica), Navajo (Athabaskan), Ulwa (Misumalpan), O'odham e Hopi (Uto-Asteca), H\&K chegam a quatro estruturas argumentais possíveis para explicar a projeção de um item lexical nuclear por meio de operações sintáticas. (Para esclarecimentos sobre os testes, v. seção 3.7.1.

É preciso notar que H\&K assumem que não só palavras "plenas" ${ }^{50}$, como verbos e preposições, podem definir e projetar uma estrutura argumental, mas também raízes acategoriais. Um exemplo de verbo que se forma a partir da projeção de uma raiz sem categoria definida é dado na estrutura (6) do texto de H\&K e reproduzida em (326) abaixo:

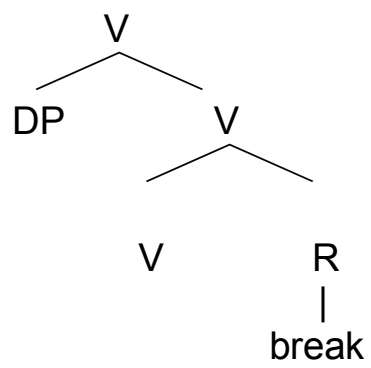

Ainda, a ideia de que a estrutura argumental de um item lexical não é necessariamente determinada pela categoria gramatical desse item é uma das diferenças entre Hale \& Keyser (2002) e Hale \& Keyser (1993). No texto de 1993, a projeção das estruturas estava ainda vinculada à categoria do item lexical, ao passo que na versão mais recente assume-se que qualquer categoria pode em princípio figurar nas quatro estruturas argumentais propostas para as línguas do mundo.

\footnotetext{
${ }^{50}$ Palavras plenas são, para H\&K, palavras que não precisam ser fonologicamente complementadas por uma base para que se constituam como palavras realmente, ou seja, não são itens defectivos, como os afixos, por exemplo. Para eles, exemplos de palavras plenas são nomes como laugh ou dance.
} 
Essas estruturas recebem o seu nome de acordo com o número de argumentos que o núcleo pode tomar, sejam eles complementos ou especificadores. As relações Núcleo-complemento e Especificador-Núcleo-Complemento são suficientes para definir as funções semânticas dos itens na estrutura, ou seja, nesse modelo, talvez seja possível afirmar que se pode prescindir da atribuição de papeis temáticos em favor de relações estruturais motivadas pela semântica dos itens. Vejamos cada estrutura com mais detalhe:

\section{a. Estrutura Argumental Monádica}

(327) Núcleo<smiles>O=[W]NCCCO</smiles>

Os autores apontam que, em inglês, verbos inergativos formados a partir de uma raiz ou de um nome são, frequentemente, representados por estruturas monádicas. Ainda, expressões analíticas, como make a fuss abaixo, e verbos transitivos simples, como kick, parecem compartilhar a mesma estrutura.

328)

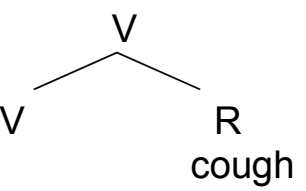

330)

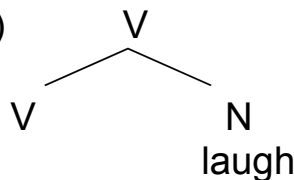

(329)

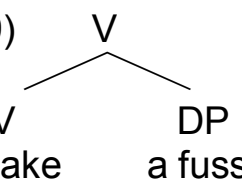

331)



É importante notar que, nas estruturas acima, temos apenas aqueles argumentos que são projetados no léxico por operações sintáticas. Outros argumentos não presentes nessas estruturas, como o especificador de make a fuss ou kick the ball, são introduzidos na sintaxe. 
A estrutura Monádica Básica cobre aqueles verbos monoargumentais que a literatura denominou de Inergativos. O núcleo lexical dessas estruturas projeta apenas uma posição de complemento e, por isso, elas são monoargumentais. No que cerne aos testes de alternância, essas estruturas não podem ser transitivizadas automaticamente e nem participam da alternância média. Só podem receber um argumento externo, agente ou causador, na sintaxe, fora da estrutura argumental.

(332) The engine coughed (O motor tossiu)

(333) *I coughed the engine. ( ${ }^{*} \mathrm{Eu}$ tossi o motor)

(334) He made a fuss (Ele fez uma bagunça)

(335) *A fuss makes easily (*Uma bagunça faz fácil)

\section{b. Estrutura Argumental Diádica Básica}

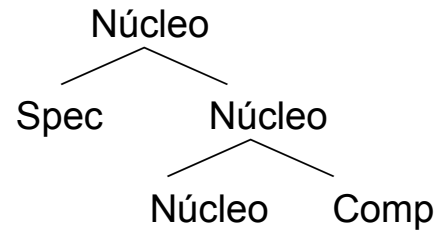

Essa estrutura tende a representar a categoria Preposição no inglês:
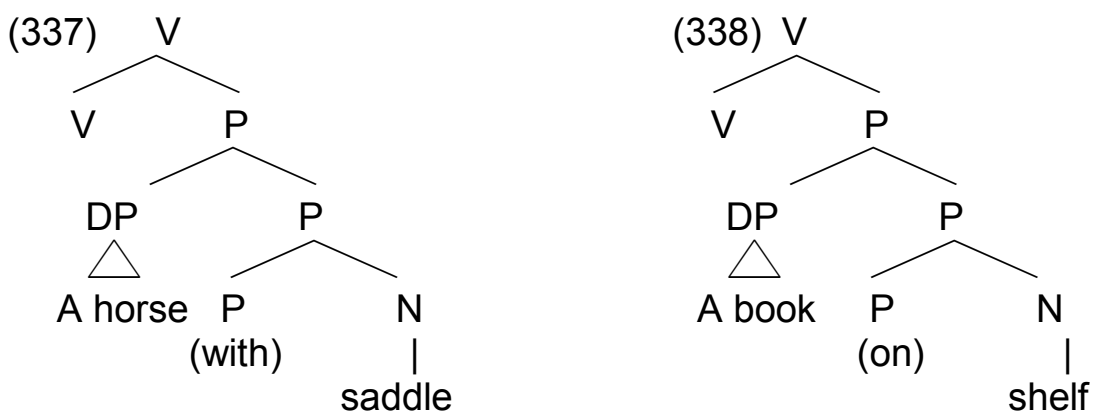

Nas estruturas em (337) e (338), o núcleo é uma preposição que toma como complemento um substantivo e como especificador um sintagma nominal. Essas 
estruturas podem ser chamadas também de depreposicionais, por terem como núcleo uma preposição que toma um núcleo nominal como seu complemento e, ainda, são conhecidas como denominais, justamente porque são derivadas, de algum modo, de um nome. É fato que preposições funcionais expressam uma relação e, por isso, pedem saturação de argumentos, projetando assim uma estrutura argumental. Essas estruturas participam da alternância média:

(339) I shelved those small books. (Eu emprateleirei aqueles livros pequenos)

(340) Small books shelf easily. (Livros pequenos emprateleiraram fácil)

(341) He saddled a quarter horse. (Ele selou um cavalo de corrida)

(342) A quarter horse saddles easily. (Cavalo de corrida sela fácil)

Verbos como os de (339) a (342) são chamados de VDs do tipo location/locatum. Os verbos como shelf têm a semântica de "colocar algo em algum lugar" e por isso são chamados de location. Já os verbos como saddle têm semântica de "fazer algo ficar com alguma coisa", locatum. Assim, em princípio, esses verbos podem ter formas analíticas, como em "put the books on the shelf" e "get the horse with a saddle", em que não haveria a operação de conflation entre os núcleos, como veremos com mais detalhes adiante.

\section{c. Estrutura Argumental Diádica Composta}

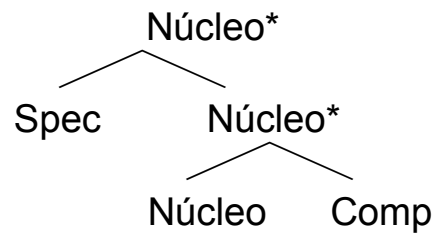

O asterisco indica que há uma diferença entre a estrutura Diádica Composta e a estrutura Diádica Básica. A diferença está em que, na Diádica Composta, o núcleo "hospedeiro" projeta um especificador por exigência de seu complemento (break, por 
exemplo, em (344)). Naquela estrutura, diádica básica, é o próprio núcleo que exige e projeta o seu especificador (with ou on) em (337) e (338)). A Diádica Composta tende a se realizar com a categoria de Adjetivo em inglês, mas não exclusivamente:

$(344)$

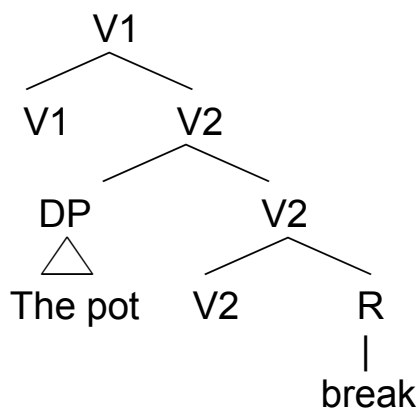

(345)



A estrutura diádica composta compreende a classe dos verbos inacusativos alternantes da teoria gerativa padrão. Muitos trabalhos em teoria gerativa padrão assumem que, nas alternâncias causativo-incoativas, haveria um processo de intransitivização a partir de um verbo transitivo (cf. Burzio, 1986, para uma das primeiras e célebres análises desse tipo $)^{51}$. Contrariamente a essa tendência, H\&K apresentam argumentos para que se assuma a forma intransitiva (inacusativa) do verbo como a primitiva. Evidências surgem da morfologia de línguas como o O’odham, que tem uma adição de morfologia ao verbo em sua forma transitiva. Em (346) e (347) abaixo, há exemplos com os verbos hu:m (esvaziar) e ha:g (derreter). Apresentamos a forma mais simples, intransitiva e, sem seguida, a forma transitiva com adição da morfologia $-i d .^{52}$

(346) hu:m > hu:mid (Esvaziar)

(347) ha:g > há:gid (Derreter)

\footnotetext{
${ }^{51}$ Burzio (1986) sugere uma transformação sintática em que o verbo deixa de atribuir função temática ao seu argumento na posição de sujeito, detematizando-o. Assim, esse mesmo verbo não poderá atribuir Caso ao seu objeto direto, que se move para a posição de sujeito e recebe lá o seu Caso, tornando-se visível para a interpretação. Essa é a chamada Generalização de Burzio.

${ }^{52}$ Apresentamos esses dois casos apenas como ilustração. Para um paradigma mais completo dos verbos desse tipo em O'odham, cf. Hale \& Keyser, 2002: 132, ex. (47). Grifo nosso.
} 
Os verbos de estrutura diádica composta sofrem o que é chamado de Transitivização automática, isto é, têm, em sua estrutura primária, uma posição para um possível especificador do núcleo transitivizador V1. Em outras palavras, por terem um especificador projetado por V2, abrem a possibilidade de serem transitivizados por V1. Eles permitem que o especificador de V2 funcione como objeto de $\mathrm{V} 1$, já que receberá caso acusativo de V1. Vejamos a estrutura abaixo:

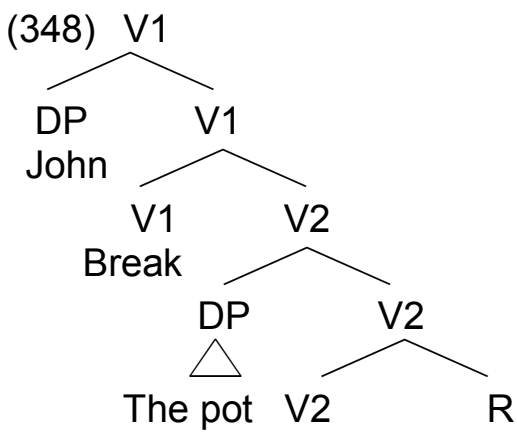

Vejamos que a estrutura em (348) tem dois núcleos básicos: uma raiz e um verbo que seleciona essa raiz. Ainda, a adição de um V1 permite a inserção de um novo especificador.

As estruturas desse tipo participam da alternância causativo-incoativa, bem como da alternância média:

(349) I broke the pot. (Eu quebrei o pote)

(350) The pot broke. (O pote quebrou)

(351) The pot breaks easily. (O pote quebra fácil)

(352) The screen cleared. (A tela clareou)

(353) I cleared the screen. (Eu clareei a tela)

(354) The sky clears easily. (O céu clareia fácil) 


\section{d. Núcleo}

Por fim, há uma estrutura com apenas um núcleo que não projeta estrutura argumental. Para o inglês, e para a maior parte das línguas do mundo, o núcleo caracteriza um nome não argumental. Como exemplos simples em português, teríamos nomes como mesa ou flor, não-predicativos.

\subsubsection{A operação Conflation ${ }^{53}$}

Outra peculiaridade do modelo de H\&K é a postulação da operação de conflation, definida, em termos gerais, como a fusão de núcleos sintáticos, em um primeiro momento, e em seguida definida como a fusão da assinatura-p ( $p$-signature ${ }^{54}$ ) de núcleos sintáticos. Em termos mais gerais, pode-se dizer que conflation é cópia e fusão da matriz fonológica de um núcleo em outro núcleo fonologicamente deficiente.

Essa operação faz-se necessária para explicar casos em que um complemento se "incorpora/funde" a um núcleo fonologicamente deficiente. Por fonologicamente deficiente, entenda-se núcleos vazios ou afixais. Assim, conflation é, na base, uma operação com motivações fonológicas e morfológicas, mas de natureza sintática. Vejamos concretamente em que casos conflation ocorre:

(355) The sky turned red. (O céu ficou/tornou-se vermelho)

(356) The sky reddened. (O céu (se) avermelhou)

No processo de formação de verbos a partir de adjetivos em inglês, o adjetivo ganha uma morfologia afixal -en, como vemos nos dados acima. Essa morfologia afixal nada mais é do que a realização fonológica do núcleo verbal que sofreu

\footnotetext{
${ }^{53}$ Não traduziremos conflation, pois a tradução mais adequada seria fusão, termo que já é utilizado em Morfologia Distribuída.

54 P-signature é definida como o conjunto de informações fonológicas inscritas no rótulo (Label) de um núcleo sintático $\mathrm{X}$. Entende-se por rótulo o conjunto de traços fonológicos, morfológicos, sintáticos e semânticos de um núcleo.
} 
conflation com o adjetivo. Na representação estrutural em (357), os núcleos sintáticos adjetival (red) e verbal (turn) são fonologicamente plenos e, assim, não há motivação para a ocorrência de conflation. A possível estrutura para (355) encontra-se em (357) e as estruturas para (356) estão em (358)/(359). Essas duas últimas estruturas apresentam a operação de conflation ocorrendo. Como há um núcleo defectivo -en em (358), há motivação para que o complemento red se mova para junto dele. A assinatura-p do núcleo adjetival, que é $\{r e d\}$, é copiada e fundida com a assinatura-p do núcleo verbal defectivo $\{$-en\}.

(357)

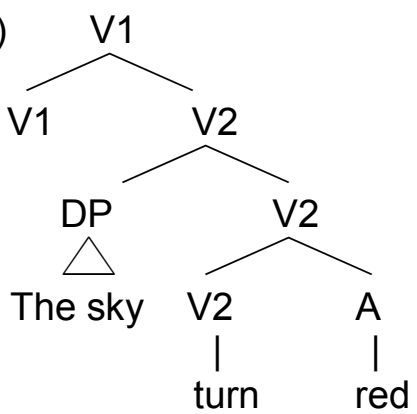

(358)

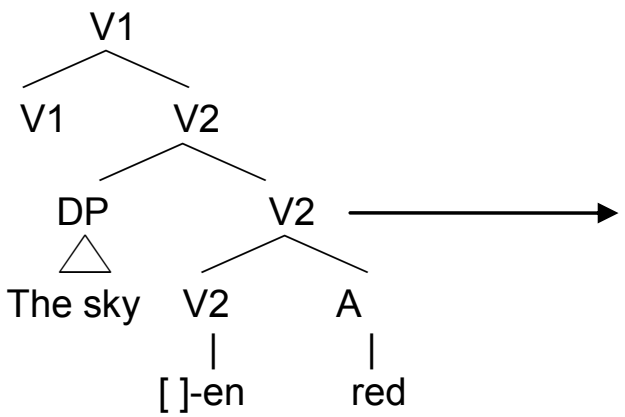



É possível encontrar bons exemplos em que conflation se aplica a núcleos fonologicamente defectivos em línguas indígenas apresentadas por H\&K. Vejamos a estrutura da língua O'odham reproduzida em (360), abaixo. 
(360)



Em (360), para que se forme o verbo de função aplicativa "construir casa para X" é preciso que ocorra conflation dos núcleos. O verbo complexo, que tem a semântica de "construir casa" só é possível pela incorporação dos elementos. Após passar de N, para V2 e então para V1, há um lugar, o especificador de V2, para a introdução do argumento "para X", completando assim a estrutura complexa do verbo.

Dizemos que conflation é motivada morfo-fonologicamente porque só ocorre com núcleos defectivos, tais como o núcleo afixal verbal -en acima e núcleos vazios, como aqueles presentes nas derivações zero de VDs do inglês: dance - dance, crycry, etc. A fusão dos núcleos sintáticos via conflation resultará em um item lexical ${ }^{55}$. A fusão de itens lexicais completos, não defectivos, é definida em termos de incorporação, uma operação às vezes confundida com conflation, mas de natureza diferente. ${ }^{56}$

Apesar das motivações morfo-fonológicas, H\&K afirmam que conflation é uma operação de natureza sintática. Assumem que conflation é um concomitante de merge e, ainda, que obedece a restrições sintáticas:

"We would like to take seriously the idea that conflation is a concomitant of merge, the operation that is fundamental in defining the projection of syntax from the lexicon. We expect that a proper understanding of

\footnotetext{
55 Em alguns casos, é preciso mais de uma realização de conflation para que se obtenha o item lexical completo, como ocorre com a formação de versões transitivas de verbos deadjetivais, em que há fusão de $A$ com V1 e de V1 com V2.

${ }^{56}$ Para uma exploração das diferenças entre incorporação e conflation Cf. H\&K (2002), especialmente capítulos 3 e 8.
} 
conflation's relationship to merge will lead automatically to an explanation of the constraints that govern it. To say that conflation is a concomitant of merge is to say that it is in some intimate manner bound up with merge, that is a part of merge in some sense." (H\&K, 2002: 61) ${ }^{57}$

Uma das vantagens em se assumir um modelo como H\&K (2002) está no tratamento que é dado aos fenômenos morfo-fonológicos com consequências para as relações sintáticas. Um dos grandes achados dessa teoria está na correlação encontrada entre ser um núcleo fonologicamente defectivo e ser um núcleo funcional. O tratamento dos afixos meramente como "agregados" sem valor sintático dos núcleos deve ser abandonado. Os autores mostram que afixos, em geral, são núcleos funcionais determinantes para a formação da sentença. Outros modelos alternativos que não expliquem a deficiência fonológica de certos núcleos e suas implicações para a sintaxe terão menor poder explicativo do que H\&K.

\subsubsection{O que é, então, ser denominal no modelo de Hale \& Keyser (2002)?}

Vimos até agora que, na aplicação da operação de conflation, há fusão de núcleos de diferentes categorias. Em geral, temos conflation de um núcleo de natureza nominal, adjetival ou uma raiz em um núcleo verbal para a formação de um verbo. Um desses casos é especialmente relevante para este trabalho, aquele em que um item nominal sofre conflation e é inserido diretamente em outro núcleo verbal ou em um núcleo preposicional e este, por sua vez, se junta ao núcleo verbal por conflation novamente, formando então VDs.

\footnotetext{
57 "Gostaríamos de levar a sério da ideia de que é um concomitante de merge, a operação que é fundamental na definição da projeção da sintaxe a partir do léxico. Esperamos que a um entendimento apropriado da relação de conflation com merge irá levar automaticamente a uma explicação das restrições que a governam. Dizer que conflation é um concomitante de merge é dizer que ele é de alguma forma íntima ligado a merge, que é em algum sentido uma parte de merge”. (Tradução nossa).
} 
A estrutura (361), abaixo, mostra a configuração da sentença He shelved the books antes da ocorrência de conflation. A estrutura (362) mostra a aplicação da operação.

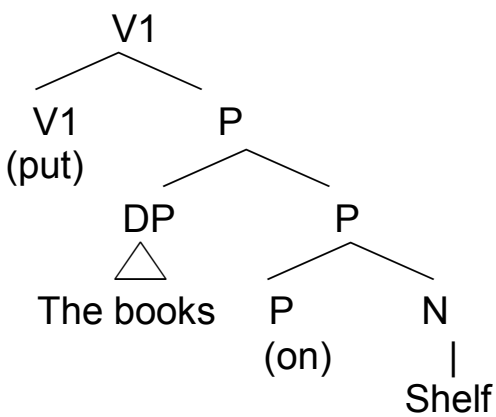

(362)

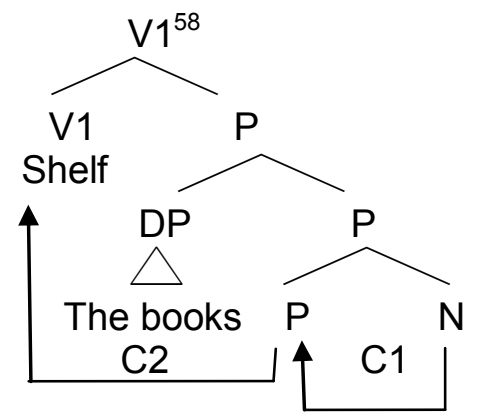

C1 indica a primeira realização de conflation entre o núcleo nominal e o núcleo preposicional e C2 indica a segunda operação entre o núcleo preposicional, já dotado da assinatura-p do núcleo nominal, e o núcleo verbal.

Até aqui, no que cerne às estruturas denominais, percebemos que as estruturas que privilegiam a aparição de um núcleo nominal subcategorizado por outro núcleo em inglês são as que se tem em (363) e (364), estrutura Monádica Básica e Diádica Básica, respectivamente:

\footnotetext{
${ }^{58} \mathrm{Não}$ devemos confundir as setas que indicam conflation com uma possível indicação de movimento. Os autores deixam claro que em conflation não há movimento. Não há evidências de que existam vestígios deixados pela ocorrência de conflation. A falta de evidência de um vestígio pode explicar, por exemplo, a realização de um objeto cognato em alguns desses verbos.
} 
(363)

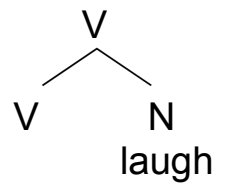

(364)

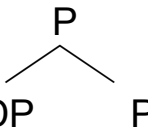

the books

(on) shelf

A estrutura diádica composta, por outro lado, envolve estados e mudanças de estado, e, em geral, projeta-se a partir de adjetivos. No entanto, isso não impede que, em certas línguas, essa estrutura seja projetada a partir de Nomes (substantivos), verbos ou raízes acategoriais.

Ainda, as assinaturas-p nominais são copiadas e fundidas em outros núcleos, V e $\mathrm{P}$, nos casos acima, deixando uma posição vazia na estrutura de onde esse item foi copiado. Observa-se nas línguas do mundo que, nessas posições de onde a assinatura-p foi "retirada", podem ocorrer objetos cognatos em estruturas, como em (365), e a realização do nome em uma paráfrase de expressão analítica, como em (366):

(365) She laughed a loud laugh. (Ela riu uma risada alta)

(366) She put the books on the shelf. (Ela colocou os livros na prateleira)

Em (365), temos a estrutura interna formada pelo núcleo verbal que estava vazio e ao qual foi incorporado o nome laugh, formando assim o verbo laugh pelo que é chamado de derivação zero (sem afixos). No entanto, apesar de o nome laugh ter sofrido conflation ele pode ser realizado na posição onde foi gerado, como em (365), indicando que essa posição continua disponível após a operação de conflation. Ainda, em (366), a inserção do verbo leve put no núcleo verbal V1 da estrutura não motivou a operação de conflation, que só se aplica a núcleos defectivos. Dessa forma, o nome shelf continuou em sua posição original na estrutura argumental. 
Concluímos assim que, para H\&K, são estruturas denominais aquelas em que um item da categoria nome $(\mathrm{N})$ sofre conflation com um núcleo para formar um novo item. Mais especificamente, VDs são aqueles em que o nome passa por conflation com um núcleo verbal diretamente, como na monádica básica (to laugh), ou se incorpora a um núcleo preposicional e depois a um núcleo verbal, como na diádica básica (to saddle, to shelf).

\subsubsection{A estrutura argumental dos VDs: uma tentativa de análise}

Ao olhar os dados do PB a partir da teoria de H\&K, pode-se perceber que alguns tipos de VDs parecem poder figurar em estruturas indicadas em H\&K como denominais no inglês, com o interessante fato de possuírem uma morfologia aberta.

Um primeiro grupo se encaixa, por meio do comportamento revelado pelos testes, no modelo das estruturas diádicas básicas, depreposicionais, segundo H\&K. Os dados mostram que os verbos não têm uma gramaticalidade perfeita em uma alternância transitivo-intransitiva. Para que haja uma sentença totalmente gramatical com a supressão do argumento externo, é preciso uma leitura medial, em que se obtém uma leitura genérica. Há a realização de uma expressão perifrástica, o que revela uma estrutura em que o substantivo se manteve em sua posição original por falta de motivações morfo-fonológicas, já que havia no núcleo verbal um verbo pleno. Por fim, há possibilidade de ocorrência de adjuntos cognatos e, em alguns casos, em vez de ocorrer com adjuntos cognatos, há a presença de adjuntos $\mathrm{H} \& \mathrm{H}$.

Dessa forma, identificamos um conjunto de verbos como engarrafar, engavetar e selar que parecem ter estruturas argumentais do tipo diádica básica, configurando, assim, estruturas depreposicionais. É interessante notar que verbos desse tipo podem ser morfologicamente sufixais ou parassintéticos. Assim, a preposição que projeta junto com o núcleo verbal a estrutura desses verbos pode ser fonologicamente 
realizada de forma defectiva, como em engarrafar, ou nula, como em selar, como ocorre na maioria das formações depreposicionais em inglês. Contudo, como proposto por H\&K, as estruturas depreposicionais podem ser do tipo location e locatum.

\subsubsection{Verbos com Estrutura Diádica Básica}

\section{a. Location}

\section{Pré-conflation}

(367)

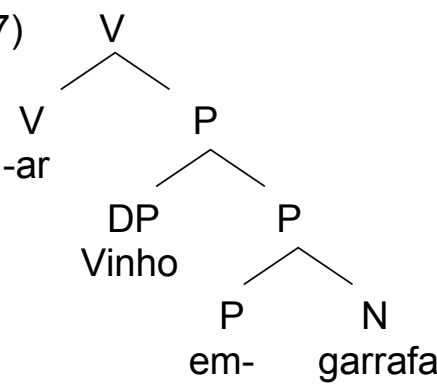

(368)



Pós-conflation

(369)

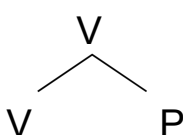

engarrafar

DP vinho

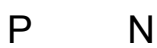

b. Locatum

Pré-conflation

(370)

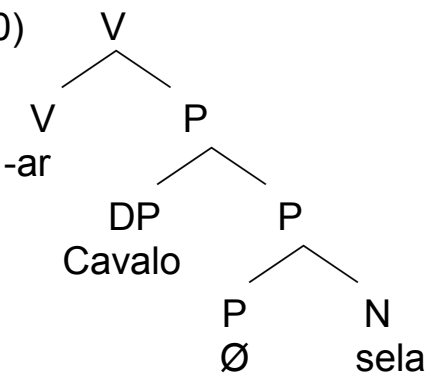

(371)

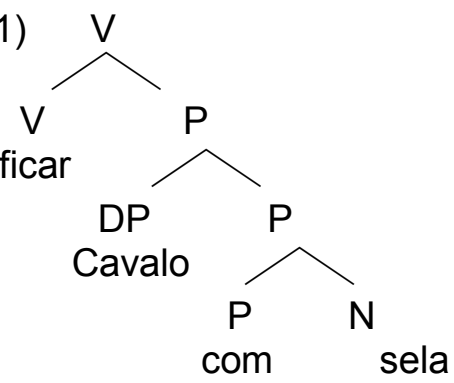


Pós-conflation

(372)

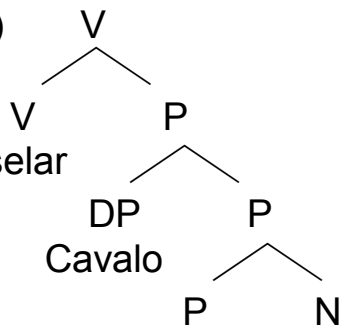

\subsubsection{Outros Verbos Denominais}

Por sua vez, com um comportamento um tanto diferente, há os verbos estudar, avaliar, enfrentar, analisar, complementar, alimentar, causar, aproveitar, desejar, testar, entre outros.

Se analisarmos as expressões perifrásticas que tais verbos assumem, com os verbos leves fazer, dar e tirar, por exemplo, é possível sugerir que esses dados configuram estruturas monádicas, como em laugh do inglês. Porém, essa assunção acarreta alguns problemas para a análise. Vejamos as estruturas a seguir:

\section{Estrutura Monádica Básica}

\section{Pré-conflation:}

(373)
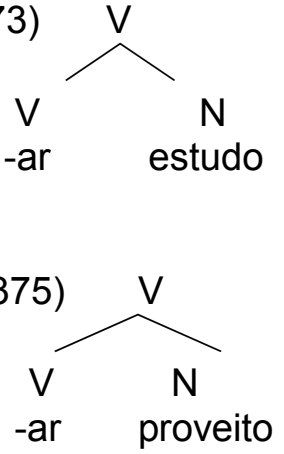

(374)

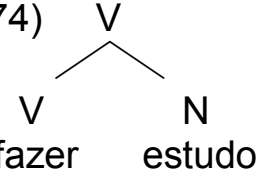

(376)

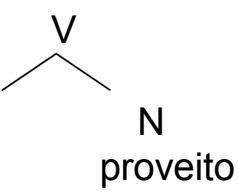


Pós- conflation:

(377)

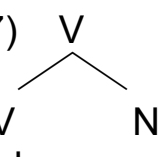

estudar
(378)

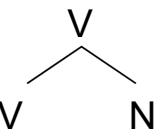

*proveitar

\subsubsection{Leitura de Maneira}

Vimos, nas descrições, que os verbos que podem ter uma leitura de maneira, com a ausência da denotação do objeto expresso pelo nome, como é o caso de martelar e escovar. $\mathrm{Na}$ análise de $\mathrm{H} \& \mathrm{~K}$, um verbo é sempre formado no léxico por operações sintáticas e depois é enviado para a sintaxe, a fim de ter sua estrutura argumental completada. Ao que parece, para esses verbos de maneira, temos duas leituras, uma que depende da formação do nome e outra que independe. Em uma análise de sintaxe lexical temos que assumir que verbos como martelar ou escovar terão uma única possibilidade de formação lexical, como representada a seguir:

(379)

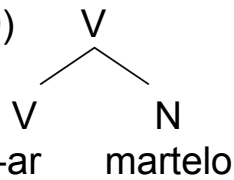

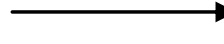

Dessa forma, essa análise acarreta o problema de que não damos conta das sentenças em que a interpretação de martelar não passa por martelo (martelar com a sola do sapato). Nessa análise, o verbo martelar sempre se forma a partir do nome martelo. Haveria, então, somente uma derivação para o verbo martelar, a denominal. Entretanto, os dados não apontam para esse caminho. 


\subsubsection{Problemas da análise}

Há três problemas com as estruturas monádicas propostas para os VDs de (373) a (380). O primeiro diz respeito ao fato de que se considerarmos esses verbos como de estrutura monádica, deveremos esperar deles um comportamento de verbos inergativos permitindo a sempre a ocorrência de objetos cognatos, o que não ocorre. O segundo diz respeito ao estatuto das preposições. Vamos aos problemas com mais detalhes.

Como já apontado na seção 3, os verbos denominais de estrutura monádica são aqueles chamados inergativos pela literatura em gramática gerativa. Esses verbos são intransitivos e podem ter um argumento externo introduzido na sintaxe, como em (381), mas nunca podem ter a introdução de um argumento interno, como mostra a agramaticalidade de (382).

(381) The children laughed. (A criança riu)

(382) *The clown laughed the children. (O palhaço riu a criança)

Se os verbos do PB mencionados acima se representassem, de fato, por estruturas monádicas, as sentenças abaixo deveriam ser agramaticais, quando não o são.

(383) Eu estudei a história da Brasil.

(384) O rapaz aproveitou a oportunidade.

Em tese, as estruturas monádicas não necessitam e não permitem a presença de um argumento interno, somente de um argumento externo. Além disso, é possível ter, com o verbo estudar, por exemplo, uma causativização, ou seja, a introdução de um causador na sintaxe, além do agente: 
(385) Os meus filhos estudaram.

(386) Eu estudei os meus filhos. ${ }^{59}$

Em seguida, o outro problema diz respeito à falta da preposição na estrutura (378). Essa estrutura prevê a existência do verbo proveitar sem a realização do prefixo. Apesar de essa realização ser possível em alguns dialetos, ela não pode ser assumida estruturalmente.

A estrutura monádica em (378), em que a formação de um verbo a partir do substantivo proveito resulta na palavra agramatical *proveitar, indica que essa não parece ser a estrutura pertinente a se assumir. Ainda, verbos como aproveitar e enfrentar não participam de alternâncias de nenhum tipo e eliminam a possibilidade de uma estrutura depreposicional.

Outra sugestão de análise seria assumir que a preposição desses verbos não está mais ativa, não tendo assim poder de projetar a estrutura argumental do verbo.

Deve-se dizer que em alguns dialetos a forma proveitar é realizada, (O rapaz proveitou da moça). No entanto, acreditamos tratar-se de algum tipo de reajuste morfo-fonológico, ou seja, a forma derivada pela sintaxe é a do verbo aproveitar, que acaba por se realizar como proveitar. Nesse sentido, a falta da preposição pode corroborar a hipótese de que ela não é mais ativa na formação sincrônica. Vejamos que as formas *garrafar ou *gavetar não são possíveis em nenhum dialeto do PB. Não nos deteremos nos detalhes desse problema agora, mas o deixaremos como questão de pesquisa.

Por fim, temos o problema revelado pelas estruturas de maneira, como a do verbo martelar. Teríamos que assumir para esse tipo de verbo uma derivação sempre denominal, o que não se confirma através dos testes.

\footnotetext{
${ }^{59}$ Esse tipo de transitivização não é aceita por algumas variedades mais rígidas do PB.
} 


\subsubsection{Conclusão da subseção}

O modelo de H\&K é muito apropriado e tem um alcance enorme frente aos dados de diversas línguas. Contudo, nos restam alguns problemas não resolvidos no tratamento de VDs do PB: o problema de que não damos conta das sentenças em que a interpretação de martelar não passa por martelo (martelar com a sola do sapato, por exemplo), em que se mantém somente o modo de realização da ação e não há necessidade da presença do objeto e o problema de que a formação de um verbo a partir do substantivo proveito resulta na palavra agramatical * proveitar.

Por esses motivos, partiremos em busca de outras alternativas de análises que possam dar conta de um maior conjunto de dados, sem, claro, descartar aqueles pontos da análise de H\&K que se mostraram adequados.

\subsection{Verbos Denominais à luz da Morfologia Distribuída}

6.2.1. Morfologia Distribuída: "Lexicalism is dead, deceased, demised, no more, passed on..." (Marantz, 1997)

O modelo da MD, formalmente introduzido por Halle e Marantz (1993), apresenta uma alternativa de análise do processo de formação de palavras que prescinde das Regras de Formação de Palavras como mecanismos gerativos do léxico.

A principal mudança e aposta da teoria está na assunção de que as mesmas operações que formam as sentenças são capazes de formar palavras. Essas operações são Merge (Concatenar) e Move (Movimento), operações de natureza sintática assumidas pelo modelo de Princípios e Parâmetros, explicitadas na Teoria de Regência e Ligação e no Programa Minimalista. 
Ainda, segundo Hale e Marantz (1993), a MD assume que a morfologia não precisa estar concentrada em um só lugar e, assim, adquirir um caráter imutável; ela pode estar distribuída entre os componentes da gramática. Tal mudança constitui uma vantagem para explicar as mudanças morfológicas introduzidas por fenômenos sintáticos. Assim, esse modelo de análise de expressões linguísticas sugere que todo o processo de formação de palavras ou sentenças ocorre no componente sintático, com possíveis alterações em um componente morfológico, pós-sintático. 
Figura 6.2.1.1. A Gramática pela MD

(1)
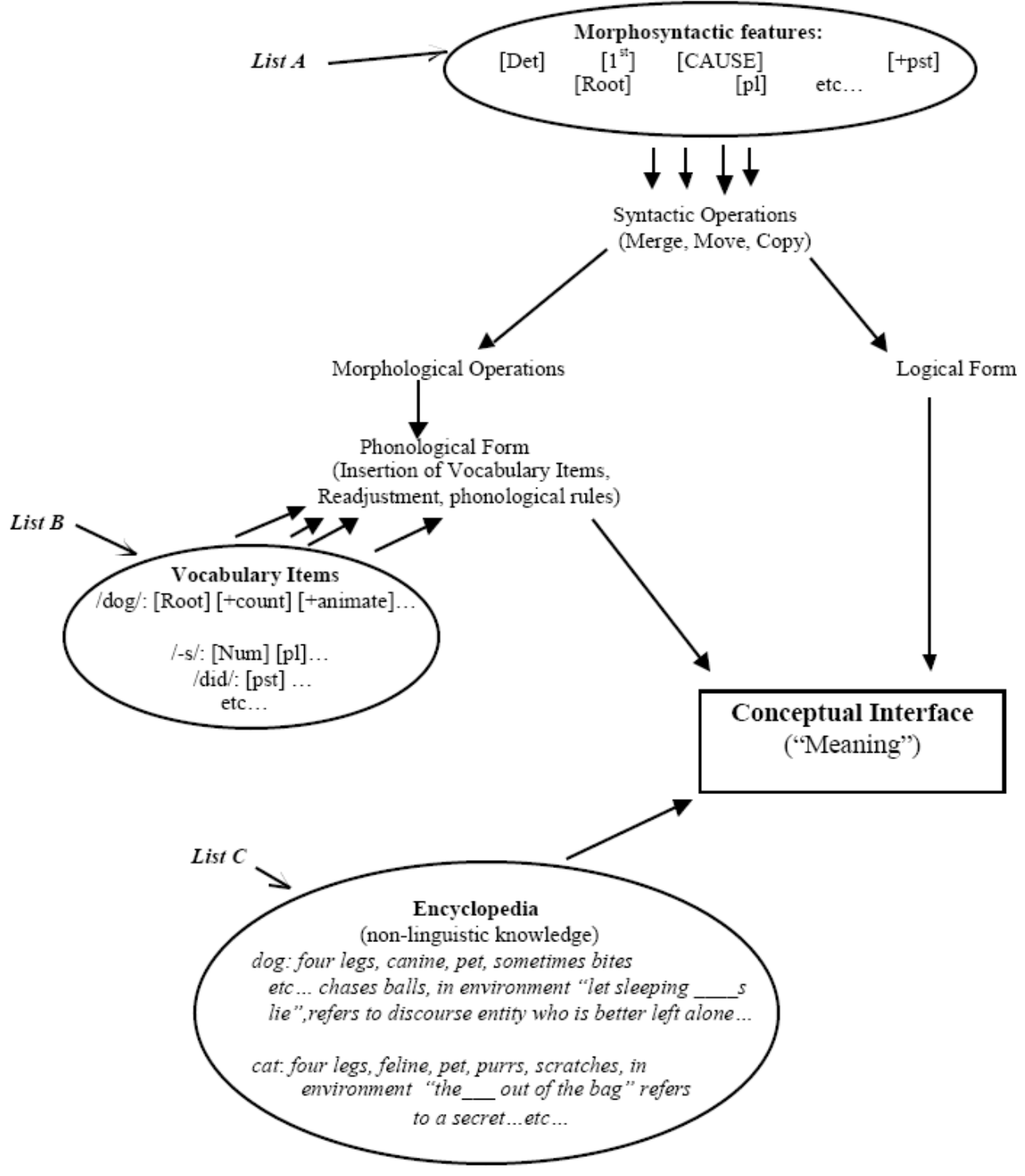

O abandono do léxico como um local gerativo e o tratamento sintático para a formação de palavras, faz que seja necessária uma reformulação da arquitetura da gramática, conforme o esquema proposto em Harley e Noyer (1999) e copiado na figura 6.2.1.1.1. 
Não pretendemos nos aprofundar nos pormenores da teoria, neste momento; procuraremos, apenas, apresentar alguns conceitos importantes para que se entenda como essa teoria pode ser relevante na explicitação das propriedades dos VDs.

Há três propriedades centrais que caracterizam a teoria: Inserção Tardia (Late Insertion); Subespecificação (Underspecification); Estrutura sintática hierárquica por toda a derivação (Syntactic Hierarchical Structure All the Way Down).

A Inserção Tardia é uma operação por meio da qual as expressões fonológicas dos nós terminais sintáticos, ou, grosso modo, morfemas abstratos, são inseridas no componente morfológico pós-sintático. A sintaxe opera somente com traços abstratos até que os Itens de Vocabulário (VIs) sejam inseridos, por uma operação chamada spell-out.

A Subespecificação é regida por uma espécie de princípio do subconjunto, sugerindo que os Vls não precisam ser plenamente especificados para serem inseridos em uma determinada posição sintática.

Por sua vez, a Estrutura Sintática Hierárquica por toda a Derivação assume que tanto elementos da sintaxe como elementos da morfologia, ambos de caráter discreto (piece-based) agrupam-se nos mesmos tipos de estruturas de constituintes, ou seja, aquelas representadas por árvores binárias.

A mudança que explica o nome da teoria está no abandono do componente lexical como um local de armazenamento estático e ao mesmo tempo gerativo. As funções supostamente desempenhadas pelo léxico são divididas em três listas, distribuídas pela gramática:

A Lista 1 (A na figura 1) pode ser vista como um léxico reduzido, pois nela fica armazenado um conjunto de raízes e de traços formais que serão manipulados pela sintaxe. 
Na Lista 2 (B na figura 1) estão os expoentes fonológicos com a especificação de seu contexto de inserção; são os chamados Itens de Vocabulário, inseridos no componente morfológico.

A Lista 3 ( $C$ na figura 1) é chamada de Enciclopédia e contém entradas enciclopédicas que relacionam itens de vocabulário a significados. É nesse local que são mantidos os significados especiais de expressões de uma língua. Dessa forma, o conteúdo da Enciclopédia é determinado por cada língua em particular.

De forma resumida, nesse modelo, a sintaxe trabalha com os traços abstratos da lista 1 (devidamente agrupados em uma numeração, como sugerem Harley \& Noyer, 1999) e gera uma estrutura sintática hierárquica. Os nós terminais podem ser derivados pela sintaxe ou inseridos como morfemas dissociados no componente morfológico, antes da inserção de Itens de Vocabulário. São, portanto, especificados com traços morfossintáticos.

Ao fim da derivação sintática e das possíveis operações morfológicas, póssintáticas, itens de vocabulário sub-especificados competem para inserção nos nós terminais. A associação dos morfemas abstratos aos itens de vocabulário, ou expoentes fonológicos, forma os Morfemas propriamente ditos. A presença de um morfema implica a existência de um nó terminal, mas a ausência de um morfema não implica a inexistência de um nó terminal: um elemento nulo pode ocupar o nó terminal.

Há somente duas classes de nós terminais: raízes ( $\sqrt{ }$, l-morphemes - lexical morphemes) e elementos gramaticais (f-morphemes - functional morphemes). As raízes se incorporam a outros elementos e projetam $\sqrt{ } P$. As raízes são acategoriais, e são os f-morfemas com que se relacionam na sintaxe que determinam sua categoria sintática: por exemplo, para se ter um verbo, será necessário compor uma raiz com uma categoria do tipo de $v^{\circ}$.

Nas próximas subseções, apresentaremos três propostas que abordam a formação e a interpretação de VDs dentro do modelo da MD. Descreveremos, em 
especial, as partes da proposta que serão relevantes para as possíveis análises dos dados do PB, em complementação à proposta de H\&K $(2002)^{60}$.

\subsubsection{Arad (2003): restrições de localidade e Verbos Denominais}

Arad (2003) apresenta uma proposta em MD para a distinção entre palavras que são diretamente formadas a partir de uma raiz nua e palavras que são formadas a partir de outras palavras, em que uma raiz já foi previamente subcategorizada por um núcleo funcional categorizador. A autora parte da proposta de Marantz (2000) ao assumir a distinção representada abaixo, nas estruturas que correspondem a palavras derivadas de raízes e palavras derivadas de palavras, respectivamente.

(387)

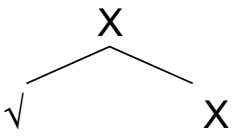

(388)

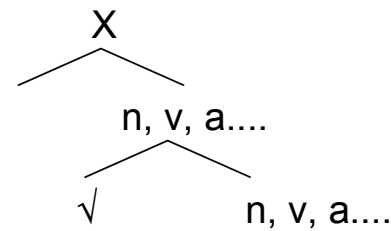

Com essa distinção entre tipos de formação, é possível reconhecer sincronicamente palavras deadjetivais, denominais e deverbais e distingui-las de palavras formadas diretamente de uma raiz. O interesse de Arad, assim como o deste trabalho, está em discutir os dados de VDs, porém, na língua Hebraica.

Contudo, é preciso que se estabeleçam testes para identificar se uma palavra apresenta uma estrutura que é formada a partir de outra palavra ou simplesmente da raiz. Não é possível, e nem desejável, uma postulação ad hoc, ou somente intuitiva, de quais palavras são ou não deadjetivais, denominais ou deverbais. A autora busca definir esses critérios a partir dos dados.

\footnotetext{
${ }^{60} \mathrm{O}$ modelo da Morfologia Distribuída não é totalmente incompatível com o modelo de H\&K (2002), esse, inclusive, serviu como base para algumas das principais assunções da MD.
} 
Em primeiro lugar, Arad coloca que, no Hebraico, palavras derivadas de raízes podem ter a elas atribuídas múltiplas e variadas interpretações ao passo que palavras derivadas a partir de outras palavras têm sua interpretação vinculada à palavra formadora, no primeiro ciclo da derivação (fase). Nesse sentido, a palavra em um segundo estágio de derivação terá sua interpretação ligada àquela da palavra formadora. Vejamos como ilustração o exemplo do hebraico em (389), a ser retomado e discutido ainda nesta seção:

(389) $\sqrt{ }$ sgr

miCCeCet misgeret 'a frame'

$\mathrm{CiCCeC}$ misger 'to frame'

(Arad, 2003:746)

Uma raiz não é uma palavra completa, ela adquire sua interpretação plena a partir da categorização por um núcleo e da sua transformação em palavra. Assim, a raiz em seu estágio inicial não tem sua interpretação "presa" a lugar algum. Diferentemente, após juntar-se a primeira categoria, a raiz torna-se palavra e tem sua interpretação fechada. Dessa forma, quando um afixo junta-se a uma palavra cujo significado já foi atribuído, essa nova palavra tem sua interpretação determinada.

Enquanto a derivação a partir de palavras constitui um processo produtivo, sistemático e semanticamente transparente, o primeiro nível da derivação, na junção da raiz com o categorizador, é o local de idiossincrasias ${ }^{61}$.

\footnotetext{
${ }^{61}$ Lemle (2008) argumenta que o primeiro merge da raiz com o morfema categorizador é o local da arbitrariedade na composição do significado da palavra. Desse modo, nesse momento, seria possível observar a tal arbitrariedade saussureana, mas não nas fases seguintes de formação de palavras complexas: "[...] a de que a parte idiossincrásica do significado fica estabelecida na categorização trazida pelo merge do mais interno dos afixos categorizadores; e a de que a parte composicional do significado de palavras complexas depende de cada um dos afixos categorizadores sucessivamente mergidos depois daquele que dá a primeira categorização." (Lemle, 2008:3)
} 
A partir de evidências empíricas, Arad sugere a existência de um critério de localidade na atribuição de significado, que forma uma espécie de domínio fechado para a interpretação, e indica que há fases na palavra:

"Locality constraint on the interpretation of roots: roots are assigned an interpretation in the environment of the first category-assigning head with which they are merged. Once this interpretation is assigned, it is carried along throughout the derivation". (Arad, 2003:747) ${ }^{62}$

É preciso que mostremos algumas evidências levantadas pela autora de que há diferenças significativas entre a formação de VDs e verbos derivados de raízes no Hebraico para que se possa entender a postulação da Restrição de Localidade. No entanto, não é necessário fazer um levantamento exaustivo dos dados. Chamaremos a esse tipo de evidência de identificação de VDs pela interpretação de Critério Semântico. Além do critério semântico, há outros dois critérios para a definição do processo de formação de uma palavra: são o Critério Morfológico e o Critério Fonológico, que veremos exemplificados adiante.

\subsubsection{Evidências do Hebraico}

Em Hebraico, a maioria das raízes consiste de consoantes segmentais, representadas pela autora como $\sqrt{ } \mathrm{CCC}$. Essas consoantes não são pronunciáveis independentemente; somente serão pronunciadas quando inseridas em um ambiente de palavra, ou seja, em um padrão vocálico. Uma mesma raiz pode culminar em

\footnotetext{
${ }^{62}$ A restrição de localidade na interpretação de raízes: raízes têm sua interpretação atribuída no ambiente do primeiro núcleo atribuidor de categoria com o qual são concatenadas. Uma vez que a interpretação é atribuída, é carregada ao longo da derivação. (Tradução nossa).
} 
verbos e nomes de diferentes significados, apesar de dividirem um tipo de conceito comum ${ }^{63}$ :

(390) $\sqrt{ }$ sgr
a. $\mathrm{CaCaC}(v)$
sagar
$v$, 'to close'
b. $\operatorname{hiCCiC}(v)$
hisgir
v, 'extradite'
c. hitCaCCeC (v)
histager
$\mathrm{v}$, 'cocoon oneself'
d. $\mathrm{CeCeC}(n)$
seger
n, 'closure'
e. CoCCayim (n)
sograyim
n, 'parentheses'
f. $\operatorname{miCCeCet}(n)$
misgeret
n, 'frame'

(Arad, 2003:743)

As formações de a - $\mathrm{f}$ acima são exemplos de palavras derivadas diretamente de raízes. No entanto, em alguns casos, há evidências na língua que mostram que há nomes formados por uma raiz e que passam a formar verbos, em um segundo estágio de derivação e a opção de tomar múltilplas interpretações não está disponível para esses casos, uma vez que a negociação de significado já foi fechada, na primeira fase da derivação, na concatenação da raiz com a categoria.

Vimos acima que a raiz $\sqrt{ } s g r$ pode receber múltiplos significados, dependendo do ambiente em que irá figurar, no entanto, o verbo formado a partir do nome misgeret em (386f) (moldura) só poderá significar emoldurar:

$\begin{array}{lll}\text { (391) } \sqrt{ } \text { sgr } & & \\ \text { miCCeCet } & \text { misgeret } & \text { 'a frame' } \\ \text { CiCCeC } & \text { misger } & \text { 'to frame' }\end{array}$

(Arad, 2003:746)

\footnotetext{
${ }^{63}$ Para uma busca da definição dos conceitos em raízes, v. Minussi, 2008:75-83.
} 
Além do Critério Semântico para a argumentação de que se deve fazer a distinção, o exemplo expõe de forma clara o critério Morfo-fonológico. O verbo contém as consoantes da raiz $\sqrt{ } s g r$ e, além delas, contém o prefixo $m$ - do padrão nominal (miCCeCet), que se preserva no padrão verbal, mas as vogais do novo verbo são típicas do padrão verbal $\mathrm{CiCCeC}$. Para a formação do nome moldura e do verbo emoldurar, Arad sugere a seguinte derivação:

\section{Nome derivado de raiz} NmiCCeCet $\sqrt{s g r}$ /misgeret/

\section{Verbo derivado do nome}

\section{Vmisger}

VCiCCeC Nmisgeret



/misger/

O exemplo de misger (emoldurar) é bem claro, por conter os três tipos de evidências possíveis para a identificação de VDs. No entanto, na ausência de evidências claras, como ocorre com os verbos de derivação zero do Inglês, as evidências semânticas prevalecem.

Kiparsky (1982) já havia notado que há verbos de derivação zero que implicam a existência do nome primitivo na descrição do evento, enquanto outros não o fazem:

(394) a. I paddled the canoe with a copy of the New York Times.

(Eu remei a canoa com uma cópia do New York Times.) 
b. String him up with a rope!

(Enforque ele com uma corda!)

c. She anchored the ship with a rock.

(Ela ancorou o navio com uma pedra.)

d. He hammered the nail with a rock.

(Ele martelou o prego com uma pedra)

(From Kiparsky's1982 example 14)

(395) a. *She taped the picture to the wall with pushpins.

(Ela "fitou" o quadro à parede com tachinhas)

b. *They chained the prisoner with a rope.

(Eles acorrentaram o prisioneiro com uma corda)

c. *Jim buttoned up his pants with a zipper.

(Jim abotoou suas calças com um zíper)

d. *Screw the fixture to the wall with nails!

(Aparafuse o suporte à parede com tachinhas)

(From Kiparky's 1982 example 16)

(Arad, 2003:756)

Para Arad, a possibilidade de o nome formador não estar presente nos exemplos (394) indica que nomes, como hammer (martelo), e verbos como to hammer (martelar) são independentemente derivados de uma raiz comum.

\section{Verbos do tipo Hammer:}

(396)

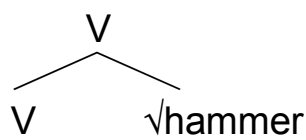

(397)

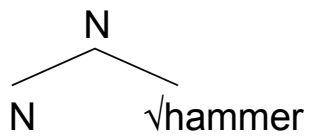


Por outro lado, a má formação das sentenças em (395) indicam que a formação do verbo depende do nome correlato e esse fato deve estar refletido na estrutura a ser proposta para verbos desse tipo.

\section{Verbos do tipo Tape:}

(398)

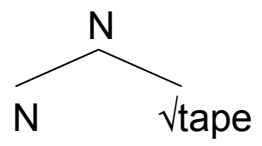

(399)

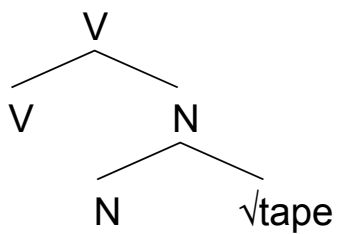

\subsubsection{Marantz (2008): Corroborando a noção de fases em palavras}

Neste trabalho, Marantz retoma as ideias colocadas em Marantz $(2000,2001)$. Naquele momento, o autor propôs que núcleos que formam categorias "lexicais" (adjetivo, nome, verbo) pudessem ser considerados núcleos de fases na palavra. A ideia de fases vem originalmente de Chomsky (2001), em que cada operação sintática teria uma interpretação correspondente e cada resultado de um merge de itens se daria em uma fase da derivação.

O trabalho de Dubinsky \& Simango (1996) foi um dos primeiros trabalhos lexicalistas a desafiar o lexicalismo estrito. Os autores apresentam dados de verbos da língua Chichewa que apresenta evidências em favor do reconhecimento da distinção entre um domínio interno e um externo na formação da palavra. Não nos deteremos nos detalhes dessa proposta, apenas apontaremos que, a partir das generalizações desse trabalho, é possível assumir que:

a) A formação interna da palavra é caracterizada por uma potencial nãoprevisibilidade na fonologia e semântica (forma e significado potencialmente especiais) e uma inabilidade para tomar como input um radical que já foi concatenado a uma categoria lexical. 
b) A formação externa da palavra é caracterizada por uma regularidade na fonologia e semântica e a habilidade de tomar como input um radical que já foi concatenado a uma categoria lexical. ${ }^{64}$

Em Marantz (2008:5), o autor retoma e reinterpreta a distinção em a e b como descrito abaixo:

"Inner morphology" attaches to roots or complex constituents below the first little $x(x=\{v, n, a\})$ node (phase head) above the root. All morphology above the first $x$ node is "outer morphology," including all "category changing" derivational morphology. ${ }^{65}$

Figura 6.2.3.1. Morfologia Interna e Externa

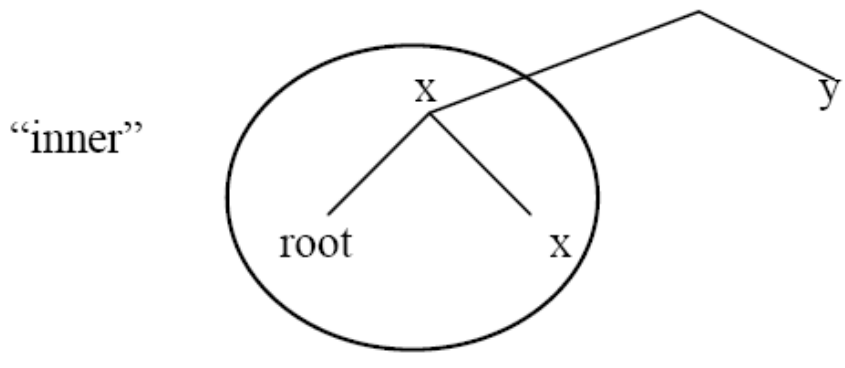

"outer"

Com essa proposta de análise, Marantz consegue evitar a ideia de que toda mudança de categoria na palavra é do âmbito lexical. As idiossincrasias não são mais explicadas por ocorrerem no léxico, mas por ocorrerem na primeira fase de formação

\footnotetext{
${ }^{64}$ Essa diferença é, por vezes, a mesma que se faz entre morfologia lexical e flexional.

65 A" Morfologia interna" se afixa a raízes ou constituintes complexos abaixo do primeiro nó x(zinho) $(x=v, n, a)$ (núcleo de fase) acima da raiz. Toda morfologia acima do primeiro nó $x$ é "morfologia externa", incluindo toda "mudança de categoria" da morfologia derivacional. (Tradução nossa).
} 
da palavra e a sistematicidade, ocorre nas fases consecutivas. No entanto, todo o processo ocorre na sintaxe. Os objetos de interpretação para LF (Logical Form) serão as fases e não as raízes somente ou a palavra toda.

A parte acima resumida de Marantz (2008) é o essencialmente necessário para este trabalho. Há aplicações dessa proposta a dados de sentenças passivas e inacusativas. A proposta apresentada está totalmente de acordo com a de Arad (2003) em que ambas sugerem a existência de fases internamente à formação das palavras.

Sobre os VDs o autor nos mostra um caso importante. Na língua Malayalam, o sufixo -ikk deriva verbos de nomes, causativos lexicais de incoativos e causativos sintáticos de verbos inergativos, respectivamente i, ii e iii retirados de Marantz:

(400) Exemplos da lingua Malayalam

Verbos de atividade agentivos derivados de nomes

(i) Kuli 'bath'

Kulikk- $\quad($ kuli + ikk $) \quad$ 'bathe' $(v)$

Causativos lexicais derivados da mesma raiz como incoativos

(ii) Culi- 'get wrinkled' (intr)

Culikk (culi+ikk-) 'wrinkle' (tr)

Causativos sintáticos derivados de verbos inergativos

(iii) Paat-

Paatikk- $\quad$ (paat+ikk-) 'to sing'

'to make $X$ sing'

Em (i), um VD é derivado através da concatenação de um $v$ a um núcleo de fase, um $n$. Há evidências fonológicas que provam que o VD em (i) é constituído por fases. Assim, por exemplo, alguns tipos de fusões podem ocorrer com os morfemas 
quando a concatenação entre $v$ e uma raiz ocorrem na mesma fase. Na concatenação de $v$ ao núcleo de uma fase, não ocorrem tais alterações morfológicas. Vejamos algumas evidências em que v se concatena diretamente à raiz implicando a ocorrência de alterações morfológicas:

a) Geminação causada quando a raiz é concatenada na mesma fase:

aat- 'swing' (root) aatt- 'to swing' (tr.)

kuump- 'fold' (root) kuupp- 'to fold' (tr.)

b) Fusão em causativos-lexicais (uma fase), mas não em causativos sintáticos (mais de uma fase):

Causativo lexical construído de raiz; fusão fonológica de ikk com a raiz

munn- munn+ikk $>$ mukk- 'to sink'

e.g., The bottle sank > I sank the bottle

$\underline{\text { Causativo sintático construído de um verbo inergativo; sem fusão }}$

munn- munn+ikk > munn-ikk- 'to take a dip (bathe)'

e.g., I took a dip in the pond > John made me take a dip in the pond.

c) Evidência de que VDs incluem um núcleo do tipo $n$ : não há fusão.

Formação de Verbo Denominal de n(zinho); sem fusão

[[tool]n ikk]v > toolikk 'bathe'

Como causativo lexical, deveria prever toott-

Com uma proposta como a apresentada em Marantz, resolve-se, por exemplo, o problema apresentado por Basílio, de se saber se a transformação de um verbo em 
nome seria um caso de derivação ou de flexão. Com Marantz, vemos que as propriedades lexicais (ou derivacionais) devem ser limitadas à primeira fase de concatenação da raiz com uma categoria. As concatenações que ocorrem depois dessa primeira fase, podem ser igualadas àquelas ditas de natureza flexional, como a concatenação com categorias funcionais, como I ou C.

Por fim, acreditamos, com essa argumentação, que há critérios palpáveis na literatura para distinguir VDs de Verbos derivados diretamente da raiz. Ao testar nossos dados, buscaremos verificar se essa distinção é realmente observável em PB.

\subsubsection{Harley (2005): a incorporação de modo}

Neste trabalho, Harley sugere duas maneiras de formar VDs em inglês: verbos que são formados pela incorporação de uma raiz nominalizada a uma estrutura argumental e verbos formados por um processo que a autora chamou de Manner Incorporation, que traduziremos por Incorporação de Modo.

Nos concentraremos aqui no segundo tipo de formação. Harley diz que esses são verbos de maneira que têm a eles um instrumento incorporado e são verbos de atividade no que se refere ao seu tipo de aspecto. Os tipos de nomes incorporados não são nem temas e nem nomes que formam verbos do tipo location/locatum, mas são instrumentos, que na estrutura sintática, estariam em sintagmas adjuntos.

Por isso, podemos ter as seguintes paráfrases após as barras para as sentenças:

(401) John hammered the metal / With a hammer, John hit the metal.

(402) Sue brushed the dog / Sue stroked the dog with a brush

(403) Jill raked the leaves / Jill pushed the leaves with a rake 
A partir de evidências como essas, a autora propõe um mecanismo chamado Manner Incorporation que faz com que um $v$ possa ser nomeado por uma raiz que descreve a maneira como o evento se dá. A operação ou a estrutura exata dessas formações ainda não é descrita com clareza no texto, mas é representada da seguinte maneira:

(404) Sue hammered the metal.

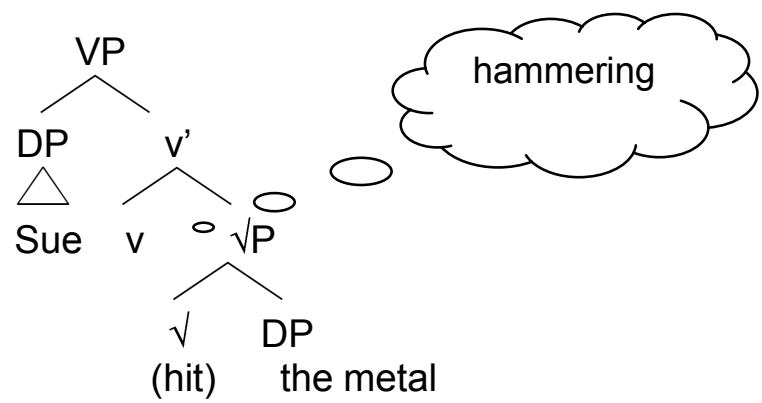

Será que a existência de sentenças como a que segue em português, já registrada em literatura anterior, pode ser uma evidência em favor de algum tipo de operação de incorporação de modo em português?

O João martelou o prego com a sola do sapato ${ }^{66}$

O fato de que o instrumento utilizado pode não ser um martelo pode ser tomado como um argumento em favor da hipótese de que a formação de martelar deixou de passar pela raiz nominal que forma martelo e, assim, martelar estaria em uma relação de Manner Incorporation, de modo semelhante à estrutura apresentada por Harley.

\footnotetext{
${ }^{66}$ Exemplo retirado de Scher (2006).
} 


\subsubsection{Análises em Morfologia Distribuída}

Nesta seção, iniciaremos uma tentativa de tratar os dados investigados nesta dissertação com base no modelo da MD (Halle \& Marantz, 1993; Marantz, 1997; Harley \& Noyer, 1999) e em H\&K (2002), tomando como referência, mais especificamente, as propostas de Marantz (2000, 2001, 2008), Harley (2005) e Arad (2003).

\subsubsection{Verbos com Estruturas Denominais sincrônicas}

Pertencem a essa classe, verbos que apresentaram gramaticalidade para os testes 3,5 e 6 conjuntamente. Alguns desses possuem objetos cognatos, apresentando gramaticalidade também para o teste 4. São eles os verbos Enfrentar, complementar, acreditar, alimentar, aproveitar, desejar, enfeitiçar, engavetar, engarrafar, encurralar, selar, martelar, escovar, cristalizar, Assustar, beneficiar, colar, praticar, criticar, relatar, misturar, resgatar, subsidiar, processar1 (jurídico),arriscar, pesquisar, apontar1 (o lápis), armazenar, interessar, ingressar, programar, influenciar, somar, apostar, sinalizar, almoçar, evidenciar, rastrear, amanhecer, capturar, adiar, cadastrar, favorecer, focar, embarcar, estrear, basear, abraçar, liderar, marcar, privilegiar, copiar, acostumar, listar, analisar, testar, empacotar, agulhar, aprimorar, memorizar, agendar, auxiliar, depositar, sediar, implementar, gerenciar, veicular, forçar, economizar, traçar1 (o desenho), suplementar, movimentar, incrementar, providenciar, registrar, regulamentar.

Dentro dessa classe, temos tanto verbos sufixais quanto verbos parassintéticos. O comportamento frente às alternâncias também varia. Vejamos as possíveis divisões. 


\subsection{Verbos com Estruturas denominais não alternantes}

Vejamos os exemplos com os verbos testar, aproveitar e enfrentar.

Testar

(406) O laboratório testou os medicamentos.

(407) *Os medicamentos testaram.

(408) *Medicamentos testam bem.

(409) Os laboratórios fizeram testes em medicamentos.

(410) Os laboratórios testaram um teste novo para os medicamentos.

(411) Os laboratórios testaram os medicamentos com um teste novo.

(412) Os laboratórios testaram os medicamentos com um experimento novo.

O verbo testar apresenta um comportamento típico de VD sincrônico. Ele não participa de ambas as alternâncias, causativo-incoativa e média, possui expressão perifrástica com o verbo leve fazer e pode ter o nome teste retomado em um adjunto cognato e um adjunto hipônimo, como experimento. Sugeriremos para a sentençabase a estrutura simplificada ${ }^{67}$ em (414) e para a sentença com expressão perifrástica a estrutura em (416)

${ }^{67}$ Como o objetivo da análise para o momento é a formação de verbo e a estrutura argumental, não nos deteremos com detalhes aos movimentos sintáticos para as categorias mais altas, como I e C. 
(413) O laboratório testou os medicamentos.

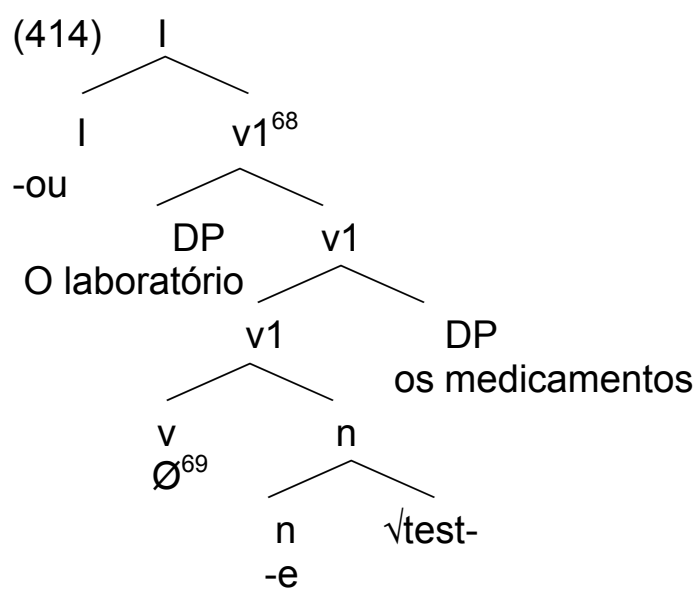

(415) Os laboratórios fizeram testes em medicamentos.

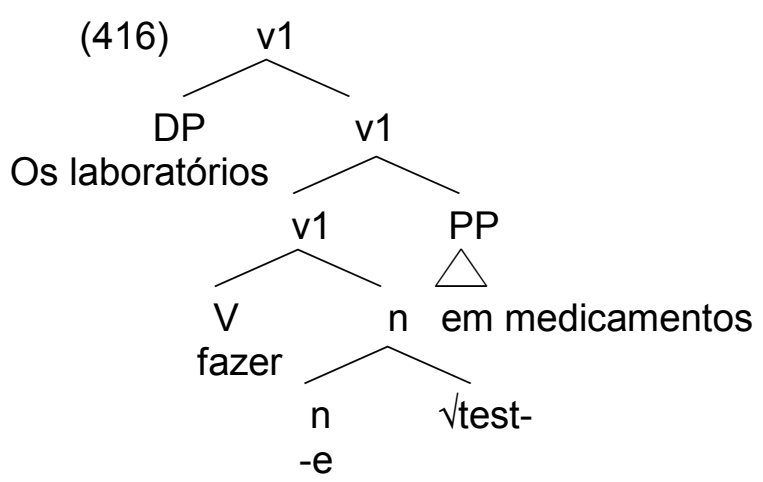

Na formação do verbo testar, temos a passagem por um estágio nominal, na formação do nome teste através da concatenação da raiz $\sqrt{ }$ test- com o núcleo $n$ e depois com o núcleo $v$. No caso de testar, o núcleo $v$ é vazio, adaptando o nome a receber uma marca flexional em I. Se fosse um verbo com marcas verbais, como o afixo -iz- em cristalizar ou -ec- em amanhecer, teríamos esse núcleo fonologicamente preenchido, como veremos no verbo amanhecer adiante. Uma outra alternativa seria

\footnotetext{
${ }^{68}$ Assumiremos, com Marantz (1997), dois tipos de v. v1 projeta um agente e é compatível com raízes que implicam causa externa ou agente enquanto v2 não tem essas características.

69 O núcleo verbal está representado pelo símbolo $\varnothing$ em todas as estruturas porque os verbos representados estão em sentenças, com marcas de flexão. No entanto, assumimos que essa posição poderia ser preenchida, por exemplo, com os materiais fonológicos que indicam a qual conjugação pertencem, ou seja, com as vogais temáticas a, e ou $i$.
} 
dizer que esse núcleo verbal é sempre preenchido por uma vogal temática $(a, e, i)$ que adapta o verbo a pertencer a uma dada conjugação $\left(1^{\circ}, 2^{\circ}, 3^{\circ}\right)$, mas nesse caso, na adição da flexão ao verbo, essa vogal temática teria de ser suprimida. No momento, representaremos o núcleo verbal por $\varnothing$ quando não houver um morfema específico.

Na primeira fase de formação de $n$, temos o primeiro spell-out que resulta na manutenção da denotação do nome teste nas sentenças formadas com testar, o que se comprova pelos nossos testes.

Se não houver a formação do verbo testar, mas a introdução de um verbo leve, o nome formado a partir da raiz não sofre movimento para concatenação com o núcleo $\mathrm{v}$, permanecendo in situ.

Aproveitar

(417) O rapaz aproveitou a oportunidade.

(418) *A oportunidade aproveitou.

(419) *Oportunidades como essa aproveitam logo.

(420) O rapaz tirou proveito da oportunidade.

(421) *O rapaz aproveitou o proveito da situação.

(422) O rapaz aproveitou a oportunidade com proveito.

(423) ?O rapaz aproveitou a oportunidade com serventia.

O verbo aproveitar não participa de ambas as alternâncias, causativo-incoativa e média, possui expressão perifrástica com o verbo leve tirar e pode ter o nome proveito retomado em um adjunto cognato. Seu adjunto metafórico ficou indeterminado no sentido de gramaticalidade na contagem. Em (425) sugerimos uma possível representação para a sentença-base e em (427) para a variação com expressão perifrástica. 
(424) O rapaz aproveitou a oportunidade.

$(425)$

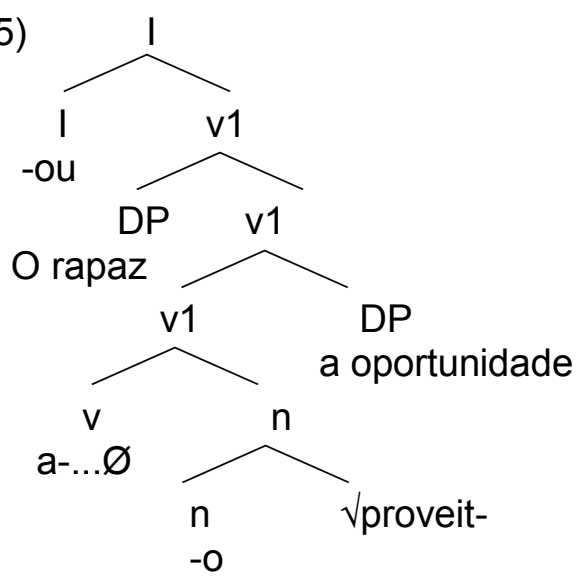

(426) O rapaz tirou proveito da oportunidade.

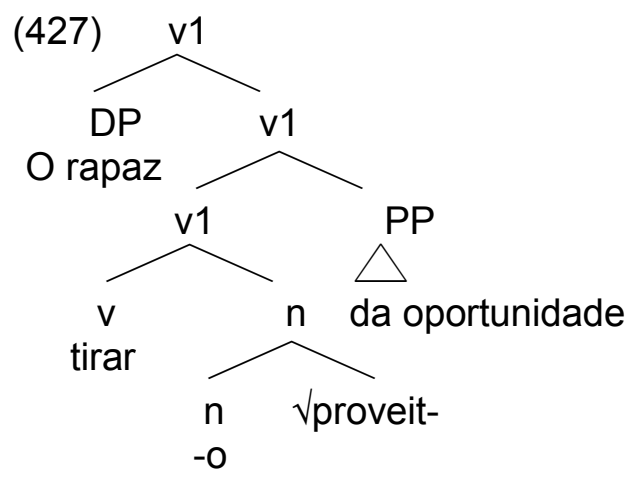

No caso de aproveitar, diferentemente de testar, trata-se de uma formação parassintética. Quando há uma paráfrase do verbo aproveitar em (426), a ocorrência de uma preposição antes do complemento indireto do verbo é obrigatória (tirar proveito $\underline{\text { de } X}$. Uma primeira sugestão seria a de que essa preposição é o correlato daquela que ocorre no verbo sintético (a-). Haveria, então, um tipo de transformação do prefixo (que seria preposicional) a- de aproveitar em de. Entretanto, descartamos essa hipótese fundamentadas pela idéia de que a forma preposicional é uma exigência da Teoria do Caso. O nome proveito não é capaz de atribuir caso ao seu complemento e, assim, uma preposição é inserida para fazê-lo. 
Sugerimos, então, a hipótese de um morfema verbal fissionado e abandonamos a ideia de uma preposição prefixal para esse verbo, mas não para outros como veremos adiante. Em outras palavras, o núcleo verbal que transforma o nome em verbo é coberto por dois morfemas, o prefixo -a e os sufixos flexionais.

Resta-nos um problema a resgatar nesse ponto. Como já dissemos, em alguns dialetos a forma proveitar é realizada, (O rapaz proveitou da moça). Se o morfema -a é inserido junto com o morfema -ar no nó terminal verbal, qual a explicação para o apagamento dessa partícula em alguns dialetos?

Uma possibilidade apontada indicaria que o prefixo -a é uma marca puramente fonológica, assim como aquela que aparece em realizações de verbos como alevantar ou avoar em alguns dialetos ${ }^{70}$. Entretanto, com relação à base proveito, atestamos somente a realização do prefixo -a em formações verbais (aproveitar) e nominalizações deverbais (aproveitamento), mas não em substantivos (*aproveito). Por isso, consideramos que essa marca deve estar necessariamente relacionada com a "função" verbal.

Assim, a hipótese adotada para casos de apagamento é a de que, para o falante que não realiza o prefixo -a, a operação de fissão não se aplica, sendo inserido somente o morfema -ar no nó terminal. Lembremos que para verbos em que o prefixo tem função sintática como é caso do prefixo relacional -en em engavetar, não é possível o apagamento *Ela gavetou três processos./*Ela pacotou três doces. Essa hipótese será melhor investigada.

\section{Enfrentar}

(428) Os meninos enfrentaram a situação.

(429) *A situação enfrentou.

\footnotetext{
${ }^{70}$ Agradeço ao Prof. Dr. Luiz Carlos Schwindt da Universidade Federal do Rio Grande do Sul por esses apontamentos acerca de fonologia durante seção da ABRALIN 2009.
} 
(430) *Situações de pavor não enfrentam facilmente.

(431) Os meninos fizeram frente à situação.

(432) ?Os meninos enfrentaram uma frente corajosa.

(433) ?Os meninos enfrentaram os outros com uma frente corajosa.

(434) O exército enfrentou a situação com uma dianteira corajosa.

Para o verbo enfrentar, também não são possíveis alternâncias, mas são possíveis expressões perifrásticas e adjuntos hipônimos e hiperônimos. Inicialmente, a morfologia de enfrentar faz pensar que esse verbo é do mesmo tipo de engavetar, empacotar, engarrafar, etc. Seu prefixo en- parece ser a preposição em, como realmente deve ter sido em formação histórica. No entanto, frente aos testes estruturais, esses verbos se comportam de maneira quase que oposta. O prefixo emnão se mostra relacional como nos verbos do tipo location e locatum. Por isso, não vamos sugerir uma estrutura relacional para esse verbo. Vamos tratar en- nesse caso somente como um prefixo que ocupa o morfema verbal junto com o sufixo -ar, um caso de fissão. Vejamos a representação estrutural para ele:

(435) Os meninos enfrentaram a situação.

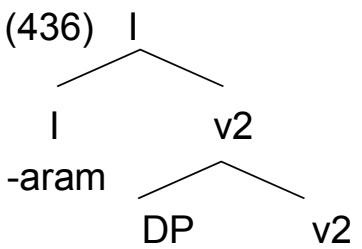

Os meninos

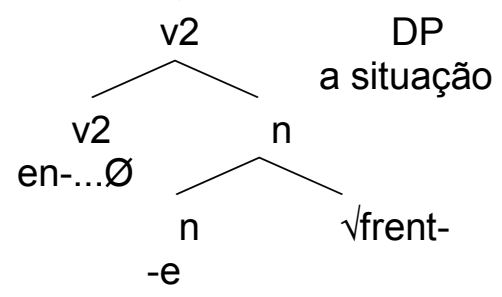


(437) Os meninos fizeram frente à situação.

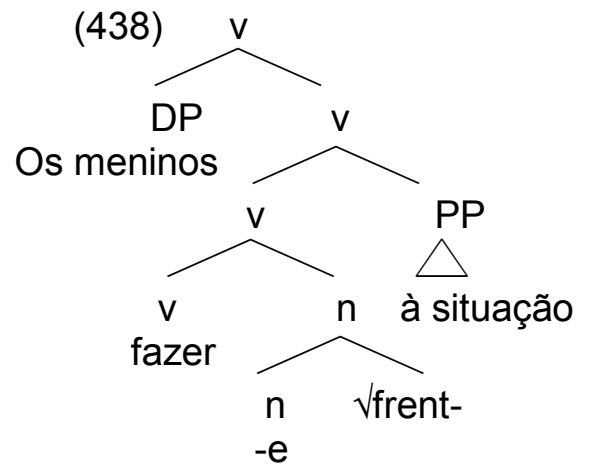

Com esses três verbos, testar, aproveitar e enfrentar, buscamos exemplificar a subclasse de verbos denominais sincrônicos não-alternantes.

\subsection{Verbos com Estruturas denominais alternantes}

Os verbos do tipo amanhecer e misturar são mais permissivos quando confrontados com os testes de alternância. Sugeriremos uma estrutura que dê conta dessa característica. Apesar de termos nomes figurando na posição de núcleo, esses verbos se comportam como os verbos cujos núcleos são adjetivos. Como H\&K já destacaram, não podemos vincular categoria a tipo de estrutura. Seguindo essa ideia, nada impede que nomes projetem estruturas parecidas com as que $\mathrm{H} \& \mathrm{~K}$ chamaram de Diádica Composta. Adaptaremos essa ideia e a trataremos no modelo de MD.

\section{Misturar}

(439) A cozinheira misturou os ingredientes.

(440) ?Os ingredientes misturaram.

(441) Ingredientes naturais misturam fácil.

(442) A cozinheira fez a mistura dos ingredientes.

(443) ?A cozinheira misturou uma mistura estranha de ingredientes.

(444) A cozinheira misturou os ingredientes com uma mistura estranha. 
(445) A cozinheira misturou os ingredientes com uma combinação estranha.

O verbo misturar participa certamente da alternância média e no que se refere à alternância causativo-incoativa, permaneceu indeterminado com grande tendência para gramaticalidade (25 gramaticais $X 15$ agramaticais). O verbo tem expressão perifrástica com o verbo fazer. Vejamos em seguida as representações para ele:

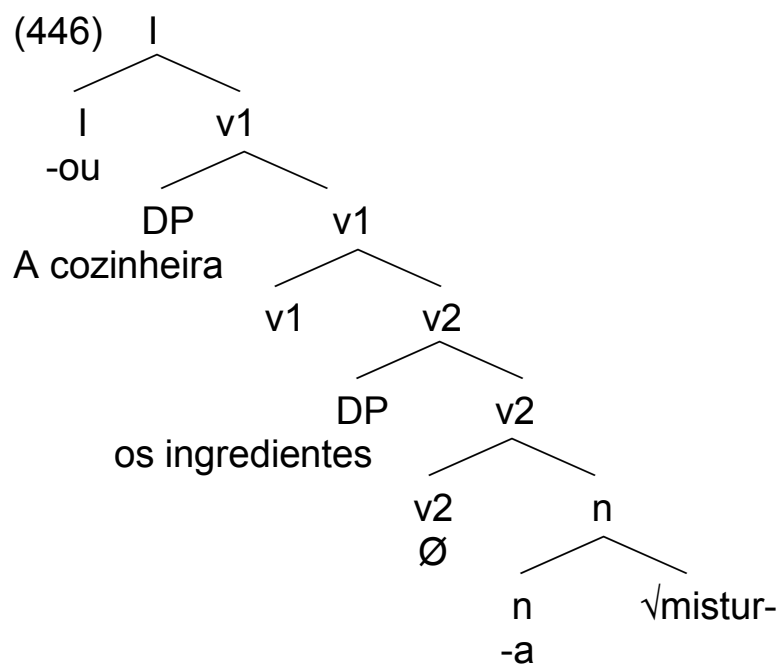

Após os movimentos, temos:

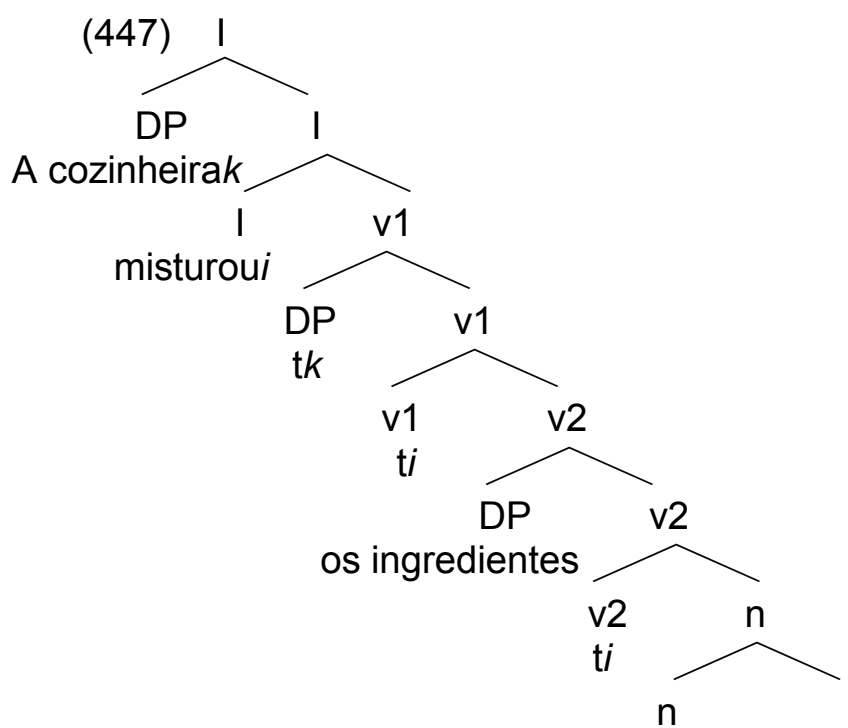


Não assumimos que nenhum tipo de vestígio é deixado após a incorporação da raiz à primeira categoria. Assumimos, com $\mathrm{H} \& \mathrm{~K}$, que, nesses casos, não há movimento, mas sim uma espécie de incorporação ou conflation. Se não houver um argumento externo que preencha a posição de especificador de I, teremos o movimento do argumento interno para a posição de especificador de I:

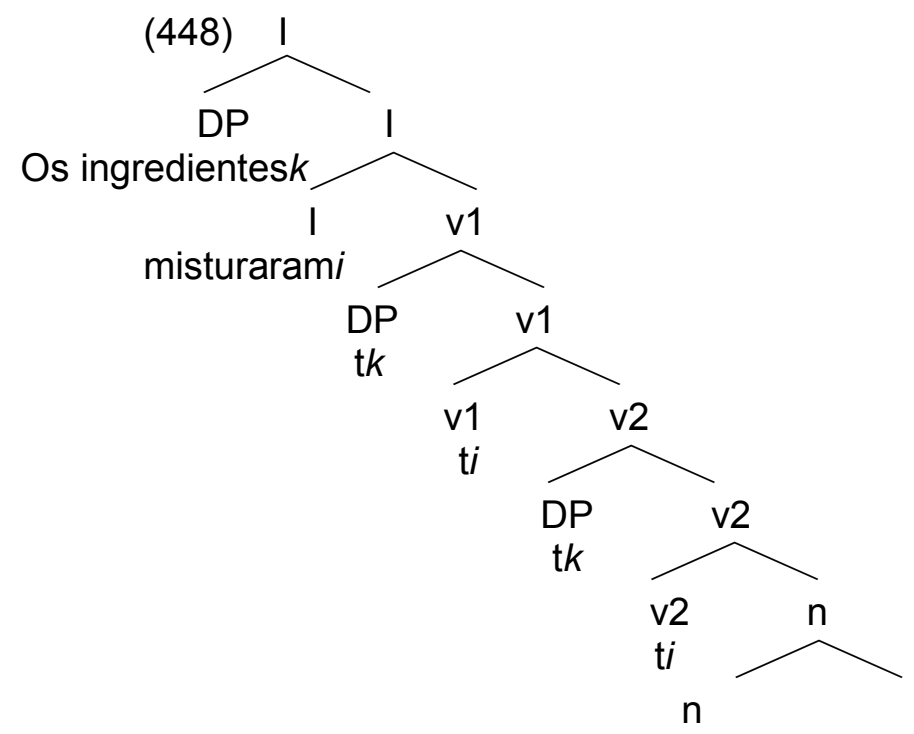

Amanhecer

(449) ?O sol amanheceu o dia.

(450) O dia amanheceu.

(451) O dia amanhece rapidamente em João Pessoa.

(452) A noite tornou-se manhã rapidamente.

(453) Amanheceu uma linda manhã.

(454) O dia amanheceu com uma linda manhã.

(455) O dia amanheceu com uma linda alvorada. 
O verbo amanhecer traz mais elementos morfológicos do que o verbo misturar: o prefixo a- e o afixo -ec- Esse último afixo indica incoatividade e essa é a marca morfológica de uma estrutura sintática de mudança de estado.

Muito interessante foi o fato de que para a sentença-base, uma versão transitiva para o verbo amanhecer, houve certa resistência por parte dos falantes do grupo em que as sentenças foram aleatorizadas. Para esses, foi mais difícil aceitar a sentença $O$ sol amanheceu o dia (3 gramaticais $\times 11$ agramaticais). Para os falantes cujo grupo estava ordenado, ou seja, receberam todas as sentenças com amanhecer em sequência, a contagem teve mais julgamentos gramaticais $(11 \times 7)$. Para todas as outras sentenças, constatou-se a gramaticalidade. Sugeriremos as seguintes estruturas para amanhecer, um verbo com alto índice de relação com o nome formador:

(456) (O sol) amanheceu o dia.

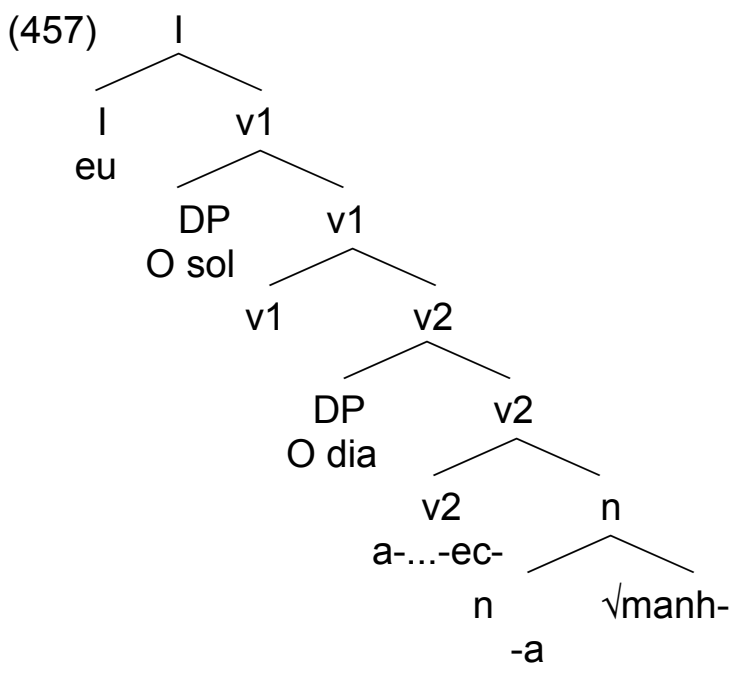


Após os movimentos:

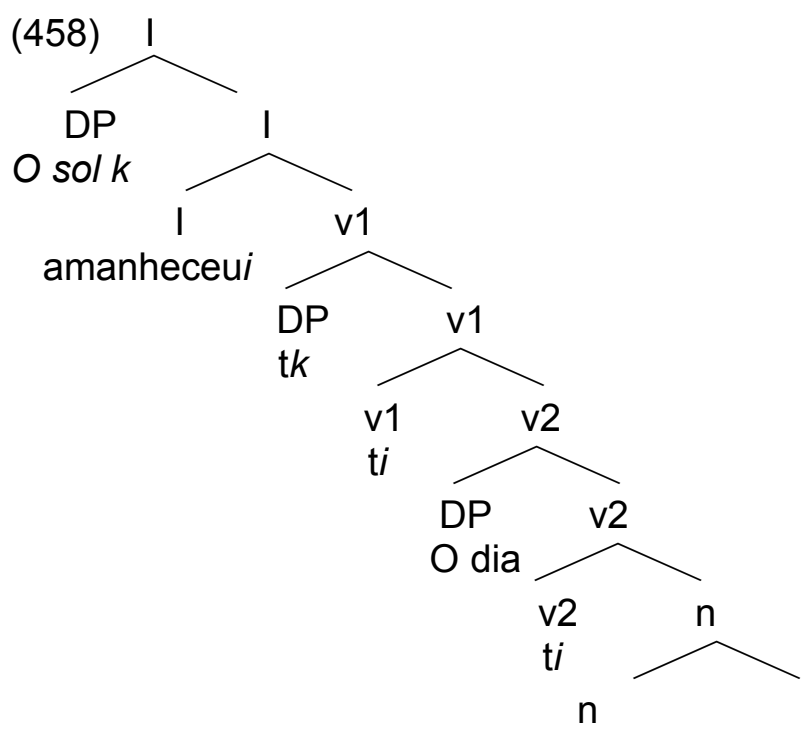

Se não há a introdução de $\mathrm{V} 1$, o DP $\mathrm{O}$ dia pode ocupar a posição de especificador de IP, satisfazendo seu caso e EPP (Extended Projection Principle):

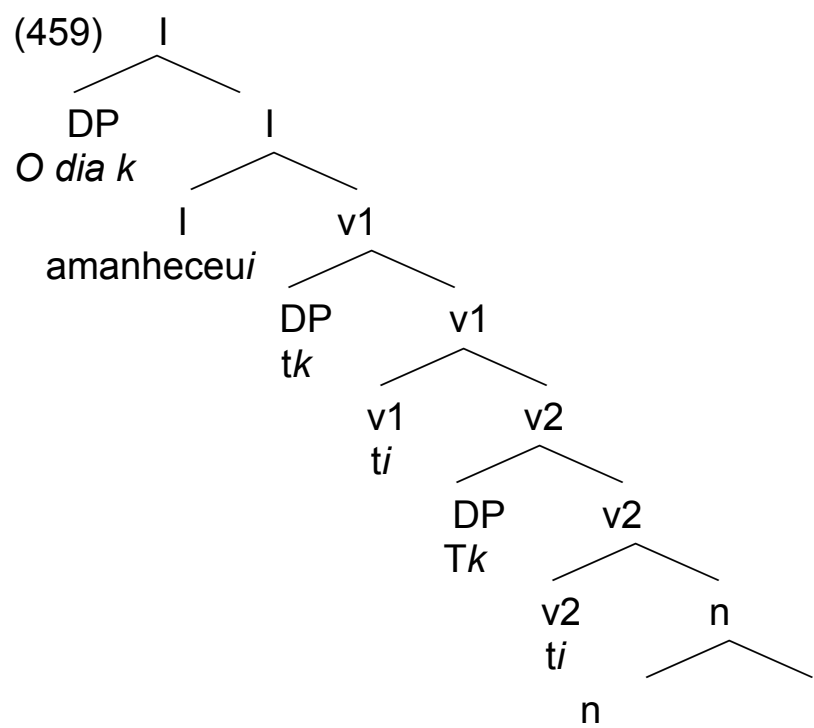


Vejamos a expressão perifrástica:

(460) O dia tornou-se manhã rapidamente.

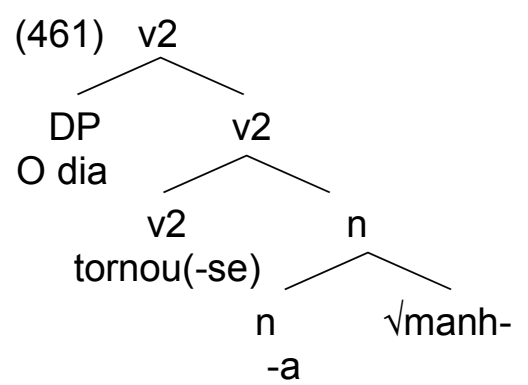

\subsection{Verbos com Estruturas location/locatum}

A análise que sugeriremos para esses verbos não é muito diferente daquela proposta em termos do modelo de H\&K. No entanto, assumindo esse modelo, nosso poder de explicação para as sentenças em que a interpretação não mantém a relação entre nome e verbo parece ter mais alcance. Apesar de considerar verbos como engarrafar e empacotar como denominais, assumimos que existem formações com interpretações especiais em que esses verbos não necessariamente necessitam de um estágio nominal, são casos especiais de sentido conotativo. No entanto, como esses verbos não aceitam presença de adjuntos que não sejam hipônimos ou hiperônimos, como mostra a sentença abaixo, preferiremos não sugerir que eles podem ter uma formação direta da raiz antes de maior investigação.

(462) ${ }^{*} \mathrm{O}$ funcionário engarrafou o vinho nas gavetas ${ }^{71}$.

(463) *A mulher empacotou os doces nas latas grandes.

\footnotetext{
${ }^{71}$ Agramaticais no sentido em que as gavetas substituíram as garrafas e as latas substituíram os pacotes. Essas sentenças não foram testadas, no entanto, foram julgadas como agramaticais durante discussão no Grupo de Morfologia Distribuída.
} 
Analisemos as estruturas para o sentido canônico de engarrafar.

\section{Engarrafar}

(464) O funcionário engarrafou o vinho branco.

(465) *O vinho branco engarrafou.

(466) ?Vinho branco engarrafa bem.

(467) O funcionário pôs o vinho branco nas garrafas.

(468) O funcionário engarrafou uma garrafa de vinho.

(469) O funcionário engarrafou o vinho branco na garrafa de vidro.

(470) O funcionário engarrafou o vinho branco.

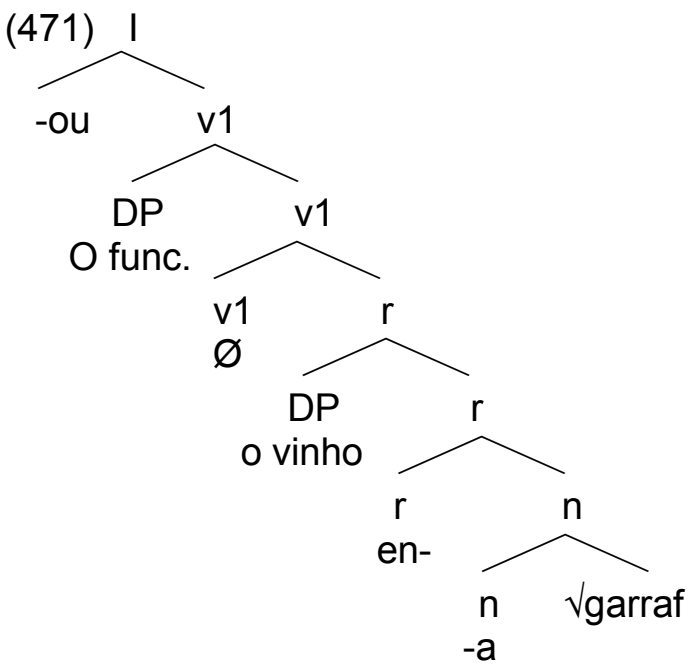

A estrutura em acima representa a interpretação em que o nome garrafa faz parte do evento. Se a frase $x$ engarrafou $y$ é realizada, a primeira interpretação é a de que alguém colocou algo em garrafa, e logo, o nome garrafa é pressuposto. Quando há incorporação do nome para a formação do verbo complexo, quando temos o verbo sintético engarrafar, não é possível afirmar a existência de um núcleo preposicional livre. A motivação para a incorporação é exatamente a existência de uma partícula defectiva, a que chamaremos de relacional (r), como faz Lemle (2008). Além disso, assumimos que nas paráfrases colocar vinho em garrafas há uma preposição que faz 
a relação entre o nome (vinho) e o locativo (garrafa ou galões). Nesses casos, há a realização independente da preposição.

(472) O funcionário pôs o vinho branco nas garrafas.

$(473)$

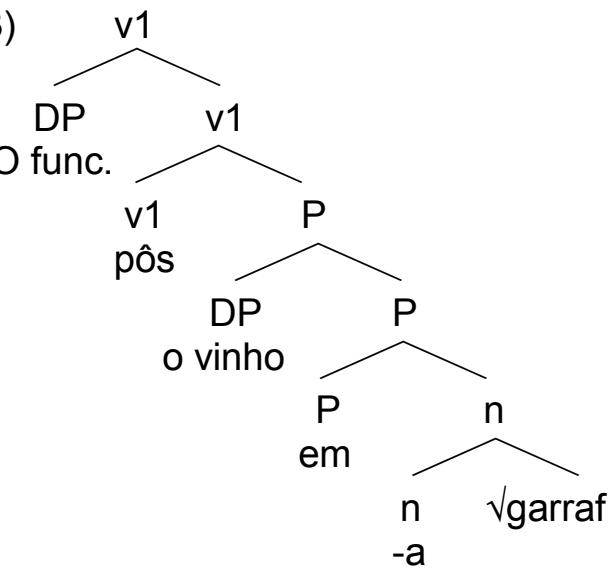

A mesma análise sugerida para o verbo engarrafar pode explicar a formação de estruturas locatum, como a do verbo selar. O que diferencia as duas estruturas é a natureza do núcleo relacionador (on-with).

Selar

(474) O peão selou o cavalo.

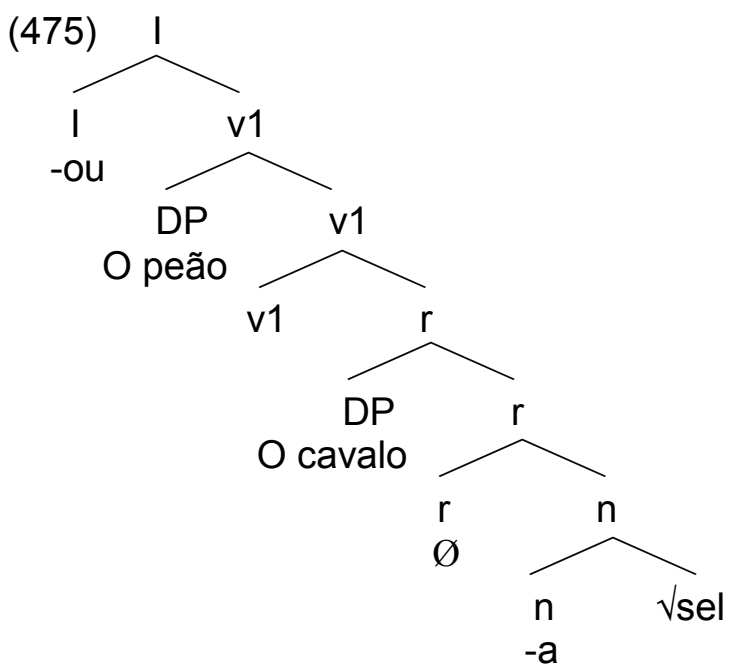


(476) O peão fez o cavalo ficar com a sela.

(477)

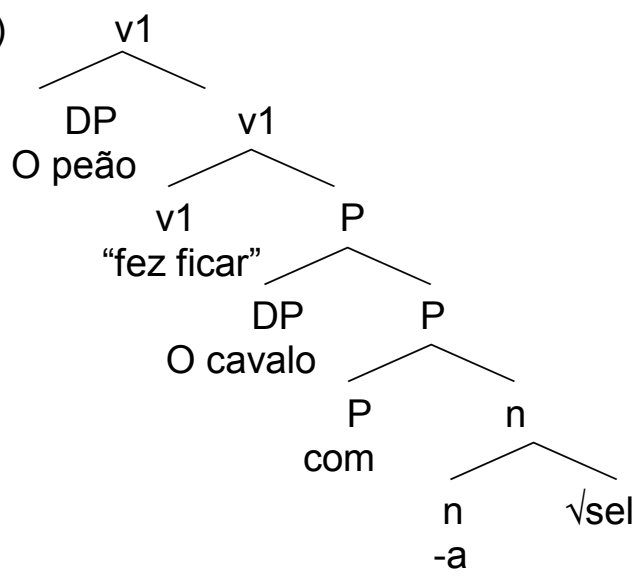

\subsubsection{Verbos com Estruturas não-denominais: derivados da raiz}

A grande diferença entre os verbos denominais sincrônicos e os nãodenominais está em que naqueles o primeiro merge ocorre entre raiz e a categoria de nome para depois se tornar verbo, enquanto nestes a raiz se concatena diretamente com o núcleo verbal $v$. Também nessa subclasse, encontramos verbos tanto sufixais quanto parassintéticos. Constituem essa classe os verbos que apresentaram agramaticalidade frente aos testes 3, (4), 5 e 6 conjuntamente. São eles os verbos acabar, arcar, arrumar, avaliar, brincar, casar, causar, concentrar, cruzar, desfrutar, faltar, apontar2 (indicar) e traçar2 (definir), processar2 (dados).

\section{Arrumar}

(478) A Paula arrumou a casa.

(479) *A casa arrumou.

(480) Casa pequena arruma rápido.

(481) *A Paula deu um rumo à casa.

(482) *A Paula arrumou um rumo da casa.

(483) *A Paula arrumou a casa com um rumo certo.

(484) *A Paula arrumou a casa com um caminho caprichado. 
(485) A Paula arrumou a casa

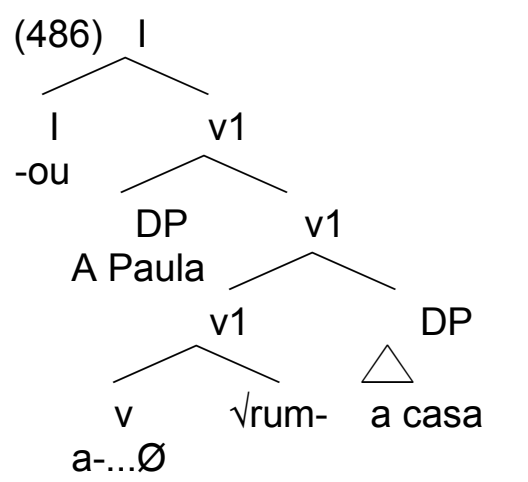

O verbo arrumar, em sentenças como as testadas, certamente não tem a interpretação de dar rumo a, mas sim de organizar, limpar, melhorar, etc. Nessa leitura, os falantes não reconhecem mais o nome rumo na formação desse verbo.

Uma possibilidade de análise diria que a raiz $\downarrow$ rum não está presente na estrutura, e, por esse motivo, parece se possível sugerir que essa raiz tenha gerado outra, nomeadamente, Varrum-. Dessa forma, daríamos conta da inatividade do prefixo $-a$, que parece ser apenar um elemento fonológico ou mesmo morfológico. Temos palavras na língua como a nominalização arrumação, o particípio arrumado(a), o nome agentivo arrumadeira, todas com sentido de "organizar", e não com sentido de rumo, e contendo o suposto prefixo a- . Essas palavras poderiam ser evidência da existência da raiz Varrum.

Entretanto, no sentido de manter uma análise mais uniforme e evitarmos a necessidade de da existência de duas raízes na lista 1, Vrum e $\sqrt{ }$ arrum, que são relacionadas de alguma forma, podemos dar conta da explicitação dos fatos novamente pela operação de fissão. Se assumirmos que o prefixo -a é também parte do morfema fissionado, como sugerimos para os outros verbos, damos conta da nãorelação entre arrumar e rumo somente pela ausência de uma fase nominal. As evidências independentes apontadas para a existência de $\sqrt{ }$ arrum- são falseáveis. A 
observação de que palavras como a nominalização arrumação, o particípio arrumado(a), o nome agentivo arrumadeira têm o prefixo -a explica-se pelo fato de que as mesmas são deverbais, formadas a partir do verbo arrumar e a explicação da presença de -a se segue da explicitação dada acima.

Nessa abordagem, podemos ainda explicar como se dá a formação do verbo para o falante que interpretada arrumar a vida como dar um rumo na vida. Ele pode estar formando outra estrutura, diferente daquela em que a raiz $\sqrt{ }$ rum é categorizada por um v diretamente. A estrutura deve ser assim:

(487) A Paula (se) arrumou (n)a vida

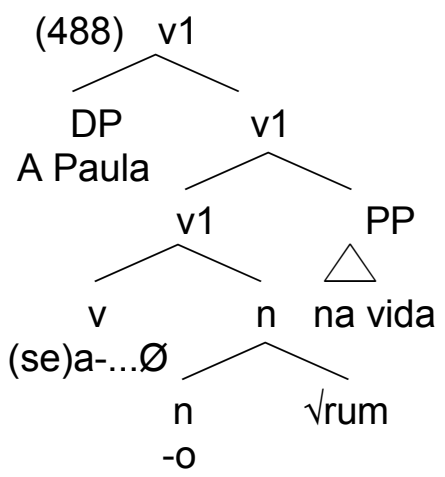

Quando o falante de PB quer formar uma perífrase de arrumar a vida, ele usa algo como Paula deu um rumo em sua vida, o que indica que o significado passa pelo nome rumo.

\section{Brincar}

O verbo brincar se comporta de forma idêntica ao verbo arrumar, com a diferença de ser somente sufixal. O núcleo verbal não sofre o processo de fissão no componente morfológico. Ficou comprovado que já não há mais relação sincrônica entre brinco e brincar. 
(489) A criança brincou com o amigo.

(490) *(Com o amigo) brincou.

(491) *(Com amigos) brinca fácil.

(492) *A criança fez brinco com o amigo.

(493) *A criança brincou um brinco com o amigo.

(494) *A criança brincou com o amigo com um brinco engraçado. ${ }^{72}$

(495) *A criança brincou com o amigo com um adereço engraçado.

(496) A criança brincou com o amigo.

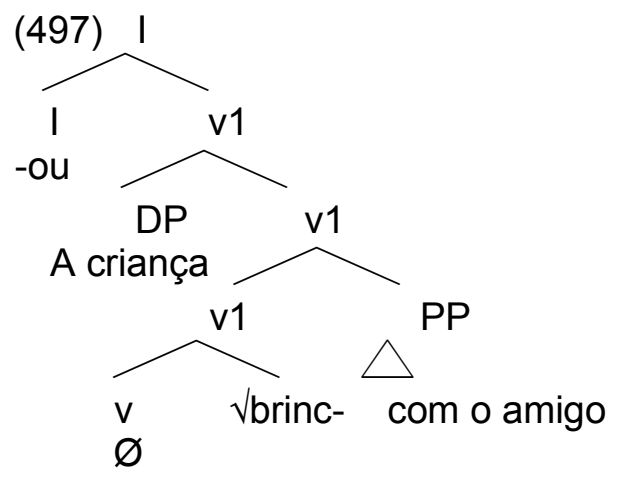

\section{Desfrutar}

O verbo desfrutar parece um caso um pouco mais complexo. Sua relação estreita com o nome formador foi abandonada há muito tempo. No momento em que o verbo se formou existia uma relação entre des- no sentido de tirar, colher, e frutos, que no sentido metafórico significara recompensas. No entanto, será que ao formular a frase com esse verbo o falante necessita recompor esse percurso histórico? Segundo os testes abaixo, não.

\footnotetext{
${ }^{72}$ As sentenças em (494) e (495) apresentam ambiguidade. Os adjuntos podem ser interpretados como adjuntos de verbo Brincar ou como adjuntos do NP sujeito criança. A segunda leitura não é relevante para nossos propósitos. Os falantes que apresentaram seus julgamentos para ela tendo em vista a primeira leitura, a julgaram como agramatical
} 
(498) O grupo desfrutou a viagem.

(499) *A viagem desfrutou.

(500) *Viagem de fim de ano desfruta muito.

(501) *O grupo não fez fruto da viagem.

(502) ?O grupo não desfrutou bons frutos da viagem.

(503) ?O grupo não desfrutou a viagem com bons frutos.

(504) Impossível formular teste.

Des- e -ar constituem um caso de morfema fissionado, apesar de os falantes não reconhecerem o nome fruto em desfrutar, a raiz está ativa. Nesse caso, vemos sentido para propor que o nome eventivo desfrute seja um deverbal, preservando a herança do verbo desfrutar, o prefixo -des.

(505)

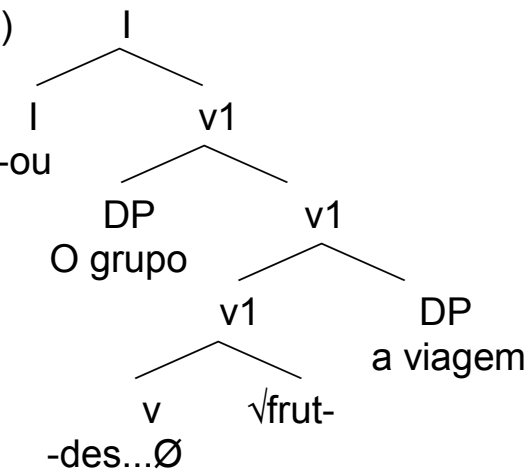

(506)

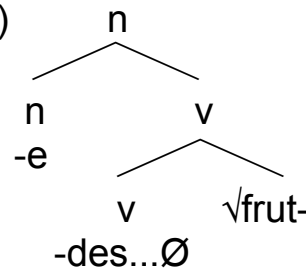

A manutenção do sentido eventivo em desfrute se dá por conta da existência da fase verbal. Outras palavras na língua parecem não ter mais o sentido de negação da base quando formadas pelo prefixo des- e servirão como evidência independente para a análise acima. O verbo desabar, por exemplo, não tem o sentido estrito de "tirar 
ou negar aba" na maioria dos casos em que ocorre, e há ainda o adjetivo desabado, que não significa "sem abas" na maior parte dos contextos, mas pode significar na expressão "chapéu desabado", por exemplo. O mesmo parece ocorrer com palavras como desesperar, desesperado, desabafar, desabafado, desgastar, desgastante, entre outros $^{73}$.

Dentre os verbos que perderam relação entre nome e verbo, apenas acabar participa de alternância causativo-incoativa e alternância média. Os verbos arrumar e filtrar participam apenas de alternância média. As estruturas de alternância para eles serão as mesmas sugeridas para verbos como misturar.

\subsubsection{Verbos com Estruturas Denominais e estruturas "de maneira"}

Assumimos que o verbo martelar, e outros como ele (agulhar, colar, escovar, martelar, traçar1), é inicialmente denominal em estruturas em que o evento foi executado com o instrumento denotado pelo nome martelo. Entretanto, as sentenças de sentido especial, conotativo, mantêm somente o modo de realização do evento e prescindem da presença do objeto. Assim, esses verbos são do grupo denominal e do grupo não-denominal ao mesmo tempo, dependendo do ambiente sintático e semântico em que ocorrem.

Para uma sentença como Eu martelei o prego em que a interpretação é a de que foi com o martelo, para todos os falantes, teríamos uma derivação tipicamente denominal.

\footnotetext{
${ }^{73}$ Afirmações iniciais e intuitivas que carecem de maior investigação.
} 
(507) Eu martelei o prego.

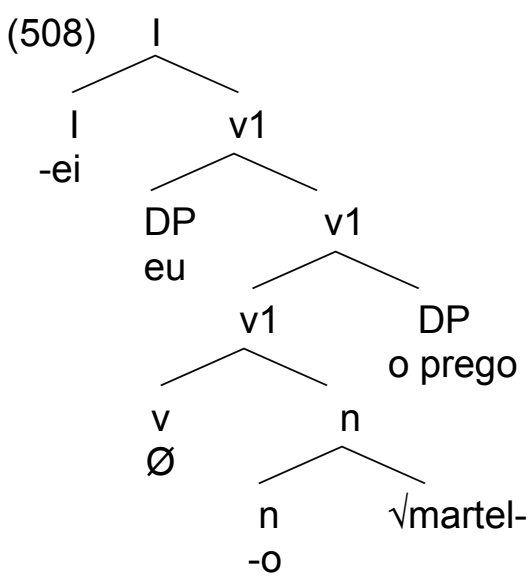

(509) Eu bati o prego com o martelo.



Na estrutura em (464), a raiz que forma bater é impregnada, de alguma forma, por um modo, por influência das características de modo da raiz que forma o instrumento martelo, como foi primeiramente notado por Harley (2005).

Diferentemente, podemos ter uma sentença em que a presença do nome martelo não é necessária e, acima de tudo, não há evidências de sua presença. 
(511) Eu martelei o prego com a sola do sapato.

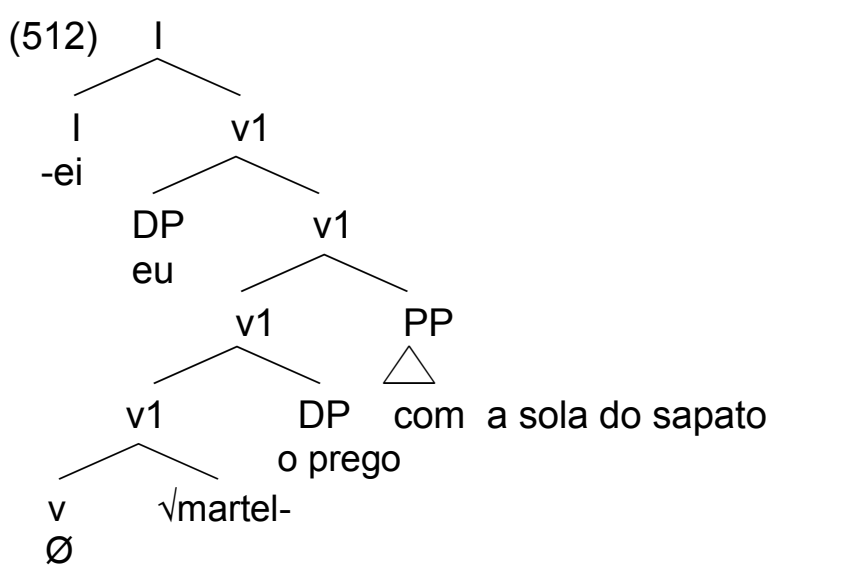

Mais uma vez, o adjunto funciona como uma pista de que nessa sentença o verbo não é formado a partir de um nome. Nessa estrutura, da mesma forma que ocorre com a anterior, a raiz de martelar é portadora de modo, mas o instrumento martelo não tem de ser necessariamente denotado pelo nome. Como afirma Arad (2003), tanto o verbo martelar quanto o nome martelo são formados pela mesma raiz, que contém exatamente as mesmas propriedades. Isso explica porque há o mesmo modo de ação na sentença em (509) e (511): a mesma raiz está presente.

A previsão é de que qualquer raiz portadora de traços de maneira, como a de martelo e martelar (bater de maneira específica), pode gerar uma estrutura verbal formada diretamente a partir dela.

\subsubsection{4. "Mesmo" verbo com comportamentos opostos. Dois verbos?}

Os verbos apontar, traçar e processar foram estudados para seus dois significados correntes na língua. Sugeriremos uma explicação simples para esses casos: uma interpretação contém uma etapa nominal e a outra não. Vejamos as representações para os verbos apontar, parassintético, e traçar, sufixal. Da mesma forma que ocorre com os verbos que podem ter estrutura de maneira, esses verbos 
são do grupo denominal e do grupo não-denominal ao mesmo tempo, dependendo do ambiente sintático e semântico em que ocorrem.

Apontar com etapa nominal

(513) O aluno apontou o lápis.

(514) ?O lápis apontou.

(515) Lápis bom aponta fácil.

(516) O menino (re)fez a ponta do lápis.

(517) O menino apontou a ponta (quebrada) do lápis.

(518) O menino apontou o lápis com a ponta fina.

(519) O menino apontou o lápis com um bico exagerada.

(520)

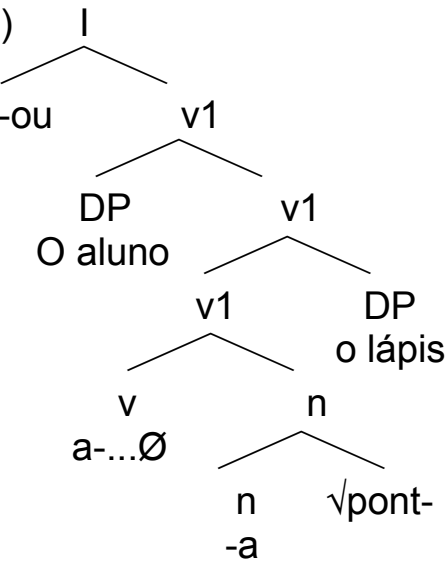

Com expressão perifrástica, temos:

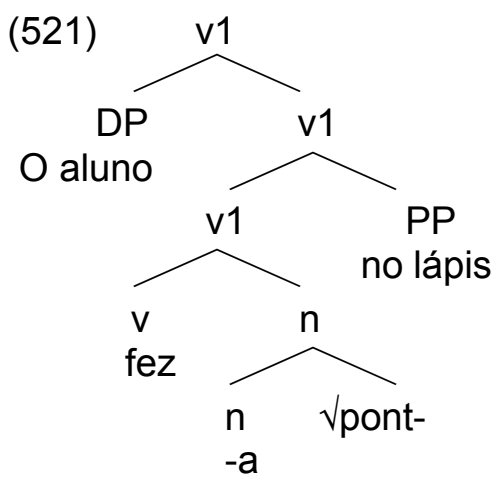


A estrutura em (502) representa a interpretação em que o falante vê a relação entre o nome ponta e o verbo apontar, no sintagma apontar o lápis, por exemplo. A partícula a-, que é considerada historicamente como uma preposição que formou o verbo apontar, sincronicamente ocupa junto com o sufixo verbal -ar a posição de núcleo da categoria verbal. Assumimos que o nó terminal do morfema verbal é fissionado em dois morfemas, o prefixo e o sufixo. A não existência das palavras *pontar e *aponta serve como evidência para nossa hipótese.

Por outro lado, na interpretação em que a presença do nome formador não é mais necessária, sugerimos uma derivação diferente para o verbo.

Apontar sem etapa nominal (indicar)

(522) A comissão apontou falhas no projeto.

(523) *As falhas apontaram.

(524) *Falhas grotescas apontam fácil.

(525) *A comissão apontou a ponta das falhas.

(526) *A comissão fez uma ponta das falhas.

(527) *A comissão apontou as falhas com a ponta fina.

(528) *A comissão apontou as falhas com um bico exagerado.

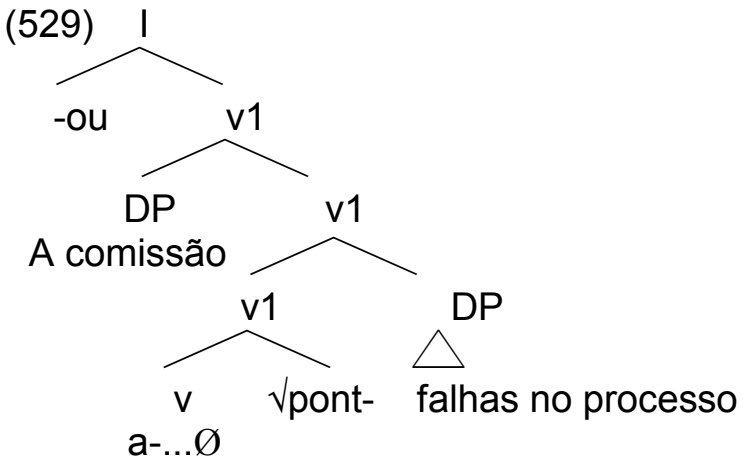

As mesmas representações servem para o verbo traçar com uma diferença morfológica: para esse, não há fissão do morfema verbal. 
Traçar com etapa nominal

(530) O desenhista traçou o desenho no papel.

(531) ${ }^{*} \mathrm{O}$ desenho traçou no papel.

(532) ?Desenho simples traça rápido.

(533) O desenhista fez os traços do desenho no papel.

(534) O desenhista traçou traços fortes no papel.

(535) O desenhista traçou o desenho no papel com traços fortes.

(536) O desenhista traçou o desenho no papel com riscos fortes.

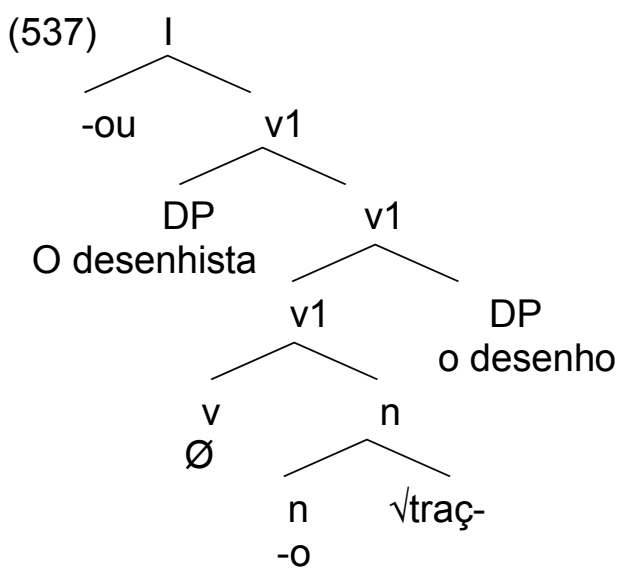

Traçar sem etapa nominal (indicar)

(538) O técnico traçou a estratégia.

(539) *A estratégia traçou.

(540) ?Estratégia simples traça rápido.

(541) ?O técnico fez os traços da estratégia.

(542) ?O técnico traçou traços fortes da estratégia.

(543) ?O técnico traçou a estratégia com traços precisos.

(544) ?O técnico traçou a estratégia com riscos fortes. ${ }^{74}$

\footnotetext{
${ }^{74}$ Apesar dos julgamentos terem se mostrado indeterminados para os testes 3 a 6 , temos de observar esses resultados em comparação aos do verbo traçar com etapa nominal, que mostram todos gramaticalidade.
} 
(545)

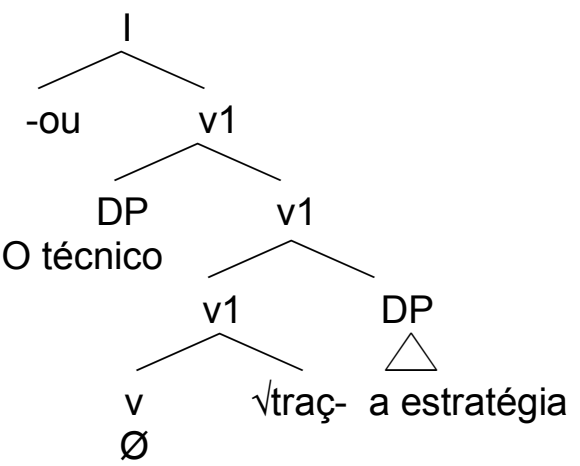

\subsubsection{Conclusão da subseção}

Nesta seção, partimos dos pressupostos da teoria da MD para dar tratamento aos dados descritos na seção 4. Baseamo-nos nos trabalhos de Arad (2003), Marantz (2008) e Harley (2005) para conseguir diferenciar estruturas com uma etapa nominal (denominais) de estruturas derivadas diretamente da raiz. Conseguimos representar estruturalmente os diferentes tipos de (supostos) VDs no que se refere ao seu comportamento sintático e sua relação semântica com os (supostos) nomes formadores.

Em primeiro lugar, conseguimos dar conta de tratar dois grandes grupos: o primeiro contém os verbos que são formados a partir da categorização de uma raiz por um nome (n) e, em seguida, por um verbo (v) (estruturas denominais sincrônicas) e o segundo por verbos que são formados pela categorização de uma raiz $(\sqrt{ })$ por um verbo (v) (estruturas não-denominais). No primeiro grupo, o dos denominais, observamos diferenças no comportamento sintático e sugerimos para eles diferentes tipos de estruturas: de alternância, de não-alternância e location/locatum. Por fim, discutimos dois tipos de fenômenos que culminam na formação tanto de verbos denominais quanto de verbos derivados diretamente da raiz para aqueles que parecem, em princípio, tratar-se de um só verbo (Verbos com estruturas denominais e estruturas de maneira e "Mesmo" verbo com comportamentos opostos). 
Concluímos que o tratamento proposta pareceu explicar de uma forma adequada e elegante os dados estudados neste trabalho. 


\section{CONCLUSÕES}

O principal objetivo deste trabalho foi atingido. Conseguimos mostrar que verbos denominais diacrônicos podem ou não manter-se como denominais em uma análise sincrônica. Para isso, fizemos usos de testes estruturais julgados por falantes nativos de PB, agregando confiabilidade aos resultados e contribuindo para uma boa descrição dos dados.

Chegamos a duas grandes classes no que se refere à formação de Verbos Denominais, os sincronicamente denominais e os que perderam a relação com o nome derivado da mesma raiz. Dentro dessas classes, encontramos heterogeneidade no que se refere ao comportamento sintático: há verbos alternantes e não alternantes, há expressões perifrásticas formadas com diversos verbos leves, como fazer, dar e tirar, e há verbos que permitem e outros que não permitem a adição de objetos cognatos, adjuntos cognatos e adjuntos hipônimos e hiperônimos. Assim, conseguimos provar que, além da comprovada existência de classes morfológicas entre os VDs (sufixais e parassintéticos), há subclasses sintáticas e semânticas.

Observamos que o tratamento mais conhecido em PB para os VDs, aquele das regras de formação de palavras, não é totalmente satisfatório para tratar essa complexa classe, especialmente no que se refere à falta de uma visão estrutural.. Sugerimos, então, um novo tipo de análise, baseada em modelos como a sintaxe lexical de H\&K (2002) e a Morfologia Distribuída (Halle \& Marantz, 1993). Concluímos que essa última possui as ferramentas necessárias para tratar a distinção entre verbos formados de nome e verbos formados diretamente de raízes. O que pode ser expandido para palavras de outras classes morfossintáticas.

Finalmente, a maior contribuição teórica deste trabalho está em que avançamos no esclarecimento da diferença entre uma formação sincrônica e diacrônica de palavras, mostrando que nem sempre a explicação histórica é a única possível. 


\section{REFERÊNCIAS BIBLIOGRÁFICAS}

Anderson, S.R. (1982) Where's morphology? Linguistic Inquiry 13, 571-612.

Arad, M. (2003) "Locality Constraints on the Interpretation of Roots: the Case of Hebrew Denominal Verbs". Natural Language and Linguistics Theory 21, 737-778.

Aronoff, M. (1976) Word formation in Generative Grammar. Cambridge: The MIT Press.

Basílio, M. (1993) "Verbos em -a(r) em português: afixação ou conversão?". Documentação de Estudos em Linguística Teórica e Aplicada, v. 9, n. 2, p. 295-304.

Basílio, M. (1996) VDs no Português Falado. In: I. G. V. KOCH (org.) Gramática do Português Falado VI: Desenvolvimentos. Campinas: Ed. Unicamp/ FAPESP: 377396.

Basílio, M. (1999) A morfologia no Brasil: indicadores e questões. DELTA, vol. 15, n. especial, p.53-70.

Bassani, I.S. (2008) Sintaxe da Transitividade: Verificação de uma proposta para as sentenças de Alternância Ergativa do Português do Brasil. Revista Virtual de Estudos da Linguagem, v.6, p.1 - 23.

Beard, R. (1995) Lexeme-morpheme base morphology. Albany: SUNY Albany Press.

Bechara, E. (2002) Moderna gramática portuguesa. Rio de Janeiro: Lucerna

Bloomfield, L. (1966[1926]) A set of postulates for the science of language. Joos, M.(eds.) Readings in Linguistic I: the development of Descriptive Linguistics in America 1925-56. Chicago: The University of Chicago Press.

Bowers, J. (2002). "Transitivity". Linguistic Inquiry 33. 2: 183-224.

Burzio, L. (1986). Italian Syntax: A Government-Binding Approach. Dortrecht: Reidel. 
Chomsky, N. (1970) Remarks on Nominalization. Readings in Transformational Grammar, edited by R. A. Jacobs \& P. S. Rosenbaum, 184-221. Waltham, Mass.: Ginn.

Chomsky, N. (2001) Derivation by Phase. In: M Kenstowicz, ed., Ken Hale: A Life in Language. Cambridge: MIT Press, 1-52.

Cunha, A.G. (1999). Dicionário etimológico Nova Fronteira da língua portuguesa. $2^{\circ}$ Ed. Rio de Janeiro : Nova Fronteira.

Di Sciullo, A.M \& E. Williams (1977) On the Definition of Word. Cambridge: MIT Press.

Dubinsky, S. \& R. Simango (1996) Passive and Stative in Chichewa: evidence for modular distinctions in grammar. Language, 72: 749-781.

Ferreira, A.G. (1988) Dicionário de Latim-Português. Porto: Porto Editora.

Hale, K. \& J. Keyser. (1993) On Argument Structure and the Lexical Expression of Syntactic Relations. In The View From Building 20. MIT Press. (2002) Prolegomenon to a theory of argument structure. MIT Press.

Halle, M. \& A. Marantz. (1993) Distributed morphology and the pieces of inflection. The View from Building 20, edited by K. Hale \& S.J. Keyser, 111-176. Cambridge, Mass.: MIT Press.

Harley, H. (2005) "How do verbs get their names? Denominal verbs, Manner Incorporation and the ontology of verb roots in English," in Nomi Erteschik-Shir and Tova Rapoport, eds., The Syntax of Aspect, 42-64. Oxford: Oxford University Press. (2007) The bipartite structure of verbs cross-linguistically. Revista da Abralin, p.45-81.

Harley, H. \& R. Noyer. (1999). State-of-the-Article: Distributed Morphology. Glot. International 4.4, pp 3-9

Harley, H \& D.H. Haugen. (2007) Are there really two different classes of instrumental denominal verbs in English? Snippets, Issue 16. 
Houaiss, A. (2002) Dicionário Eletrônico Houaiss da Língua Portuguesa. Rio de Janeiro: Objetiva.

Kato, M.A. (1999) Strong pronouns, weak pronominals and the null subject parameter. PROBUS. 11, p. 1-37.

(2000) The partial pro-drop nature and the restricted VS order in Brazilian Portuguese. In: M.A. Kato \& E.V. Negrão (eds). Brazilian Portuguese and the null subject parameter. Vervuert-Iberoamericana, 2000.

Kiparsky, P. (1982) 'Word Formation and the Lexicon', in Fred Ingeman (ed.), Proceedings of the Mid-America Linguistics Conference, University of Kansas, pp. $3-29$.

(1997) 'Remarks on Denominal Verbs', in Alex Alsina, Joan Bresnan and Peter Sells (eds.), Complex Predicates, CSLI Publications, Stanford, CA, pp. 473-499

Lakoff, G \& M. Jonhson. (1970) Metaphors we live by. The Universtity of Chicago Press, Chicago and London.

Lakoff, G. (1977) Women, fire and dangerous things. What categories reveal about the mind. The Universtity of Chicago Press, Chicago and London.

Lemle, M. (2008) Arbitrariedade saussureana: saltos e sobressaltos. Artigo apresentado no XXIII ENANPOLL. GT de Teoria da Gramática.

Lees, R.B. (1960) The Grammar of English Nominalizations. Bloomington, Indiana University Press \& Den Ilaag: Mouton.

Leung, R. (2007) Um estudo sobre os adjetivos adverbiais e os objetos cognatos no português do Brasil. Dissertação de Mestrado. Departamento de Linguística da Faculdade de Filosofia, Letras e Ciências Humanas da Universidade de São Paulo. Machado, J.P. (1967). Dicionário etimológico da língua portuguesa. $2^{\mathrm{a}}$ Ed. Lisboa: Confluência. 
Marantz, A. (1997). No escape from syntax: don't try morphological analysis in the privacy of your own lexicon", in A.Dimitriadis, L. Siegel et al., eds. University of Pennsylvania Working Papers in Linguistics, vol. 4.2, Proceedings of the 21st Annual Penn Linguistics Colloquium, p. 201-225.

(2000) Roots: the universality of Root and Pattern Morphology. Paper presented at the conference on Afro-Asiatic languages, University of Paris VII. (2001). Words. WCCFL XX Handout,USC, February, 2001. (2008). Phases and Words. New York University. Último acesso em 13 $\begin{array}{lllll}\text { de maio } & \text { de } & 2009 & \text { em }\end{array}$ http://homepages.nyu.edu/ ma988/Phase_in_Words_Final.pdf.

Minussi, R.D. (2008) A relação entre Caso e definitude no hebraico: o Construct State e a Marcação Diferencial de Objeto. Dissertação de Mestrado. Departamento de Linguística da Faculdade de Filosofia, Letras e Ciências Humanas da Universidade de São Paulo.

Peter, M.M.T. (2003) Morfologia. In: Fiorin, J.L. Introdução à Linguística II. Princípios de Análise. São Paulo, Contexto.

Rocha, L.C. (2003) Estruturas Morfológicas do Português. Minas Gerais: UFMG.

Sandmann, A.J. (1978) Competência lexical: produtividade, restrições e bloqueio. Tese de Provimento de Cátedra. Curitiba.

(1992) Morfologia Lexical. São Paulo: Contexto.

Scher, A.P. (2004) As construções com o verbo leve Dar e nominalizações em -Ada no português do Brasil. Tese de doutorado. UNICAMP.

(2006) Nominalizações em -ada em Construções com o Verbo Leve dar em Português Brasileiro. Letras de Hoje. Porto Alegre. v. 41, n 1, p. 29-48.

Sausurre, F. A. (1969). Linguística Estática e a Linguística Evolutiva. In: Curso de Linguística Geral. São Paulo: Cultrix, p. 94-116. 
Viaro, M.E. (2008) A data das Palavras. In: Revista Língua Portuguesa, Ed. 37, 11/2008. São Paulo: Editora Segmento. 
9. ANEXOS

ANEXO 01 - LISTA TOTAL DE VERBOS

ANEXO 02 - VERBOS ESTUDADOS

ANEXO 03 - EMAIL EXPLICATIVO

ANEXO 04 - AMOSTRAGEM

ANEXO 05 - TESTES E RESULTADOS

ANEXO 06 - VERBOS COM ORIGEM DUVIDOSA 
ANEXO 01 - LISTA TOTAL DE VERBOS

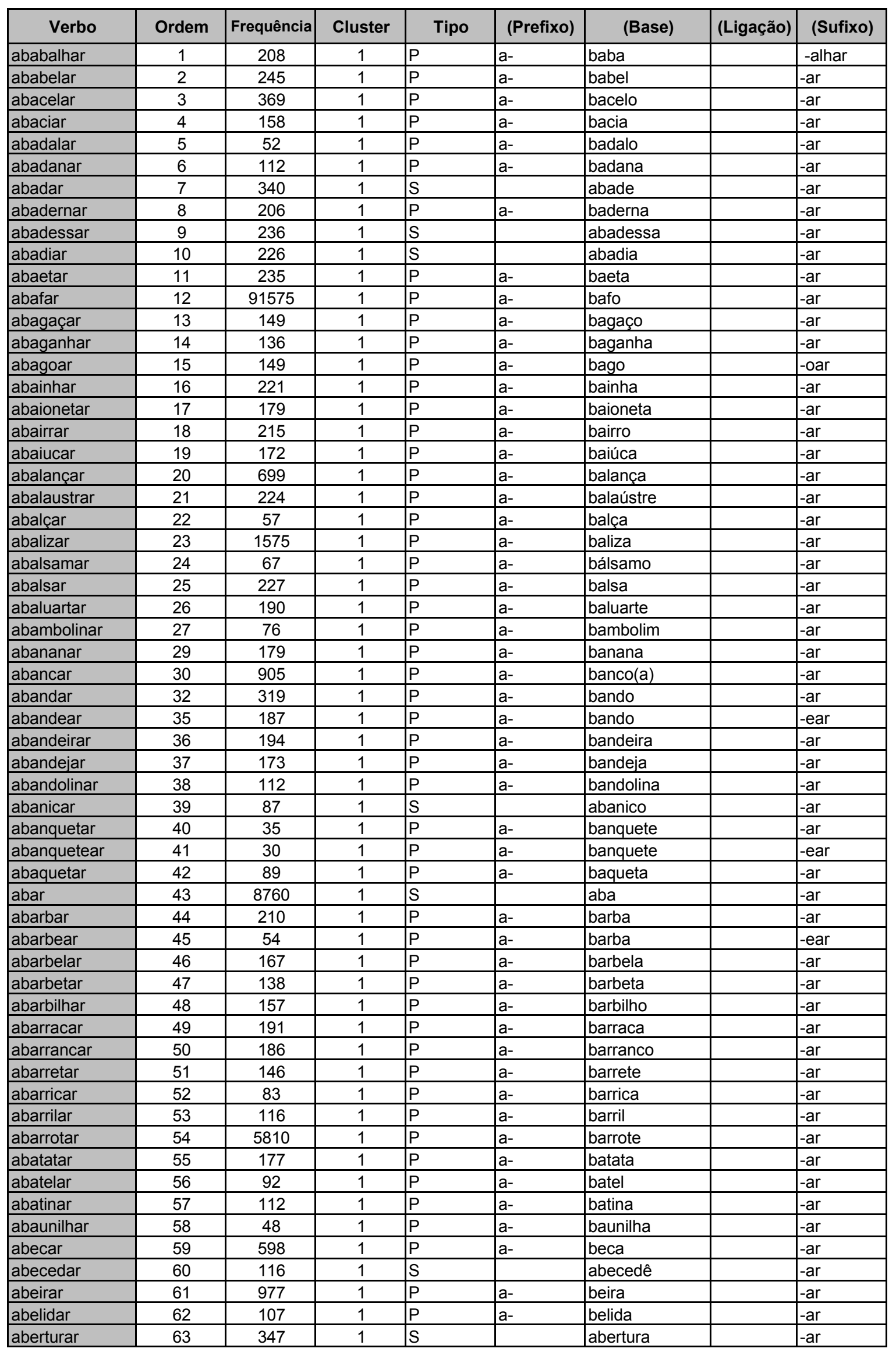




\begin{tabular}{|c|c|c|c|c|c|c|c|}
\hline abesourar & 64 & 84 & 1 & $P$ & a- & besouro & -ar \\
\hline abexigar & 65 & 62 & 1 & $P$ & a- & bexiga & -ar \\
\hline abezerrar & 66 & 0 & 1 & $P$ & a- & bezerro & -ar \\
\hline abibliotecar & 67 & 77 & 1 & $P$ & a- & biblioteca & $-a r$ \\
\hline abicar & 68 & 515 & 1 & $P$ & a- & bico & -ar \\
\hline abichar & 69 & 164 & 1 & $\mathrm{P}$ & a- & bicho & -ar \\
\hline abigodar & 70 & 18 & 1 & $P$ & a- & bigode & -ar \\
\hline abigornar & 71 & 20 & 1 & $P$ & a- & bigorna & -ar \\
\hline abilhar & 72 & 32 & 1 & $P$ & a- & bilha & -ar \\
\hline abilolar & 73 & 158 & 1 & $P$ & a- & bilola & -ar \\
\hline abiombar & 74 & 80 & 1 & $P$ & a- & biombo & -ar \\
\hline abiqueirar & 75 & 11 & 1 & $P$ & a- & biqueira & -ar \\
\hline abisagrar & 76 & 60 & 1 & $\mathrm{P}$ & a- & bisagra & -ar \\
\hline abiscoitar & 77 & 1253 & 1 & $\mathrm{P}$ & a- & biscoito & -ar \\
\hline abiscoutar & 78 & 137 & 1 & $\mathrm{P}$ & a- & biscouto & -ar \\
\hline abismar & 79 & 1258 & 1 & $S$ & & abismo & -ar \\
\hline abitar & 80 & 785 & 1 & $S$ & & abita & -ar \\
\hline abitolar & 81 & 131 & 1 & $\mathrm{P}$ & a- & bitola & -ar \\
\hline abobadar & 82 & 187 & 1 & $S$ & & abóbada & -ar \\
\hline abocadar & 83 & 1 & 1 & $\mathrm{P}$ & a- & bocado & -ar \\
\hline abocanhar & 84 & 40900 & 1 & $P$ & a- & boca & -anhar \\
\hline abocar & 85 & 333 & 1 & $P$ & a- & boca & -ar \\
\hline aboçar & 86 & 125 & 1 & $\mathrm{P}$ & a- & boçar & -ar \\
\hline abocetar & 87 & 140 & 1 & $\mathrm{P}$ & a- & boceta & -ar \\
\hline abochornar & 88 & 151 & 1 & $\mathrm{P}$ & a- & bochorno & -ar \\
\hline abodegar & 89 & 102 & 1 & $\mathrm{P}$ & a- & bodega & -ar \\
\hline abodocar & 90 & 64 & 1 & $\mathrm{P}$ & a- & bodoque & -ar \\
\hline aboiar & 91 & 742 & 1 & $\mathrm{P}$ & a- & bóia & -ar \\
\hline abojar & 93 & 99 & 1 & $\mathrm{P}$ & a- & bojo & -ar \\
\hline abolachar & 94 & 111 & 1 & $P$ & a- & bolacha & -ar \\
\hline abolar & 95 & 247 & 1 & $P$ & a- & bola & -ar \\
\hline aboldriar & 96 & 93 & 1 & $\mathrm{P}$ & a- & boldrié & -ar \\
\hline aboleimar & 97 & 81 & 1 & $P$ & a- & boleima & -ar \\
\hline aboletar & 98 & 1118 & 1 & $\mathrm{P}$ & a- & boleto & -ar \\
\hline abolinar & 99 & 120 & 1 & $P$ & a- & bolina & -ar \\
\hline abolsar & 100 & 117 & 1 & $P$ & a- & bolsa & -ar \\
\hline abombar & 101 & 144 & 1 & $P$ & a- & bomba & -ar \\
\hline abonançar & 102 & 128 & 1 & $\mathrm{P}$ & a- & bonança & -ar \\
\hline abonecar & 103 & 100 & 1 & $\mathrm{P}$ & a- & boneca & -ar \\
\hline aboquilhar & 104 & 11 & 1 & $\mathrm{P}$ & a- & boquilha & -ar \\
\hline aborbitar & 105 & 2 & 1 & $P$ & ab- & órbita & -ar \\
\hline aborbulhar & 106 & 135 & 1 & $P$ & a- & borbulha & -ar \\
\hline aborletar & 107 & 129 & 1 & $\mathrm{P}$ & a- & borleta & -ar \\
\hline abornalar & 108 & 131 & 1 & $P$ & a- & bornal & -ar \\
\hline aborrascar & 109 & 69 & 1 & $\mathrm{P}$ & a- & borrasca & -ar \\
\hline abostelar & 110 & 74 & 1 & $\mathrm{P}$ & a- & bostela & -ar \\
\hline abotecar & 111 & 81 & 1 & $S$ & & aboteca & -ar \\
\hline aboticar & 112 & 108 & 1 & $\mathrm{P}$ & a- & boteco & -ar \\
\hline abotijar & 113 & 73 & 1 & $P$ & a- & botija & -ar \\
\hline abotinar & 114 & 103 & 1 & $P$ & a- & botina & -ar \\
\hline aboubar & 115 & 89 & 1 & $\mathrm{P}$ & a- & bouba & -ar \\
\hline abraçar & 116 & 595250 & 2 & $\mathrm{P}$ & a- & braço & -ar \\
\hline abrasar & 117 & 4505 & 1 & $\mathrm{P}$ & a- & brasa & -ar \\
\hline abrasear & 118 & 87 & 1 & $\mathrm{P}$ & a- & brasa & -ear \\
\hline abrecar & 119 & 47 & 1 & $P$ & a- & breque & -ar \\
\hline abrejar & 120 & 125 & 1 & $P$ & a- & brejo & -ar \\
\hline abrenhar & 121 & 119 & 1 & $\mathrm{P}$ & a- & brenha & -ar \\
\hline abrocar & 122 & 43 & 1 & $\mathrm{P}$ & a- & broca & $-a r$ \\
\hline abrolhar & 123 & 333 & 1 & $S$ & & abrolho & -ar \\
\hline abroquelar & 124 & 322 & 1 & $P$ & a- & broquel & -ar \\
\hline abrumar & 125 & 206 & 1 & $P$ & a- & bruma & -ar \\
\hline absintar & 126 & 61 & 1 & $S$ & & absinto & -ar \\
\hline absintiar & 127 & 92 & 1 & $S$ & & absíntio & -ar \\
\hline abuanar & 128 & 2 & 1 & $\mathrm{P}$ & a- & buana & -ar \\
\hline
\end{tabular}




\begin{tabular}{|c|c|c|c|c|c|c|c|}
\hline abuçar & 129 & 7 & 1 & $\mathrm{P}$ & a- & buço & -ar \\
\hline abugalhar & 130 & 91 & 1 & $\mathrm{P}$ & a- & bugalho & -ar \\
\hline abular & 131 & 180 & 1 & $P$ & a- & bula & -ar \\
\hline abundanciar & 132 & 120 & 1 & $S$ & & abundância & -ar \\
\hline aburacar & 133 & 165 & 1 & $P$ & a- & buraco & -ar \\
\hline aburelar & 134 & 101 & 1 & $P$ & a- & burel & -ar \\
\hline aburilar & 135 & 72 & 1 & $\mathrm{P}$ & a- & buril & -ar \\
\hline acabaçar & 136 & 129 & 1 & $\mathrm{P}$ & a- & cabaça & -ar \\
\hline acabanar & 137 & 129 & 1 & $\mathrm{P}$ & a- & cabana & -ar \\
\hline acabar & 138 & 511250 & 2 & $\mathrm{P}$ & a- & cabo & -ar \\
\hline acabelar & 139 & 112 & 1 & $\mathrm{P}$ & a- & cabelo & -ar \\
\hline acabramar & 140 & 121 & 1 & $P$ & a- & cabramo & -ar \\
\hline acaçapar & 141 & 177 & 1 & $\mathrm{P}$ & a- & caçapo & -ar \\
\hline acachaçar & 142 & 2 & 1 & $\mathrm{P}$ & a- & cachaça & -ar \\
\hline acachafundar & 144 & 70 & 1 & $\mathrm{P}$ & a- & cachafundo & -ar \\
\hline acachamorrar & 145 & 0 & 1 & $\mathrm{P}$ & a- & cachamorra & -ar \\
\hline acachaporrar & 146 & 0 & 1 & $P$ & a- & cachaporra & -ar \\
\hline acachoeirar & 147 & 110 & 1 & $\mathrm{P}$ & a- & cachoeira & -ar \\
\hline acacifar & 148 & 120 & 1 & $\mathrm{P}$ & a- & cacifo & -ar \\
\hline acacular & 149 & 133 & 1 & $\mathrm{P}$ & a- & caculo & -ar \\
\hline acadeirar-se & 150 & 24 & 1 & $P$ & a- & cadeira & -ar \\
\hline academiar & 151 & 146 & 1 & $S$ & & academia & -ar \\
\hline academizar & 152 & 124 & 1 & $S$ & & academia & -izar \\
\hline açafatar & 153 & 62 & 1 & $S$ & & açafate & -ar \\
\hline açaimar & 154 & 204 & 1 & $S$ & & açaimo & -ar \\
\hline acairelar & 155 & 112 & 1 & $\mathrm{P}$ & a- & cairel & -ar \\
\hline acaixeirar & 156 & 0 & 1 & $\mathrm{P}$ & a- & caixeiro & -ar \\
\hline acajadar & 157 & 87 & 1 & $\mathrm{P}$ & a- & cajado & -ar \\
\hline acalmar & 158 & 341000 & 1 & $\mathrm{P}$ & a- & calma & -ar \\
\hline açalmar & 159 & 4 & 1 & $S$ & & açalmo & -ar \\
\hline acalorar & 160 & 1215 & 1 & $P$ & a- & calor & -ar \\
\hline acambulhar & 161 & 132 & 1 & $\mathrm{P}$ & a- & cambulha & -ar \\
\hline acampainhar & 162 & 28 & 1 & $\mathrm{P}$ & a- & campainha & -ar \\
\hline acampar & 163 & 138000 & 1 & $\mathrm{P}$ & a- & campo & -ar \\
\hline acamurçar & 164 & 115 & 1 & $\mathrm{P}$ & a- & camurça & -ar \\
\hline acanalar & 165 & 137 & 1 & $P$ & a- & canal & -ar \\
\hline acanastrar & 166 & 176 & 1 & $P$ & a- & canastra & -ar \\
\hline acancelar & 167 & 223 & 1 & $\mathrm{P}$ & a- & cancela & -ar \\
\hline acangaceirar & 168 & 173 & 1 & $\mathrm{P}$ & a- & cangaceiro & -ar \\
\hline acangalhar & 169 & 0 & 1 & $\mathrm{P}$ & a- & cangalha & -ar \\
\hline acanivetar & 170 & 160 & 1 & $\mathrm{P}$ & a- & canivete & -ar \\
\hline acanoar & 171 & 83 & 1 & $\mathrm{P}$ & a- & canoa & -ar \\
\hline acanteirar & 172 & 53 & 1 & $\mathrm{P}$ & a- & canteiro & -ar \\
\hline acanular & 173 & 86 & 1 & $P$ & a- & cânula & -ar \\
\hline acapachar & 174 & 120 & 1 & $\mathrm{P}$ & a- & capacho & -ar \\
\hline acapangar & 175 & 124 & 1 & $\mathrm{P}$ & a- & capanga & -ar \\
\hline acapitular & 176 & 126 & 1 & $\mathrm{P}$ & a- & capítulo & -ar \\
\hline acapoeirar-se & 177 & 25 & 1 & $\mathrm{P}$ & a- & capoeira & -ar \\
\hline acapuchar & 178 & 0 & 1 & $P$ & a- & capucha & -ar \\
\hline acaracolar & 179 & 1 & 1 & $P$ & a- & caracol & -ar \\
\hline acarangar & 180 & 165 & 1 & $\mathrm{P}$ & a- & carango & -ar \\
\hline acarapinhar & 181 & 212 & 1 & $P$ & a- & carapinha & -ar \\
\hline acarapuçar & 182 & 182 & 1 & $\mathrm{P}$ & a- & carapuça & -ar \\
\hline acarar & 183 & 230 & 1 & $P$ & a- & cara & -ar \\
\hline acaravelhar & 184 & 152 & 1 & $P$ & a- & caravelho & -ar \\
\hline acardumar & 185 & 71 & 1 & $P$ & a- & cardume & -ar \\
\hline acarear & 186 & 883 & 1 & $P$ & a- & cara & -ear \\
\hline acariciar & 187 & 63175 & 1 & $P$ & a- & carícia & -ar \\
\hline acaridar & 188 & 80 & 1 & $P$ & a- & caridade & -ar \\
\hline acarinhar & 189 & 4178 & 1 & $\mathrm{P}$ & a- & carinho & -ar \\
\hline acarneirar & 190 & 48 & 1 & $P$ & a- & carneiro & -ar \\
\hline acarochar & 191 & 4 & 1 & $\mathrm{P}$ & a- & carocha & -ar \\
\hline acarquilhar & 192 & 30 & 1 & $P$ & a- & carquilha & -ar \\
\hline acarraçar-se & 193 & 17 & 1 & $P$ & a- & carraça & -ar \\
\hline
\end{tabular}




\begin{tabular}{|c|c|c|c|c|c|c|c|}
\hline acarrancar & 194 & 81 & 1 & $\mathrm{P}$ & a- & carranca & -ar \\
\hline acarrapatar & 195 & 67 & 1 & $\mathrm{P}$ & a- & carrapato & -ar \\
\hline acarrear & 196 & 527 & 1 & $P$ & a- & carro & -ear \\
\hline acarretar & 197 & 335250 & 1 & $\mathrm{P}$ & a- & carreta & -ar \\
\hline acartolar & 198 & 47 & 1 & $P$ & a- & cartola & -ar \\
\hline acarunchar & 199 & 31 & 1 & $\mathrm{P}$ & a- & caruncho & -ar \\
\hline acarvalhar & 200 & 27 & 1 & $\mathrm{P}$ & a- & carvalho & -ar \\
\hline acasacar & 201 & 115 & 1 & $P$ & a- & casaco & -ar \\
\hline acasalar & 202 & 15400 & 1 & $P$ & a- & casal & -ar \\
\hline acascarrilhar & 203 & 98 & 1 & $\mathrm{P}$ & a- & cascarrilha & -ar \\
\hline acasernar & 204 & 137 & 1 & $\mathrm{P}$ & a- & caserna & -ar \\
\hline acastelar & 205 & 231 & 1 & $\mathrm{P}$ & a- & castelo & -ar \\
\hline acasular & 206 & 97 & 1 & $\mathrm{P}$ & a- & casulo & -ar \\
\hline acatarrar & 207 & 2 & 1 & $\mathrm{P}$ & a- & catarro & -ar \\
\hline acatassolar & 208 & 144 & 1 & $P$ & a- & catassol & -ar \\
\hline acaudelar & 209 & 55 & 1 & $P$ & a- & caudel & -ar \\
\hline acaudilhar & 210 & 207 & 1 & $P$ & a- & caudilho & -ar \\
\hline acavalar & 211 & 304 & 1 & $\mathrm{P}$ & a- & cavalo & -ar \\
\hline acavaletar & 212 & 106 & 1 & $\mathrm{P}$ & a- & cavalete & -ar \\
\hline acebolar & 213 & 107 & 1 & $P$ & a- & cebola & -ar \\
\hline aceleirar & 214 & 170 & 1 & $P$ & a- & celeiro & -ar \\
\hline aceniscar & 215 & 33 & 1 & $S$ & & aceno & -iscar \\
\hline acerar & 216 & 572 & 1 & $\mathrm{P}$ & a- & cera & -ar \\
\hline acetilar & 217 & 207 & 1 & $S$ & & acetila & -ar \\
\hline acevadar & 218 & 58 & 1 & $\mathrm{P}$ & a- & cevada & -ar \\
\hline achamalotar & 219 & 86 & 1 & $\mathrm{P}$ & a- & chamalote & -ar \\
\hline achaparrar & 220 & 61 & 1 & $\mathrm{P}$ & a- & chaparro & -ar \\
\hline acharoar & 221 & 111 & 1 & $P$ & a- & charão & -ar \\
\hline achichelar & 222 & 65 & 1 & $\mathrm{P}$ & a- & chichelo & -ar \\
\hline achinelar & 223 & 114 & 1 & $P$ & a- & chinelo & -ar \\
\hline achocalhar & 224 & 92 & 1 & $P$ & a- & chocalho & -ar \\
\hline acicatar & 225 & 358 & 1 & $S$ & & acicate & -ar \\
\hline acicular & 226 & 1490 & 1 & S & 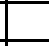 & acícula & -ar \\
\hline acidentar & 227 & 8348 & 1 & $S$ & & acidente & -ar \\
\hline acidrar & 228 & 80 & 1 & $P$ & a- & cidra & -ar \\
\hline acilar & 229 & 214 & 1 & $S$ & & acila & -ar \\
\hline acimar & 230 & 2878 & 1 & $\mathrm{P}$ & a- & cima & -ar \\
\hline acirandar & 231 & 63 & 1 & $\mathrm{P}$ & a- & ciranda & -ar \\
\hline aciumar & 232 & 15 & 1 & $\mathrm{P}$ & a- & ciúme & -ar \\
\hline aclaustrar & 233 & 63 & 1 & $\mathrm{P}$ & a- & claustro & -ar \\
\hline aclerizar & 234 & 75 & 1 & $\mathrm{P}$ & a- & clero & -izar \\
\hline aclimar & 235 & 444 & 1 & $\mathrm{P}$ & a- & clima & -ar \\
\hline acobertar & 236 & 58125 & 1 & $P$ & a- & coberta & -ar \\
\hline acobrear & 237 & 108 & 1 & $\mathrm{P}$ & a- & cobre & -ear \\
\hline acogombrar & 238 & 1 & 1 & $\mathrm{P}$ & a- & cogombro & -ar \\
\hline acogular & 239 & 93 & 1 & $P$ & a- & cogulo & -ar \\
\hline acoiçar & 240 & 44 & 1 & $P$ & a- & coice & -ar \\
\hline acoicear & 241 & 32 & 1 & $P$ & a- & coice & -ear \\
\hline acoirelar & 242 & 91 & 1 & $\mathrm{P}$ & a- & coirela & -ar \\
\hline açoitar & 243 & 6803 & 1 & $S$ & & açoite & -ar \\
\hline acolchetar & 244 & 159 & 1 & $\mathrm{P}$ & a- & colchete & -ar \\
\hline acoletar & 245 & 149 & 1 & $\mathrm{P}$ & a- & colete & -ar \\
\hline acolherar & 246 & 368 & 1 & $P$ & a- & colher & -ar \\
\hline acolitar & 247 & 324 & 1 & $S$ & & acólito & -ar \\
\hline acomadrar & 248 & 160 & 1 & $P$ & a- & comadre & -ar \\
\hline aconfradar & 249 & 173 & 1 & $\mathrm{P}$ & a- & confrade & -ar \\
\hline aconselhar & 250 & 320000 & 1 & $P$ & a- & conselho & -ar \\
\hline acontiar & 251 & 116 & 1 & $P$ & a- & contia & -ar \\
\hline açorar & 252 & 192 & 1 & $S$ & & açor & -ar \\
\hline acordelar & 253 & 84 & 1 & $P$ & a- & cordel & -ar \\
\hline acorrilhar & 254 & 149 & 1 & $\mathrm{P}$ & a- & corrilho & -ar \\
\hline acortinar & 255 & 163 & 1 & $P$ & a- & cortina & -ar \\
\hline acostar & 256 & 40250 & 1 & $\mathrm{P}$ & a- & costa & -ar \\
\hline acostumar & 257 & 517000 & 2 & $\mathrm{P}$ & a- & costume & -ar \\
\hline
\end{tabular}




\begin{tabular}{|c|c|c|c|c|c|c|c|}
\hline açotear & 258 & 0 & 1 & $S$ & & açotéia & -ar \\
\hline acoticar & 259 & 15 & 1 & $P$ & a- & cotica & -ar \\
\hline acotoar & 260 & 77 & 1 & $P$ & a- & cotão & -ar \\
\hline acotovelar & 261 & 1228 & 1 & $P$ & a- & cotovelo & $-a r$ \\
\hline acoturnar & 262 & 87 & 1 & $P$ & a- & coturno & -ar \\
\hline acovar & 263 & 134 & 1 & $\mathrm{P}$ & a- & cova & -ar \\
\hline acovilhar & 264 & 79 & 1 & $P$ & a- & covil & -ar \\
\hline acravar & 265 & 85 & 1 & $\mathrm{P}$ & a- & cravo & -ar \\
\hline acravelhar & 266 & 0 & 1 & $P$ & a- & cravelho & -ar \\
\hline acreditar & 267 & 3085000 & 3 & $P$ & a- & crédito & -ar \\
\hline acrimoniar & 268 & 111 & 1 & $S$ & & acrimônia & -ar \\
\hline acrisolar & 269 & 803 & 1 & $P$ & a- & crisol & -ar \\
\hline acuar & 270 & 4538 & 1 & $\mathrm{P}$ & a- & $\mathrm{cu}$ & -ar \\
\hline açucarar & 271 & 1660 & 1 & $S$ & & açúcar & -ar \\
\hline acuchilar & 272 & 84 & 1 & $P$ & a- & cuchila & -ar \\
\hline açudar & 273 & 185 & 1 & $S$ & & açude & -ar \\
\hline aculear & 274 & 61 & 1 & $S$ & & acúleo & -ear \\
\hline aculturar & 275 & 1865 & 1 & $\mathrm{P}$ & a- & cultura & -ar \\
\hline acumear & 276 & 111 & 1 & $S$ & & acume & -ear \\
\hline acunhar & 277 & 352 & 1 & $\mathrm{P}$ & a- & cunha & -ar \\
\hline acunhear & 278 & 63 & 1 & $\mathrm{P}$ & a- & cunha & -ear \\
\hline acupunturar & 279 & 81 & 1 & $S$ & & acupuntura & -ar \\
\hline acurralar & 280 & 80 & 1 & $P$ & a- & curral & -ar \\
\hline acurrar & 281 & 12 & 1 & $\mathrm{P}$ & a- & curro & -ar \\
\hline acutelar & 282 & 55 & 1 & $\mathrm{P}$ & a- & cutelo & -ar \\
\hline adargar & 283 & 77 & 1 & $S$ & & adarga & -ar \\
\hline adarvar & 284 & 76 & 1 & $S$ & & adarve & -ar \\
\hline adastrar & 285 & 186 & 1 & $S$ & & adastra & -ar \\
\hline adegar & 286 & 255 & 1 & $S$ & & adega & -ar \\
\hline adeusar & 287 & 83 & 1 & $P$ & a- & deus & -ar \\
\hline adiamantar & 288 & 146 & 1 & $P$ & a- & diamante & -ar \\
\hline adiantar & 289 & 782250 & 2 & $S$ & & adiante & -ar \\
\hline adiar & 290 & 758000 & 2 & $P$ & a- & dia & -ar \\
\hline adietar & 291 & 99 & 1 & $P$ & a- & dieta & -ar \\
\hline \begin{tabular}{|l} 
aditar \\
\end{tabular} & 292 & 25775 & 1 & $P$ & a- & dita & -ar \\
\hline adobar & 293 & 107 & 1 & $S$ & & adobe & -ar \\
\hline adolorar & 295 & 20 & 1 & $\mathrm{P}$ & a- & dolor & -ar \\
\hline adomingar & 296 & 66 & 1 & $\mathrm{P}$ & a- & domingo & -ar \\
\hline adonairar & 297 & 49 & 1 & $\mathrm{P}$ & a- & donaire & -ar \\
\hline adonar & 298 & 855 & 1 & $\mathrm{P}$ & a- & dono & -ar \\
\hline adonisar & 299 & 74 & 1 & $S$ & & adônis & -ar \\
\hline adriçar & 300 & 97 & 1 & $S$ & & adriça & -ar \\
\hline aduanar & 301 & 97 & 1 & $S$ & & aduana & -ar \\
\hline aduchar & 302 & 103 & 1 & $S$ & & aducha & -ar \\
\hline adufar & 303 & 108 & 1 & $S$ & & adufa & -ar \\
\hline adverbiar & 305 & 87 & 1 & $\mathrm{~S}$ & & advérbio & -ar \\
\hline aerossolizar & 306 & 2 & 1 & $S$ & & aerossol & -izar \\
\hline afaçanhar & 307 & 0 & 1 & $\mathrm{P}$ & a- & façanha & -ar \\
\hline afainar-se & 308 & 17 & 1 & $\mathrm{P}$ & a- & faina & -ar \\
\hline afamar & 309 & 2890 & 1 & $P$ & a- & fama & -ar \\
\hline afamiliar-se & 310 & 22 & 1 & $\mathrm{P}$ & a- & família & -ar \\
\hline afandangar & 311 & 5 & 1 & $\mathrm{P}$ & a- & fandango & -ar \\
\hline afarar-se & 312 & 17 & 1 & $\mathrm{P}$ & a- & faro & -ar \\
\hline afazendar-se & 313 & 53 & 1 & $\mathrm{P}$ & a- & fazenda & -ar \\
\hline afelear & 314 & 73 & 1 & $P$ & a- & $\mathrm{fel}$ & -ear \\
\hline afemear & 315 & 42 & 1 & $\mathrm{P}$ & a- & fêmea & -ar \\
\hline aferesear & 316 & 41 & 1 & S & & aférese & -ear \\
\hline afermentar & 317 & 46 & 1 & $\mathrm{P}$ & a- & fermento & -ar \\
\hline aferrar & 318 & 3645 & 1 & $P$ & a- & ferro & -ar \\
\hline aferretar & 319 & 116 & 1 & $P$ & a- & ferrete & -ar \\
\hline \begin{tabular}{|l|} 
aferretoar \\
\end{tabular} & 320 & 135 & 1 & $P$ & a- & ferrete & -oar \\
\hline aferroar & 321 & 345 & 1 & $\mathrm{P}$ & a- & ferrão & -ar \\
\hline aferrolhar & 322 & 424 & 1 & $\mathrm{P}$ & a- & ferrolho & -ar \\
\hline afervorar & 323 & 372 & 1 & $\mathrm{P}$ & a- & fervor & -ar \\
\hline
\end{tabular}




\begin{tabular}{|c|c|c|c|c|c|c|c|}
\hline afervorizar & 324 & 102 & 1 & $\mathrm{P}$ & a- & fervor & -izar \\
\hline afezoar & 325 & 1 & 1 & $\mathrm{P}$ & a- & fé & -zoar \\
\hline afiambrar & 326 & 86 & 1 & $P$ & a- & fiambre & -ar \\
\hline afiançar & 327 & 11400 & 1 & $P$ & a- & fiança & -ar \\
\hline afilar & 328 & 1130 & 1 & $P$ & a- & fila & -ar \\
\hline afistular & 329 & 69 & 1 & $\mathrm{P}$ & a- & fístula & -ar \\
\hline afitar & 331 & 159 & 1 & $P$ & a- & fita & -ar \\
\hline afiuzar & 332 & 35 & 1 & $P$ & a- & fiúza & -ar \\
\hline afivelar & 333 & 2488 & 1 & $\mathrm{P}$ & a- & fivela & -ar \\
\hline afleumar & 334 & 70 & 1 & $\mathrm{P}$ & a- & fleuma & -ar \\
\hline aflorar & 335 & 41975 & 1 & $\mathrm{P}$ & a- & flor & -ar \\
\hline afoguentar & 336 & 2 & 1 & $\mathrm{P}$ & a- & foguento & -ar \\
\hline afolar & 337 & 84 & 1 & $\mathrm{P}$ & a- & fole & -ar \\
\hline afolhar & 338 & 68 & 1 & $\mathrm{P}$ & a- & folha & -ar \\
\hline afomear & 339 & 47 & 1 & $\mathrm{P}$ & a- & fome & -ear \\
\hline aforar & 341 & 2530 & 1 & $\mathrm{P}$ & a- & fora & -ar \\
\hline aforciar & 342 & 81 & 1 & $P$ & a- & força & -iar \\
\hline aforçurar-se & 343 & 27 & 1 & $\mathrm{P}$ & a- & forçura & -ar \\
\hline aforismar & 344 & 80 & 1 & $S$ & & aforismo & -ar \\
\hline aforquilhar & 345 & 126 & 1 & $\mathrm{P}$ & a- & forquilha & -ar \\
\hline afortunar & 346 & 160 & 1 & $\mathrm{P}$ & a- & fortuna & -ar \\
\hline afragatar & 347 & 36 & 1 & $P$ & a- & fragata & -ar \\
\hline afreguesar & 348 & 68 & 1 & $\mathrm{P}$ & a- & freguês & -ar \\
\hline afrentar & 349 & 111 & 1 & $\mathrm{P}$ & a- & frente & -ar \\
\hline afretar & 350 & 763 & 1 & $\mathrm{P}$ & a- & frete & -ar \\
\hline afronhar & 351 & 99 & 1 & $\mathrm{P}$ & a- & fronha & -ar \\
\hline afrontar & 352 & 69025 & 1 & $P$ & a- & fronte & -ar \\
\hline afuliginar & 353 & 7 & 1 & $\mathrm{P}$ & a- & fuligem & -ar \\
\hline afumar & 354 & 150 & 1 & $\mathrm{P}$ & a- & fumo & -ar \\
\hline afunilar & 355 & 5455 & 1 & $P$ & a- & funil & -ar \\
\hline afuroar & 356 & 74 & 1 & $P$ & a- & furo & -oar \\
\hline afusar & 357 & 84 & 1 & $\mathrm{P}$ & a- & fuso & -ar \\
\hline afuselar & 358 & 0 & 1 & $S$ & 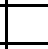 & afusel & -ar \\
\hline agadanhar & 359 & 190 & 1 & $P$ & a- & gadanho & -ar \\
\hline agaiolar & 360 & 37 & 1 & $\mathrm{P}$ & a- & gaiola & -ar \\
\hline agaitar & 361 & 37 & 1 & $\mathrm{P}$ & a- & gaita & -ar \\
\hline agalgar & 362 & 96 & 1 & $\mathrm{P}$ & a- & galga & -ar \\
\hline agalhar & 363 & 81 & 1 & $\mathrm{P}$ & a- & galho & -ar \\
\hline agarnachar & 364 & 95 & 1 & $\mathrm{P}$ & a- & garnacha & -ar \\
\hline agarrar & 365 & 245000 & 1 & $\mathrm{P}$ & a- & garra & -ar \\
\hline agarrochar & 366 & 109 & 1 & $\mathrm{P}$ & a- & garrocha & -ar \\
\hline agarrotar & 367 & 76 & 1 & $P$ & a- & garrote & -ar \\
\hline agarrunchar & 368 & 56 & 1 & $\mathrm{P}$ & a- & garruncho & -ar \\
\hline agatizar & 369 & 58 & 1 & $S$ & & ágata & -izar \\
\hline agavelar & 370 & 78 & 1 & $\mathrm{P}$ & a- & gavela & -ar \\
\hline agenciar & 371 & 12000 & 1 & $S$ & & agência & -ar \\
\hline agendar & 372 & 562500 & 2 & $S$ & & agenda & -ar \\
\hline agoniar & 373 & 753 & 1 & $S$ & & agonia & -ar \\
\hline agostar & 374 & 481 & 1 & $S$ & & agosto & -ar \\
\hline agourar & 375 & 1983 & 1 & $S$ & & agouro & -ar \\
\hline agraciar & 376 & 12100 & 1 & $\mathrm{P}$ & a- & graça & -iar \\
\hline agrafar & 377 & 171 & 1 & $S$ & & agrafe & -ar \\
\hline agranelar & 378 & 141 & 1 & $\mathrm{P}$ & a- & granel & -ar \\
\hline agranizar & 379 & 75 & 1 & $\mathrm{P}$ & a- & granizo & -ar \\
\hline agravançar & 380 & 4 & 1 & $\mathrm{P}$ & a- & gravanço & -ar \\
\hline agremiar & 381 & 632 & 1 & $\mathrm{P}$ & a- & grêmio & -ar \\
\hline agrilhoar & 382 & 507 & 1 & $P$ & a- & grilhão & -ar \\
\hline agrinaldar & 383 & 129 & 1 & $\mathrm{P}$ & a- & grinalda & -ar \\
\hline agrumar & 384 & 74 & 1 & $\mathrm{P}$ & a- & grumo & -ar \\
\hline agrumetar & 385 & 108 & 1 & $P$ & a- & grumete & -ar \\
\hline agrupar & 386 & 1222500 & 2 & $P$ & a- & grupo & -ar \\
\hline aguar & 387 & 20825 & 1 & $S$ & & água & -ar \\
\hline aguardentar & 388 & 85 & 1 & $S$ & & aguardente & -ar \\
\hline aguarelar & 389 & 80 & 1 & $\mathrm{~S}$ & & aguarela & -ar \\
\hline
\end{tabular}




\begin{tabular}{|c|c|c|c|c|c|c|c|}
\hline agüeirar & 390 & 6 & 1 & $S$ & & agüeira & -ar \\
\hline aguerrear & 391 & 80 & 1 & $P$ & a- & guerra & -ear \\
\hline aguerrilhar & 392 & 81 & 1 & $P$ & a- & guerrilha & -ar \\
\hline aguitarrar & 393 & 80 & 1 & $P$ & a- & guitarra & $-a r$ \\
\hline aguizalhar & 394 & 46 & 1 & $\mathrm{P}$ & a- & guizo & -alhar \\
\hline agulhar & 395 & 1548 & 1 & S & & agulha & -ar \\
\hline agulhear & 396 & 1 & 1 & $S$ & & agulha & -ear \\
\hline agulhetar & 397 & 89 & 1 & $S$ & & agulheta & -ar \\
\hline aiar & 398 & 262 & 1 & $S$ & & ai & -ar \\
\hline ajaezar & 399 & 145 & 1 & $\mathrm{P}$ & a- & jaez & -ar \\
\hline ajardinar & 400 & 3325 & 1 & $P$ & a- & jardim & -ar \\
\hline ajeitar & 401 & 91175 & 1 & $P$ & a- & jeito & -ar \\
\hline ajeitivar & 402 & 0 & 1 & $P$ & a- & jeito & -ivar \\
\hline ajindungar & 403 & 0 & 1 & $P$ & a- & jindungo & -ar \\
\hline ajoelhar & 404 & 38650 & 1 & $\mathrm{P}$ & a- & joelho & -ar \\
\hline ajorcar & 405 & 69 & 1 & $S$ & & ajorca & -ar \\
\hline ajornalar & 406 & 77 & 1 & $P$ & a- & jornal & -ar \\
\hline ajuizar & 407 & 119000 & 1 & $P$ & a- & juiz & -ar \\
\hline ajuramentar & 408 & 101 & 1 & $\mathrm{P}$ & a- & juramento & -ar \\
\hline ajusturar & 409 & 93 & 1 & $S$ & & ajustura & -ar \\
\hline alabastrizar & 410 & 41 & 1 & $S$ & & alabastro & -izar \\
\hline aladainhar & 411 & 0 & 1 & $P$ & a- & ladainha & -ar \\
\hline alagar & 412 & 8708 & 1 & $P$ & a- & lago & -ar \\
\hline alagartar & 413 & 62 & 1 & $\mathrm{P}$ & a- & lagarto & -ar \\
\hline alagartear & 414 & 32 & 1 & $\mathrm{P}$ & a- & lagarto & -ear \\
\hline alambicar & 415 & 190 & 1 & $S$ & & alambique & -ar \\
\hline alamborar & 416 & 66 & 1 & $S$ & & alambor & -ar \\
\hline alambrear & 417 & 0 & 1 & S & & alambre & -ar \\
\hline alamedar & 418 & 56 & 1 & $S$ & & alameda & -ar \\
\hline alampar & 419 & 18 & 1 & $\mathrm{P}$ & a- & lâmpada & -ar \\
\hline alancear & 420 & 107 & 1 & $\mathrm{P}$ & a- & lança & -ear \\
\hline alapar & 421 & 434 & 1 & $P$ & a- & lapa & -ar \\
\hline alaquear & 422 & 0 & 1 & $S$ & & alaque & -ar \\
\hline alarar & 423 & 100 & 1 & $\mathrm{P}$ & a- & Iar & -ar \\
\hline alardar & 424 & 249 & 1 & S & & alarde & -ar \\
\hline alardear & 425 & 16300 & 1 & $\mathrm{~S}$ & & alarde & -ar \\
\hline alarmar & 426 & 16300 & 1 & S & & alarme & -ar \\
\hline alavancar & 427 & 364000 & 1 & $S$ & & alavanca & -ar \\
\hline albardar & 428 & 319 & 1 & $S$ & & albarda & -ar \\
\hline alborcar & 429 & 81 & 1 & $S$ & & alborque & -ar \\
\hline alborotar & 430 & 124 & 1 & $S$ & & alboroto & -ar \\
\hline alcachofrar & 431 & 78 & 1 & S & & alcachofra & -ar \\
\hline alcagüetar & 432 & 284 & 1 & $S$ & & alcagüete & -ar \\
\hline alcalificar & 433 & 191 & 1 & $S$ & & álcali & -ficar \\
\hline alcalizar & 434 & 91 & 1 & $S$ & & álcali & -izar \\
\hline alcandorar-se & 435 & 102 & 1 & $S$ & & alcândora & -ar \\
\hline alcanforar & 436 & 80 & 1 & S & & alcânfora & -ar \\
\hline alcantilar & 437 & 104 & 1 & $\mathrm{~S}$ & & alcantil & -ar \\
\hline alcaparrar & 438 & 47 & 1 & S & & alcaparra & -ar \\
\hline alçapremar & 439 & 66 & 1 & $\mathrm{~S}$ & & alçaprema & -ar \\
\hline alçar & 440 & 49650 & 1 & $S$ & & alça & -ar \\
\hline alcatear & 441 & 70 & 1 & S & & alcatéia & -ar \\
\hline alcatifar & 442 & 144 & 1 & $\mathrm{~S}$ & & alcatifa & -ar \\
\hline alcatruzar & 443 & 92 & 1 & S & & alcatruz & -ar \\
\hline alcear & 444 & 652 & 1 & $S$ & & alça & -ear \\
\hline alcofar & 445 & 163 & 1 & S & & alcofa & -ar \\
\hline alcoolizar & 446 & 847 & 1 & $S$ & & álcool & -izar \\
\hline alcorcovar & 447 & 72 & 1 & $\mathrm{~S}$ & & alcorcova & -ar \\
\hline alcovetar & 448 & 7 & 1 & $S$ & & alcoveta & -ar \\
\hline alcovitar & 449 & 396 & 1 & $S$ & & alcoveto & -ar \\
\hline alcunhar & 450 & 722 & 1 & S & & alcunha & -ar \\
\hline aldear & 451 & 809 & 1 & $S$ & & aldeia & -ar \\
\hline aldolizar & 452 & 0 & 1 & $S$ & & aldol & -izar \\
\hline aldrabar & 453 & 269 & 1 & $\mathrm{~S}$ & & aldraba & -ar \\
\hline
\end{tabular}




\begin{tabular}{|c|c|c|c|c|c|c|c|}
\hline alegorizar & 455 & 583 & 1 & $\mathrm{~S}$ & & alegoria & -izar \\
\hline alegrar & 456 & 246250 & 1 & $\mathrm{P}$ & a- & legra & -ar \\
\hline aleirar & 457 & 101 & 1 & $P$ & a- & leira & -ar \\
\hline aleitar & 459 & 996 & 1 & $P$ & a- & leito & -ar \\
\hline aleluiar & 460 & 131 & 1 & $\mathrm{~S}$ & & aleluia & -ar \\
\hline alembar & 461 & 43 & 1 & $\mathrm{P}$ & a- & lemba & -ar \\
\hline alemoar & 462 & 88 & 1 & $S$ & & alemão & -ar \\
\hline alergizar & 463 & 50 & 1 & $S$ & & alergia & -izar \\
\hline aletrar & 464 & 216 & 1 & $\mathrm{P}$ & a- & letra & -ar \\
\hline alevedar & 465 & 61 & 1 & $\mathrm{P}$ & a- & levedo & -ar \\
\hline alfabetar & 466 & 187 & 1 & S & & alfabeto & -ar \\
\hline alfabetizar & 467 & 64600 & 1 & $S$ & & alfabeto & -izar \\
\hline alfaiar & 468 & 183 & 1 & $S$ & & alfaia & -ar \\
\hline alfaiatar & 469 & 171 & 1 & $S$ & & alfaiate & -ar \\
\hline alfandegar & 470 & 528 & 1 & $S$ & & alfândega & -ar \\
\hline alfanjar & 471 & 6 & 1 & $S$ & & alfanje & -ar \\
\hline alfarrobar & 472 & 45 & 1 & $S$ & & alfarroba & -ar \\
\hline alfazemar & 473 & 52 & 1 & $S$ & & alfazema & -ar \\
\hline alfenar & 474 & 61 & 1 & $S$ & & alfena & -ar \\
\hline alfeninar & 475 & 91 & 1 & $S$ & & alfenim & -ar \\
\hline alfinetar & 476 & 22075 & 1 & $S$ & & alfinete & -ar \\
\hline alfinetear & 477 & 81 & 1 & $S$ & & alfinete & -ear \\
\hline alfombrar & 478 & 126 & 1 & $S$ & & alfombra & -ar \\
\hline alforjar & 479 & 150 & 1 & $S$ & & alforje & -ar \\
\hline alforrar & 480 & 150 & 1 & $S$ & & alforra & -ar \\
\hline alforriar & 481 & 2585 & 1 & $S$ & & alforria & -ar \\
\hline algaliar & 482 & 154 & 1 & $\mathrm{~S}$ & & algália & -ar \\
\hline algaraviar & 483 & 138 & 1 & $S$ & & algaravia & -ar \\
\hline algazarrar & 484 & 170 & 1 & $S$ & & algazarra & -ar \\
\hline algazarrear & 485 & 55 & 1 & $S$ & & algazarra & -ear \\
\hline algebrizar & 486 & 198 & 1 & $S$ & & álgebra & -izar \\
\hline algemar & 487 & 6958 & 1 & $\mathrm{~S}$ & & algema & -ar \\
\hline algemiar & 488 & 111 & 1 & $S$ & & algemia & -ar \\
\hline algodoar & 489 & 161 & 1 & $S$ & & algodão & -ar \\
\hline algozar & 490 & 168 & 1 & $S$ & & algoz & -ar \\
\hline alguergar & 491 & 89 & 1 & $S$ & & alguergue & -ar \\
\hline aliançar & 492 & 697 & 1 & $S$ & & aliança & -ar \\
\hline alibambar & 493 & 81 & 1 & $\mathrm{P}$ & a- & libambo & -ar \\
\hline alicerçar & 494 & 16725 & 1 & $S$ & & alicerce & -ar \\
\hline alicercear & 495 & 49 & 1 & $S$ & & alicerce & -ear \\
\hline alimentar & 496 & 3042500 & 3 & $\mathrm{~S}$ & & alimento & -ar \\
\hline alinear & 497 & 1158 & 1 & $S$ & & alínea & -ar \\
\hline alinhar & 498 & 284000 & 1 & $\mathrm{P}$ & a- & linha & -ar \\
\hline alinhavar & 499 & 9755 & 1 & $S$ & & alinhavo & -ar \\
\hline alistar & 500 & 43075 & 1 & $\mathrm{P}$ & a- & lista & -ar \\
\hline aljamiar & 501 & 16 & 1 & $S$ & & aljamia & -ar \\
\hline aljofarar & 502 & 80 & 1 & $S$ & & aljôfar & -ar \\
\hline aljofrar & 503 & 188 & 1 & $S$ & & aljofre & -ar \\
\hline almagrar & 504 & 124 & 1 & $S$ & & almagre & -ar \\
\hline almajarrar & 505 & 129 & 1 & $S$ & & almajarra & -ar \\
\hline almanjarrar & 506 & 104 & 1 & $S$ & & almanjarra & -ar \\
\hline almargear & 507 & 81 & 1 & $S$ & & almarge & -ar \\
\hline almecegar & 508 & 123 & 1 & $\mathrm{~S}$ & & almécega & -ar \\
\hline almejar & 509 & 44775 & 1 & $S$ & & alma & -ejar \\
\hline almirantear & 510 & 86 & 1 & $S$ & & almirante & -ear \\
\hline almiscarar & 511 & 128 & 1 & $S$ & & almíscar & -ar \\
\hline almoçar & 512 & 834000 & 2 & $S$ & & almoço & -ar \\
\hline almocrevar & 513 & 155 & 1 & $S$ & & almocreve & -ar \\
\hline almoedar & 514 & 89 & 1 & $S$ & & almoeda & -ar \\
\hline almofaçar & 515 & 156 & 1 & $S$ & & almofaça & -ar \\
\hline almofadar & 516 & 258 & 1 & $S$ & & almofada & -ar \\
\hline almofreixar & 517 & 151 & 1 & $S$ & & almofreixe & -ar \\
\hline almondegar & 518 & 159 & 1 & $S$ & & almôndega & -ar \\
\hline almotaçar & 519 & 88 & 1 & $S$ & & almotacé & -ar \\
\hline
\end{tabular}




\begin{tabular}{|c|c|c|c|c|c|c|c|}
\hline almudar & 520 & 86 & 1 & $S$ & & almude & -ar \\
\hline aloisar & 521 & 69 & 1 & $\mathrm{P}$ & a- & Ioisa & -ar \\
\hline alojar & 522 & 39025 & 1 & $\mathrm{P}$ & a- & Ioja & -ar \\
\hline alombar & 523 & 141 & 1 & $\mathrm{P}$ & a- & lombo & -ar \\
\hline alotar & 524 & 137 & 1 & $P$ & a- & Iote & -ar \\
\hline alotransplantar & 525 & 1 & 1 & S & & alotransplante & -ar \\
\hline alousar & 526 & 98 & 1 & $\mathrm{P}$ & a- & lousa & -ar \\
\hline alpendrar & 527 & 108 & 1 & $S$ & & alpendre & -ar \\
\hline alporcar & 528 & 63 & 1 & $S$ & & alporque & -ar \\
\hline alqueirar & 529 & 59 & 1 & S & & alqueire & -ar \\
\hline alqueivar & 530 & 107 & 1 & S & & alqueive & -ar \\
\hline alquilar & 531 & 2198 & 1 & $S$ & & alquilé & -ar \\
\hline alquimiar & 533 & 86 & 1 & $S$ & & alquimia & -ar \\
\hline aluar & 534 & 4273 & 1 & $\mathrm{P}$ & a- & lua & -ar \\
\hline aluminizar & 535 & 145 & 1 & S & & alumínio & -izar \\
\hline alustrar & 536 & 1 & 1 & $S$ & & alustre & -ar \\
\hline alutar & 537 & 177 & 1 & $\mathrm{P}$ & a- & luto & -ar \\
\hline aluviar & 538 & 61 & 1 & $S$ & & aluvião & -ar \\
\hline aluzecer & 539 & 1 & 1 & $\mathrm{P}$ & a- & luz & -ecer \\
\hline aluziar & 540 & 3 & 1 & $P$ & a- & luz & -iar \\
\hline alvaiadar & 541 & 78 & 1 & $S$ & & alvaiade & -ar \\
\hline alveitarar & 542 & 87 & 1 & S & & alveitar & -ar \\
\hline alveolizar & 543 & 58 & 1 & $S$ & & alvéolo & -izar \\
\hline alvissarar & 544 & 93 & 1 & $S$ & & alvíssara & -ar \\
\hline alvitrar & 545 & 1400 & 1 & $S$ & & alvitre & -ar \\
\hline alvorar & 546 & 565 & 1 & $S$ & & alvor & -ar \\
\hline alvorecer & 547 & 109500 & 1 & $S$ & & alvor & -ecer \\
\hline alvorejar & 548 & 153 & 1 & $S$ & & alvor & -ejar \\
\hline alvoroçar & 549 & 1050 & 1 & $S$ & & alvoroço & -ar \\
\hline amaçarocar & 550 & 60 & 1 & $P$ & a- & maçaroca & -ar \\
\hline amachorrar & 551 & 73 & 1 & $P$ & a- & machorra & -ar \\
\hline amadeirar & 552 & 120 & 1 & $P$ & a- & madeira & -ar \\
\hline amadrinhar & 553 & 304 & 1 & $P$ & a- & madrinha & -ar \\
\hline amaestrar & 554 & 66 & 1 & $P$ & a- & maestre & -ar \\
\hline amagotar & 555 & 77 & 1 & $P$ & a- & magote & -ar \\
\hline amalaguetar & 556 & 0 & 1 & $\mathrm{P}$ & a- & malagueta & -ar \\
\hline amaleitar & 557 & 69 & 1 & $\mathrm{P}$ & a- & maleita & -ar \\
\hline amalgamar & 558 & 5398 & 1 & $S$ & & amálgama & -ar \\
\hline amalhar & 559 & 189 & 1 & $\mathrm{P}$ & a- & malha & -ar \\
\hline amalhoar & 560 & 69 & 1 & $\mathrm{P}$ & $a-$ & malhão & -ar \\
\hline amaltar & 561 & 101 & 1 & $\mathrm{P}$ & a- & malta & -ar \\
\hline amamentar & 562 & 92875 & 1 & $\mathrm{P}$ & a- & mama & -entar \\
\hline amancebar-se & 563 & 341 & 1 & $P$ & a- & mancebia & -ar \\
\hline amanchar-se & 564 & 22 & 1 & $P$ & a- & mancha & -ar \\
\hline amaneirar & 565 & 198 & 1 & $\mathrm{P}$ & a- & maneira & -ar \\
\hline amanequinar & 566 & 146 & 1 & $\mathrm{P}$ & a- & manequim & -ar \\
\hline amangar & 567 & 76 & 1 & $\mathrm{P}$ & a- & mango & -ar \\
\hline amanhar & 568 & 1053 & 1 & $\mathrm{P}$ & a- & manha & -ar \\
\hline amanhecer & 569 & 793000 & 2 & $\mathrm{P}$ & a- & manhã & -ecer \\
\hline amanhuçar & 570 & 1 & 1 & $\mathrm{P}$ & a- & manhuço & -ar \\
\hline amantar & 571 & 173 & 1 & $\mathrm{P}$ & a- & manta & -ar \\
\hline amanteigar & 572 & 162 & 1 & $\mathrm{P}$ & a- & manteiga & -ar \\
\hline amantelar & 573 & 84 & 1 & $\mathrm{P}$ & a- & mantel & -ar \\
\hline amantilhar & 575 & 117 & 1 & $\mathrm{P}$ & a- & mantilha & -ar \\
\hline amanuensar & 576 & 6 & 1 & S & & amanuense & -ar \\
\hline amarar & 577 & 4065 & 1 & $P$ & a- & mar & -ar \\
\hline amarasmar & 578 & 192 & 1 & $\mathrm{P}$ & a- & marasmo & -ar \\
\hline amarasmear & 579 & 215 & 1 & $\mathrm{P}$ & a- & marasmo & -ear \\
\hline amarfinar & 580 & 1 & 1 & $\mathrm{P}$ & a- & marfim & -ar \\
\hline amargurar & 581 & 3080 & 1 & S & & amargura & -ar \\
\hline amarroquinar & 582 & 79 & 1 & $P$ & a- & marroquim & -ar \\
\hline amasiar-se & 583 & 286 & 1 & S & & amásio & -ar \\
\hline amatalotar & 584 & 100 & 1 & $P$ & a- & matalote & -ar \\
\hline amatilhar & 585 & 110 & 1 & $\mathrm{P}$ & $a-$ & matilha & -ar \\
\hline
\end{tabular}




\begin{tabular}{|c|c|c|c|c|c|c|c|c|}
\hline amatronar & 586 & 100 & 1 & $\mathrm{P}$ & a- & matrona & & -ar \\
\hline amatular-se & 587 & 49 & 1 & $\mathrm{P}$ & a- & matula & & -ar \\
\hline amazelar & 588 & 111 & 1 & $\mathrm{P}$ & a- & mazela & & -ar \\
\hline ambrear & 589 & 97 & 1 & $S$ & & ambre & & -ar \\
\hline ameaçar & 590 & 298000 & 1 & S & & ameaça & & -ar \\
\hline amealhar & 591 & 13450 & 1 & $\mathrm{P}$ & a- & mealha & & -ar \\
\hline amear & 592 & 163 & 1 & $S$ & & ameia & & -ar \\
\hline amedalhar & 593 & 82 & 1 & $\mathrm{P}$ & a- & medalha & & -ar \\
\hline amelaçar & 594 & 62 & 1 & $\mathrm{P}$ & a- & melaço & & -ar \\
\hline amembranar & 595 & 1 & 1 & $\mathrm{P}$ & a- & membrana & & -ar \\
\hline amentar & 596 & 1423 & 1 & $P$ & a- & mente & & -ar \\
\hline amercear & 597 & 153 & 1 & $\mathrm{P}$ & a- & mercê & & -ar \\
\hline ametalar & 598 & 104 & 1 & $\mathrm{P}$ & a- & metal & & -ar \\
\hline amezinhar & 599 & 79 & 1 & $\mathrm{P}$ & a- & mezinha & & -ar \\
\hline amichelar & 600 & 155 & 1 & $\mathrm{P}$ & a- & michelo & & -ar \\
\hline amilenizar & 601 & 0 & 1 & $S$ & & amileno & & -izar \\
\hline amilhar & 602 & 141 & 1 & $\mathrm{P}$ & a- & milho & & -ar \\
\hline amimalhar & 603 & 146 & 1 & $P$ & a- & mimo & & -alhar \\
\hline amimar & 604 & 455 & 1 & $P$ & a- & mimo & & -ar \\
\hline aminar & 605 & 290 & 1 & S & & amina & & -ar \\
\hline amisular & 606 & 93 & 1 & $P$ & a- & mísula & & -ar \\
\hline amnesiar & 607 & 83 & 1 & S & & amnésia & & -ar \\
\hline amocambar & 608 & 91 & 1 & $P$ & a- & mocambo & & -ar \\
\hline amocar & 609 & 184 & 1 & $\mathrm{P}$ & a- & moca & & -ar \\
\hline amochilar & 610 & 57 & 1 & $P$ & a- & mochila & & -ar \\
\hline amodorrar & 611 & 119 & 1 & $\mathrm{P}$ & a- & modorra & & -ar \\
\hline amoedar & 612 & 162 & 1 & $\mathrm{P}$ & a- & moeda & & -ar \\
\hline amofinar & 613 & 1009 & 1 & $\mathrm{P}$ & a- & mofina & & -ar \\
\hline amoinar & 614 & 50 & 1 & $P$ & a- & moina & & -ar \\
\hline amoitar & 615 & 272 & 1 & $\mathrm{P}$ & a- & moita & & -ar \\
\hline amonificar & 616 & 73 & 1 & $S$ & & amônia & & -ficar \\
\hline amonizar & 617 & 64 & 1 & $S$ & & amônia & & -izar \\
\hline amontanhar & 618 & 147 & 1 & $P$ & a- & montanha & & -ar \\
\hline amontar & 619 & 834 & 1 & $P$ & a- & monte & & -ar \\
\hline amonturar & 620 & 110 & 1 & $P$ & a- & monturo & & -ar \\
\hline amoquecar & 621 & 123 & 1 & $\mathrm{P}$ & a- & moqueca & & -ar \\
\hline amordaçar & 622 & 10055 & 1 & $\mathrm{P}$ & a- & mordaça & & -ar \\
\hline amoriscar-se & 623 & 107 & 1 & $S$ & & amor & & -iscar \\
\hline amortalhar & 624 & 584 & 1 & $\mathrm{P}$ & a- & mortalha & & -ar \\
\hline amortecer & 625 & 22850 & 1 & $\mathrm{P}$ & a- & morte & & -ecer \\
\hline amortizar & 626 & 29500 & 1 & $\mathrm{P}$ & a- & morte & & -izar \\
\hline amossar & 627 & 71 & 1 & $\mathrm{P}$ & a- & mossa & & -ar \\
\hline amotar & 628 & 92 & 1 & $P$ & a- & mota & & -ar \\
\hline ampiolar & 629 & 0 & 1 & $\mathrm{P}$ & em- & piola & & -ar \\
\hline amuar & 630 & 794 & 1 & $\mathrm{P}$ & a- & $\mathrm{mu}$ & & -ar \\
\hline amulherar & 631 & 118 & 1 & $\mathrm{P}$ & a- & mulher & & -ar \\
\hline amumiar & 632 & 97 & 1 & $\mathrm{P}$ & a- & múmia & & -ar \\
\hline amunhecar & 633 & 100 & 1 & $\mathrm{P}$ & a- & munheca & & -ar \\
\hline amuralhar & 634 & 118 & 1 & $\mathrm{P}$ & a- & muralha & & -ar \\
\hline amurar & 636 & 175 & 1 & $\mathrm{P}$ & a- & muro & & -ar \\
\hline anafar & 637 & 133 & 1 & S & & anafa & & -ar \\
\hline anafear & 638 & 39 & 1 & $S$ & & anafa & & -ear \\
\hline anagalhar & 639 & 47 & 1 & $\mathrm{P}$ & a- & nagalho & & -ar \\
\hline analisar & 640 & 3507500 & 3 & $S$ & & análise & & -ar \\
\hline anarquizar & 641 & 2355 & 1 & S & & anarquia & & -izar \\
\hline anastomosar & 642 & 272 & 1 & $S$ & & anastomose & & -ar \\
\hline anatar & 643 & 261 & 1 & $\mathrm{P}$ & a- & nata & & -ar \\
\hline anateirar & 644 & 130 & 1 & $\mathrm{P}$ & a- & nateiro & & -ar \\
\hline anatomizar & 645 & 135 & 1 & $S$ & & anatomia & & -izar \\
\hline anavalhar & 646 & 106 & 1 & $\mathrm{P}$ & a- & navalha & & -ar \\
\hline anãzar & 647 & 4 & 1 & $S$ & & anão & $-\mathrm{z}-$ & -ar \\
\hline ancilosar & 648 & 104 & 1 & S & & ancilose & & -ar \\
\hline ancinhar & 649 & 139 & 1 & S & & ancinho & & -ar \\
\hline ancorar & 650 & 35775 & 1 & $S$ & & âncora & & -ar \\
\hline
\end{tabular}




\begin{tabular}{|c|c|c|c|c|c|c|c|}
\hline andaimar & 651 & 149 & 1 & $S$ & & andaime & -ar \\
\hline andoar & 652 & 76 & 1 & $S$ & & andoa & -ar \\
\hline andorinhar & 653 & 17 & 1 & $S$ & & andorinha & -ar \\
\hline anedotizar & 654 & 107 & 1 & $S$ & & anedota & -izar \\
\hline anegalhar & 655 & 67 & 1 & $P$ & a- & negalho & -ar \\
\hline anelar & 656 & 14100 & 1 & $S$ & & anel & -ar \\
\hline anemiar & 657 & 131 & 1 & $S$ & & anemia & -ar \\
\hline anemizar & 658 & 204 & 1 & $S$ & & anemia & -izar \\
\hline anestesiar & 659 & 11600 & 1 & $S$ & & anestesia & -ar \\
\hline anichar & 660 & 105 & 1 & $\mathrm{P}$ & a- & nicho & -ar \\
\hline anielar & 661 & 101 & 1 & $P$ & a- & nielo & -ar \\
\hline anilhar & 662 & 419 & 1 & $S$ & & anilho & -ar \\
\hline animizar & 663 & 116 & 1 & $S$ & & ânimo & -izar \\
\hline aninar & 664 & 141 & 1 & $S$ & & anina & -ar \\
\hline aninhar & 665 & 11975 & 1 & $\mathrm{P}$ & a- & ninho & -ar \\
\hline anisar & 666 & 166 & 1 & $S$ & & anis & -ar \\
\hline anistiar & 667 & 13425 & 1 & S & & anistia & -ar \\
\hline anodizar & 668 & 565 & 1 & $S$ & & ânodo & -izar \\
\hline anogueirar & 669 & 119 & 1 & $P$ & a- & nogueira & -ar \\
\hline anoitar & 670 & 115 & 1 & $P$ & a- & noiteounoute & -ar \\
\hline anoitecer & 671 & 151500 & 1 & $\mathrm{P}$ & a- & noiteounoute & -ecer \\
\hline anojar & 672 & 170 & 1 & $\mathrm{P}$ & a- & nojo & -ar \\
\hline anonadar & 673 & 168 & 1 & $P$ & $a-$ & nonada & -ar \\
\hline anovelar & 674 & 85 & 1 & $\mathrm{P}$ & a- & novelo & -ar \\
\hline antar & 675 & 18000 & 1 & S & & anta & -ar \\
\hline antemurar & 676 & 75 & 1 & $S$ & & antemuro & -ar \\
\hline antifonar & 677 & 8 & 1 & $S$ & & antífona & -ar \\
\hline antipatizar & 678 & 1148 & 1 & $S$ & & antipatia & -izar \\
\hline antolhar & 679 & 166 & 1 & S & & ante- & -olhar \\
\hline antologiar & 680 & 84 & 1 & $S$ & & antologia & -ar \\
\hline anzolar & 681 & 198 & 1 & $S$ & & anzol & -ar \\
\hline apachorrar-se & 682 & 29 & 1 & $\mathrm{P}$ & a- & pachorra & -ar \\
\hline apadesar & 683 & 0 & 1 & $\mathrm{P}$ & a- & padês & -ar \\
\hline apadrinhar & 684 & 8533 & 1 & $\mathrm{P}$ & a- & padrinho & -ar \\
\hline apainelar & 685 & 202 & 1 & $P$ & a- & painel & -ar \\
\hline apaiolar & 686 & 205 & 1 & $\mathrm{P}$ & a- & paiol & -ar \\
\hline apalacetar & 687 & 48 & 1 & $\mathrm{P}$ & a- & palacete & -ar \\
\hline apalancar & 688 & 290 & 1 & $P$ & $a-$ & palanque & -ar \\
\hline apalavrar & 690 & 918 & 1 & $\mathrm{P}$ & a- & palavra & -ar \\
\hline apalazar & 691 & 242 & 1 & $\mathrm{P}$ & a- & pala & -ar \\
\hline apalmar & 692 & 217 & 1 & $\mathrm{P}$ & a- & palmo & -ar \\
\hline apanagiar & 693 & 14 & 1 & $S$ & 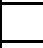 & apanágio & -ar \\
\hline apantufar & 694 & 66 & 1 & $P$ & a- & pantufa & -ar \\
\hline apapoular & 695 & 18 & 1 & $\mathrm{P}$ & a- & papoula & -ar \\
\hline aparabolar & 696 & 144 & 1 & $\mathrm{P}$ & a- & parábola & -ar \\
\hline aparafusar & 697 & 7718 & 1 & $\mathrm{P}$ & a- & parafuso & -ar \\
\hline aparamentar & 698 & 71 & 1 & $\mathrm{P}$ & a- & paramento & -ar \\
\hline aparatar & 699 & 15100 & 1 & $S$ & & aparato & -ar \\
\hline aparcar & 700 & 250 & 1 & $\mathrm{P}$ & a- & parque & -ar \\
\hline aparelhar & 701 & 39075 & 1 & $\mathrm{P}$ & a- & parelha & -ar \\
\hline aparoquiar & 702 & 40 & 1 & $\mathrm{P}$ & a- & paróquia & -ar \\
\hline aparrar & 703 & 148 & 1 & $\mathrm{P}$ & a- & parra & -ar \\
\hline aparreirar & 704 & 156 & 1 & $\mathrm{P}$ & $a-$ & parreira & -ar \\
\hline apartar & 705 & 28850 & 1 & $\mathrm{P}$ & a- & parte & -ar \\
\hline apartear & 706 & 2888 & 1 & S & & aparte & -ear \\
\hline apascoar & 707 & 21 & 1 & $P$ & $a-$ & páscoa & -ar \\
\hline apassamanar & 708 & 53 & 1 & $\mathrm{P}$ & a- & passamane & -ar \\
\hline apatanhar & 709 & 34 & 1 & $\mathrm{P}$ & a- & pata & -anhar \\
\hline apatizar & 710 & 71 & 1 & $S$ & & apatia & -izar \\
\hline apatronar & 711 & 53 & 1 & $\mathrm{P}$ & a- & patrono & -ar \\
\hline apaular & 712 & 46 & 1 & $P$ & $a-$ & paul & -ar \\
\hline apausar & 713 & 10 & 1 & $\mathrm{P}$ & a- & pausa & -ar \\
\hline apavesar & 714 & 40 & 1 & $P$ & a- & pavês & -ar \\
\hline apavorar & 715 & 22750 & 1 & $\mathrm{P}$ & a- & pavor & -ar \\
\hline
\end{tabular}




\begin{tabular}{|c|c|c|c|c|c|c|c|}
\hline apear & 716 & 5828 & 1 & $\mathrm{P}$ & a- & pé & -ar \\
\hline apeçonhar & 717 & 31 & 1 & $\mathrm{P}$ & a- & peçonha & -ar \\
\hline apedrar & 718 & 68 & 1 & $\mathrm{P}$ & a- & pedra & -ar \\
\hline apedregulhar & 719 & 70 & 1 & $P$ & a- & pedregulho & -ar \\
\hline apedrejar & 720 & 13575 & 1 & $P$ & a- & pedra & -ejar \\
\hline apegar & 721 & 49900 & 1 & $\mathrm{P}$ & a- & pego & -ar \\
\hline apendicular & 722 & 4880 & 1 & $S$ & & apendículo & -ar \\
\hline apenhorar & 723 & 60 & 1 & $P$ & a- & penhor & -ar \\
\hline apenumbrar & 724 & 6 & 1 & $\mathrm{P}$ & a- & penumbra & -ar \\
\hline apepinar & 725 & 37 & 1 & $\mathrm{P}$ & a- & pepino & -ar \\
\hline apergaminhar & 726 & 84 & 1 & $\mathrm{P}$ & a- & pergaminho & -ar \\
\hline apesentar & 727 & 622 & 1 & $P$ & a- & peso & -entar \\
\hline apestar & 728 & 71 & 1 & $\mathrm{P}$ & a- & peste & -ar \\
\hline apetitar & 729 & 106 & 1 & $S$ & & apetite & -ar \\
\hline apetrechar & 730 & 409 & 1 & $\mathrm{~S}$ & & apetrecho & -ar \\
\hline apezinhar & 731 & 43 & 1 & $\mathrm{P}$ & a- & pézinho & -ar \\
\hline apichelar & 732 & 60 & 1 & $P$ & a- & pichel & -ar \\
\hline apiedar & 733 & 2135 & 1 & $\mathrm{P}$ & a- & piedade & -ar \\
\hline apilarar & 734 & 8 & 1 & $\mathrm{P}$ & a- & pilar & -ar \\
\hline apimentar & 735 & 28550 & 1 & $\mathrm{P}$ & a- & pimenta & -ar \\
\hline apimpolhar-se & 736 & 0 & 1 & $P$ & a- & pimpolho & -ar \\
\hline apincelar & 737 & 55 & 1 & $P$ & a- & pincel & -ar \\
\hline apingentar & 738 & 23 & 1 & $P$ & a- & pingente & -ar \\
\hline apinhar & 739 & 331 & 1 & $\mathrm{P}$ & a- & pinha & -ar \\
\hline apintalhar & 740 & 28 & 1 & $\mathrm{P}$ & a- & pintalha & -ar \\
\hline apipar & 741 & 37 & 1 & $\mathrm{P}$ & a- & pipa & -ar \\
\hline apiramidar & 742 & 6 & 1 & $\mathrm{P}$ & a- & pirâmide & -ar \\
\hline aplainar & 743 & 8433 & 1 & $\mathrm{P}$ & a- & plaina & -ar \\
\hline apocopar & 744 & 63 & 1 & $S$ & & apócope & -ar \\
\hline apoderar & 745 & 45125 & 1 & $\mathrm{P}$ & a- & poder & -ar \\
\hline apolainar & 746 & 0 & 1 & $P$ & a- & polaina & -ar \\
\hline apolentar & 747 & 84 & 1 & $\mathrm{P}$ & a- & polenta & -ar \\
\hline apoliticalhar & 748 & 6 & 1 & $\mathrm{P}$ & a- & politicalha & -ar \\
\hline apologizar & 749 & 129 & 1 & S & & apologia & -izar \\
\hline apompar & 750 & 7 & 1 & $P$ & a- & pompa & -ar \\
\hline apontar & 751 & 1118750 & 2 & $\mathrm{P}$ & a- & ponta & -ar \\
\hline apontoar & 754 & 116 & 1 & $P$ & a- & ponto & -ar \\
\hline apoquentar & 755 & 1455 & 1 & $\mathrm{P}$ & a- & pouco & -entar \\
\hline aporismar & 756 & 61 & 1 & $S$ & & aporismo & -ar \\
\hline aporrear & 757 & 156 & 1 & $P$ & a- & porra & -ear \\
\hline aporretar & 758 & 45 & 1 & $\mathrm{P}$ & a- & porrete & -ar \\
\hline aporrinhar & 759 & 5073 & 1 & $P$ & a- & porra & -inhar \\
\hline aportar & 760 & 62400 & 1 & $\mathrm{P}$ & a- & porto & -ar \\
\hline aportelar & 761 & 3 & 1 & $P$ & a- & portela & -ar \\
\hline aportilhar & 762 & 25 & 1 & $\mathrm{P}$ & a- & portilha & -ar \\
\hline apospontar & 763 & 5 & 1 & $\mathrm{P}$ & a- & posponto & -ar \\
\hline apossar & 764 & 25050 & 1 & $\mathrm{P}$ & a- & posse & -ar \\
\hline apossear-se & 765 & 27 & 1 & $\mathrm{P}$ & a- & posse & -ear \\
\hline apostar & 766 & 848750 & 2 & $S$ & & aposta & -ar \\
\hline apostasiar & 767 & 78 & 1 & $S$ & & apostasia & -ar \\
\hline apostemar & 768 & 131 & 1 & $S$ & & apostema & -ar \\
\hline apostilar & 769 & 3835 & 1 & $S$ & & apostila & -ar \\
\hline apostolar & 770 & 1340 & 1 & $\mathrm{~S}$ & & apóstolo & -ar \\
\hline apostolizar & 771 & 42 & 1 & $S$ & & apóstolo & -izar \\
\hline apostrofar & 772 & 281 & 1 & $S$ & & apóstrofe & -ar \\
\hline apoteosar & 774 & 42 & 1 & $S$ & & apoteose & -ar \\
\hline apotrar-se & 775 & 31 & 1 & $P$ & a- & potro & -ar \\
\hline apoucar & 776 & 354 & 1 & $P$ & a- & pouco & -ar \\
\hline apozemar & 777 & 45 & 1 & $S$ & & apózema & -ar \\
\hline apragatar & 778 & 71 & 1 & $\mathrm{~S}$ & & apragata & -ar \\
\hline apreçar & 779 & 1943 & 1 & $P$ & a- & preço & -ar \\
\hline apresar & 780 & 4380 & 1 & $\mathrm{P}$ & a- & presa & -ar \\
\hline apresbiterar-se & 781 & 66 & 1 & $P$ & a- & presbítero & -ar \\
\hline apresilhar & 782 & 108 & 1 & $\mathrm{P}$ & a- & presilha & -ar \\
\hline
\end{tabular}




\begin{tabular}{|c|c|c|c|c|c|c|c|}
\hline apressar & 783 & 174000 & 1 & $\mathrm{P}$ & a- & pressa & -ar \\
\hline apresuntar & 784 & 138 & 1 & $\mathrm{P}$ & a- & presunto & -ar \\
\hline aprimorar & 785 & 1820000 & 2 & $P$ & a- & primor & -ar \\
\hline aproar & 786 & 1380 & 1 & $P$ & a- & proa & -ar \\
\hline aprochar & 787 & 60 & 1 & $S$ & & aproche & -ar \\
\hline aproejar & 788 & 176 & 1 & $\mathrm{P}$ & a- & proa & -ejar \\
\hline apropositar & 789 & 176 & 1 & $S$ & & a-propósito & -ar \\
\hline aproveitar & 790 & 2950000 & 3 & $P$ & a- & proveito & -ar \\
\hline aprumar & 791 & 5558 & 1 & $P$ & a- & prumo & -ar \\
\hline apuar & 792 & 144 & 1 & $\mathrm{P}$ & a- & pua & -ar \\
\hline apulhastrar-se & 793 & 0 & 1 & $\mathrm{P}$ & a- & pulhastro & -ar \\
\hline apunhalar & 794 & 6418 & 1 & $\mathrm{P}$ & a- & punhal & -ar \\
\hline apunhar & 795 & 91 & 1 & $\mathrm{P}$ & a- & punho & -ar \\
\hline aquadrilhar & 796 & 64 & 1 & $\mathrm{P}$ & a- & quadrilha & -ar \\
\hline aquaplanar & 797 & 858 & 1 & $S$ & & aquaplano & -ar \\
\hline aquapunturar & 798 & 45 & 1 & $S$ & & aquapuntura & -ar \\
\hline aquarelar & 799 & 499 & 1 & $S$ & & aquarela & -ar \\
\hline aquartelar & 801 & 1893 & 1 & $P$ & a- & quartel & -ar \\
\hline aquartilhar & 802 & 75 & 1 & $\mathrm{P}$ & a- & quartilho & -ar \\
\hline aquelar & 803 & 122 & 1 & $S$ & & aquele & -ar \\
\hline aquilhar & 804 & 0 & 1 & $P$ & a- & quilha & -ar \\
\hline aquilombar & 805 & 178 & 1 & $P$ & a- & quilombo & -ar \\
\hline aramar & 806 & 5450 & 1 & $S$ & & arame & -ar \\
\hline arapuar & 807 & 15 & 1 & $S$ & & arapuá & -ar \\
\hline arar & 808 & 25450 & 1 & $S$ & & ar & -ar \\
\hline araviar & 809 & 9 & 1 & $S$ & & aravia & -ar \\
\hline arcabouçar & 810 & 13 & 1 & $S$ & & arcabouço & -ar \\
\hline arcabuzar & 811 & 93 & 1 & $S$ & & arcabuz & -ar \\
\hline arcabuzear & 812 & 46 & 1 & $S$ & & arcabuz & -ear \\
\hline arcar & 813 & 1205000 & 2 & $S$ & & arca & -ar \\
\hline arco-irisar & 814 & 1 & 1 & $S$ & & arco-íris & -ar \\
\hline ardosiar & 815 & 22 & 1 & $S$ & & ardósia & -ar \\
\hline arejar & 816 & 14625 & 1 & $S$ & & ar & -ejar \\
\hline arengar & 817 & 1025 & 1 & $S$ & & arenga & -ar \\
\hline arenguear & 818 & 64 & 1 & $S$ & & arenga & -ear \\
\hline arestizar & 819 & 24 & 1 & $S$ & & aresta & -izar \\
\hline argamassar & 820 & 138 & 1 & $S$ & & argamassa & -ar \\
\hline argentar & 821 & 103 & 1 & $S$ & & argento & -ar \\
\hline argentear & 822 & 66 & 1 & $S$ & & argento & -ear \\
\hline argolar & 823 & 162 & 1 & $S$ & & argola & -ar \\
\hline arguciar & 824 & 28 & 1 & $S$ & & argúcia & -ar \\
\hline argueirar & 825 & 38 & 1 & $\mathrm{~S}$ & & argueiro & -ar \\
\hline aricar & 826 & 77 & 1 & S & & ar- & -icar \\
\hline aripar & 827 & 49 & 1 & $S$ & & aripo & -ar \\
\hline armazenar & 828 & 1009000 & 2 & $S$ & & armazém & -ar \\
\hline arnesar & 829 & 132 & 1 & $S$ & & arnês & -ar \\
\hline arnicar & 830 & 15 & 1 & $\mathrm{~S}$ & & arnica & -ar \\
\hline aromar & 831 & 287 & 1 & $S$ & & aroma & -ar \\
\hline arpejar & 832 & 487 & 1 & S & & arpejo & -ar \\
\hline arquear & 833 & 8013 & 1 & $S$ & & $\operatorname{arco}$ & -ear \\
\hline arquejar & 834 & 1765 & 1 & $S$ & & arco & -ejar \\
\hline arquivar & 835 & 209000 & 1 & $S$ & & arquivo & -ar \\
\hline arrabaldar & 836 & 30 & 1 & $S$ & & arrabalde & -ar \\
\hline arraçar & 837 & 189 & 1 & $P$ & a- & raça & -ar \\
\hline \begin{tabular}{|l|} 
arracimar-se \\
\end{tabular} & 838 & 13 & 1 & $\mathrm{P}$ & a- & racimo & -ar \\
\hline arramalhar & 839 & 153 & 1 & $\mathrm{P}$ & a- & ramalho & -ar \\
\hline arramar & 840 & 273 & 1 & $P$ & a- & rama & -ar \\
\hline arranchar & 841 & 671 & 1 & $\mathrm{P}$ & a- & rancho & -ar \\
\hline arrancorar-se & 842 & 19 & 1 & $P$ & a- & rancor & -ar \\
\hline arratelar & 843 & 66 & 1 & $S$ & & arrátel & -ar \\
\hline arrebanhar & 844 & 11950 & 1 & $\mathrm{P}$ & a- & rebanho & -ar \\
\hline arrebatar & 845 & 26625 & 1 & $\mathrm{P}$ & a- & rebate & -ar \\
\hline arrebicar & 846 & 261 & 1 & $S$ & & arrebique & -ar \\
\hline arrebitar & 847 & 1793 & 1 & $S$ & & arrebite & -ar \\
\hline
\end{tabular}




\begin{tabular}{|c|c|c|c|c|c|c|c|}
\hline arrebolar & 848 & 226 & 1 & $S$ & & arrebol & -ar \\
\hline arregimentar & 849 & 19025 & 1 & $\mathrm{P}$ & a- & regimento & -ar \\
\hline arrendar & 850 & 31375 & 1 & $S$ & & renda & -ar \\
\hline arrepolhar & 851 & 78 & 1 & $\mathrm{P}$ & a- & repolho & -ar \\
\hline arrevesar & 852 & 101 & 1 & $P$ & a- & revés & -ar \\
\hline arriçar & 853 & 56 & 1 & $S$ & & ouriço & -ar \\
\hline arridar & 854 & 137 & 1 & $S$ & & arrida & -ar \\
\hline arrimar & 855 & 2315 & 1 & $P$ & a- & rima & -ar \\
\hline arriscar & 856 & 1120000 & 2 & $P$ & a- & risco & -ar \\
\hline arrobar & 857 & 636 & 1 & $S$ & & arroba & -ar \\
\hline arrochar & 859 & 14200 & 1 & $S$ & & arrocho & -ar \\
\hline arroiar & 860 & 91 & 1 & $S$ & & arroio & -ar \\
\hline arrolar & 861 & 44850 & 1 & $\mathrm{P}$ & a- & rol & -ar \\
\hline arrolhar & 863 & 950 & 1 & $\mathrm{P}$ & a- & rolha & -ar \\
\hline arrostar & 864 & 4755 & 1 & $\mathrm{P}$ & a- & rosto & -ar \\
\hline arroupar & 865 & 97 & 1 & $P$ & a- & roupa & -ar \\
\hline arruaçar & 866 & 246 & 1 & $S$ & & arruaça & -ar \\
\hline arruar & 867 & 2098 & 1 & $\mathrm{P}$ & a- & rua & -ar \\
\hline arrugar & 868 & 231 & 1 & $\mathrm{P}$ & a- & ruga & -ar \\
\hline arruinar & 869 & 44475 & 1 & $P$ & a- & ruína & -ar \\
\hline arrumar & 870 & 1747500 & 2 & $\mathrm{P}$ & a- & rumo & -ar \\
\hline artefatar & 871 & 71 & 1 & $S$ & & artefato & -ar \\
\hline artificiar & 872 & 98 & 1 & $S$ & & artifício & -ar \\
\hline arvorar & 873 & 8323 & 1 & $\mathrm{~S}$ & & árvore & -ar \\
\hline arvorejar & 874 & 134 & 1 & $\mathrm{~S}$ & & árvore & -ejar \\
\hline asar & 875 & 3988 & 1 & $S$ & & asa & -ar \\
\hline ascetizar & 876 & 114 & 1 & $S$ & & asceta & -izar \\
\hline ascomar & 877 & 460 & 1 & $S$ & & ascoma & -ar \\
\hline ascuar & 878 & 47 & 1 & $S$ & & áscua & -ar \\
\hline asfaltar & 879 & 44825 & 1 & $S$ & & asfalto & -ar \\
\hline asfixiar & 880 & 10188 & 1 & $S$ & & asfixia & -ar \\
\hline asilar & 881 & 14425 & 1 & $S$ & & asilo & -ar \\
\hline asir & 882 & 1530 & 1 & $S$ & & asa & -ir \\
\hline asnear & 883 & 282 & 1 & $S$ & & asno & -ear \\
\hline asneirar & 884 & 130 & 1 & $S$ & & asneira & -ar \\
\hline aspar & 885 & 7680 & 1 & $S$ & & aspa & -ar \\
\hline aspear & 886 & 258 & 1 & $S$ & & aspa & -ear \\
\hline asquear & 887 & 6 & 1 & $S$ & & asco & -ear \\
\hline assalariar & 888 & 1445 & 1 & $\mathrm{P}$ & a- & salário & -ar \\
\hline assamarrar & 889 & 0 & 1 & $\mathrm{P}$ & a- & samarra & -ar \\
\hline assanhar & 890 & 2635 & 1 & $P$ & a- & sanha & -ar \\
\hline assapateirar & 891 & 48 & 1 & $\mathrm{P}$ & a- & sapateiro & -ar \\
\hline assedar & 892 & 262 & 1 & $\mathrm{P}$ & a- & seda & -ar \\
\hline assediar & 893 & 14825 & 1 & $S$ & & assédio & -ar \\
\hline assenzalar & 894 & 134 & 1 & $\mathrm{P}$ & a- & senzala & -ar \\
\hline assepsiar & 895 & 118 & 1 & $\mathrm{~S}$ & & assepsia & -ar \\
\hline assertar & 896 & 353 & 1 & $S$ & & asserto & -ar \\
\hline assevandijar & 897 & 156 & 1 & $P$ & a- & sevandija & -ar \\
\hline assibilar & 898 & 241 & 1 & $\mathrm{P}$ & a- & sibilo & -ar \\
\hline assidrar & 899 & 220 & 1 & $P$ & a- & sidra & -ar \\
\hline assinalar & 900 & 441750 & 1 & $\mathrm{P}$ & a- & sinal & -ar \\
\hline assisar & 901 & 55 & 1 & $\mathrm{P}$ & a- & siso & -ar \\
\hline assoberbar & 902 & 900 & 1 & $\mathrm{P}$ & a- & soberba & -ar \\
\hline assoldadar & 903 & 166 & 1 & $\mathrm{P}$ & a- & soldada & -ar \\
\hline assoldar & 904 & 53 & 1 & $P$ & a- & soldo & -ar \\
\hline assolear & 905 & 163 & 1 & $P$ & a- & sol & -ear \\
\hline assombrar & 906 & 35025 & 1 & $\mathrm{P}$ & a- & sombra & -ar \\
\hline assovelar & 907 & 83 & 1 & $\mathrm{P}$ & a- & sovela & -ar \\
\hline assurdinar & 908 & 84 & 1 & $P$ & a- & surdina & -ar \\
\hline assustar & 909 & 458000 & 1 & $P$ & a- & susto & -ar \\
\hline astilhar & 910 & 0 & 1 & $S$ & & astilha & -ar \\
\hline astuciar & 911 & 121 & 1 & $S$ & & astúcia & -ar \\
\hline atabalar & 912 & 76 & 1 & $S$ & & atabal & -ar \\
\hline atabernar & 913 & 81 & 1 & $\mathrm{P}$ & a- & taberna & -ar \\
\hline
\end{tabular}




\begin{tabular}{|c|c|c|c|c|c|c|c|}
\hline atalaiar & 914 & 153 & 1 & $S$ & & atalaia & -ar \\
\hline atalhar & 915 & 5188 & 1 & $P$ & a- & talho & -ar \\
\hline atamancar & 916 & 127 & 1 & $P$ & a- & tamanco & -ar \\
\hline atapetar & 917 & 412 & 1 & $P$ & a- & tapete & $-a r$ \\
\hline atapulhar & 918 & 90 & 1 & $P$ & a- & tapulho & -ar \\
\hline atarefar & 919 & 506 & 1 & $\mathrm{P}$ & a- & tarefa & -ar \\
\hline atarraxar & 920 & 1215 & 1 & $P$ & a- & tarraxa & -ar \\
\hline atartarugar & 921 & 0 & 1 & $P$ & a- & tartaruga & -ar \\
\hline atassalhar & 922 & 189 & 1 & $P$ & a- & tassalho & -ar \\
\hline atavizar-se & 923 & 0 & 1 & $S$ & & átavo & -izar \\
\hline atear & 924 & 34350 & 1 & $\mathrm{P}$ & a- & teia & -ar \\
\hline atediar & 925 & 73 & 1 & $P$ & a- & tédio & -ar \\
\hline atelhar & 926 & 63 & 1 & $\mathrm{P}$ & a- & telha & -ar \\
\hline atemorizar & 927 & 6415 & 1 & $\mathrm{P}$ & a- & temor & -izar \\
\hline atempar & 928 & 123 & 1 & $\mathrm{P}$ & a- & tempo & -ar \\
\hline atenorar & 929 & 145 & 1 & $P$ & a- & tenor & -ar \\
\hline aterrar & 930 & 19275 & 1 & $P$ & a- & terra & -ar \\
\hline aterrizar & 931 & 4630 & 1 & $\mathrm{P}$ & a- & terra & -izar \\
\hline aterrorar & 932 & 74 & 1 & $\mathrm{P}$ & a- & terror & -ar \\
\hline aterrorizar & 933 & 25425 & 1 & $\mathrm{P}$ & a- & terror & -izar \\
\hline atesourar & 934 & 0 & 1 & $P$ & a- & tesouro & -ar \\
\hline atilhar & 935 & 15 & 1 & $S$ & & atilho & -ar \\
\hline atintar & 936 & 106 & 1 & $\mathrm{P}$ & a- & tinta & -ar \\
\hline atitar & 937 & 133 & 1 & $\mathrm{~S}$ & & atito & -ar \\
\hline atoalhar & 938 & 85 & 1 & $\mathrm{P}$ & a- & toalha & -ar \\
\hline atoleimar & 939 & 108 & 1 & $\mathrm{P}$ & a- & toleima & -ar \\
\hline atomatar & 940 & 124 & 1 & $\mathrm{P}$ & a- & tomate & -ar \\
\hline atomizar & 941 & 915 & 1 & $\mathrm{~S}$ & & átomo & -izar \\
\hline atoniar & 942 & 53 & 1 & $\mathrm{~S}$ & 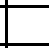 & atonia & -ar \\
\hline atopetar & 943 & 132 & 1 & $\mathrm{P}$ & a- & topete & -ar \\
\hline atorar & 944 & 513 & 1 & $P$ & a- & toro & -ar \\
\hline atorçalar & 945 & 109 & 1 & $\mathrm{P}$ & a- & torçal & -ar \\
\hline atormentar & 946 & 43775 & 1 & $\mathrm{P}$ & a- & tormento & -ar \\
\hline atorrear & 947 & 54 & 1 & $\mathrm{P}$ & a- & torre & -ar \\
\hline atoucinhar & 948 & 53 & 1 & $P$ & a- & toucinho & -ar \\
\hline atrafegar-se & 949 & 22 & 1 & $\mathrm{P}$ & a- & tráfego & -ar \\
\hline atranqueirar & 950 & 174 & 1 & $\mathrm{P}$ & a- & tranqueira & -ar \\
\hline atravancar & 951 & 4983 & 1 & $\mathrm{P}$ & a- & travanca & -ar \\
\hline atravincar & 952 & 77 & 1 & $\mathrm{P}$ & a- & travinca & -ar \\
\hline \begin{tabular}{|l} 
atreguar \\
\end{tabular} & 953 & 111 & 1 & $\mathrm{P}$ & a- & trégua & -ar \\
\hline atrelar & 954 & 29650 & 1 & $P$ & a- & trela & -ar \\
\hline atrofiar & 955 & 5468 & 1 & $S$ & & atrofia & -ar \\
\hline atrombar & 956 & 39 & 1 & $\mathrm{P}$ & a- & tromba & -ar \\
\hline atropar & 957 & 100 & 1 & $\mathrm{P}$ & a- & tropa & -ar \\
\hline atropelar & 958 & 111500 & 1 & $\mathrm{P}$ & a- & tropel & -ar \\
\hline atropilhar & 959 & 68 & 1 & $\mathrm{P}$ & a- & tropilha & -ar \\
\hline atropinizar & 960 & 72 & 1 & $S$ & & atropina & -izar \\
\hline atulhar & 961 & 879 & 1 & $\mathrm{P}$ & a- & tulha & -ar \\
\hline augir & 962 & 69 & 1 & $S$ & & auge & -ir \\
\hline aureolar & 963 & 618 & 1 & $S$ & & auréola & -ar \\
\hline aureolizar & 964 & 88 & 1 & $S$ & & auréola & -izar \\
\hline aurorear & 965 & 84 & 1 & $S$ & & aurora & -ear \\
\hline aurorejar & 966 & 24 & 1 & $S$ & & aurora & -ejar \\
\hline auspiciar & 967 & 538 & 1 & $S$ & & auspício & -ar \\
\hline austar & 968 & 1515 & 1 & $S$ & & aúste & -ar \\
\hline autocopiar & 969 & 160 & 1 & $S$ & & autocópia & -ar \\
\hline automatizar & 970 & 85300 & 1 & $S$ & & autômato & -izar \\
\hline autopsiar & 971 & 373 & 1 & $S$ & & autópsia & -ar \\
\hline auxiliar & 972 & 557000 & 2 & $S$ & & auxílio & -ar \\
\hline avacalhar & 973 & 29250 & 1 & $P$ & a- & vaca & -alhar \\
\hline \begin{tabular}{|l|} 
avagarar \\
\end{tabular} & 974 & 41 & 1 & $P$ & a- & vagar & -ar \\
\hline avaliar & 975 & 3847500 & 3 & $\mathrm{P}$ & a- & valia & -ar \\
\hline avalizar & 976 & 12800 & 1 & $S$ & & aval & -izar \\
\hline avampirar & 977 & 35 & 1 & $\mathrm{P}$ & a- & vampiro & -ar \\
\hline
\end{tabular}




\begin{tabular}{|c|c|c|c|c|c|c|c|}
\hline avarandar & 978 & 140 & 1 & $P$ & a- & varanda & -ar \\
\hline avariar & 979 & 2088 & 1 & $S$ & & avaria & -ar \\
\hline avençar & 980 & 629 & 1 & $S$ & & avença & -ar \\
\hline aventar & 981 & 11275 & 1 & $P$ & a- & vento & -ar \\
\hline aventurar & 983 & 412000 & 1 & $S$ & & aventura & -ar \\
\hline averbar & 985 & 14925 & 1 & $\mathrm{P}$ & a- & verba & -ar \\
\hline averdugar & 986 & 45 & 1 & $\mathrm{P}$ & a- & verdugo & -ar \\
\hline avergonhar & 987 & 159 & 1 & $P$ & a- & vergonha & -ar \\
\hline avezar & 989 & 179 & 1 & $P$ & a- & vez & -ar \\
\hline aviar & 990 & 7958 & 1 & $P$ & a- & via & -ar \\
\hline avigorar & 991 & 844 & 1 & $P$ & a- & vigor & -ar \\
\hline avistar & 992 & 82100 & 1 & $P$ & a- & vista & -ar \\
\hline avitualhar & 993 & 77 & 1 & $\mathrm{P}$ & a- & vitualha & -ar \\
\hline avolumar & 994 & 4193 & 1 & $\mathrm{P}$ & a- & volume & -ar \\
\hline axicarar & 995 & 75 & 1 & $\mathrm{P}$ & a- & xícara & -ar \\
\hline axorcar & 996 & 69 & 1 & $S$ & & axorca & -ar \\
\hline azabumbar & 997 & 76 & 1 & $P$ & a- & zabumba & -ar \\
\hline azafamar & 998 & 133 & 1 & $S$ & & azáfama & -ar \\
\hline azagaiar & 999 & 102 & 1 & $S$ & & azagaia & -ar \\
\hline azamboar & 1000 & 100 & 1 & $\mathrm{P}$ & a- & zamboa & -ar \\
\hline azar & 1001 & 333250 & 1 & $S$ & & azo & -ar \\
\hline azarar & 1002 & 10300 & 1 & $S$ & & azar & -ar \\
\hline azebrar & 1003 & 176 & 1 & $S$ & & azebre & -ar \\
\hline azeitar & 1004 & 4593 & 1 & $S$ & & azeite & -ar \\
\hline azinhavrar & 1005 & 252 & 1 & $S$ & & azinhavre & -ar \\
\hline aziumar & 1006 & 257 & 1 & $S$ & & aziúme & -ar \\
\hline azorragar & 1007 & 314 & 1 & $S$ & & azorrague & -ar \\
\hline azotar & 1008 & 484 & 1 & $S$ & & azoto & -ar \\
\hline azougar & 1009 & 613 & 1 & $S$ & & azougue & -ar \\
\hline azulejar & 1010 & 2263 & 1 & $S$ & & azulejo & -ar \\
\hline babar & 1011 & 107000 & 1 & $S$ & & baba & -ar \\
\hline babear & 1012 & 2025 & 1 & $S$ & & baba- & -ear \\
\hline babelizar & 1013 & 40 & 1 & $S$ & & babel- & -izar \\
\hline bacelar & 1014 & 247500 & 1 & $S$ & & bacelo & -ar \\
\hline bacharelar & 1015 & 848 & 1 & $S$ & & bacharel & -ar \\
\hline badalar & 1016 & 22050 & 1 & $S$ & & badalo & -ar \\
\hline badalejar & 1017 & 155 & 1 & $S$ & & badalo & -ejar \\
\hline badanar & 1018 & 64 & 1 & $S$ & & badana & -ar \\
\hline badernar & 1019 & 1740 & 1 & S & & baderna & -ar \\
\hline bafejar & 1020 & 1218 & 1 & $S$ & & bafo & -ejar \\
\hline baforar & 1021 & 461 & 1 & $S$ & & bafo & -ar \\
\hline baguear & 1022 & 133 & 1 & S & & bago & -ear \\
\hline bagunçar & 1023 & 40975 & 1 & $S$ & & bagunça & -ar \\
\hline baguncear & 1024 & 147 & 1 & S & & bagunça & -ear \\
\hline bainhar & 1025 & 121 & 1 & $S$ & & bainha & -ar \\
\hline balançar & 1026 & 187750 & 1 & $S$ & & balança & -ar \\
\hline balancear & 1027 & 57200 & 1 & $S$ & & balança & -ear \\
\hline balastrar & 1028 & 94 & 1 & $S$ & & balastro & -ar \\
\hline balaustrar & 1029 & 97 & 1 & $S$ & & balaústre & -ar \\
\hline balburdiar & 1030 & 172 & 1 & $S$ & & balbúrdia & -ar \\
\hline baldear & 1031 & 1593 & 1 & $S$ & & balde & -ear \\
\hline baldrocar & 1032 & 132 & 1 & $S$ & & baldroca & -ar \\
\hline balear & 1033 & 10020 & 1 & $S$ & & bala & -ear \\
\hline balizar & 1034 & 40650 & 1 & $S$ & & baliza & -ar \\
\hline baloar & 1035 & 71 & 1 & $S$ & & balão & -ar \\
\hline balsamar & 1036 & 182 & 1 & $\mathrm{~S}$ & & bálsamo & -ar \\
\hline balsear & 1037 & 6 & 1 & $S$ & & balsa & -ear \\
\hline bambochar & 1038 & 154 & 1 & $S$ & & bambocha & -ar \\
\hline bancar & 1039 & 386750 & 1 & $S$ & & banco & -ar \\
\hline bancarrotear & 1040 & 97 & 1 & $S$ & & bancarrota & -ear \\
\hline \begin{tabular}{|l} 
bandar \\
\end{tabular} & 1041 & 6715 & 1 & $\mathrm{~S}$ & & banda & -ar \\
\hline bandarilhar & 1042 & 91 & 1 & $S$ & & bandarilha & -ar \\
\hline bandarrear & 1043 & 205 & 1 & $S$ & & bandarra & -ear \\
\hline bandear & 1044 & 3230 & 1 & $S$ & & banda & -ear \\
\hline
\end{tabular}




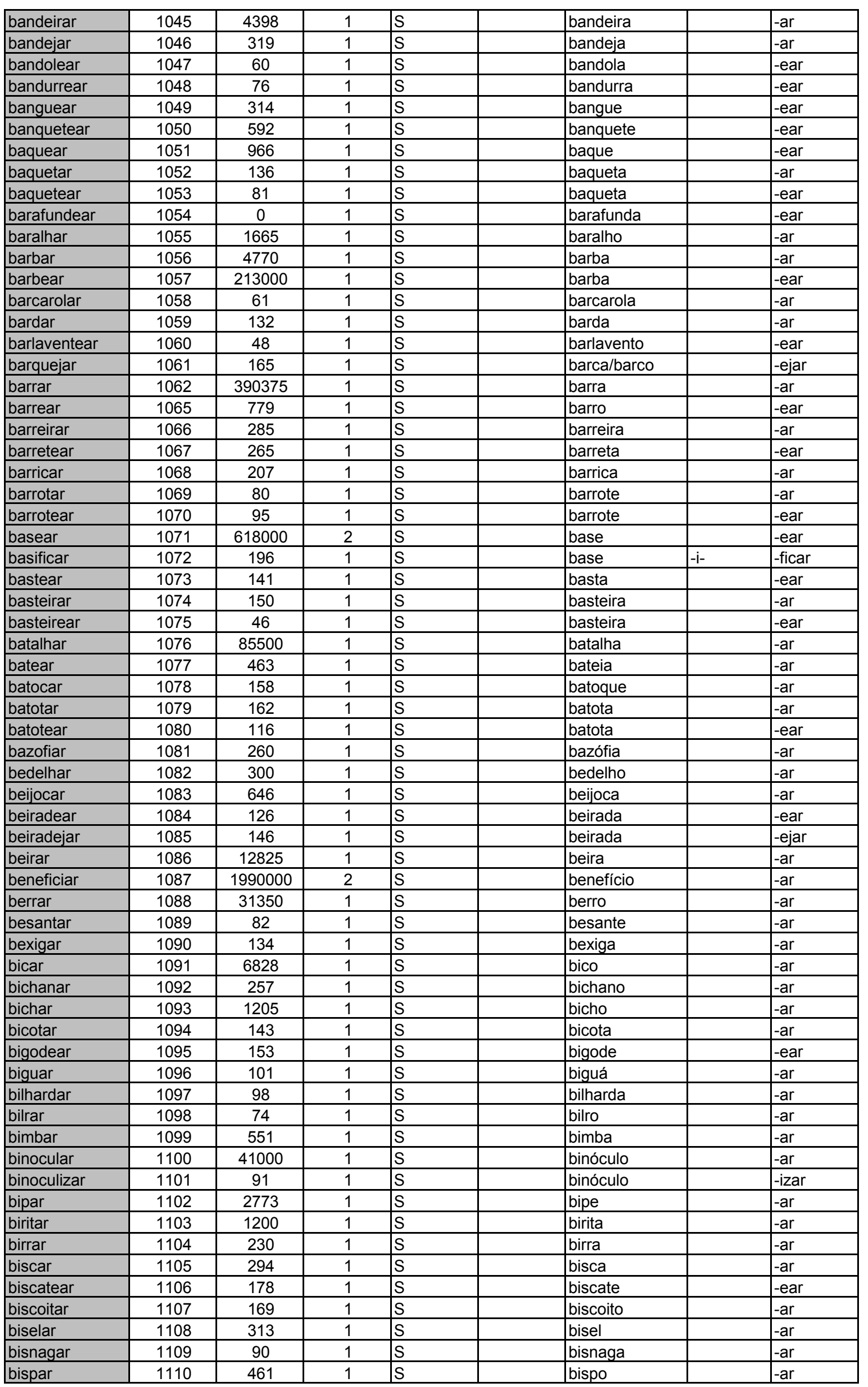




\begin{tabular}{|c|c|c|c|c|c|c|c|}
\hline bispontar & 1111 & 59 & 1 & $\mathrm{P}$ & bis- & ponto & -ar \\
\hline bitolar & 1112 & 2410 & 1 & $S$ & & bitola & -ar \\
\hline blandiciar & 1113 & 61 & 1 & $\mathrm{~S}$ & & blandícia & -ar \\
\hline \begin{tabular}{|l|} 
blefar \\
\end{tabular} & 1114 & 9913 & 1 & $S$ & & blefe & -ar \\
\hline blocar & 1115 & 3395 & 1 & $S$ & & bloco & -ar \\
\hline boatar & 1116 & 440 & 1 & S & & boato & $-a r$ \\
\hline bobinar & 1117 & 4220 & 1 & $S$ & & bobina & -ar \\
\hline bocanhar & 1118 & 25 & 1 & $S$ & & bocanha & -ar \\
\hline bocar & 1119 & 634 & 1 & $S$ & & boca & -ar \\
\hline boçar & 1120 & 177 & 1 & S & & boça & -ar \\
\hline bocejar & 1121 & 12675 & 1 & $S$ & & boca & -ejar \\
\hline bocelar & 1122 & 136 & 1 & $S$ & & bocel & -ar \\
\hline bochacrar & 1123 & 0 & 1 & $\mathrm{~S}$ & & bochacro & $-a r$ \\
\hline bochechar & 1124 & 2203 & 1 & $\mathrm{~S}$ & & bochecha & -ar \\
\hline bodar & 1125 & 531 & 1 & $S$ & & bode & -ar \\
\hline bodejar & 1126 & 259 & 1 & $S$ & & bode & -ejar \\
\hline bofar & 1127 & 107 & 1 & $S$ & & bofe & -ar \\
\hline bofetear & 1128 & 170 & 1 & $\mathrm{~S}$ & & bofete & -ear \\
\hline boiar & 1129 & 16200 & 1 & $S$ & & bóia & -ar \\
\hline boicotear & 1130 & 2640 & 1 & $\mathrm{~S}$ & & boicote & -ear \\
\hline bolar & 1131 & 144000 & 1 & $S$ & & bola & -ar \\
\hline bolear & 1132 & 1536 & 1 & $S$ & & bola & -ear \\
\hline boletar & 1134 & 271 & 1 & $S$ & & boleto & -ar \\
\hline bolichar & 1135 & 148 & 1 & $\mathrm{~S}$ & & boliche & -ar \\
\hline bolichear & 1136 & 163 & 1 & $\mathrm{~S}$ & & boliche & -ear \\
\hline bolinar & 1137 & 4860 & 1 & $S$ & & bolina & -ar \\
\hline boloirar & 1138 & 10 & 1 & $\mathrm{~S}$ & & boloiro & $-a r$ \\
\hline bolorecer & 1139 & 116 & 1 & $S$ & & bolor & -ecer \\
\hline bolotar & 1140 & 40 & 1 & $\mathrm{~S}$ & & bolota & -ar \\
\hline bolsar & 1141 & 457 & 1 & $S$ & & bolsa & -ar \\
\hline bombardar & 1142 & 91 & 1 & $S$ & & bombarda & -ar \\
\hline bombardear & 1143 & 78600 & 1 & $\mathrm{~S}$ & & bombarda & -ear \\
\hline bombear & 1144 & 24825 & 1 & $S$ & & bomba & -ear \\
\hline bombejar & 1145 & 75 & 1 & $S$ & & bomba & -ejar \\
\hline bonançar & 1146 & 113 & 1 & $S$ & & bonança & -ar \\
\hline bonecar & 1147 & 190 & 1 & $\mathrm{~S}$ & & boneca & -ar \\
\hline boquear & 1148 & 481 & 1 & $S$ & & boca & -ear \\
\hline boquejar & 1149 & 486 & 1 & $\mathrm{~S}$ & & boca & -ejar \\
\hline boquizar & 1150 & 0 & 1 & $\mathrm{~S}$ & & boca & -izar \\
\hline borboletear & 1151 & 1113 & 1 & $S$ & & borboleta & -ear \\
\hline borborinhar & 1152 & 101 & 1 & $\mathrm{~S}$ & & borborinho & -ar \\
\hline borbotoar & 1153 & 106 & 1 & $S$ & & borbotão & -ar \\
\hline bordar & 1154 & 239000 & 1 & $\mathrm{~S}$ & & borda & -ar \\
\hline bordear & 1155 & 263 & 1 & $S$ & & borda & -ear \\
\hline bordejar & 1156 & 905 & 1 & $S$ & & borda & -ejar \\
\hline borraçar & 1157 & 59 & 1 & $S$ & & borraça & -ar \\
\hline borregar & 1158 & 134 & 1 & $S$ & & borrego & -ar \\
\hline borriçar & 1159 & 79 & 1 & $S$ & & borriço & -ar \\
\hline borriscar & 1160 & 85 & 1 & $S$ & & borrisco & -ar \\
\hline bosquejar & 1161 & 521 & 1 & $S$ & & bosque & -ejar \\
\hline bostar & 1163 & 1625 & 1 & $S$ & & bosta & -ar \\
\hline bostear & 1164 & 146 & 1 & $S$ & & bosta & -ear \\
\hline bostejar & 1165 & 947 & 1 & $S$ & & bosta & -ejar \\
\hline botocar & 1166 & 123 & 1 & $S$ & & botoque & -ar \\
\hline bouchar & 1167 & 124 & 1 & $S$ & & boucha & -ar \\
\hline boxear & 1168 & 1473 & 1 & $S$ & & boxe & -ar \\
\hline bracear & 1169 & 152 & 1 & $S$ & & braço & -ear \\
\hline bracejar & 1170 & 922 & 1 & $S$ & & braço & -ejar \\
\hline bradejar & 1171 & 117 & 1 & $S$ & & brado & -ejar \\
\hline bralhar & 1172 & 81 & 1 & $S$ & & bralha & -ar \\
\hline bravatear & 1173 & 463 & 1 & $S$ & & bravata & -ear \\
\hline brear & 1174 & 190 & 1 & $S$ & & breu & -ar \\
\hline brecar & 1175 & 19700 & 1 & $S$ & & breque & -ar \\
\hline brechar & 1176 & 427 & 1 & $S$ & & brecha & -ar \\
\hline
\end{tabular}




\begin{tabular}{|c|c|c|c|c|c|c|}
\hline bridar & 1177 & 223 & 1 & $S$ & brida & -ar \\
\hline brincar & 1178 & 1992500 & 2 & $S$ & brinco & -ar \\
\hline briquetar & 1179 & 206 & 1 & $S$ & briquete & -ar \\
\hline brocar & 1180 & 2023 & 1 & $S$ & broca & -ar \\
\hline bromar & 1181 & 548 & 1 & $S$ & bromo & -ar \\
\hline bronquear & 1182 & 850 & 1 & $S$ & bronca & -ear \\
\hline broquear & 1183 & 788 & 1 & $S$ & broca & -ear \\
\hline broquelar & 1184 & 102 & 1 & $S$ & broquel & -ar \\
\hline brossar & 1185 & 136 & 1 & S & brossa & -ar \\
\hline bruxar & 1186 & 190 & 1 & $S$ & bruxa & -ar \\
\hline bruxear & 1187 & 128 & 1 & $S$ & bruxa & -ear \\
\hline bubuiar & 1188 & 123 & 1 & $S$ & bubuia & -ar \\
\hline buçalar & 1189 & 102 & 1 & $S$ & buçal & -ar \\
\hline bular & 1190 & 6633 & 1 & $S$ & bula & -ar \\
\hline bulhar & 1191 & 196 & 1 & $S$ & bulha & -ar \\
\hline bumbar & 1192 & 3178 & 1 & $S$ & bumba & -ar \\
\hline buracar & 1193 & 81 & 1 & $S$ & buraco & -ar \\
\hline burburinhar & 1194 & 154 & 1 & $S$ & burburinho & -ar \\
\hline burilar & 1195 & 3795 & 1 & $S$ & buril & -ar \\
\hline burlar & 1196 & 452000 & 1 & $S$ & burla & -ar \\
\hline burocratizar & 1197 & 5860 & 1 & $S$ & burocrata & -izar \\
\hline burrar & 1198 & 49 & 1 & $S$ & burra & -ar \\
\hline burrear & 1199 & 8 & 1 & $\mathrm{~S}$ & burra & -ear \\
\hline burricar & 1200 & 17 & 1 & $S$ & burrico & -ar \\
\hline bussolar & 1201 & 660 & 1 & $S$ & bússola & -ar \\
\hline butucar & 1202 & 115 & 1 & $S$ & butuca & -ar \\
\hline cabalar & 1203 & 1703 & 1 & $S$ & cabala & -ar \\
\hline cabecear & 1204 & 25400 & 1 & $S$ & cabeça & -ear \\
\hline caborocar & 1205 & 82 & 1 & $S$ & caboroca & -ar \\
\hline cabrar & 1206 & 941 & 1 & $\mathrm{~S}$ & cabra & -ar \\
\hline cabrear & 1207 & 210 & 1 & $S$ & cabra & -ear \\
\hline cabrestear & 1208 & 412 & 1 & $S$ & cabresto & -ear \\
\hline caçambar & 1209 & 185 & 1 & $S$ & caçamba & -ar \\
\hline cachar & 1210 & 831 & 1 & $S$ & cacho & -ar \\
\hline cachear & 1211 & 4500 & 1 & $S$ & cacho & -ear \\
\hline \begin{tabular}{|c|} 
cachetar \\
\end{tabular} & 1212 & 178 & 1 & $S$ & cacheta & -ar \\
\hline cachimbar & 1213 & 437 & 1 & $\mathrm{~S}$ & cachimbo & -ar \\
\hline cacicar & 1214 & 135 & 1 & $S$ & cacique & -ar \\
\hline cacifar & 1215 & 2295 & 1 & $S$ & cacifo & -ar \\
\hline cacimbar & 1216 & 101 & 1 & $S$ & cacimba & -ar \\
\hline cacofoniar & 1218 & 102 & 1 & $S$ & cacofonia & -ar \\
\hline cacofonizar & 1219 & 213 & 1 & $\mathrm{~S}$ & cacofonia & -izar \\
\hline cadastrar & 1220 & 726000 & 2 & $S$ & cadastro & -ar \\
\hline cadaverizar & 1221 & 122 & 1 & $S$ & cadáver & -izar \\
\hline cadenciar & 1222 & 4710 & 1 & $S$ & cadência & -ar \\
\hline \begin{tabular}{|l|} 
cadinhar \\
\end{tabular} & 1223 & 116 & 1 & $S$ & cadinho & -ar \\
\hline cadmiar & 1224 & 110 & 1 & $S$ & cádmio & -ar \\
\hline cafangar & 1225 & 129 & 1 & $S$ & cafanga & -ar \\
\hline cafeinar & 1226 & 45 & 1 & $\mathrm{~S}$ & cafeína & -ar \\
\hline cafelar & 1227 & 100 & 1 & $S$ & cafelo & -ar \\
\hline cafifar & 1228 & 173 & 1 & $\mathrm{~S}$ & cafifa & -ar \\
\hline caftinar & 1229 & 73 & 1 & $S$ & caftina & -ar \\
\hline cafungar & 1230 & 901 & 1 & $S$ & cafungo & -ar \\
\hline caibrar & 1231 & 148 & 1 & $S$ & caibro & -ar \\
\hline cainhar & 1232 & 273 & 1 & $S$ & caim & -ar \\
\hline cairelar & 1233 & 157 & 1 & $\mathrm{~S}$ & cairel & -ar \\
\hline caitituar & 1234 & 213 & 1 & $S$ & caititu & -ar \\
\hline caixeirar & 1235 & 159 & 1 & $S$ & caixeiro & -ar \\
\hline calabrear & 1236 & 307 & 1 & $S$ & calabre & -ear \\
\hline calabrotear & 1237 & 148 & 1 & $S$ & calabrote & -ear \\
\hline calafriar & 1238 & 223 & 1 & $\mathrm{~S}$ & calafrio & -ar \\
\hline calamistrar & 1239 & 144 & 1 & $\mathrm{~S}$ & calamistro & -ar \\
\hline \begin{tabular}{|l|} 
calandrar \\
\end{tabular} & 1240 & 435 & 1 & $\mathrm{~S}$ & calandra & -ar \\
\hline calanguear & 1241 & 198 & 1 & $\mathrm{~S}$ & calango & -ear \\
\hline
\end{tabular}




\begin{tabular}{|c|c|c|c|c|c|c|c|}
\hline calar & 1242 & 795500 & 2 & $S$ & cala & & -ar \\
\hline calcetar & 1243 & 907 & 1 & $S$ & calceta & & -ar \\
\hline caldear & 1244 & 510 & 1 & $S$ & caldo & & -ear \\
\hline calear & 1245 & 92 & 1 & $S$ & cal & & -ear \\
\hline calejar & 1246 & 1433 & 1 & $S$ & calo & & -ejar \\
\hline calemburar & 1247 & 82 & 1 & S & calembur & & -ar \\
\hline calhar & 1248 & 72350 & 1 & $S$ & calha & & -ar \\
\hline calibrar & 1249 & 62500 & 1 & $S$ & calibre & & -ar \\
\hline calmar & 1250 & 4258 & 1 & $S$ & calma & & -ar \\
\hline calorificar & 1251 & 158 & 1 & $S$ & calor & $-i-$ & -ficar \\
\hline calotear & 1252 & 492 & 1 & S & calote & & -ear \\
\hline cambalhotar & 1253 & 114 & 1 & $S$ & cambalhota & & -ar \\
\hline cambitar & 1254 & 104 & 1 & S & cambito & & -ar \\
\hline caminhar & 1255 & 1260000 & 2 & S & caminho & & -ar \\
\hline campainhar & 1256 & 231 & 1 & S & campainha & & -ar \\
\hline campanular & 1257 & 295 & 1 & $S$ & campânula & & -ar \\
\hline campar & 1258 & 1503 & 1 & S & campo & & -ar \\
\hline campear & 1259 & 3838 & 1 & $S$ & campo & & -ear \\
\hline canalizar & 1260 & 70750 & 1 & $S$ & canal & & -izar \\
\hline cancerizar & 1261 & 245 & 1 & S & câncer & & -izar \\
\hline canchear & 1262 & 178 & 1 & $S$ & cancha & & -ear \\
\hline cançonetear & 1263 & 0 & 1 & S & cançoneta & & -ear \\
\hline candidatar & 1264 & 432250 & 1 & S & candidato & & -ar \\
\hline candilar & 1265 & 173 & 1 & S & cândi & $-1-$ & -ar \\
\hline candongar & 1266 & 199 & 1 & S & candonga & & -ar \\
\hline canear & 1267 & 54 & 1 & $S$ & cana & & -ear \\
\hline canforar & 1268 & 130 & 1 & S & cânfora & & -ar \\
\hline cangotear & 1269 & 22 & 1 & S & cangote & & -ear \\
\hline canivetear & 1270 & 231 & 1 & S & canivete & & -ear \\
\hline cantaridar & 1271 & 181 & 1 & $S$ & cantárida & & -ar \\
\hline cantarolar & 1272 & 127250 & 1 & S & cantar & -ola & -ar \\
\hline cantear & 1273 & 210 & 1 & S & canto & & -ear \\
\hline canudar & 1274 & 30 & 1 & $S$ & canudo & & -ar \\
\hline capangar & 1275 & 183 & 1 & S & capanga & & -ar \\
\hline capatazar & 1276 & 92 & 1 & $S$ & capataz & & -ar \\
\hline capatazear & 1277 & 82 & 1 & S & capataz & & -ear \\
\hline capear & 1278 & 983 & 1 & $S$ & capa & & -ear \\
\hline capiangar & 1279 & 200 & 1 & S & capiango & & -ar \\
\hline capinar & 1280 & 8785 & 1 & S & capim & & -ar \\
\hline capoeirar & 1281 & 234 & 1 & $S$ & capoeira & & -ar \\
\hline caprichar & 1282 & 48925 & 1 & S & capricho & & -ar \\
\hline capsular & 1283 & 11600 & 1 & S & cápsula & & -ar \\
\hline capturar & 1284 & 776000 & 2 & S & captura & & -ar \\
\hline capuchar & 1285 & 104 & 1 & S & capucha & & -ar \\
\hline caquear & 1286 & 128 & 1 & $S$ & caco & & -ear \\
\hline carabinear & 1287 & 228 & 1 & S & carabina & & -ear \\
\hline caracolar & 1288 & 346 & 1 & S & caracol & & -ar \\
\hline caracolear & 1289 & 266 & 1 & S & caracol & & -ear \\
\hline caracolejar & 1290 & 62 & 1 & $S$ & caracol & & -ejar \\
\hline carambolar & 1291 & 300 & 1 & $S$ & carambola & & -ar \\
\hline caraminholar & 1292 & 73 & 1 & $S$ & caraminhola & & -ar \\
\hline caramunhar & 1293 & 118 & 1 & $S$ & caramunha & & -ar \\
\hline caranguejar & 1294 & 325 & 1 & S & caranguejo & & -ar \\
\hline caranguejolar & 1295 & 80 & 1 & $S$ & caranguejola & & -ar \\
\hline carantonhar & 1296 & 81 & 1 & S & carantonha & & -ar \\
\hline carbonatar & 1297 & 270 & 1 & $S$ & carbonato & & -ar \\
\hline carbonizar & 1298 & 3608 & 1 & S & carbono & & -izar \\
\hline carburizar & 1299 & 19 & 1 & S & carbureto & & -izar \\
\hline carcavar & 1300 & 142 & 1 & S & corcova & & -ar \\
\hline carcerar & 1301 & 294 & 1 & S & cárcere & & -ar \\
\hline cardanhar & 1302 & 0 & 1 & S & cardanho & & -ar \\
\hline cardar & 1303 & 638 & 1 & S & cardo & & -ar \\
\hline cardear & 1304 & 247 & 1 & S & cardo & & -ear \\
\hline carduçar & 1305 & 68 & 1 & S & carduça & & -ar \\
\hline
\end{tabular}




\begin{tabular}{|c|c|c|c|c|c|c|}
\hline carear & 1306 & 618 & 1 & $S$ & cara & -ear \\
\hline carenar & 1307 & 597 & 1 & $S$ & carena & -ar \\
\hline carguejar & 1308 & 92 & 1 & $S$ & carga & -ejar \\
\hline cariar & 1309 & 526 & 1 & $S$ & cárie & -ar \\
\hline caricaturar & 1310 & 2185 & 1 & $S$ & caricatura & -ar \\
\hline carimbar & 1311 & 34750 & 1 & $S$ & carimbo & -ar \\
\hline carnar & 1312 & 276 & 1 & $S$ & carne & -ar \\
\hline carnavalizar & 1313 & 1385 & 1 & $S$ & carnaval & -izar \\
\hline carpetar & 1314 & 218 & 1 & $S$ & carpete & -ar \\
\hline carpetear & 1315 & 188 & 1 & $S$ & carpeta & -ear \\
\hline carranquear & 1316 & 311 & 1 & $S$ & carranca & -ear \\
\hline carrapatar-se & 1317 & 20 & 1 & $S$ & carrapato & -ar \\
\hline carrapatear & 1318 & 192 & 1 & $S$ & carrapato & -ear \\
\hline carrear & 1319 & 19575 & 1 & $\mathrm{~S}$ & carro & -ear \\
\hline carrejar & 1320 & 83 & 1 & $S$ & carro & -ejar \\
\hline cartar & 1321 & 1810 & 1 & $S$ & carta & -ar \\
\hline cartear & 1322 & 671 & 1 & $S$ & carta & -ear \\
\hline \begin{tabular}{|l|} 
cartelizar \\
\end{tabular} & 1323 & 293 & 1 & $S$ & cartel & -izar \\
\hline carujar & 1324 & 3 & 1 & $\mathrm{~S}$ & caruja & -ar \\
\hline carunchar & 1325 & 142 & 1 & $S$ & caruncho & -ar \\
\hline casalar & 1326 & 750 & 1 & $S$ & casal & -ar \\
\hline casamatar & 1327 & 147 & 1 & $S$ & casamata & -ar \\
\hline casamentear & 1328 & 78 & 1 & $S$ & casamento & -ear \\
\hline casar & 1329 & 1722500 & 2 & $S$ & casa & -ar \\
\hline cascalhar & 1330 & 1670 & 1 & $S$ & cascalho & -ar \\
\hline cascatear & 1331 & 2008 & 1 & $\mathrm{~S}$ & cascata & -ear \\
\hline casear & 1332 & 4040 & 1 & $S$ & casa & -ear \\
\hline casquejar & 1333 & 91 & 1 & $\mathrm{~S}$ & casco & -ejar \\
\hline cassandrear & 1334 & 56 & 1 & $S$ & cassandra & -ear \\
\hline castanholar & 1335 & 213 & 1 & $S$ & castanhola & -ar \\
\hline castear & 1336 & 352 & 1 & $S$ & casta & -ear \\
\hline catadupejar & 1337 & 176 & 1 & $S$ & catadupa & -ejar \\
\hline catalisar & 1338 & 14900 & 1 & $\mathrm{~S}$ & catálise & -ar \\
\hline \begin{tabular}{|l} 
catalogar \\
\end{tabular} & 1339 & 49900 & 1 & $S$ & catálogo & -ar \\
\hline cataplasmar & 1340 & 73 & 1 & $S$ & cataplasma & -ar \\
\hline catapultar & 1341 & 3723 & 1 & $S$ & catapulta & -ar \\
\hline catear & 1342 & 242 & 1 & $S$ & cata & -ear \\
\hline categorizar & 1343 & 28600 & 1 & $S$ & categoria & -izar \\
\hline catembar & 1344 & 0 & 1 & $S$ & catembe & -ar \\
\hline cateterizar & 1345 & 455 & 1 & $S$ & cateter & -izar \\
\hline \begin{tabular}{|l|} 
catexizar \\
\end{tabular} & 1346 & 45 & 1 & $S$ & catexe & -izar \\
\hline catimbar & 1347 & 979 & 1 & $S$ & catimba & -ar \\
\hline \begin{tabular}{|l|} 
caturritar \\
\end{tabular} & 1348 & 114 & 1 & $S$ & caturrita & -ar \\
\hline caudilhar & 1349 & 111 & 1 & $S$ & caudilho & -ar \\
\hline causar & 1350 & 2990000 & 3 & $S$ & causa & -ar \\
\hline cautelar & 1351 & 569000 & 2 & $S$ & cautela & -ar \\
\hline cavacar & 1352 & 235 & 1 & $S$ & cavaco & -ar \\
\hline cavalar & 1353 & 18675 & 1 & $S$ & cavalo & -ar \\
\hline cavalear & 1354 & 124 & 1 & $S$ & cavalo & -ear \\
\hline cavaquear & 1355 & 492 & 1 & $S$ & cavaco & -ear \\
\hline \begin{tabular}{|l|} 
cavear \\
\end{tabular} & 1356 & 156 & 1 & $S$ & cava & -ear \\
\hline cavilhar & 1357 & 173 & 1 & $S$ & cavilha & -ar \\
\hline cavoucar & 1358 & 1313 & 1 & $S$ & cavouco & -ar \\
\hline cecear & 1359 & 246 & 1 & $S$ & cêcê & -ar \\
\hline cedilhar & 1360 & 177 & 1 & $S$ & cedilha & -ar \\
\hline ceifar & 1361 & 15150 & 1 & $S$ & ceifa & -ar \\
\hline cementar & 1362 & 210 & 1 & $S$ & cemento & -ar \\
\hline censurar & 1363 & 189000 & 1 & $S$ & censura & -ar \\
\hline centelhar & 1364 & 616 & 1 & $S$ & centelha & -ar \\
\hline centrar & 1365 & 75700 & 1 & $S$ & centro & -ar \\
\hline cepilhar & 1366 & 154 & 1 & $S$ & cepilho & -ar \\
\hline ceratinizar & 1367 & 143 & 1 & $S$ & ceratina & -izar \\
\hline cercilhar & 1368 & 150 & 1 & $S$ & cercilho & -ar \\
\hline cerdear & 1369 & 95 & 1 & $\mathrm{~S}$ & cerda & -ear \\
\hline
\end{tabular}




\begin{tabular}{|c|c|c|c|c|c|c|}
\hline cerimoniar & 1370 & 176 & 1 & $S$ & cerimônia & -ar \\
\hline cervejar & 1371 & 663 & 1 & $S$ & cerveja & -ar \\
\hline cesurar & 1372 & 136 & 1 & $\mathrm{~S}$ & cesura & -ar \\
\hline chacinar & 1373 & 1480 & 1 & $S$ & chacina & -ar \\
\hline chacotear & 1374 & 573 & 1 & $S$ & chacota & -ear \\
\hline chairar & 1375 & 128 & 1 & $S$ & chaira & -ar \\
\hline chalaçar & 1376 & 145 & 1 & $S$ & chalaça & -ar \\
\hline chalacear & 1377 & 237 & 1 & $\mathrm{~S}$ & chalaça & -ear \\
\hline chamegar & 1378 & 4640 & 1 & $S$ & chamego & -ar \\
\hline chamejar & 1379 & 1210 & 1 & S & chama & -ejar \\
\hline champanhizar & 1380 & 60 & 1 & $S$ & champanhe & -izar \\
\hline chancear & 1381 & 142 & 1 & $S$ & chança & -ear \\
\hline chanfrar & 1382 & 2323 & 1 & $S$ & chanfro & -ar \\
\hline changar & 1383 & 190 & 1 & $\mathrm{~S}$ & changa & -ar \\
\hline changuear & 1384 & 227 & 1 & $\mathrm{~S}$ & changa & -ear \\
\hline chapar & 1385 & 6780 & 1 & $S$ & chapa & -ar \\
\hline chapear & 1386 & 1330 & 1 & $S$ & chapa & -ear \\
\hline charamelar & 1387 & 72 & 1 & $S$ & charamela & -ar \\
\hline chargear & 1388 & 57 & 1 & $S$ & charge & -ar \\
\hline charquear & 1389 & 233 & 1 & $\mathrm{~S}$ & charque & -ear \\
\hline charutear & 1390 & 136 & 1 & $S$ & charuto & -ear \\
\hline chasquear & 1391 & 302 & 1 & $\mathrm{~S}$ & chasco & -ear \\
\hline chavascar & 1392 & 147 & 1 & $S$ & chavasco & -ar \\
\hline chavear & 1393 & 5408 & 1 & $\mathrm{~S}$ & chave & -ear \\
\hline chavetar & 1394 & 134 & 1 & $S$ & chaveta & -ar \\
\hline chavetear & 1395 & 5 & 1 & $S$ & chaveta & -ear \\
\hline chefiar & 1396 & 55450 & 1 & $\mathrm{~S}$ & chefe & -iar \\
\hline chiar & 1397 & 24125 & 1 & $S$ & chio & -ar \\
\hline chiatar & 1398 & 140 & 1 & $S$ & chiata & -ar \\
\hline chibar & 1399 & 223 & 1 & $S$ & chibo & -ar \\
\hline chibatar & 1400 & 347 & 1 & $S$ & chibata & -ar \\
\hline chibatear & 1401 & 235 & 1 & $S$ & chibata & -ear \\
\hline chicanar & 1402 & 317 & 1 & $S$ & chicana & -ar \\
\hline chicanear & 1403 & 218 & 1 & $S$ & chicana & -ear \\
\hline chichar & 1404 & 124 & 1 & $\mathrm{~S}$ & chicha & -ar \\
\hline chicotar & 1405 & 181 & 1 & $\mathrm{~S}$ & chicote & -ar \\
\hline chicotear & 1406 & 5223 & 1 & $S$ & chicote & -ear \\
\hline chifrar & 1408 & 3350 & 1 & $\mathrm{~S}$ & chifre & -ar \\
\hline chinchar & 1409 & 1020 & 1 & $\mathrm{~S}$ & chincha & $-a r$ \\
\hline chiqueirar & 1410 & 90 & 1 & $S$ & chiqueiro & -ar \\
\hline chiripear & 1411 & 87 & 1 & $\mathrm{~S}$ & chiripa & -ear \\
\hline chispar & 1412 & 422 & 1 & $S$ & chispa & -ar \\
\hline chispear & 1413 & 114 & 1 & $\mathrm{~S}$ & chispa & -ear \\
\hline chocalhar & 1414 & 1105 & 1 & $S$ & chocalho & -ar \\
\hline chocar & 1415 & 114500 & 1 & $S$ & choca & -ar \\
\hline choferar & 1416 & 62 & 1 & $S$ & chofer & -ar \\
\hline chofrar & 1417 & 109 & 1 & $S$ & chofre & -ar \\
\hline chorrilhar & 1418 & 96 & 1 & $S$ & chorrilho & -ar \\
\hline \begin{tabular}{|l|} 
choutear \\
\end{tabular} & 1419 & 139 & 1 & $S$ & chouto & -ear \\
\hline chuchar & 1420 & 710 & 1 & $S$ & chucho & -ar \\
\hline chumaçar & 1421 & 129 & 1 & $S$ & chumaço & -ar \\
\hline chumbear & 1422 & 149 & 1 & $\mathrm{~S}$ & chúmbea & -ar \\
\hline chumear & 1423 & 128 & 1 & $S$ & chúmea & -ear \\
\hline churrasquear & 1424 & 891 & 1 & $S$ & churrasco & -ear \\
\hline chusmar & 1425 & 141 & 1 & $S$ & chusma & -ar \\
\hline chutar & 1426 & 263000 & 1 & $S$ & chute & -ar \\
\hline chuviscar & 1427 & 1713 & 1 & $S$ & chuvisco & -ar \\
\hline cianosar & 1428 & 29 & 1 & $S$ & cianose & -ar \\
\hline cicatrizar & 1429 & 26375 & 1 & $S$ & cicatriz & -ar \\
\hline cicerar & 1430 & 102 & 1 & $S$ & cícero & -ar \\
\hline ciceronear & 1431 & 1338 & 1 & $S$ & cicerone & -ar \\
\hline ciceronizar & 1432 & 24 & 1 & $S$ & cicerone & -izar \\
\hline cifar & 1433 & 256 & 1 & $S$ & cifa & -ar \\
\hline cifrar & 1434 & 7963 & 1 & $S$ & cifra & -ar \\
\hline
\end{tabular}




\begin{tabular}{|c|c|c|c|c|c|c|c|}
\hline cigarrar & 1435 & 92 & 1 & $S$ & cigarro & & -ar \\
\hline cigarrear & 1436 & 147 & 1 & $S$ & cigarro & & -ear \\
\hline cilhar & 1438 & 210 & 1 & $S$ & cilha & & -ar \\
\hline cilindrar & 1439 & 974 & 1 & $S$ & cilindro & & -ar \\
\hline cimentar & 1440 & 8508 & 1 & S & cimento & & -ar \\
\hline cincar & 1441 & 146 & 1 & S & cinco & & -ar \\
\hline cinchar & 1443 & 248 & 1 & $S$ & cincha & & -ar \\
\hline cinematografar & 1444 & 195 & 1 & S & cinematógrafo & & -ar \\
\hline cintar & 1445 & 956 & 1 & $S$ & cinta & & -ar \\
\hline cintear & 1446 & 51 & 1 & S & cinta & & -ear \\
\hline cinturar & 1447 & 429 & 1 & $S$ & cintura & & -ar \\
\hline cinzelar & 1448 & 829 & 1 & $S$ & cinzel & & -ar \\
\hline cipoar & 1449 & 99 & 1 & $S$ & cipó & & -ar \\
\hline cirandar & 1450 & 8955 & 1 & $S$ & ciranda & & -ar \\
\hline circuitar & 1451 & 1543 & 1 & S & circuito & & -ar \\
\hline circunstanciar & 1452 & 857 & 1 & $S$ & circunstância & & -ar \\
\hline cisalhar & 1453 & 1040 & 1 & S & cisalha & & -ar \\
\hline ciscar & 1454 & 4950 & 1 & $S$ & cisco & & -ar \\
\hline cismar & 1455 & 10075 & 1 & S & cisma & & -ar \\
\hline ciumar & 1456 & 401 & 1 & $S$ & ciúme & & -ar \\
\hline clangorar & 1457 & 109 & 1 & S & clangor & & -ar \\
\hline clangorejar & 1458 & 108 & 1 & S & clangor & & -ejar \\
\hline claudicar & 1459 & 1600 & 1 & S & cláudio & & -icar \\
\hline clausular & 1460 & 1115 & 1 & $S$ & cláusula & & -ar \\
\hline clausurar & 1461 & 394 & 1 & $S$ & clausura & & -ar \\
\hline clemenciar & 1462 & 90 & 1 & $S$ & clemência & & -ar \\
\hline clinicar & 1463 & 7963 & 1 & $S$ & clínica & & -ar \\
\hline clonar & 1464 & 396000 & 1 & $S$ & clone & & -ar \\
\hline clorar & 1465 & 758 & 1 & S & cloro & & -ar \\
\hline cloroformizar & 1466 & 77 & 1 & $S$ & clorofórmio & & -izar \\
\hline cobiçar & 1467 & 12850 & 1 & $S$ & cobiça & & -ar \\
\hline cocar & 1468 & 54600 & 1 & S & coca & & -ar \\
\hline cochar & 1469 & 8340 & 1 & S & cocha & & -ar \\
\hline cochichar & 1471 & 5403 & 1 & $S$ & cochicho & & -ar \\
\hline cocular & 1472 & 75 & 1 & $S$ & coculo & & -ar \\
\hline codear & 1473 & 82 & 1 & S & côdea & & -ar \\
\hline codilhar & 1474 & 176 & 1 & $S$ & codilho & & -ar \\
\hline cogular & 1475 & 105 & 1 & $S$ & cogulo & & -ar \\
\hline cogumelar & 1476 & 38 & 1 & $S$ & cogumelo & & -ar \\
\hline coicear & 1477 & 200 & 1 & $S$ & coice & & -ear \\
\hline coicinhar & 1478 & 29 & 1 & $S$ & coice & & -inhar \\
\hline coimar & 1479 & 114 & 1 & $S$ & coima & & -ar \\
\hline coisar & 1480 & 3120 & 1 & $S$ & coisa & & -ar \\
\hline coisificar & 1481 & 1480 & 1 & $S$ & coisa & $-i-$ & -ficar \\
\hline coivarar & 1482 & 166 & 1 & $S$ & coivara & & -ar \\
\hline colapsar & 1483 & 4105 & 1 & S & colapso & & -ar \\
\hline colar & 1484 & 1855000 & 2 & $S$ & cola & & -ar \\
\hline colchetar & 1485 & 193 & 1 & $S$ & colchete & & -ar \\
\hline colear & 1486 & 703 & 1 & $S$ & colo & & -ear \\
\hline colecistografar & 1487 & 23 & 1 & S & coleciste & -0- & -grafar \\
\hline coletar & 1488 & 477750 & 1 & $S$ & coleta & & -ar \\
\hline colmar & 1489 & 12950 & 1 & $S$ & colmo & & -ar \\
\hline colonizar & 1490 & 30700 & 1 & $S$ & colônia & & -izar \\
\hline colorear & 1491 & 1403 & 1 & $S$ & color & & -ear \\
\hline colorir & 1492 & 361500 & 1 & $S$ & color- & & -ir \\
\hline colorizar & 1493 & 1788 & 1 & $S$ & color- & & -izar \\
\hline colostomizar & 1494 & 34 & 1 & $S$ & colostomia & & -izar \\
\hline colquicinizar & 1495 & 6 & 1 & $S$ & colquicina & & -izar \\
\hline coltarizar & 1496 & 97 & 1 & $S$ & coltar & & -izar \\
\hline comanditar & 1497 & 217 & 1 & $S$ & comandita & & -ar \\
\hline comboiar & 1498 & 514 & 1 & $S$ & comboio & & -ar \\
\hline comediar & 1499 & 486 & 1 & $S$ & comédia & & -ar \\
\hline cometear & 1500 & 36 & 1 & $S$ & cometa & & -ear \\
\hline comisturar & 1501 & 83 & 1 & $S$ & comistura & & -ar \\
\hline
\end{tabular}




\begin{tabular}{|c|c|c|c|c|c|c|c|}
\hline compartimentar & 1502 & 2210 & 1 & $S$ & & compartimento & -ar \\
\hline complementar & 1503 & 3312500 & 3 & $S$ & & complemento & -ar \\
\hline compromissar & 1504 & 1670 & 1 & $S$ & & compromisso & -ar \\
\hline computadorizar & 1505 & 304 & 1 & $S$ & & computador & -izar \\
\hline conceitear & 1506 & 55 & 1 & $S$ & & conceito & -ear \\
\hline concentrar & 1507 & 853250 & 2 & $\mathrm{P}$ & con- & centro & -ar \\
\hline concubinar-se & 1508 & 49 & 1 & $S$ & & concubina & -ar \\
\hline condimentar & 1509 & 5108 & 1 & $S$ & & condimento & -ar \\
\hline conferenciar & 1510 & 2050 & 1 & $S$ & & conferência & -ar \\
\hline confidenciar & 1511 & 7458 & 1 & $S$ & & confidência & -ar \\
\hline conflitar & 1512 & 19300 & 1 & S & & conflito & -ar \\
\hline \begin{tabular}{|l|} 
confrontar \\
\end{tabular} & 1513 & 177000 & 1 & $\mathrm{P}$ & con- & fronte & -ar \\
\hline congonhar & 1514 & 161 & 1 & $S$ & & congonha & -ar \\
\hline congraçar & 1515 & 1500 & 1 & $\mathrm{P}$ & com- & graça & -ar \\
\hline conjecturar & 1516 & 9005 & 1 & $S$ & & conjectura & -ar \\
\hline conluiar & 1517 & 215 & 1 & $S$ & & conluio & -ar \\
\hline consciencizar & 1518 & 8 & 1 & $S$ & & consciência & -izar \\
\hline \begin{tabular}{|l|} 
conselhar \\
\end{tabular} & 1519 & 587 & 1 & $S$ & & conselho & -ar \\
\hline consograr & 1520 & 7 & 1 & $S$ & & consogro & -ar \\
\hline consorciar & 1521 & 3695 & 1 & $S$ & & consórcio & -ar \\
\hline contagiar & 1522 & 109000 & 1 & $S$ & & contágio & -ar \\
\hline conteirar & 1523 & 542 & 1 & $S$ & & conteira & -ar \\
\hline contingenciar & 1524 & 9018 & 1 & $\mathrm{~S}$ & & contingência & -ar \\
\hline contornear & 1525 & 490 & 1 & $S$ & & contorno & -ear \\
\hline contrabandear & 1526 & 10210 & 1 & $S$ & & contrabando & -ear \\
\hline contracenar & 1527 & 25975 & 1 & $S$ & & contracena & -ar \\
\hline contracunhar & 1528 & 107 & 1 & $S$ & & contracunho & -ar \\
\hline contradançar & 1529 & 134 & 1 & $S$ & & contradança & -ar \\
\hline contraditar & 1530 & 7498 & 1 & $S$ & & contradita & -ar \\
\hline contramalhar & 1531 & 63 & 1 & $S$ & & contramalha & -ar \\
\hline \begin{tabular}{|c|} 
contramarcar \\
\end{tabular} & 1532 & 71 & 1 & $S$ & & contramarca & -ar \\
\hline contramarchar & 1533 & 77 & 1 & $S$ & & contramarcha & -ar \\
\hline contraminar & 1534 & 93 & 1 & $S$ & & contramina & -ar \\
\hline contramurar & 1535 & 53 & 1 & $S$ & & contramuro & -ar \\
\hline contranivelar & 1536 & 54 & 1 & $S$ & & contranível & -ar \\
\hline \begin{tabular}{|l|} 
contra-ofertar \\
\end{tabular} & 1537 & 128 & 1 & $S$ & & contra-oferta & -ar \\
\hline contrapesar & 1538 & 348 & 1 & $S$ & & contrapeso & -ar \\
\hline contrapontar & 1539 & 47 & 1 & $S$ & & contraponto & -ar \\
\hline contrapontear & 1540 & 121 & 1 & $S$ & & contraponto & -ear \\
\hline contraprovar & 1541 & 170 & 1 & $S$ & & contraprova & -ar \\
\hline contra-reformar & 1542 & 93 & 1 & $S$ & & contra-reforma & -ar \\
\hline contra-selar & 1543 & 88 & 1 & $\mathrm{~S}$ & & contra-selo & -ar \\
\hline contrastear & 1544 & 140 & 1 & $S$ & & contraste & -ear \\
\hline contratelar & 1545 & 117 & 1 & $S$ & & contratela & -ar \\
\hline contratipar & 1546 & 37 & 1 & $S$ & & contratipo & -ar \\
\hline contraventar & 1547 & 97 & 1 & $S$ & & contravento & -ar \\
\hline conveniar & 1548 & 15550 & 1 & $S$ & & convênio & -ar \\
\hline copar & 1549 & 2105 & 1 & $S$ & & copa & -ar \\
\hline copelar & 1550 & 92 & 1 & S & & copela & -ar \\
\hline \begin{tabular}{|l|} 
copiar \\
\end{tabular} & 1551 & 518000 & 2 & $S$ & & cópia & -ar \\
\hline copidescar & 1552 & 294 & 1 & $S$ & & copidesque & -ar \\
\hline copiografar & 1553 & 72 & 1 & $S$ & & copiógrafo & -ar \\
\hline copolimerizar & 1554 & 57 & 1 & $S$ & & copolímero & -izar \\
\hline coqueificar & 1555 & 68 & 1 & $S$ & & coque & -ficar \\
\hline \begin{tabular}{|c|} 
corcovar \\
\end{tabular} & 1556 & 138 & 1 & $S$ & & corcova & -ar \\
\hline corcovear & 1557 & 1273 & 1 & $S$ & & corcovo & -ear \\
\hline cordear & 1558 & 194 & 1 & $S$ & & corda & -ear \\
\hline coreografar & 1559 & 2370 & 1 & $S$ & & coreógrafo & -ar \\
\hline corrupiar & 1560 & 107 & 1 & $S$ & & corrupio & -ar \\
\hline \begin{tabular}{|l|} 
cortilhar \\
\end{tabular} & 1561 & 82 & 1 & $S$ & & corte & -ilhar \\
\hline cortinar & 1562 & 178 & 1 & $S$ & & cortina & -ar \\
\hline corvejar & 1563 & 214 & 1 & $S$ & & corvo & -ejar \\
\hline coscosear & 1564 & 70 & 1 & $S$ & & coscós & -ear \\
\hline co-segurar & 1565 & 34 & 1 & $S$ & & co-seguro & -ar \\
\hline
\end{tabular}




\begin{tabular}{|c|c|c|c|c|c|c|c|c|}
\hline cosmopolizar & 1566 & 142 & 1 & $S$ & & cosmópole & & -izar \\
\hline costear & 1567 & 1348 & 1 & $S$ & & costa & & -ear \\
\hline costelar & 1568 & 198 & 1 & $S$ & & costela & & -ar \\
\hline costumar & 1569 & 5555 & 1 & $S$ & & costume & & -ar \\
\hline costurar & 1570 & 86075 & 1 & $S$ & & costura & & -ar \\
\hline cotiar & 1571 & 124 & 1 & $S$ & & cote & & -iar \\
\hline couraçar & 1572 & 409 & 1 & $S$ & & couraça & & -ar \\
\hline courear & 1573 & 196 & 1 & $S$ & & couro & & -ear \\
\hline coutar & 1574 & 115 & 1 & $S$ & & couto & & -ar \\
\hline covear & 1575 & 129 & 1 & $S$ & & cova & & -ear \\
\hline crasear & 1576 & 243 & 1 & $S$ & & crase & & -ear \\
\hline cravejar & 1577 & 428 & 1 & $S$ & & cravo & & -ejar \\
\hline credenciar & 1578 & 105250 & 1 & $S$ & & credência & & -ar \\
\hline creosotar & 1579 & 78 & 1 & $S$ & & creosoto & & -ar \\
\hline crepusculejar & 1580 & 109 & 1 & $S$ & & crepúsculo & & -ejar \\
\hline criptoanalisar & 1581 & 137 & 1 & $S$ & & criptoanálise & & -ar \\
\hline criptografar & 1582 & 40775 & 1 & $S$ & & criptógrafo & & -ar \\
\hline crisalidar & 1583 & 241 & 1 & $S$ & & crisálida & & -ar \\
\hline crismar & 1584 & 3855 & 1 & $S$ & & crisma & & -ar \\
\hline cristalizar & 1585 & 20700 & 1 & $S$ & & cristal & & -izar \\
\hline criticar & 1586 & 1405000 & 2 & $S$ & & crítica & & -ar \\
\hline crocodilar & 1587 & 51 & 1 & $S$ & & crocodilo & & -ar \\
\hline cromar & 1588 & 6523 & 1 & S & & cromo & & -ar \\
\hline cromatografar & 1589 & 16 & 1 & S & & cromatógrafo & & -ar \\
\hline cromizar & 1590 & 0 & 1 & $S$ & & cromo & & -izar \\
\hline cronometrar & 1591 & 10850 & 1 & $S$ & & cronômetro & & -ar \\
\hline cruzar & 1592 & 517000 & 2 & $S$ & & cruz & & -ar \\
\hline cruzetar & 1593 & 7 & 1 & $S$ & & cruzeta & & -ar \\
\hline cucurbitar & 1594 & 105 & 1 & $S$ & & cucúrbita & & -ar \\
\hline \begin{tabular}{|l} 
culatrar \\
\end{tabular} & 1595 & 66 & 1 & $S$ & & culatra & & -ar \\
\hline cumprimentar & 1596 & 170750 & 1 & $S$ & & cumprimento & & -ar \\
\hline curarizar & 1597 & 90 & 1 & $S$ & & curare & & -izar \\
\hline curetar & 1598 & 937 & 1 & $S$ & & cureta & & -ar \\
\hline currar & 1599 & 1140 & 1 & $S$ & & curra & & -ar \\
\hline curto-circuitar & 1600 & 1230 & 1 & S & & curto-circuito & & -ar \\
\hline curvejar & 1601 & 58 & 1 & $\mathrm{~S}$ & & curva & & -ejar \\
\hline curvetear & 1602 & 199 & 1 & $S$ & & curveta & & -ear \\
\hline \begin{tabular}{|l} 
cuspilhar \\
\end{tabular} & 1603 & 175 & 1 & $\mathrm{~S}$ & & cuspe & & -ilhar \\
\hline cuspinhar & 1604 & 140 & 1 & $S$ & & cuspe & & -inhar \\
\hline custear & 1605 & 266000 & 1 & $S$ & & custo & & -ear \\
\hline \begin{tabular}{|l} 
custodiar \\
\end{tabular} & 1606 & 4665 & 1 & $S$ & & custódia & & -ar \\
\hline cutisar & 1607 & 95 & 1 & S & & cútis & & -ar \\
\hline dadivar & 1608 & 224 & 1 & $S$ & & dádiva & & -ar \\
\hline daguerreotipar & 1609 & 118 & 1 & $S$ & & daguerreótipo & & -ar \\
\hline dançaricar & 1610 & 74 & 1 & $S$ & & dançarico & & -ar \\
\hline dançarilhar & 1611 & 0 & 1 & $S$ & & dança & $-r-$ & -ilhar \\
\hline datar & 1612 & 29900 & 1 & S & & data & & -ar \\
\hline debenturar & 1613 & 165 & 1 & $S$ & & debênture & & -ar \\
\hline debochar & 1614 & 13650 & 1 & $S$ & & deboche & & -ar \\
\hline debruar & 1615 & 387 & 1 & $S$ & & debrum & & -ar \\
\hline decapsular & 1616 & 54 & 1 & $P$ & de- & cápsula & & -ar \\
\hline decepar & 1617 & 8675 & 1 & $P$ & de- & cepo & & -ar \\
\hline decilitrar & 1618 & 62 & 1 & $S$ & & decilitro & & -ar \\
\hline decloretar & 1619 & 0 & 1 & $P$ & de- & cloreto & & -ar \\
\hline \begin{tabular}{|l|} 
decretar \\
\end{tabular} & 1620 & 218750 & 1 & $S$ & & decreto & & -ar \\
\hline dedar & 1621 & 37475 & 1 & $S$ & & dedo & & -ar \\
\hline dedetizar & 1622 & 4145 & 1 & $S$ & & dedetê & & -izar \\
\hline dedilhar & 1623 & 13200 & 1 & $S$ & & dedo & -ilho & -ar \\
\hline defasar & 1624 & 1403 & 1 & $P$ & de- & fase & & -ar \\
\hline defaunar & 1625 & 34 & 1 & $P$ & de- & fauna & & -ar \\
\hline defesar & 1626 & 167 & 1 & $S$ & & defesa & & -ar \\
\hline defibrinar & 1627 & 62 & 1 & $P$ & de- & fibrina & & -ar \\
\hline deflegmar & 1628 & 91 & 1 & $P$ & de- & flegma & & -ar \\
\hline deflocular & 1629 & 95 & 1 & $\mathrm{P}$ & de- & flóculo & & -ar \\
\hline
\end{tabular}




\begin{tabular}{|c|c|c|c|c|c|c|c|c|}
\hline defumar & 1630 & 5095 & 1 & $\mathrm{P}$ & de- & fumo & & -ar \\
\hline degasar & 1631 & 99 & 1 & $\mathrm{P}$ & de- & gás & & -ar \\
\hline deletrear & 1632 & 170 & 1 & $P$ & de- & letra & & -ear \\
\hline delombar & 1633 & 58 & 1 & $P$ & de- & lombo & & -ar \\
\hline demasiar & 1634 & 202 & 1 & $S$ & & demasia & & -ar \\
\hline demitizar & 1635 & 300 & 1 & $\mathrm{P}$ & de- & mito & & -izar \\
\hline demitologizar & 1636 & 9 & 1 & $\mathrm{P}$ & de- & mitologia & & -izar \\
\hline demografizar & 1637 & 2 & 1 & $S$ & & demógrafo & & -izar \\
\hline demonizar & 1638 & 8510 & 1 & $S$ & & demônio & & -izar \\
\hline dentar & 1639 & 722 & 1 & $S$ & & dente & & -ar \\
\hline dentear & 1640 & 718 & 1 & $S$ & & dente & & -ear \\
\hline denticular & 1641 & 120 & 1 & $S$ & & dentículo & & -ar \\
\hline depositar & 1642 & 556500 & 2 & $S$ & & depósito & & -ar \\
\hline dermatosar & 1643 & 40 & 1 & $S$ & & dermatose & & -ar \\
\hline derrabar & 1644 & 209 & 1 & $P$ & de- & rabo & & -ar \\
\hline derrocar & 1645 & 534 & 1 & $\mathrm{P}$ & de- & roca & & -ar \\
\hline desabelhar & 1646 & 736 & 1 & $P$ & des- & abelha & & -ar \\
\hline desacadelar & 1647 & 0 & 1 & $\mathrm{P}$ & des- & cadela & & -ar \\
\hline \begin{tabular}{|l|} 
desairar \\
\end{tabular} & 1648 & 134 & 1 & S & & desaire & & -ar \\
\hline desalmar & 1649 & 81 & 1 & $\mathrm{P}$ & des- & alma & & -ar \\
\hline desaminar & 1650 & 999 & 1 & $P$ & des- & amina & & -ar \\
\hline desaminizar & 1651 & 10 & 1 & $P$ & des- & amina & & -izar \\
\hline desasnar & 1652 & 290 & 1 & $P$ & des- & asno & & -ar \\
\hline desautorar & 1653 & 129 & 1 & $\mathrm{P}$ & des- & autor & & -ar \\
\hline desbagoar & 1654 & 142 & 1 & $\mathrm{P}$ & des- & bago & $-0-$ & -ar \\
\hline desbagulhar & 1655 & 132 & 1 & $\mathrm{P}$ & des- & bagulho & & -ar \\
\hline desbalçar & 1656 & 102 & 1 & $\mathrm{P}$ & des- & balça & & -ar \\
\hline desbancar & 1657 & 76400 & 1 & $\mathrm{P}$ & des- & banco & & -ar \\
\hline desbandar & 1658 & 146 & 1 & $\mathrm{P}$ & des- & bando & & -ar \\
\hline desbandeirar & 1659 & 153 & 1 & $\mathrm{P}$ & des- & bandeira & & -ar \\
\hline desbarbar & 1660 & 161 & 1 & $P$ & des- & barba & & -ar \\
\hline desbarrancar & 1661 & 350 & 1 & $\mathrm{P}$ & des- & barranco & & -ar \\
\hline desbarretar & 1662 & 145 & 1 & $\mathrm{P}$ & des- & barrete & & -ar \\
\hline desbarrigar & 1663 & 111 & 1 & $\mathrm{P}$ & des- & barriga & & -ar \\
\hline desbeiçar & 1664 & 113 & 1 & $\mathrm{P}$ & des- & beiço & & -ar \\
\hline desbocar & 1665 & 450 & 1 & $\mathrm{P}$ & des- & boca & & -ar \\
\hline desbolotar & 1666 & 131 & 1 & $P$ & des- & bolota & & -ar \\
\hline desboroar & 1667 & 86 & 1 & $\mathrm{P}$ & des- & boroa & & -ar \\
\hline desbragar & 1668 & 74 & 1 & $\mathrm{P}$ & des- & braga & & -ar \\
\hline desbriar & 1669 & 71 & 1 & $\mathrm{P}$ & des- & brio & & -ar \\
\hline desbuchar & 1670 & 46 & 1 & $\mathrm{P}$ & des- & bucho & & -ar \\
\hline descabaçar & 1671 & 1283 & 1 & $\mathrm{P}$ & des- & cabaço & & -ar \\
\hline descabeçar & 1672 & 503 & 1 & $\mathrm{P}$ & des- & cabeça & & -ar \\
\hline descabelar & 1673 & 6750 & 1 & $P$ & des- & cabelo & & -ar \\
\hline descabrear & 1674 & 287 & 1 & $\mathrm{P}$ & des- & cabra & & -ear \\
\hline descachaçar & 1675 & 313 & 1 & $\mathrm{P}$ & des- & cachaça & & -ar \\
\hline descadeirar & 1676 & 662 & 1 & $\mathrm{P}$ & des- & cadeira & & -ar \\
\hline descafeinar & 1677 & 390 & 1 & $\mathrm{P}$ & des- & cafeína & & -ar \\
\hline descafeinizar & 1678 & 6 & 1 & $P$ & des- & cafeína & & -izar \\
\hline descalar & 1679 & 83 & 1 & $P$ & des- & cala & & -ar \\
\hline descaliçar & 1680 & 305 & 1 & $\mathrm{P}$ & des- & caliça & & -ar \\
\hline descaminhar & 1681 & 167 & 1 & $P$ & des- & caminho & & -ar \\
\hline descamisar & 1682 & 139 & 1 & $\mathrm{P}$ & des- & camisa & & -ar \\
\hline descampar & 1683 & 108 & 1 & $P$ & des- & campo & & -ar \\
\hline descancelar & 1684 & 121 & 1 & $\mathrm{P}$ & des- & cancela & & -ar \\
\hline descangotar & 1685 & 74 & 1 & $P$ & des- & cangote & & -ar \\
\hline descanhotar & 1686 & 94 & 1 & $P$ & des- & canhota & & -ar \\
\hline descantar & 1687 & 271 & 1 & $P$ & des- & canto & & -ar \\
\hline descantear & 1688 & 85 & 1 & $P$ & des- & canto & & -ear \\
\hline descapelar & 1689 & 64 & 1 & $\mathrm{P}$ & des- & capela & & -ar \\
\hline descapotar & 1690 & 40 & 1 & $P$ & des- & capota & & -ar \\
\hline descapsular & 1691 & 91 & 1 & $\mathrm{P}$ & des- & cápsula & & -ar \\
\hline descarapuçar & 1692 & 74 & 1 & $P$ & des- & carapuça & & -ar \\
\hline descarar & 1693 & 116 & 1 & $\mathrm{P}$ & des- & cara & & -ar \\
\hline
\end{tabular}




\begin{tabular}{|c|c|c|c|c|c|c|c|}
\hline descarbonar & 1694 & 58 & 1 & $\mathrm{P}$ & des- & carbono & -ar \\
\hline descarbonatar & 1695 & 70 & 1 & $\mathrm{P}$ & des- & carbonato & -ar \\
\hline descarboxilar & 1696 & 100 & 1 & $\mathrm{P}$ & des- & carboxila & -ar \\
\hline descarnar & 1697 & 1013 & 1 & $\mathrm{P}$ & des- & carne & -ar \\
\hline descaroçar & 1698 & 799 & 1 & $\mathrm{P}$ & des- & caroço & -ar \\
\hline descarolar & 1700 & 51 & 1 & $P$ & des- & carolo & -ar \\
\hline descarrar & 1701 & 88 & 1 & $\mathrm{P}$ & des- & carro & -ar \\
\hline descarretar & 1702 & 6 & 1 & $P$ & des- & carreta & -ar \\
\hline descarrilar & 1703 & 2678 & 1 & $\mathrm{P}$ & des- & carril & -ar \\
\hline descartar & 1704 & 284250 & 1 & $\mathrm{P}$ & des- & carta & -ar \\
\hline descascar & 1705 & 59500 & 1 & $P$ & des- & casco & -ar \\
\hline descaspar & 1706 & 71 & 1 & $\mathrm{P}$ & des- & caspa & -ar \\
\hline descasular & 1707 & 0 & 1 & $\mathrm{P}$ & des- & casulo & -ar \\
\hline descaudar & 1708 & 66 & 1 & $\mathrm{P}$ & des- & cauda & -ar \\
\hline descelular & 1709 & 74 & 1 & $\mathrm{P}$ & des- & célula & -ar \\
\hline descerebrar & 1710 & 154 & 1 & $\mathrm{P}$ & des- & cérebro & -ar \\
\hline descerebrizar & 1711 & 14 & 1 & $\mathrm{P}$ & des- & cérebro & -izar \\
\hline deschancelar & 1712 & 87 & 1 & $\mathrm{P}$ & des- & chancela & -ar \\
\hline descloretar & 1713 & 68 & 1 & $\mathrm{P}$ & des- & cloreto & -ar \\
\hline descodear & 1714 & 65 & 1 & $\mathrm{P}$ & des- & côdea & -ar \\
\hline descogotear & 1715 & 56 & 1 & $\mathrm{P}$ & des- & cogote & -ear \\
\hline descorajar & 1716 & 62 & 1 & $P$ & des- & coragem & -ar \\
\hline descordar & 1717 & 11275 & 1 & $P$ & des- & corda & -ar \\
\hline descorticar & 1718 & 169 & 1 & $\mathrm{P}$ & des- & córtice & -ar \\
\hline descortiçar & 1719 & 188 & 1 & $\mathrm{P}$ & des- & cortiça & -ar \\
\hline descortinar & 1720 & 20925 & 1 & $\mathrm{P}$ & des- & cortina & -ar \\
\hline descotoar & 1721 & 63 & 1 & $\mathrm{P}$ & des- & cotão & -ar \\
\hline descraveirar & 1722 & 7 & 1 & $\mathrm{P}$ & des- & craveira & -ar \\
\hline descreditar & 1723 & 733 & 1 & $\mathrm{P}$ & des- & crédito & -ar \\
\hline desculturar & 1724 & 1 & 1 & $\mathrm{P}$ & des- & cultura & -ar \\
\hline descupinizar & 1725 & 99 & 1 & $\mathrm{P}$ & des- & cupim & -izar \\
\hline desdentar & 1726 & 190 & 1 & $\mathrm{P}$ & des- & dente & -ar \\
\hline desejar & 1727 & 2917500 & 3 & S & & desejo & -ar \\
\hline desemoinhar & 1728 & 60 & 1 & $\mathrm{P}$ & des- & moinha & -ar \\
\hline desempapar & 1729 & 32 & 1 & $P$ & des- & papo & -ar \\
\hline desempecilhar & 1730 & 49 & 1 & $\mathrm{P}$ & des- & empecilho & -ar \\
\hline desesperançar & 1731 & 456 & 1 & $S$ & & desesperança & -ar \\
\hline desfarelar & 1732 & 243 & 1 & $P$ & des- & farelo & -ar \\
\hline desfavelar & 1733 & 192 & 1 & $\mathrm{P}$ & des- & favela & -ar \\
\hline desfeitear & 1734 & 620 & 1 & $S$ & & desfeita & -ear \\
\hline desfibrar & 1735 & 897 & 1 & $\mathrm{P}$ & des- & fibra & -ar \\
\hline desfibrinar & 1736 & 99 & 1 & $\mathrm{P}$ & des- & fibrina & -ar \\
\hline desfivelar & 1737 & 55 & 1 & $\mathrm{P}$ & des- & fivela & -ar \\
\hline desflegmar & 1738 & 55 & 1 & $\mathrm{P}$ & des- & flegma & -ar \\
\hline desflorar & 1739 & 853 & 1 & $\mathrm{P}$ & des- & flor & -ar \\
\hline desfolhar & 1740 & 4325 & 1 & $\mathrm{P}$ & des- & folha & -ar \\
\hline desfrutar & 1741 & 763500 & 2 & $\mathrm{P}$ & des- & fruto & -ar \\
\hline desgarrar & 1742 & 5970 & 1 & $\mathrm{P}$ & des- & garra & -ar \\
\hline desgasar & 1743 & 103 & 1 & $\mathrm{P}$ & des- & gás & -ar \\
\hline desgraçar & 1744 & 3113 & 1 & S & & desgraça & -ar \\
\hline desgraciar & 1745 & 126 & 1 & $S$ & & desgraça & -iar \\
\hline desgramar & 1746 & 18 & 1 & $S$ & & desgrama & -ar \\
\hline desgraxar & 1747 & 75 & 1 & $\mathrm{P}$ & des- & graxa & -ar \\
\hline desgrenhar & 1748 & 213 & 1 & $P$ & des- & grenha & -ar \\
\hline desgrilhoar & 1749 & 76 & 1 & $\mathrm{P}$ & des- & grilhão & -ar \\
\hline desgrinaldar & 1750 & 80 & 1 & $P$ & des- & grinalda & -ar \\
\hline desguampar & 1751 & 85 & 1 & $P$ & des- & guampa & -ar \\
\hline desinsetar & 1752 & 33 & 1 & $P$ & des- & inseto & -ar \\
\hline deslapar & 1753 & 149 & 1 & $P$ & des- & lapa & -ar \\
\hline desleitar & 1754 & 197 & 1 & $\mathrm{P}$ & des- & leite & -ar \\
\hline deslendear & 1755 & 145 & 1 & $P$ & des- & lêndea & -ar \\
\hline deslinguar & 1756 & 72 & 1 & $\mathrm{P}$ & des- & língua & -ar \\
\hline deslodar & 1757 & 73 & 1 & $P$ & des- & lodo & -ar \\
\hline deslombar & 1758 & 82 & 1 & $\mathrm{P}$ & des- & lombo & -ar \\
\hline
\end{tabular}




\begin{tabular}{|c|c|c|c|c|c|c|c|}
\hline desluvar & 1759 & 0 & 1 & $\mathrm{P}$ & des- & luva & -ar \\
\hline desmalhar & 1760 & 214 & 1 & $\mathrm{P}$ & des- & malha & -ar \\
\hline desmanivar & 1761 & 179 & 1 & $P$ & des- & maniva & -ar \\
\hline desmastrar & 1762 & 178 & 1 & $\mathrm{P}$ & des- & mastro & -ar \\
\hline desmatar & 1763 & 40350 & 1 & $P$ & des- & mato & -ar \\
\hline desmazelar & 1764 & 123 & 1 & $\mathrm{P}$ & des- & mazela & -ar \\
\hline desmedular & 1765 & 78 & 1 & $\mathrm{P}$ & des- & medula & -ar \\
\hline desmembrar & 1766 & 27325 & 1 & $\mathrm{P}$ & des- & membro & -ar \\
\hline desmielinar & 1767 & 9 & 1 & $\mathrm{P}$ & des- & mielina & -ar \\
\hline desmiolar & 1768 & 108 & 1 & $\mathrm{P}$ & des- & miolo & -ar \\
\hline desmiuçar & 1769 & 35 & 1 & $\mathrm{P}$ & des- & miúça & -ar \\
\hline desmoedar & 1770 & 0 & 1 & $P$ & des- & moeda & -ar \\
\hline desmoldar & 1771 & 485 & 1 & $\mathrm{P}$ & des- & molde & -ar \\
\hline desmuscular & 1772 & 9 & 1 & $\mathrm{P}$ & des- & músculo & -ar \\
\hline desnalgar-se & 1773 & 23 & 1 & $\mathrm{P}$ & des- & nalga & -ar \\
\hline desnastrar & 1774 & 89 & 1 & $\mathrm{P}$ & des- & nastro & -ar \\
\hline desnatar & 1775 & 549 & 1 & $P$ & des- & nata & -ar \\
\hline desnaturar & 1776 & 5385 & 1 & $\mathrm{P}$ & des- & natura & -ar \\
\hline desneixar & 1777 & 0 & 1 & $\mathrm{P}$ & des- & nexo & -ar \\
\hline desnervar & 1778 & 83 & 1 & $\mathrm{P}$ & des- & nervo & -ar \\
\hline desnevar & 1779 & 121 & 1 & $P$ & des- & neve & -ar \\
\hline desninhar & 1780 & 41 & 1 & $P$ & des- & ninho & -ar \\
\hline desnitrar & 1781 & 64 & 1 & $\mathrm{P}$ & des- & nitro & -ar \\
\hline desnoitar & 1782 & 0 & 1 & $\mathrm{P}$ & des- & noite & -ar \\
\hline desnovelar & 1783 & 232 & 1 & $\mathrm{P}$ & des- & novelo & -ar \\
\hline desnucar & 1784 & 128 & 1 & $\mathrm{P}$ & des- & nuca & -ar \\
\hline desolhar & 1785 & 227 & 1 & $\mathrm{P}$ & des- & olho & -ar \\
\hline desopercular & 1786 & 71 & 1 & $\mathrm{P}$ & des- & opérculo & -ar \\
\hline desorbitar & 1787 & 125 & 1 & $\mathrm{P}$ & des- & órbita & -ar \\
\hline desorelhar & 1788 & 96 & 1 & $\mathrm{P}$ & des- & orelha & -ar \\
\hline desovar & 1789 & 16925 & 1 & $P$ & des- & ovo & -ar \\
\hline despadrar & 1790 & 255 & 1 & $\mathrm{P}$ & des- & padre & -ar \\
\hline despaletar & 1791 & 54 & 1 & $\mathrm{P}$ & des- & paleta & -ar \\
\hline despaletear & 1792 & 229 & 1 & $\mathrm{P}$ & des- & paleta & -ear \\
\hline despalmar & 1793 & 238 & 1 & $\mathrm{P}$ & des- & palma & -ar \\
\hline despampanar & 1794 & 234 & 1 & $\mathrm{P}$ & des- & pâmpano & -ar \\
\hline despapar & 1795 & 226 & 1 & $P$ & des- & papo & -ar \\
\hline desparrar & 1796 & 253 & 1 & $\mathrm{P}$ & des- & parra & -ar \\
\hline despear & 1797 & 326 & 1 & $\mathrm{P}$ & des- & pé & -ar \\
\hline despecuniar & 1798 & 46 & 1 & $\mathrm{P}$ & des- & pecúnia & -ar \\
\hline despedaçar & 1799 & 15100 & 1 & $\mathrm{P}$ & des- & pedaço & -ar \\
\hline despedrar & 1800 & 10 & 1 & $\mathrm{P}$ & des- & pedra & -ar \\
\hline despeitar & 1801 & 296 & 1 & S & & despeito & -ar \\
\hline despencar & 1802 & 49500 & 1 & $P$ & des- & penca & -ar \\
\hline despesar & 1803 & 157 & 1 & $S$ & & despesa & -ar \\
\hline despestanar & 1804 & 6 & 1 & $\mathrm{P}$ & des- & pestana & -ar \\
\hline despetalar & 1805 & 1483 & 1 & $\mathrm{P}$ & des- & pétala & -ar \\
\hline despiedar & 1806 & 85 & 1 & S & & despiedade & -ar \\
\hline despingar & 1807 & 1 & 1 & $P$ & des- & pingo & -ar \\
\hline despinhalizar & 1808 & 8 & 1 & $P$ & des- & pinhal & -izar \\
\hline despiolhar & 1809 & 58 & 1 & $\mathrm{P}$ & des- & piolho & -ar \\
\hline despistar & 1810 & 92600 & 1 & $P$ & des- & pista & -ar \\
\hline despolpar & 1811 & 807 & 1 & $\mathrm{P}$ & des- & polpa & -ar \\
\hline despontar & 1812 & 47950 & 1 & $P$ & des- & ponta & -ar \\
\hline desportilhar & 1813 & 92 & 1 & $\mathrm{P}$ & des- & portilha & -ar \\
\hline despossar & 1814 & 81 & 1 & $P$ & des- & posse & -ar \\
\hline despostigar & 1815 & 70 & 1 & $P$ & des- & postigo & -ar \\
\hline despraguejar & 1816 & 21 & 1 & $P$ & des- & praga & -ejar \\
\hline despresilhar & 1817 & 101 & 1 & $P$ & des- & presilha & -ar \\
\hline desprimorar & 1818 & 131 & 1 & $\mathrm{P}$ & des- & primor & -ar \\
\hline desprumar & 1819 & 30 & 1 & $P$ & des- & prumo & -ar \\
\hline despucelar & 1820 & 61 & 1 & $\mathrm{P}$ & des- & pucela & -ar \\
\hline desquadrilhar & 1821 & 105 & 1 & $P$ & des- & quadril & -ar \\
\hline desqueixar & 1822 & 94 & 1 & $\mathrm{P}$ & des- & queixo & -ar \\
\hline
\end{tabular}




\begin{tabular}{|c|c|c|c|c|c|c|c|}
\hline desquiciar & 1823 & 127 & 1 & $\mathrm{P}$ & des- & quício & -ar \\
\hline desrabar & 1824 & 140 & 1 & $\mathrm{P}$ & des- & rabo & -ar \\
\hline desraizar & 1825 & 140 & 1 & $P$ & des- & raiz- & -ar \\
\hline desrugar & 1826 & 65 & 1 & $P$ & des- & ruga & -ar \\
\hline dessaborar & 1827 & 153 & 1 & $\mathrm{P}$ & des- & sabor & -ar \\
\hline dessaburrar & 1828 & 154 & 1 & $\mathrm{P}$ & des- & saburra & -ar \\
\hline desselar & 1829 & 188 & 1 & $\mathrm{P}$ & des- & sela & -ar \\
\hline dessexuar & 1830 & 50 & 1 & $\mathrm{P}$ & des- & sexo & -ar \\
\hline dessinalar & 1831 & 1 & 1 & $\mathrm{P}$ & des- & sinal & -ar \\
\hline dessoalhar & 1832 & 30 & 1 & $\mathrm{P}$ & des- & soalho & -ar \\
\hline dessolar & 1833 & 77 & 1 & $\mathrm{P}$ & des- & sola & -ar \\
\hline dessossegar & 1834 & 59 & 1 & $\mathrm{P}$ & des- & sossego & -ar \\
\hline destabocar & 1835 & 229 & 1 & $\mathrm{P}$ & des- & taboca & -ar \\
\hline destampar & 1836 & 2863 & 1 & $\mathrm{P}$ & des- & tampa & -ar \\
\hline destaquear & 1837 & 244 & 1 & $S$ & & destaque & -ear \\
\hline desterneirar & 1838 & 250 & 1 & $\mathrm{P}$ & des- & terneiro & -ar \\
\hline desterrar & 1839 & 3280 & 1 & $\mathrm{P}$ & des- & terra & -ar \\
\hline destoar & 1840 & 10008 & 1 & $\mathrm{P}$ & des- & tom & -ar \\
\hline destocar & 1841 & 499 & 1 & $\mathrm{P}$ & des- & toca & -ar \\
\hline destopetear & 1842 & 75 & 1 & $\mathrm{P}$ & des- & topete & -ear \\
\hline destorar & 1843 & 83 & 1 & $\mathrm{P}$ & des- & tora & -ar \\
\hline destoucar & 1844 & 166 & 1 & $P$ & des- & touca & -ar \\
\hline destrajar & 1845 & 0 & 1 & $\mathrm{P}$ & des- & traje & -ar \\
\hline destrambelhar & 1846 & 380 & 1 & $\mathrm{P}$ & des- & trambelho & -ar \\
\hline destravancar & 1847 & 106 & 1 & $\mathrm{P}$ & des- & travanca & -ar \\
\hline destrelar & 1848 & 84 & 1 & $\mathrm{P}$ & des- & trela & -ar \\
\hline destripar & 1850 & 336 & 1 & $\mathrm{P}$ & des- & tripa & -ar \\
\hline destronar & 1851 & 26775 & 1 & $\mathrm{P}$ & des- & trono & -ar \\
\hline destronizar & 1852 & 145 & 1 & $\mathrm{P}$ & des- & trono & -izar \\
\hline destropilhar & 1853 & 17 & 1 & $\mathrm{P}$ & des- & tropilha & -ar \\
\hline destrunfar & 1854 & 102 & 1 & $\mathrm{P}$ & des- & trunfa & -ar \\
\hline desunhar & 1855 & 175 & 1 & $\mathrm{P}$ & des- & unha & -ar \\
\hline desvaliar & 1856 & 185 & 1 & $S$ & & desvalia & -ar \\
\hline desventrar & 1857 & 199 & 1 & $\mathrm{P}$ & des- & ventre & -ar \\
\hline desventurar & 1858 & 183 & 1 & $\mathrm{P}$ & des- & ventura & -ar \\
\hline desvergonhar & 1859 & 81 & 1 & $\mathrm{P}$ & des- & vergonha & -ar \\
\hline desvidraçar & 1860 & 76 & 1 & $\mathrm{P}$ & des- & vidraça & -ar \\
\hline desviscerar & 1861 & 87 & 1 & $\mathrm{P}$ & des- & víscera & -ar \\
\hline desvolumar & 1862 & 50 & 1 & $\mathrm{P}$ & des- & volume & -ar \\
\hline detençar & 1863 & 6 & 1 & $S$ & & detença & -ar \\
\hline diademar & 1864 & 96 & 1 & $\mathrm{~S}$ & & diadema & -ar \\
\hline diagramar & 1865 & 8015 & 1 & $S$ & & diagrama & -ar \\
\hline dialisar & 1866 & 243 & 1 & $S$ & & diálise & -ar \\
\hline dialogar & 1867 & 310750 & 1 & $S$ & & diálogo & -ar \\
\hline diamantizar & 1868 & 172 & 1 & $S$ & & diamante & -izar \\
\hline dicionariar & 1869 & 117 & 1 & $S$ & & dicionário & -ar \\
\hline dicionarizar & 1870 & 294 & 1 & $S$ & & dicionário & -izar \\
\hline dicotomizar & 1871 & 2010 & 1 & $S$ & & dicotomia & -izar \\
\hline diesar & 1872 & 77 & 1 & $S$ & & diese & -ar \\
\hline diferençar & 1873 & 3778 & 1 & $S$ & & diferença & -ar \\
\hline digitalinizar & 1874 & 2 & 1 & $S$ & & digitalina & -izar \\
\hline diligenciar & 1875 & 45075 & 1 & $S$ & & diligência & -ar \\
\hline dinamitar & 1876 & 4985 & 1 & $\mathrm{~S}$ & & dinamite & -ar \\
\hline diplomaciar & 1877 & 146 & 1 & $S$ & & diplomacia & -ar \\
\hline discar & 1878 & 59475 & 1 & $S$ & & disco & -ar \\
\hline disgramar & 1879 & 6 & 1 & $S$ & & disgrama & -ar \\
\hline disparatar & 1880 & 557 & 1 & $S$ & & disparate & -ar \\
\hline dissaborear & 1881 & 67 & 1 & $S$ & & dissabor & -ear \\
\hline dissidiar & 1882 & 228 & 1 & $S$ & & dissídio & -ar \\
\hline distanciar & 1883 & 90175 & 1 & $S$ & & distância & -ar \\
\hline distratar & 1884 & 1550 & 1 & $S$ & & distrato & -ar \\
\hline ditongar & 1885 & 130 & 1 & $S$ & & ditongo & -ar \\
\hline divorciar & 1886 & 23625 & 1 & $S$ & & divórcio & -ar \\
\hline documentar & 1887 & 146500 & 1 & $\mathrm{~S}$ & & documento & -ar \\
\hline
\end{tabular}




\begin{tabular}{|c|c|c|c|c|c|c|c|}
\hline dolarizar & 1888 & 1518 & 1 & $S$ & & dólar & -izar \\
\hline dolomitizar & 1889 & 56 & 1 & $S$ & & dolomita & -izar \\
\hline domiciliar & 1890 & 660000 & 2 & $S$ & & domicílio & -ar \\
\hline donairear & 1891 & 105 & 1 & $S$ & & donaire & -ear \\
\hline donear & 1892 & 76 & 1 & $S$ & & dona & -ear \\
\hline dosar & 1893 & 53575 & 1 & $S$ & & dose & -ar \\
\hline dosear & 1894 & 419 & 1 & $S$ & & dose & -ear \\
\hline doutrinar & 1895 & 12225 & 1 & $S$ & & doutrina & -ar \\
\hline drogar & 1896 & 29525 & 1 & $S$ & & droga & -ar \\
\hline droguear & 1897 & 54 & 1 & $S$ & & droga & -ear \\
\hline duchar & 1898 & 130 & 1 & $S$ & & ducha & -ar \\
\hline duetar & 1899 & 366 & 1 & $S$ & & dueto & -ar \\
\hline dulçorar & 1900 & 0 & 1 & S & & dulçor & -ar \\
\hline ebanizar & 1901 & 59 & 1 & $S$ & & ébano & -izar \\
\hline ecar & 1902 & 2963 & 1 & $S$ & & eco & -ar \\
\hline eclipsar & 1903 & 4100 & 1 & $S$ & & eclipse & -ar \\
\hline ecoar & 1904 & 47475 & 1 & S & & eco & -ar \\
\hline ecocardiografar & 1905 & 0 & 1 & S & & ecocardiografia & -ar \\
\hline ecoencefalografa & 1906 & 0 & 1 & $S$ & & ecoencefalografia & -ar \\
\hline ecografar & 1907 & 54 & 1 & $S$ & & ecografia & -ar \\
\hline economizar & 1908 & 987500 & 2 & $S$ & & economia & -izar \\
\hline edenizar & 1909 & 178 & 1 & S & & éden & -izar \\
\hline eficaciar & 1910 & 5 & 1 & $S$ & & eficácia & -ar \\
\hline egoismar & 1911 & 0 & 1 & $S$ & & egoísmo & -ar \\
\hline eguar & 1912 & 112 & 1 & $S$ & & égua & -ar \\
\hline eivar & 1913 & 1135 & 1 & $S$ & & eiva & -ar \\
\hline eixar & 1914 & 2068 & 1 & $S$ & & eixo & -ar \\
\hline elar & 1915 & 1320 & 1 & $S$ & & elo & -ar \\
\hline elencar & 1916 & 38150 & 1 & $S$ & & elenco & -ar \\
\hline eletrolisar & 1917 & 956 & 1 & S & & eletrólise & -ar \\
\hline eletronar & 1918 & 1 & 1 & $S$ & & elétron & -ar \\
\hline eletrotipar & 1919 & 84 & 1 & $S$ & & eletrótipo & -ar \\
\hline elipsar & 1920 & 113 & 1 & $S$ & & elipse & -ar \\
\hline elitizar & 1921 & 3293 & 1 & $S$ & & elite & -izar \\
\hline emaçar & 1922 & 100 & 1 & $P$ & en- & maço & -ar \\
\hline emadeirar & 1923 & 95 & 1 & $P$ & en- & madeira & -ar \\
\hline emadeixar & 1924 & 83 & 1 & $\mathrm{P}$ & en- & madeixa & -ar \\
\hline emagotar & 1925 & 99 & 1 & $P$ & en- & magote & -ar \\
\hline emalar & 1926 & 201 & 1 & $\mathrm{P}$ & en- & mala & -ar \\
\hline emanchar & 1927 & 52 & 1 & $\mathrm{P}$ & en- & mancha & -ar \\
\hline emanocar & 1928 & 117 & 1 & $\mathrm{P}$ & en- & manoca & -ar \\
\hline emantar & 1929 & 143 & 1 & $P$ & en- & manta & -ar \\
\hline emarar-se & 1930 & 22 & 1 & $P$ & en- & mar & -ar \\
\hline emastrar & 1931 & 74 & 1 & $P$ & en- & mastro & -ar \\
\hline ematilhar & 1932 & 0 & 1 & $P$ & en- & matilha & -ar \\
\hline embacelar & 1933 & 249 & 1 & $P$ & em- & bacelo & -ar \\
\hline embagulhar & 1934 & 56 & 1 & $P$ & em- & bagulho & -ar \\
\hline embalar & 1935 & 148000 & 1 & $P$ & em- & bala & -ar \\
\hline embalçar & 1936 & 273 & 1 & $\mathrm{P}$ & em- & balça & -ar \\
\hline embalsamar & 1937 & 6630 & 1 & $P$ & em- & bálsamo & -ar \\
\hline embalsar & 1938 & 143 & 1 & $P$ & em- & balsa & -ar \\
\hline embananar & 1939 & 1685 & 1 & $P$ & em- & banana & -ar \\
\hline embandar & 1940 & 287 & 1 & $\mathrm{P}$ & em- & bando & -ar \\
\hline embandeirar & 1941 & 788 & 1 & $\mathrm{P}$ & em- & bandeira & -ar \\
\hline embaraçar & 1942 & 25975 & 1 & $\mathrm{P}$ & em- & baraço & -ar \\
\hline embarbascar & 1943 & 72 & 1 & $P$ & em- & barbasco & -ar \\
\hline embarbecer & 1944 & 69 & 1 & $\mathrm{P}$ & em- & barba & -ecer \\
\hline embarbelar & 1945 & 85 & 1 & $\mathrm{P}$ & em- & barbela & -ar \\
\hline embarbilhar & 1946 & 67 & 1 & $\mathrm{P}$ & em- & barbilho & -ar \\
\hline embarcar & 1947 & 649000 & 2 & $\mathrm{P}$ & em- & barca & -ar \\
\hline embarrancar & 1948 & 89 & 1 & $P$ & em- & barranco & -ar \\
\hline embarrar & 1950 & 271 & 1 & $\mathrm{P}$ & em- & barra & -ar \\
\hline embarrear & 1951 & 104 & 1 & $\mathrm{P}$ & em- & barro & -ear \\
\hline embarreirar & 1952 & 638 & 1 & $\mathrm{P}$ & em- & barreira & -ar \\
\hline
\end{tabular}




\begin{tabular}{|c|c|c|c|c|c|c|c|}
\hline embarrelar & 1953 & 85 & 1 & $\mathrm{P}$ & em- & barrela & -ar \\
\hline embarretar-se & 1954 & 0 & 1 & $\mathrm{P}$ & em- & barrete & -ar \\
\hline embarrigar & 1955 & 358 & 1 & $\mathrm{P}$ & em- & barriga & -ar \\
\hline embarrilar & 1956 & 145 & 1 & $\mathrm{P}$ & em- & barril & -ar \\
\hline embasar & 1957 & 98650 & 1 & $\mathrm{P}$ & em- & base & -ar \\
\hline embastar & 1958 & 82 & 1 & $P$ & em- & basta & -ar \\
\hline embeiçar & 1959 & 206 & 1 & $\mathrm{P}$ & em- & beiço & -ar \\
\hline embelezar & 1960 & 48450 & 1 & $P$ & em- & beleza & -ar \\
\hline embernar & 1961 & 171 & 1 & $\mathrm{P}$ & em- & berne & -ar \\
\hline embetesgar & 1962 & 118 & 1 & $\mathrm{P}$ & em- & betesga & -ar \\
\hline embezerrar & 1963 & 108 & 1 & $\mathrm{P}$ & em- & bezerro & -ar \\
\hline embiocar & 1964 & 175 & 1 & $P$ & em- & bioco & -ar \\
\hline embirar & 1965 & 61 & 1 & $S$ & & embira & -ar \\
\hline emblemar & 1966 & 126 & 1 & $\mathrm{~S}$ & & emblema & -ar \\
\hline embocetar & 1967 & 51 & 1 & $P$ & em- & boceta & -ar \\
\hline embodegar & 1968 & 195 & 1 & $\mathrm{P}$ & em- & bodega & -ar \\
\hline embodocar-se & 1969 & 25 & 1 & $\mathrm{P}$ & em- & bodoque & -ar \\
\hline emboizar & 1970 & 180 & 1 & $\mathrm{P}$ & em- & boiz & -ar \\
\hline embolar & 1971 & 15288 & 1 & $\mathrm{P}$ & em- & bola & -ar \\
\hline embolorar & 1973 & 784 & 1 & $\mathrm{P}$ & em- & bolor & -ar \\
\hline embolotar & 1974 & 373 & 1 & $P$ & em- & bolota & -ar \\
\hline embolsar & 1975 & 30425 & 1 & $P$ & em- & bolsa & -ar \\
\hline embonecar & 1976 & 737 & 1 & $P$ & em- & boneca & -ar \\
\hline embornalar & 1977 & 81 & 1 & $P$ & em- & bornal & -ar \\
\hline emborrascar & 1978 & 86 & 1 & $\mathrm{P}$ & em- & borrasca & -ar \\
\hline embostar & 1979 & 98 & 1 & $P$ & em- & bosta & -ar \\
\hline embostear & 1980 & 125 & 1 & $P$ & em- & bosta & -ear \\
\hline embostelar & 1981 & 86 & 1 & $\mathrm{P}$ & em- & bostela & -ar \\
\hline embotelhar & 1982 & 74 & 1 & $P$ & em- & botelha & -ar \\
\hline embotijar & 1983 & 87 & 1 & $P$ & em- & botija & -ar \\
\hline embraçar & 1984 & 269 & 1 & $P$ & em- & braço & -ar \\
\hline embrenhar & 1985 & 12800 & 1 & $\mathrm{P}$ & em- & brenha & -ar \\
\hline embretar & 1986 & 359 & 1 & $\mathrm{P}$ & em- & brete & -ar \\
\hline embridar & 1987 & 103 & 1 & $P$ & em- & brida & -ar \\
\hline embrincar & 1988 & 221 & 1 & $P$ & em- & brinco & -ar \\
\hline embruacar & 1989 & 88 & 1 & $P$ & em- & bruaca & -ar \\
\hline embrumar & 1990 & 101 & 1 & $P$ & em- & bruma & -ar \\
\hline embruxar & 1991 & 132 & 1 & $\mathrm{P}$ & em- & bruxa & -ar \\
\hline embuçar & 1992 & 275 & 1 & $\mathrm{P}$ & em- & buço & -ar \\
\hline embuchar & 1993 & 1580 & 1 & $P$ & em- & bucho & -ar \\
\hline embudar & 1995 & 78 & 1 & $S$ & & embude & -ar \\
\hline emburacar & 1996 & 457 & 1 & $P$ & em- & buraco & -ar \\
\hline emburricar & 1997 & 159 & 1 & $P$ & em- & burrico & -ar \\
\hline embustear & 1998 & 89 & 1 & $S$ & & embuste & -ear \\
\hline ementar & 1999 & 924 & 1 & $S$ & & ementa & -ar \\
\hline emoldar & 2000 & 89 & 1 & $P$ & e- & molde & -ar \\
\hline emoldurar & 2001 & 9190 & 1 & $\mathrm{P}$ & e- & moldura & -ar \\
\hline emonar & 2002 & 85 & 1 & $\mathrm{P}$ & em- & mono & -ar \\
\hline emordaçar & 2003 & 72 & 1 & $P$ & em- & mordaça & -ar \\
\hline emortecer & 2004 & 92 & 1 & $P$ & em- & morte & -ecer \\
\hline emostar & 2005 & 264 & 1 & $\mathrm{P}$ & em- & mosto & -ar \\
\hline empacar & 2006 & 7020 & 1 & $P$ & em- & paco & -ar \\
\hline empacavirar & 2007 & 79 & 1 & $\mathrm{P}$ & em- & pacavira & -ar \\
\hline empaçocar & 2008 & 277 & 1 & $P$ & em- & paçoca & -ar \\
\hline empacotar & 2009 & 33450 & 1 & $P$ & em- & pacote & -ar \\
\hline empaiolar & 2010 & 298 & 1 & $P$ & em- & paiol & -ar \\
\hline empaletar & 2011 & 264 & 1 & $P$ & em- & palete & -ar \\
\hline empalheirar & 2012 & 269 & 1 & $P$ & em- & palheiro & -ar \\
\hline empalmar & 2013 & 971 & 1 & $P$ & em- & palma & -ar \\
\hline empampanar & 2014 & 260 & 1 & $\mathrm{P}$ & em- & pâmpano & -ar \\
\hline empancar & 2015 & 199 & 1 & $P$ & em- & panca & -ar \\
\hline empaneirar & 2016 & 84 & 1 & $\mathrm{P}$ & em- & paneiro & -ar \\
\hline empantanar & 2017 & 205 & 1 & $P$ & em- & pântano & -ar \\
\hline empantufar-se & 2018 & 45 & 1 & $\mathrm{P}$ & em- & pantufa & -ar \\
\hline
\end{tabular}




\begin{tabular}{|c|c|c|c|c|c|c|c|c|}
\hline empanturrar & 2019 & 5965 & 1 & $\mathrm{P}$ & em- & panturra & & -ar \\
\hline empapar & 2020 & 984 & 1 & $\mathrm{P}$ & em- & papa & & -ar \\
\hline empapuçar & 2022 & 418 & 1 & $\mathrm{P}$ & em- & papo & & -uçar \\
\hline emparedar & 2023 & 3463 & 1 & $P$ & em- & parede & & -ar \\
\hline emparelhar & 2024 & 7330 & 1 & $P$ & em- & parelha & & -ar \\
\hline emparrar & 2025 & 83 & 1 & $\mathrm{P}$ & em- & parra & & -ar \\
\hline emparreirar & 2026 & 81 & 1 & $\mathrm{P}$ & em- & parreira & & -ar \\
\hline emparvar & 2027 & 112 & 1 & $\mathrm{P}$ & em- & parva & & -ar \\
\hline empastar & 2028 & 533 & 1 & $\mathrm{P}$ & em- & pasta & & -ar \\
\hline empavesar & 2029 & 148 & 1 & $\mathrm{P}$ & em- & pavês & & -ar \\
\hline empecilhar & 2030 & 207 & 1 & $S$ & & empecilho & & -ar \\
\hline empeçonhar & 2031 & 114 & 1 & $P$ & em- & peçonha & & -ar \\
\hline empedrar & 2032 & 1658 & 1 & $\mathrm{P}$ & em- & pedra & & -ar \\
\hline empegar & 2033 & 311 & 1 & $\mathrm{P}$ & em- & pego & & -ar \\
\hline empeiticar & 2034 & 169 & 1 & $\mathrm{P}$ & em- & peitica & & -ar \\
\hline empelamar & 2035 & 184 & 1 & $P$ & em- & pelame & & -ar \\
\hline empelicar & 2036 & 189 & 1 & $P$ & em- & pelica & & -ar \\
\hline empendoar & 2037 & 198 & 1 & $\mathrm{P}$ & em- & pendão & & -ar \\
\hline empepinar & 2038 & 181 & 1 & $\mathrm{P}$ & em- & pepino & & -ar \\
\hline emperlar & 2039 & 74 & 1 & $\mathrm{P}$ & em- & perla & & -ar \\
\hline empernar & 2040 & 83 & 1 & $P$ & em- & perna & & -ar \\
\hline empertigar & 2041 & 319 & 1 & $P$ & em- & pértiga & & -ar \\
\hline empestar & 2042 & 424 & 1 & $P$ & em- & peste & & -ar \\
\hline empestear & 2043 & 852 & 1 & $P$ & em- & peste & & -ear \\
\hline empetecar & 2044 & 251 & 1 & $\mathrm{P}$ & em- & peteca & & -ar \\
\hline empezar & 2045 & 116500 & 1 & $P$ & em- & pez & & -ar \\
\hline empezinhar & 2046 & 90 & 1 & $P$ & em- & pez & & -inhar \\
\hline empicotar & 2047 & 166 & 1 & $\mathrm{P}$ & em- & picota & & -ar \\
\hline empilchar & 2048 & 147 & 1 & $P$ & em- & pilcha & & -ar \\
\hline empilecar & 2049 & 69 & 1 & $\mathrm{P}$ & em- & pileque & & -ar \\
\hline empinar & 2050 & 68900 & 1 & $P$ & em- & pino & & -ar \\
\hline empipocar & 2051 & 359 & 1 & $\mathrm{P}$ & em- & pipoca & & -ar \\
\hline empistolar & 2052 & 108 & 1 & $\mathrm{P}$ & em- & pistolão & & -ar \\
\hline emplacar & 2053 & 233000 & 1 & $P$ & em- & placa & & -ar \\
\hline emplastar & 2054 & 281 & 1 & $S$ & & emplasto & & -ar \\
\hline empoar & 2055 & 369 & 1 & $\mathrm{P}$ & em- & pó & & -ar \\
\hline empoçar & 2056 & 875 & 1 & $\mathrm{P}$ & em- & poço & & -ar \\
\hline empocilgar & 2057 & 115 & 1 & $\mathrm{P}$ & em- & pocilga & & -ar \\
\hline empolar & 2058 & 749 & 1 & $S$ & & empola & & -ar \\
\hline empoleirar & 2059 & 1170 & 1 & $\mathrm{P}$ & em- & poleiro & & -ar \\
\hline empolmar & 2060 & 134 & 1 & $\mathrm{P}$ & em- & polme & & -ar \\
\hline empomadar & 2061 & 68 & 1 & $\mathrm{P}$ & em- & pomada & & -ar \\
\hline empopar & 2062 & 129 & 1 & $\mathrm{P}$ & em- & popa & & -ar \\
\hline empossar & 2063 & 40650 & 1 & $P$ & em- & posse & & -ar \\
\hline empostar & 2064 & 314 & 1 & $\mathrm{P}$ & em- & posta & & -ar \\
\hline empostemar & 2065 & 32 & 1 & $\mathrm{P}$ & em- & postema & & -ar \\
\hline emprateleirar & 2066 & 203 & 1 & $\mathrm{P}$ & em- & prateleira & & -ar \\
\hline emprazar & 2067 & 289 & 1 & $\mathrm{P}$ & em- & prazo & & -ar \\
\hline empresar & 2068 & 7660 & 1 & $S$ & & empresa & & -ar \\
\hline emproar & 2069 & 196 & 1 & $P$ & em- & proa & & -ar \\
\hline empunhar & 2070 & 19375 & 1 & $\mathrm{P}$ & em- & punho & & -ar \\
\hline empupar & 2071 & 333 & 1 & $P$ & em- & pupa & & -ar \\
\hline enaipar & 2072 & 66 & 1 & $\mathrm{P}$ & en- & naipe & & -ar \\
\hline enamorar & 2073 & 9645 & 1 & $P$ & en- & amor & & -ar \\
\hline enastrar & 2074 & 73 & 1 & $P$ & en- & nastro & & -ar \\
\hline enatar & 2075 & 70 & 1 & $P$ & en- & nata & & -ar \\
\hline enateirar & 2076 & 65 & 1 & $P$ & en- & nateiro & & -ar \\
\hline encabar & 2077 & 352 & 1 & $P$ & en- & cabo & & -ar \\
\hline encabeçar & 2078 & 24100 & 1 & $P$ & en- & cabeça & & -ar \\
\hline encabeirar & 2080 & 285 & 1 & $\mathrm{P}$ & en- & cabo & -eiro & -ar \\
\hline encabelar & 2081 & 312 & 1 & $P$ & en- & cabelo & & -ar \\
\hline encabelizar & 2082 & 69 & 1 & $\mathrm{P}$ & en- & cabelo & & -izar \\
\hline encabrestar & 2083 & 735 & 1 & $P$ & en- & cabresto & & -ar \\
\hline encaçapar & 2084 & 2415 & 1 & $P$ & en- & caçapa & & -ar \\
\hline
\end{tabular}




\begin{tabular}{|c|c|c|c|c|c|c|c|}
\hline encachaçar & 2085 & 118 & 1 & $\mathrm{P}$ & en- & cachaça & -ar \\
\hline encachar & 2086 & 658 & 1 & $\mathrm{P}$ & en- & cacha & -ar \\
\hline encachoeirar & 2087 & 237 & 1 & $\mathrm{P}$ & en- & cachoeira & -ar \\
\hline encacholar & 2088 & 231 & 1 & $\mathrm{P}$ & en- & cachola & -ar \\
\hline encadear & 2089 & 6993 & 1 & $P$ & en- & cadeia & -ar \\
\hline encadeirar & 2090 & 230 & 1 & $\mathrm{P}$ & en- & cadeira & -ar \\
\hline encadernar & 2091 & 11600 & 1 & $\mathrm{P}$ & en- & caderno & -ar \\
\hline encafuar & 2092 & 549 & 1 & $\mathrm{P}$ & en- & cafua & -ar \\
\hline encafurnar & 2093 & 235 & 1 & $\mathrm{P}$ & en- & cafurna & -ar \\
\hline encagaçar & 2094 & 226 & 1 & $P$ & en- & cagaço & -ar \\
\hline encaibrar & 2095 & 245 & 1 & $P$ & en- & caibro & -ar \\
\hline encaieirar & 2096 & 54 & 1 & $\mathrm{P}$ & en- & caieira & -ar \\
\hline encaixar & 2097 & 432000 & 1 & $\mathrm{P}$ & en- & caixa & -ar \\
\hline encaixilhar & 2098 & 198 & 1 & $\mathrm{P}$ & en- & caixilho & -ar \\
\hline encaixotar & 2099 & 3618 & 1 & $\mathrm{P}$ & en- & caixote & -ar \\
\hline encalacrar & 2100 & 460 & 1 & $\mathrm{P}$ & en- & calacre & -ar \\
\hline encaldeirar & 2101 & 56 & 1 & $\mathrm{P}$ & en- & caldeira & -ar \\
\hline encalecer & 2102 & 57 & 1 & $\mathrm{P}$ & en- & calo & -ecer \\
\hline encaleirar & 2103 & 43 & 1 & $P$ & en- & caleira & -ar \\
\hline encaliçar & 2104 & 105 & 1 & $\mathrm{P}$ & en- & caliça & -ar \\
\hline encalistar & 2105 & 68 & 1 & $\mathrm{P}$ & en- & calisto & -ar \\
\hline encalombar & 2106 & 54 & 1 & $\mathrm{P}$ & en- & calombo & -ar \\
\hline encamarotar & 2107 & 49 & 1 & $P$ & en- & camarote & -ar \\
\hline encambulhar & 2108 & 71 & 1 & $P$ & en- & cambulho & -ar \\
\hline encamisar & 2109 & 699 & 1 & $\mathrm{P}$ & en- & camisa & -ar \\
\hline encampar & 2110 & 16675 & 1 & $P$ & en- & campo & -ar \\
\hline encamurçar & 2111 & 69 & 1 & $\mathrm{P}$ & en- & camurça & -ar \\
\hline encanar & 2112 & 4188 & 1 & $\mathrm{P}$ & en- & cana & -ar \\
\hline encanastrar & 2113 & 82 & 1 & $\mathrm{P}$ & en- & canastra & -ar \\
\hline encangalhar & 2114 & 127 & 1 & $\mathrm{P}$ & en- & cangalha & -ar \\
\hline encangotar & 2115 & 82 & 1 & $P$ & en- & cangote & -ar \\
\hline encaniçar & 2116 & 87 & 1 & $\mathrm{P}$ & en- & caniço & -ar \\
\hline encanoar & 2117 & 116 & 1 & $\mathrm{P}$ & en- & canoa & -ar \\
\hline encanteirar & 2118 & 144 & 1 & $P$ & en- & canteiro & -ar \\
\hline encapachar & 2119 & 93 & 1 & $\mathrm{P}$ & en- & capacho & -ar \\
\hline encapar & 2120 & 16400 & 1 & $P$ & en- & capa & -ar \\
\hline encapelar & 2121 & 265 & 1 & $P$ & en- & capela & -ar \\
\hline encapoeirar & 2123 & 103 & 1 & $P$ & en- & capoeira & -ar \\
\hline encapotar & 2124 & 342 & 1 & $\mathrm{P}$ & en- & capote & -ar \\
\hline encaprichar-se & 2125 & 40 & 1 & $\mathrm{P}$ & en- & capricho & -ar \\
\hline encapuzar & 2126 & 288 & 1 & $\mathrm{P}$ & en- & capuz & -ar \\
\hline encaramujar & 2127 & 126 & 1 & $\mathrm{P}$ & en- & caramujo & -ar \\
\hline encarangar & 2128 & 194 & 1 & $P$ & en- & carango & -ar \\
\hline encarapinhar & 2129 & 141 & 1 & $\mathrm{P}$ & en- & carapinha & -ar \\
\hline encarapitar & 2130 & 403 & 1 & $P$ & en- & carrapito & -ar \\
\hline encarapuçar & 2131 & 100 & 1 & $\mathrm{P}$ & em- & carapuça & -ar \\
\hline encarar & 2132 & 1380000 & 2 & $\mathrm{P}$ & en- & cara & -ar \\
\hline encardumar & 2133 & 124 & 1 & $P$ & en- & cardume & -ar \\
\hline encargar & 2134 & 3935 & 1 & $P$ & en- & carga & -ar \\
\hline encarijar & 2135 & 85 & 1 & $P$ & en- & carijo & -ar \\
\hline encarneirar & 2136 & 118 & 1 & $\mathrm{P}$ & en- & carneiro & -ar \\
\hline encarniçar & 2137 & 220 & 1 & $P$ & en- & carniça & -ar \\
\hline encaroçar & 2138 & 1338 & 1 & $\mathrm{P}$ & en- & caroço & -ar \\
\hline encarochar & 2139 & 78 & 1 & $\mathrm{P}$ & en- & carocha & -ar \\
\hline encarquilhar & 2140 & 299 & 1 & $\mathrm{P}$ & en- & carquilha & -ar \\
\hline encarrancar & 2141 & 83 & 1 & $P$ & en- & carranca & -ar \\
\hline encarrapichar-se & 2142 & 45 & 1 & $P$ & en- & carrapicho & -ar \\
\hline encarrar & 2143 & 1110 & 1 & $\mathrm{P}$ & en- & carro & -ar \\
\hline encarraspanar-s & 2144 & 56 & 1 & $\mathrm{P}$ & en- & carraspana & -ar \\
\hline encarreirar & 2145 & 234 & 1 & $\mathrm{P}$ & en- & carreira & -ar \\
\hline encarrilar & 2146 & 190 & 1 & $P$ & en- & carril & -ar \\
\hline encartar & 2147 & 2640 & 1 & $P$ & en- & carta & -ar \\
\hline encascar & 2148 & 99 & 1 & $\mathrm{P}$ & en- & casco & -ar \\
\hline encasquetar & 2149 & 471 & 1 & $\mathrm{P}$ & en- & casquete & -ar \\
\hline
\end{tabular}




\begin{tabular}{|c|c|c|c|c|c|c|c|}
\hline encasquilhar & 2150 & 76 & 1 & $\mathrm{P}$ & en- & casquilha & -ar \\
\hline encastelar & 2151 & 1068 & 1 & $\mathrm{P}$ & en- & castelo & -ar \\
\hline encasular & 2152 & 222 & 1 & $\mathrm{P}$ & en- & casulo & -ar \\
\hline encatarrar & 2153 & 65 & 1 & $\mathrm{P}$ & en- & catarro & -ar \\
\hline encatarroar & 2154 & 60 & 1 & $\mathrm{P}$ & en- & catarro & -oar \\
\hline encauchar & 2155 & 58 & 1 & $\mathrm{P}$ & en- & caucho & -ar \\
\hline encausticar & 2156 & 52 & 1 & $S$ & & encáustica & -ar \\
\hline encavacar & 2157 & 135 & 1 & $\mathrm{P}$ & en- & cavaco & -ar \\
\hline encavalar & 2158 & 1145 & 1 & $\mathrm{P}$ & en- & cavalo & -ar \\
\hline encavernar & 2159 & 70 & 1 & $\mathrm{P}$ & en- & caverna & -ar \\
\hline encelar & 2160 & 144 & 1 & $P$ & en- & cela & -ar \\
\hline enceleirar & 2161 & 93 & 1 & $\mathrm{P}$ & en- & celeiro & -ar \\
\hline encenar & 2162 & 37200 & 1 & $\mathrm{P}$ & en- & cena & -ar \\
\hline encepar & 2163 & 67 & 1 & $\mathrm{P}$ & en- & cepo & -ar \\
\hline encerebrar & 2164 & 58 & 1 & $\mathrm{P}$ & en- & cérebro & -ar \\
\hline enceroular & 2165 & 54 & 1 & $\mathrm{P}$ & en- & ceroula & -ar \\
\hline encestar & 2166 & 1373 & 1 & $P$ & en- & cesta & -ar \\
\hline enchacotar & 2167 & 112 & 1 & $S$ & & enchacota & -ar \\
\hline encharcar & 2168 & 10400 & 1 & $P$ & en- & charco & -ar \\
\hline encharolar & 2169 & 67 & 1 & $P$ & en- & charola & -ar \\
\hline enchoçar & 2170 & 70 & 1 & $P$ & en- & choça & -ar \\
\hline encimar & 2171 & 934 & 1 & $P$ & en- & cima & -ar \\
\hline encinzeirar & 2172 & 1 & 1 & $P$ & en- & cinzeiro & -ar \\
\hline encistar & 2173 & 265 & 1 & $\mathrm{P}$ & en- & cisto & -ar \\
\hline enciumar & 2174 & 796 & 1 & $\mathrm{P}$ & en- & ciúme & -ar \\
\hline enclaustrar & 2175 & 102 & 1 & $\mathrm{P}$ & en- & claustro & -ar \\
\hline enclausurar & 2176 & 5605 & 1 & $\mathrm{P}$ & en- & clausura & -ar \\
\hline encloacar & 2177 & 110 & 1 & $\mathrm{P}$ & en- & cloaca & -ar \\
\hline encobertar & 2178 & 887 & 1 & $\mathrm{P}$ & en- & coberta & -ar \\
\hline encocurutar & 2179 & 299 & 1 & $\mathrm{P}$ & en- & cocuruto & -ar \\
\hline encofar & 2180 & 294 & 1 & $P$ & en- & cofo & -ar \\
\hline encofrar & 2181 & 269 & 1 & $P$ & en- & cofre & -ar \\
\hline encoifar & 2182 & 271 & 1 & $P$ & en- & coifa & -ar \\
\hline encolar & 2183 & 326 & 1 & $P$ & en- & cola & -ar \\
\hline encoleirar & 2185 & 375 & 1 & $P$ & en- & coleira & -ar \\
\hline encolerizar & 2186 & 2053 & 1 & $\mathrm{P}$ & en- & cólera & -izar \\
\hline encomiar & 2187 & 357 & 1 & $S$ & & encômio & -ar \\
\hline encomissar & 2188 & 66 & 1 & $\mathrm{P}$ & en- & comisso & -ar \\
\hline encomoroçar & 2189 & 36 & 1 & $\mathrm{P}$ & en- & cômoro & -oçar \\
\hline enconcar & 2190 & 66 & 1 & $\mathrm{P}$ & en- & conca & -ar \\
\hline encondar & 2191 & 406 & 1 & $\mathrm{P}$ & en- & conde & -ar \\
\hline encoronhar & 2192 & 53 & 1 & $\mathrm{P}$ & en- & coronha & -ar \\
\hline encorpar & 2193 & 19400 & 1 & $P$ & en- & corpo & -ar \\
\hline encorrear & 2194 & 66 & 1 & $P$ & en- & correia & -ar \\
\hline encorrilhar & 2195 & 97 & 1 & $\mathrm{P}$ & en- & corrilho & -ar \\
\hline encortelhar & 2196 & 60 & 1 & $\mathrm{P}$ & en- & cortelho & -ar \\
\hline encortiçar & 2197 & 64 & 1 & $\mathrm{P}$ & en- & cortiço & -ar \\
\hline encortinar & 2198 & 89 & 1 & $\mathrm{P}$ & en- & cortina & -ar \\
\hline encoscorar & 2199 & 73 & 1 & $P$ & en- & coscoro & -ar \\
\hline encostar & 2200 & 208250 & 1 & $\mathrm{P}$ & en- & costa & -ar \\
\hline encostelar & 2201 & 71 & 1 & $\mathrm{P}$ & en- & costela & -ar \\
\hline encouraçar & 2202 & 139 & 1 & $\mathrm{P}$ & en- & couraça & -ar \\
\hline encourar & 2203 & 147 & 1 & $\mathrm{P}$ & en- & couro & -ar \\
\hline encovar & 2204 & 124 & 1 & $P$ & en- & cova & -ar \\
\hline encovilar & 2205 & 59 & 1 & $\mathrm{P}$ & en- & covil & -ar \\
\hline encravar & 2206 & 3203 & 1 & $P$ & en- & cravo & -ar \\
\hline encravelhar & 2207 & 78 & 1 & $P$ & en- & cravelha & -ar \\
\hline encriptar & 2208 & 12575 & 1 & $P$ & en- & cripta & -ar \\
\hline encristar-se & 2209 & 68 & 1 & $P$ & en- & crista & -ar \\
\hline encrostar & 2210 & 240 & 1 & $\mathrm{P}$ & en- & crosta & -ar \\
\hline encruzar & 2211 & 224 & 1 & $P$ & en- & cruz & -ar \\
\hline encucar & 2212 & 2603 & 1 & $\mathrm{P}$ & en- & cuca & -ar \\
\hline encucharrar & 2213 & 113 & 1 & $P$ & en- & cucharra & -ar \\
\hline encumear & 2214 & 111 & 1 & $\mathrm{P}$ & en- & cume & -ar \\
\hline
\end{tabular}




\begin{tabular}{|c|c|c|c|c|c|c|c|c|}
\hline encurralar & 2215 & 11025 & 1 & $\mathrm{P}$ & en- & curral & & -ar \\
\hline endefluxar-se & 2216 & 23 & 1 & $\mathrm{P}$ & en- & defluxo & & -ar \\
\hline endemoniar & 2217 & 56 & 1 & $P$ & en- & demônio & & -ar \\
\hline endentecer & 2218 & 157 & 1 & $P$ & en- & dente & & -ecer \\
\hline endeusar & 2219 & 6555 & 1 & $P$ & en- & deus & & -ar \\
\hline endinheirar & 2220 & 180 & 1 & $\mathrm{P}$ & en- & dinheiro & & -ar \\
\hline endividar & 2221 & 38300 & 1 & $\mathrm{P}$ & en- & dívida & & -ar \\
\hline endomingar & 2222 & 86 & 1 & $\mathrm{P}$ & en- & domingo & & -ar \\
\hline endorsar & 2223 & 177 & 1 & $\mathrm{P}$ & en- & dorso & & -ar \\
\hline enervar & 2224 & 2718 & 1 & $\mathrm{P}$ & en- & nervo & & -ar \\
\hline enesgar & 2225 & 79 & 1 & $\mathrm{P}$ & en- & nesga & & -ar \\
\hline enevar & 2226 & 1 & 1 & $P$ & en- & neve & & -ar \\
\hline enevoar & 2227 & 846 & 1 & $\mathrm{P}$ & en- & névoa & & -ar \\
\hline enfaixar & 2228 & 3565 & 1 & $\mathrm{P}$ & en- & faixa & & -ar \\
\hline enfanicar-se & 2229 & 21 & 1 & $P$ & en- & fanico & & -ar \\
\hline enfardar & 2230 & 1523 & 1 & $\mathrm{P}$ & en- & fardo & & -ar \\
\hline enfardelar & 2231 & 105 & 1 & $P$ & en- & fardel & & -ar \\
\hline enfarelar & 2232 & 132 & 1 & $\mathrm{P}$ & en- & farelo & & -ar \\
\hline enfarinhar & 2233 & 3538 & 1 & $\mathrm{P}$ & en- & farinha & & -ar \\
\hline enfarpelar & 2234 & 160 & 1 & $\mathrm{P}$ & en- & farpela & & -ar \\
\hline enfarrapar & 2235 & 133 & 1 & $P$ & en- & farrapo & & -ar \\
\hline enfartar & 2236 & 4830 & 1 & $S$ & & enfarte & & -ar \\
\hline enfastiar & 2237 & 1518 & 1 & $P$ & en- & fastio & & -ar \\
\hline enfatiotar & 2238 & 185 & 1 & $\mathrm{P}$ & en- & fatiota & & -ar \\
\hline enfeirar & 2239 & 132 & 1 & $\mathrm{P}$ & en- & feira & & -ar \\
\hline enfeixar & 2240 & 2583 & 1 & $P$ & en- & feixe & & -ar \\
\hline enfeltrar & 2241 & 166 & 1 & $P$ & en- & feltro & & -ar \\
\hline enferrujar & 2242 & 10170 & 1 & $\mathrm{P}$ & en- & ferrugem & & -ar \\
\hline enfestar & 2243 & 745 & 1 & $P$ & en- & festa & & -ar \\
\hline enfeudar & 2244 & 222 & 1 & $\mathrm{P}$ & en- & feudo & & -ar \\
\hline enfiar & 2245 & 231000 & 1 & $P$ & en- & fio & & -ar \\
\hline enfileirar & 2246 & 5845 & 1 & $P$ & en- & fileira & & -ar \\
\hline enfistular & 2247 & 117 & 1 & $\mathrm{P}$ & en- & fístula & & -ar \\
\hline enfitar & 2248 & 215 & 1 & $P$ & en- & fita & & -ar \\
\hline enfivelar & 2249 & 81 & 1 & $P$ & en- & fivela & & -ar \\
\hline enflanelar & 2250 & 88 & 1 & $P$ & en- & flanela & & -ar \\
\hline enfobiar & 2251 & 88 & 1 & $P$ & en- & fobia & & -ar \\
\hline enfocar & 2252 & 76425 & 1 & $\mathrm{P}$ & en- & foco & & -ar \\
\hline enfogar & 2253 & 95 & 1 & $P$ & en- & fogo & & -ar \\
\hline enfolhar & 2254 & 155 & 1 & $P$ & en- & folha & & -ar \\
\hline enfolipar & 2255 & 90 & 1 & $\mathrm{P}$ & en- & folipo & & -ar \\
\hline enforcar & 2256 & 29500 & 1 & $P$ & en- & forca & & -ar \\
\hline enforjar & 2257 & 100 & 1 & $\mathrm{P}$ & en- & forja & & -ar \\
\hline enfornar & 2258 & 332 & 1 & $P$ & en- & forno & & -ar \\
\hline enfragar & 2259 & 135 & 1 & $\mathrm{P}$ & en- & fraga & & -ar \\
\hline enfranquear & 2260 & 118 & 1 & $S$ & & enfranque & & -ear \\
\hline enfrascar & 2261 & 207 & 1 & $\mathrm{P}$ & en- & frasco & & -ar \\
\hline enfrenesiar & 2262 & 138 & 1 & $\mathrm{P}$ & en- & frenesi & & -ar \\
\hline enfrentar & 2263 & 3820000 & 3 & $P$ & en- & frente & & -ar \\
\hline enfrestar & 2264 & 110 & 1 & $P$ & en- & fresta & & -ar \\
\hline enfrondar & 2265 & 95 & 1 & $\mathrm{P}$ & en- & fronde & & -ar \\
\hline enfronhar & 2266 & 1170 & 1 & $P$ & en- & fronha & & -ar \\
\hline enfrutar & 2267 & 46 & 1 & $\mathrm{P}$ & en- & fruto & & -ar \\
\hline enfrutecer & 2268 & 89 & 1 & $P$ & en- & fruto & & -ecer \\
\hline enfumar & 2269 & 100 & 1 & $P$ & en- & fumo & & -ar \\
\hline enfumarar & 2270 & 86 & 1 & $P$ & en- & fumo & $-r-$ & -ar \\
\hline enfunilar & 2271 & 61 & 1 & $P$ & en- & funil & & -ar \\
\hline enfurecer & 2272 & 7463 & 1 & $P$ & en- & fúria & & -ecer \\
\hline enfuriar & 2273 & 98 & 1 & $P$ & en- & fúria & & -ar \\
\hline enfurnar & 2274 & 1853 & 1 & $P$ & en- & furna & & -ar \\
\hline enfusar & 2275 & 83 & 1 & $P$ & en- & fuso & & -ar \\
\hline engaçar & 2276 & 156 & 1 & $S$ & & engaço & & -ar \\
\hline engadelhar & 2277 & 164 & 1 & $P$ & en- & gadelha & & -ar \\
\hline engafecer & 2278 & 54 & 1 & $P$ & en- & gafa & & -ecer \\
\hline
\end{tabular}




\begin{tabular}{|c|c|c|c|c|c|c|c|c|}
\hline engaiolar & 2279 & 1043 & 1 & $\mathrm{P}$ & en- & gaiola & & -ar \\
\hline engalhardetar & 2280 & 179 & 1 & $\mathrm{P}$ & en- & galhardete & & -ar \\
\hline enganchar & 2281 & 973 & 1 & $\mathrm{P}$ & en- & gancho & & -ar \\
\hline engarantar & 2282 & 74 & 1 & $P$ & en- & garante & & -ar \\
\hline engarapar & 2283 & 80 & 1 & $\mathrm{P}$ & en- & garapa & & -ar \\
\hline engarfar & 2284 & 102 & 1 & $\mathrm{P}$ & en- & garfo & & -ar \\
\hline engarrafar & 2285 & 6188 & 1 & $\mathrm{P}$ & en- & garrafa & & -ar \\
\hline engarrar & 2286 & 16 & 1 & $\mathrm{P}$ & en- & garra & & -ar \\
\hline engarupar-se & 2287 & 36 & 1 & $\mathrm{P}$ & en- & garupa & & -ar \\
\hline engastalhar & 2288 & 157 & 1 & $\mathrm{P}$ & en- & gastalho & & -ar \\
\hline engatilhar & 2289 & 3030 & 1 & $\mathrm{P}$ & en- & gatilho & & -ar \\
\hline engavelar & 2290 & 172 & 1 & $\mathrm{P}$ & en- & gavela & & -ar \\
\hline engavetar & 2291 & 8700 & 1 & $\mathrm{P}$ & en- & gaveta & & -ar \\
\hline engelhar & 2292 & 474 & 1 & $\mathrm{P}$ & en- & gelha & & -ar \\
\hline engenhar & 2293 & 7965 & 1 & $S$ & & engenho & & -ar \\
\hline engessar & 2294 & 16575 & 1 & $\mathrm{P}$ & en- & gesso & & -ar \\
\hline englobar & 2295 & 191000 & 1 & $P$ & en- & globo & & -ar \\
\hline englobular & 2296 & 125 & 1 & $\mathrm{P}$ & en- & glóbulo & & -ar \\
\hline engodar & 2297 & 1775 & 1 & $S$ & & engodo & & -ar \\
\hline engolfar & 2298 & 2290 & 1 & $\mathrm{P}$ & en- & golfo & & -ar \\
\hline engomar & 2299 & 12150 & 1 & $P$ & en- & goma & & -ar \\
\hline engonçar & 2300 & 171 & 1 & $S$ & & engonço & & -ar \\
\hline engonhar & 2301 & 22 & 1 & $S$ & & engonha & & -ar \\
\hline engordurar & 2302 & 1560 & 1 & $\mathrm{P}$ & en- & gordura & & -ar \\
\hline engorrar-se & 2303 & 34 & 1 & $\mathrm{P}$ & en- & gorra & & -ar \\
\hline engraçar & 2304 & 2875 & 1 & $\mathrm{P}$ & en- & graça & & -ar \\
\hline engradar & 2305 & 180 & 1 & $P$ & en- & grade & & -ar \\
\hline engradear & 2306 & 116 & 1 & $\mathrm{P}$ & en- & grade & & -ear \\
\hline engralhar & 2307 & 0 & 1 & $\mathrm{P}$ & en- & gralho & & -ar \\
\hline engrampar & 2308 & 235 & 1 & $\mathrm{P}$ & en- & grampo & & -ar \\
\hline engravatar & 2309 & 235 & 1 & $P$ & en- & gravata & & -ar \\
\hline engravatizar & 2310 & 131 & 1 & $\mathrm{P}$ & en- & gravata & & -izar \\
\hline engraxar & 2311 & 12525 & 1 & $P$ & en- & graxa & & -ar \\
\hline engrelar & 2312 & 138 & 1 & $P$ & en- & grelo & & -ar \\
\hline engrenhar & 2313 & 155 & 1 & $\mathrm{P}$ & en- & grenha & & -ar \\
\hline engrilar & 2314 & 67 & 1 & $\mathrm{P}$ & en- & grilo & & -ar \\
\hline engrinaldar & 2315 & 466 & 1 & $\mathrm{P}$ & en- & grinalda & & -ar \\
\hline engripar & 2316 & 329 & 1 & $\mathrm{P}$ & en- & gripe & & -ar \\
\hline engrumar & 2317 & 103 & 1 & $\mathrm{P}$ & en- & grumo & & -ar \\
\hline engrumecer & 2318 & 34 & 1 & $\mathrm{P}$ & en- & grumo & & -ecer \\
\hline enguirlandar & 2319 & 49 & 1 & $\mathrm{P}$ & en- & guirlanda & & -ar \\
\hline engulhar & 2320 & 133 & 1 & $S$ & & engulho & & -ar \\
\hline engulosinar & 2321 & 54 & 1 & $\mathrm{P}$ & en- & gulosina & & -ar \\
\hline enigmar & 2322 & 110 & 1 & $S$ & & enigma & & -ar \\
\hline enjaular & 2323 & 2333 & 1 & $\mathrm{P}$ & en- & jaula & & -ar \\
\hline enjugar & 2324 & 385 & 1 & $P$ & en- & jugo & & -ar \\
\hline enlabiar & 2325 & 103 & 1 & $P$ & en- & lábia & & -ar \\
\hline enlabirintar & 2326 & 111 & 1 & $\mathrm{P}$ & en- & labirinto & & -ar \\
\hline enlaçar & 2327 & 7583 & 1 & $\mathrm{P}$ & en- & laço & & -ar \\
\hline enlaçarotar & 2328 & 28 & 1 & $\mathrm{P}$ & en- & laçarote & & -ar \\
\hline enladeirar & 2329 & 122 & 1 & $\mathrm{P}$ & en- & ladeira & & -ar \\
\hline enlaivar & 2330 & 105 & 1 & $\mathrm{P}$ & en- & laivo & & -ar \\
\hline enlambujar & 2331 & 103 & 1 & $\mathrm{P}$ & en- & lambujem & & -ar \\
\hline enlamear & 2332 & 2678 & 1 & $\mathrm{P}$ & en- & lama & & -ear \\
\hline enlaminar & 2333 & 111 & 1 & $P$ & en- & lâmina & & -ar \\
\hline enlanzar & 2334 & 109 & 1 & $\mathrm{P}$ & en- & Iã & $-\mathrm{z}-$ & -ar \\
\hline enlapar & 2335 & 88 & 1 & $P$ & en- & lapa & & -ar \\
\hline enlatar & 2336 & 1593 & 1 & $\mathrm{P}$ & en- & lata & & -ar \\
\hline enleivar & 2337 & 80 & 1 & $\mathrm{P}$ & en- & leiva & & -ar \\
\hline enliçar & 2338 & 172 & 1 & $P$ & en- & liço & & -ar \\
\hline enlocar & 2339 & 123 & 1 & $P$ & en- & loca & & -ar \\
\hline enlodaçar & 2340 & 61 & 1 & $\mathrm{P}$ & en- & lodo & & -açar \\
\hline enlodar & 2341 & 139 & 1 & $\mathrm{P}$ & en- & lodo & & -ar \\
\hline enlojar & 2342 & 63 & 1 & $\mathrm{P}$ & en- & Ioja & & -ar \\
\hline
\end{tabular}




\begin{tabular}{|c|c|c|c|c|c|c|c|}
\hline enlombar & 2343 & 76 & 1 & $\mathrm{P}$ & en- & lombo & -ar \\
\hline enlousar & 2344 & 56 & 1 & $\mathrm{P}$ & en- & lousa & -ar \\
\hline enluarar & 2345 & 274 & 1 & $P$ & en- & luar & -ar \\
\hline enlurar & 2346 & 57 & 1 & $P$ & en- & lura & -ar \\
\hline enlutar & 2347 & 641 & 1 & $P$ & en- & luto & -ar \\
\hline enluvar & 2348 & 193 & 1 & $P$ & en- & luva & -ar \\
\hline enodoar & 2349 & 612 & 1 & $P$ & en- & nódoa & -ar \\
\hline enoitar & 2350 & 59 & 1 & $P$ & en- & noite & -ar \\
\hline enoitecer & 2351 & 98 & 1 & $\mathrm{P}$ & en- & noite & -ecer \\
\hline enovelar & 2352 & 704 & 1 & $P$ & en- & novelo & -ar \\
\hline enquadrilhar & 2353 & 99 & 1 & $P$ & en- & quadrilha & -ar \\
\hline enquartar & 2354 & 191 & 1 & $P$ & en- & quarto & -ar \\
\hline enqueijar & 2355 & 95 & 1 & $\mathrm{P}$ & en- & queijo & -ar \\
\hline enqueixar & 2356 & 54 & 1 & $\mathrm{P}$ & en- & queixo & -ar \\
\hline enrabar & 2357 & 6455 & 1 & $\mathrm{P}$ & en- & rabo & $-\mathrm{ar}$ \\
\hline enrabeirar & 2358 & 49 & 1 & $P$ & en- & rabeira & -ar \\
\hline enraiar & 2359 & 331 & 1 & $P$ & en- & raio & -ar \\
\hline enraivar & 2360 & 177 & 1 & $\mathrm{P}$ & en- & raiva & -ar \\
\hline enraivecer & 2361 & 1418 & 1 & $\mathrm{P}$ & en- & raiva & -ecer \\
\hline enraizar & 2362 & 11575 & 1 & $\mathrm{P}$ & en- & raiz & -ar \\
\hline enramalhetar & 2363 & 93 & 1 & $P$ & en- & ramalhete & -ar \\
\hline enramilhetar & 2364 & 92 & 1 & $P$ & en- & ramilhete & -ar \\
\hline enranchar & 2365 & 67 & 1 & $P$ & en- & rancho & -ar \\
\hline enrascar & 2366 & 329 & 1 & $P$ & en- & rasca & -ar \\
\hline enredar & 2367 & 11200 & 1 & $\mathrm{P}$ & en- & rede & -ar \\
\hline enredear & 2368 & 74 & 1 & $\mathrm{P}$ & en- & rede & -ear \\
\hline enredouçar & 2369 & 114 & 1 & $\mathrm{P}$ & en- & redouça & -ar \\
\hline enregueirar & 2370 & 0 & 1 & $\mathrm{P}$ & en- & regueira & -ar \\
\hline enrelhar & 2371 & 110 & 1 & $P$ & en- & relha & -ar \\
\hline enrelvar & 2372 & 102 & 1 & $\mathrm{P}$ & en- & relva & -ar \\
\hline enremelar & 2373 & 1 & 1 & $P$ & en- & remela & -ar \\
\hline enremissar & 2374 & 96 & 1 & $\mathrm{P}$ & en- & remissa & -ar \\
\hline enrendar & 2375 & 5 & 1 & $\mathrm{P}$ & en- & renda & -ar \\
\hline enrenquear & 2376 & 55 & 1 & $\mathrm{P}$ & en- & renque & -ear \\
\hline enrepolhar & 2377 & 103 & 1 & $\mathrm{P}$ & en- & repolho & -ar \\
\hline enresinar & 2378 & 72 & 1 & $P$ & en- & resina & -ar \\
\hline enresmar & 2379 & 116 & 1 & $P$ & en- & resma & -ar \\
\hline enrestar-se & 2380 & 88 & 1 & $\mathrm{P}$ & en- & resto & -ar \\
\hline enriar & 2381 & 44 & 1 & $P$ & en- & rio & -ar \\
\hline enripar & 2382 & 104 & 1 & $P$ & en- & ripa & -ar \\
\hline enristar & 2383 & 123 & 1 & $\mathrm{P}$ & en- & riste & -ar \\
\hline enrizar & 2384 & 103 & 1 & $P$ & en- & riz- & -ar \\
\hline enrocar & 2385 & 157 & 1 & $\mathrm{P}$ & en- & roca & -ar \\
\hline enrodilhar & 2387 & 434 & 1 & $\mathrm{P}$ & en- & rodilha & -ar \\
\hline enrodrigar & 2388 & 53 & 1 & $\mathrm{P}$ & en- & rodriga & -ar \\
\hline enrolar & 2389 & 215000 & 1 & $\mathrm{P}$ & en- & rolo & -ar \\
\hline enrolhar & 2390 & 134 & 1 & $\mathrm{P}$ & en- & rolha & -ar \\
\hline enroquear & 2391 & 23 & 1 & $\mathrm{P}$ & en- & roqueia & -ar \\
\hline enroquetar & 2392 & 27 & 1 & $P$ & en- & roquete & -ar \\
\hline enroscar & 2393 & 16250 & 1 & $P$ & en- & rosca & -ar \\
\hline enrotar & 2394 & 40 & 1 & $\mathrm{P}$ & en- & rota & -ar \\
\hline enroupar & 2395 & 282 & 1 & $P$ & en- & roupa & -ar \\
\hline enrugar & 2396 & 4710 & 1 & $\mathrm{P}$ & en- & ruga & -ar \\
\hline ensaboar & 2397 & 9678 & 1 & $P$ & en- & sabão & -ar \\
\hline ensaburrar & 2398 & 159 & 1 & $P$ & en- & saburra & -ar \\
\hline ensacar & 2399 & 8745 & 1 & $P$ & en- & saco & -ar \\
\hline ensaiar & 2400 & 93838 & 1 & $S$ & & ensaio & -ar \\
\hline ensaibrar & 2402 & 294 & 1 & $\mathrm{P}$ & en- & saibro & -ar \\
\hline ensalivar & 2403 & 147 & 1 & $P$ & en- & saliva & -ar \\
\hline ensalmar & 2404 & 161 & 1 & $\mathrm{P}$ & en- & salmo & -ar \\
\hline ensalmourar & 2405 & 110 & 1 & $P$ & en- & salmoura & -ar \\
\hline ensamarrar & 2406 & 166 & 1 & $\mathrm{P}$ & en- & samarra & -ar \\
\hline ensambenitar & 2407 & 158 & 1 & $P$ & en- & sambenito & -ar \\
\hline ensandalar & 2408 & 159 & 1 & $\mathrm{P}$ & en- & sândalo & -ar \\
\hline
\end{tabular}




\begin{tabular}{|c|c|c|c|c|c|c|c|c|}
\hline ensanduichar & 2409 & 107 & 1 & $\mathrm{P}$ & en- & sanduíche & & -ar \\
\hline ensanefar & 2410 & 111 & 1 & $\mathrm{P}$ & en- & sanefa & & -ar \\
\hline ensangüentar & 2411 & 656 & 1 & $\mathrm{P}$ & en- & sangue & & -entar \\
\hline ensanguinhar & 2412 & 107 & 1 & $\mathrm{P}$ & en- & sangue & & -inhar \\
\hline ensanhar & 2413 & 100 & 1 & $P$ & en- & sanha & & -ar \\
\hline ensapezar & 2414 & 47 & 1 & $\mathrm{P}$ & en- & sapê & $-\mathrm{z-}$ & -ar \\
\hline ensardinhar & 2415 & 64 & 1 & $\mathrm{P}$ & en- & sardinha & & -ar \\
\hline ensarilhar & 2416 & 411 & 1 & $\mathrm{P}$ & en- & sarilho & & -ar \\
\hline ensarnecer & 2417 & 111 & 1 & $\mathrm{P}$ & en- & sarna & & -ecer \\
\hline ensarrafar & 2418 & 105 & 1 & $\mathrm{P}$ & en- & sarrafo & & -ar \\
\hline ensaruar & 2419 & 54 & 1 & $\mathrm{P}$ & en- & saruá & & -ar \\
\hline ensaudar & 2420 & 80 & 1 & $P$ & en- & saúde & & -ar \\
\hline ensebar & 2421 & 677 & 1 & $\mathrm{P}$ & en- & sebo & & -ar \\
\hline ensedar & 2423 & 91 & 1 & $\mathrm{P}$ & en- & seda & & -ar \\
\hline enseiar & 2424 & 91 & 1 & $\mathrm{P}$ & en- & seio & & -ar \\
\hline enseirar & 2425 & 139 & 1 & $\mathrm{P}$ & en- & seira & & -ar \\
\hline enseivar & 2426 & 104 & 1 & $P$ & en- & seiva & & -ar \\
\hline enselvar & 2427 & 55 & 1 & $\mathrm{P}$ & en- & selva & & -ar \\
\hline ensementar & 2428 & 139 & 1 & $\mathrm{P}$ & en- & semente & & -ar \\
\hline ensilar & 2429 & 916 & 1 & $\mathrm{P}$ & en- & silo & & -ar \\
\hline ensilvar & 2430 & 114 & 1 & $P$ & en- & silva & & -ar \\
\hline ensoalhar & 2431 & 49 & 1 & $P$ & en- & soalha & & -ar \\
\hline ensoalheirar & 2432 & 72 & 1 & $\mathrm{P}$ & en- & soalheira & & -ar \\
\hline ensoberbar & 2433 & 100 & 1 & $P$ & en- & soberba & & -ar \\
\hline ensoberbecer & 2434 & 861 & 1 & $\mathrm{P}$ & en- & soberba & & -ecer \\
\hline ensoleirar & 2435 & 95 & 1 & $\mathrm{P}$ & en- & soleira & & -ar \\
\hline ensombrar & 2436 & 461 & 1 & $\mathrm{P}$ & en- & sombra & & -ar \\
\hline ensombrear & 2437 & 146 & 1 & $\mathrm{P}$ & en- & sombra & & -ear \\
\hline ensombrecer & 2438 & 267 & 1 & $\mathrm{P}$ & en- & sombra & & -ecer \\
\hline ensopar & 2439 & 2073 & 1 & $\mathrm{P}$ & en- & sopa & & -ar \\
\hline ensovacar & 2440 & 107 & 1 & $P$ & en- & sovaco & & -ar \\
\hline ensurroar & 2441 & 108 & 1 & $\mathrm{P}$ & en- & surrão & & -ar \\
\hline entabicar & 2442 & 59 & 1 & $\mathrm{P}$ & en- & tabica & & -ar \\
\hline entabocar & 2443 & 169 & 1 & $P$ & en- & taboca & & -ar \\
\hline entabuar & 2444 & 253 & 1 & $\mathrm{P}$ & en- & tábua & & -ar \\
\hline entabular & 2445 & 7505 & 1 & $P$ & en- & tábula & & -ar \\
\hline entaipar & 2446 & 303 & 1 & $P$ & en- & taipa & & -ar \\
\hline entalar & 2447 & 2250 & 1 & $\mathrm{P}$ & en- & tala & & -ar \\
\hline entaleigar & 2448 & 115 & 1 & $P$ & en- & taleiga & & -ar \\
\hline entaleirar & 2449 & 109 & 1 & $P$ & en- & taleira & & -ar \\
\hline entalhar & 2450 & 4320 & 1 & $\mathrm{P}$ & en- & talha & & -ar \\
\hline entaliscar & 2451 & 212 & 1 & $P$ & en- & talisca & & -ar \\
\hline entancar & 2452 & 97 & 1 & $P$ & en- & tanque & & -ar \\
\hline entangar & 2453 & 87 & 1 & $\mathrm{P}$ & en- & tanga & & -ar \\
\hline entanguecer & 2454 & 143 & 1 & $\mathrm{P}$ & en- & tango & & -ecer \\
\hline entanguir & 2455 & 190 & 1 & $\mathrm{P}$ & en- & tango & & -ir \\
\hline entaniçar & 2456 & 122 & 1 & $\mathrm{P}$ & en- & taniça & & -ar \\
\hline entapetar & 2457 & 84 & 1 & $\mathrm{P}$ & en- & tapete & & -ar \\
\hline entardecer & 2458 & 146500 & 1 & $P$ & en- & tarde & & -ecer \\
\hline entarraxar & 2459 & 56 & 1 & $P$ & en- & tarraxa & & -ar \\
\hline entear & 2460 & 235 & 1 & $\mathrm{P}$ & en- & teia & & -ar \\
\hline entediar & 2461 & 4895 & 1 & $P$ & en- & tédio & & -ar \\
\hline entelar & 2462 & 823 & 1 & $\mathrm{P}$ & en- & tela & & -ar \\
\hline entelhar & 2463 & 135 & 1 & $P$ & en- & telha & & -ar \\
\hline enterrar & 2464 & 162250 & 1 & $P$ & en- & terra & & -ar \\
\hline entesourar & 2465 & 2153 & 1 & $P$ & en- & tesouro & & -ar \\
\hline entijucar & 2466 & 88 & 1 & $P$ & en- & tijuco & & -ar \\
\hline entintar & 2467 & 239 & 1 & $P$ & en- & tinta & & -ar \\
\hline entocar & 2468 & 1353 & 1 & $P$ & en- & toca & & -ar \\
\hline entoucar & 2469 & 75 & 1 & $\mathrm{P}$ & en- & touca & & -ar \\
\hline entouçar & 2470 & 63 & 1 & $P$ & en- & touça & & -ar \\
\hline entourar & 2471 & 116 & 1 & $\mathrm{P}$ & en- & touro & & -ar \\
\hline entourir & 2472 & 47 & 1 & $P$ & en- & touro & & -ir \\
\hline entrajar & 2473 & 310 & 1 & $P$ & en- & traje & & -ar \\
\hline
\end{tabular}




\begin{tabular}{|c|c|c|c|c|c|c|c|c|}
\hline entralhar & 2474 & 269 & 1 & $\mathrm{P}$ & en- & tralha & & -ar \\
\hline entrançar & 2475 & 1258 & 1 & $\mathrm{P}$ & en- & trança & & -ar \\
\hline entranhar & 2476 & 2470 & 1 & $S$ & & entranha & & -ar \\
\hline entranqueirar & 2477 & 236 & 1 & $P$ & en- & tranqueira & & -ar \\
\hline entrapar & 2478 & 251 & 1 & $P$ & em- & trapo & & -ar \\
\hline entrastar & 2479 & 57 & 1 & $\mathrm{P}$ & en- & traste & & -ar \\
\hline entravar & 2480 & 6440 & 1 & $\mathrm{P}$ & en- & trave & & -ar \\
\hline entrechar & 2481 & 210 & 1 & $S$ & & entrecho & & -ar \\
\hline entrefolhar & 2482 & 50 & 1 & $S$ & & entrefolha & & -ar \\
\hline entrelinhar & 2483 & 109 & 1 & $S$ & & entrelinha & & -ar \\
\hline entremear & 2484 & 2745 & 1 & S & & entremeio & & -ar \\
\hline entressolhar & 2485 & 56 & 1 & $S$ & & entressolho & & -ar \\
\hline entretalhar & 2486 & 66 & 1 & $S$ & & entretalho & & -ar \\
\hline entretelar & 2487 & 117 & 1 & $S$ & & entretela & & -ar \\
\hline entrevar & 2488 & 1113 & 1 & $P$ & en- & treva & & -ar \\
\hline entrevecer & 2489 & 84 & 1 & $P$ & en- & treva & & -ecer \\
\hline entrevistar & 2490 & 357000 & 1 & $S$ & & entrevista & & -ar \\
\hline entrincheirar & 2491 & 1608 & 1 & $\mathrm{P}$ & en- & trincheira & & -ar \\
\hline entrombar & 2492 & 60 & 1 & $\mathrm{P}$ & en- & tromba & & -ar \\
\hline entronar & 2493 & 350 & 1 & $\mathrm{P}$ & en- & trono & & -ar \\
\hline entronear & 2494 & 50 & 1 & $P$ & en- & trono & & -ear \\
\hline entropilhar & 2495 & 105 & 1 & $P$ & en- & tropilha & & -ar \\
\hline entrosar & 2496 & 22550 & 1 & $S$ & & entrosa & & -ar \\
\hline entroviscar & 2497 & 105 & 1 & $P$ & en- & trovisco & & -ar \\
\hline entrudar & 2499 & 106 & 1 & $S$ & & entrudo & & -ar \\
\hline entubar & 2500 & 9750 & 1 & $\mathrm{P}$ & en- & tubo & & -ar \\
\hline entufar & 2501 & 193 & 1 & $\mathrm{P}$ & em- & tufo & & -ar \\
\hline entujucar & 2502 & 79 & 1 & $P$ & en- & tujuco & & -ar \\
\hline entulhar & 2503 & 4500 & 1 & $P$ & en- & tulha & & -ar \\
\hline entupigaitar & 2504 & 161 & 1 & $P$ & entupir & gaita & & -ar \\
\hline enturmar & 2505 & 16950 & 1 & $P$ & en- & turma & & -ar \\
\hline entusiasmar & 2506 & 20600 & 1 & $S$ & & entusiasmo & & -ar \\
\hline envalar & 2507 & 84 & 1 & $P$ & en- & vala & & -ar \\
\hline envanecer & 2508 & 99 & 1 & $P$ & en- & vão & & -ecer \\
\hline envarar & 2509 & 102 & 1 & $P$ & en- & vara & & -ar \\
\hline envaretar & 2510 & 176 & 1 & $P$ & en- & vareta & & -ar \\
\hline envasar & 2512 & 6691 & 1 & $\mathrm{P}$ & en- & vaso & & -ar \\
\hline envasilhar & 2513 & 273 & 1 & $\mathrm{P}$ & en- & vasilha & & -ar \\
\hline envelopar & 2514 & 9163 & 1 & $S$ & & envelope & & -ar \\
\hline enveredar & 2515 & 33900 & 1 & $\mathrm{P}$ & en- & vereda & & -ar \\
\hline envergar & 2516 & 6285 & 1 & $P$ & en- & verga & & -ar \\
\hline envergonhar & 2517 & 56375 & 1 & $P$ & en- & vergonha & & -ar \\
\hline envernizar & 2518 & 5100 & 1 & $P$ & en- & verniz & & -ar \\
\hline enverrugar & 2519 & 128 & 1 & $\mathrm{P}$ & en- & verruga & & -ar \\
\hline envessar & 2520 & 139 & 1 & $S$ & & envesso & & -ar \\
\hline enviçar & 2521 & 74 & 1 & $P$ & en- & viço & & -ar \\
\hline envidilhar & 2522 & 83 & 1 & $P$ & en- & vide & & -ilhar \\
\hline envidraçar & 2523 & 299 & 1 & $P$ & en- & vidraça & & -ar \\
\hline enviesar & 2524 & 1740 & 1 & $\mathrm{P}$ & en- & viés & & -ar \\
\hline \begin{tabular}{|l} 
envigar \\
\end{tabular} & 2525 & 45 & 1 & $\mathrm{P}$ & en- & viga & & -ar \\
\hline envisgar & 2526 & 75 & 1 & $\mathrm{P}$ & en- & visgo & & -ar \\
\hline enviveirar & 2527 & 124 & 1 & $\mathrm{P}$ & en- & viveiro & & -ar \\
\hline envultar & 2528 & 16 & 1 & $P$ & en- & vulto & & -ar \\
\hline enxadar & 2529 & 104 & 1 & $S$ & & enxada & & -ar \\
\hline enxadear & 2530 & 71 & 1 & $S$ & & enxada & & -ear \\
\hline enxalmar & 2531 & 61 & 1 & $\mathrm{~S}$ & & enxalmo & & -ar \\
\hline enxampuar & 2532 & 0 & 1 & $\mathrm{P}$ & en- & xampu & & -ar \\
\hline enxaquetar & 2533 & 111 & 1 & $\mathrm{P}$ & en- & xaque & $-t-$ & -ar \\
\hline enxarciar & 2534 & 108 & 1 & $S$ & & enxárcia & & -ar \\
\hline enxecar & 2535 & 2 & 1 & $S$ & & enxeco & & -ar \\
\hline enxequetar & 2536 & 88 & 1 & $\mathrm{P}$ & en- & xeque & $-\mathrm{t}-$ & -ar \\
\hline enxercar & 2537 & 93 & 1 & $S$ & & enxerca & & -ar \\
\hline enxodozar-se & 2538 & 22 & 1 & $\mathrm{P}$ & en- & xodó & $-\mathrm{z}-$ & -ar \\
\hline enxofrar & 2539 & 114 & 1 & $S$ & & enxofre & & -ar \\
\hline
\end{tabular}




\begin{tabular}{|c|c|c|c|c|c|c|c|}
\hline enxovar & 2540 & 81 & 1 & $S$ & & enxova & -ar \\
\hline enxundiar & 2541 & 83 & 1 & $S$ & & enxúndia & -ar \\
\hline epidemiar & 2542 & 2565 & 1 & $S$ & & epidemia & -ar \\
\hline epigrafar & 2543 & 244 & 1 & $S$ & & epígrafe & -ar \\
\hline epilogar & 2544 & 223 & 1 & $S$ & & epílogo & -ar \\
\hline episodiar & 2545 & 120 & 1 & $S$ & & episódio & -ar \\
\hline epistolar & 2546 & 16750 & 1 & $S$ & & epístola & -ar \\
\hline epistolizar & 2547 & 6 & 1 & $S$ & & epístola & -izar \\
\hline epitelizar & 2548 & 24 & 1 & $S$ & & epitélio & -izar \\
\hline epitetar & 2549 & 131 & 1 & $S$ & & epíteto & -ar \\
\hline equimosar & 2550 & 202 & 1 & $S$ & & equimose & -ar \\
\hline erar & 2551 & 2968 & 1 & $S$ & & era & -ar \\
\hline erisipelar & 2552 & 78 & 1 & $S$ & & erisipela & -ar \\
\hline ervar & 2553 & 448 & 1 & $S$ & & erva & -ar \\
\hline ervecer & 2554 & 96 & 1 & $S$ & & erva & -ecer \\
\hline esbaforir-se & 2555 & 56 & 1 & $P$ & es- & bafo & -ir \\
\hline esbagaçar & 2556 & 827 & 1 & $\mathrm{P}$ & es- & bagaço & -ar \\
\hline esbaganhar & 2557 & 68 & 1 & $\mathrm{P}$ & es- & baganha & -ar \\
\hline esbagoar & 2558 & 160 & 1 & $P$ & es- & bago & -oar \\
\hline esbagulhar & 2559 & 130 & 1 & $\mathrm{P}$ & es- & bagulho & -ar \\
\hline esbaldar-se & 2560 & 488 & 1 & $P$ & es- & balde & -ar \\
\hline esbandeirar & 2561 & 104 & 1 & $\mathrm{P}$ & es- & bandeira & -ar \\
\hline esbandulhar & 2562 & 120 & 1 & $\mathrm{P}$ & es- & bandulho & -ar \\
\hline esbarbar & 2563 & 127 & 1 & $\mathrm{P}$ & es- & barba & -ar \\
\hline esbarbotar & 2564 & 130 & 1 & $\mathrm{P}$ & es- & barbote & -ar \\
\hline esbarrancar & 2565 & 75 & 1 & $P$ & es- & barranco & -ar \\
\hline esbarrar & 2566 & 51325 & 1 & $P$ & es- & barra & -ar \\
\hline esbarrigar & 2567 & 124 & 1 & $\mathrm{P}$ & es- & barriga & -ar \\
\hline esbarroar & 2568 & 75 & 1 & $S$ & & esbarro & -oar \\
\hline esbarrocar & 2569 & 237 & 1 & $P$ & es- & barroca & -ar \\
\hline esbeiçar & 2570 & 99 & 1 & $\mathrm{P}$ & es- & beiço & -ar \\
\hline esbirrar & 2571 & 73 & 1 & $S$ & & esbirro & -ar \\
\hline esbofar & 2572 & 170 & 1 & $\mathrm{P}$ & es- & bofe & -ar \\
\hline esborniar & 2573 & 129 & 1 & $S$ & & esbórnia & -ar \\
\hline esboroar & 2574 & 1265 & 1 & $\mathrm{P}$ & es- & boroa & -ar \\
\hline esborrachar & 2575 & 3125 & 1 & $\mathrm{P}$ & es- & borracha & -ar \\
\hline esborregar & 2576 & 116 & 1 & $\mathrm{P}$ & es- & borrego & -ar \\
\hline esbrasear & 2577 & 228 & 1 & $\mathrm{P}$ & es- & brasa & -ear \\
\hline esbugalhar & 2578 & 691 & 1 & $P$ & es- & bugalho & $-a r$ \\
\hline esburacar & 2579 & 1373 & 1 & $P$ & es- & buraco & -ar \\
\hline escabelar & 2580 & 1333 & 1 & $\mathrm{P}$ & es- & cabelo & -ar \\
\hline escabulhar & 2581 & 234 & 1 & $S$ & & escabulho & -ar \\
\hline escacar & 2582 & 84 & 1 & $\mathrm{P}$ & es- & caco & -ar \\
\hline escacholar & 2583 & 223 & 1 & $\mathrm{P}$ & es- & cachola & -ar \\
\hline escadear & 2584 & 231 & 1 & $S$ & & escada & -ear \\
\hline \begin{tabular}{|l|} 
escadeirar \\
\end{tabular} & 2585 & 248 & 1 & $\mathrm{P}$ & es- & cadeira & -ar \\
\hline escafandrar & 2586 & 43 & 1 & S & & escafandro & -ar \\
\hline escaiolar & 2587 & 76 & 1 & $S$ & & escaiola & -ar \\
\hline escaliçar & 2588 & 59 & 1 & $P$ & es- & caliça & -ar \\
\hline escalpar & 2589 & 120 & 1 & $S$ & & escalpo & -ar \\
\hline escalpelar & 2590 & 818 & 1 & $S$ & & escalpelo & -ar \\
\hline escalpelizar & 2591 & 119 & 1 & $S$ & & escalpelo & -izar \\
\hline escalrachar & 2592 & 70 & 1 & $S$ & & escalracho & -ar \\
\hline escambar & 2593 & 172 & 1 & $S$ & & escambo & -ar \\
\hline escamisar & 2594 & 70 & 1 & $P$ & es- & camisa & -ar \\
\hline escampar & 2595 & 226 & 1 & $P$ & es- & campo & -ar \\
\hline escancelar & 2596 & 64 & 1 & $P$ & es- & cancelo & -ar \\
\hline escanerizar & 2597 & 159 & 1 & $S$ & & escâner & -izar \\
\hline escangalhar & 2598 & 926 & 1 & $P$ & es- & cangalho & -ar \\
\hline \begin{tabular}{|l|} 
escanganhar \\
\end{tabular} & 2599 & 72 & 1 & $P$ & es- & canganho & -ar \\
\hline escangotar & 2600 & 90 & 1 & $\mathrm{P}$ & es- & cangote & -ar \\
\hline escantilhar & 2601 & 78 & 1 & $P$ & es- & cantilho & -ar \\
\hline escaquear & 2602 & 64 & 1 & $S$ & & escaque & -ear \\
\hline escaqueirar & 2603 & 83 & 1 & $\mathrm{P}$ & es- & caqueiro & -ar \\
\hline
\end{tabular}




\begin{tabular}{|c|c|c|c|c|c|c|c|}
\hline escaramuçar & 2604 & 202 & 1 & $S$ & & escaramuça & -ar \\
\hline escaramucear & 2605 & 21 & 1 & $S$ & & escaramuça & -ear \\
\hline escarapelar & 2606 & 57 & 1 & $\mathrm{P}$ & es- & carapela & -ar \\
\hline escarar-se & 2607 & 0 & 1 & $\mathrm{P}$ & es- & cara & -ar \\
\hline escaravelhar & 2608 & 60 & 1 & S & & escaravelho & -ar \\
\hline escarchar & 2609 & 61 & 1 & $S$ & & escarcha & -ar \\
\hline escardar & 2610 & 28 & 1 & $\mathrm{P}$ & es- & cardo & -ar \\
\hline escardear & 2611 & 86 & 1 & $\mathrm{P}$ & es- & cardo & -ear \\
\hline escardilhar & 2612 & 49 & 1 & $S$ & & escardilho & -ar \\
\hline escarduçar & 2613 & 58 & 1 & $\mathrm{P}$ & es- & carduça & -ar \\
\hline escarmentar & 2614 & 360 & 1 & $S$ & & escarmento & -ar \\
\hline escarnar & 2615 & 160 & 1 & $\mathrm{P}$ & es- & carne & -ar \\
\hline escarolar & 2616 & 77 & 1 & $\mathrm{P}$ & es- & carolo & -ar \\
\hline escarpar & 2617 & 181 & 1 & $S$ & & escarpa & -ar \\
\hline escarpelar & 2618 & 58 & 1 & $\mathrm{P}$ & es- & carpela & -ar \\
\hline escarrapichar & 2619 & 72 & 1 & $\mathrm{P}$ & es- & carrapicho & -ar \\
\hline escasquear & 2620 & 62 & 1 & $P$ & es- & casco & -ear \\
\hline escatelar & 2621 & 448 & 1 & $S$ & & escatel & -ar \\
\hline escavaçar & 2622 & 63 & 1 & $P$ & es- & cava & -açar \\
\hline escaveirar & 2623 & 83 & 1 & $P$ & es- & caveira & -ar \\
\hline esclerosar & 2624 & 338 & 1 & $S$ & & esclerose & -ar \\
\hline escodear & 2625 & 244 & 1 & $P$ & es- & côdea & -ear \\
\hline escoicear & 2626 & 732 & 1 & $P$ & es- & coice & -ear \\
\hline escoicinhar & 2627 & 262 & 1 & $\mathrm{P}$ & es- & coice & -inhar \\
\hline escoliar & 2628 & 68 & 1 & $S$ & & escólio & -ar \\
\hline escoltar & 2629 & 14450 & 1 & $S$ & & escolta & -ar \\
\hline escopear & 2630 & 82 & 1 & $S$ & & escopro & -ear \\
\hline escopetear & 2631 & 75 & 1 & $S$ & & escopeta & -ear \\
\hline escorar & 2632 & 12450 & 1 & $S$ & & escora & -ar \\
\hline escorçar & 2633 & 94 & 1 & $S$ & & escorço & -ar \\
\hline escoriar & 2634 & 228 & 1 & $S$ & & escória & -ar \\
\hline escornichar & 2635 & 64 & 1 & $P$ & es- & cornicho & -ar \\
\hline escortinar & 2636 & 75 & 1 & $P$ & es- & cortina & -ar \\
\hline escorvar & 2637 & 2345 & 1 & S & & escorva & -ar \\
\hline escovilhar & 2638 & 80 & 1 & S & & escovilha & -ar \\
\hline escriturar & 2639 & 23925 & 1 & $S$ & & escritura & -ar \\
\hline escrofularizar & 2640 & 0 & 1 & $S$ & & escrofulária & -izar \\
\hline escrupulear & 2641 & 75 & 1 & $S$ & & escrúpulo & -ear \\
\hline escrupulizar & 2642 & 117 & 1 & $S$ & & escrúpulo & -izar \\
\hline escudar & 2643 & 2958 & 1 & $S$ & & escudo & -ar \\
\hline escudeirar & 2644 & 179 & 1 & $S$ & & escudeiro & -ar \\
\hline escudelar & 2645 & 180 & 1 & $S$ & & escudela & -ar \\
\hline esculturar & 2646 & 480 & 1 & S & & escultura & -ar \\
\hline escumar & 2647 & 565 & 1 & $S$ & & escuma & -ar \\
\hline escumilhar & 2648 & 184 & 1 & $S$ & & escumilha & -ar \\
\hline esfacelar & 2649 & 3733 & 1 & S & & esfácelo & -ar \\
\hline esfanicar & 2650 & 155 & 1 & $\mathrm{P}$ & es- & fanico & -ar \\
\hline esfarelar & 2651 & 4873 & 1 & $\mathrm{P}$ & es- & farelo & -ar \\
\hline esfarinhar & 2652 & 456 & 1 & $P$ & es- & farinha & -ar \\
\hline esfiapar & 2653 & 231 & 1 & $\mathrm{P}$ & es- & fiapo & -ar \\
\hline esflorar & 2654 & 170 & 1 & $\mathrm{P}$ & es- & flor & -ar \\
\hline esfoguetear & 2655 & 130 & 1 & $\mathrm{P}$ & es- & foguete & -ear \\
\hline esfolhar & 2656 & 393 & 1 & $\mathrm{P}$ & es- & folha & -ar \\
\hline esfomear & 2657 & 343 & 1 & $\mathrm{P}$ & es- & fome & -ear \\
\hline esfrangalhar & 2658 & 339 & 1 & $\mathrm{P}$ & es- & frangalho & -ar \\
\hline esfuracar & 2659 & 98 & 1 & $P$ & es- & furaco & -ar \\
\hline esgadanhar & 2660 & 188 & 1 & $\mathrm{P}$ & es- & gadanho & -ar \\
\hline esgaivar & 2661 & 162 & 1 & $\mathrm{P}$ & es- & gaiva & -ar \\
\hline esganar & 2662 & 7258 & 1 & $\mathrm{P}$ & es- & gana & -ar \\
\hline esgaravatar & 2663 & 329 & 1 & $\mathrm{P}$ & es- & garavato & -ar \\
\hline esgaravatear & 2664 & 63 & 1 & $P$ & es- & garavato & -ear \\
\hline esgardunhar & 2665 & 61 & 1 & $\mathrm{P}$ & es- & gardunho & -ar \\
\hline esgorjar & 2666 & 109 & 1 & $P$ & es- & gorja & -ar \\
\hline esgotar & 2667 & 186000 & 1 & $\mathrm{P}$ & es- & gota & -ar \\
\hline
\end{tabular}




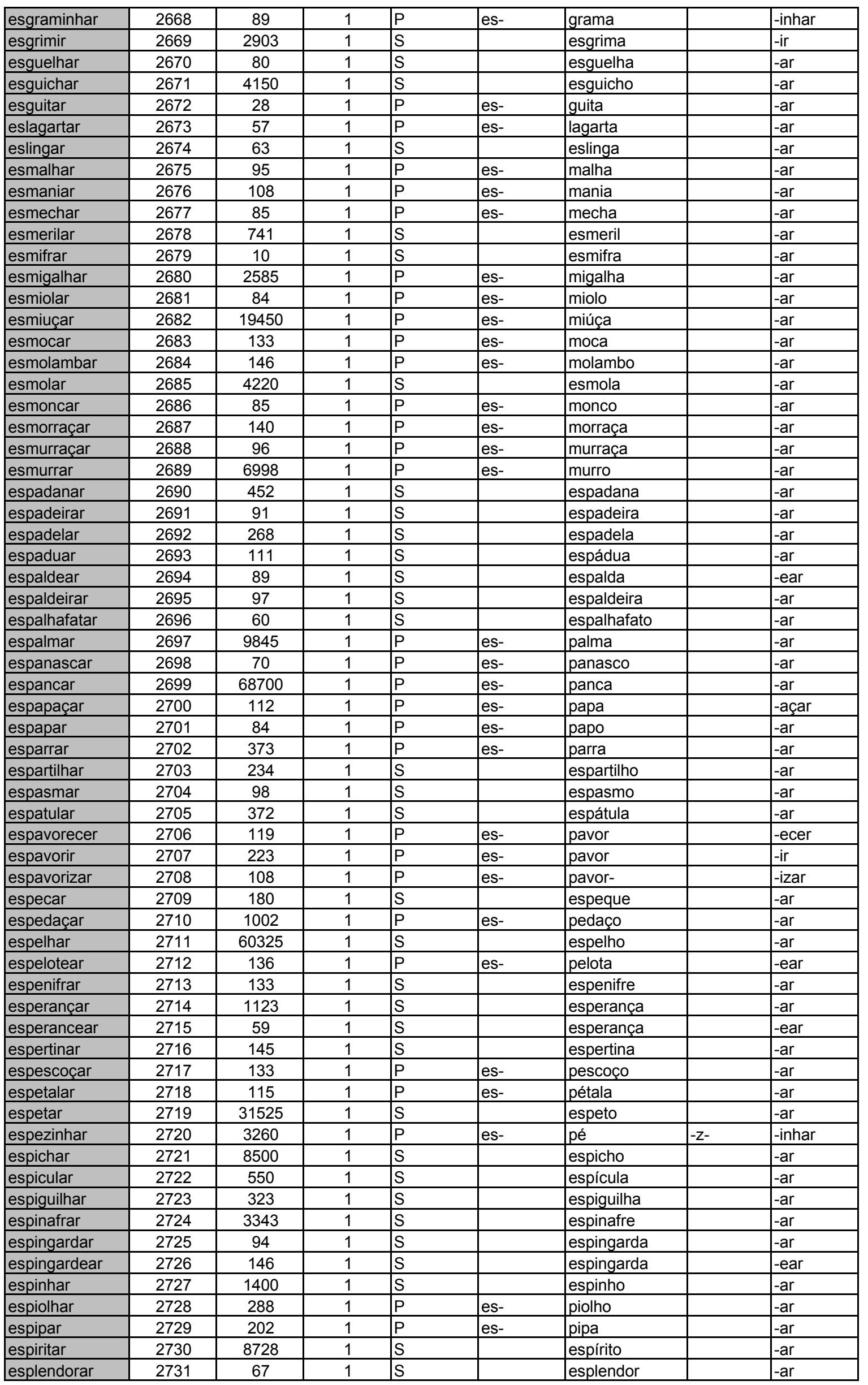




\begin{tabular}{|c|c|c|c|c|c|c|c|}
\hline espoar & 2732 & 189 & 1 & $\mathrm{P}$ & es- & pó & -ar \\
\hline espojar & 2733 & 963 & 1 & $\mathrm{P}$ & es- & pó & -ejar \\
\hline espoldrar & 2734 & 71 & 1 & $P$ & es- & poldra & -ar \\
\hline espoletar & 2735 & 212 & 1 & $S$ & & espoleta & -ar \\
\hline espoletear & 2736 & 181 & 1 & $S$ & & espoleta & -ear \\
\hline espolinhar-se & 2737 & 148 & 1 & $\mathrm{P}$ & es- & pó & -inhar \\
\hline espontar & 2738 & 225 & 1 & $\mathrm{P}$ & es- & ponta & -ar \\
\hline esporular & 2739 & 652 & 1 & $S$ & & espórulo & -ar \\
\hline espostejar & 2740 & 159 & 1 & $P$ & es- & posta & -ejar \\
\hline espotrejar & 2741 & 15 & 1 & $\mathrm{P}$ & es- & potro & -ejar \\
\hline espragatar & 2742 & 131 & 1 & $\mathrm{P}$ & es- & pragata & -ar \\
\hline espraiar & 2743 & 5920 & 1 & $\mathrm{P}$ & es- & praia & -ar \\
\hline espreguiçar & 2744 & 7865 & 1 & $\mathrm{P}$ & es- & preguiça & -ar \\
\hline espritar-se & 2745 & 22 & 1 & $S$ & & espírito & -ar \\
\hline espulgar & 2746 & 134 & 1 & $P$ & es- & pulga & -ar \\
\hline espumejar & 2747 & 214 & 1 & $S$ & & espuma & -ejar \\
\hline esquadrar & 2748 & 400 & 1 & $S$ & & esquadro & -ar \\
\hline esquadrejar & 2749 & 1103 & 1 & $S$ & & esquadro & -ejar \\
\hline esquadriar & 2750 & 208 & 1 & $S$ & & esquadria & -ar \\
\hline esquadrilhar & 2752 & 277 & 1 & $P$ & es- & quadrilha & -ar \\
\hline esquartejar & 2753 & 13125 & 1 & $P$ & es- & quarto & -ejar \\
\hline esquartelar & 2754 & 177 & 1 & $P$ & es- & quartel & -ar \\
\hline esquartilhar & 2755 & 46 & 1 & $P$ & es- & quarto & -ilhar \\
\hline esquiar & 2756 & 34900 & 1 & $S$ & & esqui & -ar \\
\hline esquifar & 2757 & 95 & 1 & $S$ & & esquife & -ar \\
\hline esquinar & 2758 & 137 & 1 & $S$ & & esquina & -ar \\
\hline estabular & 2759 & 286 & 1 & $S$ & & estábulo & -ar \\
\hline estacar & 2760 & 2430 & 1 & $S$ & & estaca & -ar \\
\hline estadear & 2761 & 713 & 1 & $S$ & & estado & -ear \\
\hline estafetar & 2762 & 118 & 1 & $S$ & & estafeta & -ar \\
\hline \begin{tabular}{|l|} 
estagiar \\
\end{tabular} & 2763 & 90450 & 1 & $S$ & & estágio & -ar \\
\hline estaiar & 2764 & 199 & 1 & $S$ & & estai & -ar \\
\hline \begin{tabular}{|l|} 
estaleirar \\
\end{tabular} & 2765 & 148 & 1 & $S$ & & estaleiro & -ar \\
\hline estalidar & 2766 & 155 & 1 & $S$ & & estalido & -ar \\
\hline estambrar & 2767 & 145 & 1 & $S$ & & estambre & -ar \\
\hline estampar & 2768 & 82275 & 1 & $S$ & & estampa & -ar \\
\hline estampilhar & 2769 & 160 & 1 & $S$ & & estampilha & -ar \\
\hline estanciar & 2770 & 708 & 1 & $S$ & & estância & -ar \\
\hline estanhar & 2771 & 931 & 1 & $S$ & & estanho & -ar \\
\hline estaquear & 2772 & 441 & 1 & $S$ & & estaca & -ear \\
\hline estardalhaçar & 2773 & 85 & 1 & $S$ & & estardalhaço & -ar \\
\hline estatuar & 2774 & 115 & 1 & $\mathrm{~S}$ & & estátua & -ar \\
\hline esteirar & 2775 & 411 & 1 & $S$ & & esteira & -ar \\
\hline estenosar & 2777 & 115 & 1 & $S$ & & estenose & -ar \\
\hline estenotipar & 2778 & 130 & 1 & $S$ & & estenótipo & -ar \\
\hline esterar & 2779 & 136 & 1 & $S$ & & estere & -ar \\
\hline estercar & 2780 & 381 & 1 & $S$ & & esterco & -ar \\
\hline estereotipar & 2781 & 3683 & 1 & $S$ & & estereotipia & -ar \\
\hline esterificar & 2782 & 174 & 1 & $S$ & & éster & -ficar \\
\hline \begin{tabular}{|l|} 
estertorar \\
\end{tabular} & 2783 & 335 & 1 & $S$ & & estertor & -ar \\
\hline estertorizar & 2784 & 11 & 1 & $S$ & & estertor & -izar \\
\hline estesiar & 2785 & 48 & 1 & $S$ & & estesia & -ar \\
\hline estesourar & 2786 & 7 & 1 & $P$ & es- & tesoura & -ar \\
\hline estetizar & 2787 & 842 & 1 & $S$ & & esteta & -izar \\
\hline \begin{tabular}{|l} 
estevar \\
\end{tabular} & 2788 & 159 & 1 & $S$ & & esteva & -ar \\
\hline estilar & 2789 & 835 & 1 & $\mathrm{~S}$ & & estilo & -ar \\
\hline estiletar & 2790 & 69 & 1 & $S$ & & estilete & -ar \\
\hline estiletear & 2791 & 62 & 1 & $S$ & & estilete & -ear \\
\hline estilhaçar & 2792 & 4630 & 1 & S & & estilhaço & -ar \\
\hline estilhar & 2793 & 94 & 1 & $S$ & & estilha & -ar \\
\hline estilizar & 2794 & 8095 & 1 & $S$ & & estilo & -izar \\
\hline estolar & 2795 & 1520 & 1 & $S$ & & estol & -ar \\
\hline estomentar & 2796 & 69 & 1 & $\mathrm{P}$ & es- & tomento & -ar \\
\hline estonar & 2797 & 149 & 1 & $P$ & es- & tona & -ar \\
\hline
\end{tabular}




\begin{tabular}{|c|c|c|c|c|c|c|c|}
\hline estopar & 2798 & 338 & 1 & $S$ & & estopa & -ar \\
\hline estopetar & 2799 & 68 & 1 & $\mathrm{P}$ & es- & topete & -ar \\
\hline estornicar & 2800 & 0 & 1 & $\mathrm{P}$ & es- & torno & -icar \\
\hline estradar & 2801 & 3880 & 1 & $S$ & & estrada & -ar \\
\hline estrategiar & 2802 & 92 & 1 & S & & estratégia & -ar \\
\hline estrear & 2803 & 645000 & 2 & $S$ & & estréia & -ar \\
\hline estrelar & 2804 & 127750 & 1 & $S$ & & estrela & -ar \\
\hline estrelejar & 2805 & 96 & 1 & $S$ & & estrela & -ejar \\
\hline \begin{tabular}{|l|} 
estremar \\
\end{tabular} & 2806 & 1413 & 1 & $S$ & & estrema & -ar \\
\hline estrepar & 2807 & 3410 & 1 & S & & estrepe & -ar \\
\hline estrepitar & 2808 & 267 & 1 & $S$ & & estrépito & -ar \\
\hline estressar & 2809 & 52225 & 1 & $S$ & & estresse & -ar \\
\hline estriar & 2810 & 532 & 1 & $S$ & & estria & -ar \\
\hline estribar & 2811 & 1483 & 1 & $S$ & & estribo & -ar \\
\hline estribilhar & 2812 & 123 & 1 & $S$ & & estribilho & -ar \\
\hline estricar & 2813 & 15 & 1 & $S$ & & estrica & -ar \\
\hline estrigar & 2814 & 77 & 1 & S & & estriga & -ar \\
\hline estripar & 2815 & 2450 & 1 & $P$ & es- & tripo & -ar \\
\hline estrondar & 2816 & 1530 & 1 & S & & estrondo & -ar \\
\hline estrondear & 2817 & 589 & 1 & $S$ & & estrondo & -ear \\
\hline estropear & 2818 & 332 & 1 & $P$ & es- & tropa & -ear \\
\hline estropeliar & 2819 & 36 & 1 & S & & estropelia & -ar \\
\hline estrotejar & 2820 & 50 & 1 & $P$ & es- & trote & -ejar \\
\hline estrumar & 2821 & 265 & 1 & $S$ & & estrume & -ar \\
\hline estrupidar & 2822 & 81 & 1 & $S$ & & estrupido & -ar \\
\hline estruturar & 2823 & 348000 & 1 & $S$ & & estrutura & -ar \\
\hline estucar & 2824 & 394 & 1 & $S$ & & estuque & $-a r$ \\
\hline estuchar & 2825 & 91 & 1 & $\mathrm{P}$ & es- & tocha & -ar \\
\hline estudar & 2826 & 4580000 & 3 & $S$ & & estudo & -ar \\
\hline estuporar & 2827 & 728 & 1 & $S$ & & estupor & -ar \\
\hline esturdiar & 2828 & 76 & 1 & $S$ & & estúrdia & -ar \\
\hline esventar & 2829 & 81 & 1 & $P$ & es- & vento & -ar \\
\hline esvidar & 2830 & 71 & 1 & $P$ & es- & vide & -ar \\
\hline esviscerar & 2831 & 85 & 1 & $P$ & es- & víscera & -ar \\
\hline esvoaçar & 2832 & 3875 & 1 & $P$ & es- & vôo & -açar \\
\hline esvoejar & 2833 & 92 & 1 & $\mathrm{P}$ & es- & Vôo & -ejar \\
\hline esvurmar & 2834 & 132 & 1 & $\mathrm{P}$ & es- & vurmo & -ar \\
\hline eterizar & 2835 & 174 & 1 & $S$ & & éter & -izar \\
\hline etimologizar & 2836 & 105 & 1 & $S$ & & etimologia & -izar \\
\hline etiquetar & 2837 & 25900 & 1 & $S$ & & etiqueta & $-a r$ \\
\hline eufonizar & 2838 & 107 & 1 & $S$ & & eufonia & -izar \\
\hline euforizar & 2839 & 25 & 1 & $S$ & & euforia & -izar \\
\hline eventrar & 2840 & 93 & 1 & $P$ & e- & ventre & -ar \\
\hline evidenciar & 2841 & 821000 & 2 & $S$ & & evidência & -ar \\
\hline exclaustrar & 2842 & 1 & 1 & $P$ & ex- & claustro & -ar \\
\hline excretar & 2843 & 3738 & 1 & S & & excreto & -ar \\
\hline exemplificar & 2844 & 464000 & 1 & $S$ & & exemplo & -ficar \\
\hline exiliar & 2845 & 91 & 1 & S & & exílio & -ar \\
\hline exitar & 2846 & 6843 & 1 & S & & êxito & -ar \\
\hline exorcismar & 2847 & 496 & 1 & S & & exorcismo & -ar \\
\hline exordiar & 2848 & 128 & 1 & S & & exórdio & -ar \\
\hline expedrar & 2849 & 193 & 1 & $\mathrm{P}$ & ex- & pedra & -ar \\
\hline experienciar & 2850 & 15900 & 1 & $S$ & & experiência & -ar \\
\hline extratar & 2851 & 381 & 1 & $S$ & & extrato & $-a r$ \\
\hline extravaganciar & 2852 & 76 & 1 & S & & extravagância & -ar \\
\hline extravasar & 2853 & 32550 & 1 & $P$ & extra- & vaso & -ar \\
\hline extraviar & 2854 & 14150 & 1 & $\mathrm{P}$ & extra- & via & -ar \\
\hline fabulizar & 2855 & 109 & 1 & S & & fábula & -izar \\
\hline facear & 2856 & 6538 & 1 & $S$ & & face & -ear \\
\hline faceciar & 2857 & 26 & 1 & S & & facécia & $-a r$ \\
\hline facejar & 2858 & 106 & 1 & $S$ & & face & -ejar \\
\hline facetar & 2859 & 984 & 1 & S & & faceta & -ar \\
\hline facetear & 2860 & 187 & 1 & $S$ & & faceta & -ear \\
\hline fachar & 2861 & 1120 & 1 & $S$ & & facha & -ar \\
\hline
\end{tabular}









\begin{tabular}{|c|c|c|c|c|c|c|c|}
\hline filigranar & 2927 & 361 & 1 & $S$ & filigrana & & -ar \\
\hline filmar & 2928 & 435500 & 1 & $S$ & filme & & -ar \\
\hline filoxerar & 2929 & 108 & 1 & $S$ & filoxera & & -ar \\
\hline \begin{tabular}{|l} 
filtrar \\
\end{tabular} & 2930 & 501500 & 2 & $S$ & filtro & & -ar \\
\hline fimbriar & 2931 & 161 & 1 & $S$ & fímbria & & -ar \\
\hline financiar & 2932 & 378500 & 1 & $S$ & finança & -i- & -ar \\
\hline fintar & 2934 & 3024 & 1 & $S$ & finta & & -ar \\
\hline fissurar & 2935 & 816 & 1 & $S$ & fissura & & -ar \\
\hline fistular & 2936 & 261 & 1 & $S$ & fístula & & -ar \\
\hline fistulizar & 2937 & 135 & 1 & $S$ & fístula & & -izar \\
\hline flagiciar & 2938 & 79 & 1 & $S$ & flagício & & -ar \\
\hline flamear & 2939 & 7100 & 1 & $S$ & flama & & -ear \\
\hline flamejar & 2940 & 2380 & 1 & $S$ & flama & & -ejar \\
\hline flanquear & 2941 & 2665 & 1 & $S$ & flanco & & -ear \\
\hline flautar & 2942 & 124 & 1 & $S$ & flauta & & -ar \\
\hline flautear & 2943 & 374 & 1 & $\mathrm{~S}$ & flauta & & -ear \\
\hline flechar & 2944 & 1763 & 1 & $S$ & flecha & & -ar \\
\hline flertar & 2945 & 65325 & 1 & $S$ & flerte & & -ar \\
\hline flocular & 2946 & 757 & 1 & $S$ & flóculo & & -ar \\
\hline florar & 2947 & 1605 & 1 & $S$ & flor & & -ar \\
\hline florear & 2948 & 2650 & 1 & $S$ & flor & & -ear \\
\hline florejar & 2949 & 258 & 1 & $S$ & flor & & -ejar \\
\hline florestar & 2950 & 2940 & 1 & $\mathrm{~S}$ & floresta & & -ar \\
\hline floretear & 2951 & 255 & 1 & $S$ & floreta & & -ear \\
\hline fluorar & 2952 & 135 & 1 & $S$ & flúor & & -ar \\
\hline focar & 2953 & 693000 & 2 & $S$ & foco & & -ar \\
\hline fofocar & 2954 & 17550 & 1 & $S$ & fofoca & & -ar \\
\hline foguear & 2955 & 217 & 1 & $\mathrm{~S}$ & fogo & & -ear \\
\hline foguetear & 2956 & 200 & 1 & $S$ & foguete & & -ear \\
\hline foiçar & 2957 & 237 & 1 & $\mathrm{~S}$ & foice & & -ar \\
\hline folclorizar & 2958 & 493 & 1 & $S$ & folclore & & -izar \\
\hline \begin{tabular}{|l|} 
folear \\
\end{tabular} & 2959 & 1083 & 1 & $S$ & fole & & -ar \\
\hline folhar & 2960 & 3143 & 1 & $S$ & folha & & -ar \\
\hline folhear & 2961 & 37750 & 1 & $S$ & folha & & -ear \\
\hline folhetear & 2962 & 185 & 1 & $S$ & folheta & & -ear \\
\hline foliar & 2963 & 106000 & 1 & $S$ & folia & & -ar \\
\hline fonologizar & 2965 & 0 & 1 & $S$ & fonologia & & -izar \\
\hline forcar & 2966 & 11525 & 1 & $S$ & forca & & -ar \\
\hline forçar & 2967 & 1060000 & 2 & $S$ & força & & -ar \\
\hline forcejar & 2968 & 752 & 1 & $\mathrm{~S}$ & força & & -ejar \\
\hline forjar & 2969 & 68700 & 1 & $S$ & forja & & -ar \\
\hline forjicar & 2970 & 128 & 1 & $\mathrm{~S}$ & forja & & -icar \\
\hline formiguejar & 2971 & 73 & 1 & $S$ & formiga & & -ejar \\
\hline formilhar & 2972 & 86 & 1 & $S$ & formilho & & -ar \\
\hline formolar & 2973 & 38 & 1 & $\mathrm{~S}$ & formol & & -ar \\
\hline formolizar & 2974 & 107 & 1 & $S$ & formol & & -izar \\
\hline formular & 2975 & 312000 & 1 & $S$ & fórmula & & -ar \\
\hline fornear & 2976 & 1200 & 1 & $S$ & forno & & -ear \\
\hline fornejar & 2977 & 149 & 1 & $\mathrm{~S}$ & forno & & -ejar \\
\hline forniziar & 2978 & 32 & 1 & $S$ & fornízio & & -ar \\
\hline forquilhar & 2979 & 148 & 1 & $\mathrm{~S}$ & forquilha & & -ar \\
\hline fortalezar & 2980 & 163 & 1 & $S$ & fortaleza & & -ar \\
\hline fosfatar & 2981 & 106 & 1 & $S$ & fosfato & & -ar \\
\hline fosforilar & 2982 & 496 & 1 & $S$ & fosforila & & -ar \\
\hline fossar & 2983 & 625 & 1 & $S$ & fossa & & -ar \\
\hline fotear & 2984 & 78 & 1 & $\mathrm{~S}$ & fota & & -ear \\
\hline fotocopiar & 2985 & 4420 & 1 & $S$ & fotocópia & & -ar \\
\hline fotolitar & 2986 & 47 & 1 & $S$ & fotolito & & -ar \\
\hline fototipar & 2987 & 73 & 1 & $\mathrm{~S}$ & fotótipo & & -ar \\
\hline fototipiar & 2988 & 78 & 1 & $S$ & fototipia & & -ar \\
\hline fradar-se & 2989 & 23 & 1 & $\mathrm{~S}$ & frade & & -ar \\
\hline fradejar & 2990 & 106 & 1 & $S$ & frade & & -ejar \\
\hline fragatear & 2991 & 113 & 1 & $S$ & fragata & & -ear \\
\hline fragmentar & 2992 & 29025 & 1 & $\mathrm{~S}$ & fragmento & & -ar \\
\hline
\end{tabular}




\begin{tabular}{|c|c|c|c|c|c|c|c|}
\hline fragorar & 2993 & 150 & 1 & $S$ & fragor & & -ar \\
\hline fraguar & 2994 & 173 & 1 & $S$ & frágua & & -ar \\
\hline fraldar & 2995 & 377 & 1 & $S$ & fralda & & -ar \\
\hline fraldear & 2996 & 58 & 1 & $S$ & fralda & & -ear \\
\hline fraldejar & 2997 & 73 & 1 & $S$ & fralda & & -ejar \\
\hline francesiar & 2998 & 161 & 1 & $\mathrm{~S}$ & francesia & & -ar \\
\hline frangalhar & 2999 & 201 & 1 & $S$ & frangalho & & -ar \\
\hline frangalhotear & 3000 & 79 & 1 & $S$ & frangalhote & & -ear \\
\hline franguear & 3001 & 90 & 1 & $\mathrm{~S}$ & frango & & -ear \\
\hline franjar & 3002 & 220 & 1 & $S$ & franja & & -ar \\
\hline frasear & 3003 & 11900 & 1 & $\mathrm{~S}$ & frase & & -ear \\
\hline fraturar & 3004 & 7638 & 1 & $S$ & fratura & & -ar \\
\hline freirar & 3005 & 174 & 1 & $\mathrm{~S}$ & freire & & -ar \\
\hline frenesiar & 3006 & 163 & 1 & $S$ & frenesi & & $-a r$ \\
\hline frentear & 3007 & 168 & 1 & $S$ & frente & & -ear \\
\hline fresar & 3008 & 5690 & 1 & $S$ & fresa & & -ar \\
\hline fretar & 3009 & 9175 & 1 & $S$ & frete & & -ar \\
\hline fretejar & 3010 & 102 & 1 & $S$ & frete & & -ejar \\
\hline frisar & 3012 & 224375 & 1 & $S$ & friso & & -ar \\
\hline frondar & 3013 & 138 & 1 & $S$ & fronde & & -ar \\
\hline frondear & 3014 & 118 & 1 & $S$ & fronde & & -ear \\
\hline frondejar & 3015 & 161 & 1 & $S$ & fronde & & -ejar \\
\hline frontar & 3016 & 902 & 1 & $S$ & fronte & & -ar \\
\hline frontear & 3017 & 228 & 1 & $S$ & fronte & & -ear \\
\hline frufrulhar & 3018 & 95 & 1 & $S$ & frufru & & -Ihar \\
\hline frufrutar & 3019 & 85 & 1 & $S$ & frufru & $-t-$ & -ar \\
\hline frutar & 3020 & 925 & 1 & $S$ & fruto & & -ar \\
\hline frutear & 3021 & 149 & 1 & $\mathrm{~S}$ & fruto & & -ear \\
\hline fubecar & 3022 & 145 & 1 & $S$ & fubeca & & -ar \\
\hline fuçar & 3023 & 89625 & 1 & $S$ & fuça & & -ar \\
\hline fugar & 3025 & 423 & 1 & $S$ & fuga & & -ar \\
\hline \begin{tabular}{|l} 
fumarar \\
\end{tabular} & 3026 & 103 & 1 & $S$ & fumo & $-r-$ & -ar \\
\hline fumear & 3027 & 137 & 1 & S & fumo & & -ear \\
\hline fundamentar & 3028 & 236500 & 1 & $S$ & fundamento & & -ar \\
\hline fundilhar & 3029 & 179 & 1 & $S$ & fundilho & & -ar \\
\hline furdunçar & 3030 & 87 & 1 & $S$ & furdunço & & -ar \\
\hline furtar & 3031 & 189000 & 1 & $S$ & furto & & -ar \\
\hline furticar & 3032 & 2 & 1 & $S$ & furto & & -icar \\
\hline fuscar & 3033 & 530 & 1 & $S$ & fusca & & -ar \\
\hline futricar & 3034 & 3120 & 1 & $S$ & futrica & & -ar \\
\hline gabaritar & 3035 & 8988 & 1 & $S$ & gabarito & & -ar \\
\hline gadanhar & 3036 & 179 & 1 & $S$ & gadanha & & -ar \\
\hline gadunhar & 3037 & 154 & 1 & $S$ & gadunha & & -ar \\
\hline gafar & 3039 & 433 & 1 & $S$ & gafe & & -ar \\
\hline gafeirar & 3040 & 83 & 1 & $S$ & gafeira & & -ar \\
\hline gafejar & 3041 & 58 & 1 & $S$ & gafa & & -ejar \\
\hline gaifonar & 3042 & 107 & 1 & $S$ & gaifona & & -ar \\
\hline gaitear & 3043 & 125 & 1 & $S$ & gaita & & -ear \\
\hline gaivar & 3044 & 112 & 1 & $S$ & gaiva & & -ar \\
\hline galdropar & 3045 & 0 & 1 & $S$ & galdrope & & -ar \\
\hline galear & 3046 & 584 & 1 & $S$ & galé & & -ar \\
\hline galhardear & 3048 & 128 & 1 & $S$ & rad.degalhardia & & -ear \\
\hline galhofar & 3049 & 300 & 1 & $\mathrm{~S}$ & galhofa & & -ar \\
\hline galhofear & 3050 & 129 & 1 & $S$ & galhofa & & -ear \\
\hline galicismar & 3051 & 182 & 1 & $S$ & galicismo & & -ar \\
\hline galimar & 3052 & 254 & 1 & $S$ & galimo & & -ar \\
\hline galimatizar & 3053 & 177 & 1 & $S$ & galimatias & & -izar \\
\hline galopear & 3054 & 386 & 1 & $S$ & galope & & -ear \\
\hline galvanotipar & 3055 & 111 & 1 & $S$ & galvanotipia & & -ar \\
\hline gambetear & 3056 & 196 & 1 & $S$ & gambeta & & -ear \\
\hline gananciar & 3057 & 125 & 1 & $S$ & ganância & & -ar \\
\hline ganchar & 3058 & 187 & 1 & $S$ & gancho & & -ar \\
\hline ganchear & 3059 & 64 & 1 & $\mathrm{~S}$ & gancho & & -ear \\
\hline gandaiar & 3060 & 666 & 1 & $S$ & gandaia & & -ar \\
\hline
\end{tabular}




\begin{tabular}{|c|c|c|c|c|c|c|c|}
\hline gangrenar & 3061 & 729 & 1 & $S$ & gangrena & & -ar \\
\hline garabulhar & 3062 & 202 & 1 & $S$ & garabulho & & -ar \\
\hline garançar & 3063 & 74 & 1 & $S$ & garança & & -ar \\
\hline garavetar & 3064 & 159 & 1 & $S$ & garaveto & & -ar \\
\hline garfar & 3065 & 1923 & 1 & S & garfo & & -ar \\
\hline gargalaçar & 3066 & 137 & 1 & $S$ & gargalo & & -açar \\
\hline gargalhadear & 3067 & 163 & 1 & $S$ & gargalhada & & -ear \\
\hline gargantuar & 3068 & 55 & 1 & $S$ & gargântua & & -ar \\
\hline garimpar & 3069 & 48475 & 1 & $S$ & garimpo & & -ar \\
\hline garoar & 3070 & 2168 & 1 & S & garoa & & -ar \\
\hline garrear & 3071 & 87 & 1 & $S$ & garra & & -ear \\
\hline garrotar & 3072 & 170 & 1 & $S$ & garrote & & -ar \\
\hline garrotear & 3073 & 1378 & 1 & $S$ & garrote & & -ear \\
\hline gasear & 3074 & 246 & 1 & $S$ & gás & & -ear \\
\hline gasificar & 3075 & 121 & 1 & S & gás & $-\mathrm{i}-$ & -ficar \\
\hline gaspear & 3076 & 109 & 1 & $S$ & gáspea & & -ar \\
\hline gatafunhar & 3077 & 134 & 1 & S & gatafunho & & -ar \\
\hline gatear & 3078 & 178 & 1 & $S$ & gato & & -ear \\
\hline gatinhar & 3079 & 1693 & 1 & S & gatinha & & -ar \\
\hline gaucherear & 3080 & 136 & 1 & $S$ & gaucheria & & -ear \\
\hline gaudiar & 3081 & 82 & 1 & $S$ & gáudio & & -ar \\
\hline gaudinar & 3082 & 18 & 1 & S & gáudio & $-n-$ & -ar \\
\hline gazetar & 3083 & 116 & 1 & $S$ & gazeta & & -ar \\
\hline gazetear & 3084 & 398 & 1 & $S$ & gazeta & & -ear \\
\hline gebar & 3085 & 1400 & 1 & $S$ & geba & & -ar \\
\hline gelatinizar & 3086 & 370 & 1 & $S$ & gelatina & & -izar \\
\hline geleificar & 3087 & 86 & 1 & $S$ & geléia & $-\mathrm{i}-$ & -ficar \\
\hline gelificar & 3088 & 283 & 1 & $S$ & gel & $-\mathrm{i}-$ & -ficar \\
\hline genrear & 3089 & 158 & 1 & $S$ & genro & & -ear \\
\hline geometrizar & 3090 & 303 & 1 & $S$ & geometria & & -izar \\
\hline gerenciar & 3091 & 1370000 & 2 & $S$ & gerência & & -ar \\
\hline gessar & 3092 & 237 & 1 & S & gesso & & -ar \\
\hline ginasticar & 3093 & 73 & 1 & S & ginástica & & -ar \\
\hline ginetear & 3094 & 473 & 1 & $S$ & ginete & & -ear \\
\hline \begin{tabular}{|l|} 
girandolar \\
\end{tabular} & 3095 & 100 & 1 & S & girândola & & -ar \\
\hline gizar & 3096 & 2850 & 1 & $S$ & giz & & -ar \\
\hline glaçar & 3097 & 195 & 1 & $S$ & glace & & -ar \\
\hline gladiar & 3098 & 315 & 1 & $S$ & gládio & & -ar \\
\hline glicerinar & 3099 & 77 & 1 & $S$ & glicerina & & -ar \\
\hline glosar & 3100 & 4023 & 1 & $S$ & glosa & & -ar \\
\hline godemizar & 3101 & 0 & 1 & $S$ & godeme & & -izar \\
\hline godiar & 3102 & 0 & 1 & $S$ & gódia & & -ar \\
\hline goelar & 3103 & 101 & 1 & $S$ & goela & & -ar \\
\hline goivar & 3104 & 160 & 1 & $S$ & goiva & & -ar \\
\hline golear & 3105 & 50100 & 1 & $S$ & $\mathrm{gol}$ & & -ear \\
\hline golejar & 3106 & 156 & 1 & $S$ & gole & & -ejar \\
\hline golelhar & 3107 & 155 & 1 & $S$ & golelha & & -ar \\
\hline golpear & 3108 & 33750 & 1 & $S$ & golpe & & -ear \\
\hline gomar & 3109 & 2183 & 1 & S & goma & & -ar \\
\hline gondolar & 3111 & 92 & 1 & $S$ & gôndola & & -ar \\
\hline gongar & 3112 & 872 & 1 & $S$ & gongo & & -ar \\
\hline gorjear & 3113 & 2060 & 1 & $S$ & gorja & & -ear \\
\hline gornir & 3114 & 90 & 1 & $S$ & gorne & & -ir \\
\hline gotear & 3115 & 167 & 1 & $S$ & gota & & -ear \\
\hline gotejar & 3116 & 6488 & 1 & $S$ & gota & & -ejar \\
\hline gracejar & 3117 & 3798 & 1 & $S$ & graça & & -ejar \\
\hline graçolar & 3118 & 111 & 1 & $S$ & graçola & & -ar \\
\hline gradar & 3119 & 1090 & 1 & $S$ & grade & & -ar \\
\hline gradear & 3120 & 1678 & 1 & $S$ & grade & & -ear \\
\hline gradejar & 3121 & 136 & 1 & $S$ & grade & & -ejar \\
\hline gradinar & 3122 & 267 & 1 & $S$ & gradim & & -ar \\
\hline grafitar & 3124 & 6753 & 1 & $S$ & grafite & & -ar \\
\hline grafitizar & 3125 & 26 & 1 & $S$ & grafite & & -izar \\
\hline gralhar & 3126 & 508 & 1 & $S$ & gralha & & -ar \\
\hline
\end{tabular}




\begin{tabular}{|c|c|c|c|c|c|c|}
\hline gralhear & 3127 & 164 & 1 & $S$ & gralha & -ear \\
\hline gramar & 3128 & 3423 & 1 & $S$ & grama & -ar \\
\hline gramaticar & 3129 & 216 & 1 & $S$ & gramática & -ar \\
\hline graminhar & 3130 & 85 & 1 & $S$ & graminho & -ar \\
\hline grampar & 3131 & 149 & 1 & $S$ & grampo & -ar \\
\hline grampear & 3132 & 23000 & 1 & $S$ & grampo & -ear \\
\hline granitar & 3133 & 113 & 1 & $S$ & granita & -ar \\
\hline granizar & 3134 & 180 & 1 & $S$ & granizo & -ar \\
\hline granjear & 3135 & 6410 & 1 & $S$ & granja & -ear \\
\hline granular & 3136 & 31500 & 1 & $S$ & grânulo & -ar \\
\hline gravancear & 3137 & 23 & 1 & $S$ & gravanço & -ear \\
\hline gravatear & 3138 & 333 & 1 & $S$ & gravata & -ear \\
\hline gravetar & 3139 & 159 & 1 & $S$ & graveto & -ar \\
\hline graxear & 3140 & 127 & 1 & $S$ & graxa & -ear \\
\hline grelar & 3141 & 365 & 1 & $S$ & grelo & -ar \\
\hline grelhar & 3142 & 17250 & 1 & $S$ & grelha & -ar \\
\hline grilar & 3143 & 2860 & 1 & $S$ & grilo & -ar \\
\hline grinaldar & 3144 & 111 & 1 & $S$ & grinalda & -ar \\
\hline gripar & 3145 & 1498 & 1 & S & gripe & -ar \\
\hline grosar & 3147 & 231 & 1 & $S$ & grosa & -ar \\
\hline grudar & 3148 & 47850 & 1 & $S$ & grude & -ar \\
\hline grumecer & 3149 & 100 & 1 & $S$ & grumo & -ecer \\
\hline \begin{tabular}{|l} 
grupar \\
\end{tabular} & 3150 & 2103 & 1 & $S$ & grupo & -ar \\
\hline guaiar & 3151 & 239 & 1 & $S$ & guai & -ar \\
\hline guampear & 3152 & 84 & 1 & $S$ & guampa & -ear \\
\hline guardear & 3153 & 69 & 1 & $S$ & guarda & -ear \\
\hline guedelhar & 3154 & 2 & 1 & $S$ & guedelha & -ar \\
\hline guerrear & 3155 & 34550 & 1 & S & guerra & -ear \\
\hline guerrilhar & 3156 & 503 & 1 & $S$ & guerrilha & -ar \\
\hline guilhotinar & 3157 & 773 & 1 & $S$ & guilhotina & -ar \\
\hline guinchar & 3159 & 3333 & 1 & $S$ & guincho & -ar \\
\hline guisar & 3160 & 1030 & 1 & $S$ & guisa & -ar \\
\hline guitarrear & 3161 & 227 & 1 & $S$ & guitarra & -ear \\
\hline guizalhar & 3162 & 153 & 1 & $S$ & guizo & -alhar \\
\hline guleimar & 3163 & 0 & 1 & $S$ & guleima & -ar \\
\hline gulosinar & 3164 & 66 & 1 & $S$ & gulosina & -ar \\
\hline hachurar & 3165 & 574 & 1 & $S$ & hachura & -ar \\
\hline halitar & 3166 & 81 & 1 & $S$ & hálito & $-a r$ \\
\hline harmonizar & 3167 & 136500 & 1 & $S$ & harmonia & -izar \\
\hline harpar & 3168 & 120 & 1 & $S$ & harpa & -ar \\
\hline harpear & 3169 & 138 & 1 & $S$ & harpa & -ear \\
\hline harpejar & 3170 & 167 & 1 & $S$ & harpa & -ejar \\
\hline hastear & 3171 & 9410 & 1 & $S$ & haste & -ear \\
\hline hastilhar & 3172 & 80 & 1 & $S$ & hastilha & -ar \\
\hline hectometrar & 3173 & 22 & 1 & $S$ & hectômetro & -ar \\
\hline hegemonizar & 3174 & 1355 & 1 & $S$ & hegemonia & -izar \\
\hline heleborizar & 3175 & 128 & 1 & $S$ & heléboro & -izar \\
\hline hematizar & 3176 & 225 & 1 & $S$ & hematia & -izar \\
\hline hematosar-se & 3177 & 0 & 1 & $S$ & hematose & -ar \\
\hline hemodialisar & 3178 & 9 & 1 & $S$ & hemodiálise & -ar \\
\hline hemolisar & 3179 & 115 & 1 & $\mathrm{~S}$ & hemólise & -ar \\
\hline heresiar & 3180 & 63 & 1 & $\mathrm{~S}$ & heresia & -ar \\
\hline heterotransplant & 3181 & 0 & 1 & $S$ & heterotransplante & -ar \\
\hline hiatizar & 3182 & 85 & 1 & $S$ & hiato & -izar \\
\hline hidratar & 3183 & 74600 & 1 & $S$ & hidrato & -ar \\
\hline hidrolisar & 3184 & 2718 & 1 & $S$ & hidrólise & -ar \\
\hline hidroxilar & 3185 & 61 & 1 & $S$ & hidroxila & -ar \\
\hline hierarquizar & 3186 & 16400 & 1 & $S$ & hierarquia & -izar \\
\hline hifenizar & 3187 & 646 & 1 & S & hífen & -izar \\
\hline higienizar & 3188 & 16875 & 1 & $S$ & higiene & -izar \\
\hline hiperbolizar & 3189 & 334 & 1 & S & hipérbole & -izar \\
\hline hiperestesiar & 3190 & 79 & 1 & $S$ & hiperestesia & $-a r$ \\
\hline hipertrofiar & 3191 & 3990 & 1 & $S$ & hipertrofia & -ar \\
\hline \begin{tabular}{|l|} 
hipofisectomizar \\
\end{tabular} & 3192 & 0 & 1 & $\mathrm{~S}$ & hipofisectomia & -izar \\
\hline
\end{tabular}




\begin{tabular}{|c|c|c|c|c|c|c|c|c|}
\hline hipostasiar & 3193 & 548 & 1 & $S$ & & hipóstase & & -iar \\
\hline hipostenizar & 3194 & 8 & 1 & $S$ & & hipostenia & & -izar \\
\hline hipotecar & 3195 & 11175 & 1 & $S$ & & hipoteca & & -ar \\
\hline hipotrofiar & 3196 & 11 & 1 & $S$ & & hipotrofia & & -ar \\
\hline hissopar & 3197 & 94 & 1 & $S$ & & hissope & & -ar \\
\hline historiar & 3198 & 7145 & 1 & $S$ & & história & & -ar \\
\hline historizar & 3199 & 264 & 1 & $S$ & & história & & -izar \\
\hline holandizar & 3200 & 92 & 1 & $S$ & & holanda & & -izar \\
\hline holografar & 3201 & 51 & 1 & $S$ & & holograma & & -grafar \\
\hline homicidiar & 3202 & 90 & 1 & $S$ & & homicídio & & -iar \\
\hline homiliar & 3203 & 121 & 1 & $S$ & & homilia & & -ar \\
\hline homiziar & 3204 & 819 & 1 & $S$ & & homizio & & -ar \\
\hline honorar & 3205 & 295 & 1 & $S$ & & honor & & -ar \\
\hline horar & 3206 & 5823 & 1 & $S$ & & hora & & -ar \\
\hline horizontar & 3207 & 131 & 1 & $S$ & & horizonte & & -ar \\
\hline horoscopizar & 3208 & 93 & 1 & $S$ & & horóscopo & & -izar \\
\hline horrorizar & 3209 & 2518 & 1 & $S$ & & horror & & -izar \\
\hline hortar & 3210 & 816 & 1 & $S$ & & horta & & -ar \\
\hline humificar & 3211 & 80 & 1 & $S$ & & humo & $-\mathrm{i}-$ & -ficar \\
\hline humorizar & 3212 & 243 & 1 & $S$ & & humor & & -izar \\
\hline iconizar & 3213 & 154 & 1 & $S$ & & ícone & & -izar \\
\hline idear & 3214 & 1973 & 1 & $S$ & & idéia & & -ar \\
\hline ideologizar & 3215 & 1453 & 1 & $S$ & & ideologia & & -izar \\
\hline idilizar & 3216 & 46 & 1 & $S$ & & idílio & & -izar \\
\hline ignominiar & 3217 & 120 & 1 & $S$ & & ignomínia & & -ar \\
\hline igualhar & 3218 & 121 & 1 & $S$ & & igualha & & -ar \\
\hline ilhar & 3219 & 1418 & 1 & $S$ & & ilha & & -ar \\
\hline iluviar & 3220 & 14 & 1 & $S$ & & ilúvio & & -ar \\
\hline imbicar & 3221 & 234 & 1 & $P$ & im- & bico & & -ar \\
\hline impaludar & 3222 & 135 & 1 & $P$ & im- & palude & & -ar \\
\hline impetar & 3223 & 110 & 1 & $S$ & & ímpeto & & -ar \\
\hline impeticar & 3224 & 99 & 1 & $S$ & & ímpeto & & -icar \\
\hline implementar & 3225 & 1397500 & 2 & $S$ & & implemento & & $-a r$ \\
\hline impontar & 3226 & 54 & 1 & $S$ & im- & ponto & & -ar \\
\hline imposturar & 3227 & 104 & 1 & $S$ & & impostura & & -ar \\
\hline imprensar & 3228 & 1448 & 1 & $P$ & im- & prensa & & -ar \\
\hline impulsar & 3229 & 4670 & 1 & $S$ & & impulso & & -ar \\
\hline incendiar & 3230 & 145000 & 1 & $S$ & & incêndio & & -ar \\
\hline incrementar & 3231 & 704000 & 2 & $S$ & & incremento & & -ar \\
\hline indiciar & 3232 & 45200 & 1 & $S$ & & indício & & -ar \\
\hline indisciplinar & 3233 & 2078 & 1 & $S$ & & indisciplina & & -ar \\
\hline indulgenciar & 3234 & 231 & 1 & $S$ & & indulgência & & -ar \\
\hline indultar & 3235 & 1153 & 1 & $S$ & & indulto & & -ar \\
\hline indumentar & 3236 & 185 & 1 & $S$ & & indumento & & -ar \\
\hline industriar & 3237 & 374 & 1 & $S$ & & indústria & & -ar \\
\hline inerciar & 3238 & 206 & 1 & $S$ & & inércia & & -ar \\
\hline inervar & 3239 & 570 & 1 & $P$ & in- & nervo & & -ar \\
\hline infartar & 3240 & 6665 & 1 & $S$ & & infarto & & -ar \\
\hline infernar & 3241 & 301 & 1 & $\mathrm{~S}$ & & inferno & & -ar \\
\hline infernizar & 3242 & 28225 & 1 & $S$ & & inferno & & -izar \\
\hline influenciar & 3243 & 884500 & 2 & $S$ & & influência & & -ar \\
\hline infortunar & 3244 & 181 & 1 & $S$ & & infortuna & & -ar \\
\hline ingressar & 3245 & 936500 & 2 & $S$ & & ingresso & & -ar \\
\hline insoniar & 3246 & 82 & 1 & $S$ & & insônia & & -ar \\
\hline instrumentar & 3247 & 36600 & 1 & $S$ & & instrumento & & -ar \\
\hline insular & 3248 & 50225 & 1 & $S$ & & ínsula & & -ar \\
\hline interessar & 3249 & 986250 & 2 & $S$ & & interesse & & -ar \\
\hline interfonar & 3250 & 1320 & 1 & $S$ & & interfone & & -ar \\
\hline interpresar & 3251 & 75 & 1 & $S$ & & interpresa & & -ar \\
\hline intrigalhar & 3252 & 33 & 1 & $S$ & & intrigalha & & -ar \\
\hline invaginar & 3253 & 227 & 1 & $\mathrm{P}$ & in- & vagina & & -ar \\
\hline invectivar & 3254 & 563 & 1 & $S$ & & invectiva & & -ar \\
\hline invejar & 3255 & 26900 & 1 & $S$ & & inveja & & -ar \\
\hline inventariar & 3256 & 27500 & 1 & $S$ & & inventário & & -ar \\
\hline
\end{tabular}




\begin{tabular}{|c|c|c|c|c|c|c|c|}
\hline invernar & 3257 & 1838 & 1 & $S$ & inverno & & -ar \\
\hline iodar & 3258 & 161 & 1 & $S$ & iodo & & -ar \\
\hline ionizar & 3259 & 2538 & 1 & $\mathrm{~S}$ & íon & & -izar \\
\hline iotizar & 3260 & 72 & 1 & $S$ & iota & & -izar \\
\hline irar & 3261 & 20300 & 1 & $S$ & ira & & -ar \\
\hline irizar & 3262 & 8740 & 1 & $S$ & iriz & & -ar \\
\hline ironizar & 3263 & 24800 & 1 & $S$ & ironia & & -izar \\
\hline islamizar & 3264 & 516 & 1 & $S$ & islame & & -izar \\
\hline jabear & 3265 & 83 & 1 & $S$ & jabe & & -ear \\
\hline jactanciar-se & 3266 & 71 & 1 & S & jactância & & -ar \\
\hline jaezar & 3267 & 108 & 1 & $\mathrm{~S}$ & jaez & & -ar \\
\hline janar & 3268 & 290 & 1 & $S$ & jana & & -ar \\
\hline janelar & 3269 & 277 & 1 & $S$ & janela & & -ar \\
\hline jarretar & 3270 & 185 & 1 & $\mathrm{~S}$ & jarrete & & -ar \\
\hline jarretear & 3271 & 88 & 1 & $\mathrm{~S}$ & jarrete & & -ear \\
\hline jarundar & 3272 & 0 & 1 & $S$ & jarundo & & -ar \\
\hline jaspear & 3273 & 134 & 1 & $S$ & jaspe & & -ear \\
\hline javrar & 3274 & 153 & 1 & $S$ & javre & & -ar \\
\hline jazzificar & 3275 & 54 & 1 & $S$ & jazz & $-\mathrm{i}-$ & -ficar \\
\hline jiboiar & 3276 & 267 & 1 & $\mathrm{~S}$ & jibóia & & -ar \\
\hline joguetar & 3277 & 105 & 1 & $S$ & joguete & & -ar \\
\hline joguetear & 3278 & 161 & 1 & $\mathrm{~S}$ & joguete & & -ear \\
\hline jongar & 3279 & 167 & 1 & $S$ & jongo & & -ar \\
\hline jornadear & 3280 & 610 & 1 & $S$ & jornada & & -ear \\
\hline jornalizar & 3281 & 88 & 1 & $S$ & jornal & & -izar \\
\hline jorrar & 3283 & 35100 & 1 & $S$ & jorra & & -ar \\
\hline jugadar & 3284 & 93 & 1 & $\mathrm{~S}$ & jugada & & -ar \\
\hline jugar & 3285 & 37025 & 1 & $S$ & jugo & & -ar \\
\hline juncar & 3286 & 389 & 1 & $\mathrm{~S}$ & junco & & -ar \\
\hline juramentar & 3287 & 285 & 1 & $S$ & juramento & & -ar \\
\hline justiçar & 3288 & 1823 & 1 & $S$ & justiça & & -ar \\
\hline labirintar & 3289 & 175 & 1 & $\mathrm{~S}$ & labirinto & & -ar \\
\hline lacaiar & 3290 & 128 & 1 & $S$ & lacaio & & -ar \\
\hline lacar & 3291 & 2360 & 1 & $S$ & laca & & -ar \\
\hline laçar & 3292 & 25025 & 1 & $S$ & laço & & -ar \\
\hline lacrar & 3293 & 38650 & 1 & $\mathrm{~S}$ & lacre & & -ar \\
\hline lacrear & 3294 & 144 & 1 & $S$ & lacre & & -ear \\
\hline lactonizar & 3295 & 1 & 1 & $\mathrm{~S}$ & lactona & & -izar \\
\hline ladrilhar & 3296 & 2770 & 1 & $S$ & ladrilho & & -ar \\
\hline ladroeirar & 3297 & 78 & 1 & $S$ & ladroeira & & -ar \\
\hline lagartear & 3298 & 942 & 1 & $\mathrm{~S}$ & lagarto & & -ear \\
\hline lagrimar & 3299 & 802 & 1 & $S$ & lágrima & & -ar \\
\hline lagrimejar & 3300 & 232 & 1 & $\mathrm{~S}$ & lágrima & & -ejar \\
\hline Iajear & 3301 & 139 & 1 & $S$ & laje & & -ear \\
\hline lambancear & 3302 & 94 & 1 & $S$ & lambança & & -ear \\
\hline lamelar & 3303 & 12475 & 1 & $S$ & lamela & & -ar \\
\hline laminar & 3304 & 38875 & 1 & $S$ & lâmina & & -ar \\
\hline lampadejar & 3305 & 112 & 1 & $S$ & lâmpada & & -ejar \\
\hline lampejar & 3306 & 839 & 1 & $S$ & lampa & & -ejar \\
\hline lamuriar & 3307 & 2873 & 1 & $S$ & lamúria & & -ar \\
\hline lancetar & 3308 & 776 & 1 & $S$ & lanceta & & -ar \\
\hline lanchar & 3309 & 23375 & 1 & $S$ & lanche & & -ar \\
\hline lantejoilar & 3310 & 76 & 1 & $S$ & lantejoila & & -ar \\
\hline lantejoular & 3311 & 106 & 1 & $S$ & lantejoula & & -ar \\
\hline lanternar & 3312 & 367 & 1 & $S$ & lanterna & & -ar \\
\hline lapear & 3313 & 174 & 1 & $S$ & lapo & & -ear \\
\hline lapisar & 3314 & 84 & 1 & $S$ & lápis & & -ar \\
\hline laquear & 3315 & 1225 & 1 & $S$ & laquê & & -ar \\
\hline larachear & 3316 & 70 & 1 & $S$ & laracha & & -ear \\
\hline larapiar & 3317 & 283 & 1 & $S$ & larápio & & -ar \\
\hline lardear & 3318 & 457 & 1 & $S$ & lardo & & -ear \\
\hline larear & 3319 & 66 & 1 & $S$ & laré & & -ar \\
\hline lascar & 3320 & 61025 & 1 & $S$ & lasca & & -ar \\
\hline lastrar & 3321 & 479 & 1 & $S$ & lastro & & -ar \\
\hline
\end{tabular}




\begin{tabular}{|c|c|c|c|c|c|c|c|}
\hline lastrear & 3322 & 10950 & 1 & $S$ & lastro & & -ear \\
\hline laudanizar & 3324 & 64 & 1 & $S$ & láudano & & -izar \\
\hline lavorear & 3325 & 0 & 1 & $S$ & lavor & & -ear \\
\hline lavourar & 3326 & 155 & 1 & $S$ & lavoura & & -ar \\
\hline lazeirar & 3327 & 130 & 1 & $S$ & lazeira & & -ar \\
\hline legrar & 3328 & 107 & 1 & $\mathrm{~S}$ & legra & & -ar \\
\hline leiautar & 3329 & 129 & 1 & $S$ & leiaute & & -ar \\
\hline leirar & 3330 & 100 & 1 & $S$ & leira & & -ar \\
\hline leitar & 3331 & 233 & 1 & $\mathrm{~S}$ & leite & & -ar \\
\hline lembar & 3332 & 3738 & 1 & $S$ & lemba & & -ar \\
\hline lengalengar & 3333 & 77 & 1 & $S$ & lengalenga & & -ar \\
\hline lenhar & 3334 & 2283 & 1 & $S$ & lenha & & -ar \\
\hline lenhificar-se & 3335 & 2 & 1 & $\mathrm{~S}$ & lenha & $-i-$ & -ficar \\
\hline lentejoular & 3336 & 68 & 1 & $S$ & lentejoula & & -ar \\
\hline lesmar & 3337 & 145 & 1 & $S$ & lesma & & -ar \\
\hline letargiar & 3338 & 93 & 1 & $S$ & letargia & & -ar \\
\hline letrear & 3339 & 139 & 1 & $S$ & letra & & -ear \\
\hline lexicografar & 3340 & 106 & 1 & $S$ & lexicógrafo & & -ar \\
\hline libelar & 3341 & 113 & 1 & $S$ & libelo & & -ar \\
\hline \begin{tabular}{|l} 
librinar \\
\end{tabular} & 3342 & 84 & 1 & $S$ & librina & & -ar \\
\hline licenciar & 3343 & 132000 & 1 & $S$ & licença & & -iar \\
\hline lidar & 3344 & 1540000 & 2 & $S$ & lide & & -ar \\
\hline liderar & 3345 & 590750 & 2 & $S$ & líder & & -ar \\
\hline limar & 3346 & 11200 & 1 & $S$ & $\operatorname{limo}$ & & -ar \\
\hline lingar & 3347 & 314 & 1 & $S$ & linga & & -ar \\
\hline \begin{tabular}{|l|} 
linimentar \\
\end{tabular} & 3348 & 108 & 1 & $S$ & linimento & & -ar \\
\hline linotipar & 3349 & 102 & 1 & $S$ & linotipo & & -ar \\
\hline lipolisar & 3350 & 0 & 1 & $S$ & lipólise & & -ar \\
\hline lisonjar & 3351 & 82 & 1 & $S$ & lisonja & & -ar \\
\hline lisonjear & 3352 & 3728 & 1 & $S$ & lisonja & & -ear \\
\hline listar & 3353 & 508500 & 2 & $S$ & lista & & -ar \\
\hline listrar & 3354 & 423 & 1 & $S$ & listra & & -ar \\
\hline literaturar & 3355 & 150 & 1 & $S$ & literatura & & -ar \\
\hline \begin{tabular}{|l|} 
litigiar \\
\end{tabular} & 3356 & 121 & 1 & $S$ & litígio & & -ar \\
\hline litografar & 3357 & 233 & 1 & $S$ & litógrafo & & -ar \\
\hline \begin{tabular}{|l|} 
livelar \\
\end{tabular} & 3358 & 101 & 1 & $S$ & livel & & -ar \\
\hline lixar & 3359 & 43125 & 1 & $S$ & lixa & & -ar \\
\hline lixiviar & 3360 & 992 & 1 & $S$ & lixívia & & -ar \\
\hline lobolar & 3361 & 24 & 1 & $S$ & lobolo & & -ar \\
\hline lobotomizar & 3362 & 166 & 1 & $S$ & lobotomia & & -izar \\
\hline \begin{tabular}{|l} 
logicar \\
\end{tabular} & 3363 & 248 & 1 & $S$ & lógica & & -ar \\
\hline lombear & 3364 & 108 & 1 & $S$ & lombo & & -ear \\
\hline lombear-se & 3365 & 25 & 1 & $S$ & lomba & & -ear \\
\hline lombilhar & 3366 & 64 & 1 & $S$ & lombilho & & -ar \\
\hline lorotar & 3367 & 124 & 1 & $S$ & Iorota & & -ar \\
\hline lotar & 3368 & 181000 & 1 & $S$ & lote & & -ar \\
\hline lotear & 3369 & 8605 & 1 & $S$ & lote & & -ear \\
\hline louçainhar & 3370 & 78 & 1 & $S$ & louçainha & & -ar \\
\hline lousar & 3371 & 7 & 1 & $S$ & lousa & & -ar \\
\hline \begin{tabular}{|l|} 
louvaminhar \\
\end{tabular} & 3372 & 123 & 1 & $S$ & louvaminha & & -ar \\
\hline \begin{tabular}{|l} 
Iudibriar \\
\end{tabular} & 3373 & 37900 & 1 & $S$ & ludíbrio & & -ar \\
\hline \begin{tabular}{|l|} 
lufar \\
\end{tabular} & 3374 & 638 & 1 & $S$ & lufa & & -ar \\
\hline lumpesinar & 3375 & 79 & 1 & $S$ & lumpesinato & & -ar \\
\hline Iupar & 3376 & 966 & 1 & $S$ & lupa & & -ar \\
\hline Iurar & 3377 & 5590 & 1 & $S$ & lura & & -ar \\
\hline lustrar & 3378 & 11725 & 1 & $S$ & lustro & & -ar \\
\hline luteinizar & 3379 & 21 & 1 & $S$ & luteína & & -izar \\
\hline Iuxar & 3380 & 1338 & 1 & $S$ & luxo & & -ar \\
\hline macadamizar & 3381 & 551 & 1 & $S$ & macadame & & -izar \\
\hline maçanetar & 3382 & 102 & 1 & $S$ & maçaneta & & -ar \\
\hline maçar & 3383 & 1318 & 1 & $\mathrm{~S}$ & maça & & -ar \\
\hline maçarocar & 3384 & 99 & 1 & $S$ & maçaroca & & -ar \\
\hline macetar & 3385 & 634 & 1 & $\mathrm{~S}$ & macete & & -ar \\
\hline macetear & 3386 & 285 & 1 & $S$ & macete & & -ear \\
\hline
\end{tabular}




\begin{tabular}{|c|c|c|c|c|c|c|c|}
\hline machadar & 3387 & 255 & 1 & $\mathrm{~S}$ & & machado & -ar \\
\hline maconhar & 3388 & 41 & 1 & $S$ & & maconha & -ar \\
\hline macucar & 3389 & 189 & 1 & $\mathrm{~S}$ & & macuco & -ar \\
\hline madeirar & 3390 & 366 & 1 & $S$ & & madeira & -ar \\
\hline madeirizar & 3391 & 1 & 1 & $S$ & & madeira & -izar \\
\hline madeixar-se & 3392 & 25 & 1 & $\mathrm{~S}$ & & madeixa & -ar \\
\hline madonizar & 3393 & 0 & 1 & $S$ & & madona & -izar \\
\hline madornar & 3394 & 128 & 1 & $S$ & & madorna & -ar \\
\hline madorrar & 3395 & 97 & 1 & $S$ & & madorra & -ar \\
\hline madrigalizar & 3396 & 142 & 1 & $\mathrm{~S}$ & & madrigal & -izar \\
\hline madrinhar & 3397 & 148 & 1 & $S$ & & madrinha & -ar \\
\hline magnetizar & 3398 & 3443 & 1 & $S$ & & magneto & -izar \\
\hline majorar & 3399 & 19475 & 1 & $S$ & & major- & -ar \\
\hline malar & 3400 & 9955 & 1 & $S$ & & mala & -ar \\
\hline maleficiar & 3401 & 205 & 1 & $S$ & & malefício & -ar \\
\hline malenconizar & 3402 & 5 & 1 & $S$ & & malenconia & -izar \\
\hline malhar & 3406 & 207000 & 1 & $S$ & & malha & -ar \\
\hline malhetar & 3407 & 127 & 1 & $S$ & & malhete & -ar \\
\hline maliciar & 3408 & 664 & 1 & $S$ & & malícia & -ar \\
\hline malinguar & 3409 & 37 & 1 & $\mathrm{P}$ & mal- & língua & -ar \\
\hline malocar & 3410 & 531 & 1 & $S$ & & maloca & -ar \\
\hline maltar & 3411 & 297 & 1 & $S$ & & malte & -ar \\
\hline mamparrear & 3412 & 150 & 1 & $S$ & & mamparra & -ear \\
\hline mamujar & 3413 & 111 & 1 & $S$ & & mama & -ujar \\
\hline manchar & 3414 & 145000 & 1 & $S$ & & mancha & -ar \\
\hline manchetar & 3415 & 157 & 1 & $S$ & & manchete & -ar \\
\hline mandriar & 3416 & 271 & 1 & $\mathrm{~S}$ & & mândria & -ar \\
\hline mandrilar & 3417 & 1348 & 1 & $S$ & & mandril & -ar \\
\hline maneirar & 3418 & 18575 & 1 & $S$ & & maneira & -ar \\
\hline mangabar & 3419 & 260 & 1 & $S$ & & mangaba & -ar \\
\hline mangar & 3420 & 4298 & 1 & $S$ & & manga & -ar \\
\hline mangonar & 3421 & 111 & 1 & $\mathrm{~S}$ & & mangona & -ar \\
\hline mangonear & 3422 & 104 & 1 & $S$ & & mangona & -ear \\
\hline mangorrear & 3423 & 77 & 1 & $S$ & & mangorra & -ear \\
\hline mangrar & 3424 & 98 & 1 & $S$ & & mangra & -ar \\
\hline manheirar & 3425 & 80 & 1 & $S$ & & manheira & -ar \\
\hline maniganciar & 3426 & 252 & 1 & $S$ & & manigância & -ar \\
\hline manilhar & 3427 & 188 & 1 & $S$ & & manilha & -ar \\
\hline manivelar & 3428 & 176 & 1 & $\mathrm{~S}$ & & manivela & -ar \\
\hline manocar & 3429 & 1465 & 1 & $S$ & & manoca & -ar \\
\hline mantar & 3430 & 4820 & 1 & $\mathrm{~S}$ & & manta & -ar \\
\hline mantear & 3431 & 266 & 1 & $S$ & & manta & -ear \\
\hline manufaturar & 3432 & 4783 & 1 & $S$ & & manufatura & -ar \\
\hline mapear & 3433 & 346000 & 1 & $S$ & & mapa & -ear \\
\hline maquiar & 3434 & 73975 & 1 & $S$ & & maquia & -ar \\
\hline marafonear & 3435 & 187 & 1 & $S$ & & marafona & -ear \\
\hline maragatear & 3436 & 88 & 1 & $S$ & & maragato & -ear \\
\hline marambaiar & 3437 & 104 & 1 & $S$ & & marambaia & -ar \\
\hline maranhar & 3438 & 110 & 1 & $S$ & & maranha & -ar \\
\hline marasmar & 3439 & 112 & 1 & $S$ & & marasmo & -ar \\
\hline marcar & 3440 & 566000 & 2 & $\mathrm{~S}$ & & marca & -ar \\
\hline marceneirar & 3441 & 217 & 1 & $S$ & & marceneiro & -ar \\
\hline marear & 3442 & 2780 & 1 & $\mathrm{~S}$ & & mar- & -ear \\
\hline marejar & 3443 & 1790 & 1 & $S$ & & mar & -ejar \\
\hline marfinizar & 3444 & 76 & 1 & $S$ & & marfim & -izar \\
\hline margar & 3445 & 734 & 1 & $S$ & & marga & -ar \\
\hline margear & 3446 & 1783 & 1 & $S$ & & margem & -ar \\
\hline marimbar & 3448 & 148 & 1 & $S$ & & marimba & -ar \\
\hline marinhar & 3449 & 173 & 1 & $S$ & & marinha & -ar \\
\hline mariposar & 3450 & 103 & 1 & $S$ & & mariposa & -ar \\
\hline mariposear & 3451 & 81 & 1 & $S$ & & mariposa & -ear \\
\hline marlotar & 3452 & 80 & 1 & $S$ & & marlota & -ar \\
\hline marmelar & 3453 & 50 & 1 & $S$ & & marmelo & -ar \\
\hline marmorear & 3454 & 139 & 1 & $S$ & & mármore & -ear \\
\hline
\end{tabular}




\begin{tabular}{|c|c|c|c|c|c|c|}
\hline marmorizar & 3455 & 245 & 1 & $S$ & mármore & -izar \\
\hline marombar & 3456 & 463 & 1 & $S$ & maromba & -ar \\
\hline marombear & 3457 & 78 & 1 & $S$ & maromba & -ear \\
\hline marrar & 3458 & 885 & 1 & $S$ & marra & -ar \\
\hline marretar & 3459 & 2160 & 1 & $S$ & marreta & -ar \\
\hline marroquinar & 3460 & 119 & 1 & S & marroquim & -ar \\
\hline marteirar & 3461 & 81 & 1 & $S$ & marteiro & -ar \\
\hline martelar & 3462 & 13950 & 1 & $S$ & martelo & -ar \\
\hline martelejar & 3463 & 125 & 1 & $S$ & martelo & -ejar \\
\hline marulhar & 3464 & 2553 & 1 & $S$ & marulho & -ar \\
\hline mascarar & 3465 & 73275 & 1 & $S$ & máscara & -ar \\
\hline mascatear & 3466 & 453 & 1 & $S$ & mascate & -ear \\
\hline massagear & 3467 & 41200 & 1 & $S$ & massagem & -ear \\
\hline mastrear & 3468 & 115 & 1 & $S$ & mastro & -ear \\
\hline matabichar & 3469 & 8 & 1 & $S$ & mata-bicho & -ar \\
\hline matear & 3470 & 605 & 1 & $S$ & mato & -ear \\
\hline matejar & 3471 & 177 & 1 & $S$ & mato & -ejar \\
\hline matinar & 3472 & 211 & 1 & $S$ & matina & -ar \\
\hline matizar & 3473 & 21200 & 1 & $S$ & matriz & -ar \\
\hline matracar & 3474 & 669 & 1 & $S$ & matraca & -ar \\
\hline matracolejar & 3475 & 139 & 1 & $S$ & matraca & -ejar \\
\hline matraquear & 3476 & 1328 & 1 & $S$ & matraca & -ear \\
\hline matricular & 3477 & 382750 & 1 & $S$ & matrícula & -ar \\
\hline matrimoniar & 3478 & 304 & 1 & $S$ & matrimônio & -ar \\
\hline matrucar & 3479 & 148 & 1 & $S$ & matruco & -ar \\
\hline maturrangar & 3480 & 142 & 1 & $S$ & maturrango & -ar \\
\hline maturranguear & 3481 & 137 & 1 & $S$ & maturrango & -ear \\
\hline maturrenguear & 3482 & 141 & 1 & $S$ & maturrengo & -ear \\
\hline maxixar & 3483 & 299 & 1 & $S$ & maxixe & -ar \\
\hline mazelar & 3484 & 337 & 1 & $S$ & mazela & -ar \\
\hline mealhar & 3485 & 174 & 1 & $S$ & mealha & -ar \\
\hline meandrar & 3486 & 228 & 1 & $S$ & meandro & -ar \\
\hline mechar & 3487 & 648 & 1 & $S$ & mecha & -ar \\
\hline medalhar & 3488 & 808 & 1 & $S$ & medalha & -ar \\
\hline medicamentar & 3489 & 290 & 1 & $S$ & medicamento & -ar \\
\hline medicinar & 3490 & 252 & 1 & $S$ & medicina & -ar \\
\hline medular & 3491 & 51700 & 1 & $S$ & medula & -ar \\
\hline melancolizar & 3492 & 187 & 1 & $S$ & melancolia & -izar \\
\hline melar & 3493 & 32225 & 1 & $S$ & mel & -ar \\
\hline melindrar & 3495 & 6073 & 1 & $S$ & melindre & -ar \\
\hline melodiar & 3496 & 265 & 1 & $S$ & melodia & -ar \\
\hline melodizar & 3497 & 183 & 1 & $S$ & melodia & -izar \\
\hline memoriar & 3498 & 206 & 1 & $S$ & memória & -ar \\
\hline memorizar & 3499 & 564500 & 2 & $S$ & memória & -izar \\
\hline menstruar & 3500 & 21325 & 1 & $S$ & mênstruo & -ar \\
\hline mentar & 3501 & 55200 & 1 & $S$ & mente & -ar \\
\hline mentirolar & 3502 & 171 & 1 & $S$ & mentirola & -ar \\
\hline mentorear & 3503 & 603 & 1 & $S$ & mentor & -ear \\
\hline mercadejar & 3504 & 1305 & 1 & $\mathrm{~S}$ & mercado & -ejar \\
\hline mercadizar & 3505 & 127 & 1 & $S$ & mercado & -izar \\
\hline mercanciar & 3506 & 241 & 1 & $S$ & mercancia & -ar \\
\hline metabolizar & 3507 & 11575 & 1 & $S$ & metábole & -izar \\
\hline metafisicar & 3508 & 81 & 1 & $S$ & metafísica & -ar \\
\hline metaforizar & 3509 & 1763 & 1 & $S$ & metáfora & -izar \\
\hline metalizar & 3510 & 1380 & 1 & $S$ & metal & -izar \\
\hline metamorfosear & 3511 & 5053 & 1 & $S$ & metamorfose & -ear \\
\hline metilar & 3512 & 207 & 1 & $S$ & metila & -ar \\
\hline metodizar & 3513 & 938 & 1 & $S$ & método & -izar \\
\hline metralhar & 3514 & 6250 & 1 & $S$ & metralha & -ar \\
\hline mezinhar & 3515 & 93 & 1 & $S$ & mezinha & -ar \\
\hline miar & 3516 & 13125 & 1 & $\mathrm{~S}$ & miau & -ar \\
\hline micar & 3517 & 549 & 1 & $S$ & mico & -ar \\
\hline microfilmar & 3518 & 1550 & 1 & $S$ & microfilme & -ar \\
\hline microminiaturiza & 3519 & 1 & 1 & $S$ & microminiatura & -izar \\
\hline
\end{tabular}




\begin{tabular}{|c|c|c|c|c|c|c|c|}
\hline mielinizar & 3520 & 19 & 1 & $S$ & mielina & & -izar \\
\hline migalhar & 3521 & 180 & 1 & $S$ & migalha & & -ar \\
\hline migar & 3522 & 747 & 1 & $S$ & miga & & -ar \\
\hline milhar & 3523 & 28950 & 1 & $S$ & milho & & -ar \\
\hline milimetrar & 3524 & 180 & 1 & S & milímetro & & -ar \\
\hline mimar & 3525 & 43000 & 1 & S & mimo & & -ar \\
\hline mimeografar & 3526 & 421 & 1 & $S$ & mimeógrafo & & -ar \\
\hline mimicar & 3527 & 152 & 1 & S & mímica & & -ar \\
\hline miniaturar & 3528 & 266 & 1 & $S$ & miniatura & & -ar \\
\hline miniaturizar & 3529 & 2093 & 1 & S & miniatura & & -izar \\
\hline ministrificar & 3530 & 137 & 1 & $S$ & ministro & $-\mathrm{i}-$ & -ficar \\
\hline minuciar & 3531 & 429 & 1 & $S$ & minúcia & & -ar \\
\hline minudenciar & 3532 & 1058 & 1 & $S$ & minudência & & -ar \\
\hline minutar & 3533 & 6630 & 1 & $S$ & minuta & & -ar \\
\hline mirrar & 3534 & 672 & 1 & S & mirra & & -ar \\
\hline missar & 3535 & 270 & 1 & $S$ & missa & & -ar \\
\hline misturar & 3536 & 1220000 & 2 & S & mistura & & -ar \\
\hline mitificar & 3537 & 2223 & 1 & S & mito & $-\mathrm{i}-$ & -ficar \\
\hline mitridatizar & 3538 & 89 & 1 & S & mitridato & & -izar \\
\hline mobiliar & 3539 & 14325 & 1 & $S$ & mobília & & -ar \\
\hline mocar & 3540 & 14025 & 1 & $S$ & moca & & -ar \\
\hline moçar & 3541 & 302 & 1 & $S$ & moça & & -ar \\
\hline mocozear & 3542 & 259 & 1 & $S$ & mocó & $-z-$ & -ear \\
\hline modelar & 3543 & 761250 & 2 & $S$ & modelo & & -ar \\
\hline modorrar & 3544 & 276 & 1 & $S$ & modorra & & -ar \\
\hline mofar & 3545 & 10175 & 1 & $S$ & mofo & & -ar \\
\hline mofumbar & 3546 & 81 & 1 & $S$ & mofumbo & & -ar \\
\hline mogangar & 3547 & 76 & 1 & $S$ & moganga & & -ar \\
\hline moinar & 3548 & 68 & 1 & $S$ & moina & & -ar \\
\hline moinhar & 3549 & 54 & 1 & $S$ & moinho & & -ar \\
\hline moitar & 3550 & 111 & 1 & $S$ & moita & & -ar \\
\hline mojicar & 3551 & 86 & 1 & S & mojica & & -ar \\
\hline moldar & 3552 & 121500 & 1 & S & molde & & -ar \\
\hline moldear & 3553 & 268 & 1 & $S$ & molde & & -ear \\
\hline molinhar & 3554 & 136 & 1 & $S$ & molinha & & -ar \\
\hline monarquiar & 3555 & 160 & 1 & $S$ & monarquia & & -ar \\
\hline moncar & 3556 & 258 & 1 & $S$ & monco & & -ar \\
\hline monodiar & 3557 & 60 & 1 & $S$ & monodia & & -ar \\
\hline monologar & 3558 & 1228 & 1 & $S$ & monólogo & & -ar \\
\hline monotipar & 3559 & 64 & 1 & $S$ & monotipo & & -ar \\
\hline monotongar & 3560 & 7 & 1 & $S$ & monotongo & & -ar \\
\hline montear & 3561 & 421 & 1 & $S$ & monte & & -ear \\
\hline moquecar & 3563 & 102 & 1 & $S$ & moqueca & & -ar \\
\hline morcegar & 3564 & 1485 & 1 & $S$ & morcego & & -ar \\
\hline mordaçar & 3565 & 147 & 1 & $S$ & mordaça & & -ar \\
\hline mordomear & 3566 & 83 & 1 & S & mordomo & & -ear \\
\hline morfinizar & 3567 & 192 & 1 & $S$ & morfina & & -izar \\
\hline morgar & 3568 & 2178 & 1 & $S$ & morgue & & -ar \\
\hline mosquetear & 3569 & 111 & 1 & S & mosquete & & -ear \\
\hline mostrengar & 3570 & 117 & 1 & S & mostrengo & & -ar \\
\hline motejar & 3571 & 647 & 1 & S & mote & & -ejar \\
\hline movimentar & 3572 & 736500 & 2 & $S$ & movimento & & -ar \\
\hline moxamar & 3573 & 88 & 1 & $S$ & moxama & & -ar \\
\hline mujimbar & 3574 & 0 & 1 & $S$ & mujimbo & & -ar \\
\hline multar & 3575 & 182000 & 1 & S & multa & & -ar \\
\hline mumificar & 3576 & 1288 & 1 & $S$ & múmia & & -ficar \\
\hline mungangar & 3577 & 1 & 1 & S & mungango & & -ar \\
\hline muralhar & 3578 & 138 & 1 & $S$ & muralha & & -ar \\
\hline murar & 3579 & 4080 & 1 & $S$ & muro & & -ar \\
\hline murmulhar & 3580 & 128 & 1 & $S$ & murmulho & & -ar \\
\hline murmurejar & 3581 & 518 & 1 & $S$ & murmúrio & & -ejar \\
\hline murmurinhar & 3582 & 191 & 1 & S & murmurinho & & -ar \\
\hline \begin{tabular}{|l} 
musicar \\
\end{tabular} & 3583 & 8870 & 1 & $S$ & música & & -ar \\
\hline musiquear & 3584 & 165 & 1 & $S$ & música & & -ear \\
\hline
\end{tabular}




\begin{tabular}{|c|c|c|c|c|c|c|c|}
\hline muxoxar & 3585 & 144 & 1 & $S$ & muxoxo & & -ar \\
\hline muxoxear & 3586 & 91 & 1 & $S$ & muxoxo & & -ear \\
\hline nadificar & 3587 & 221 & 1 & $S$ & nada & $-\mathrm{i}-$ & -ficar \\
\hline naipar & 3588 & 126 & 1 & $S$ & naipe & & -ar \\
\hline namoricar & 3589 & 269 & 1 & $S$ & namorico & & -ar \\
\hline namoriscar & 3590 & 255 & 1 & S & namorisco & & -ar \\
\hline nanar & 3591 & 9468 & 1 & $S$ & nana & & -ar \\
\hline narcisar-se & 3592 & 106 & 1 & $S$ & narciso & & -ar \\
\hline navalhar & 3593 & 410 & 1 & $S$ & navalha & & -ar \\
\hline neblinar & 3594 & 276 & 1 & $S$ & neblina & & -ar \\
\hline nebulizar & 3595 & 782 & 1 & $S$ & nébula & & -izar \\
\hline necropsiar & 3596 & 234 & 1 & $S$ & necropsia & & -ar \\
\hline necrosar & 3597 & 1178 & 1 & $S$ & necrose & & -ar \\
\hline nectarizar & 3598 & 106 & 1 & $S$ & néctar & & -izar \\
\hline negaçar & 3599 & 0 & 1 & $S$ & negaça & & -ar \\
\hline negacear & 3600 & 1015 & 1 & $S$ & negaça & & -ear \\
\hline negligenciar & 3601 & 45575 & 1 & $S$ & negligência & & -iar \\
\hline neologismar & 3602 & 123 & 1 & $S$ & neologismo & & -ar \\
\hline neologizar & 3603 & 96 & 1 & $S$ & neologia & & -izar \\
\hline nesgar & 3604 & 12 & 1 & $S$ & nesga & & -ar \\
\hline neurastenizar & 3605 & 437 & 1 & $S$ & neurastenia & & -izar \\
\hline neviscar & 3606 & 79 & 1 & $S$ & neve & & -iscar \\
\hline nicotinar & 3607 & 0 & 1 & $S$ & nicotina & & -ar \\
\hline nicotinizar & 3608 & 0 & 1 & $S$ & nicotina & & -izar \\
\hline nigelar & 3609 & 87 & 1 & $S$ & nigela & & -ar \\
\hline ninar & 3610 & 104000 & 1 & $S$ & nina & & -ar \\
\hline ninhar & 3611 & 181 & 1 & $S$ & ninho & & -ar \\
\hline niquelar & 3612 & 722 & 1 & $S$ & níquel & & -ar \\
\hline nitratar & 3613 & 93 & 1 & $S$ & nitrato & & -ar \\
\hline nitretar & 3614 & 106 & 1 & $S$ & nitreto & & -ar \\
\hline noivar & 3615 & 8828 & 1 & $S$ & noiva & & -ar \\
\hline nomenclaturar & 3616 & 151 & 1 & $S$ & nomenclatura & & -ar \\
\hline nostalgizar & 3617 & 162 & 1 & $S$ & nostalgia & & -izar \\
\hline noticiar & 3618 & 61225 & 1 & $S$ & notícia & & -ar \\
\hline novelar & 3619 & 309 & 1 & $S$ & novela & & -ar \\
\hline nuançar & 3620 & 714 & 1 & $S$ & nuance & & -ar \\
\hline nuclear & 3621 & 375250 & 1 & $\mathrm{~S}$ & núcleo & & -ar \\
\hline nupciar-se & 3622 & 31 & 1 & $S$ & núpcias & & -ar \\
\hline objetificar & 3623 & 597 & 1 & $S$ & objeto & $-i-$ & -ficar \\
\hline oblatar & 3624 & 117 & 1 & $S$ & oblata & & -ar \\
\hline obradar & 3625 & 46 & 1 & $S$ & obrada & & -ar \\
\hline obsequiar & 3626 & 2045 & 1 & $S$ & obséquio & & -ar \\
\hline obstaculizar & 3627 & 44050 & 1 & $S$ & obstáculo & & -izar \\
\hline odiar & 3628 & 225750 & 1 & $S$ & ódio & & -ar \\
\hline odorizar & 3629 & 171 & 1 & $S$ & odor & & -izar \\
\hline oferendar & 3630 & 485 & 1 & $S$ & oferenda & & -ar \\
\hline ofertar & 3631 & 398000 & 1 & $S$ & oferta & & -ar \\
\hline oficiar & 3632 & 47400 & 1 & $S$ & ofício & & -ar \\
\hline oitavar & 3633 & 574 & 1 & $S$ & oitavo & & -ar \\
\hline ojerizar & 3634 & 150 & 1 & $S$ & ojeriza & & -ar \\
\hline olear & 3635 & 639 & 1 & $S$ & óleo & & -ar \\
\hline oligarquizar & 3636 & 211 & 1 & $S$ & oligarquia & & -izar \\
\hline ombrear & 3637 & 4643 & 1 & $S$ & ombro & & -ear \\
\hline onanizar & 3638 & 148 & 1 & $S$ & onanismo & & -izar \\
\hline ondar & 3639 & 1205 & 1 & $S$ & onda & & -ar \\
\hline ondear & 3640 & 1138 & 1 & $S$ & onda & & -ear \\
\hline ondejar & 3641 & 79 & 1 & $S$ & onda & & -ejar \\
\hline onzenar & 3642 & 120 & 1 & $S$ & onzena & & -ar \\
\hline onzenear & 3643 & 72 & 1 & $S$ & onzena & & -ear \\
\hline opiar & 3644 & 279 & 1 & $S$ & ópio & & -ar \\
\hline opuscular & 3645 & 30 & 1 & $S$ & opúsculo & & -ar \\
\hline oracular & 3646 & 5038 & 1 & $S$ & oráculo & & -ar \\
\hline oraculizar & 3647 & 83 & 1 & $S$ & oráculo & & -izar \\
\hline orbitar & 3648 & 6838 & 1 & $S$ & órbita & & -ar \\
\hline
\end{tabular}




\begin{tabular}{|c|c|c|c|c|c|c|}
\hline orelhar & 3649 & 294 & 1 & $S$ & orelha & -ar \\
\hline organsinar & 3650 & 97 & 1 & $S$ & organsim & -ar \\
\hline orgulhar & 3651 & 114000 & 1 & $S$ & orgulho & -ar \\
\hline originar & 3652 & 83475 & 1 & $S$ & origem & -ar \\
\hline ornamentar & 3653 & 15900 & 1 & $S$ & ornamento & -ar \\
\hline orquestrar & 3654 & 11125 & 1 & S & orquestra & -ar \\
\hline ortografar & 3655 & 257 & 1 & $S$ & ortografia & -ar \\
\hline orvalhar & 3656 & 999 & 1 & $S$ & orvalho & -ar \\
\hline ourar & 3658 & 263 & 1 & $S$ & ouro & -ar \\
\hline ourelar & 3659 & 22 & 1 & $S$ & ourela & -ar \\
\hline ouriçar & 3660 & 731 & 1 & $S$ & ouriço & -ar \\
\hline outonear & 3661 & 103 & 1 & $S$ & outono & -ear \\
\hline ovular & 3662 & 9108 & 1 & $S$ & óvulo & -ar \\
\hline oxidar & 3663 & 14650 & 1 & $S$ & óxido & -ar \\
\hline oxidular & 3664 & 108 & 1 & $S$ & oxídulo & -ar \\
\hline oxigenar & 3665 & 16975 & 1 & $S$ & oxigênio & -ar \\
\hline Ozonar & 3666 & 72 & 1 & $S$ & ozônio & -ar \\
\hline ozonizar & 3667 & 122 & 1 & $S$ & ozônio & -izar \\
\hline pacejar & 3668 & 101 & 1 & $S$ & paço & -ejar \\
\hline padejar & 3669 & 316 & 1 & $S$ & pada & -ejar \\
\hline padrar-se & 3670 & 36 & 1 & $S$ & padre & -ar \\
\hline pagaiar & 3671 & 3 & 1 & $S$ & pagaia & -ar \\
\hline paginar & 3672 & 8160 & 1 & $S$ & página & -ar \\
\hline pagodear & 3673 & 7048 & 1 & $S$ & pagode & -ear \\
\hline paivar & 3674 & 116 & 1 & $S$ & paivo & -ar \\
\hline palancar & 3675 & 467 & 1 & $S$ & palanca & $-a r$ \\
\hline palanquear & 3676 & 303 & 1 & $S$ & palanque & -ar \\
\hline palatizar & 3677 & 103 & 1 & S & palato & -izar \\
\hline palavrear & 3678 & 1093 & 1 & $S$ & palavra & -ear \\
\hline paleografar & 3679 & 89 & 1 & $S$ & paleografia & -ar \\
\hline palestrar & 3680 & 27325 & 1 & $S$ & palestra & -ar \\
\hline palestrear & 3681 & 95 & 1 & $S$ & palestra & -ear \\
\hline paletar & 3682 & 669 & 1 & $S$ & paleta & $-a r$ \\
\hline paletear & 3683 & 157 & 1 & $S$ & paleta & -ear \\
\hline palhetar & 3684 & 3505 & 1 & $S$ & palheta & -ar \\
\hline palhetear & 3685 & 152 & 1 & $S$ & palheta & -ear \\
\hline palitar & 3686 & 2350 & 1 & $S$ & palito & -ar \\
\hline palmar & 3687 & 225500 & 1 & $S$ & palmo & -ar \\
\hline palmatoriar & 3688 & 211 & 1 & $S$ & palmatória & $-a r$ \\
\hline palmear & 3689 & 553 & 1 & $S$ & palmo & -ear \\
\hline palmejar & 3690 & 211 & 1 & $S$ & palma & -ejar \\
\hline palmetear & 3691 & 191 & 1 & $S$ & palmeta & -ear \\
\hline palmilhar & 3692 & 3510 & 1 & $S$ & palmilha & -ar \\
\hline palomar & 3693 & 12675 & 1 & $S$ & paloma & -ar \\
\hline palombar & 3694 & 128 & 1 & $S$ & palomba & -ar \\
\hline palorejar & 3695 & 59 & 1 & $S$ & palor & -ejar \\
\hline palrear & 3696 & 236 & 1 & $S$ & palra & -ear \\
\hline panar & 3697 & 561 & 1 & $S$ & pão & -ar \\
\hline pandegar & 3698 & 242 & 1 & $S$ & pândega & -ar \\
\hline pandulhar & 3699 & 176 & 1 & $S$ & pandulho & -ar \\
\hline panfletar & 3700 & 2920 & 1 & $S$ & panfleto & -ar \\
\hline pangaiar & 3701 & 135 & 1 & $S$ & pangaio & $-a r$ \\
\hline panificar & 3702 & 170 & 1 & $S$ & pão & -ficar \\
\hline panriar & 3703 & 107 & 1 & $S$ & pânria & -ar \\
\hline pantanizar & 3704 & 95 & 1 & $S$ & pântano & -izar \\
\hline pantomimar & 3705 & 99 & 1 & $S$ & pantomima & -ar \\
\hline pantominar & 3706 & 187 & 1 & $S$ & pantomina & -ar \\
\hline paparicar & 3707 & 6123 & 1 & $S$ & paparico & -ar \\
\hline parabenizar & 3708 & 392000 & 1 & $S$ & parabéns & -izar \\
\hline parabolizar & 3709 & 639 & 1 & $S$ & parábola & -izar \\
\hline paracletear & 3710 & 103 & 1 & $S$ & paracleto & -ear \\
\hline paradear & 3711 & 107 & 1 & $S$ & parada & -ear \\
\hline paradoxar & 3712 & 110 & 1 & $\mathrm{~S}$ & paradoxo & -ar \\
\hline parafinar & 3713 & 431 & 1 & $S$ & parafina & $-a r$ \\
\hline
\end{tabular}




\begin{tabular}{|c|c|c|c|c|c|c|c|}
\hline parafrasear & 3714 & 9390 & 1 & $S$ & paráfrase & & -ear \\
\hline parafusar & 3715 & 16600 & 1 & $S$ & parafuso & & -ar \\
\hline paragrafar & 3716 & 133 & 1 & $S$ & parágrafo & & -ar \\
\hline paramentar & 3717 & 1270 & 1 & $S$ & paramento & & -ar \\
\hline parametrizar & 3718 & 7068 & 1 & $S$ & parâmetro & & -izar \\
\hline paraninfar & 3719 & 881 & 1 & $S$ & paraninfo & & -ar \\
\hline parapeitar & 3720 & 72 & 1 & $S$ & parapeito & & -ar \\
\hline parcelar & 3721 & 373000 & 1 & $S$ & parcela & & -ar \\
\hline parchear & 3722 & 285 & 1 & $S$ & parche & & -ar \\
\hline parear & 3723 & 4410 & 1 & $S$ & párea & & -ar \\
\hline parentesar & 3724 & 0 & 1 & $S$ & parêntese & & -ar \\
\hline parentesiar & 3725 & 0 & 1 & $S$ & parêntese & & -iar \\
\hline parlamentar & 3726 & 2542500 & 3 & $S$ & parlamento & & -ar \\
\hline parlamentear & 3727 & 168 & 1 & $\mathrm{~S}$ & parlamento & & -ear \\
\hline parlendar & 3728 & 290 & 1 & $S$ & parlenda & & -ar \\
\hline parlengar & 3729 & 148 & 1 & $S$ & parlenga & & -ar \\
\hline parodiar & 3730 & 7120 & 1 & $S$ & paródia & & -ar \\
\hline paroquiar & 3731 & 167 & 1 & $S$ & paróquia & & -ar \\
\hline parrafar & 3732 & 102 & 1 & S & párrafo & & -ar \\
\hline parrar-se & 3733 & 23 & 1 & $S$ & parra & & -ar \\
\hline partilhar & 3734 & 271500 & 1 & $S$ & partilha & & -ar \\
\hline parvoeirar & 3735 & 118 & 1 & $S$ & parvoeira & & -ar \\
\hline pascoar & 3736 & 217 & 1 & $S$ & páscoa & & -ar \\
\hline pasigrafar & 3737 & 90 & 1 & $S$ & pasigrafia & & -ar \\
\hline pasquinar & 3738 & 89 & 1 & $S$ & pasquim & & -ar \\
\hline passagear & 3739 & 215 & 1 & $S$ & passagem & & -ear \\
\hline passajar & 3740 & 272 & 1 & $S$ & passagem & & -ar \\
\hline passamanar & 3741 & 221 & 1 & $\mathrm{~S}$ & passamane & & -ar \\
\hline passarinhar & 3742 & 1130 & 1 & $S$ & passarinho & & -ar \\
\hline passinhar & 3743 & 85 & 1 & $S$ & passinho & & -ar \\
\hline pastejar & 3744 & 558 & 1 & $S$ & pasto & & -ejar \\
\hline pastichar & 3745 & 229 & 1 & $S$ & pasticho & & -ar \\
\hline pastilhar & 3746 & 226 & 1 & $S$ & pastilha & & -ar \\
\hline pastinhar & 3747 & 127 & 1 & $S$ & pastinha & & -ar \\
\hline patear & 3748 & 1020 & 1 & $S$ & pata & & -ear \\
\hline patinar & 3749 & 19675 & 1 & $S$ & patim & & -ar \\
\hline patranhar & 3751 & 174 & 1 & $S$ & patranha & & -ar \\
\hline patrolar & 3752 & 2265 & 1 & $S$ & patrola & & -ar \\
\hline pau-a-picar & 3753 & 0 & 1 & $S$ & pau-a-pique & & -ar \\
\hline pautar & 3754 & 116750 & 1 & $S$ & pauta & & -ar \\
\hline pautear & 3755 & 197 & 1 & $S$ & pauta & & -ear \\
\hline pavejar & 3756 & 102 & 1 & $S$ & paveia & & -ar \\
\hline paxalizar & 3757 & 198 & 1 & $S$ & paxá & $-1-$ & -izar \\
\hline pazear & 3758 & 514 & 1 & $S$ & paz & & -ear \\
\hline pealar & 3759 & 513 & 1 & $\mathrm{~S}$ & pealo & & -ar \\
\hline pear & 3760 & 89850 & 1 & $S$ & peia & & -ar \\
\hline pechinchar & 3761 & 12525 & 1 & S & pechincha & & -ar \\
\hline pedrar & 3762 & 206 & 1 & $S$ & pedra & & -ar \\
\hline peguilhar & 3763 & 162 & 1 & $S$ & peguilha & & -ar \\
\hline peidar & 3764 & 25300 & 1 & $S$ & peido & & -ar \\
\hline peidorrar & 3765 & 3 & 1 & $\mathrm{~S}$ & peido & -orra & -ar \\
\hline peidorrear & 3766 & 106 & 1 & $\mathrm{~S}$ & peido & -orra & -ear \\
\hline peitar & 3767 & 19425 & 1 & $S$ & peito & & -ar \\
\hline peitorrear & 3768 & 140 & 1 & $S$ & peito & & -ear \\
\hline peixar & 3769 & 192 & 1 & $S$ & peixe & & -ar \\
\hline pelar & 3770 & 6300 & 1 & $S$ & pele & & -ar \\
\hline peleguear & 3771 & 145 & 1 & $S$ & pelego & & -ear \\
\hline pelejar & 3772 & 16700 & 1 & $S$ & pêlo & & -ejar \\
\hline pelotear & 3773 & 166 & 1 & S & pelota & & -ear \\
\hline pendenciar & 3774 & 161 & 1 & $S$ & pendência & & -ar \\
\hline peneirar & 3775 & 25075 & 1 & $S$ & peneira & & -ar \\
\hline peniscar & 3776 & 133 & 1 & $S$ & penisco & & -ar \\
\hline penitenciar & 3777 & 3578 & 1 & $S$ & penitência & & -ar \\
\hline pensamentear & 3778 & 147 & 1 & $\mathrm{~S}$ & pensamento & & -ear \\
\hline
\end{tabular}




\begin{tabular}{|c|c|c|c|c|c|c|}
\hline pentear & 3779 & 97850 & 1 & $S$ & pente & -ear \\
\hline pentelhar & 3780 & 9510 & 1 & $S$ & pentelho & -ar \\
\hline penumbrar & 3781 & 154 & 1 & $S$ & penumbra & -ar \\
\hline pepinar & 3782 & 126 & 1 & $S$ & pepino & -ar \\
\hline percintar & 3783 & 193 & 1 & $S$ & percinta & -ar \\
\hline perfilar & 3784 & 5725 & 1 & $S$ & perfil & -ar \\
\hline pergaminhar & 3785 & 42 & 1 & $S$ & pergaminho & -ar \\
\hline perifrasear & 3786 & 89 & 1 & $S$ & perífrase & -ear \\
\hline perigar & 3787 & 2293 & 1 & S & perigo & -ar \\
\hline periodizar & 3788 & 1095 & 1 & $S$ & período & -izar \\
\hline peritonizar & 3789 & 69 & 1 & $S$ & peritônio & -izar \\
\hline perlar & 3790 & 139 & 1 & $S$ & perla & -ar \\
\hline perlongar & 3791 & 182 & 1 & $S$ & perlongo & -ar \\
\hline pernear & 3792 & 261 & 1 & $S$ & perna & -ear \\
\hline peroxidar & 3793 & 135 & 1 & $S$ & peróxido & -ar \\
\hline perpendicular & 3794 & 87925 & 1 & $S$ & perpendículo & -ar \\
\hline perspectivar & 3795 & 1735 & 1 & $S$ & perspectiva & -ar \\
\hline peruar & 3796 & 2685 & 1 & $S$ & peru & -ar \\
\hline pescocear & 3797 & 109 & 1 & $S$ & pescoço & -ear \\
\hline pesgar & 3798 & 132 & 1 & $S$ & pesga & -ar \\
\hline pespontar & 3799 & 692 & 1 & $S$ & pesponto & -ar \\
\hline pespontear & 3800 & 112 & 1 & $S$ & pesponto & -ear \\
\hline pesquisar & 3801 & 1042500 & 2 & $S$ & pesquisa & -ar \\
\hline pestanejar & 3802 & 35925 & 1 & $S$ & pestana & -ejar \\
\hline pestear & 3803 & 163 & 1 & $S$ & peste & -ear \\
\hline petar & 3804 & 33575 & 1 & $S$ & peta & -ar \\
\hline petardar & 3805 & 144 & 1 & $S$ & petardo & -ar \\
\hline petardear & 3806 & 140 & 1 & $S$ & petardo & -ear \\
\hline petear & 3807 & 170 & 1 & $S$ & peta & -ear \\
\hline petecar & 3808 & 301 & 1 & $S$ & peteca & -ar \\
\hline petequear & 3809 & 113 & 1 & $S$ & peteca & -ear \\
\hline petiscar & 3810 & 6505 & 1 & $S$ & petisco & -ar \\
\hline petrechar & 3811 & 156 & 1 & $S$ & petrecho & -ar \\
\hline petrolear & 3812 & 129 & 1 & $S$ & petróleo & -ar \\
\hline pezunhar & 3813 & 1 & 1 & $S$ & pezunho & -ar \\
\hline piançar & 3814 & 120 & 1 & $S$ & pianço & -ar \\
\hline picanear & 3815 & 114 & 1 & $\mathrm{~S}$ & picana & -ear \\
\hline piçarrar & 3816 & 211 & 1 & $S$ & piçarra & -ar \\
\hline pichar & 3817 & 17500 & 1 & $S$ & piche & -ar \\
\hline picotar & 3818 & 13075 & 1 & $S$ & picote & -ar \\
\hline picuar & 3819 & 108 & 1 & $S$ & picuá & -ar \\
\hline picuinhar & 3820 & 10 & 1 & $S$ & picuinha & -ar \\
\hline pigarrar & 3821 & 90 & 1 & $S$ & pigarro & -ar \\
\hline pigarrear & 3822 & 2665 & 1 & $S$ & pigarro & -ear \\
\hline pigmentar & 3823 & 10100 & 1 & $S$ & pigmento & -ar \\
\hline pilchar-se & 3824 & 13 & 1 & $S$ & pilcha & -ar \\
\hline pilheriar & 3825 & 448 & 1 & $S$ & pilhéria & -ar \\
\hline pilotear & 3826 & 361 & 1 & $S$ & pilota & -ear \\
\hline pimbar & 3827 & 143 & 1 & S & pimba & -ar \\
\hline pimpolhar & 3828 & 89 & 1 & $S$ & pimpolho & -ar \\
\hline pinar & 3829 & 40900 & 1 & $S$ & pino & -ar \\
\hline pinçar & 3830 & 10800 & 1 & $S$ & pinça & -ar \\
\hline pincelar & 3831 & 28950 & 1 & S & pincel & -ar \\
\hline pindongar & 3832 & 83 & 1 & $S$ & pindonga & -ar \\
\hline pinelar & 3833 & 45 & 1 & $S$ & pinel & -ar \\
\hline pingolar & 3834 & 118 & 1 & $S$ & pingo & -ar \\
\hline pinguelear & 3835 & 105 & 1 & S & pinguela & -ear \\
\hline pinicar & 3836 & 960 & 1 & $S$ & pinico & -ar \\
\hline pinotear & 3837 & 280 & 1 & $S$ & pinote & -ear \\
\hline pintainhar & 3838 & 142 & 1 & $S$ & pintainho & -ar \\
\hline piolhar & 3839 & 102 & 1 & S & piolho & -ar \\
\hline piparotear & 3840 & 102 & 1 & S & piparote & -ear \\
\hline pipetar & 3841 & 3220 & 1 & $S$ & pipeta & -ar \\
\hline pipocar & 3842 & 29800 & 1 & $S$ & pipoca & -ar \\
\hline
\end{tabular}




\begin{tabular}{|c|c|c|c|c|c|c|c|}
\hline pipoquear & 3843 & 162 & 1 & $S$ & pipoca & & -ear \\
\hline piquetar & 3844 & 125 & 1 & $S$ & piqueta & & -ar \\
\hline piquetear & 3845 & 170 & 1 & $\mathrm{~S}$ & piquete & & -ear \\
\hline pirilampar & 3846 & 31 & 1 & $S$ & pirilampo & & -ar \\
\hline pirilampear & 3847 & 166 & 1 & $S$ & pirilampo & & -ear \\
\hline pirilampejar & 3848 & 152 & 1 & $S$ & pirilampo & & -ejar \\
\hline pirolisar & 3849 & 42 & 1 & $S$ & pirólise & & -ar \\
\hline pirraçar & 3850 & 972 & 1 & $\mathrm{~S}$ & pirraça & & -ar \\
\hline pirracear & 3851 & 138 & 1 & $S$ & pirraça & & -ear \\
\hline piruetar & 3852 & 494 & 1 & S & pirueta & & -ar \\
\hline pirulitar & 3853 & 334 & 1 & $S$ & pirulito & & -ar \\
\hline pisoar & 3854 & 144 & 1 & $S$ & pisão & & -ar \\
\hline pitar & 3855 & 860 & 1 & $S$ & pito & & -ar \\
\hline plagiar & 3856 & 30250 & 1 & $\mathrm{~S}$ & plágio & & -ar \\
\hline planchar & 3857 & 835 & 1 & $\mathrm{~S}$ & plancha & & $-\mathrm{ar}$ \\
\hline planchear & 3858 & 232 & 1 & $S$ & plancha & & -ear \\
\hline plaquear & 3859 & 149 & 1 & $S$ & placa & & -ear \\
\hline plasmolisar & 3860 & 74 & 1 & $\mathrm{~S}$ & plasmólise & & -ar \\
\hline platinar & 3861 & 109 & 1 & $S$ & platina & & -ar \\
\hline plebiscitar & 3862 & 232 & 1 & $\mathrm{~S}$ & plebiscito & & -ar \\
\hline pleitar & 3863 & 3258 & 1 & $S$ & pleito & & -ar \\
\hline pleitear & 3864 & 271000 & 1 & $S$ & pleito & & -ear \\
\hline plugar & 3865 & 66425 & 1 & $S$ & plugue & & -ar \\
\hline plumejar & 3866 & 29 & 1 & $\mathrm{~S}$ & pluma & & -ejar \\
\hline podometrar & 3867 & 87 & 1 & $S$ & podômetro & & -ar \\
\hline poetizar & 3868 & 6050 & 1 & $S$ & poeta & & -izar \\
\hline poiar & 3869 & 638 & 1 & $\mathrm{~S}$ & poio & & -ar \\
\hline poitar & 3870 & 327 & 1 & $\mathrm{~S}$ & poita & & -ar \\
\hline polcar & 3871 & 252 & 1 & $\mathrm{~S}$ & polca & & -ar \\
\hline polear & 3872 & 138 & 1 & $S$ & polé & & -ar \\
\hline polemicar & 3873 & 191 & 1 & $S$ & polêmica & & -ar \\
\hline polemizar & 3874 & 52800 & 1 & $\mathrm{~S}$ & polêmica & & -izar \\
\hline policiar & 3875 & 25250 & 1 & $\mathrm{~S}$ & polícia & & -ar \\
\hline poligrafar & 3876 & 87 & 1 & $\mathrm{~S}$ & polígrafo & & -ar \\
\hline polimentar & 3877 & 89 & 1 & $S$ & polimento & & -ar \\
\hline politicar & 3878 & 1700 & 1 & $S$ & política & & -ar \\
\hline politizar & 3879 & 22775 & 1 & $S$ & política & & -izar \\
\hline poltronear-se & 3880 & 32 & 1 & $\mathrm{~S}$ & poltrona & & -ear \\
\hline polvilhar & 3881 & 58200 & 1 & $S$ & polvilho & & -ar \\
\hline pomadear & 3882 & 92 & 1 & $S$ & pomada & & -ear \\
\hline pompear & 3883 & 204 & 1 & $\mathrm{~S}$ & pompa & & -ear \\
\hline pongar & 3884 & 490 & 1 & $S$ & ponga & & -ar \\
\hline pontaletar & 3885 & 94 & 1 & $\mathrm{~S}$ & pontalete & & -ar \\
\hline pontapear & 3886 & 266 & 1 & $S$ & pontapé & & -ar \\
\hline pontar & 3887 & 987 & 1 & $S$ & ponta & & -ar \\
\hline pontear & 3889 & 2495 & 1 & $S$ & ponto & & -ear \\
\hline pontificar & 3891 & 3223 & 1 & $S$ & pontífice & & -ar \\
\hline pontilhar & 3892 & 1855 & 1 & $S$ & ponto & -ilho & -ar \\
\hline pontoar & 3893 & 131 & 1 & $S$ & ponto & & -ar \\
\hline porejar & 3895 & 565 & 1 & $S$ & poro & & -ejar \\
\hline porfiar & 3897 & 1373 & 1 & $\mathrm{~S}$ & porfia & & -ar \\
\hline porfirizar & 3898 & 159 & 1 & $\mathrm{~S}$ & pórfiro & & -izar \\
\hline pormenorizar & 3899 & 3735 & 1 & $S$ & pormenor & & -izar \\
\hline pororocar & 3900 & 148 & 1 & $S$ & pororoca & & -ar \\
\hline portear & 3901 & 158 & 1 & $S$ & porte & & -ar \\
\hline posfaciar & 3902 & 96 & 1 & $S$ & posfácio & & -ar \\
\hline pospontar & 3903 & 111 & 1 & $S$ & posponto & & -ar \\
\hline postear & 3904 & 995 & 1 & $S$ & poste & & -ear \\
\hline postejar & 3905 & 156 & 1 & $S$ & posta & & -ejar \\
\hline postemar & 3906 & 165 & 1 & $S$ & postema & & -ar \\
\hline potenciar & 3907 & 7660 & 1 & $S$ & potência & & -ar \\
\hline potocar & 3908 & 103 & 1 & $S$ & potoca & & -ar \\
\hline potrear & 3909 & 104 & 1 & $S$ & potro & & -ear \\
\hline pracear & 3910 & 232 & 1 & $S$ & praça & & -ear \\
\hline
\end{tabular}




\begin{tabular}{|c|c|c|c|c|c|c|c|}
\hline pracejar & 3911 & 153 & 1 & $S$ & & praça & -ejar \\
\hline pragalhar & 3912 & 28 & 1 & $S$ & & praga & -Ihar \\
\hline praguejar & 3913 & 6365 & 1 & $S$ & & praga & -ejar \\
\hline pranchar & 3914 & 1083 & 1 & $S$ & & prancha & -ar \\
\hline pranchear & 3915 & 200 & 1 & $S$ & & prancha & -ear \\
\hline prantear & 3916 & 5073 & 1 & $S$ & & pranto & -ear \\
\hline pratear & 3917 & 1680 & 1 & $S$ & & prata & -ear \\
\hline praticar & 3918 & 1547500 & 2 & $S$ & & prática & -ar \\
\hline prebendar & 3919 & 88 & 1 & $\mathrm{~S}$ & & prebenda & -ar \\
\hline precintar & 3920 & 282 & 1 & $S$ & & precinta & -ar \\
\hline predicamentar & 3921 & 122 & 1 & $S$ & & predicamento & -ar \\
\hline prefaciar & 3922 & 4608 & 1 & $S$ & & prefácio & -ar \\
\hline pregar & 3923 & 615000 & 2 & $S$ & & prega & -ar \\
\hline preguear & 3924 & 387 & 1 & $S$ & & prega & -ear \\
\hline preguiçar & 3925 & 557 & 1 & $S$ & & preguiça & -ar \\
\hline preitear & 3926 & 362 & 1 & $S$ & & preito & -ear \\
\hline preitejar & 3927 & 106 & 1 & $S$ & & preito & -ejar \\
\hline prelaciar & 3928 & 79 & 1 & $S$ & & prelacia & -ar \\
\hline preliar & 3929 & 182 & 1 & $S$ & & prélio & -ar \\
\hline preludiar & 3930 & 372 & 1 & $S$ & & prelúdio & -ar \\
\hline prendar & 3931 & 496 & 1 & $\mathrm{~S}$ & & prenda & -ar \\
\hline presenciar & 3932 & 156500 & 1 & $S$ & & presença & -iar \\
\hline presilhar & 3933 & 131 & 1 & $\mathrm{~S}$ & & presilha & -ar \\
\hline pressagiar & 3934 & 1378 & 1 & $S$ & & presságio & -ar \\
\hline prestimanear & 3935 & 73 & 1 & $S$ & & prestímano & -ear \\
\hline primaverar & 3936 & 286 & 1 & $S$ & & primavera & -ar \\
\hline priorizar & 3937 & 468500 & 1 & $S$ & & prioridade & -izar \\
\hline privilegiar & 3938 & 559500 & 2 & $S$ & & privilégio & -ar \\
\hline processar & 3939 & 1170000 & 2 & $S$ & & processo & -ar \\
\hline proejar & 3940 & 87 & 1 & $S$ & & proa & -ejar \\
\hline profaçar & 3941 & 118 & 1 & $P$ & pro- & face & -ar \\
\hline programar & 3942 & 904500 & 2 & $S$ & & programa & -ar \\
\hline prologar & 3943 & 567 & 1 & $S$ & & prólogo & -ar \\
\hline propagandear & 3944 & 5210 & 1 & $S$ & & propaganda & -ear \\
\hline propolisar & 3945 & 95 & 1 & $\mathrm{~S}$ & & própolis & -ar \\
\hline protocolar & 3946 & 168500 & 1 & $S$ & & protocolo & -ar \\
\hline protocolizar & 3947 & 13600 & 1 & $\mathrm{~S}$ & & protocolo & -izar \\
\hline proverbiar & 3948 & 102 & 1 & $S$ & & provérbio & -ar \\
\hline providenciar & 3949 & 698500 & 2 & $S$ & & providência & -ar \\
\hline prudenciar & 3950 & 98 & 1 & $S$ & & prudência & -ar \\
\hline prumar & 3951 & 192 & 1 & $S$ & & prumo & -ar \\
\hline psicanalisar & 3952 & 1538 & 1 & $S$ & & psicanálise & -ar \\
\hline psicologar & 3953 & 77 & 1 & $S$ & & psicólogo & -ar \\
\hline psicologizar & 3954 & 737 & 1 & $S$ & & psicologia & -izar \\
\hline puitar & 3955 & 139 & 1 & $S$ & & puíta & -ar \\
\hline pulear & 3956 & 62 & 1 & $S$ & & pulo & -ear \\
\hline pulicar & 3957 & 223 & 1 & S & & pulo & -icar \\
\hline pupilar & 3958 & 6228 & 1 & $S$ & & pupilo & -ar \\
\hline rabear & 3959 & 770 & 1 & S & & rabo & -ear \\
\hline rabejar & 3960 & 145 & 1 & $S$ & & rabo & -ejar \\
\hline rabequear & 3961 & 62 & 1 & $S$ & & rabeca & -ear \\
\hline rabiar & 3962 & 1400000 & 2 & $S$ & & rábia & -ar \\
\hline rabiscar & 3963 & 19575 & 1 & $S$ & & rabo & -iscar \\
\hline rabotar & 3964 & 61 & 1 & $S$ & & rabote & -ar \\
\hline rabujar & 3965 & 195 & 1 & $S$ & & rabugem & -ar \\
\hline rabular & 3966 & 220 & 1 & $S$ & & rábula & -ar \\
\hline rabulear & 3967 & 117 & 1 & $S$ & & rábula & -ear \\
\hline rabulejar & 3968 & 131 & 1 & $S$ & & rábula & -ejar \\
\hline racear & 3969 & 119 & 1 & $\mathrm{~S}$ & & raça & -ear \\
\hline radiodiagnostical & 3970 & 81 & 1 & $S$ & & radiodiagnóstico & -ar \\
\hline radiografar & 3971 & 4840 & 1 & $\mathrm{~S}$ & & radiografia & -ar \\
\hline rafear & 3972 & 18 & 1 & $S$ & & rafe & -ear \\
\hline rafiar & 3973 & 69 & 1 & $S$ & & ráfia & -ar \\
\hline raiar & 3975 & 70975 & 1 & $S$ & & raio & -ar \\
\hline
\end{tabular}




\begin{tabular}{|c|c|c|c|c|c|c|c|}
\hline raivar & 3976 & 354 & 1 & $S$ & & raiva & -ar \\
\hline raivecer & 3977 & 123 & 1 & $S$ & & raiva & -ecer \\
\hline raivejar & 3978 & 93 & 1 & $S$ & & raiva & -ejar \\
\hline ralar & 3979 & 64550 & 1 & $S$ & & rela & -ar \\
\hline ramalhar & 3980 & 437 & 1 & $S$ & & ramalho & -ar \\
\hline ramelar & 3981 & 184 & 1 & S & & ramela & -ar \\
\hline ramilhetar & 3982 & 118 & 1 & $S$ & & ramilhete & -ar \\
\hline rampear & 3983 & 119 & 1 & $S$ & & rampa & -ear \\
\hline rangar & 3984 & 2348 & 1 & $S$ & & rango & -ar \\
\hline ranquear & 3985 & 2485 & 1 & $S$ & & ranque & -ar \\
\hline rapelar & 3986 & 2820 & 1 & $S$ & & rapel & -ar \\
\hline rapinar & 3987 & 925 & 1 & $S$ & & rapina & -ar \\
\hline rasoirar & 3988 & 113 & 1 & $S$ & & rasoira & -ar \\
\hline rasourar & 3989 & 143 & 1 & $S$ & & rasoura & -ar \\
\hline rastear & 3990 & 954 & 1 & $S$ & & rasto & -ear \\
\hline rasteirar & 3991 & 167 & 1 & $S$ & & rasteira & -ar \\
\hline rastejar & 3992 & 19525 & 1 & S & & rasto & -ejar \\
\hline rastelar & 3993 & 501 & 1 & $S$ & & rastelo & -ar \\
\hline rastrear & 3994 & 794500 & 2 & $S$ & & rastro & -ear \\
\hline rasurar & 3996 & 4790 & 1 & $S$ & & rasura & -ar \\
\hline ravinhar & 3997 & 2 & 1 & $S$ & & raiva & -inhar \\
\hline realejar & 3998 & 169 & 1 & S & & realejo & -ar \\
\hline rebalsar & 3999 & 75 & 1 & $P$ & re- & balsa & -ar \\
\hline rebarbar & 4000 & 1275 & 1 & $S$ & & rebarba & -ar \\
\hline rebatar & 4001 & 119 & 1 & $S$ & & rebate & -ar \\
\hline rebatinhar & 4002 & 62 & 1 & $S$ & & rebatinha & -ar \\
\hline rebenquear & 4003 & 137 & 1 & $S$ & & rebenque & -ear \\
\hline rebiopsiar & 4004 & 36 & 1 & $\mathrm{P}$ & re- & biópsia & -ar \\
\hline rebitar & 4005 & 2075 & 1 & $S$ & & rebite & -ar \\
\hline rebombar & 4006 & 272 & 1 & $S$ & & rebombo & -ar \\
\hline reboquear & 4007 & 116 & 1 & $S$ & & reboque & -ear \\
\hline rebordar & 4008 & 201 & 1 & $P$ & re- & bordo & -ar \\
\hline rebuçar & 4009 & 168 & 1 & $P$ & re- & buço & -ar \\
\hline rebuliçar & 4010 & 82 & 1 & $S$ & & rebuliço & -ar \\
\hline recachar & 4011 & 213 & 1 & $S$ & & recacho & -ar \\
\hline recadejar & 4012 & 0 & 1 & $S$ & & recado & -ejar \\
\hline recapar & 4013 & 987 & 1 & $\mathrm{P}$ & re- & capa & -ar \\
\hline recargar & 4014 & 10400 & 1 & $S$ & & recarga & -ar \\
\hline recartilhar & 4015 & 255 & 1 & $S$ & & recartilha & -ar \\
\hline receitar & 4016 & 50850 & 1 & $S$ & & receita & -ar \\
\hline recibar & 4017 & 85 & 1 & $S$ & & recibo & -ar \\
\hline reciclar & 4018 & 259750 & 1 & $P$ & re- & ciclo & -ar \\
\hline recoltar & 4019 & 34 & 1 & $S$ & & recolta & -ar \\
\hline recostar & 4020 & 8590 & 1 & $P$ & re- & costa & -ar \\
\hline recovar & 4021 & 65 & 1 & $S$ & & récova & -ar \\
\hline recuar & 4022 & 262000 & 1 & $P$ & re- & $\mathrm{cu}$ & -ar \\
\hline redar & 4023 & 576 & 1 & $S$ & & rede & -ar \\
\hline redemoinhar & 4024 & 867 & 1 & $S$ & & redemoinho & -ar \\
\hline \begin{tabular}{|l} 
redizimar \\
\end{tabular} & 4025 & 8 & 1 & $\mathrm{P}$ & re- & dízima & -ar \\
\hline redomoinhar & 4026 & 81 & 1 & $S$ & & redomoinho & -ar \\
\hline redopiar & 4027 & 117 & 1 & $S$ & & redopio & -ar \\
\hline reencontrar & 4028 & 434000 & 1 & $S$ & & reencontro & -ar \\
\hline refegar & 4029 & 164 & 1 & $S$ & & refego & -ar \\
\hline referenciar & 4030 & 61250 & 1 & $S$ & & referência & -ar \\
\hline refestelar-se & 4031 & 746 & 1 & $P$ & re- & festa & -elar \\
\hline reflar & 4032 & 127 & 1 & $S$ & & refle & -ar \\
\hline reflorestar & 4033 & 22125 & 1 & $P$ & re- & floresta & -ar \\
\hline refluxar & 4034 & 155 & 1 & $S$ & & refluxo & -ar \\
\hline refogar & 4035 & 54900 & 1 & $P$ & re- & fogo & -ar \\
\hline refolhar & 4036 & 304 & 1 & $S$ & & refolho & -ar \\
\hline refugiar & 4037 & 35650 & 1 & $\mathrm{~S}$ & & refúgio & -ar \\
\hline regatar & 4038 & 1503 & 1 & $S$ & & regata & -ar \\
\hline registar & 4039 & 371000 & 1 & $S$ & & registo & -ar \\
\hline registrar & 4040 & 685250 & 2 & $S$ & & registro & -ar \\
\hline
\end{tabular}




\begin{tabular}{|c|c|c|c|c|c|c|c|}
\hline regoar & 4041 & 88 & 1 & $S$ & & rego & -oar \\
\hline regolfar & 4042 & 91 & 1 & $\mathrm{P}$ & re- & golfo & -ar \\
\hline regraxar & 4043 & 58 & 1 & $S$ & & regraxo & -ar \\
\hline regressar & 4044 & 90000 & 1 & $S$ & & regresso & -ar \\
\hline regulamentar & 4045 & 662000 & 2 & $S$ & & regulamento & -ar \\
\hline reixar & 4046 & 100 & 1 & $S$ & & reixa & -ar \\
\hline relampadear & 4047 & 201 & 1 & $S$ & & relâmpado & -ear \\
\hline relampadejar & 4048 & 208 & 1 & $S$ & & relâmpado & -ejar \\
\hline relampear & 4049 & 813 & 1 & $S$ & & relampo & -ear \\
\hline relancear & 4050 & 443 & 1 & $S$ & & relance & -ear \\
\hline relar & 4051 & 4500 & 1 & $S$ & & rela & -ar \\
\hline relatar & 4052 & 1382500 & 2 & $S$ & & relato & -ar \\
\hline relentar & 4053 & 100 & 1 & $S$ & & relento & -ar \\
\hline relhar & 4054 & 161 & 1 & S & & relha & -ar \\
\hline relumear & 4055 & 59 & 1 & $S$ & & relume & -ear \\
\hline relvejar & 4056 & 149 & 1 & $S$ & & relva & -ejar \\
\hline remangar & 4057 & 205 & 1 & $\mathrm{P}$ & re- & manga & -ar \\
\hline \begin{tabular}{|l|} 
remansar-se \\
\end{tabular} & 4058 & 31 & 1 & $S$ & & remanso & -ar \\
\hline remansear & 4059 & 242 & 1 & $\mathrm{~S}$ & & remanso & -ear \\
\hline remelar & 4060 & 167 & 1 & $S$ & & remela & -ar \\
\hline remembrar & 4061 & 395 & 1 & $\mathrm{P}$ & re- & membro & -ar \\
\hline remercear & 4062 & 71 & 1 & $\mathrm{P}$ & re- & mercê & -ar \\
\hline remessar & 4063 & 150 & 1 & $S$ & & remesso & -ar \\
\hline remoinhar & 4064 & 281 & 1 & $\mathrm{P}$ & re- & moinho & -ar \\
\hline remoquear & 4065 & 75 & 1 & $S$ & & remoque & -ar \\
\hline rendar & 4066 & 1484 & 1 & $\mathrm{~S}$ & & renda & -ar \\
\hline rendilhar & 4068 & 188 & 1 & $S$ & & rendilha & -ar \\
\hline renomear & 4069 & 128000 & 1 & $\mathrm{~S}$ & & renome & -ar \\
\hline repelar & 4070 & 174 & 1 & $S$ & & repelo & -ar \\
\hline repertoriar & 4071 & 665 & 1 & $S$ & & repertório & -ar \\
\hline repolhar & 4072 & 73 & 1 & $S$ & & repolho & -ar \\
\hline repontar & 4073 & 1400 & 1 & $P$ & re- & ponta & -ar \\
\hline repostar & 4074 & 6260 & 1 & $\mathrm{~S}$ & & reposta & -ar \\
\hline reprisar & 4075 & 23575 & 1 & $S$ & & reprise & -ar \\
\hline repulsar & 4076 & 614 & 1 & $S$ & & repulsa & -ar \\
\hline requintar & 4077 & 1030 & 1 & $\mathrm{P}$ & re- & quinto & -ar \\
\hline resgatar & 4078 & 1192500 & 2 & $S$ & & resgate & -ar \\
\hline resinar & 4079 & 1970 & 1 & $S$ & & resina & -ar \\
\hline resinificar & 4080 & 166 & 1 & $S$ & & resina & -ficar \\
\hline resmar & 4081 & 124 & 1 & $S$ & & resma & -ar \\
\hline respaldar & 4082 & 40350 & 1 & $\mathrm{P}$ & re- & espalda & -ar \\
\hline respigar & 4083 & 1445 & 1 & $\mathrm{P}$ & re- & espiga & -ar \\
\hline \begin{tabular}{|l|} 
respingar \\
\end{tabular} & 4084 & 9563 & 1 & $P$ & res- & pingo & -ar \\
\hline responsar & 4085 & 199 & 1 & $S$ & & responso & -ar \\
\hline respostar & 4086 & 4205 & 1 & $S$ & & resposta & -ar \\
\hline ressabiar & 4087 & 218 & 1 & $S$ & & ressábio & -ar \\
\hline ressacar & 4088 & 417 & 1 & $S$ & & ressaca & -ar \\
\hline \begin{tabular}{|l|} 
ressaibar \\
\end{tabular} & 4089 & 77 & 1 & $S$ & & ressaibo & -ar \\
\hline restolhar & 4090 & 262 & 1 & $S$ & & restolho & -ar \\
\hline reticenciar & 4091 & 250 & 1 & $S$ & & reticência & -ar \\
\hline \begin{tabular}{|l} 
reticular \\
\end{tabular} & 4092 & 14300 & 1 & $S$ & & retícula & -ar \\
\hline retoricar & 4093 & 177 & 1 & $S$ & & retórica & -ar \\
\hline retrotrair & 4094 & 241 & 1 & $P$ & retro- & -trair & \\
\hline reverenciar & 4095 & 38550 & 1 & $S$ & & reverência & -ar \\
\hline revezar & 4096 & 23800 & 1 & $\mathrm{P}$ & re- & vez & -ar \\
\hline revigorar & 4097 & 26425 & 1 & $\mathrm{P}$ & re- & vigor & -ar \\
\hline reviravoltear & 4098 & 68 & 1 & $S$ & & reviravolta & -ear \\
\hline revistar & 4099 & 25950 & 1 & $P$ & re- & vista & -ar \\
\hline revoltear & 4100 & 181 & 1 & $\mathrm{P}$ & re- & volta & -ear \\
\hline ribeirar & 4101 & 92 & 1 & $S$ & & ribeira & -ar \\
\hline ribombar & 4102 & 3308 & 1 & $S$ & & ribombo & -ar \\
\hline ricochetar & 4103 & 153 & 1 & $S$ & & ricochete & -ar \\
\hline ricochetear & 4104 & 2455 & 1 & $S$ & & ricochete & -ear \\
\hline ridicularizar & 4105 & 31825 & 1 & $\mathrm{~S}$ & & ridicularia & -izar \\
\hline
\end{tabular}




\begin{tabular}{|c|c|c|c|c|c|c|}
\hline rimar & 4106 & 42150 & 1 & $S$ & rima & -ar \\
\hline rinhar & 4107 & 109 & 1 & $S$ & rinha & -ar \\
\hline ripar & 4108 & 65825 & 1 & $S$ & ripa & -ar \\
\hline ritmar & 4109 & 1755 & 1 & $S$ & ritmo & -ar \\
\hline ritmizar & 4110 & 90 & 1 & $S$ & ritmo & -izar \\
\hline rizar & 4111 & 5268 & 1 & $S$ & riz & -ar \\
\hline rocar & 4112 & 7558 & 1 & $S$ & roque & -ar \\
\hline rodar & 4113 & 2072500 & 2 & $S$ & rodo & -ar \\
\hline rodear & 4114 & 38350 & 1 & $S$ & roda & -ear \\
\hline rodilhar & 4115 & 127 & 1 & $S$ & rodilha & -ar \\
\hline rodrigar & 4116 & 62 & 1 & S & rodriga & -ar \\
\hline rolar & 4117 & 1332500 & 2 & $S$ & rola & -ar \\
\hline roletar & 4118 & 535 & 1 & $S$ & rolete & -ar \\
\hline roletear & 4119 & 39 & 1 & $S$ & rolete & -ear \\
\hline rolhar & 4120 & 208 & 1 & $S$ & rolha & -ar \\
\hline romanear & 4121 & 349 & 1 & $S$ & romana & -ear \\
\hline ronchar & 4122 & 100 & 1 & $S$ & roncha & -ar \\
\hline rondar & 4123 & 25100 & 1 & $S$ & ronda & -ar \\
\hline rondear & 4124 & 103 & 1 & $S$ & ronda & -ear \\
\hline roscar & 4125 & 2293 & 1 & $S$ & rosca & -ar \\
\hline rosetar & 4126 & 2083 & 1 & $S$ & roseta & -ar \\
\hline \begin{tabular}{|l|} 
rosetear \\
\end{tabular} & 4127 & 136 & 1 & $S$ & roseta & -ear \\
\hline rosquear & 4128 & 8243 & 1 & $S$ & rosca & -ear \\
\hline rostear & 4129 & 107 & 1 & $S$ & rosto & -ear \\
\hline roteirizar & 4130 & 5123 & 1 & $S$ & roteiro & -izar \\
\hline rotinizar & 4131 & 567 & 1 & $S$ & rotina & -izar \\
\hline rotular & 4132 & 56475 & 1 & $S$ & rótulo & -ar \\
\hline roupar & 4133 & 1035 & 1 & $S$ & roupa & -ar \\
\hline rouxinolar & 4134 & 16 & 1 & $S$ & rouxinol & -ar \\
\hline rouxinolear & 4135 & 76 & 1 & $S$ & rouxinol & -ear \\
\hline ruborescer & 4136 & 126 & 1 & $S$ & rubor & -ecer \\
\hline ruborizar & 4137 & 2190 & 1 & $S$ & rubor & -izar \\
\hline rubricar & 4138 & 23275 & 1 & $S$ & rubrica & -ar \\
\hline rufiar & 4139 & 157 & 1 & $S$ & rufião & -ar \\
\hline rugar & 4140 & 317 & 1 & $S$ & ruga & -ar \\
\hline ruidar & 4141 & 102 & 1 & $S$ & ruído & -ar \\
\hline rumar & 4142 & 18450 & 1 & $S$ & rumo & -ar \\
\hline rumorar & 4143 & 80 & 1 & $S$ & rumor & -ar \\
\hline rumorejar & 4144 & 825 & 1 & $S$ & rumor & -ejar \\
\hline rusgar & 4145 & 102 & 1 & $S$ & rusga & -ar \\
\hline \begin{tabular}{|l|} 
sabadear \\
\end{tabular} & 4146 & 248 & 1 & $S$ & sábado & -ear \\
\hline sabatinar & 4147 & 3473 & 1 & $S$ & sabatina & -ar \\
\hline sabichar & 4148 & 146 & 1 & S & saber & -ichar \\
\hline saborear & 4149 & 208000 & 1 & $S$ & sabor & -ear \\
\hline sabugar & 4150 & 194 & 1 & $S$ & sabugo & -ar \\
\hline sacholar & 4151 & 98 & 1 & $S$ & sachola & -ar \\
\hline sacolejar & 4152 & 5743 & 1 & S & sacola & -ejar \\
\hline sacramentar & 4153 & 13650 & 1 & $S$ & sacramento & -ar \\
\hline safrejar & 4154 & 145 & 1 & $S$ & safra & -ejar \\
\hline saibrar & 4155 & 121 & 1 & $S$ & saibro & -ar \\
\hline salariar & 4156 & 102 & 1 & $S$ & salário & -ar \\
\hline salificar & 4157 & 48 & 1 & $S$ & sal- & -ficar \\
\hline salitrar & 4158 & 85 & 1 & $S$ & salitre & -ar \\
\hline salitrizar & 4159 & 31 & 1 & $S$ & salitre & -izar \\
\hline salmear & 4160 & 223 & 1 & $S$ & salmo & -ear \\
\hline salmodiar & 4161 & 1110 & 1 & $\mathrm{~S}$ & salmodia & -ar \\
\hline salmourar & 4162 & 91 & 1 & $S$ & salmoura & -ar \\
\hline salsar & 4163 & 68 & 1 & $S$ & salsa & -ar \\
\hline saltear & 4164 & 772 & 1 & $\mathrm{~S}$ & salto & -ear \\
\hline \begin{tabular}{|l|} 
salvaguardar \\
\end{tabular} & 4165 & 62700 & 1 & $S$ & salvaguarda & -ar \\
\hline samangar & 4166 & 168 & 1 & $\mathrm{~S}$ & samango & -ar \\
\hline sambar & 4167 & 103000 & 1 & $S$ & samba & -ar \\
\hline sambarcar & 4168 & 104 & 1 & $S$ & sambarco & -ar \\
\hline sambear & 4169 & 148 & 1 & $S$ & samba & -ear \\
\hline
\end{tabular}




\begin{tabular}{|c|c|c|c|c|c|c|c|}
\hline sambenitar & 4170 & 96 & 1 & $S$ & sambenito & & -ar \\
\hline sanduichar & 4171 & 91 & 1 & $S$ & sanduíche & & -ar \\
\hline sanfonar & 4172 & 1218 & 1 & $S$ & sanfona & & -ar \\
\hline sanfoninar & 4173 & 135 & 1 & $S$ & sanfonina & & -ar \\
\hline sanguinhar & 4174 & 198 & 1 & $S$ & sanga & -inho & -ar \\
\hline sanjar & 4175 & 1195 & 1 & $S$ & sanja & & -ar \\
\hline sapatear & 4176 & 4725 & 1 & $S$ & sapato & & -ear \\
\hline sapear & 4177 & 687 & 1 & $S$ & sapo & & -ear \\
\hline sapejar & 4178 & 133 & 1 & $S$ & sapo & & -ejar \\
\hline sapremar & 4179 & 130 & 1 & $S$ & saprema & & -ar \\
\hline sarabandear & 4180 & 185 & 1 & $S$ & sarabanda & & -ear \\
\hline saracotear & 4181 & 3523 & 1 & $S$ & saracote & & -ear \\
\hline saraivar & 4182 & 236 & 1 & $S$ & saraiva & & -ar \\
\hline sargentear & 4183 & 112 & 1 & $S$ & sargento & & -ear \\
\hline sarilhar & 4184 & 107 & 1 & $S$ & sarilho & & -ar \\
\hline sarjar & 4185 & 242 & 1 & $S$ & sarja & & -ar \\
\hline sarrafear & 4186 & 320 & 1 & $S$ & sarrafo & & -ear \\
\hline sarrar & 4187 & 1070 & 1 & $S$ & sarro & & -ar \\
\hline sartar & 4188 & 272 & 1 & $S$ & sarta & & -ar \\
\hline satirizar & 4189 & 10675 & 1 & $S$ & sátira & & -izar \\
\hline satrapear & 4190 & 85 & 1 & $S$ & sátrapa & & -ear \\
\hline sedar & 4191 & 5788 & 1 & $S$ & seda & & -ar \\
\hline sedear & 4192 & 287 & 1 & $S$ & seda & & -ear \\
\hline sediar & 4193 & 530250 & 2 & $S$ & sede & & -iar \\
\hline sedimentar & 4194 & 75725 & 1 & $S$ & sedimento & & -ar \\
\hline segmentar & 4195 & 54800 & 1 & $S$ & segmento & & -ar \\
\hline selar & 4196 & 193000 & 1 & $S$ & sela & & -ar \\
\hline semitonar & 4197 & 329 & 1 & S & semitom & & -ar \\
\hline sentenciar & 4198 & 19275 & 1 & $S$ & sentença & -i- & -ar \\
\hline seqüenciar & 4199 & 6460 & 1 & $S$ & seqüência & & -ar \\
\hline seriar & 4200 & 1078 & 1 & $S$ & série & & -ar \\
\hline seringar & 4201 & 191 & 1 & $S$ & seringa & & -ar \\
\hline serpear & 4202 & 393 & 1 & $S$ & serpe & & -ear \\
\hline serpejar & 4203 & 127 & 1 & $S$ & serpe & & -ejar \\
\hline serpentar & 4204 & 77 & 1 & $S$ & serpente & & -ar \\
\hline serpentear & 4205 & 1578 & 1 & $S$ & serpente & & -ear \\
\hline serrear & 4206 & 82 & 1 & $S$ & serra & & -ear \\
\hline serrilhar & 4207 & 990 & 1 & $S$ & serrilha & & -ar \\
\hline serrotar & 4208 & 112 & 1 & $S$ & serrote & & -ar \\
\hline sesmar & 4209 & 261 & 1 & $S$ & sesma & & -ar \\
\hline sestear & 4210 & 883 & 1 & $S$ & sesta & & -ear \\
\hline sevandijar & 4211 & 99 & 1 & $S$ & sevandija & & -ar \\
\hline seviciar & 4212 & 748 & 1 & $S$ & sevícia & & -ar \\
\hline sexar & 4213 & 545 & 1 & $S$ & sexo & & -ar \\
\hline siglar & 4214 & 162 & 1 & $S$ & sigla & & -ar \\
\hline siglizar & 4215 & 44 & 1 & $S$ & sigla & & -izar \\
\hline silabar & 4216 & 319 & 1 & $S$ & sílaba & & -ar \\
\hline silenciar & 4217 & 171000 & 1 & $S$ & silêncio & & -ar \\
\hline silhuetar & 4218 & 107 & 1 & $S$ & silhueta & & -ar \\
\hline silicatar & 4219 & 62 & 1 & $S$ & silicato & & -ar \\
\hline simbolizar & 4220 & 51350 & 1 & $S$ & símbolo & & -izar \\
\hline simetrizar & 4221 & 198 & 1 & $S$ & simetria & & -izar \\
\hline simpatizar & 4222 & 17025 & 1 & $S$ & simpatia & & -izar \\
\hline sinalizar & 4223 & 843750 & 2 & $S$ & sinal & & -izar \\
\hline sincopar & 4224 & 635 & 1 & $S$ & síncope & & -ar \\
\hline sincopizar & 4225 & 138 & 1 & $S$ & síncope & & -izar \\
\hline sinetar & 4227 & 1849 & 1 & $S$ & sineta & & -ar \\
\hline sinizar & 4228 & 4 & 1 & $S$ & sino- & & -izar \\
\hline sinonimizar & 4229 & 241 & 1 & $S$ & sinônimo & & -izar \\
\hline sintecar & 4230 & 164 & 1 & $S$ & sinteco & & -ar \\
\hline sinterizar & 4231 & 567 & 1 & $S$ & sínter & & -izar \\
\hline sintonizar & 4232 & 92275 & 1 & $S$ & sintonia & & -izar \\
\hline sinucar & 4233 & 115 & 1 & $S$ & sinuca & & -ar \\
\hline sirgar & 4234 & 100 & 1 & $S$ & sirga & & -ar \\
\hline
\end{tabular}




\begin{tabular}{|c|c|c|c|c|c|c|c|c|}
\hline sirigaitar & 4235 & 157 & 1 & $S$ & & sirigaita & & -ar \\
\hline sisar & 4236 & 3818 & 1 & $S$ & & sisa & & -ar \\
\hline sitiar & 4237 & 3173 & 1 & $S$ & & sítio & & -ar \\
\hline soalhar & 4239 & 200 & 1 & $S$ & & soalha & & -ar \\
\hline soborralhar & 4240 & 35 & 1 & $S$ & & soborralho & & -ar \\
\hline sobraçar & 4241 & 489 & 1 & $P$ & so- & braço & & -ar \\
\hline sobrasar & 4242 & 236 & 1 & $P$ & so- & brasa & & -ar \\
\hline sobreleitar & 4243 & 7 & 1 & $S$ & & sobreleito & & -ar \\
\hline sobrelinhar & 4244 & 1 & 1 & $\mathrm{P}$ & sobre- & linha & & -ar \\
\hline sobrenomear & 4245 & 74 & 1 & $S$ & & sobrenome & & -ear \\
\hline sobrepartilhar & 4246 & 98 & 1 & $S$ & & sobrepartilha & & -ar \\
\hline sobre-roldar & 4247 & 75 & 1 & $S$ & & sobre-rolda & & -ar \\
\hline sobressaltear & 4248 & 127 & 1 & $S$ & & sobressalto & & -ear \\
\hline sobretaxar & 4249 & 4045 & 1 & $\mathrm{~S}$ & & sobretaxa & & -ar \\
\hline socar & 4250 & 134000 & 1 & $S$ & & soca & & -ar \\
\hline sochantrear & 4251 & 81 & 1 & $S$ & & sochantre & & -ear \\
\hline soçocar & 4252 & 100 & 1 & $S$ & & soçoca & & -ar \\
\hline socrestar & 4253 & 10 & 1 & $S$ & & socresta & & -ar \\
\hline sodar & 4254 & 622 & 1 & S & & soda & & -ar \\
\hline sodomizar & 4255 & 1835 & 1 & S & & sodomia & & -izar \\
\hline sofismar & 4256 & 2523 & 1 & $S$ & & sofisma & & -ar \\
\hline sofraldar & 4257 & 133 & 1 & $S$ & & sofralda & & -ar \\
\hline sogar & 4258 & 3130 & 1 & $S$ & & soga & & -ar \\
\hline sograr & 4259 & 93 & 1 & $S$ & & sogro & & -ar \\
\hline solancar & 4260 & 128 & 1 & $S$ & & solanco & & -ar \\
\hline solapar & 4261 & 11500 & 1 & $S$ & & solapa & & -ar \\
\hline solar & 4263 & 446000 & 1 & $S$ & & solo & & -ar \\
\hline solavancar & 4265 & 118 & 1 & $S$ & & solavanco & & -ar \\
\hline soletrar & 4266 & 22475 & 1 & $\mathrm{P}$ & so- & letra & & -ar \\
\hline soliloquiar & 4267 & 183 & 1 & $S$ & & solilóquio & & -ar \\
\hline solinhar & 4268 & 185 & 1 & $P$ & so- & linha & & -ar \\
\hline \begin{tabular}{|l|} 
solmizar \\
\end{tabular} & 4269 & 29 & 1 & $S$ & & sol & $\mathrm{mi}$ & -izar \\
\hline soluçar & 4270 & 19425 & 1 & $S$ & & soluço & & -ar \\
\hline solvatar & 4271 & 69 & 1 & $S$ & & solvato & & -ar \\
\hline somar & 4272 & 857500 & 2 & $S$ & & soma & & -ar \\
\hline sombrar & 4273 & 584 & 1 & $S$ & & sombra & & -ar \\
\hline sombrear & 4274 & 5638 & 1 & $S$ & & sombra & & -ear \\
\hline sombrejar & 4275 & 173 & 1 & $S$ & & sombra & & -ejar \\
\hline sondar & 4276 & 38600 & 1 & $S$ & & sonda & & -ar \\
\hline sonecar & 4277 & 60 & 1 & $S$ & & soneca & & -ar \\
\hline sonetar & 4278 & 183 & 1 & $S$ & & soneto & & -ar \\
\hline sonetear & 4279 & 122 & 1 & $S$ & & soneto & & -ear \\
\hline sopapar & 4280 & 103 & 1 & $S$ & & sopapo & & -ar \\
\hline sopapear & 4281 & 134 & 1 & $S$ & & sopapo & & -ear \\
\hline sopear & 4282 & 254 & 1 & $\mathrm{P}$ & so- & pé & & -ar \\
\hline sopetear & 4283 & 80 & 1 & $S$ & & sopa & -eta & -ear \\
\hline sopontar & 4284 & 78 & 1 & $\mathrm{P}$ & so- & ponto & & -ar \\
\hline \begin{tabular}{|l|} 
soporizar \\
\end{tabular} & 4285 & 83 & 1 & $S$ & & sopor & & -izar \\
\hline sopresar & 4286 & 92 & 1 & $\mathrm{P}$ & so- & presa & & -ar \\
\hline soquear & 4287 & 239 & 1 & $S$ & & soco & & -ear \\
\hline soqueixar & 4288 & 77 & 1 & $S$ & & soqueixo & & -ar \\
\hline soquetear & 4289 & 132 & 1 & $S$ & & soquete & & -ear \\
\hline \begin{tabular}{|l|} 
sororocar \\
\end{tabular} & 4290 & 100 & 1 & $S$ & & sororoca & & -ar \\
\hline sorrabar & 4291 & 104 & 1 & $P$ & so- & rabo & & -ar \\
\hline sortear & 4292 & 103000 & 1 & $S$ & & sorte & & -ear \\
\hline sorvar & 4293 & 126 & 1 & $S$ & & sorva & & -ar \\
\hline sotaquear & 4294 & 75 & 1 & $S$ & & sotaque & & -ar \\
\hline sotaventear & 4295 & 96 & 1 & $S$ & & sotavento & & -ear \\
\hline \begin{tabular}{|l|} 
soterrar \\
\end{tabular} & 4296 & 4928 & 1 & $\mathrm{P}$ & so- & terra & & -ar \\
\hline sovelar & 4297 & 91 & 1 & $S$ & & sovela & & -ar \\
\hline sovietizar & 4298 & 185 & 1 & $S$ & & soviete & & -izar \\
\hline subcontratar & 4299 & 16375 & 1 & $S$ & & subcontrato & & -ar \\
\hline suberificar-se & 4300 & 0 & 1 & $S$ & & súber & $-i-$ & -ficar \\
\hline suberizar-se & 4301 & 1 & 1 & $\mathrm{~S}$ & & súber & & -izar \\
\hline
\end{tabular}




\begin{tabular}{|c|c|c|c|c|c|c|c|}
\hline subgrupar & 4302 & 42 & 1 & $S$ & & subgrupo & -ar \\
\hline sublinhar & 4303 & 60925 & 1 & $S$ & & sublinha & -ar \\
\hline subminiaturizar & 4304 & 0 & 1 & $\mathrm{~S}$ & & subminiatura & -izar \\
\hline subsidiar & 4305 & 1185000 & 2 & $S$ & & subsídio & -ar \\
\hline subsolar & 4306 & 436 & 1 & $S$ & & subsolo & -ar \\
\hline substanciar & 4307 & 3630 & 1 & S & & substância & -ar \\
\hline subterrar & 4308 & 77 & 1 & $\mathrm{P}$ & sub- & terra & -ar \\
\hline subtitular & 4309 & 568 & 1 & $S$ & & subtítulo & -ar \\
\hline sucatar & 4310 & 136 & 1 & $S$ & & sucata & -ar \\
\hline sucatear & 4311 & 6048 & 1 & S & & sucata & -ear \\
\hline suciar & 4312 & 116 & 1 & $S$ & & súcia & -ar \\
\hline sufixar & 4313 & 109 & 1 & $S$ & & sufixo & -ar \\
\hline sulaventear & 4314 & 112 & 1 & $S$ & & sulavento & -ear \\
\hline sulfatar & 4315 & 270 & 1 & $S$ & & sulfato & -ar \\
\hline sulfatizar & 4316 & 168 & 1 & $\mathrm{~S}$ & & sulfato & -izar \\
\hline sulfetar & 4317 & 155 & 1 & $S$ & & sulfeto & -ar \\
\hline sulfitar & 4318 & 77 & 1 & $S$ & & sulfito & -ar \\
\hline sulfurar & 4319 & 108 & 1 & $S$ & & súlfur & -ar \\
\hline sulfuretar & 4320 & 88 & 1 & $S$ & & sulfureto & -ar \\
\hline sulfurizar & 4321 & 30 & 1 & $\mathrm{~S}$ & & súlfur & -izar \\
\hline sultanear & 4322 & 79 & 1 & $S$ & & sultão & -ear \\
\hline sumagrar & 4323 & 119 & 1 & $S$ & & sumagre & -ar \\
\hline sumular & 4324 & 18150 & 1 & $S$ & & súmula & -ar \\
\hline supercalandrar & 4325 & 257 & 1 & $S$ & & supercalandra & -ar \\
\hline superciliar & 4326 & 730 & 1 & $S$ & & supercílio & -ar \\
\hline suplementar & 4327 & 841750 & 2 & $S$ & & suplemento & $-a r$ \\
\hline supliciar & 4328 & 627 & 1 & $S$ & & suplício & $-a r$ \\
\hline surdinar & 4329 & 108 & 1 & $\mathrm{~S}$ & & surdina & -ar \\
\hline surfar & 4330 & 132500 & 1 & $\mathrm{~S}$ & & surfe & -ar \\
\hline surpresar & 4331 & 520 & 1 & $S$ & & surpresa & -ar \\
\hline surrar & 4332 & 11900 & 1 & $S$ & & surro & -ar \\
\hline surribar & 4333 & 206 & 1 & $\mathrm{P}$ & sub- & riba & -ar \\
\hline sururucar & 4334 & 128 & 1 & $\mathrm{~S}$ & & sururuca & -ar \\
\hline sutar & 4335 & 137 & 1 & $\mathrm{~S}$ & & suta & -ar \\
\hline suturar & 4336 & 3473 & 1 & $S$ & & sutura & -ar \\
\hline tabaquear & 4337 & 198 & 1 & $S$ & & tabaco & -ear \\
\hline tabelar & 4338 & 12925 & 1 & $S$ & & tabela & -ar \\
\hline tabernear & 4339 & 153 & 1 & $\mathrm{~S}$ & & taberna & -ear \\
\hline tabicar & 4340 & 129 & 1 & $S$ & & tabica & -ar \\
\hline tabizar & 4342 & 82 & 1 & $S$ & & tabi & $-a r$ \\
\hline taboquear & 4343 & 120 & 1 & $\mathrm{~S}$ & & taboca & -ear \\
\hline tacar & 4344 & 56375 & 1 & $S$ & & taca & -ar \\
\hline tachar & 4346 & 6778 & 1 & $S$ & & tacho & -ar \\
\hline tachear & 4347 & 176 & 1 & $S$ & & tacha & -ear \\
\hline tachonar & 4348 & 120 & 1 & $S$ & & tachona & -ar \\
\hline tagantar & 4349 & 112 & 1 & $S$ & & tagante & -ar \\
\hline tagantear & 4350 & 106 & 1 & $S$ & & tagante & -ear \\
\hline tainar & 4351 & 555 & 1 & $S$ & & taina & -ar \\
\hline taipar & 4352 & 128 & 1 & $S$ & & taipa & -ar \\
\hline tairocar & 4353 & 0 & 1 & $S$ & & tairoca & -ar \\
\hline talingar & 4354 & 131 & 1 & $S$ & & talinga & -ar \\
\hline taludar & 4355 & 105 & 1 & $S$ & & talude & -ar \\
\hline tamancar & 4356 & 168 & 1 & $S$ & & tamanco & -ar \\
\hline tamanquear & 4357 & 167 & 1 & $S$ & & tamanco & -ear \\
\hline tamborejar & 4358 & 21 & 1 & $S$ & & tambor & -ejar \\
\hline tamborilar & 4359 & 1795 & 1 & $S$ & & tamboril & -ar \\
\hline tamisar & 4360 & 188 & 1 & $S$ & & tamis & -ar \\
\hline tampar & 4361 & 52800 & 1 & $S$ & & tampa & -ar \\
\hline tangar & 4363 & 2303 & 1 & $S$ & & tango & -ar \\
\hline tangenciar & 4364 & 5313 & 1 & $S$ & & tangência & -ar \\
\hline tanoar & 4365 & 278 & 1 & $S$ & & tanoa & -ar \\
\hline tapetar & 4366 & 402 & 1 & $S$ & & tapete & -ar \\
\hline tapizar & 4367 & 848 & 1 & $S$ & & tapiz & -ar \\
\hline tapulhar & 4368 & 102 & 1 & $S$ & & tapulho & -ar \\
\hline
\end{tabular}




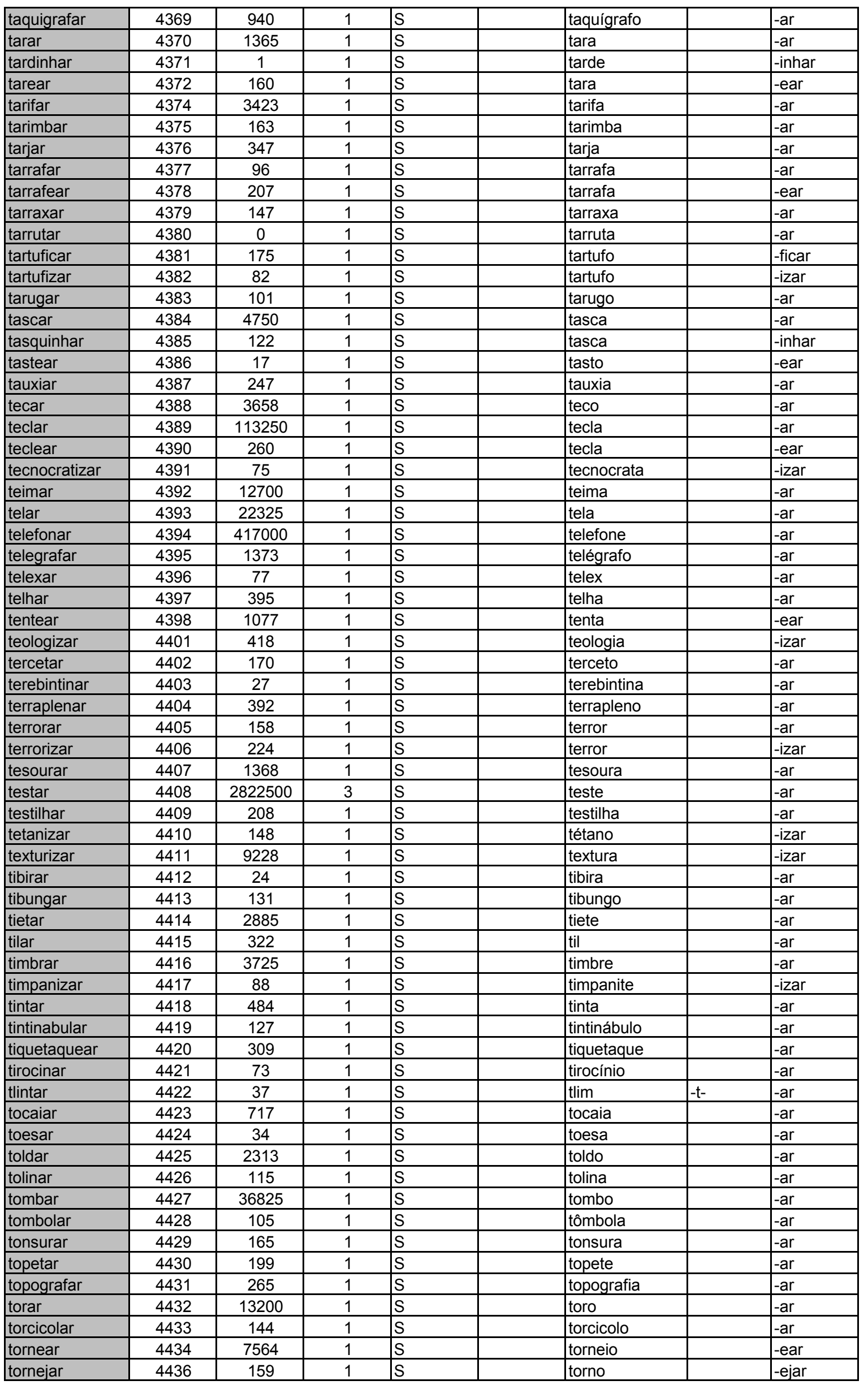




\begin{tabular}{|c|c|c|c|c|c|c|c|}
\hline torpedear & 4437 & 3305 & 1 & $S$ & & torpedo & -ear \\
\hline torrear & 4438 & 168 & 1 & $S$ & & torre & -ear \\
\hline torrejar & 4439 & 135 & 1 & $S$ & & torre & -ejar \\
\hline torturar & 4440 & 207000 & 1 & $S$ & & tortura & -ar \\
\hline torvelinhar & 4441 & 126 & 1 & $S$ & & torvelinho & -ar \\
\hline tossicar & 4442 & 97 & 1 & S & & tosse & -icar \\
\hline toucar & 4443 & 336 & 1 & $S$ & & touca & -ar \\
\hline tourear & 4444 & 2510 & 1 & $S$ & & touro & -ear \\
\hline toutear & 4445 & 92 & 1 & $S$ & & touta & -ear \\
\hline traçar & 4446 & 780000 & 2 & $S$ & & traça & -ar \\
\hline tracejar & 4447 & 896 & 1 & $S$ & & traço & -ejar \\
\hline tradar & 4448 & 332 & 1 & $S$ & & trado & -ar \\
\hline tradear & 4449 & 210 & 1 & $S$ & & trado & -ear \\
\hline trafeguear & 4450 & 112 & 1 & $S$ & & tráfego & -ear \\
\hline tragediar & 4451 & 8 & 1 & $S$ & & tragédia & -ar \\
\hline traguear & 4452 & 180 & 1 & $S$ & & trago & -ear \\
\hline trajar & 4453 & 11075 & 1 & $S$ & & traje & -ar \\
\hline tralhar & 4454 & 799 & 1 & $S$ & & tralha & -ar \\
\hline tramar & 4455 & 15950 & 1 & $S$ & & trama & -ar \\
\hline trambicar & 4456 & 537 & 1 & $S$ & & trambique & -ar \\
\hline trambolhar & 4457 & 187 & 1 & $S$ & & trambolho & -ar \\
\hline tramelar & 4458 & 112 & 1 & $S$ & & tramela & -ar \\
\hline tramitar & 4459 & 75525 & 1 & $S$ & & trâmite & -ar \\
\hline tramontar & 4460 & 185 & 1 & $P$ & tra- & monte & -ar \\
\hline trampolinar & 4461 & 120 & 1 & $S$ & & trampolina & -ar \\
\hline trançar & 4462 & 7100 & 1 & $S$ & & trança & -ar \\
\hline tranquear & 4463 & 193 & 1 & $S$ & & tranco & -ear \\
\hline tranqueirar & 4464 & 461 & 1 & $S$ & & tranqueira & -ar \\
\hline transar & 4465 & 206000 & 1 & $S$ & & transa & -ar \\
\hline transbordar & 4466 & 44225 & 1 & $\mathrm{P}$ & trans- & borda & -ar \\
\hline transcursar & 4467 & 98 & 1 & $S$ & & transcurso & -ar \\
\hline transistorizar & 4468 & 91 & 1 & $S$ & & transistor & -izar \\
\hline transitar & 4469 & 439000 & 1 & $S$ & & trânsito & -ar \\
\hline transladar & 4470 & 4908 & 1 & $S$ & & translado & -ar \\
\hline transmetilar & 4471 & 1 & 1 & $P$ & trans- & metil- & -ar \\
\hline transmontar & 4472 & 230 & 1 & $P$ & trans- & monte & -ar \\
\hline transvasar & 4473 & 361 & 1 & $\mathrm{P}$ & trans- & vaso & -ar \\
\hline transviar & 4474 & 927 & 1 & $\mathrm{P}$ & trans- & via & -ar \\
\hline trapacear & 4475 & 72300 & 1 & $S$ & & trapaça & -ear \\
\hline trapear & 4476 & 517 & 1 & $S$ & & trapo & -ear \\
\hline trapejar & 4477 & 253 & 1 & $S$ & & trapo & -ejar \\
\hline traquejar & 4478 & 221 & 1 & $S$ & & traque & -ejar \\
\hline traquitanar & 4479 & 81 & 1 & $S$ & & traquitana & -ar \\
\hline trasbordar & 4480 & 703 & 1 & $P$ & tras- & borda & -ar \\
\hline trasguear & 4481 & 146 & 1 & $S$ & & trasgo & -ear \\
\hline trasladar & 4482 & 5940 & 1 & $S$ & & traslado & -ar \\
\hline trastear & 4483 & 116 & 1 & $S$ & & traste & -ear \\
\hline trastejar & 4484 & 1613 & 1 & $S$ & & traste & -ejar \\
\hline travar & 4485 & 437000 & 1 & $S$ & & trave & -ar \\
\hline travejar & 4486 & 692 & 1 & $S$ & & trave & -ejar \\
\hline trebelhar & 4487 & 120 & 1 & $S$ & & trebelho & -ar \\
\hline trejeitar & 4488 & 118 & 1 & $S$ & & trejeito & -ar \\
\hline trejeitear & 4489 & 110 & 1 & $S$ & & trejeito & -ear \\
\hline tremar & 4490 & 516 & 1 & $S$ & & trema & -ar \\
\hline tremoçar & 4491 & 1 & 1 & $S$ & & tremoço & -ar \\
\hline trepanar & 4492 & 218 & 1 & $S$ & & trépano & -ar \\
\hline tresmalhar & 4493 & 302 & 1 & $P$ & tres- & malha & -ar \\
\hline tresnoitar & 4494 & 156 & 1 & $P$ & tres- & noite & -ar \\
\hline tretear & 4495 & 90 & 1 & $S$ & & treta & -ear \\
\hline \begin{tabular}{|l|} 
triangular \\
\end{tabular} & 4496 & 134250 & 1 & $S$ & & triângulo & -ar \\
\hline triar & 4497 & 16200 & 1 & $S$ & & triagem & -ar \\
\hline tribofar & 4498 & 149 & 1 & $S$ & & tribofe & -ar \\
\hline tributar & 4499 & 79175 & 1 & $S$ & & tributo & -ar \\
\hline trifurcar & 4500 & 120 & 1 & $\mathrm{P}$ & tri- & furca & -ar \\
\hline
\end{tabular}




\begin{tabular}{|c|c|c|c|c|c|c|}
\hline trilar & 4501 & 826 & 1 & $S$ & trilo & -ar \\
\hline trincafiar & 4502 & 156 & 1 & $S$ & trincafio & -ar \\
\hline trincheirar & 4503 & 85 & 1 & $S$ & trincheira & -ar \\
\hline trintar & 4504 & 160 & 1 & $S$ & trinta & -ar \\
\hline trissar & 4505 & 234 & 1 & $S$ & trisso & -ar \\
\hline trocadilhar & 4506 & 169 & 1 & $S$ & trocadilho & -ar \\
\hline trociscar & 4507 & 147 & 1 & $S$ & trocisco & -ar \\
\hline troiar & 4508 & 111 & 1 & $S$ & tróia & -ar \\
\hline trombar & 4509 & 13700 & 1 & $S$ & tromba & -ar \\
\hline trombetar & 4510 & 70 & 1 & $S$ & trombeta & -ar \\
\hline trombetear & 4511 & 1315 & 1 & $S$ & trombeta & -ear \\
\hline trompar & 4512 & 230 & 1 & $S$ & trompa & -ar \\
\hline trompear & 4513 & 127 & 1 & $S$ & trompa & -ear \\
\hline trompejar & 4514 & 44 & 1 & $S$ & trompa & -ejar \\
\hline tronar & 4515 & 2243 & 1 & $\mathrm{~S}$ & trono- & -ar \\
\hline tronear & 4516 & 164 & 1 & $S$ & trono & -ear \\
\hline tronejar & 4518 & 159 & 1 & $S$ & trono & -ejar \\
\hline tropear & 4520 & 1086 & 1 & $S$ & tropa & -ear \\
\hline tropeliar & 4521 & 124 & 1 & S & tropel & -iar \\
\hline troquilhar & 4522 & 92 & 1 & S & troquilha & -ar \\
\hline troviscar & 4523 & 141 & 1 & $S$ & trovisco & -ar \\
\hline trucar & 4524 & 1775 & 1 & S & truque & -ar \\
\hline trunfar & 4526 & 287 & 1 & $S$ & trunfo & -ar \\
\hline trupar & 4527 & 59 & 1 & $\mathrm{~S}$ & trupe & -ar \\
\hline tubar & 4528 & 4285 & 1 & $S$ & tubo & -ar \\
\hline tuberculinizar & 4529 & 150 & 1 & $S$ & tuberculina & -izar \\
\hline tuberculizar & 4530 & 163 & 1 & S & tubérculo & -izar \\
\hline tuberizar & 4531 & 72 & 1 & $\mathrm{~S}$ & túbera & -izar \\
\hline tubular & 4532 & 219500 & 1 & S & túbulo & -ar \\
\hline tufar & 4533 & 230 & 1 & $S$ & tufo & -ar \\
\hline tunar & 4534 & 31700 & 1 & $S$ & tuna & -ar \\
\hline tundar & 4535 & 247 & 1 & S & tunda & -ar \\
\hline turbinar & 4536 & 195250 & 1 & $S$ & turbina & -ar \\
\hline turibular & 4537 & 118 & 1 & S & turíbulo & -ar \\
\hline turturinar & 4538 & 119 & 1 & S & turturino & -ar \\
\hline \begin{tabular}{|l} 
tutelar \\
\end{tabular} & 4539 & 518250 & 2 & $\mathrm{~S}$ & tutela & -ar \\
\hline unhar & 4540 & 633 & 1 & $S$ & unha & -ar \\
\hline untar & 4541 & 62275 & 1 & $\mathrm{~S}$ & unto & -ar \\
\hline upar & 4542 & 465000 & 1 & $S$ & upa & -ar \\
\hline urrar & 4543 & 6195 & 1 & $S$ & urro & -ar \\
\hline urticar & 4544 & 123 & 1 & S & urtica & -ar \\
\hline urtigar & 4545 & 157 & 1 & $S$ & urtiga & -ar \\
\hline usinar & 4546 & 7078 & 1 & S & usina & -ar \\
\hline usurar & 4547 & 111 & 1 & $S$ & usura & -ar \\
\hline vacinar & 4548 & 201750 & 1 & $S$ & vacina & -ar \\
\hline vagear & 4549 & 67 & 1 & S & vage & -ear \\
\hline \begin{tabular}{|l} 
vaguear \\
\end{tabular} & 4551 & 10475 & 1 & $S$ & vaga & -ear \\
\hline vaguejar & 4552 & 154 & 1 & S & rad.devagar & -ejar \\
\hline vaiar & 4553 & 23325 & 1 & $S$ & vaia & -ar \\
\hline valorar & 4554 & 22100 & 1 & $S$ & valor & -ar \\
\hline valorizar & 4555 & 1137500 & 2 & $S$ & valor & -izar \\
\hline valsar & 4556 & 2563 & 1 & $\mathrm{~S}$ & valsa & -ar \\
\hline valsear & 4557 & 59 & 1 & $\mathrm{~S}$ & valsa & -ear \\
\hline vampirizar & 4558 & 1203 & 1 & $S$ & vampiro & -izar \\
\hline vangloriar & 4559 & 22075 & 1 & $\mathrm{~S}$ & vanglória & -ar \\
\hline \begin{tabular}{|l|} 
vaporizar \\
\end{tabular} & 4560 & 5793 & 1 & $\mathrm{~S}$ & vapor & -izar \\
\hline vaqueanar & 4561 & 112 & 1 & $S$ & vaqueano & -ar \\
\hline vaquejar & 4562 & 267 & 1 & $S$ & vaca & -ejar \\
\hline varejar & 4563 & 737 & 1 & $S$ & vara & -ejar \\
\hline variolizar & 4564 & 5 & 1 & $\mathrm{~S}$ & varíola & -izar \\
\hline vasquear & 4565 & 152 & 1 & $S$ & vasca & -ear \\
\hline vasquejar & 4566 & 151 & 1 & $\mathrm{~S}$ & vasca & -ejar \\
\hline vassoirar & 4567 & 114 & 1 & $S$ & vassoira & -ar \\
\hline vassourar & 4568 & 265 & 1 & $\mathrm{~S}$ & vassoura & -ar \\
\hline
\end{tabular}




\begin{tabular}{|c|c|c|c|c|c|c|}
\hline veiar & 4569 & 217 & 1 & $S$ & veia & -ar \\
\hline veicular & 4571 & 1215000 & 2 & $S$ & veículo & -ar \\
\hline velear & 4572 & 206 & 1 & $S$ & vela & -ear \\
\hline velejar & 4573 & 90225 & 1 & $S$ & vela & -ejar \\
\hline vendar & 4574 & 8780 & 1 & $S$ & venda & -ar \\
\hline veneficiar & 4575 & 187 & 1 & $S$ & venefício & -iar \\
\hline veniagar & 4576 & 93 & 1 & $S$ & veniaga & -ar \\
\hline ventar & 4577 & 8765 & 1 & $S$ & vento & -ar \\
\hline \begin{tabular}{|l|} 
ventejar \\
\end{tabular} & 4578 & 10 & 1 & $S$ & vento & -ejar \\
\hline verbetar & 4579 & 80 & 1 & $S$ & verbete & -ar \\
\hline verdascar & 4580 & 185 & 1 & $S$ & verdasca & -ar \\
\hline verear & 4581 & 602 & 1 & $S$ & vereda & -ar \\
\hline vergalhar & 4582 & 146 & 1 & $S$ & vergalho & -ar \\
\hline vergar & 4583 & 5168 & 1 & $S$ & verga & -ar \\
\hline vergastar & 4584 & 983 & 1 & $\mathrm{~S}$ & vergasta & $-\mathrm{ar}$ \\
\hline vergonhar & 4585 & 296 & 1 & $S$ & vergonha & -ar \\
\hline vergontear & 4586 & 129 & 1 & $S$ & vergôntea & -ar \\
\hline vermicular & 4587 & 1493 & 1 & $S$ & vermículo & -ar \\
\hline verrumar & 4588 & 320 & 1 & S & verruma & -ar \\
\hline versar & 4589 & 57250 & 1 & S & verso & -ar \\
\hline versejar & 4590 & 7893 & 1 & $S$ & verso & -ejar \\
\hline vezar & 4591 & 421 & 1 & S & vezo & -ar \\
\hline viçar & 4592 & 665 & 1 & $S$ & viço & -ar \\
\hline vicejar & 4593 & 3818 & 1 & $S$ & viço & -ejar \\
\hline vidar & 4594 & 26800 & 1 & $S$ & vide & -ar \\
\hline vidrar & 4595 & 2773 & 1 & $S$ & vidro & -ar \\
\hline vigar & 4596 & 1400 & 1 & $S$ & viga & -ar \\
\hline vigorizar & 4597 & 211 & 1 & $S$ & vigor & -izar \\
\hline vilegiaturar & 4598 & 61 & 1 & S & vilegiatura & -ar \\
\hline \begin{tabular}{|l|} 
vilipendiar \\
\end{tabular} & 4599 & 4588 & 1 & $S$ & vilipêndio & -ar \\
\hline vincar & 4600 & 7290 & 1 & $S$ & vinco & -ar \\
\hline virgular & 4601 & 662 & 1 & $S$ & vírgula & -ar \\
\hline visgar & 4602 & 85 & 1 & $S$ & visgo & -ar \\
\hline visporar & 4603 & 147 & 1 & S & víspora & -ar \\
\hline \begin{tabular}{|l|} 
vistoriar \\
\end{tabular} & 4604 & 82000 & 1 & S & vistoria & -ar \\
\hline vitaminar & 4605 & 2405 & 1 & $S$ & vitamina & -ar \\
\hline vitaminizar & 4606 & 161 & 1 & $S$ & vitamina & -izar \\
\hline vitoriar & 4607 & 393 & 1 & $\mathrm{~S}$ & vitória & -ar \\
\hline vitriolar & 4608 & 144 & 1 & $S$ & vitríolo & -ar \\
\hline vitriolizar & 4609 & 142 & 1 & $S$ & vitríolo & -izar \\
\hline vitualhar & 4610 & 30 & 1 & S & vitualha & -ar \\
\hline \begin{tabular}{|l|} 
viuvar \\
\end{tabular} & 4611 & 149 & 1 & $S$ & viúva & -ar \\
\hline vivar & 4612 & 15200 & 1 & S & viva & -ar \\
\hline vivenciar & 4613 & 220750 & 1 & $S$ & vivência & -ar \\
\hline vocabularizar & 4614 & 140 & 1 & $S$ & vocabulário & -izar \\
\hline voejar & 4615 & 1123 & 1 & S & vôo & -ejar \\
\hline volear & 4616 & 270 & 1 & $S$ & vôlei & -ear \\
\hline voltear & 4617 & 1820 & 1 & S & volta & -ear \\
\hline volumar & 4618 & 319 & 1 & $S$ & volume & -ar \\
\hline volutear & 4619 & 228 & 1 & $S$ & voluta & -ear \\
\hline vozear & 4620 & 997 & 1 & $S$ & voz & -ear \\
\hline warrantar & 4621 & 171 & 1 & $\mathrm{~S}$ & warrant & -ar \\
\hline xavecar & 4622 & 6048 & 1 & $\mathrm{~S}$ & xaveco & -ar \\
\hline xerocopiar & 4623 & 945 & 1 & $S$ & xerocópia & -ar \\
\hline xumbergar & 4624 & 132 & 1 & $\mathrm{~S}$ & xumberga & -ar \\
\hline zabumbar & 4625 & 326 & 1 & $\mathrm{~S}$ & zabumba & -ar \\
\hline zagunchar & 4626 & 109 & 1 & $S$ & zaguncho & -ar \\
\hline zangar & 4627 & 8708 & 1 & $S$ & zanga & -ar \\
\hline zangarilhar & 4628 & 110 & 1 & $S$ & zangarilho & -ar \\
\hline zanguizarrar & 4629 & 0 & 1 & $\mathrm{~S}$ & zanguizarra & -ear \\
\hline zanguizarrear & 4630 & 166 & 1 & $\mathrm{~S}$ & zanguizarra & -ear \\
\hline zarelhar & 4631 & 126 & 1 & $\mathrm{~S}$ & zarelho & -ar \\
\hline zargunchar & 4632 & 116 & 1 & $S$ & zarguncho & -ar \\
\hline zebrar & 4633 & 1510 & 1 & $\mathrm{~S}$ & zebra & -ar \\
\hline
\end{tabular}




\begin{tabular}{|l|c|c|c|l|l|l|l|l|}
\hline Zerar & 4634 & 280750 & 1 & S & & zero & & -ar \\
\hline ziguezaguear & 4635 & 2035 & 1 & S & & ziguezague & & -ar \\
\hline zincar & 4636 & 457 & 1 & S & & zinco & & -ar \\
\hline zingar & 4637 & 195 & 1 & S & & zinga & & -ar \\
\hline zonar & 4638 & 682 & 1 & S & & zona & & -ar \\
\hline zonear & 4639 & 3103 & 1 & S & & zona & & -ear \\
\hline zorragar & 4640 & 79 & 1 & S & & zorrague & -ar \\
\hline zumbaiar & 4641 & 148 & 1 & S & & zumbaia & -ar \\
\hline zumbificar & 4642 & 1075 & 1 & S & & zumbi & -ficar \\
\hline Zurrar & 4643 & 1125 & 1 & S & & zurro & & -ar \\
\hline
\end{tabular}




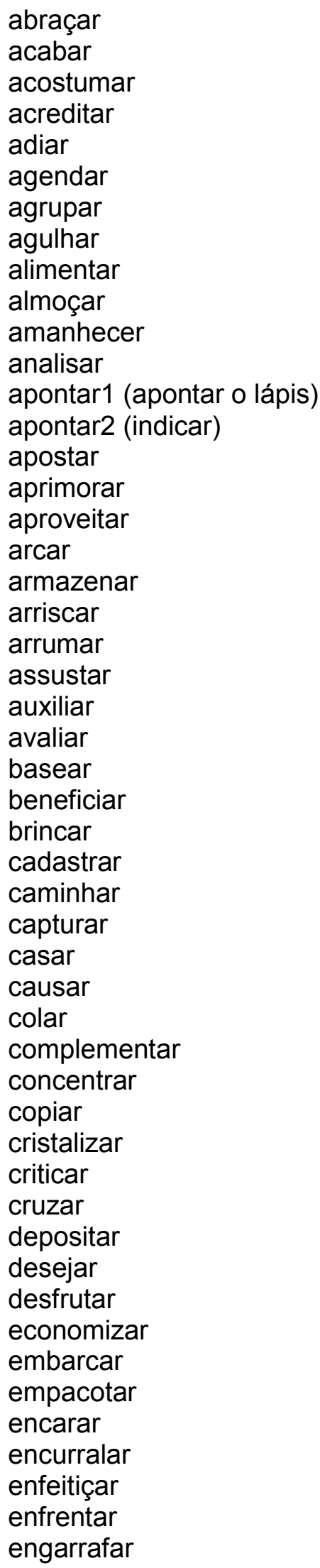

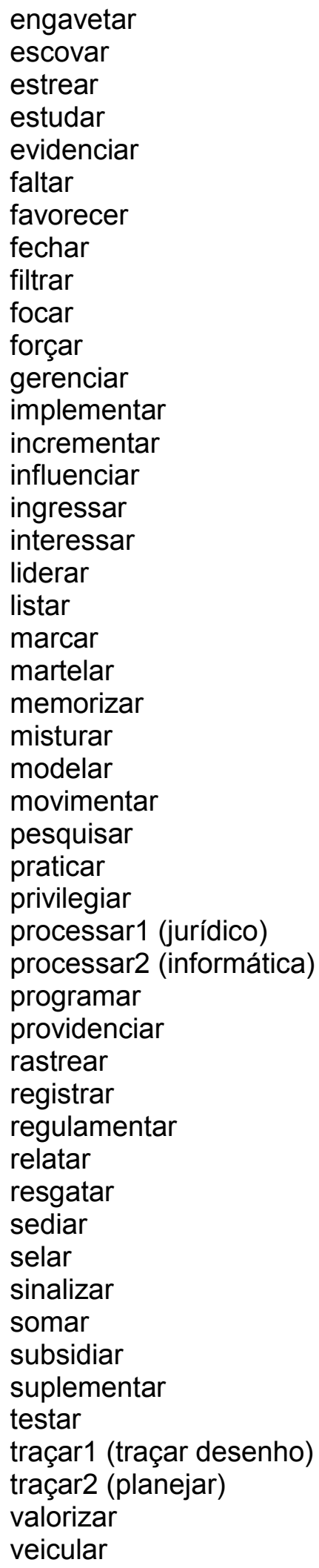


ANEXO 03

EMAIL EXPLICATIVO

INSTRUÇÕES PARA O TESTE:

Leia a frase e diga se ela poderia ser falada por alguém.

Não importa se a frase é gramaticalmente correta ou não, o que importa é se ela é ACEITÁVEL (SIM) ou se ela é ESTRANHA (NÃO) de acordo com sua intuição.

Link do questionário 01

Muito obrigada!

\section{Question Pro} Privacy | Security

Surveys | Email Marketing | Web Polls 


\section{AMOSTRAGEM}

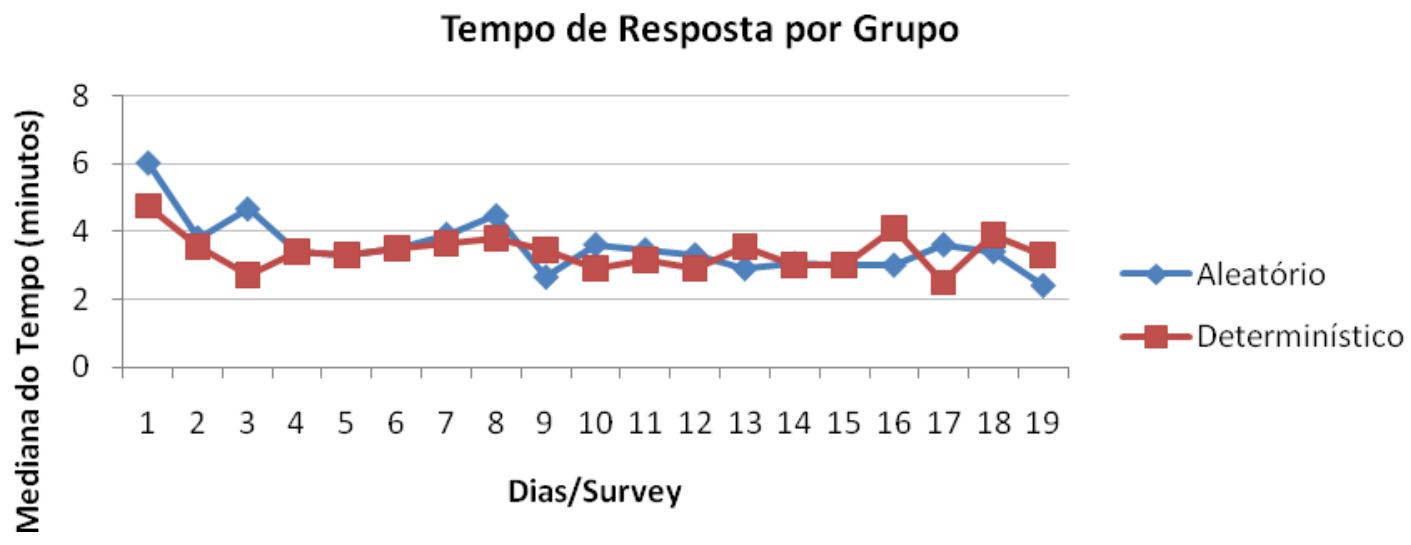

O gráfico acima mostra a mediana do tempo de resposta em minutos em ambos os grupos, Aleatório e Ordenado ou Determinístico, e o gráfico abaixo mostra o a mediana do tempo de resposta em minutos para os dois grupos juntos. Aparentemente, depois do primeiro dia de pesquisa, o tempo de resposta diminuiu, o que pode indicar uma habilidade adquirida para responder o teste.

Tempo de Resposta Geral (Det+Alea)

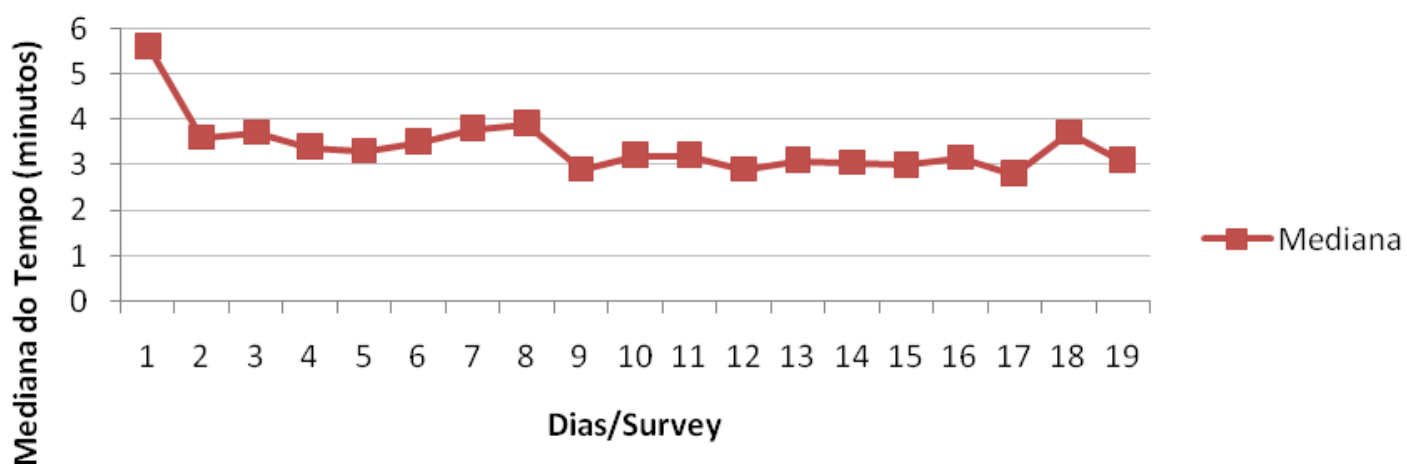




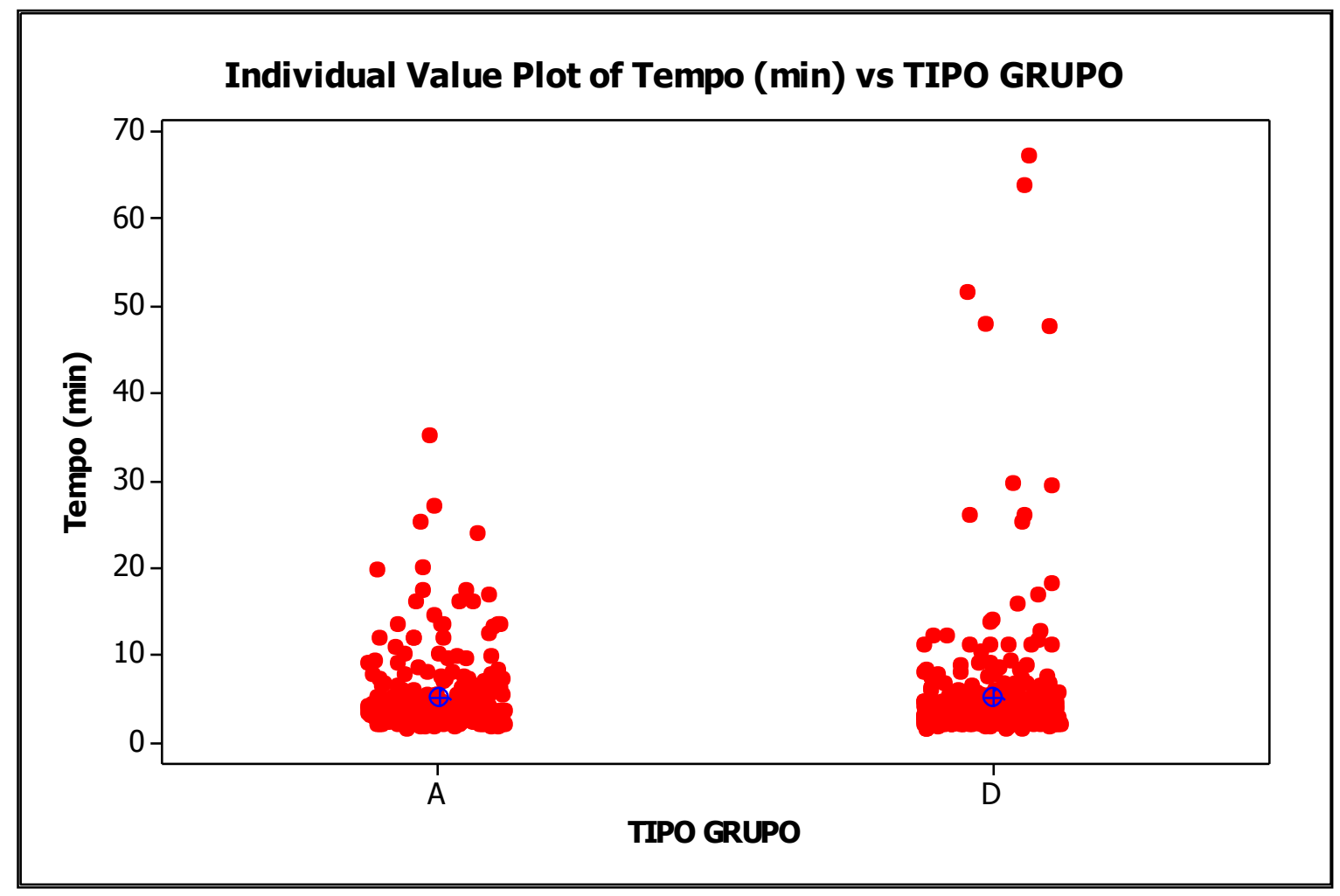

Os grupos aleatório (A) e ordenado (D) obtiveram um tempo médio de resposta (médias) estatisticamente iguais (Valor $p=0,84$ ). Abaixo o teste $t$ de diferença de médias.

Difference $=m u(A)-m u(D)$

Estimate for difference: $-0,098493$

95\% Cl for difference: $(-1,073083 ; 0,876097)$

T-Test of difference $=0$ (vs not $=): T-$ Value $=-0,20 \quad P$-Value $=0,843$ DF $=$ 619

Both use Pooled StDev $=6,1496$ 
ANEXO 05 - TESTES

\begin{tabular}{|c|c|c|c|c|c|}
\hline \multirow[b]{2}{*}{ Verbo } & \multirow[b]{2}{*}{ Tipo Sentença } & \multirow[b]{2}{*}{ Sentença } & \multicolumn{2}{|c|}{ Resultados ORD+ALEA } & \multirow{2}{*}{$\begin{array}{c}\text { Significância } \\
5 \%\end{array}$} \\
\hline & & & SIM & NÃO & \\
\hline estudar & 1.Alternância Causativo-Incoativa ou Transitivo-intransitiva & A vida marinha estudou. & 3 & 33 & DIF \\
\hline estudar & 2.Alternância Média & A vida marinha estuda fácil. & 3 & 36 & DIF \\
\hline estudar & 3.Expressão perifrástica & Eu fiz um estudo sobre a vida marinha. & 32 & 1 & DIF \\
\hline estudar & 4.Objetos Cognatos & Eu estudei um estudo sobre a vida marinha. & 25 & 11 & DIF \\
\hline estudar & 5.Adjuntos Cognatos & Eu estudei a vida marinha com um estudo minucioso. & 26 & 6 & DIF \\
\hline estudar & 6.Adjuntos Hipônimos e Hiperônimos & Eu estudei a vida marinha com uma leitura tranquila. & 26 & 8 & DIF \\
\hline avaliar & 1.Alternância Causativo-Incoativa ou Transitivo-intransitiva & Os alunos avaliaram. & 18 & 14 & IGUAL \\
\hline avaliar & 2.Alternância Média & Os alunos de 4 a série avaliam bem. & 19 & 16 & IGUAL \\
\hline avaliar & 3.Expressão perifrástica & A professora fez uma boa valia dos alunos. & 13 & 21 & IGUAL \\
\hline avaliar & 4.Objetos Cognatos & A professora avaliou uma avaliação fraca. & 15 & 18 & IGUAL \\
\hline avaliar & 5.Adjuntos Cognatos & A professora avaliou os alunos com uma valia deficiente. & 9 & 25 & DIF \\
\hline avaliar & 6.Adjuntos Hipônimos e Hiperônimos & A professora avaliou os alunos com um teste deficiente & 31 & 2 & DIF \\
\hline avaliar & Sentença-base & O Professor avaliou os alunos. & 34 & 0 & DIF \\
\hline enfrentar & 1.Alternância Causativo-Incoativa ou Transitivo-intransitiva & A situação enfrentou. & 2 & 37 & DIF \\
\hline enfrentar & 3.Expressão perifrástica & Os meninos fizeram frente à situação. & 32 & 2 & DIF \\
\hline enfrentar & 4.Objetos Cognatos & Os meninos enfrentaram uma frente corajosa. & 15 & 21 & IGUAL \\
\hline enfrentar & 5.Adjuntos Cognatos & Os meninos enfrentaram os outros com uma frente corajosa. & 14 & 20 & IGUAL \\
\hline enfrentar & 6.Adjuntos Hipônimos e Hiperônimos & O exército enfrentou a situação com uma dianteira corajosa. & 27 & 9 & DIF \\
\hline enfrentar & Sentença-base & Os meninos enfrentaram a situação. & 33 & 0 & DIF \\
\hline complementar & 1.Alternância Causativo-Incoativa ou Transitivo-intransitiva & A minha fala complementou. & 9 & 25 & DIF \\
\hline complementar & 2.Alternância Média & Falas curtas complementam bem. & 18 & 14 & IGUAL \\
\hline complementar & 3.Expressão perifrástica & Ele fez um complemento à minha fala. & 34 & 2 & DIF \\
\hline complementar & 4.Objetos Cognatos & Ele complementou um complemento estranho à minha fala. & 9 & 25 & DIF \\
\hline complementar & 5.Adjuntos Cognatos & Ele complementou a minha fala com um complemento estranho. & 24 & 10 & DIF \\
\hline complementar & 6.Adjuntos Hipônimos e Hiperônimos & Ele complementou a minha fala com um adendo desconexo. & 31 & 3 & DIF \\
\hline complementar & Sentença-base & Ele complementou a minha fala. & 31 & 1 & DIF \\
\hline acreditar & 1.Alternância Causativo-Incoativa ou Transitivo-intransitiva & O sujeito acreditou. & 24 & 12 & IGUAL \\
\hline acreditar & 2.Alternância Média & Sujeitos como esse acreditam fácil. & 23 & 12 & IGUAL \\
\hline acreditar & 3.Expressão perifrástica & Eu dei um crédito ao sujeito. & 37 & 2 & DIF \\
\hline acreditar & 4.Objetos Cognatos & Eu acreditei um crédito enorme nele. & 3 & 31 & DIF \\
\hline acreditar & 5.Adjuntos Cognatos & Eu acreditei nele com um crédito sem tamanho. & 13 & 21 & IGUAL \\
\hline
\end{tabular}

Página 1 


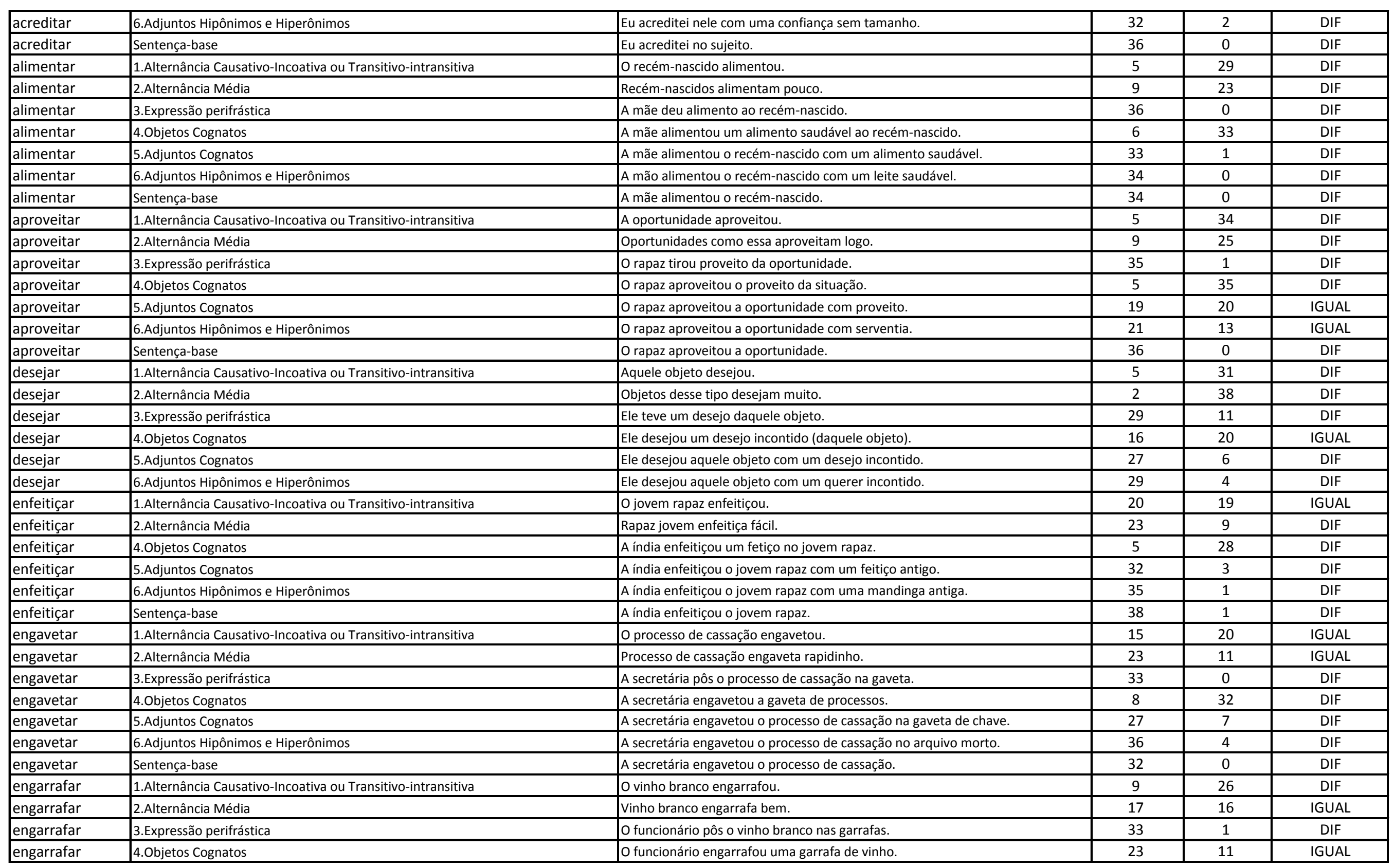




\begin{tabular}{|c|c|c|c|c|c|}
\hline engarrafar & 5.Adjuntos Cognatos & O funcionário engarrafou o vinho branco na garrafa de vidro. & 30 & 1 & DIF \\
\hline engarrafar & 6.Adjuntos Hipônimos e Hiperônimos & O funcionário engarrafou o vinho branco nos galões errados. & 34 & 1 & DIF \\
\hline engarrafar & Sentença-base & O funcionário engarrafou o vinho branco. & 37 & 1 & DIF \\
\hline encurralar & 1.Alternância Causativo-Incoativa ou Transitivo-intransitiva & O boi bravo encurralou. & 12 & 22 & IGUAL \\
\hline encurralar & 3.Expressão perifrástica & O peão pôs o boi no curral. & 33 & 1 & DIF \\
\hline encurralar & 4.Objetos Cognatos & O peão encurralou um curral de boi. & 12 & 21 & IGUAL \\
\hline encurralar & 5.Adjuntos Cognatos & O peão encurralou o boi bravo no curral menor. & 31 & 1 & DIF \\
\hline encurralar & 6.Adjuntos Hipônimos e Hiperônimos & O peão encurralou o boi bravo no cercado menor. & 32 & 1 & DIF \\
\hline encurralar & Sentença-base & O peão encurralou o boi bravo. & 33 & 0 & DIF \\
\hline selar & 1.Alternância Causativo-Incoativa ou Transitivo-intransitiva & O cavalo selou. & 9 & 26 & DIF \\
\hline selar & 2.Alternância Média & Cavalo manso sela rápido. & 25 & 10 & DIF \\
\hline selar & 3.Expressão perifrástica & O peão pôs a sela no cavalo. & 35 & 0 & DIF \\
\hline selar & 4.Objetos Cognatos & O peão selou a sela no cavalo. & 22 & 13 & IGUAL \\
\hline selar & 5.Adjuntos Cognatos & O peão selou o cavalo com a sela nova. & 34 & 1 & DIF \\
\hline selar & 6.Adjuntos Hipônimos e Hiperônimos & O peão selou o cavalo com um pedaço de couro velho. & 37 & 2 & DIF \\
\hline selar & Sentença-base & O peão selou o cavalo. & 33 & 0 & DIF \\
\hline martelar & 1.Alternância Causativo-Incoativa ou Transitivo-intransitiva & O prego martelou. & 11 & 23 & IGUAL \\
\hline martelar & 3.Expressão perifrástica & Eu bati o prego com o martelo. & 38 & 1 & DIF \\
\hline martelar & 4.Objetos Cognatos & Eu martelei o martelo no prego. & 13 & 22 & IGUAL \\
\hline martelar & 5.Adjuntos Cognatos & Eu martelei o prego com o martelo grande. & 32 & 1 & DIF \\
\hline martelar & 6.Adjuntos Hipônimos e Hiperônimos & Eu martelei o prego com a sola do sapato. & 32 & 1 & DIF \\
\hline martelar & Sentença-base & Eu martelei o prego. & 38 & 0 & DIF \\
\hline escovar & 1.Alternância Causativo-Incoativa ou Transitivo-intransitiva & O cabelo escovou. & 9 & 22 & DIF \\
\hline escovar & 2.Alternância Média & Cabelo liso escova fácil. & 33 & 5 & DIF \\
\hline escovar & 3.Expressão perifrástica & A moça arrumou o cabelo com a escova. & 33 & 0 & DIF \\
\hline escovar & 4.Objetos Cognatos & A moça escovou a escova no cabelo. & 10 & 28 & DIF \\
\hline escovar & 5.Adjuntos Cognatos & A moça escovou o cabelo com a escova de madeira. & 33 & 0 & DIF \\
\hline escovar & 6.Adjuntos Hipônimos e Hiperônimos & A moça escovou o cabelo com o pente de madeira. & 37 & 1 & DIF \\
\hline escovar & Sentença-base & A moça escovou o cabelo. & 38 & 0 & DIF \\
\hline cristalizar & 1.Alternância Causativo-Incoativa ou Transitivo-intransitiva & O açúcar cristalizou. & 31 & 3 & DIF \\
\hline cristalizar & 2.Alternância Média & Açúcar de confeiteiro cristaliza rápido. & 31 & 2 & DIF \\
\hline cristalizar & 3.Expressão perifrástica & A fábrica fez cristal do açúcar. & 24 & 10 & DIF \\
\hline cristalizar & 4. Objetos Cognatos & A fábrica cristalizou o cristal no açúcar. & 9 & 23 & DIF \\
\hline assustar & 1.Alternância Causativo-Incoativa ou Transitivo-intransitiva & A criança assustou. & 27 & 9 & DIF \\
\hline
\end{tabular}

Página 3 


\begin{tabular}{|c|c|c|c|c|c|}
\hline assustar & 2.Alternância Média & Criança pequena assusta fácil. & 29 & 7 & DIF \\
\hline assustar & 3.Expressão perifrástica & O palhaço deu um susto na criança. & 34 & 0 & DIF \\
\hline assustar & 4.Objetos Cognatos & O palhaço assustou um susto enorme na criança. & 4 & 30 & DIF \\
\hline assustar & 5.Adjuntos Cognatos & O palhaço assustou a criança com um susto enorme. & 24 & 12 & IGUAL \\
\hline assustar & Sentença-base & O palhaço assustou a criança. & 34 & 0 & DIF \\
\hline beneficiar & 1.Alternância Causativo-Incoativa ou Transitivo-intransitiva & Os mais pobres beneficiaram. & 10 & 24 & DIF \\
\hline beneficiar & 2.Alternância Média & Os mais pobres beneficiam facilmente. & 11 & 21 & IGUAL \\
\hline beneficiar & 3.Expressão perifrástica & O modelo econômico deu beneficios aos mais pobres. & 33 & 1 & DIF \\
\hline beneficiar & 4.Objetos Cognatos & O modelo econômico beneficou um benefício bom aos mais pobres. & 7 & 29 & DIF \\
\hline beneficiar & 5.Adjuntos Cognatos & O modelo econômico beneficiou os mais pobres com benefícios úteis. & 27 & 8 & DIF \\
\hline beneficiar & 6.Adjuntos Hipônimos e Hiperônimos & O Modelo econômico beneficiou os mais pobres com favores úteis. & 26 & 9 & DIF \\
\hline beneficiar & Sentença-base & O modelo econômico beneficiou os mais pobres. & 36 & 0 & DIF \\
\hline colar & 1.Alternância Causativo-Incoativa ou Transitivo-intransitiva & O caderno colou. & 24 & 8 & DIF \\
\hline colar & 2.Alternância Média & Caderno de folha boa cola fácil. & 25 & 9 & DIF \\
\hline colar & 3.Expressão perifrástica & Eu colocou cola no caderno. & 34 & 0 & DIF \\
\hline colar & 4.Objetos Cognatos & Eu colei a cola no caderno. & 18 & 18 & IGUAL \\
\hline colar & 5.Adjuntos Cognatos & Eu colei o caderno com cola branca. & 39 & 0 & DIF \\
\hline colar & Sentença-base & Eu colei o caderno. & 34 & 2 & DIF \\
\hline casar & 1.Alternância Causativo-Incoativa ou Transitivo-intransitiva & Com o João casou. & 11 & 23 & IGUAL \\
\hline casar & 2.Alternância Média & Com o João casa fácil. & 13 & 19 & IGUAL \\
\hline casar & 3.Expressão perifrástica & A Maria fez uma casa com o João. ( Como paráfrase para casar) & 11 & 22 & IGUAL \\
\hline casar & 4.Objetos Cognatos & A Maria casou uma casa com o João. & 0 & 36 & DIF \\
\hline casar & 5.Adjuntos Cognatos & A Maria casou com o João com uma casa linda. & 7 & 26 & DIF \\
\hline casar & 6.Adjuntos Hipônimos e Hiperônimos & A Maria casou com o João com um lar lindo. & 12 & 20 & IGUAL \\
\hline casar & Sentença-base & A Maria casou com o João. & 38 & 1 & DIF \\
\hline praticar & 1.Alternância Causativo-Incoativa ou Transitivo-intransitiva & Yoga praticou. & 4 & 30 & DIF \\
\hline praticar & 2.Alternância Média & Método de Yoga bom pratica fácil. & 5 & 28 & DIF \\
\hline praticar & 3.Expressão perifrástica & Ela fez uma prática de yoga. & 28 & 7 & DIF \\
\hline praticar & 4.Objetos Cognatos & Ela praticou uma prática de yoga tranqüila. & 8 & 27 & DIF \\
\hline praticar & 5.Adjuntos Cognatos & Ela praticou yoga com uma prática tranqüila. & 20 & 18 & IGUAL \\
\hline praticar & 6.Adjuntos Hipônimos e Hiperônimos & Ela praticou yoga com um treino tranqüilo. & 25 & 9 & DIF \\
\hline praticar & Sentença-base & Ela praticou yoga. & 33 & 0 & DIF \\
\hline faltar & 1.Alternância Causativo-Incoativa ou Transitivo-intransitiva & À aula faltou. & 10 & 25 & DIF \\
\hline faltar & 5.Adjuntos Cognatos & $\mathrm{O}$ aluno faltou à aula com uma falta inesperada. & 14 & 19 & IGUAL \\
\hline
\end{tabular}

Página 4 


\begin{tabular}{|l|l|}
\hline faltar & 6.Adjuntos Hipônimos e Hiperônimos \\
\hline faltar & Sentença-base \\
\hline criticar & 1.Alternância Causativo-Incoativa ou Transitivo-intransitiva \\
\hline criticar & 2.Alternância Média \\
\hline criticar & 3.Expressão perifrástica \\
\hline criticar & 4.Objetos Cognatos \\
\hline criticar & 5.Adjuntos Cognatos \\
\hline criticar & 6.Adjuntos Hipônimos e Hiperônimos \\
\hline criticar & Sentença-base \\
\hline relatar & 1.Alternância Causativo-Incoativa ou Transitivo-intransitiva \\
\hline relatar & 2.Alternância Média \\
\hline relatar & 3.Expressão perifrástica \\
\hline relatar & 4.Objetos Cognatos \\
\hline relatar & 5.Adjuntos Cognatos \\
\hline relatar & 6.Adjuntos Hipônimos e Hiperônimos \\
\hline relatar & Sentença-base \\
\hline encarar & 1.Alternância Causativo-Incoativa ou Transitivo-intransitiva \\
\hline encarar & 2.Alternância Média \\
\hline encarar & 3.Expressão perifrástica \\
\hline encarar & 4.Objetos Cognatos \\
\hline encarar & 5.Adjuntos Cognatos \\
\hline encarar & 6.Adjuntos Hipônimos e Hiperônimos \\
\hline encarar & Sentença-base \\
\hline caminhar & 1.Alternância Causativo-Incoativa ou Transitivo-intransitiva \\
\hline caminhar & 2.Alternância Média \\
\hline caminhar & 3.Expressão perifrástica \\
\hline caminhar & 4.Objetos Cognatos \\
\hline caminhar & 5.Adjuntos Cognatos \\
\hline caminhar & 6.Adjuntos Hipônimos e Hiperônimos \\
\hline caminhar & Sentença-base \\
\hline agrupar & 1.Alternância Causativo-Incoativa ou Transitivo-intransitiva \\
\hline agrupar & 2.Alternância Média \\
\hline agrupar & 3.Expressão perifrástica \\
\hline agrupar & 4.Objetos Cognatos \\
\hline agrupar & 5.Adjuntos Cognatos \\
\hline agrupar & 6.Adjuntos Hipônimos e Hiperônimos \\
\hline agrupar & Sentença-base \\
\hline misturar & \\
\hline misturar & \\
\hline
\end{tabular}

O Aluno faltou à aula esse ano com ausências inesperadas.

0 aluno faltou à aula.

A seleção criticou.

Seleção brasileira critica muito.

O Lula fez uma crítica à seleção.

O Lula criticou uma crítica construtiva à seleção.

Lula criticou a seleção com uma crítica construtiva.

Lula criticou a seleção com um parecer negativo.

Lula criticou a seleção.

Falhas relataram.

Falhas inesperadas relatam fácil.

O piloto fez um relato das falhas.

O piloto relatou um breve relato sobre as falhas.

O piloto relatou as falhas com um breve relato.

O piloto relatou as falhas com um breve resumo.

O piloto relatou falhas.

A guarda encarou.

Guardas de poucos homens encaram fácil.

Dorival fez uma cara à guarda.

Dorival encarou uma cara aos guardas.

Dorival encarou a guarda de cara limpa.

Dorival encarou a guarda com o rosto limpo.

Dorival encarou a guarda.

Na lua caminhou.

Na lua caminha bem.

O homem fez um caminho na lua.

O homem caminhou um caminho curto na lua.

O homem caminhou na lua por um caminho curto.

O homem caminhou na lua por um trecho curto.

O homem caminhou na lua.

Os times agruparam.

Os times agruparam bem.

O sorteio fez o grupo dos times.

O sorteio agrupou três grupos de times bons.

O sorteio agrupou os times com grupos bons.

O sorteio agrupou os times com turmas boas.

O sorteio agrupou os times.

Os ingredientes misturaram.

Ingredientes naturais misturam fácil.

\begin{tabular}{|c|c|c|}
\hline 20 & 19 & IGUAL \\
\hline 34 & 0 & DIF \\
\hline 5 & 28 & DIF \\
\hline 10 & 23 & DIF \\
\hline 33 & 0 & DIF \\
\hline 10 & 25 & DIF \\
\hline 28 & 5 & DIF \\
\hline 29 & 2 & DIF \\
\hline 31 & 0 & DIF \\
\hline 6 & 25 & DIF \\
\hline 9 & 22 & DIF \\
\hline 33 & 0 & DIF \\
\hline 15 & 18 & IGUAL \\
\hline 25 & 9 & DIF \\
\hline 33 & 2 & DIF \\
\hline 35 & 0 & DIF \\
\hline 14 & 21 & IGUAL \\
\hline 8 & 23 & DIF \\
\hline 17 & 16 & IGUAL \\
\hline 0 & 38 & DIF \\
\hline 37 & 2 & DIF \\
\hline 31 & 4 & DIF \\
\hline 33 & 0 & DIF \\
\hline 11 & 25 & DIF \\
\hline 14 & 25 & IGUAL \\
\hline 30 & 4 & DIF \\
\hline 12 & 21 & IGUAL \\
\hline 28 & 7 & DIF \\
\hline 35 & 1 & DIF \\
\hline 32 & 1 & DIF \\
\hline 22 & 14 & IGUAL \\
\hline 24 & 9 & DIF \\
\hline 19 & 15 & IGUAL \\
\hline 26 & 7 & DIF \\
\hline 26 & 7 & DIF \\
\hline 29 & 6 & DIF \\
\hline 32 & 0 & DIF \\
\hline 25 & 15 & IGUAL \\
\hline 25 & 9 & DIF \\
\hline
\end{tabular}

Página 5 


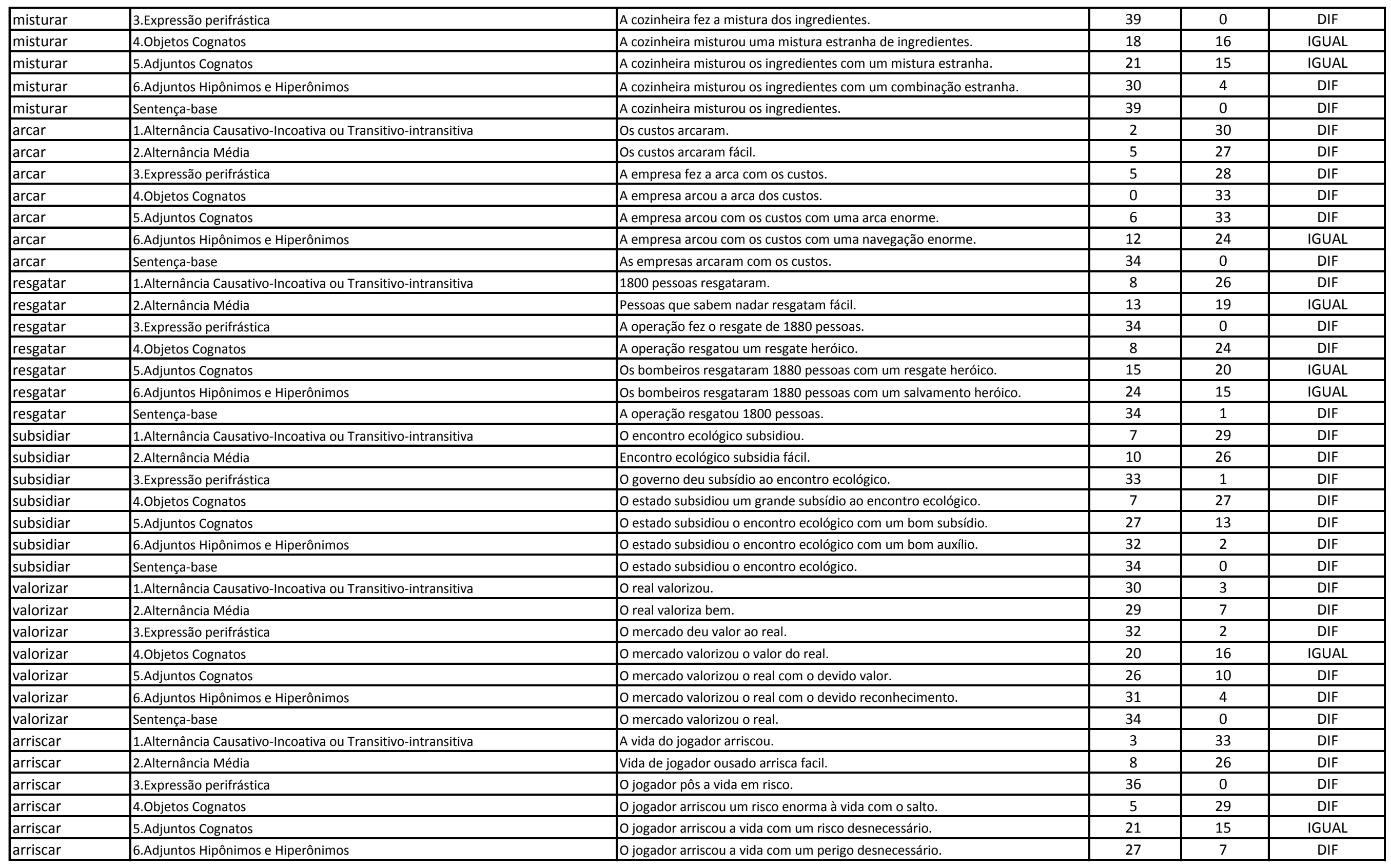




\begin{tabular}{|c|c|}
\hline arriscar & Sentença-base \\
\hline pesquisar & 1.Alternância Causativo-Incoativa ou Transitivo-intransitiva \\
\hline pesquisar & 2.Alternância Média \\
\hline pesquisar & 3.Expressão perifrástica \\
\hline pesquisar & 4.Objetos Cognatos \\
\hline pesquisar & 5.Adjuntos Cognatos \\
\hline pesquisar & 6.Adjuntos Hipônimos e Hiperônimos \\
\hline pesquisar & Sentença-base \\
\hline armazenar & 1.Alternância Causativo-Incoativa ou Transitivo-intransitiva \\
\hline armazenar & 2.Alternância Média \\
\hline armazenar & 3.Expressão perifrástica \\
\hline armazenar & 4.Objetos Cognatos \\
\hline armazenar & 5.Adjuntos Cognatos \\
\hline armazenar & 6.Adjuntos Hipônimos e Hiperônimos \\
\hline armazenar & Sentença-base \\
\hline interessar & 1.Alternância Causativo-Incoativa ou Transitivo-intransitiva \\
\hline interessar & 2.Alternância Média \\
\hline interessar & 3.Expressão perifrástica \\
\hline interessar & 4. Objetos Cognatos \\
\hline interessar & 5.Adjuntos Cognatos \\
\hline interessar & 6.Adjuntos Hipônimos e Hiperônimos \\
\hline interessar & Sentença-base \\
\hline ingressar & 1.Alternância Causativo-Incoativa ou Transitivo-intransitiva \\
\hline ingressar & 2.Alternância Média \\
\hline ingressar & 3.Expressão perifrástica \\
\hline ingressar & 4.Objetos Cognatos \\
\hline ingressar & 5.Adjuntos Cognatos \\
\hline ingressar & 6.Adjuntos Hipônimos e Hiperônimos \\
\hline ingressar & Sentença-base \\
\hline programar & 1.Alternância Causativo-Incoativa ou Transitivo-intransitiva \\
\hline programar & 2.Alternância Média \\
\hline programar & 3.Expressão perifrástica \\
\hline programar & 4.Objetos Cognatos \\
\hline programar & 5.Adjuntos Cognatos \\
\hline programar & 6.Adjuntos Hipônimos e Hiperônimos \\
\hline programar & Sentença-base \\
\hline influenciar & 1.Alternância Causativo-Incoativa ou Transitivo-intransitiva \\
\hline influenciar & 2.Alternância Média \\
\hline
\end{tabular}

O jogador arriscou a vida.

Voluntários pesquisaram.

Voluntários dispostos pesquisam rápido.

A instituição fez pesquisa com voluntários.

A instituição pesquisou pesquisas longas com voluntários.

A instituição pesquisou os voluntários com pesquisas longas e enfadonhas.

A instituição pesquisou os voluntários com estudos longos.

A instituição pesquisou volutários.

Os documentos armazenaram.

Documentos organizados armazenam rápido.

A secretária colocou os documentos no armazém.

A secretária armazenou o armazém dos documentos.

A secretária armazenou os documentos no armazém pequeno.

A secretária armazenou os documentos no armário pequeno.

A secretária armazenou os documentos.

O público interessou.

Público animado interessa fácil.

O show causou interesse no público.

O show interessou um grande interesse no público.

O show interessou o público com imenso interesse.

O show interessou o público com imenso entusiamo.

O show interessou o público.

No país ingressou.

Nesse páis ingressa fácil.

O estrangeiro fez o ingresso no páis pela manhã.

O estrangeiro ingressou um ingresso muito tranqüilo.

O estrangeiro ingressou no país com um ingresso muito tranqüilo.

O estrangeiro ingressou no país com uma entrada muito tranqüilo.

O estrangeiro ingressou no país.

A festa programou.

Festa de aniversário em buffet programa fácil.

A galera fez o programa da festa.

A galera programou um programa curto.

A galera programou a festa com um programa curto.

A galera programou a festa com uma agenda curta.

A galera programou a festa.

Os estudantes influenciaram.

Estudantes despreparados influenciam fácil.

\begin{tabular}{|c|c|c|}
\hline 32 & 1 & DIF \\
\hline 23 & 17 & IGUAL \\
\hline 27 & 9 & DIF \\
\hline 33 & 1 & DIF \\
\hline 9 & 26 & DIF \\
\hline 22 & 11 & IGUAL \\
\hline 25 & 10 & DIF \\
\hline 31 & 5 & DIF \\
\hline 6 & 32 & DIF \\
\hline 16 & 16 & IGUAL \\
\hline 28 & 5 & DIF \\
\hline 2 & 29 & DIF \\
\hline 31 & 4 & DIF \\
\hline 32 & 1 & DIF \\
\hline 37 & 1 & DIF \\
\hline 8 & 31 & DIF \\
\hline 9 & 24 & DIF \\
\hline 35 & 0 & DIF \\
\hline 5 & 26 & DIF \\
\hline 14 & 19 & IGUAL \\
\hline 22 & 10 & IGUAL \\
\hline 30 & 3 & DIF \\
\hline 11 & 21 & IGUAL \\
\hline 11 & 23 & IGUAL \\
\hline 32 & 3 & DIF \\
\hline 7 & 25 & DIF \\
\hline 15 & 23 & IGUAL \\
\hline 28 & 4 & DIF \\
\hline 35 & 0 & DIF \\
\hline 5 & 27 & DIF \\
\hline 13 & 20 & IGUAL \\
\hline 33 & 1 & DIF \\
\hline 20 & 11 & IGUAL \\
\hline 19 & 14 & IGUAL \\
\hline 22 & 10 & IGUAL \\
\hline 33 & 0 & DIF \\
\hline 9 & 25 & DIF \\
\hline 17 & 22 & IGUAL \\
\hline
\end{tabular}

Página 7 


\begin{tabular}{|c|c|c|c|c|c|}
\hline influenciar & 3.Expressão perifrástica & Aquele livro causou influência sobre os estudantes. & 38 & 2 & DIF \\
\hline influenciar & 4.Objetos Cognatos & Aquele livro influenciou uma influência boa sobre os estudantes. & 6 & 30 & DIF \\
\hline influenciar & 5.Adjuntos Cognatos & Aquele livro influenciou os estudantes com uma influência boa. & 19 & 17 & IGUAL \\
\hline influenciar & 6.Adjuntos Hipônimos e Hiperônimos & Aquele livro influenciou os estudantes com uma persuasão boa. & 20 & 19 & IGUAL \\
\hline fechar & 1.Alternância Causativo-Incoativa ou Transitivo-intransitiva & A porta fechou. & 34 & 2 & DIF \\
\hline fechar & 2.Alternância Média & Porta sanfonada não fecha fácil. & 31 & 3 & DIF \\
\hline fechar & 3.Expressão perifrástica & O Paulo colocou o fecho na porta. & 31 & 2 & DIF \\
\hline fechar & 4.Objetos Cognatos & O João fechou um fecho pequeno da porta. & 10 & 24 & DIF \\
\hline fechar & 5.Adjuntos Cognatos & O João fechou a porta usando o fecho pequeno. & 25 & 10 & DIF \\
\hline fechar & 6.Adjuntos Hipônimos e Hiperônimos & O João fechou a porta usando a tranca pequena. & 33 & 1 & DIF \\
\hline fechar & Sentença-base & Paulo fechou a porta. & 35 & 0 & DIF \\
\hline somar & 1.Alternância Causativo-Incoativa ou Transitivo-intransitiva & Os meus gastos somaram. & 11 & 23 & IGUAL \\
\hline somar & 2.Alternância Média & Meus gastos fixos somam muito. & 23 & 11 & IGUAL \\
\hline somar & 3.Expressão perifrástica & O contador fez a soma dos meus gastos. & 36 & 0 & DIF \\
\hline somar & 4.Objetos Cognatos & O contador somou uma soma assustadora dos meus gastos. & 15 & 19 & IGUAL \\
\hline somar & 5.Adjuntos Cognatos & O contador somou meus gastos em uma soma assustadora. & 19 & 20 & IGUAL \\
\hline concentrar & 1.Alternância Causativo-Incoativa ou Transitivo-intransitiva & Os votos concentraram. & 9 & 26 & DIF \\
\hline concentrar & 2.Alternância Média & Votos de cidade pequena concentram fácil. & 15 & 18 & IGUAL \\
\hline concentrar & 3.Expressão perifrástica & O candidato fez um centro da maioria dos votos. & 5 & 30 & DIF \\
\hline concentrar & 4. Objetos Cognatos & O candidato concentrou um centro absoluto da maioria dos votos. & 1 & 35 & DIF \\
\hline concentrar & 5.Adjuntos Cognatos & O candidato concentrou a maioria dos votos com um centro absoluto. & 8 & 26 & DIF \\
\hline concentrar & 6.Adjuntos Hipônimos e Hiperônimos & O candidato concentrou a maioria dos votos com um meio absoluto. & 8 & 28 & DIF \\
\hline concentrar & Sentença-base & O candidato concentrou a maioria dos votos. & 32 & 0 & DIF \\
\hline apostar & 1.Alternância Causativo-Incoativa ou Transitivo-intransitiva & O salário apostou no jogo. & 7 & 29 & DIF \\
\hline apostar & 2.Alternância Média & Salário baixo aposta fácil no jogo. & 6 & 29 & DIF \\
\hline apostar & 3.Expressão perifrástica & O rapaz fez uma aposta do salário no jogo. & 27 & 9 & DIF \\
\hline apostar & 4.Objetos Cognatos & O rapaz apostou uma grande aposta no jogo. & 22 & 14 & IGUAL \\
\hline apostar & 5.Adjuntos Cognatos & O rapaz apostou o salário no jogo com uma aposta arriscada. & 25 & 14 & IGUAL \\
\hline apostar & 6.Adjuntos Hipônimos e Hiperônimos & O rapaz apostou o salário no jogo com uma disputa arriscada. & 24 & 10 & DIF \\
\hline apostar & Sentença-base & O rapaz apostou o salário no jogo. & 39 & 0 & DIF \\
\hline sinalizar & 1.Alternância Causativo-Incoativa ou Transitivo-intransitiva & O esconderijo das drogas sinalizou. & 5 & 29 & DIF \\
\hline sinalizar & 2.Alternância Média & Esconderijo de drogas sinaliza fácil. & 11 & 21 & IGUAL \\
\hline sinalizar & 5.Adjuntos Cognatos & O policial sinalizou o esconderijo das drogas com um sinal esquisito. & 27 & 5 & DIF \\
\hline sinalizar & 6.Adjuntos Hipônimos e Hiperônimos & O policial sinalizou o esconderijo das drogas com um gesto esquisito. & 34 & 0 & DIF \\
\hline
\end{tabular}




\begin{tabular}{|c|c|c|c|c|c|}
\hline sinalizar & Sentença-base & O policial sinalizou o esconderijo das drogas. & 31 & 0 & DIF \\
\hline almoçar & 1.Alternância Causativo-Incoativa ou Transitivo-intransitiva & Cedo almoçou. & 6 & 24 & DIF \\
\hline almoçar & 2.Alternância Média & Cedo almoça melhor. & 5 & 28 & DIF \\
\hline almoçar & 3.Expressão perifrástica & A família comeu o almoço cedo. & 27 & 5 & DIF \\
\hline almoçar & 5.Adjuntos Cognatos & A família almoçou cedo hoje em um almoço pequeno. & 17 & 15 & IGUAL \\
\hline almoçar & 6.Adjuntos Hipônimos e Hiperônimos & A família almoçou cedo hoje em uma refeição pequena. & 17 & 15 & IGUAL \\
\hline almoçar & Sentença-base & A família almoçou cedo. & 38 & 0 & DIF \\
\hline evidenciar & 1.Alternância Causativo-Incoativa ou Transitivo-intransitiva & O fato evidenciou (com o estudo). & 9 & 25 & DIF \\
\hline evidenciar & 2.Alternância Média & Fatos claros evidenciam rapidamente. & 17 & 20 & IGUAL \\
\hline evidenciar & 3.Expressão perifrástica & O estudo deu evidências aos fatos. & 29 & 3 & DIF \\
\hline evidenciar & 4.Objetos Cognatos & O estudo evidenciou evidências claras sobre os fatos. & 10 & 22 & IGUAL \\
\hline evidenciar & 5.Adjuntos Cognatos & O estudo evidenciou os fatos com evidências claras. & 23 & 10 & DIF \\
\hline evidenciar & 6.Adjuntos Hipônimos e Hiperônimos & O estudo evidenciou os fatos com provas claras. & 29 & 3 & DIF \\
\hline evidenciar & Sentença-base & O estudo evidenciou o fato. & 30 & 0 & DIF \\
\hline rastrear & 1.Alternância Causativo-Incoativa ou Transitivo-intransitiva & Contas ilegais rastrearam. & 8 & 22 & DIF \\
\hline rastrear & 2.Alternância Média & Contas altas rastreiam facilmente. & 18 & 14 & IGUAL \\
\hline rastrear & 3.Expressão perifrástica & A comissão encontrou rastros de contas ilegais. & 31 & 1 & DIF \\
\hline rastrear & 5.Adjuntos Cognatos & A comissão rastreou contas ilegais através de rastros claros. & 24 & 8 & DIF \\
\hline rastrear & 6.Adjuntos Hipônimos e Hiperônimos & A comissão rastreou contas ilegais através de pistas claras. & 36 & 1 & DIF \\
\hline rastrear & Sentença-base & A comissão rastreou contas ilegais. & 30 & 0 & DIF \\
\hline amanhecer & 1.Alternância Causativo-Incoativa ou Transitivo-intransitiva & O dia amanheceu. & 32 & 0 & DIF \\
\hline amanhecer & 2.Alternância Média & O dia amanhece rapidamente em João Pessoa. & 36 & 1 & DIF \\
\hline amanhecer & 3.Expressão perifrástica & A noite tornou-se manhã rapidamente. & 31 & 1 & DIF \\
\hline amanhecer & 4.Objetos Cognatos & Amanheceu uma linda manhã. & 26 & 4 & DIF \\
\hline amanhecer & 5.Adjuntos Cognatos & O dia amanheceu com uma linda manhã. & 28 & 4 & DIF \\
\hline amanhecer & 6.Adjuntos Hipônimos e Hiperônimos & O dia amanheceu com uma linda alvorada. & 30 & 2 & DIF \\
\hline amanhecer & Sentença-base & O sol amanheceu o dia. & 14 & 18 & IGUAL \\
\hline capturar & 1.Alternância Causativo-Incoativa ou Transitivo-intransitiva & O fugitivo capturou. & 7 & 26 & DIF \\
\hline capturar & 2.Alternância Média & ?Fugitivo recente captura rápido. & 15 & 17 & IGUAL \\
\hline capturar & 3.Expressão perifrástica & A polícia fez a captura do fugitivo. & 31 & 0 & DIF \\
\hline capturar & 4.Objetos Cognatos & *A polícia capturou uma captura rápida do fugitivo. & 4 & 29 & DIF \\
\hline capturar & 5.Adjuntos Cognatos & A polícia capturou o fugitivo com uma captura rápida. & 15 & 23 & IGUAL \\
\hline capturar & 6.Adjuntos Hipônimos e Hiperônimos & A polícia capturou o fugitivo com uma prisão rápida. & 22 & 12 & IGUAL \\
\hline desfrutar & 3.Expressão perifrástica & O grupo não fez fruto da viagem. & 8 & 23 & DIF \\
\hline
\end{tabular}

Página 9 


\begin{tabular}{|c|c|c|c|c|c|}
\hline desfrutar & 4.Objetos Cognatos & O grupo não desfrutou bons frutos da viagem. & 13 & 20 & IGUAL \\
\hline desfrutar & 5.Adjuntos Cognatos & O grupo não desfrutou a viagem com bons frutos. & 11 & 21 & IGUAL \\
\hline desfrutar & 6.Adjuntos Hipônimos e Hiperônimos & - & 0 & 0 & - \\
\hline desfrutar & Sentença-base & O grupo desfrutou a viagem. & 30 & 2 & DIF \\
\hline modelar & 1.Alternância Causativo-Incoativa ou Transitivo-intransitiva & A peça de cerâmica modelou. & 8 & 24 & DIF \\
\hline modelar & 2.Alternância Média & Peça de cerâmica modela bem. & 25 & 7 & DIF \\
\hline modelar & 3.Expressão perifrástica & $\mathrm{O}$ artista fez um modelo da peça de cerâmica. & 32 & 0 & DIF \\
\hline modelar & 4.Objetos Cognatos & O artista modelou um ótimo modelo da peça de cerâmica. & 16 & 14 & IGUAL \\
\hline modelar & 5.Adjuntos Cognatos & $\mathrm{O}$ artista modelou a peça de cerâmica por um modelo novo. & 16 & 18 & IGUAL \\
\hline modelar & 6.Adjuntos Hipônimos e Hiperônimos & $\mathrm{O}$ artista modelou a peça de cerâmica por um exemplar novo. & 21 & 11 & IGUAL \\
\hline modelar & Sentença-base & O artista modelou a peça de cerâmica. & 32 & 0 & DIF \\
\hline adiar & 1.Alternância Causativo-Incoativa ou Transitivo-intransitiva & O lançamento do produto adiou. & 15 & 16 & IGUAL \\
\hline adiar & 2.Alternância Média & Lançamento de produto esperado sempre adia. & 21 & 16 & IGUAL \\
\hline adiar & 3.Expressão perifrástica & A empresa acrescentou dia ao lançamento dos produtos. & 25 & 7 & DIF \\
\hline adiar & 4.Objetos Cognatos & A empresa adiou dia no lançamento dos produtos. & 23 & 11 & IGUAL \\
\hline adiar & 5.Adjuntos Cognatos & - & 0 & 0 & - \\
\hline adiar & 6.Adjuntos Hipônimos e Hiperônimos & - & 0 & 0 & - \\
\hline adiar & Sentença-base & A empresa adiou o lançamento do produto. & 32 & 0 & DIF \\
\hline cadastrar & 2.Alternância Média & Dados pequenos cadastram rápido. & 24 & 13 & IGUAL \\
\hline cadastrar & 3.Expressão perifrástica & A recepcionista fez o cadastro dos candidatos. & 34 & 0 & DIF \\
\hline cadastrar & 4.Objetos Cognatos & A receocionista cadastrou um cadastro imenso de candidatos. & 16 & 16 & IGUAL \\
\hline cadastrar & 5.Adjuntos Cognatos & A recepcionista cadastrou os candidatos em um cadastro imenso. & 24 & 8 & DIF \\
\hline cadastrar & 6.Adjuntos Hipônimos e Hiperônimos & A recepcionista cadastrou os candidatos em um registro imenso. & 26 & 4 & DIF \\
\hline cadastrar & Sentença-base & A recepcionista cadastrou os candidatos. & 34 & 0 & DIF \\
\hline favorecer & 1.Alternância Causativo-Incoativa ou Transitivo-intransitiva & Os parentes favoreceram. & 5 & 26 & DIF \\
\hline favorecer & 2.Alternância Média & Parentes de políticos favorecem muito. & 4 & 28 & DIF \\
\hline favorecer & 3.Expressão perifrástica & O político fez favores a seus parentes. & 31 & 0 & DIF \\
\hline favorecer & 4. Objetos Cognatos & O político favoreceu favores indevidos aos seus parentes. & 8 & 29 & DIF \\
\hline favorecer & 5.Adjuntos Cognatos & O político favoreceu seus parentes com de favores indevidos. & 32 & 5 & DIF \\
\hline favorecer & 6.Adjuntos Hipônimos e Hiperônimos & O político favoreceu seus parentes com de benefícios indevidos. & 32 & 4 & DIF \\
\hline favorecer & Sentença-base & O político favoreceu os parentes. & 31 & 1 & DIF \\
\hline focar & 1.Alternância Causativo-Incoativa ou Transitivo-intransitiva & Gramática focou nas aulas. & 6 & 30 & DIF \\
\hline focar & 2.Alternância Média & Gramática foca fácil nas aulas. & 8 & 25 & DIF \\
\hline focar & 3.Expressão perifrástica & O professor colocou foco em gramática nas aulas. & 28 & 5 & DIF \\
\hline focar & 6.Adjuntos Hipônimos e Hiperônimos & O professor focou em gramática nas aulas com uma atenção especial. & 24 & 6 & DIF \\
\hline focar & Sentença-base & O professor focou em gramática nas aulas. & 28 & 3 & DIF \\
\hline
\end{tabular}




\begin{tabular}{|c|c|c|c|c|c|}
\hline embarcar & 1.Alternância Causativo-Incoativa ou Transitivo-intransitiva & A mercadoria embarcou. & 25 & 11 & DIF \\
\hline embarcar & 2.Alternância Média & Mercadoria organizada embarca fácil. & 30 & 6 & DIF \\
\hline embarcar & 3.Expressão perifrástica & Os marinheiros colocaram a mercadoria no barco. & 33 & 0 & DIF \\
\hline embarcar & 4.Objetos Cognatos & Os marinheiros embarcaram o barco com mercadorias. & 16 & 21 & IGUAL \\
\hline embarcar & 6.Adjuntos Hipônimos e Hiperônimos & Os marinheiros embarcaram a mercadoria em um navio de carga. & 35 & 2 & DIF \\
\hline embarcar & Sentença-base & Os marinheiros embarcaram a mercadoria. & 33 & 0 & DIF \\
\hline estrear & 1.Alternância Causativo-Incoativa ou Transitivo-intransitiva & A série Alice estreou. & 28 & 3 & DIF \\
\hline estrear & 2.Alternância Média & Boas séries estream sempre. & 26 & 5 & DIF \\
\hline estrear & 3.Expressão perifrástica & HBO fez a estréia da série Alice. & 31 & 2 & DIF \\
\hline estrear & 4.Objetos Cognatos & HBO estreou a estréia esperada de Alice. & 12 & 25 & DIF \\
\hline estrear & 5.Adjuntos Cognatos & HBO estreou a série Alice com estréia inesperada. & 18 & 15 & IGUAL \\
\hline estrear & 6.Adjuntos Hipônimos e Hiperônimos & HBO estreou a série Alice com lançamento inesperado. & 23 & 10 & DIF \\
\hline estrear & Sentença-base & HBO estrou a série Alice. & 29 & 3 & DIF \\
\hline basear & 1.Alternância Causativo-Incoativa ou Transitivo-intransitiva & Em evidências baseou. & 6 & 30 & DIF \\
\hline basear & 2.Alternância Média & Em evidências baseia fácil. & 1 & 30 & DIF \\
\hline basear & 3.Expressão perifrástica & O juiz usou como base as evidências. & 32 & 1 & DIF \\
\hline basear & 4.Objetos Cognatos & O juiz se baseou a base em evidências. & 2 & 27 & DIF \\
\hline basear & 6.Adjuntos Hipônimos e Hiperônimos & O juiz se baseou em evidências com fundamentos sólidos. & 32 & 1 & DIF \\
\hline basear & Sentença-base & O juiz se baseou em evidências & 31 & 0 & DIF \\
\hline abraçar & 1.Alternância Causativo-Incoativa ou Transitivo-intransitiva & O amigo abraçou. & 13 & 19 & IGUAL \\
\hline abraçar & 2.Alternância Média & Amigo bacana abraço sempre. & 22 & 10 & IGUAL \\
\hline abraçar & 3.Expressão perifrástica & O garoto deu um abraço no amigo. & 33 & 0 & DIF \\
\hline abraçar & 4.Objetos Cognatos & O garoto abraçou um abraço carinhoso no amigo. & 9 & 22 & DIF \\
\hline abraçar & 5.Adjuntos Cognatos & O garoto abraçou o amigo com um abraço carinhoso. & 28 & 3 & DIF \\
\hline abraçar & 6.Adjuntos Hipônimos e Hiperônimos & ?O garoto abraçou o amigo com um aperto carinhoso. & 31 & 5 & DIF \\
\hline abraçar & Sentença-base & O garoto abraçou o amigo. & 32 & 0 & DIF \\
\hline liderar & 1.Alternância Causativo-Incoativa ou Transitivo-intransitiva & A comissão liderou. & 9 & 22 & DIF \\
\hline liderar & 2.Alternância Média & Comissão pequena lidera fácil. & 15 & 17 & IGUAL \\
\hline liderar & 3.Expressão perifrástica & O presidente foi o líder da comissão. & 31 & 0 & DIF \\
\hline liderar & 4.Objetos Cognatos & O presidente liderou o líder da comissão. & 14 & 22 & IGUAL \\
\hline liderar & 5.Adjuntos Cognatos & O presidente liderou a comissão com um líder firme. & 9 & 20 & IGUAL \\
\hline liderar & 6.Adjuntos Hipônimos e Hiperônimos & O presidente liderou a comissão com um condutor firme. & 11 & 22 & IGUAL \\
\hline liderar & Sentença-base & O presidente liderou a comissão. & 30 & 0 & DIF \\
\hline marcar & 3.Expressão perifrástica & O cinto de segurança fez uma marca na minha roupa. & 31 & 0 & DIF \\
\hline marcar & 4.Objetos Cognatos & O cinto de segurança marcou uma marca horrível na minha roupa. & 12 & 19 & IGUAL \\
\hline
\end{tabular}

Página 11 


\begin{tabular}{|l|l|}
\hline marcar & 5.Adjuntos Cognatos \\
\hline marcar & 6.Adjuntos Hipônimos e Hiperônimos \\
\hline marcar & Sentença-base \\
\hline privilegiar & 1.Alternância Causativo-Incoativa ou Transitivo-intransitiva \\
\hline privilegiar & 2.Alternância Média \\
\hline privilegiar & 3.Expressão perifrástica \\
\hline privilegiar & 4.Objetos Cognatos \\
\hline privilegiar & 5.Adjuntos Cognatos \\
\hline privilegiar & 6.Adjuntos Hipônimos e Hiperônimos \\
\hline privilegiar & Sentença-base \\
\hline copiar & 1.Alternância Causativo-Incoativa ou Transitivo-intransitiva \\
\hline copiar & 2.Alternância Média \\
\hline copiar & 3.Expressão perifrástica \\
\hline copiar & 4.Objetos Cognatos \\
\hline copiar & 5.Adjuntos Cognatos \\
\hline copiar & 6.Adjuntos Hipônimos e Hiperônimos \\
\hline copiar & Sentença-base \\
\hline acostumar & 1.Alternância Causativo-Incoativa ou Transitivo-intransitiva \\
\hline acostumar & 2.Alternância Média \\
\hline acostumar & 3.Expressão perifrástica \\
\hline acostumar & 4.Objetos Cognatos \\
\hline acostumar & 5.Adjuntos Cognatos \\
\hline acostumar & 6.Adjuntos Hipônimos e Hiperônimos \\
\hline acostumar & Sentença-base \\
\hline cruzar & 1.Alternância Causativo-Incoativa ou Transitivo-intransitiva \\
\hline cruzar & 2.Alternância Média \\
\hline cruzar & 3.Expressão perifrástica \\
\hline cruzar & 4.Objetos Cognatos \\
\hline cruzar & 5.Adjuntos Cognatos \\
\hline cruzar & 6.Adjuntos Hipônimos e Hiperônimos \\
\hline cruzar & Sentença-base \\
\hline acabar & 1.Alternância Causativo-Incoativa ou Transitivo-intransitiva \\
\hline acabar & 2.Alternância Média \\
\hline acabar & 4.Objetos Cognatos \\
\hline acabar & 5.Adjuntos Cognatos \\
\hline acabar & 6.Adjuntos Hipônimos e Hiperônimos \\
\hline acabar & \\
\hline listar & \\
\hline
\end{tabular}

O cinto de segurança marcou minha roupa com uma marca horrível.

\begin{tabular}{|c|c|c|}
\hline 30 & 6 & DIF \\
\hline 27 & 4 & DIF \\
\hline 32 & 0 & DIF \\
\hline 5 & 31 & DIF \\
\hline 5 & 26 & DIF \\
\hline 29 & 0 & DIF \\
\hline 4 & 27 & DIF \\
\hline 19 & 10 & IGUAL \\
\hline 33 & 4 & DIF \\
\hline 30 & 1 & DIF \\
\hline 13 & 16 & IGUAL \\
\hline 22 & 10 & IGUAL \\
\hline 31 & 0 & DIF \\
\hline 17 & 20 & IGUAL \\
\hline 17 & 16 & IGUAL \\
\hline 20 & 11 & IGUAL \\
\hline 31 & 0 & DIF \\
\hline 9 & 21 & DIF \\
\hline 9 & 23 & DIF \\
\hline 32 & 0 & DIF \\
\hline 3 & 33 & DIF \\
\hline 2 & 34 & DIF \\
\hline 10 & 18 & IGUAL \\
\hline 35 & 0 & DIF \\
\hline 8 & 21 & DIF \\
\hline 14 & 16 & IGUAL \\
\hline 13 & 16 & IGUAL \\
\hline 4 & 27 & DIF \\
\hline 11 & 19 & IGUAL \\
\hline 0 & 0 & - \\
\hline 30 & 0 & DIF \\
\hline 22 & 8 & DIF \\
\hline 24 & 8 & DIF \\
\hline 1 & 29 & DIF \\
\hline 3 & 27 & DIF \\
\hline 7 & 24 & DIF \\
\hline 31 & 1 & DIF \\
\hline 6 & 25 & DIF \\
\hline
\end{tabular}

de segurança marcou minha roupa com um amassado horrível.

O cinto de segurança marcou minha roupa.

O filho privilegiou.

Filho de político privilegia sempre.

O ministro deu privilégios ao filho.

O ministro privilegiou um privilégio enorme ao filho.

O ministro privilegiou o filho com um privilégio enorme.

o ministro privilegiou o filho com uma facilidade enorme.

O ministrou privilegiou o filho.

Os arquivos copiaram.

Arquivo pequeno copia rápido.

Eu fiz uma cópia dos textos.

Eu copiei uma cópia ruim dos textos.

Eu copiei os arquivos com uma cópia ruim.

Eu copiei os arquivos com uma xerox ruim.

Eu copiei os arquivos.

Sem os pais acostumou a dormir.

Sem os pais acostuma fácil a dormir.

bebê adquiriu o costume de dormir sem os pais.

O bebê acostumou o costume de dormir sem os pais.

O bebê acostumou a dormir sem os pais com um costume recente.

O bebê acostumou a dormir sem os pais com um hábito recente.

O bebê (se) acostumou a dormir sem os pais.

O caminho cruzou.

Caminho pequeno cruza rápido.

Ela fez uma cruz com o caminho.

Ela cruzou uma cruz estreita com o caminho.

Ela cruzou o caminho com uma cruz estreita.

Ela cruzou o caminho.

O relatório acabou.

Relatório de aula acaba rápido.

Ele acabou um cabo do relatório.

Ele acabou o relatório com um cabo grande.

Ele acabou o relatório com uma ponta grande.

Ele acabou o realatório.

Os voluntários listaram. 


\begin{tabular}{|c|c|}
\hline listar & 2.Alternância Média \\
\hline listar & 3.Expressão perifrástica \\
\hline listar & 4.Objetos Cognatos \\
\hline listar & 5.Adjuntos Cognatos \\
\hline listar & 6.Adjuntos Hipônimos e Hiperônimos \\
\hline listar & Sentença-base \\
\hline filtrar & 1.Alternância Causativo-Incoativa ou Transitivo-intransitiva \\
\hline filtrar & 2.Alternância Média \\
\hline filtrar & 3.Expressão perifrástica \\
\hline filtrar & 4.Objetos Cognatos \\
\hline filtrar & 5.Adjuntos Cognatos \\
\hline filtrar & 6.Adjuntos Hipônimos e Hiperônimos \\
\hline filtrar & Sentença-base \\
\hline analisar & 1.Alternância Causativo-Incoativa ou Transitivo-intransitiva \\
\hline analisar & 2.Alternância Média \\
\hline analisar & 3.Expressão perifrástica \\
\hline analisar & 4.Objetos Cognatos \\
\hline analisar & 5.Adjuntos Cognatos \\
\hline analisar & 6.Adjuntos Hipônimos e Hiperônimos \\
\hline analisar & Sentença-base \\
\hline causar & 1.Alternância Causativo-Incoativa ou Transitivo-intransitiva \\
\hline causar & 2.Alternância Média \\
\hline causar & 3.Expressão perifrástica \\
\hline causar & 4. Objetos Cognatos \\
\hline causar & 5.Adjuntos Cognatos \\
\hline causar & 6.Adjuntos Hipônimos e Hiperônimos \\
\hline causar & Sentença-base \\
\hline testar & 1.Alternância Causativo-Incoativa ou Transitivo-intransitiva \\
\hline testar & 2.Alternância Média \\
\hline testar & 3.Expressão perifrástica \\
\hline testar & 4.Objetos Cognatos \\
\hline testar & 5.Adjuntos Cognatos \\
\hline testar & 6.Adjuntos Hipônimos e Hiperônimos \\
\hline testar & Sentença-base \\
\hline empacotar & 1.Alternância Causativo-Incoativa ou Transitivo-intransitiva \\
\hline empacotar & 2.Alternância Média \\
\hline empacotar & 3.Expressão perifrástica \\
\hline empacotar & 4.Objetos Cognatos \\
\hline
\end{tabular}

Poucos voluntários listam rápido.

A marinha fez a lista dos voluntários.

A marinha listou uma lista completa dos voluntários.

A marinha listou os voluntários com/em uma lista completa.

A marinha listou os voluntários com/em um registro completo.

A marinha listou os voluntários.

A água filtrou.

Água limpa filtra rápido.

A máquina fez o filtro da água.

A máquina filtrou um filtro ruim da água.

A máquina filtrou a água com um filtro ruim.

A máquina filtrou a água com um purificação ruim.

A máquina filtrou a água.

Os relatórios analisaram.

Relatórios de pesquisa analisam rápido.

chefe fez uma análise minuciosa dos relatórios.

chefe analisou uma análise minuciosa.

chefe analisou os relatórios com uma análise minuciosa.

O chefe analisou os relatórios com um dossiê minucioso.

chefe analisou os relatórios.

A briga causou.

Briga de rua causa fácil.

bando fez uma causa a briga.

$O$ bando causou uma causa estúpida.

O bando causou a briga por uma causa estúpida.

O bando causou a briga por um motivo estúpido.

bando causou a briga.

Os medicamentos testaram.

Medicamentos testam bem.

S laboratórios fizeram testes em medicamentos.

Os laboratórios testaram um teste novo para os medicamentos.

Os laboratórios testaram os medicamentos com um teste novo.

Os laboratórios testaram os medicamentos com um experimento novo.

laboratório testou os medicamentos.

Os doces empacotaram.

Doce quente não empacota bem.

A doceira pôs os doces no pacote.

A doceira empacotou (n)um pacote de doces.

\begin{tabular}{|c|c|c|}
\hline 9 & 20 & IGUAL \\
\hline 28 & 0 & DIF \\
\hline 18 & 12 & IGUAL \\
\hline 19 & 11 & IGUAL \\
\hline 23 & 5 & DIF \\
\hline 31 & 1 & DIF \\
\hline 21 & 10 & IGUAL \\
\hline 26 & 6 & DIF \\
\hline 19 & 16 & IGUAL \\
\hline 3 & 25 & DIF \\
\hline 22 & 9 & DIF \\
\hline 20 & 8 & DIF \\
\hline 30 & 1 & DIF \\
\hline 5 & 24 & DIF \\
\hline 15 & 14 & IGUAL \\
\hline 29 & 0 & DIF \\
\hline 5 & 23 & DIF \\
\hline 20 & 7 & DIF \\
\hline 20 & 11 & IGUAL \\
\hline 30 & 1 & DIF \\
\hline 6 & 22 & DIF \\
\hline 6 & 25 & DIF \\
\hline 3 & 26 & DIF \\
\hline 3 & 31 & DIF \\
\hline 17 & 12 & IGUAL \\
\hline 25 & 3 & DIF \\
\hline 31 & 0 & DIF \\
\hline 5 & 22 & DIF \\
\hline 9 & 22 & DIF \\
\hline 30 & 1 & DIF \\
\hline 21 & 8 & DIF \\
\hline 29 & 2 & DIF \\
\hline 26 & 2 & DIF \\
\hline 29 & 0 & DIF \\
\hline 8 & 20 & DIF \\
\hline 24 & 7 & DIF \\
\hline 29 & 0 & DIF \\
\hline 28 & 3 & DIF \\
\hline
\end{tabular}

Página 13 


\begin{tabular}{|l|l|}
\hline empacotar & 5.Adjuntos Cognatos \\
\hline empacotar & 6.Adjuntos Hipônimos e Hiperônimos \\
\hline empacotar & Sentença-base \\
\hline agulhar & 1.Alternância Causativo-Incoativa ou Transitivo-intransitiva \\
\hline agulhar & 2.Alternância Média \\
\hline agulhar & 3.Expressão perifrástica \\
\hline agulhar & 4.Objetos Cognatos \\
\hline agulhar & Sentença-base \\
\hline brincar & 1.Alternância Causativo-Incoativa ou Transitivo-intransitiva \\
\hline brincar & 2.Alternância Média \\
\hline brincar & 3.Expressão perifrástica \\
\hline brincar & 4.Objetos Cognatos \\
\hline brincar & 5.Adjuntos Cognatos \\
\hline brincar & 6.Adjuntos Hipônimos e Hiperônimos \\
\hline brincar & Sentença-base \\
\hline aprimorar & 1.Alternância Causativo-Incoativa ou Transitivo-intransitiva \\
\hline aprimorar & 2.Alternância Média \\
\hline aprimorar & 3.Expressão perifrástica \\
\hline aprimorar & 4.Objetos Cognatos \\
\hline aprimorar & 5.Adjuntos Cognatos \\
\hline aprimorar & 6.Adjuntos Hipônimos e Hiperônimos \\
\hline aprimorar & Sentença-base \\
\hline arrumar & 1.Alternância Causativo-Incoativa ou Transitivo-intransitiva \\
\hline arrumar & 2.Alternância Média \\
\hline arrumar & 3.Expressão perifrástica \\
\hline arrumar & 4.Objetos Cognatos \\
\hline arrumar & 5.Adjuntos Cognatos \\
\hline arrumar & 6.Adjuntos Hipônimos e Hiperônimos \\
\hline arrumar & Sentença-base \\
\hline memorizar & 1.Alternância Causativo-Incoativa ou Transitivo-intransitiva \\
\hline memorizar & 2.Alternância Média \\
\hline memorizar & 3.Expressão perifrástica \\
\hline memorizar & 4.Objetos Cognatos \\
\hline memorizar & 5.Adjuntos Cognatos \\
\hline memorizar & 6.Adjuntos Hipônimos e Hiperônimos \\
\hline memorizar & Sentença-base \\
\hline agendar & 1.Alternância Causativo-Incoativa ou Transitivo-intransitiva \\
\hline agendarstica \\
\hline agendar & \\
\hline
\end{tabular}

A doceira empacotou os doces no pacote maior.

A doceira empacotou os doces na caixa maior.

A doceira empacotou os doces.

O dedo agulhou.

Dedo de costureira destraída agulha toda hora.

A costureira furou o dedo com a agulha.

A costureira agulhou a agulha no dedo.

A costureira agulhou o dedo.

(Com o amigo) brincou.

Com amigos) brinca fácil.

A criança fez brinco com o amigo. (no sentido de brincou).

A cirança brincou um brinco com o amigo.

A criança brincou com o amigo com um brinco engraçado.

A criança brincou com o amigo com um adereço engraçado.

A criança brincou com o amigo.

método de ensino aprimorou.

Um bom método de ensino aprimora fácil.

p professor deu primor ao método de ensino.

p professor aprimorou o primor do método de ensino.

professor aprimorou o método de ensino com um primor imenso.

p professor aprimorou o método de ensino com um capricho imenso.

o professor aprimorou o método de ensino.

A casa arrumou.

Casa pequena arruma rápido.

Paula deu um rumo à casa.

A Paula arrumou um rumo da casa.

A Paula arrumou a casa com um rumo certo.

A Paula arrumou a casa com um caminho caprichado.

A Paula arrumou a casa.

A tabuada memorizou.

Tabuada memoriza rápido.

Destudante guardou a tabuada na memória.

0 estudante memorizou uma memória completa da tabuada.

Destudante memorizou a tabuada com uma memória completa.

O estudante memorizou a tabuada com uma lembrança completa.

estudante memorizou a tabuada.

reunião agendou.

Reunião urgente agenda rápido.

A assistente colocou a reunião na agenda.

\begin{tabular}{|c|c|c|}
\hline 27 & 2 & DIF \\
\hline 30 & 1 & DIF \\
\hline 31 & 0 & DIF \\
\hline 4 & 24 & DIF \\
\hline 13 & 18 & IGUAL \\
\hline 31 & 0 & DIF \\
\hline 8 & 20 & DIF \\
\hline 28 & 1 & DIF \\
\hline 12 & 21 & IGUAL \\
\hline 9 & 21 & DIF \\
\hline 2 & 29 & DIF \\
\hline 1 & 32 & DIF \\
\hline 11 & 20 & IGUAL \\
\hline 21 & 10 & IGUAL \\
\hline 31 & 0 & DIF \\
\hline 13 & 18 & IGUAL \\
\hline 16 & 15 & IGUAL \\
\hline 21 & 8 & DIF \\
\hline 6 & 30 & DIF \\
\hline 14 & 16 & IGUAL \\
\hline 29 & 2 & DIF \\
\hline 33 & 0 & DIF \\
\hline 8 & 23 & DIF \\
\hline 23 & 6 & DIF \\
\hline 16 & 15 & IGUAL \\
\hline 4 & 29 & DIF \\
\hline 5 & 24 & DIF \\
\hline 6 & 27 & DIF \\
\hline 30 & 0 & DIF \\
\hline 7 & 22 & DIF \\
\hline 17 & 14 & IGUAL \\
\hline 30 & 3 & DIF \\
\hline 2 & 29 & DIF \\
\hline 6 & 27 & DIF \\
\hline 11 & 22 & IGUAL \\
\hline 32 & 0 & DIF \\
\hline 7 & 30 & DIF \\
\hline 23 & 10 & DIF \\
\hline 29 & 1 & DIF \\
\hline
\end{tabular}

Página 14 


\begin{tabular}{|c|c|c|c|c|c|}
\hline agendar & 4.Objetos Cognatos & A assistente agendou uma agenda completa da reunião. & 9 & 27 & DIF \\
\hline agendar & 5.Adjuntos Cognatos & A assistente agendou a reunião em uma agenda apertada. & 18 & 13 & IGUAL \\
\hline agendar & 6.Adjuntos Hipônimos e Hiperônimos & A assistente agendou a reunião em uma programação apertada. & 26 & 3 & DIF \\
\hline agendar & Sentença-base & A assistente agendou a reunião. & 29 & 0 & DIF \\
\hline auxiliar & 2.Alternância Média & Professor experiente auxilia pouco. & 22 & 10 & IGUAL \\
\hline auxiliar & 3.Expressão perifrástica & O monitor deu auxílio ao professor na aula. & 31 & 0 & DIF \\
\hline auxiliar & 4.Objetos Cognatos & O monitor auxilou um ótimo auxílio ao professor na aula. & 4 & 32 & DIF \\
\hline auxiliar & 5.Adjuntos Cognatos & O monitor auxiliou o professor com um ótimo auxílio. & 15 & 17 & IGUAL \\
\hline auxiliar & 6.Adjuntos Hipônimos e Hiperônimos & O monitor auxiliou o professor com uma ótima ajuda. & 25 & 8 & DIF \\
\hline auxiliar & Sentença-base & O monitor auxiliou o professor na aula. & 31 & 0 & DIF \\
\hline depositar & 1.Alternância Causativo-Incoativa ou Transitivo-intransitiva & A tese depositou. & 9 & 21 & DIF \\
\hline depositar & 2.Alternância Média & Tese boa deposita rápido. & 12 & 21 & IGUAL \\
\hline depositar & 3.Expressão perifrástica & O aluno fez o depósito da tese. & 34 & 3 & DIF \\
\hline depositar & 4.Objetos Cognatos & O aluno depositou um depósito rápido da tese. & 8 & 24 & DIF \\
\hline depositar & 5.Adjuntos Cognatos & O aluno depositou a tese com um depósito rápido. & 14 & 22 & IGUAL \\
\hline depositar & 6.Adjuntos Hipônimos e Hiperônimos & ?0 aluno depositou a tese com uma entrega rápido. & 15 & 16 & IGUAL \\
\hline depositar & Sentença-base & $\mathrm{O}$ aluno depositou a tese. & 29 & 1 & DIF \\
\hline sediar & 2.Alternância Média & Jogos olímpicos sediam com qualidade. & 2 & 28 & DIF \\
\hline sediar & 3.Expressão perifrástica & A China foi a sede dos jogos olímpicos. & 30 & 0 & DIF \\
\hline sediar & 4.Objetos Cognatos & A China sediou uma boa sede os jogos olímpicos. & 5 & 28 & DIF \\
\hline sediar & 5.Adjuntos Cognatos & A China sediou os jogos olímpicos com uma boa sede. & 16 & 13 & IGUAL \\
\hline sediar & 6.Adjuntos Hipônimos e Hiperônimos & A China sediou os jogos olímpicos com uma boa estrutura. & 31 & 0 & DIF \\
\hline sediar & Sentença-base & A China sediou os jogos olímpicos. & 32 & 0 & DIF \\
\hline implementar & 1.Alternância Causativo-Incoativa ou Transitivo-intransitiva & O novo sistema implementou. & 9 & 23 & DIF \\
\hline implementar & 2.Alternância Média & Sistema interativo implementa fácil. & 19 & 10 & IGUAL \\
\hline implementar & 3.Expressão perifrástica & O governo fez o implemento do novo sistema. & 25 & 5 & DIF \\
\hline implementar & 4.Objetos Cognatos & O governo implementou um implemento ao novo sistema. & 7 & 22 & DIF \\
\hline implementar & 5.Adjuntos Cognatos & O governo implementou o novo sistema com um implemento moderno. & 14 & 17 & IGUAL \\
\hline implementar & 6.Adjuntos Hipônimos e Hiperônimos & O governo implementou o novo sistema com um complemento moderno. & 24 & 9 & DIF \\
\hline implementar & Sentença-base & O governo implementou o novo sistema. & 33 & 0 & DIF \\
\hline gerenciar & 1.Alternância Causativo-Incoativa ou Transitivo-intransitiva & A equipe gerenciou. & 12 & 17 & IGUAL \\
\hline gerenciar & 2.Alternância Média & Equipe boa gerencia fácil. & 19 & 10 & IGUAL \\
\hline gerenciar & 5.Adjuntos Cognatos & João gerenciou a equipe com uma gerência impecável. & 22 & 11 & IGUAL \\
\hline
\end{tabular}

Página 15 


\begin{tabular}{|c|c|c|c|c|c|}
\hline gerenciar & 6.Adjuntos Hipônimos e Hiperônimos & João gerenciou a equipe com uma administração impecável. & 31 & 1 & DIF \\
\hline gerenciar & Sentença-base & João gerenciou a equipe. & 29 & 0 & DIF \\
\hline veicular & 1.Alternância Causativo-Incoativa ou Transitivo-intransitiva & A notícia veiculou. & 10 & 22 & IGUAL \\
\hline veicular & 2.Alternância Média & Notícia ruim veicula rápido. & 19 & 9 & IGUAL \\
\hline veicular & 4.Objetos Cognatos & A imprensa veiculou um veículo enorme de notícia. & 2 & 28 & DIF \\
\hline veicular & 5.Adjuntos Cognatos & A imprensa veiculou a notícia em todos os veículos. & 25 & 10 & DIF \\
\hline veicular & 6.Adjuntos Hipônimos e Hiperônimos & A imprensa veiculou a notícia em todos os meios de comunicação. & 29 & 0 & DIF \\
\hline veicular & Sentença-base & A imprensa veiculou a notícia. & 32 & 0 & DIF \\
\hline forçar & 1.Alternância Causativo-Incoativa ou Transitivo-intransitiva & A porta forçou. & 7 & 21 & DIF \\
\hline forçar & 2.Alternância Média & Porta de plástico força fácil. & 12 & 18 & IGUAL \\
\hline forçar & 3.Expressão perifrástica & O ladrão empurrou a porta com força. & 32 & 0 & DIF \\
\hline forçar & 4.Objetos Cognatos & O ladrão forçou a força na porta. & 3 & 25 & DIF \\
\hline forçar & 5.Adjuntos Cognatos & O ladrão forçou a porta com uma força brusca. & 23 & 7 & DIF \\
\hline forçar & 6.Adjuntos Hipônimos e Hiperônimos & O ladrão foçou a porta com um vigor intenso. & 26 & 4 & DIF \\
\hline forçar & Sentença-base & O ladrão forçou a porta. & 32 & 0 & DIF \\
\hline economizar & 1.Alternância Causativo-Incoativa ou Transitivo-intransitiva & Dinheiro economizou nas compras. & 3 & 29 & DIF \\
\hline economizar & 2.Alternância Média & Dinheiro contado economiza bem. & 12 & 18 & IGUAL \\
\hline economizar & 4.Objetos Cognatos & A mãe economizou a ecomonia nas compras. & 5 & 30 & DIF \\
\hline economizar & 5.Adjuntos Cognatos & A mãe economizou o dinheiro das compras com uma economia sofrida. & 19 & 17 & IGUAL \\
\hline economizar & 6.Adjuntos Hipônimos e Hiperônimos & A mãe economizou o dinheiro das compras com uma poupação sofrida. & 13 & 17 & IGUAL \\
\hline economizar & Sentença-base & A mãe economizou dinheiro nas compras. & 36 & 0 & DIF \\
\hline suplementar & 1.Alternância Causativo-Incoativa ou Transitivo-intransitiva & O orçamento suplementou. & 6 & 24 & DIF \\
\hline suplementar & 2.Alternância Média & Orçamentos iniciais suplementam fácil. & 15 & 21 & IGUAL \\
\hline suplementar & 3.Expressão perifrástica & Ele fez um suplemento ao orçamento. & 26 & 4 & DIF \\
\hline suplementar & 4.Objetos Cognatos & Ele suplementou um suplemento de 10 mil reais ao orçamento. & 9 & 23 & DIF \\
\hline suplementar & 5.Adjuntos Cognatos & Ele suplementou o orçamento com um suplemento de 10 mil reais. & 20 & 12 & IGUAL \\
\hline suplementar & 6.Adjuntos Hipônimos e Hiperônimos & Ele suplementou o orçamento com um complemento de 10 mil reais. & 27 & 3 & DIF \\
\hline suplementar & Sentença-base & Ele suplementou o orçamento com 10 mil reais. & 28 & 2 & DIF \\
\hline movimentar & 1.Alternância Causativo-Incoativa ou Transitivo-intransitiva & O barco movimentou. & 22 & 14 & IGUAL \\
\hline movimentar & 2.Alternância Média & Barco a vela movimenta bem. & 20 & 9 & IGUAL \\
\hline movimentar & 3.Expressão perifrástica & O atleta colocou o barco em movimento. & 33 & 0 & DIF \\
\hline movimentar & 4.Objetos Cognatos & O atleta movimentou movimentos rápidos no barco. & 6 & 23 & DIF \\
\hline movimentar & Sentença-base & O atleta movimentou o barco. & 31 & 0 & DIF \\
\hline
\end{tabular}




\begin{tabular}{|c|c|}
\hline incrementar & 2.Alternância Média \\
\hline incrementar & 3.Expressão perifrástica \\
\hline incrementar & 4.Objetos Cognatos \\
\hline incrementar & 5.Adjuntos Cognatos \\
\hline incrementar & 6.Adjuntos Hipônimos e Hiperônimos \\
\hline incrementar & Sentença-base \\
\hline providenciar & 1.Alternância Causativo-Incoativa ou Transitivo-intransitiva \\
\hline providenciar & 2.Alternância Média \\
\hline providenciar & 3.Expressão perifrástica \\
\hline providenciar & 4.Objetos Cognatos \\
\hline providenciar & 5.Adjuntos Cognatos \\
\hline providenciar & 6.Adjuntos Hipônimos e Hiperônimos \\
\hline providenciar & Sentença-base \\
\hline registrar & 1.Alternância Causativo-Incoativa ou Transitivo-intransitiva \\
\hline registrar & 2.Alternância Média \\
\hline registrar & 3.Expressão perifrástica \\
\hline registrar & 4.Objetos Cognatos \\
\hline registrar & 5.Adjuntos Cognatos \\
\hline registrar & 6.Adjuntos Hipônimos e Hiperônimos \\
\hline registrar & Sentença-base \\
\hline regulamentar & 1.Alternância Causativo-Incoativa ou Transitivo-intransitiva \\
\hline regulamentar & 2.Alternância Média \\
\hline regulamentar & 3.Expressão perifrástica \\
\hline regulamentar & 4. Objetos Cognatos \\
\hline regulamentar & 5.Adjuntos Cognatos \\
\hline regulamentar & 6.Adjuntos Hipônimos e Hiperônimos \\
\hline regulamentar & Sentença-base \\
\hline processar1 & 1.Alternância Causativo-Incoativa ou Transitivo-intransitiva \\
\hline processar1 & 2.Alternância Média \\
\hline processar1 & 3.Expressão perifrástica \\
\hline processar1 & 4.Objetos Cognatos \\
\hline processar1 & 5.Adjuntos Cognatos \\
\hline processar1 & 6.Adjuntos Hipônimos e Hiperônimos \\
\hline processar1 & Sentença-base \\
\hline processar2 & 1.Alternância Causativo-Incoativa ou Transitivo-intransitiva \\
\hline processar2 & 2.Alternância Média \\
\hline processar2 & 3.Expressão perifrástica \\
\hline processar2 & 4.Objetos Cognatos \\
\hline processar2 & 5.Adjuntos Cognatos \\
\hline
\end{tabular}

Festa cara incrementa fácil.

As luzes deram um incremento especial à festa.

As luzes incrementaram um incremento especial à festa.

As luzes incrementaram a festa com um incremento especial.

As luzes incrementaram a festa com uma melhora especial.

As luzes incrementaram a festa.

O jantar providenciou.

Jantar pequeno providencia fácil.

Ana tomou providências para o jantar.

Ana providenciou uma providência eficaz para o jantar.

Ana providenciou o jantar com providências eficazes.

Ana providenciou o jantar com medidas eficazes.

Ana providenciou o jantar.

As compras registraram.

Compras com código de barras registram rápido.

A caixa fez o registro das compras.

A caixa registrou um registro rápido das compras.

A caixa registrou as compras com um longo registro.

A caixa registrou as compras com um longo cadastro.

A caixa registrou as compras.

A lei regulamentou.

Leis aprovadas regulamentam rápido.

O juiz colocou a lei em regulamento.

O juiz regulamentou um regulamento coerente da lei.

O juiz regulamentou uma lei em um regulamento coerente.

O juiz regulamentou uma lei em um estatuto coerente.

O juiz regulamentou a lei.

O chefe processou.

Chefes corruptos processam rápido.

funcionário pôs um processo no chefe.

o funcionário processou um processo contra o chefe.

O funcionário processou o chefe com um processo pesado.

O funcionário processou o chefe com uma ação pesada.

O funcionário processou o chefe.

Os dados processaram.

Poucos dados processam rápido.

O computador fez o processo dos dados.

O computador processou um processo lento dos dados.

O computador processou os dados com um processo lento.

\begin{tabular}{|c|c|c|}
\hline 14 & 19 & IGUAL \\
\hline 31 & 0 & DIF \\
\hline 4 & 29 & DIF \\
\hline 12 & 21 & IGUAL \\
\hline 25 & 11 & DIF \\
\hline 30 & 0 & DIF \\
\hline 6 & 24 & DIF \\
\hline 12 & 20 & IGUAL \\
\hline 30 & 1 & DIF \\
\hline 3 & 27 & DIF \\
\hline 17 & 12 & IGUAL \\
\hline 35 & 1 & DIF \\
\hline 32 & 0 & DIF \\
\hline 6 & 24 & DIF \\
\hline 23 & 7 & DIF \\
\hline 36 & 0 & DIF \\
\hline 12 & 19 & IGUAL \\
\hline 18 & 12 & IGUAL \\
\hline 22 & 14 & IGUAL \\
\hline 30 & 1 & DIF \\
\hline 13 & 18 & IGUAL \\
\hline 21 & 11 & IGUAL \\
\hline 23 & 10 & DIF \\
\hline 11 & 21 & IGUAL \\
\hline 17 & 19 & IGUAL \\
\hline 22 & 11 & IGUAL \\
\hline 36 & 0 & DIF \\
\hline 13 & 20 & IGUAL \\
\hline 13 & 19 & IGUAL \\
\hline 29 & 5 & DIF \\
\hline 4 & 31 & DIF \\
\hline 23 & 11 & IGUAL \\
\hline 31 & 2 & DIF \\
\hline 35 & 0 & DIF \\
\hline 24 & 16 & IGUAL \\
\hline 25 & 8 & DIF \\
\hline 25 & 10 & DIF \\
\hline 11 & 22 & IGUAL \\
\hline 20 & 20 & IGUAL \\
\hline
\end{tabular}

Página 17 


\begin{tabular}{|c|c|}
\hline processar2 & 6.Adjuntos Hipônimos e Hiperônimos \\
\hline processar2 & Sentença-base \\
\hline apontar1 & 1.Alternância Causativo-Incoativa ou Transitivo-intransitiva \\
\hline apontar1 & 2.Alternância Média \\
\hline apontar1 & 3.Expressão perifrástica \\
\hline apontar1 & 4.Objetos Cognatos \\
\hline apontar1 & 5.Adjuntos Cognatos \\
\hline apontar1 & 6.Adjuntos Hipônimos e Hiperônimos \\
\hline apontar1 & Sentença-base \\
\hline acabar & 3.Expressão perifrástica \\
\hline agulhar & 5.Adjuntos Cognatos \\
\hline agulhar & 6.Adjuntos Hipônimos e Hiperônimos \\
\hline apontar2 & 1.Alternância Causativo-Incoativa ou Transitivo-intransitiva \\
\hline apontar2 & 2.Alternância Média \\
\hline apontar2 & 3.Expressão perifrástica \\
\hline apontar2 & 4.Objetos Cognatos \\
\hline apontar2 & 5.Adjuntos Cognatos \\
\hline apontar2 & 6.Adjuntos Hipônimos e Hiperônimos \\
\hline apontar2 & Sentença-base \\
\hline desejar & Sentença-base \\
\hline enfeitiçar & 3.Expressão perifrástica \\
\hline incrementar & 1.Alternância Causativo-Incoativa ou Transitivo-intransitiva \\
\hline traçar1 & 1.Alternância Causativo-Incoativa ou Transitivo-intransitiva \\
\hline traçar1 & 2.Alternância Média \\
\hline traçar1 & 3.Expressão perifrástica \\
\hline traçar1 & 4.Objetos Cognatos \\
\hline traçar1 & 5.Adjuntos Cognatos \\
\hline traçar1 & 6.Adjuntos Hipônimos e Hiperônimos \\
\hline traçar1 & Sentença-base \\
\hline traçar2 & 1.Alternância Causativo-Incoativa ou Transitivo-intransitiva \\
\hline traçar2 & 2.Alternância Média \\
\hline traçar2 & 3.Expressão perifrástica \\
\hline traçar2 & 4. Objetos Cognatos \\
\hline traçar2 & 5.Adjuntos Cognatos \\
\hline traçar2 & 6.Adjuntos Hipônimos e Hiperônimos \\
\hline traçar2 & Sentença-base \\
\hline
\end{tabular}

O computador processou os dados com uma rodada lenta.

O computador processou os dados.

O lápis apontou.

Lápis bom aponta fácil.

O menino (re)fez a ponta do lápis.

O menino apontou a ponta (qeubrada) do lápis.

O menino apontou o lápis com a ponta fina.

O menino apontou o lápis com um bico exagerado.

O aluno apontou o lápis.

Ele pôs cabo no relatório.

A costureira agulhou o dedo com a agulha mais fina.

A enfermeira agulhou o dedo com a injeção do paciente.

As falhas apontaram.

Falhas grotescas apontam fácil.

A comissão fez uma ponta das falhas.

A comissão apontou a ponta das falhas.

A comissão apontou as falhas com a ponta fina.

A comissão apontou as falhas com um bico exagerada.

A comissão apontou falhas no projeto.

Ele desejou aquele objeto.

A índia colocou um feitiço no jovem rapaz.

A festa incrementou.

O desenho traçou no papel.

Desenho simples traça rápido.

O desenhista fez os traços do desenho no papel.

O desenhista traçou traços fortes no papel.

O desenhista traçou o desenho no papel com traços fortes.

O desenhista traçou o desenho no papel com riscos fortes.

O desenhista traçou o desenho no papel.

A estratégia traçou.

Estratégia simples traça rápido.

O técnico fez os traços da estratégia.

O técnico traçou traços fortes da estratégia.

O técnico traçou a estratégia com traços precisos.

O técnicotraçou a estratégia com riscos fortes.

O técnico traçou a estratégia.

\begin{tabular}{|c|c|c|}
\hline 21 & 15 & IGUAL \\
\hline 32 & 0 & DIF \\
\hline 15 & 23 & IGUAL \\
\hline 30 & 5 & DIF \\
\hline 33 & 0 & DIF \\
\hline 29 & 3 & DIF \\
\hline 30 & 5 & DIF \\
\hline 25 & 10 & DIF \\
\hline 35 & 0 & DIF \\
\hline 21 & 14 & IGUAL \\
\hline 24 & 5 & DIF \\
\hline 25 & 6 & DIF \\
\hline 7 & 26 & DIF \\
\hline 10 & 25 & DIF \\
\hline 6 & 27 & DIF \\
\hline 8 & 30 & DIF \\
\hline 10 & 23 & DIF \\
\hline 12 & 22 & IGUAL \\
\hline 31 & 0 & DIF \\
\hline 39 & 0 & DIF \\
\hline 36 & 0 & DIF \\
\hline 12 & 24 & IGUAL \\
\hline 7 & 23 & DIF \\
\hline 19 & 17 & IGUAL \\
\hline 33 & 2 & DIF \\
\hline 24 & 6 & DIF \\
\hline 27 & 4 & DIF \\
\hline 25 & 3 & DIF \\
\hline 32 & 0 & DIF \\
\hline 5 & 27 & DIF \\
\hline 13 & 17 & IGUAL \\
\hline 20 & 10 & IGUAL \\
\hline 11 & 21 & IGUAL \\
\hline 18 & 13 & IGUAL \\
\hline 16 & 14 & IGUAL \\
\hline 32 & 0 & DIF \\
\hline
\end{tabular}




\section{ANEXO 06 - ORIGEM DUVIDOSA}

\begin{tabular}{|c|c|c|c|c|c|}
\hline & Verbo & Nome & Dicionário Etimológico CUNHA & Dicionário Etimológico MACHADO & \begin{tabular}{|c|} 
(latim) \\
Dicionário Português - Latim (Ferreira, \\
1988) \\
\end{tabular} \\
\hline 1 & analisar & análise & $\begin{array}{c}\text { "analisAR | -ly- } 1981 \text { |do fr. Anlyser" p. } \\
43\end{array}$ & $\begin{array}{l}\text { "De análise, se não do fr. Analyser. Em } \\
\text { 1871.DV." P. } 242\end{array}$ & Excutire \\
\hline 2 & causar & causa & $\begin{array}{l}\text { "CausAR vb. 'ser causa de' Do latim } \\
\text { causari, pretextar, alegar " p. } 167 \\
\end{array}$ & "Do latim causari, pretextar, alegar". & afferre, edere, exhibere.. \\
\hline 3 & testar & teste & $\begin{array}{l}\text { 1-'deixar em testamento' Do lat, testari. } \\
\text { 2- testAR XX. P. } 767\end{array}$ & $\begin{array}{c}\text { "Do latim testare, tardio, em vez de } \\
\text { testari." p. } 2210\end{array}$ & Testari $=$ fazer testamento \\
\hline 4 & empacotar & pacote & $\begin{array}{l}\text { " } \rightarrow \text { PACA2" (Paca2 = fardo, pacote). P. } \\
292\end{array}$ & - & - \\
\hline 5 & agulhar & agulha & - & $\begin{array}{l}\text { "Do latim *aculeare com influência de } \\
\text { agulha? Séc XVII". P. } 158 \\
\end{array}$ & picar com agulha (aliquem) acu pungere \\
\hline 6 & brincar & brinco & $\begin{array}{c}\text { "brincAR vb. Divertir-se, entreter-se XVI" } \\
\text { p. } 124\end{array}$ & $\begin{array}{c}\text { "o substantivo brinco significando } \\
\text { <pingente> seja o latim vinc(u)lum, } \\
\text { independente portanto de } \\
\text { brinco, substantivo rizotônico do verbo } \\
\text { brincar". P, } 465\end{array}$ & ludere, se oblectare \\
\hline 7 & aprimorar & primor & $" \rightarrow$ PRIMEIRO". P. 60 & - & perficere (aperfeiçoar) \\
\hline 8 & arrumar & rumo & "Do fr. Arrumer". p. 72 & "Do fr. Arrumer". p. 322. & disponere, digerere \\
\hline 9 & implementar & implemento & - & - & - \\
\hline 10 & gerenciar & gerência & - & - & $\begin{array}{c}\text { gerência = adminiatratio, gestio, } \\
\text { dispensatio.. }\end{array}$ \\
\hline 11 & veicular & veículo & "veiculAR| vehi -1899" p. 813 & - & veículo = vehiculum \\
\hline 12 & forçar & força & "forçAR XIII". P. 364 & $\begin{array}{l}\text { "Do latim *fortiare der de fortia séc XIII". } \\
\text { P. } 1068\end{array}$ & cogere, necessitatem aferre \\
\hline 13 & economizar & economia & "economizAR" p. 283 & $\begin{array}{l}\text { "Do fr economiser em 1813, Morais" p. } \\
846\end{array}$ & fazer economia = sumptui parcere \\
\hline 14 & movimentar & movimento & $\begin{array}{l}\text { "moviMENTAR } 1899 \text { Adapt do fr } \\
\text { mouvementer" p. } 536\end{array}$ & - & $\begin{array}{c}\text { movimentar }=\text { movere }, \text { agere } \ldots \\
\text { Movimento }=\text { motio }\end{array}$ \\
\hline
\end{tabular}




\begin{tabular}{|c|c|c|c|c|c|}
\hline 15 & incrementar & incremento & $\begin{array}{l}\text { "incrementAR XX do lat. Med. } \\
\text { Incrementare". P. } 432\end{array}$ & $\begin{array}{l}\text { "Do lat. Incrementare, 'aumentar'". P. } \\
1277\end{array}$ & - \\
\hline 16 & providenciar & providência & $" \rightarrow$ PROVER". P. 643 & - & providere \\
\hline 17 & registrar & registro & "registrAR" p. 672 & V. registar (Do registo)". P. 1977 & prescribere, referre... \\
\hline 18 & suplementar & suplemento & "suplementAR adj 2g" p. 744 & $\begin{array}{l}\text { "Do fr. Supplementaire. Em 1890, } \\
\text { segundo Morais". P. } 2159\end{array}$ & $\begin{array}{c}\text { Só a acepção de adjetivo } \\
\text { Suplemento = supplementum }\end{array}$ \\
\hline 19 & traçar & traça & $\begin{array}{l}\text { "riscar, fazer uma linha,XVI do lat vulg } \\
\text { *tractiare." p. } 779\end{array}$ & "riscar, do lat *tractiare Séc XVI" p. 2233 & scribere, describere, ducere \\
\hline 20 & regulamentar & regulamento & $" \rightarrow$ REGRA". P. 672 & - & constituere, componere \\
\hline 21 & agendar & agenda & - & - & agenda $=$ pugillares \\
\hline 22 & memorizar & memória & "memorizAR XX". P. 512 & "v. Do fr. Mémorizer." p. 1542 & $\begin{aligned} \mathrm{V} & =- \\
\text { memória } & =\text { memoria }\end{aligned}$ \\
\hline 24 & auxiliar & auxílio & "auxiliAR vb. XVIII do lat auxiliare". P. 85 & "Do lat. Auxiliare, auxiliari". P. 355 & adiuvare \\
\hline 25 & depositar & depósito & $" \rightarrow$ DEPOR". P. 248 & "v. De depósito. Séc XVII". P. 783 & $\begin{array}{c}\text { ponere, deponere, habere aliquid } \\
\text { depositum }\end{array}$ \\
\hline 26 & sediar & sede & - & - & sede $=$ sitis \\
\hline 27 & filtrar & filtro & "Do fr. Filtrer". P. 358 & "Do fr. Filtrer. Em 1813". P. 1046 & saccare, colare \\
\hline
\end{tabular}

